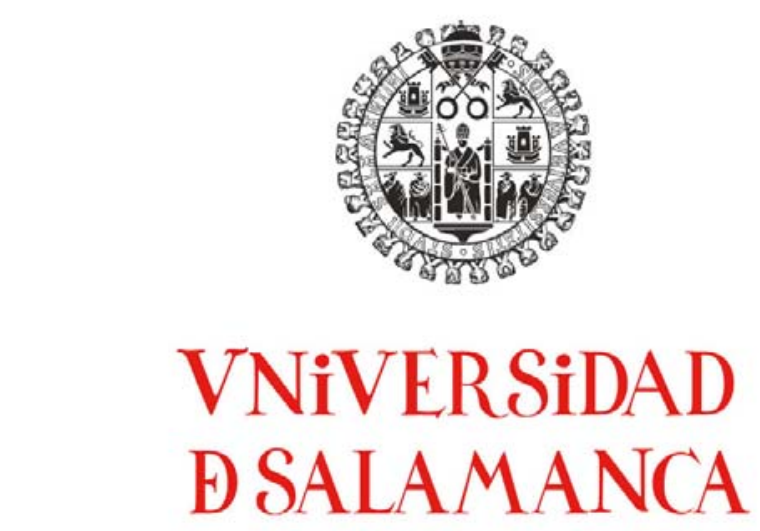

Facultad de Derecho

Departamento de Derecho Privado

Área de Derecho Civil

\title{
LA REPUDIACIÓN \\ DE LA HERENCIA \\ EN EL CODIGO CIVIL
}

Tesis doctoral

Ignacio Sánchez Cid

Salamanca 2012 
VNiVERSIDAD

DSALAMANCA

Facultad de Derecho

Departamento de Derecho Privado

Área de Derecho Civil

\section{LA REPUDIACIÓN \\ DE LA HERENCIA \\ EN EL CODIGO CIVIL}

Tesis Doctoral presentada por:

Ignacio Sánchez Cid, para optar al Grado de Doctor, bajo la dirección de la Prof ${ }^{a}$ Dr $^{a} D^{a} M^{a}$ José Herrero García.

El Doctorando

Vo. Bo. de la Directora 
Mi más sincera y profunda gratitud a todas aquellas personas, que no voy a citar de forma expresa por si el olvido de alguna de ellas les provocare lógico malestar, que con su aliento y afecto me han animado y apoyado en la ardua y lenta tarea que, en el quehacer de cada día, ha supuesto la realización de esta Tesis.

No obstante, sí quisiera dedicársela de foma explícita, sin orden de preferencia, a mis tres Rosas: mi madre, mi abuela y mi hija.

Y, mi más sincero agradecimiento a la Profa Dra Ma José Herrero García, que, sin ella, esta Tesis nunca habría sido posible. 


\section{INDICE}

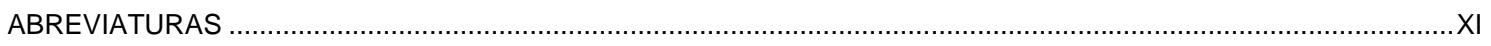

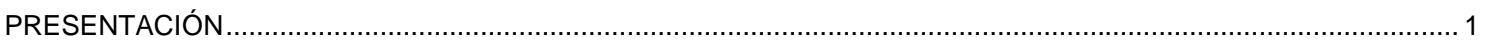

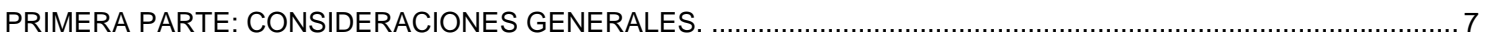

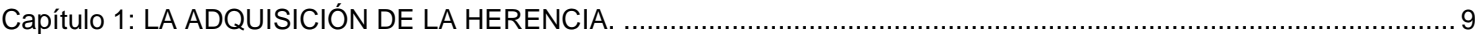

1.- LA SUCESIÓN MORTIS CAUSA.

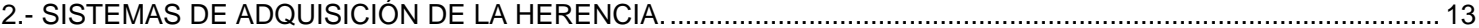

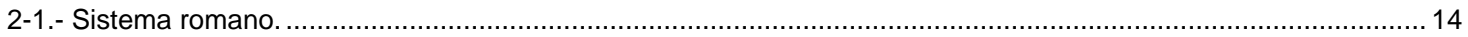

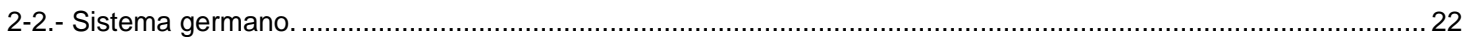

2-3.- Sistemas actuales.................2 27

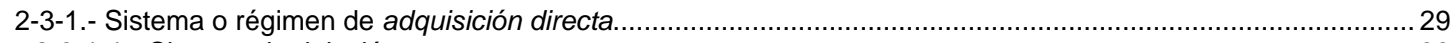

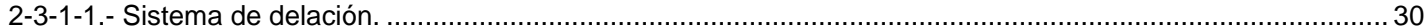

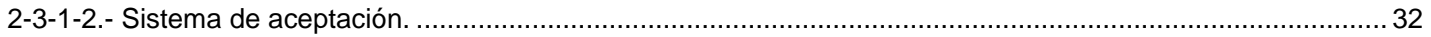

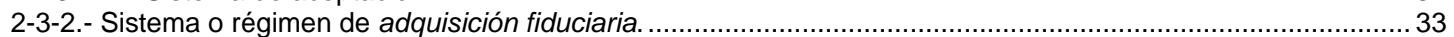

2-3-3.- Sistema o régimen de adquisición directa por investidura...................................................................... 34

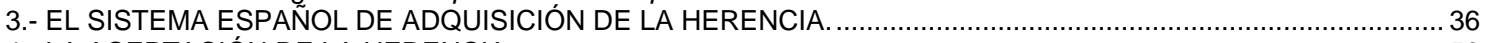

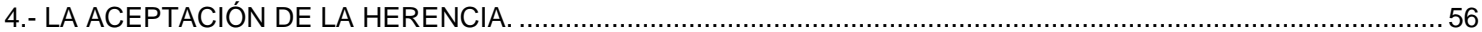

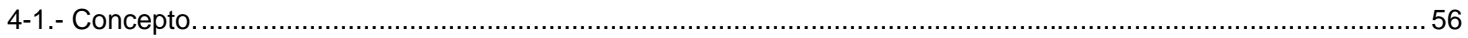

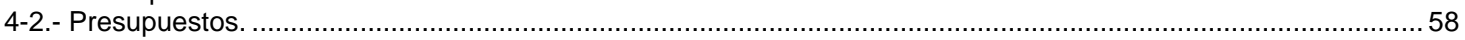

4-2-1.- Objetivos. ................... 58

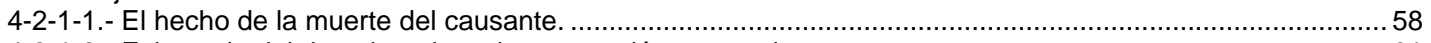

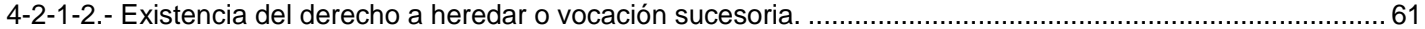

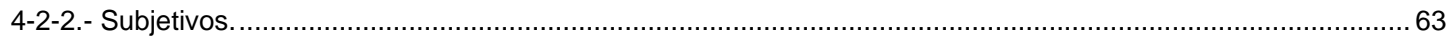

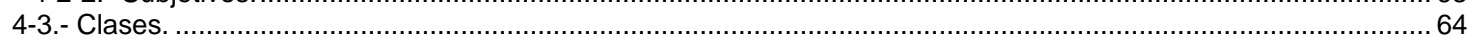

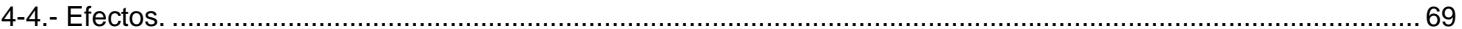

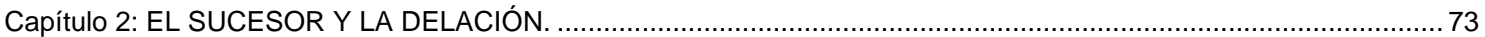

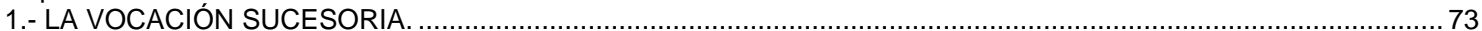

2.- LA DELACIÓN.

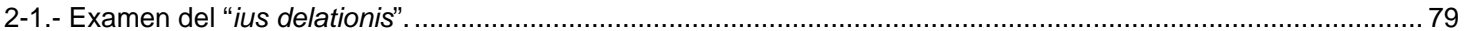

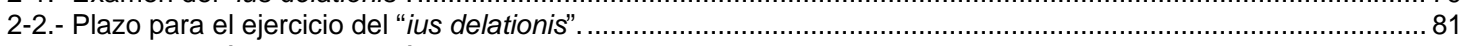

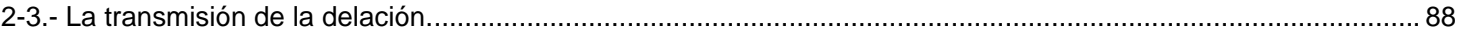

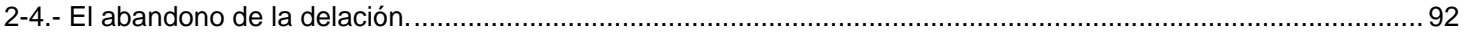

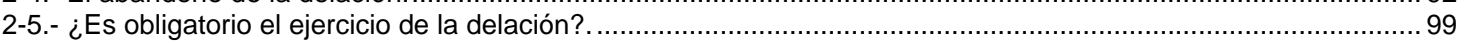

2-6.- Cuando la delación solo consiste en la aceptación. ................................................................................. 105

3.- LA PERDIDA DE LA FACULTAD DE REPUDIAR EN EL CASO DEL ARTÍCULO 1002 DEL CODIGO CIVIL.........107

3-1.- Qué se entiende por "perder la facultad de renunciarla". ....................................................................... 109

3-2.- Empleo equívoco del término "heredero"................................................................................................ 111

3-3.- Qué se ha de entender por "sustaer u ocultar algunos efectos de la herencia". .................................................... 112

3-4.- En qué momento han de producirse los hechos.................................................................................. 116

3-5.- ¿Puede el sucesor, pese a la sanción, manifestar su voluntad de repudiar? ................................................... 122

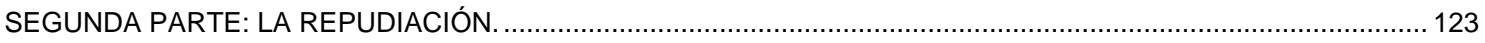

Capítulo 3: LA REPUDIACIÓN DE LA HERENCIA. ORÍGENES Y DEFINICIÓN. ................................................... 125

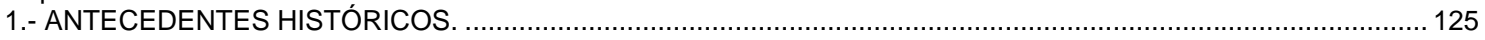

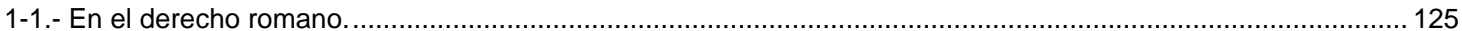

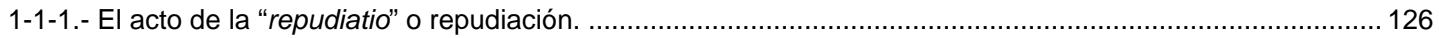

1-1-2.- Institución de heredero bajo la condición "si volet". ................................................................................. 129

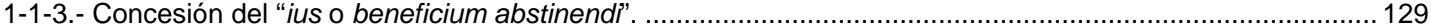

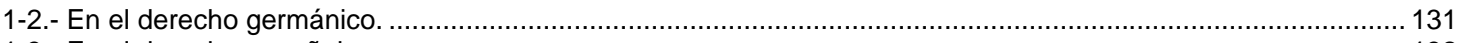

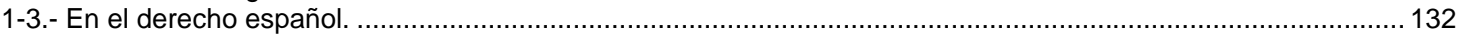

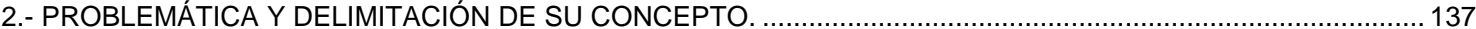

3.- LA RENUNCIA .

3-1.- Clases de renuncia.............................. 142

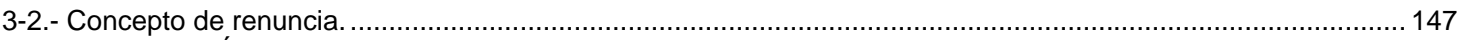

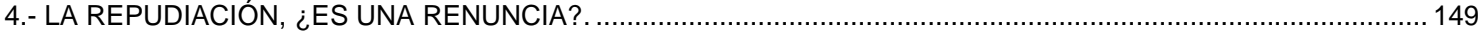

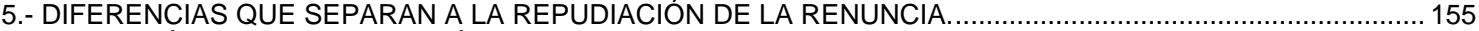

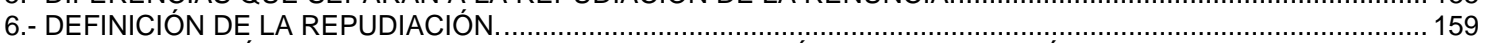

7.- LA REPUDIACIÓN Y LOS CASOS DE RENUNCIA DEL ARTÍCULO 1000 DEL CÓDIGO CIVIL...........................164

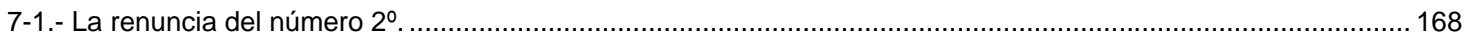

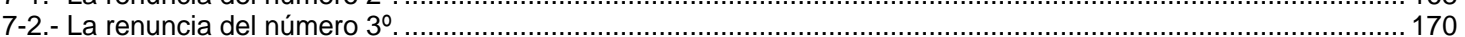




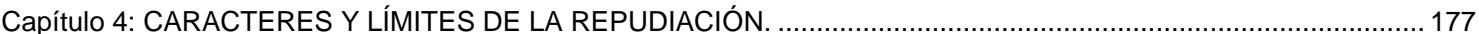

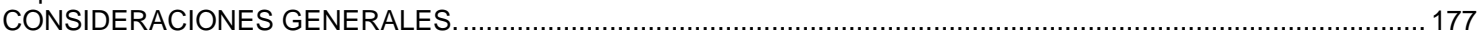

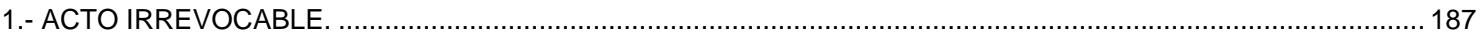

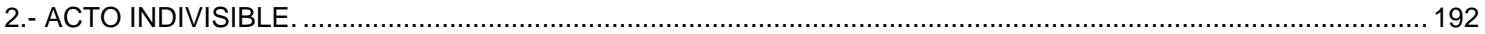

2-1.- La indivisibilidad desde el punto de vista del sujeto............................................................................ 199

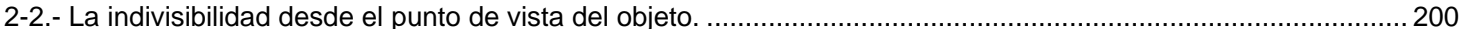

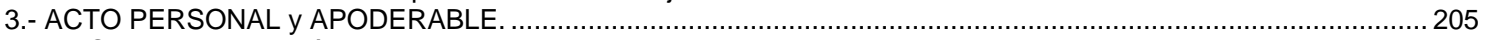

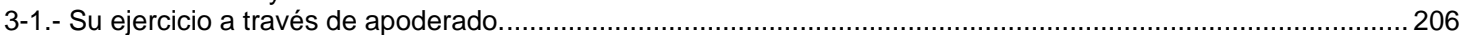

3-2.- Los acreedores y el ejercicio de la delación. ..................................................................................... 207

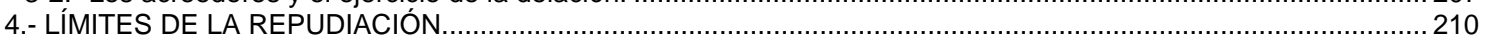

4-1.- Los pactos sucesorios.................................................. 210

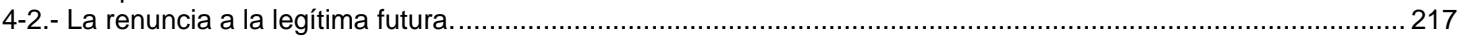

Capítulo 5: LA REPUDIACIÓN EN EL CASO DE PLURALIDAD DE TÍTULOS Y/O DE CUOTAS...............................2221

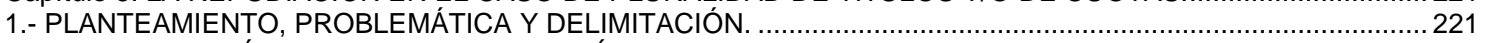

2.- LA REPUDIACIÓN ANTE UNO O VARIOS TÍTULOS SUCESORIOS Y VARIAS PORCIONES O CUOTAS. $\ldots \ldots . . .223$

2-1.- La repudiación cuando hay un solo título y varias porciones o cuotas de la herencia......................................225

2-2.- La repudiación cuando hay varios títulos y una o varias porciones o cuotas de la herencia. ……............................225

3.- EL ARTÍCULO 1009 DEL CÓDIGO CIVIL: DELIMITACIÓN DEL ÁMBITO DE SU APLICACIÓN. .........................232

3-1.- Interpretación del párrafo primero y presupuestos para su aplicación. .............................................................2 234

3-2.- Interpretación del párrafo segundo y presupuestos para su aplicación ....................................................2239

4.- LA REPUDIACIÓN EN EL CASO DE COEXISTENCIA DE LA SUCESIÓN TESTADA E INTESTADA..................246

4-1.- Que exista simultaneidad o compatibilidad entre ambas sucesiones..........................................................2.250

4-2.- Apertura de la sucesión intestada porque la testada se frustre o sea insuficiente......................................... 251

4-3.- Apertura de la sucesión intestada por ineficacia de la testada o de la institución de heredero...........................254

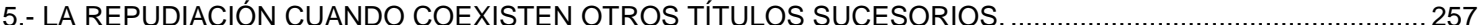

5-1.- Que quien repudie como transmisario sea llamado después como sucesor abintestato. ............................... 257

5-2.- Que quien repudie como transmisario vuelva a ser llamado como sustituto a resultas de dicha repudiación. ... 260

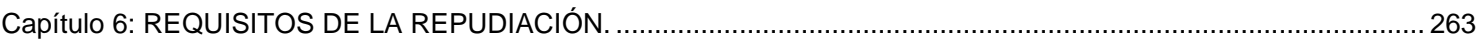

1.- REQUISITOS SUBJETIVOS.

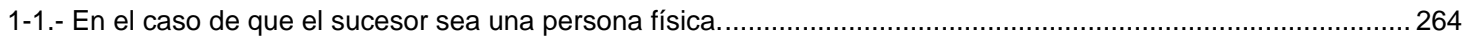

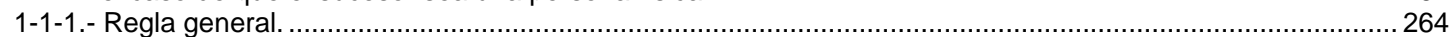

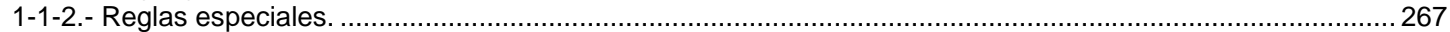

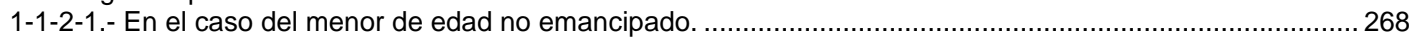

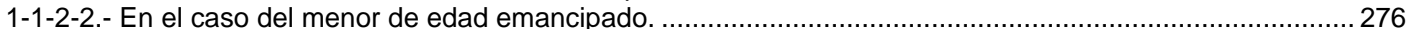

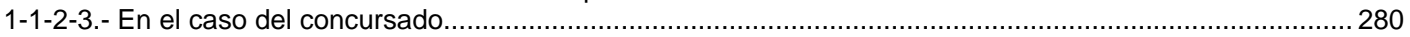

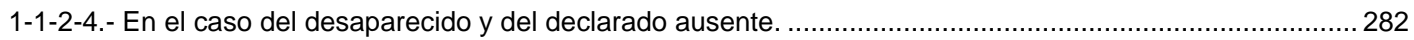

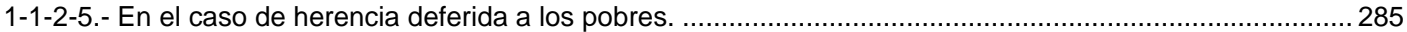

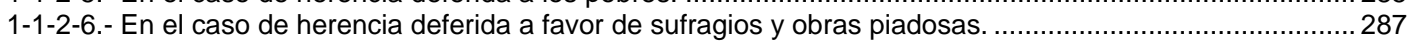

1-2.- En el caso de que el sucesor sea una persona jurídica. ..................................................................... 289

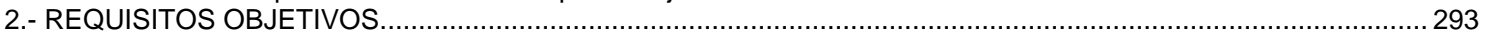

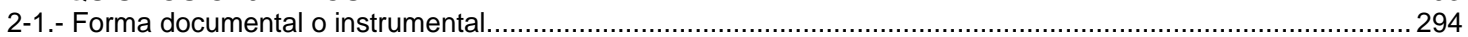

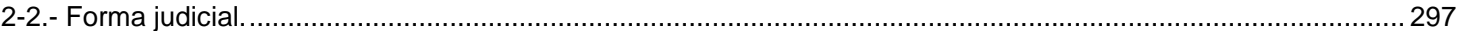

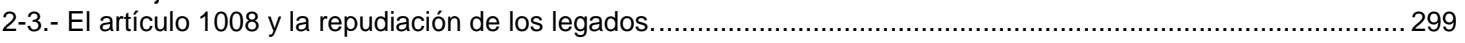

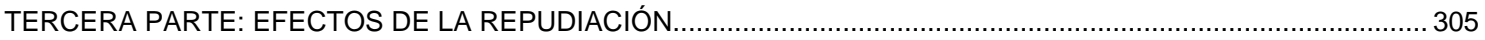

Capítulo 7: EFECTOS DE LA REPUDIACIÓN (I): EN RELACIÓN A LOS SUJETOS INTERESADOS EN LA

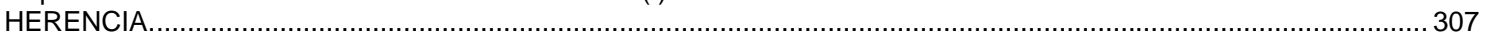

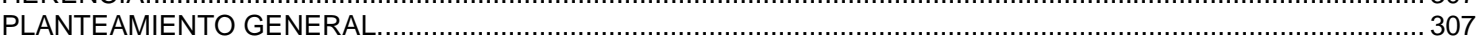

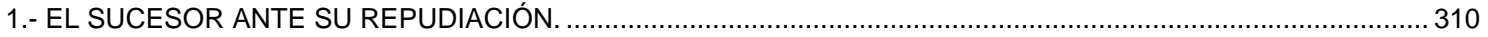

1-1.- Cuando hubiere hecho uso del derecho de deliberar.

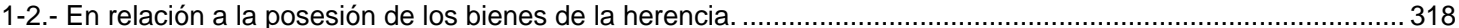

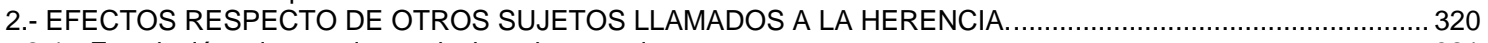

2-1.- En relación a los sustitutos designados por el causante. ........................................................................ 321

2-2.- En el caso de sustitución fideicomisaria. ............................................................................................ 322

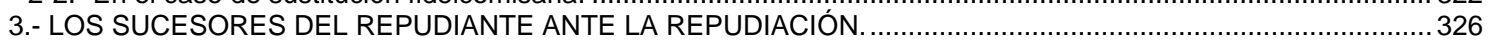

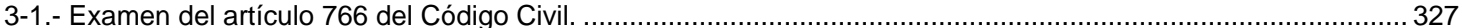

3-2.- El derecho de representación en el caso de repudiación. ……........................................................................ 333

Capítulo 8: EFECTOS DE LA REPUDIACIÓN (II): EN RELACIÓN A LO QUE SE REPUDIA Y SU DESTINO POSTERIOR......

1. - INTRODUCCIÓN

2.- EN EL ÁMBITO DE LA SUCESIÓN TESTADA.

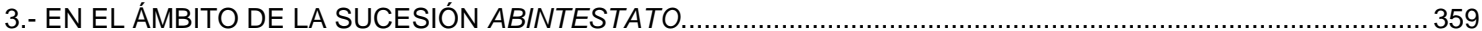

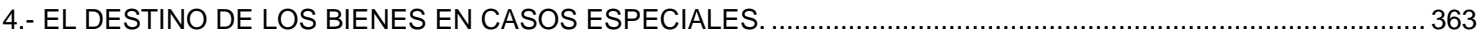

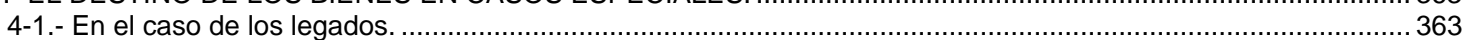

4-2.- En el caso de la legítima. ..umumumum 365

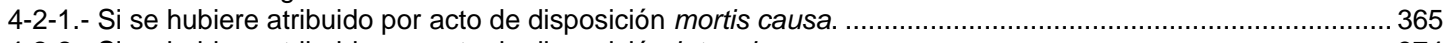

4-2-2.- Si se hubiere atribuido por acto de disposición inter vivos................................................................. 374

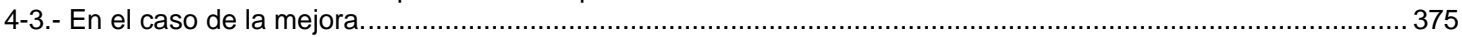

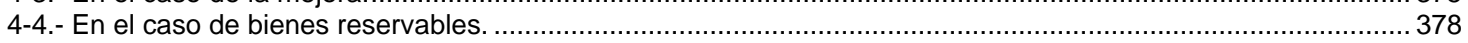

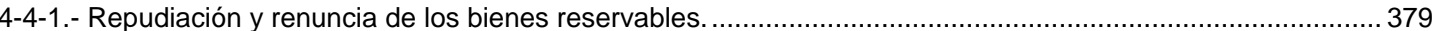

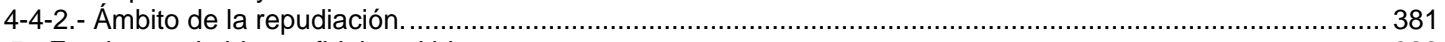

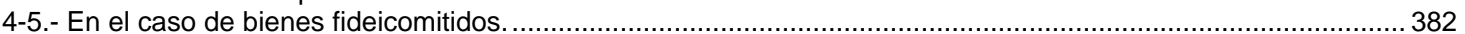




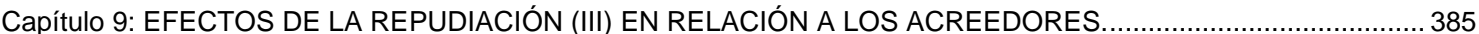

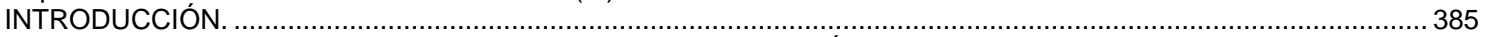

1.- LOS ACREEDORES DE LA HERENCIA ANTE LA REPUDIACIÓN.

2.- LOS ACREEDORES PARTICULARES DEL SUCESOR ANTE LA REPUDIACIÓN.......................................... 388

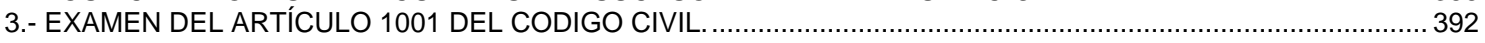

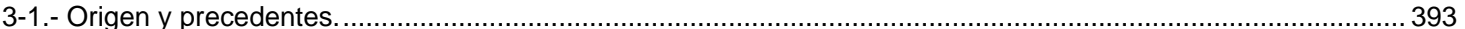

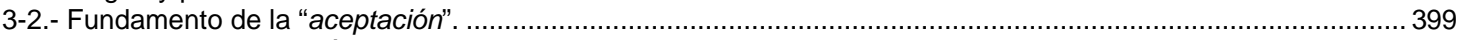

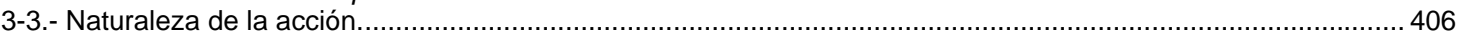

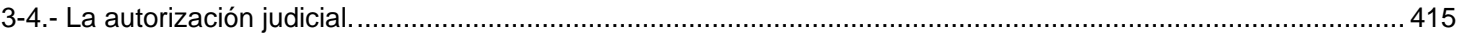

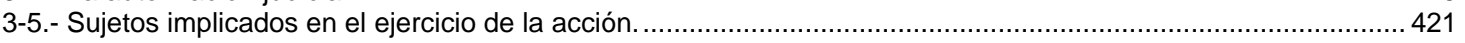

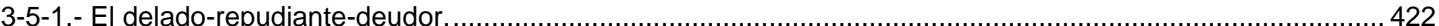

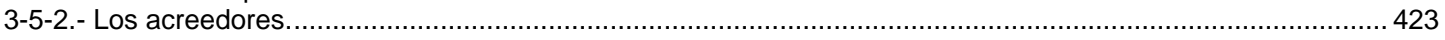

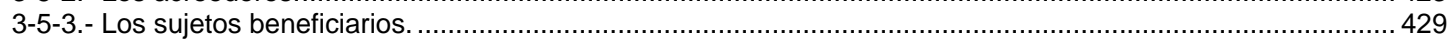

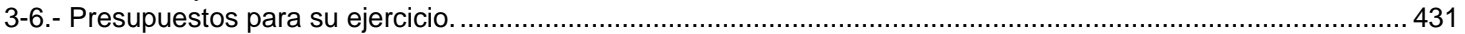

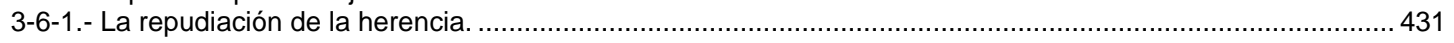

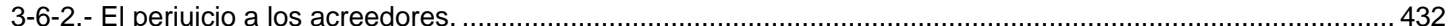

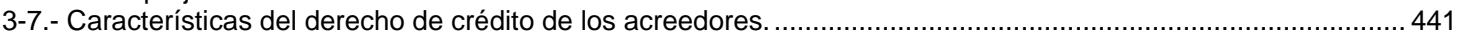

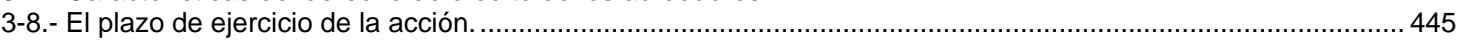

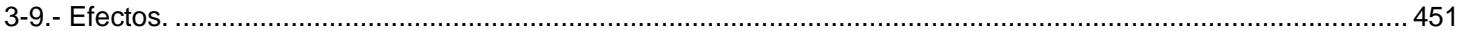

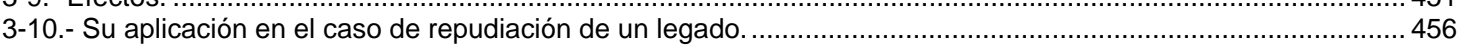

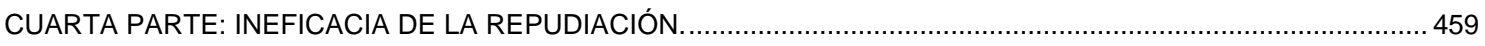

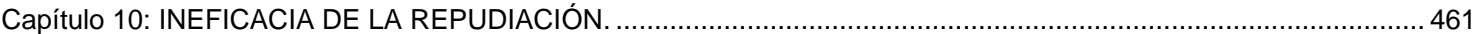

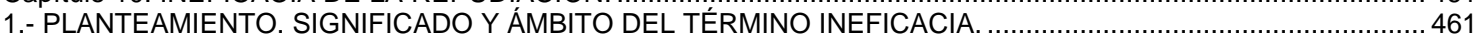

2.- LA INEFICACIA APLICADA A LA REPUDIACIÓN .................................................................... 468

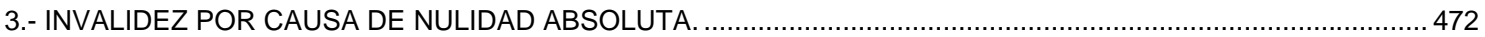

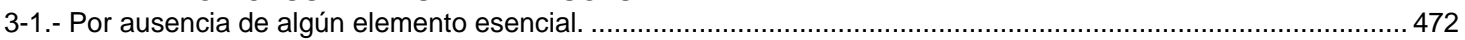

3-1-1.- Cuando la repudiación se hace en vida del causante........................................................................ 473

3-1-2.- Sin estar cierto del fallecimiento del de cuius o sin que exista vocación sucesoria........................................... 474

3-1-3.- Ausencia de capacidad o consentimiento para emitir la declaración. ..................................................... 476

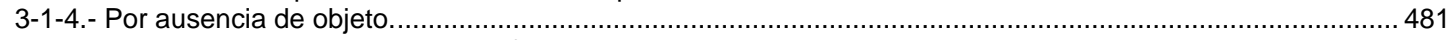

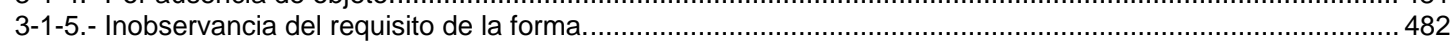

3-2.- Por infracción de normas imperativas o prohibitivas........................................................................... 483

3-2-1.- Cuando la declaración se hace de forma parcial. .............................................................................. 483

3-2-2.- Cuando la declaración se hace bajo condición o a término. ................................................................... 483

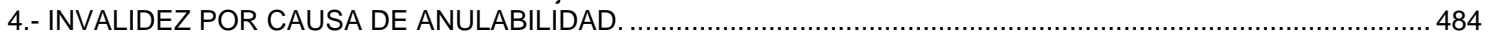

4-1.- En el caso de que existiere un vicio del consentimiento......................................................................... 484

4-2.- En el caso de repudiación por un menor de edad no emancipado.............................................................. 487

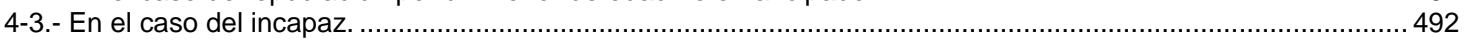

4-4.- En el caso de representación legal si no se ha obtenido autorización judicial. ............................................. 499

4-5.- En el caso de infracción de lo dispuesto en los artículos 993 y 994 CC. ....................................................... 502

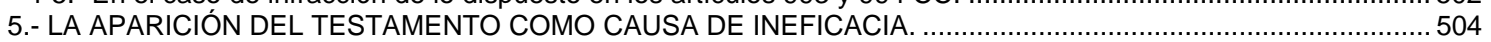

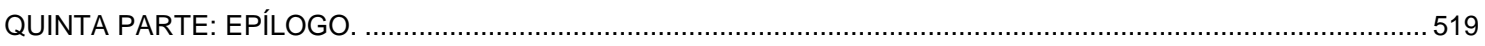

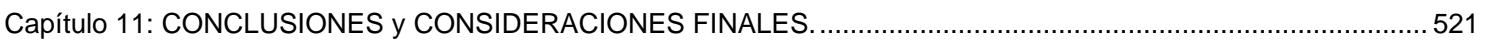

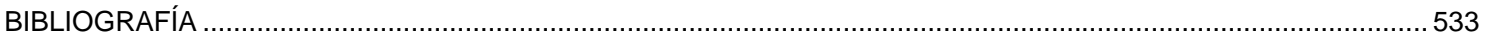




\section{ABREVIATURAS}

AAMN

a. C.

ABGB

AC

ADC

AP

Art. Arts

BGB

BOA

BOCyL

BOE

BOIB

C

CC

Cco

CDFA

CDCFIB

CDCFN

CE

$\mathrm{CP}$

D

d. C.

DA

DF

DGRN

DOCE

DOG

DOGC
Anales de la Academia Matritense del Notariado.

Antes de Cristo.

Allgemeine Bürgerliches Gesetzbuch (Código Civil austriaco).

Actualidad Civil.

Anuario de Derecho Civil.

Audiencia Provincial.

Artículo, artículos.

Bürguerliches Gesetzbuch (Código Civil alemán).

Boletín Oficial de Aragón.

Boletín Oficial de Castilla y León.

Boletín Oficial del Estado

Boletín Oficial de las Islas Baleares.

Codex de Justiniano.

Código Civil.

Código de Comercio de 1885.

Código de Derecho Foral de Aragón aprobado por Decreto Legislativo 1/2011, de 22 de marzo, que refunde la legislación civil foral de Aragón.

Compilación de Derecho Civil Foral de Baleares. Texto Refundido aprobado por Decreto Legislativo, 79/1990, de 6 de septiembre.

Compilación de Derecho Civil Foral de Navarra, o Fuero Nuevo, aprobado por Ley, 1/1973, de 1 de marzo.

Constitución Española de 1978.

Código Penal aprobado por Ley Orgánica, 10/1995, de 23 de noviembre.

Digesto.

Después de Cristo.

Disposición Adicional.

Disposición Final.

Dirección General de los Registros y del Notariado.

Diario Oficial de la Comunidad Europea.

Diario Oficial de Galicia.

Diario Oficial de la Generalitat de Cataluña. 


\begin{tabular}{|c|c|}
\hline DOGCV & Diario Oficial de la Generalitat de Valencia. \\
\hline DT & Disposición Transitoria. \\
\hline ERPL & European Review of Private Law. \\
\hline ET & Estatuto de los Trabajadores. \\
\hline Fdto dcho & Fundamento de Derecho. \\
\hline FNN & Fuero Nuevo de Navarra. \\
\hline LC & Ley, 22/2003, de 9 de julio, Concursal. \\
\hline LCF & $\begin{array}{l}\text { Ley, 9/1998, de } 15 \text { de julio, de la Generalitat de Cataluña, de } \\
\text { Código de Familia. }\end{array}$ \\
\hline LDCF & $\begin{array}{l}\text { Ley 3/1992, de } 1 \text { de julio, de Derecho Civil Foral del Pais } \\
\text { Vasco. }\end{array}$ \\
\hline LDCG & Ley, 2/2006, de 14 de junio, de Derecho Civil de Galicia. \\
\hline LEC & Ley de Enjuiciamiento Civil. \\
\hline LECr & Ley de Enjuiciamiento Criminal. \\
\hline LGT & Ley General Tributaria. \\
\hline LH & Ley Hipotecaria. \\
\hline LOPJ & Ley Orgánica, 6/1985, de 1 de julio, del Poder Judicial. \\
\hline LOPJM & $\begin{array}{l}\text { Ley Orgánica, 1/1996, de } 15 \text { de enero, de Protección Jurídica } \\
\text { del Menor. }\end{array}$ \\
\hline LORPM & $\begin{array}{l}\text { Ley Orgánica, } 5 / 2000 \text {, de } 12 \text { de enero, de Responsabilidad } \\
\text { Penal del Menor. }\end{array}$ \\
\hline LOTC & $\begin{array}{l}\text { Ley Orgánica, 2/1979, de } 3 \text { de octubre, del Tribunal } \\
\text { Constitucional. }\end{array}$ \\
\hline LRC & Ley del Registro Civil. \\
\hline Op. cit. & Obra citada. \\
\hline $\mathrm{pp}$ & Pie de página. \\
\hline RAE & Real Academia Española de la Lengua. \\
\hline RCDI & Revista Crítica de Derecho Inmobiliario. \\
\hline $\mathrm{RD}$ & Real Decreto. \\
\hline RDLeg & Real Decreto Legislativo. \\
\hline Res DGRN, RDGRN & $\begin{array}{l}\text { Resolución de la Dirección General de los Registros y Del } \\
\text { Notariado. }\end{array}$ \\
\hline RDL & Real Decreto Ley. \\
\hline RDLeg & Real Decreto Legislativo. \\
\hline RDP & Revista de Derecho Privado. \\
\hline RDN & Revista de Derecho Notarial. \\
\hline RGLJ & Revista General de Legislación y Jurisprudencia. \\
\hline $\mathrm{RH}$ & Reglamento Hipotecario. \\
\hline RJ & Repertorio de Jurisprudencia Aranzadi. \\
\hline
\end{tabular}


$\mathrm{RN}$

RRC

RTC

$\mathrm{S}, \mathrm{ST}, \mathrm{St}$

SAP, SSAP

STC, SSTC

STS, SSTS

STSJ, SSTSJ

TC

TS

TSJ

UE
Reglamento Notarial.

Reglamento del Registro Civil.

Repertorio de Jurisprudencia del Tribunal Constitucional de Aranzadi.

Sentencia.

Sentencia/s de Audiencia Provincial.

Sentencia/s del Tribunal Constitucional.

Sentencia/s del Tribunal Supremo.

Sentencia/s de Tribunal Superior de Justicia.

Tribunal Constitucional.

Tribunal Supremo.

Tribunal Superior de Justicia.

Unión Europea. 


\section{PRESENTACIÓN}

Llama, sin duda alguna, la atención el hecho de que una adquisición patrimonial gratuita, como es la que proviene de una sucesión mortis causa, sea objeto de rechazo por parte de quien es llamado a ella, que es lo que supone la repudiación, por que, salvo que se trate de una herencia damnosa o deficitaria, no causa perjuicio alguno y sí, por el contrario, ofrece la posibilidad de obtener un beneficio o ingreso económico y de mejorar, en consecuencia, tanto desde el punto de vista patrimonial como personal.

Señalaba MANRESA ${ }^{1}$ en este sentido que, "se cree vulgarmente que el renunciar a la herencia no puede tener más objeto que liberarse de responsabilidades pecuniarias: pero es lo cierto que esto se evita, sin necesidad de renunciar, aceptando a beneficio de inventario, y que, muchas veces, la renuncia obedece al deseo de favorecer a otros coherederos, o al de evitar cuestiones y disgustos que no pueden apreciarse en dinero, o a sentimientos y razones que extraordinariamente se desconocen, pero que tienen su razón de ser". ROGEL VIDE, por su parte ${ }^{2}$, dice que "descubrir estos motivos es difícil, en verdad", citando la STS de 1 de febrero de 1957 (RJ 697), según la cual, "la aceptación y repudiación de la herencia son actos enteramente voluntarios y libres, por ser diversas $y$, a veces, de carácter íntimo $y$ personal, las razones que inducen a un heredero a repudiar la herencia, sin que el renunciante esté obligado a revelarlas". Además de difícil ese descubrimiento, añade ROGEL a continuación, "es profundamente interesante, pues, aun cuando, jurídicamente puedan ser irrelevantes, nos permitirán descubrir la vigencia de la repudiación en toda su riqueza y variedad", y señala hasta ocho motivos distintos ${ }^{3}$ rastreando, como él dice, sentencias del Tribunal Supremo.

\footnotetext{
${ }^{1}$ Comentarios al Código Civil español. T. VII (arts 912 a 1087). 6a Ed. Revisada por BONET RAMÓN. Instituto Editorial REUS. Madrid. 1943. Pág 418.

${ }^{2}$ Renuncia y repudiación de la herencia. Colección Derecho español contemporáneo. Editorial REUS. Madrid. 2011. Pág 151 y ss.

${ }^{3}$ Son los siguientes: impedir el ingreso en el patrimonio de una herencia dañosa (SSTS de 4 de julio de 1955 y 14 de marzo de 1957, RJ 2324 y 1162); favorecer a las personas que han de beneficiarse de la repudiación (STS de 9 de diciembre de 1992, RJ 10130); perjudicar a los legitimarios del repudiante (STS de 23 de mayo de 1955, RJ 1707); perjudicar a los acreedores del repudiante (STS de 30 de mayo de 2003, RJ 3917); perjudicar a los potenciales reservatarios (SSTS de 1 de febrero de 1957 y 16 de junio de
} 
Se trata de un acto que tiene una gran trascendencia e importancia en diferentes órdenes: en primer lugar, para quien lo realiza, como antes se ha apuntado, también por las consecuencias jurídicas que de él se derivan en lo que se refiere al destino de aquello que es objeto de repudio; además, va a repercutir sobre toda una multiplicidad de personas: demás sucesores, sustitutos, sucesores del sucesor, acreedores, etc. A ello se le suma que, en la relación personal que, en su caso, tenga quien repudia hacia el causante, tal acto entraña o supone un desaire, un reproche, incluso un gesto de desprecio hacia él, su honra y memoria, que, si se da la circunstancia de que es un familiar o pariente próximo, como puede ser un progenitor, hace de este acto, en no pocas ocasiones, un disgusto o un drama familiar.

También tiene una gran repercusión en la transmisión mortis causa de los bienes de la herencia porque supone una alteración o cambio del destino de los mismos inicialmente previsto por el causante o por la ley. Lo que se acentúa o agrava cuando se trata de bienes que han pertenecido de manera secular o inmemorial a una familia y han pasado de unas manos a otras, de generación en generación, porque supone una quiebra o ruptura en el orden de suceder ya que trastoca el iter o camino que de manera, no ya normal, sino, incluso natural, han de llevar esos bienes. En este sentido, el sucesor al repudiar la herencia a que ha sido llamado, no solo contraría y se opone, incluso niega y frustra con su comportamiento la voluntad del causante o de la ley, sino que da lugar a que el destino que van a tener los bienes objeto de esa herencia contradiga la voluntad del testador, sea distinto al que él previó, alterando así los planes que éste hizo en vida, salvo que hubiere tenido la previsión de decir cual sería su destino en este caso. A raiz de la repudiación se produce un cambio en la dirección o trayectoria de esos bienes que, haciendo un simil, es semejante al de un tren que, a la salida de una estación, toma una vía diferente a la que le correspondería para ir a su verdadero destino como consecuencia de un imprevisto o accidental cambio de agujas.

Sin embargo, a la repudiación, desde el punto de vista doctrinal, y a la vista de la bibliografía existente, a nuestro juicio, no se le ha prestado la suficiente atención o no ha sido objeto de un estudio y análisis, de la misma manera y con la misma extensión y profundidad que su antónimo, la aceptación de la herencia. Cuando se ha estudiado el sistema de adquisición de herencia de nuestro ordenamiento jurídico, entendemos que se ha hecho más hincapié, en la aceptación, que en la repudiación, porque las referencias a ésta han sido, incluso podríamos decir que, de forma colateral o en el seno de la familia; testimoniar la enemistad con el causante (STS de 25 de enero de 1962, RJ 562). 
incidental, en el sentido de que, al tiempo que se analizaba la aceptación, se hacía una alusión a la repudiación, o se ha insistido más, o parece que se le ha dado más realce e importancia a la declaración de aceptación que a la de repudiación. Los artículos e investigaciones doctrinales versan más sobre el examen del ius delationis, la vocación y delación hereditaria, la aceptación y adquisición de la herencia, etc, pero son muy escasos los que aborden estricta y directamente, incluso en exclusividad y de forma monográfica, además, en profundidad, el hecho de la repudiación de la herencia y sus consecuencias.

A este respecto, y sin perjuicio de cuanto más adelante se expondrá, a nuestro parecer, y al sentir mayoritario de un gran sector de la doctrina y la jurisprudencia, bien es cierto que, en nuestro ordenamiento jurídico, sin aceptación de la herencia no hay adquisición de la misma, pero, no es menos cierto que, si no se quiere adquirir, es preciso, obligatoria y necesariamente tener que repudiar porque, a nuestro juicio, en el engranaje y sistema de la adquisición mortis causa, la misma importancia que tiene la aceptación, tiene la repudiación, de tal manera que no se puede entender la adquisición de una herencia, tanto sin una como sin otra. Podríamos decir que, tal vez, buena "culpa" de ello lo tiene, en cierta medida, la ausencia de una adecuada regulación en nuestro sistema sucesorio mortisa causa en orden a establecer de forma clara y precisa cómo se produce dicha adquisición, como también el ejercicio de una y otra opción, tanto de la aceptación, como de la repudiación, lo que provoca numerosas lagunas y carencias en su régimen jurídico, tal y como se verá a lo largo de la exposición y desarrollo de este trabajo.

En otro orden de argumentos, y desde otro punto de vista, es un tema que se puede considerar todo un clásico dentro del Derecho de Sucesiones, pero que, pese a ello, no se presta a grandes novedades, como tampoco a grandes cambios, dado el carácter eminentemente técnico que caracteriza a esta rama del Derecho Civil. Por ello, tal vez, es una de las instituciones que menos cambios ha sufrido a lo largo de los más de cien años de existencia del Código Civil. No obstante, como se puede apreciar a raiz de la reunión de la Asociación de Profesores de Derecho Civil, celebrada en Santander en el mes de febrero del año 2006, se está planteando por parte de ciertos sectores de la doctrina la necesidad de aires de renovación ante la obsolescencia que presenta el régimen jurídico sucesorio actual en algunos aspectos o cuestiones, como luego veremos, así como para ponerlo en consonancia con las necesidades sociales, económicas, familiares y patrimoniales de la sociedad actual, muy diferentes de las que imperaban a finales del siglo XIX cuando se redactó el Código Civil. Cambios que 
ya se están haciendo en algunas Comunidades Autónomas como, Cataluña o Valencia, o se está propugnando por algun sector de la doctrina en el País Vasco, dada la fragmentación legislativa que hay en esta materia en el territorio de dicha Comunidad Autónoma.

Nosotros, por todo ello, dada la importancia y trascendencia que tiene, en nuestra opinión, el acto de la repudiación de la herencia en el ámbito de la sucesión mortis causa y de la transmisión de los bienes o patrimonio de una persona, entendemos que existen razones sobradas y justificadas para realizar un estudio y análisis en profundidad del mismo, referido al ámbito del Código Civil, en la totalidad de sus aspectos, en todos sus ámbitos y facetas, analizando al mismo tiempo algunas de las cuestiones que, a nuestro juicio, pudieren tener cierto interés y se pudieren suscitar en su ejercicio. Estudio en el que también vamos a exponer toda una serie de cuestiones que, si bien, unas están latentes en su régimen jurídico y se pueden sobreentender o presumir a resultas de la interpretación de los preceptos legales, hay otras sobre las que dicho régimen legal guarda silencio, o se encuentran en una situación de nebulosa u oscuridad, lo que provoca, en no pocas ocasiones, problemas en la práctica, dudas, discrepancias y división dentro de la doctrina, por lo que, entendemos, es preciso manifestar tanto unas como otras, porque las carencias a que antes aludíamos del régimen legal vigente impide, en ocasiones, que se puedan conocer, lo que da lugar a numerosas lagunas, controversias, polémicas y posiciones encontradas, tanto en la doctrina, como en el ejercicio de este derecho.

Se inicia este estudio haciendo una serie de consideraciones de carácter general que hacen referencia a la situación del sucesor ante la herencia al tiempo que se analizan: por un lado, los tradicionales y clásicos sistemas romano y germano de adquisición de herencia, con especial énfasis en el primero analizando sus orígenes y las vicisitudes que se produjeron hasta llegar a su forma de ser actual dado que, como se expondrá y analizará en su momento, es el sistema que, al decir mayoritario de la doctrina y de la jurisprudencia, rige en nuestro ordenamiento jurídico y, por otro lado, los sistemas que rigen en la actualidad en el ámbito del Derecho comparado. Concluye esta primera parte con un análisis de la delación y de algunas cuestiones que puede suscitar en su ejercicio, de entre las que destaca la posibilidad de su abandono, la obligatoriedad o no de su ejercicio, así como la especial situación que se produce cuando solo consiste en la posibilidad de aceptar cuando ésta se impone ex lege, o se le priva al sucesor de la facultad de repudiar a modo de sanción civil por razón del comportamiento que él ha tenido hacia la herencia a que ha sido llamado. 
El estudio particular y concreto de la repudiación se inicia con una exposición de sus antecedentes y evolución histórica, lo que ayudará a entender su sentido y significado actual, al que sigue una delimitación de su concepto al objeto de saber en sentido estricto, técnico y jurídico, en que consiste. Ello nos exige, obligatoria e inevitablemente, por un lado, hacer un minucioso examen y comparativa de la misma con la institución de la renuncia, dada la gran semejanza o analogía que existe entre ambas, y por otro, como consecuencia de ello, analizar la cuestión de si la repudiación es una modalidad de renuncia habida cuenta, además, de la existencia de algunos actos, aquellos a que se refiere el artículo 1000 del Código Civil en sus números $2^{\circ}$ y $3^{\circ}$, que ofrecen cierta confusión porque los tacha como de renuncia y respecto de los cuales se plantea, además, si se pueden considerar como un caso de repudiación. Tambien son objeto de análisis los presupuestos y requisitos que se exigen para su ejercicio con especial énfasis de aquellos supuestos, complejos y problemáticos, por otro lado, donde el sucesor es llamado a una pluralidad de títulos y/o de cuotas, dada la insuficiencia que, en este punto, presenta el artículo 1009 del Código Civil.

Analizar esta institución no tiene sentido, si no se examinan con detenimiento cuáles son los efectos que de la misma se derivan al ser éste, sin duda alguna, uno de sus aspectos más trascendentales porque, como ya hemos apuntado, tiene una gran repercusión y consecuencias en muy diferentes órdenes ya que afecta, no solo a las personas que, directa o indirectamente, están llamadas a la sucesión, sino también a los sucesores del sucesor que repudia, que, la mayoría de las veces, es estirpe del causante y que son, sin duda alguna, unos de los grandes perjudicados a resultas de la repudiación. En este sentido, se plantea la cuestión de cómo evitar el perjuicio que para ellos supone dicho acto, lo que nos lleva a analizar uno de los grandes interrogantes de nuestro Derecho de Sucesiones cual es, si es o no aplicable aquí el derecho de representación como mecanismo para salvaguardar sus derechos.

Otros perjudicados a resultas de la repudiación pueden ser los acreedores, tanto de la herencia, como los particulares del sucesor que ha repudiado, porque se plantea la cuestión de qué ocurre acerca de los créditos que unos y otros sean titulares en los términos de, si aquellos tienen algún medio de defensa ante el repudio del sucesor, y éstos, los particulares del repudiante, si, de alguna manera, pueden dirigirse contra aquellos bienes de la herencia que han sido objeto de repudio al no poder ser objeto de ejecución por haber entrado en su patrimonio, si bien, en este caso, como un mecanismo de defensa de sus intereses, está el ejercicio de la acción que sanciona el artículo 1001 del Código Civil. 
Y, por último, nuestro estudio se cierra con un examen del también complejo y problemático tema de la ineficacia de la declaración de repudio, sus diferentes clases, así como de distintos supuestos que, a nuestro juicio, se pueden producir en cada una de ellas, así como las consecuencias jurídicas que de los mismos se derivan. Aquí destaca la gran parquedad e insuficiencia que del Código Civil porque sólo contiene un precepto relativo a la ineficacia, el artículo 997 que, además de incompleto, es inexacto y equívoco, como luego veremos.

Ciertamente, esta es nuestra pretensión, como también contribuir, en la medida de lo posible, a dar respuestas y soluciones a algunos de los problemas y cuestiones que plantea la repudiación de una herencia en el ámbito del Código Civil, aunque somos conscientes de que sólo, en el mejor de los casos, podemos aportar sobre ello un pequeño grano de arena en este proceloso $\mathrm{y}$, siempre discutible y apasionante, mundo del Derecho. 


\section{PRIMERA PARTE: CONSIDERACIONES GENERALES.}




\section{Capítulo 1: LAADQUISICIÓN DE LA HERENCIA.}

1.- La sucesión mortis causa. 2.- Sistemas de adquisición de la herencia. 2-1.- Sistema romano. 2-2.- Sistema germano. 2-3.- Sistemas actuales. 2-3-1.- Sistema o régimen de adquisición directa. 2-3-1-1.- Sistema de delación. 2-3-1-2.- Sistema de aceptación. 2-32.- Sistema o régimen de adquisición fiduciaria. 2-3-3.- Sistema o régimen de adquisición directa por investidura. 3.- El sistema español de adquisición de la herencia. 4.- La aceptación de la herencia. 4-1.- Concepto. 4-2.- Presupuestos. 4-2-1.- Objetivos. 4-2-1-1.- El hecho de la muerte del causante. 4-2-1-2.- Existencia del derecho a heredar o vocación sucesoria. 4-2-2.- Subjetivos. 4-3.- Clases. 4-4.- Efectos.

\section{1.- LA SUCESIÓN MORTIS CAUSA.}

Ya desde antigüo, la perpetuación y/o transmisión de la propiedad en el tiempo, y no ya tanto en vida de su titular, sino, más bien, cuando éste faltaba a resultas de su fallecimiento, ha preocupado al Hombre en todas las sociedades y culturas que han existido y se han ido sucediendo a lo largo de la Historia, lo que ha dado lugar a que este hecho, no solo haya sido objeto de regulación por los diferentes ordenamientos jurídicos que han existido desde los albores de la Humanidad hasta nuestros días, sino también, de estudio y análisis por infinidad de autores desde múltiples perspectivas o puntos de vista: jurídico, familiar, político, cultural, social, económico, ético, moral, religioso, filosófico, mercantil, fiscal, etc. Tal hecho, por otro lado, ha dado lugar al fenómeno y a la institución jurídica conocida más comúnmente, ya desde antigüo, con el nombre de, "successio in universum ius", "successio per universitatem", en el lenguaje de los compiladores, o de manera más abreviada y usual, también la más frecuente, "sucesión" o, sucesión mortis causa. 
Sin embargo, la sucesión mortis causa, no solo se ha configurado a lo largo de la historia de la Humanidad como el mecanismo o instrumento por excelencia del que se ha servido el hombre para transmitir el patrimonio de que era titular una persona en vida una vez que había fallecido a favor de, normalmente, sus parientes más próximos -no de forma libre y voluntaria, sino forzosa o necesaria, al menos en sus orígenes como luego veremos-, sino también, como el medio de perpetuación o conservación de dicho patrimonio a lo largo de las sucesivas generaciones dentro de una familia. Por otro lado, en sus orígenes y después, a lo largo de varios siglos, también se concibió, principal y fundamentalmente, como el medio a través del cual se mantuvo y perpetuó la familia en el tiempo, su estructura, así como el papel y función que estaba llamada a cumplir dentro de la Sociedad, siendo ésta una de las principales circunstancias que propiciaron su aparición, según veremos más adelante al examinar los orígenes de los históricos y tradicionales sistemas sucesorios, romano y germano.

No obstante, en el derecho y sociedad actual, como pone de relieve DELGADO ECHEVERRIA ${ }^{4}$ citando a GIUSEPPE y FABRICIO PANZA ${ }^{5}$, y a MARCO COMPORTI ${ }^{6}$, es opinión muy extendida en la generalidad de la doctrina actual y de los profesionales del Derecho, el hecho de que, el Derecho de Sucesiones ha dejado de ser el medio vertebrador de la sociedad, la familia y el patrimonio, al tiempo que ya no tiene la importancia y trascendencia que tuvo en épocas pasadas debido a circunstancias de muy variada índole de la realidad social y económica de nuestros días ${ }^{7}$, en particular, los cambios acaecidos en la familia con la aparición de nuevas manifestaciones de la misma, las modificaciones que se han producido en diversas instituciones del Derecho de Familia, la aparición de patrimonios y empresas familiares, protección de discapacitados, las transformaciones que se han producido en el patrimonio y la propiedad, etc, lo que ha motivado la demanda o exigencia, por parte de la doctrina, de que se lleven a cabo cambios, algunos profundos, en el régimen jurídico del Derecho de Sucesiones.

4 “Una propuesta de política del Derecho en materia de sucesiones por causa de muerte”. En Derecho de Sucesiones. Presente y futuro. XII Jornadas de la Asociación de Profesores de Derecho Civil. Servicio de Publicaciones de la Universidad de Murcia. 2006. Pág 86 y ss.

De igual manera, se puede encontrar la anterior publicación, así como las distintas ponencias y comunicaciones presentadas al tema elegido para debate en la celebración de las jornadas de la Asociación celebradas en Santander, en el mes de febrero del año 2006, en la siguiente dirección: http://derechocivil.net/ponencias/.

${ }^{5}$ Successioni in generale tra codice civile e Costituzione, en el Trattato di diritto civile del Consiglio Nazionale del Notariato. VIII. 2. Edizioni Scientifiche Italiane. Nápoles. 2004. Pág 1.

6 “Considerazioni conclusive e prospettive di riforma legislativa”, en La trasmissione familiare della richezza. Limiti e prospettive di riforma del diritto successorio. CEDAM. Padua. 1995. Pág 179.

7 En este sentido, vid: ZOPPINI: Le successioni in diritto comparato. En Tratatto di diritto comparato diretto da R. Sacco. UTET. Turín. 2002. Pág. 8 ss. Citado por DELGADO ECHEVERRIA. 
Ello ha dado lugar a un profundo cambio en la función social de la herencia ${ }^{8}$, y a un amplio debate y reflexión dentro de la doctrina, y los profesionales del derecho, entre los que destacan Notarios ${ }^{9}$ y Registradores, que reclaman un profundo cambio y la elaboración de una política jurídica, acorde con ello, para el Derecho de Sucesiones y la conveniencia de reformas, algunas profundas por su trascendencia, en algunas de sus instituciones así como en diferentes aspectos y cuestiones de esta rama del Derecho Civil $^{10}$. En este sentido, el régimen jurídico del Código Civil en esta materia, está prácticamente intacto desde que entró en vigor hace ya más de cien años, porque las modificaciones o reformas que ha sufrido desde entonces, aunque numerosas ${ }^{11} y$ puntuales -la mayoría de las veces han obedecido a unos objetivos muy concretos o han sido consecuencia de cambios introducidos en otros sectores del ordenamiento jurídico-, han sido de escasa trascendencia porque no han afectado, en esencia, ni al sistema, ni a los rasgos definitorios y principios básicos o pilares fundamentales sobre los que se sustenta, heredados de nuestra legislación y tradición histórica.

${ }^{8}$ En opinión de DELGADO ECHEVERRIA: "La herencia no constituye en nuestra sociedad el soporte económico principal para la vida de los individuos. El trabajo es el medio ordinario para subvenir a las necesidades de las personas y nadie puede exigir que el Derecho le garantice una vida sin trabajar, pudiendo. Los desheredados -aquellos, tan numerosos, a quienes sus padres nada pudieron dejar, no sólo aquellos pocos a quienes sus padres no quisieron dejar nada- no están excluidos de la sociedad. La educación, la sanidad y las pensiones cumplen las principales funciones que la transmisión de los bienes de la familia tenía hace un siglo. La sociedad pretende ofrecer a todos oportunidades iguales, con independencia de la fortuna familiar.

Por otra parte, las grandes fortunas no se transmiten a las siguientes generaciones por los cauces del Derecho civil de sucesiones, sino preferentemente por instrumentos del Derecho de sociedades. En cualquier caso, no está al alcance del Derecho civil de sucesiones el hipotético objetivo de redistribuir la propiedad entre los ciudadanos con ocasión del fallecimiento de los más ricos; y el actual debate -no sólo en España- sobre la supresión del impuesto de sucesiones hace pensar que tampoco está en el ambiente una política que pretenda alcanzar este objetivo por otros medios” (Op. cit.: pág 86).

${ }^{9}$ Así, entre otros: GARCÍA SÁNCHEZ, J A: "Las instituciones sucesorias". El Notario del siglo XXI. Revista on line del Colegio Notarial de Madrid. Marzo-abril de 2009. № 24.

10 DELGADO ECHEVERRIA, hace una propuesta que, en su opinión, está basada en consideraciones de oportunidad y presenta un elenco de siete posibles objetivos de una reforma del Derecho de sucesiones y que podrían ser (Op. cit.: pág 99 y ss.):

"I. Mejorar la posición del cónyuge viudo en la sucesión de su consorte.

II. Reducir las legítimas y configurarlas con mayor flexibilidad.

III. Admitir instrumentos distintos del testamento unipersonal (testamento mancomunado, pactos sucesorios, donaciones mortis causa). Dentro de los pactos sucesorios, aborda la cuestión de la conveniencia de suprimir o no el párrafo $2^{\circ}$ del artículo 1271 del Código Civil, así como de introducir en el Código la posibilidad de renuncia anticipada a la legítima, es decir, derogar el artículo 816.

IV. Reconocer derechos sucesorios en las uniones estables de pareja.

$V$. Reconocer derechos sucesorios en otras situaciones de convivencia.

VI. Hacer más funcional la regulación de la responsabilidad por deudas hereditarias.

VII. [Otras cuestiones] Generalizar la representación sucesoria a la sucesión voluntaria, -lo que incide en la cuestión que abordaremos en el capítulo octavo de si se admite o no para el caso de repudiación de la herencia-. Dar nueva regulación a la preterición no intencional. Introducir la ineficacia por ley de las disposiciones entre cónyuges cuando se separan o divorcian".

${ }^{11}$ Vid, en este sentido, DELGADO ECHEVERRIA (Op. cit.: pág 90 y ss). 
Así, los grandes principios o pilares básicos sobre los que se asienta y fundamenta nuestro actual Derecho de Sucesiones, las instituciones jurídicas que lo integran y las normas que lo regulan, se puede decir que están prácticamente intactos, ya que continúan siendo los mismos desde hace ya más de un siglo, lo que reclama una puesta al día de las mismas (entre otros, SÁNCHEZ ARISTI ${ }^{12}$ ). Exigencias de cambio que se justifican en adecuar las instituciones del Derecho de Sucesiones a las necesidades que demanda la sociedad actual del siglo XXI y a la realidad social, económica, familiar y patrimonial que hay en ella, muy diferentes de las que existían cuando se promulgó el Código Civil. En este sentido, ya se han producido algunos cambios en las leyes sucesorias más recientes como son: la Ley 10/2008, de 10 de julio, del libro cuarto del Código Civil, sobre sucesiones, de la Generaliat de Cataluña, o el Código del Derecho Foral de Aragón aprobado como Texto Refundido por Decreto Legislativo 1/2011, de 22 de marzo, del Gobierno de Aragón. O el anteproyecto del año 2009 de la futura ley de sucesiones de la Generalitat de la Comunidad Autónoma de Valencia ${ }^{13}$, enmarcada en el desarrollo del derecho foral valenciano tras su Ley de Régimen Económico Matrimonial, apuntan cambios importantes en este sentido. Pero, dejemos, por el momento, la actualidad que suscita en la doctrina estos aires de cambio este campo del Derecho Civil sobre lo que ya volveremos más adelante al tratar más en detalle algunas de las cuestiones que en él se debaten y que están en directa relación con el objeto de nuestra tesis.

Ya centrándonos en el análisis de la sucesión mortis causa, ante la delación u oferta hereditaria que tiene el sujeto que ha sido llamado a aquella, éste tendrá la opción de aceptarla o rechazarla, dado el sistema sucesorio que, al decir mayoritario de la doctrina, como luego veremos, rige en nuestro ordenamiento, el latino o romano, siendo éste, el rechazo o repudiación, el que aquí nos interesa. No obstante, creemos oportuno detenernos antes en ver cómo es, o cómo se produce, la adquisición de la herencia porque, a nuestro juicio, no solo se puede entender mejor el hecho de la repudiación, sino que esta tesis sobre la misma quedaría incompleta sin ella.

12 "Propuesta para una reforma del Código Civil en materia de pactos sucesorios". En Derecho de Sucesiones. Presente y futuro. XII Jornadas de la Asociación de Profesores de Derecho Civil. Servicio de Publicaciones de la Universidad de Murcia. 2006. Pág 477 y ss.

${ }^{13}$ Ver en el siguiente enlace:

http://www.notariosyregistradores.com/PROYECTOS/proyectos\%20concretos/valenciasucesiones.htm. 


\section{2.- SISTEMAS DE ADQUISICIÓN DE LA HERENCIA.}

De todos es conocida la existencia y prevalencia en los ordenamientos jurídicos actuales de dos sistemas sucesorios distintos en orden a la adquisición de una herencia ${ }^{14}$, que, clásica, histórica y tradicionalmente, son, el sistema latino-romano y el sistema germano, contrapuestos entre sí y sobre los que la doctrina ha vertido una amplia y vasta cantidad de literatura ${ }^{15}$.

Son dos sistemas que, si bien son distintos por la diferente forma o mecanismo que adoptan en orden a la adquisición de la herencia, ya que, tanto la delación como

${ }^{14}$ En este sentido, la STS de 9 de junio de 1964 (RJ 3216), por citar alguna de las más conocidas, expone, de manera sintética y desde un punto de vista histórico, los dos sistemas que han existido de adquisición de herencia. También la SAP Oviedo de 10 de junio de 1999 (Sección 5ª), -AC 1999\6058-.

${ }^{15}$ Así, entre otras muchas publicaciones:

ALBALADEJO: Anotaciones de Derecho español al Derecho de Sucesiones, Parte General, de CICU. Publicaciones del Real Colegio de España en Bolonia. 1964; Comentarios al Código Civil y Compilaciones Forales. T XII. Vol 2². Arts 959 a 987 del Código Civil. EDERSA. Madrid. 1981; Curso de Derecho Civil. T. V. Sucesiones. Librería Bosch. 1979-1980. Barcelona. 1982; Derecho civil. I. Introducción y parte general. Vol. 1: Introducción y derecho de la persona. Vol. 2: La relación, las cosas y los hechos jurídicos. Librería BOSCH. Barcelona. 1975.; CAPILLA RONCERO, LOPEZ y LOPEZ, ROCA i TRÍAS, y otros: Derecho de sucesiones. TIRANT LO BLANCH. Valencia 1992; CASTÁN TOBEÑAS: Derecho Civil Español Común y Foral. T. VI. Vol 1. REUS S.A. Madrid. 1978. Pág 133 y ss; "El problema de la determinación del título de herencia". RGLJ. 1959; "La concepción estructural de la herencia (Discurso de apertura de Tribunales)”. RGLJ Madrid. 1959; "La dogmática de la herencia y su crisis actual”. RGLJ. 1959. $2^{\circ}$ sem; CLEMENTE DE DIEGO: Instituciones de Derecho Civil Español. T. III. Derecho de Sucesiones. Derecho hereditario. Madrid. 1932. (nueva edición revisada y puesta al día por COSSIO y GULLÓN. Madrid. 1959); DE GASPERI, L.: Tratado de Derecho Hereditario. Tomo I. Parte General. Tipografía Editora Argentina. Buenos Aires. 1953; DÍEZ-PICAZO: Sistema de Derecho Civil. Vol. IV. Derecho de Familia. Derecho de Sucesiones. Ed. TECNOS S.A. Madrid. 1997. $7^{\text {a }}$ Edición; ESPÍN CÁNOVAS: Manual de Derecho civil español. Vol. V. EDERSA. Madrid. 1978; GARCIABERNARDO LANDETA: "Designación "mortis causa”, vocación hereditaria y adquisición automática”. RDN. No XXIV. abril-junio 1959; GITRAMA GONZÁLEZ. M: Comentarios al Código Civil y Compilaciones Forales. (art 988 a 1034 CC). T XIV. Vol 1º. EDERSA. Madrid. 1989; LACRUZ, ALBALADEJO: Derecho de sucesiones. Parte General. Librería Bosch. Barcelona. 1961. Pág 131 y ss; LACRUZ BERDEJO, SANCHO REBULLIDA: Derecho de Sucesiones. I. Librería Bosch. Barcelona. 1971. Pág 54; Elementos de Derecho Civil. T. V. Derecho de sucesiones. $5^{\mathrm{a}}$ Ed. José $\mathrm{M}^{\mathrm{a}}$ Bosch Editor. S.A. Barcelona. 1993; LACRUZ BERDEJO, SANCHO REBULLIDA, LUNA SERRANO y otros: Elementos de Derecho Civil. T. V. Sucesiones. Ed. DYKINSON. Madrid. 2001; MANRESA: Comentarios al Código Civil español. T. VII (arts 912 a 1087). 6 ${ }^{\mathrm{a}}$ Ed. Revisada por BONET RAMÓN. Instituto Editorial REUS. Madrid. 1943. Pág 343; NUÑEZ LAGOS: "El derecho sucesorio ante la tradición española y el Código Civil”. RGLJ. T. XXI. Madrid. 1951; PUIG BRUTAU: Fundamentos de Derecho Civil. T. V. Vol $1^{\circ}$. $2^{\text {a }}$ Ed. Bosch, Casa editorial, S.A. Barcelona. 1975. Pág 159; ROGEL VIDÉ: “Renuncia y repudiación de la herencia”. RGLJ. T II. 1980. Pags 221 y ss, y 323 y ss; ROCA SASTRE: "La adquisición hereditaria en el derecho comparado" y "La designación, la vocación y la delación sucesorias”. En Estudios sobre sucesiones. Tomo I. Madrid. Instituto de España. 1981; "Problemática de la Ciencia del Derecho”. Libro Homenaje al Profesor José $M^{a}$ Pi Suñer. Editorial BOSCH. Barcelona. 1962. Págs 735 a 770; “La adquisición y la repudiación de la herencia en el derecho común y en el derecho foral”. Estudios de Derecho Privado. Vol II. Sucesiones. RDP. Madrid. 1948. Pág 1 y ss; ROCA SASTRE MUNCUNILL: Derecho de Sucesiones. T. I. 1989. T. II. 1991. T. III. 1994. Bosch. Casa Editorial S.A. Barcelona; SÁNCHEZ ROMÁN: Estudios de Derecho civil. T. VI. Derecho de Sucesiones. $2^{\text {a }}$ Ed. Madrid. Sucesores de Rivadeneyra. 1910; ROYO MARTÍNEZ: Exposición elemental del Derecho civil español: Derecho sucesorio “mortis causa”. Sevilla. 1951; VALLET DE GOYTISOLO: Estudios de derecho sucesorio. Ed. Montecorvo. Madrid. 1983; Panorama del Derecho de Sucesiones. II Perspectiva dinámica. Ed. Civitas S.A. Madrid. 1984. Pág 419 y ss. 
las declaraciones de aceptación y/o de repudiación, actúan en uno y otro de diferente forma, con un significado y trascendencia jurídica distinta, después se vienen a equiparar o identificar en cuanto a su resultado o efectos dado el carácter retroactivo que, en el sistema romano, tiene la declaración de voluntad del sucesor al momento de la apertura de la sucesión.

Pero, hoy, en la actualidad, junto a ellos, existen otros que podemos denominar, intermedios o eclécticos, que examinaremos más adelante, porque toman elementos de uno y otro para organizar u ordenar la transmisión hereditaria del patrimonio mortis causa a resultas del fallecimiento de una persona y la consiguiente repudiación, o adquisición, de la herencia.

Por otro lado, uno y otro sistema, romano y germano, hunden sus raíces y toman su origen y significado en los ordenamientos jurídicos de las respectivas sociedades en que cada uno de ellos nació y se desarrolló respectivamente, el Derecho Romano y el Derecho Germano. Y, a su vez, tanto en uno como en otro, la sucesión mortis causa va a estar íntimamente ligada y condicionada en su evolución y desarrollo con la de dos instituciones sociales que han tenido una gran importancia y trascendencia en las diferentes etapas y sociedades que se han ido sucediendo a lo largo de la Historia, al igual que sigue ocurriendo en el momento actual, y que son: la propiedad y la familia. Instituciones van a condicionar, no solo el sistema de sucesión mortis causa, sino también el diferente modo de adquirir y rechazar una herencia.

\section{2-1.- Sistema romano.}

En él, la adquisición de la herencia se caracteriza y tiene lugar por la exigencia, necesaria e indefectible, de que han de concurrir dos elementos o presupuestos sin los cuales no se puede producir: la delación del sucesor y su declaración de voluntad de aceptación, o adición, de la herencia a la que ha sido llamado. Mientras que, si no quiere adquirir y ser heredero, necesariamente ha de manifestar su voluntad de repudio. Así pues, la vocación y subsiguiente delación derivada de la misma, por sí solas no son suficientes para que se produzca la transmisión mortis causa de los bienes, sino que es preciso, además, el concurso e intervención del delado, para manifestar su voluntad de aceptar, de forma expresa o tácita, deducida ésta última de la realización de determinados actos, si quiere adquirir, como también, en caso contrario, ha de repudiar la herencia, si lo que no quiere es suceder mortis causa a aquella persona de cuya sucesión se trate y a la que él ha sido llamado. 
Como bien dice ROCA SASTRE ${ }^{16}$, en el sistema romano el supuesto de hecho o factum que determina la adquisición de la herencia estaría integrado, además de la apertura de la sucesión y la vocación o llamamiento del sucesor, por la aceptación del sucesor, declaración de voluntad que se retrotrae al momento de la apertura de la sucesión o muerte del de cuius.

El sucesor, ante el ius delationis, se podrá manifestar con total y absoluta libertad, ya sea de manera positiva o afirmativa, aceptando la oferta hereditaria hecha en su favor, ya negativa, repudiándola. Se trata de declaraciones que, por otro lado, son, no ya solo antinómicas, antitéticas u opuestas entre sí por razón de su distinto significado gramatical y resultado que de una y otra se derivan, sino porque se excluyen entre sí de manera recíproca, ya que la emisión o exteriorización de una de ellas, impide o excluye, de forma instantánea y automática, la posibilidad de poder manifestar la otra ${ }^{17}$. Y, por otro lado, son declaraciones irrevocables porque, una vez realizadas, no se pueden deshacer o invalidar después mediante declaración de signo contrario. De lo que se deriva el efecto, o consecuencia, al tiempo que característica, de que, la repudiación en este sistema sucesorio no tiene por objeto deshacer, enervar o invalidar la adquisición de la herencia, como ocurre en el sistema germano, y sí rechazar de forma pura y simple dicha herencia, desentendiéndose de ella el delado como si la vocación sucesoria para él no se hubiese producido.

Así, en el sistema sucesorio romano la delación tiene la función de conceder al vocado la oportunidad de decidir, de forma libre y voluntaria, si quiere entrar en el proceso sucesorio mortis causa a que ha sido llamado al tener la opción de aceptar, o repudiar, la herencia deferida a su favor: solo si acepta, ya sea de forma expresa o tácita, asumirá la condición o título de heredero y adquirirá los bienes, porción o cuota que le hubiesen sido deferidos, mientras que, en caso contrario, si no quiere ser tal heredero, en consecuencia, rechazar la herencia, necesariamente tendrá que repudiar, pero no para evitar la adquisición de la herencia, sino como acto demostrativo de que no quiere ser sucesor. La vocación sucesoria va a dar lugar a la delación que ofrecerá, u ofertará, al llamado la posibilidad de adquirir o rechazar la herencia, siendo por ello indefectiblemente necesaria su intervención para que se produzca dicha adquisición.

16 “La adquisición hereditaria en el Derecho Comparado”. Cit: Pág. 424.

${ }^{17}$ No ocurre lo mismo, como luego se expondrá, en el sistema germano donde, para el sucesor, solo existe, en principio, la declaración de repudio dado que no es necesario que acepte para ser heredero ya que tiene esta condición de forma automática desde el mismo instante de la apertura de la sucesión, aunque, si acepta, ratifica la adquisición ope legis, ya realizada. Ahora bien, si repudia, no solo rechaza y destruye la adquisición ya producida, sino que excluye de forma definitiva la posibilidad de poder, en su caso, aceptar y con ello, ratificar, la adquisición de herencia ya realizada. 
Como consecuencia de lo anterior, es característica peculiar de este sistema sucesorio la existencia en él de un lapso o período de tiempo, más o menos largo, que va desde el momento de la apertura de la sucesión hasta aquel en que el delado se pronuncia sobre la oferta hereditaria conocido como, herencia yacente, o hereditas iacet, que no existe en el sistema germano. No obstante, se trata de una situación meramente temporal o transitoria ya que la declaración de voluntad del heredero, consecuencia del ejercicio del ius delationis, una vez realizada, se retrotrae al momento del fallecimiento del causante, de tal manera que borra o hace desaparecer este período de interinidad en que se encontraba la herencia, y, a resultas de ello, se viene a equiparar al sistema germano.

Pero, este sistema, que toma su denominación de la Sociedad y Derecho que lo creó y en el que después se desarrolló, el romano, no siempre ha sido así, porque, en sus orígenes y a lo largo de varios siglos, tuvo una finalidad, cometido, y mecanismo de funcionamiento muy diferente del actual, ya que fue evolucionando y se fue transformando como consecuencia de los cambios que se produjeron en la sociedad romana a lo largo de su Historia, hasta dar lugar al que hoy conocemos en el momento presente y adoptado por ordenamientos jurídicos actuales como son, por excelencia, el italiano o el español, según la opinión más generalizada dentro de nuestra doctrina.

En sus orígenes, y a lo largo de varios siglos en la historia del Derecho Romano, toma su razón de ser del significado y papel que desempeñó en la sociedad romana la sucesión mortis causa al configurarse como medio o instrumento de perpetuación y mantenimiento de la familia ${ }^{18}$.

${ }^{18}$ Los orígenes de la sucesión mortis causa y de la herencia, o hereditas, en el Derecho romano, han dado lugar a distintas hipótesis y a la elaboración de diferentes teorías dentro de la doctrina en lo que se refiere al momento en que nace pero, sobre todo, en lo relativo a su fundamento o al hecho que justificó o motivó su aparición con la intención de aclarar su fisionomía.

En este sentido, en lo que sí están de acuerdo la inmensa mayoría de los romanistas, aunque pueden diferir entre sí por razón de los argumentos invocados por cada uno de ellos para sostener su respectiva teoría o posición, (entre otros, GANS, SHOM, PAIS, PEROZZI, SCHULIN, BONFANTE, BIONDI, VOCI, SCIALOJA, IGLESIAS, ARIAS RAMOS), es el hecho de que, el derecho sucesorio romano tiene en la época histórica, en los primeros albores de sus orígenes, un fundamento o carácter predominantemente familiar, aunque el objeto de la herencia lo fue el patrimonio.

Así, con anterioridad a la Ley de las XII Tablas (año 451 a. C.), según una de las teorías más extendidas dentro de la doctrina (en este sentido, acerca de ésta y otras teorías: ARIAS RAMOS: Derecho romano. II. Obligaciones. Familia. Sucesiones. Ed. EDERSA. 18 a ed. Madrid. 1994. Pág 806 y ss), la sucesión mortis causa tuvo por finalidad exclusiva la transmisión de un patrimonio que no era de titularidad individual, de una sola persona, sino que era de la gens o grupo familiar, de un jefe de familia a los miembros de ésta. El patrimonio estaba vinculado a una familia y la familia, a su vez, se conserva y permanece en el tiempo a través de la sucesión. La hereditas y la successio, responden a la estructura del organismo familiar, por lo que prevalece el carácter personal sobre el patrimonial, de ahí que hereditas y familia estén en íntima y estrecha relación hasta el punto de que, en los textos de las Doce Tablas y en el propio GAYO, son o se emplean como equivalentes. 
Así, en la primera fase de su evolución, la figura del heres, o heredero, tuvo en la sucesión mortis causa un carácter más personal que patrimonial ya que, a través de él, se producía la continuidad o perpetuación de la soberanía ejercida hasta el momento de su fallecimiento por el pater familias sobre el grupo familiar, si bien, después, unido de manera inexorable a ello, aunque no era relevante, adquiría de forma subsidiaria o derivativa, un patrimonio, por cuanto el fin u objetivo primordial que se le asignó fue precisamente ocupar el puesto y la función que tuvo el pater dentro de la familia ${ }^{19}$. La sucesión se configura así, en estos momentos, de manera casi única, como el modo de perpetuar la jefatura familiar y no la de transmitir un patrimonio, aunque después, de forma accesoria, así se producía ${ }^{20}$.

Pero, para que esto fuera así y, además, no se frustrase, sobre todo, por la voluntad del heres, era preciso que tal cambio de personas se produjese de manera forzosa u obligatoria. Así, como consecuencia de esa íntima relación o interconexión que había entre la successio, la hereditas y la familia, en la sucesión mortis causa se confunden, en este momento, delación y adición o adquisición porque aquella, la delación, lleva implícita ésta, la adquisición. La sucesión y adquisición de la herencia, no solo se producía de pleno derecho, de forma automática desde el mismo instante o momento en que tenía lugar el fallecimiento del pater familias, sin necesidad de declaración de aceptación por parte del heres, sino que para él la aditio era obligatoria o forzosa porque se le imponía de forma imperativa y no podía rechazar bajo ningún

${ }^{19}$ El heres tiene en la sucesión un carácter universal porque ocupa el lugar que desempeñaba en vida el pater familias, aunque después adquiriese un patrimonio. De ahí que sea un elemento o presupuesto imprescindible y esencial para la validez del testamento al ser cabeza y fundamento del mismo sin el cual no podía existir [“velut caput fundamentum totius testamenti” decía GAYO (2,229), y MODESTINO: "sine heredis institutione nihil in testamento scriptum valet"].

Como consecuencia de ello, él es quien va a continuar con el culto a los antepasados -del que ya forma parte el pater que acaba de fallecer-. De ahí que se diga que el heres, es successor, porque sucede in locum o, in locum et in ius defuncti, según la terminología clásica, más tarde, ya en el lenguaje de los compiladores, successio in universum ius o successio per universitatem, es decir, sucede en la posición jurídica unitaria vinculada al universo de la familia, hasta el punto de que el heres no recoge, no recibe, no realiza la aditio, sino que es la domus la que se perpetua en él (SCHULZ: Derecho romano clásico. Traducción española de Santa Cruz Teigeiro. Barcelona. 1960. Pag 193 y ss).

Por otro lado, del carácter universal que tuvo la institución de heredero en el Derecho Romano, se derivaron distintos principios o reglas:

a) "nemo pro parte testatus pro parte intestatus decere potest", de la que se derivó la incompatibilidad de la sucesión testada e intestada,

b) "ius adscrescendi", o acrecimiento forzoso, o no decrecimiento de las porciones de la herencia vacantes por cualquier causa,

c) “ut vel omnia admittentur, vel omnia repudientur”, o totalidad de la aceptación y /o repudiación de la herencia, de tal manera que o se aceptaba todo, o se repudiaba todo,

d) de la consideración como heredero universal del llamado ex re certa sin concurrir con heres ex asse.

${ }^{20}$ En Roma, la muerte de un filius familias, de una mater familias in manu, o de un ciudadano cualquiera, no daba lugar a la apertura de la sucesión. La sucesión sólo se abría cuando fallecía un pater familias (SCIALOJA: Diritto ereditario romano. Concetti fondamentali. Roma. 1934. Pág 6). 
concepto el llamamiento que se había producido a su favor. En realidad, no podía repudiar, y no porque el sistema sucesorio no se lo permitiese, sino porque en él no se contemplaba o admitía esa posibilidad. Era algo total y absolutamente inconcebible.

La sucesión mortis causa, en consecuencia, no era voluntaria, sino forzosa u obligatoria, porque el heres no podía, ni tenía forma alguna de sustraerse a la delación que se producía a su favor por disposición de la ley. No podía impedir el llamamiento, como tampoco lo podía rechazar. Tanto en la sucesión testada como intestada, adquiría la herencia de forma automática, ipso iure ${ }^{21}$, por el solo hecho de la delación, acto seguido a que ésta se hubiere producido, aunque solo se hubiere sobrevivido al causante por breves instantes, sin necesidad de realizar o exteriorizar acto 0 manifestación alguna de su voluntad, y no ya solo sin saberlo, sino, además, sin el concurso de su voluntad, incluso en contra de su voluntad ("sine velint, sine nolint heres fit": GAIO 2, 157), porque no tenía la más mínima posibilidad de poder repudiar, de tal manera que no podía sustraerse al papel de ser el continuador de la personalidad de quien fuera su padre. No obstante, como luego veremos en el capítulo tercero al tratar de los antecedentes de la repudiación, se adoptaron algunas medidas por parte del Pretor que suavizaron la posición del heres. Como también, por otro lado, podía suceder que perdiera esta condición a través de una desheredación expresa, o exheredatio, por parte del causante.

Por tanto, el heres no tenía la posibilidad de adir la herencia libremente según su voluntad, o de repudiarla, como tampoco de poder transmitir el ius delationis. De ahí que se le llamase "heredes necessarii"22, así como el conocido aforismo "semel heres,

${ }^{21}$ GAYO II, 152-154, 157-159, 161; DIGESTO 29, 2, 15 y 16; JUSTINIANO, Instituciones II, 19.

${ }^{22}$ También se les conoció con el nombre de "domestici heredes" porque formaban parte de la casa del difunto, ya por estar bajo su potestas o manus, ya fuere por su condición de libre o de servil. Dentro de ellos, se distinguió entre:

a) los "heredes sui et neccessarii", o simplemente "heredes sui": eran aquellas personas que estaban sujetas directamente a la potestas del pater familias -los filii in potestate o hijos del difunto en el momento de su muerte, los filiorum loco sunt o hijos naturales y adoptivos- (IGLESIAS: Derecho Romano. Instituciones de Derecho Privado. Ed. ARIEL. Barcelona. 1972. Pág 589), o a la manus del causante -uxor in manu-, la mujer.

Estos heres, al tiempo que fueron sucesores forzosos del pater, fueron también los continuadores necesarios de la personalidad del causante -continuatio dominii-, y no podían sustraerse o impedir los efectos o consecuencias que se pudieren derivar contra él de una herencia que fuese perjudicial o dañosa porque su pasivo fuese mayor que el activo -hereditas damnosa-, ya que asumían una responsabilidad ultra vires hereditatis porque se veían obligados a pagar y responder con sus propios bienes de las deudas del causante. se podía perder esta condición a través de una desheredación expresa por parte del causante.

b) Junto a los anteriores, estaban los heredes simplemente "neccessarii", que eran los esclavos instituidos herederos después de haber obtenido su libertad en testamento (manumitidos en el Derecho clásico). Hasta ese momento, estaban bajo la dominica potestas y simultáneamente se les concedía la libertad e instituía en testamento. Desde este instante adquieren la herencia ipso iure, sin necesidad de aceptación y sin posibilidad de poder repudiar, al igual que los heredes sui, por ser ya heredes necessarii como éstos. 
semper heres". Estos herederos tenían la condición de forzosos, o necesarios, porque no podían sustraerse a la delación sucesoria. De ahí también el carácter forzoso que se producía en la subrogación de la titularidad del patrimonio relicto.

En este sentido, manifiesta ROYO MARTíNEZ ${ }^{23}$ que, los "heredes necessarii" "estaban abocados a la aventura sucesoria o al sacrificio cierto. No podían sustraerse a la herencia dañosa y eran implacablemente sacrificados a los despilfarros o a la desgracia padecida por el causante en su gestión económica".

No obstante, en el caso de los heredes sui et neccessarii, como veremos más adelante ${ }^{24}$, su situación se suavizó a través de dos mecanismos: en el caso de los sui, la posibilidad de poder rechazar la sucesión fue posible cuando el testador lo había instituido heredero bajo la condición suspensiva potestativa "si volet" (Titius, si volet, heres esto -D 28,7,12-), y a través de la concesión por parte del Pretor, desde la época de Cicerón (siglo I a.C.), del denominado "ius o beneficium abstinendi", que permitió evitar el daño que, en su caso, se pudiese derivar en su contra de una herencia dañosa. $Y$, respecto de los esclavos, ya libertos, los instituidos herederos por parte de su señor en el testamento, el Pretor les concedió, si no una forma de repudio, sí un medio de defensa, que fue el "beneficium separationis" para que no respondiesen frente a los acreedores del difunto con los bienes que hubiesen adquirido después de quedar manumitidos a la muerte del patrono.

Así se concibió el sistema sucesorio romano durante gran parte de su historia, a través de la aditio automática, sin necesidad de aceptación por parte del heres, y la correlativa inexistencia o imposibilidad de poder repudiar la herencia.

Más tarde, esta concepción personalista de la sucesión mortis causa, a resultas de los cambios que se produjeron con el paso del tiempo en la estructura de la familia y la pérdida de peso e importancia que ésta va teniendo de forma paulatina en la sociedad y mundo romanos, se transforma poco a poco y evoluciona hasta invertirse

La admisión de los esclavos como herederos fue una artimaña que se utilizó para evitar la infamia que podía producir para la familia una herencia excesivamente dañosa o, como dice ROGEL VIDE (Op. cit.: pág 225), fue “esencialmente prosaica”. Así, un de cuius insolvente evitaba que el honor de su familia se viera perjudicado, siendo el esclavo quien soportaba las consecuencias que pudieren derivarse de las deudas de la herencia o de la insolvencia del causante en el procedimiento de la bonorum venditio ya que no gozaban del derecho de abstención o "beneficium abstinendi" concedido a los "sui".

No obstante, apunta VOLTERRA (Instituciones de derecho privado romano. Ed. Civitas S.A. Madrid. 1986. Pág 709. Cita pp $\mathrm{n}^{\circ}$ 44) que se discute en la doctrina sobre el significado de los dos adjetivos sui y necessarii. Un pasaje de GAYO $(2,157)$ y dos de PAULO (D. 28, 2, 11; 48, 20, 7, pr), el último de los cuales se sospecha que está interpolado, ponen de manifiesto que en los siglos II y III d. C., los juristas romanos no estaban seguros de los motivos por los cuales se usaban los dos adjetivos.

${ }^{23}$ Derecho sucesorio “mortis causa”. Sevilla. 1951. Pág 266.

${ }^{24}$ Véase en el capítulo tercero las distintas formas que existieron de poder repudiar la herencia. 
los términos y configurarse como un medio de transmisión, más de un patrimonio, que de una posición personalista ${ }^{25}$.

Una de las circunstancias que se puede considerar como de las más decisivas y que más contribuyó a que se produjese el cambio que se puede considerar sustancial y trascendental, decisivo en la evolución de la sucesión mortis causa y en el sistema de adquisición de la herencia, fue la posibilidad de poder instituir heredero a personas extrañas, no vinculadas a la casa ni a la potestas del pater. Son los denominados "heredes extranei" (o personas ajenas a la familia, aunque, en realidad, tuvieron esta condición cualesquiera otros herederos que no estuviesen en la categoría de los heredes necessarii), llamados también, "heredes voluntarii", porque el hecho de que formasen parte del proceso sucesorio va a depender exclusivamente de su voluntad ya que en ellos la adición o adquisición de la herencia sólo tendrá lugar a través de la aceptación ${ }^{26}$. Desde este momento, la delación ya no es automática y no basta por sí sola para que tenga lugar la aditio hereditatis, sino que se distingue entre delación y adición de la herencia, de tal manera que estos herederos van a tener la oportunidad de poder pronunciarse sobre la oferta hereditaria que han recibido y decidir libremente si aceptan o si repudian la herencia.

Ello va a hacer que, desde entonces, el ius delationis sea el derecho que tiene el heres extranei ante la herencia que le ha sido deferida y que le permitirá, adquirir la herencia (adir, o ir a la herencia ${ }^{27}$ ), y el título o condición de heres, así como los bienes, porción o cuota a que fue llamado, que sólo podrá tener lugar a través de la aceptación, o, en caso contrario, rechazar dicho llamamiento, con la consiguiente pérdida de la porción o cuota que le fue deferida, lo que sólo podrá hacer a través de la "repudiatio", o repudiación. Y, si se daba la circunstancia de que el heredero

${ }^{25}$ Vid, entre otras muchas publicaciones: IGLESIAS SANTOS: "La herencia en el derecho romano y en el derecho moderno”. AAMN. T nº 6. Año 1952. Pág 36 y ss.

En este sentido, IGLESIAS, entre otras cosas manifiesta que "la moderna categoría de los derechos patrimoniales, donde se comprenden los derechos reales y los derechos de obligaciones, como contrapuestos a los derechos de familia, no se da en los originarios tiempos romanos. Allí los derechos de familia y los derechos reales no representan sino el lado interno de la potestas ejercida por el jefe familiar. La propiedad se concentra en el pater familias, pero como consecuencia de una situación extrasubjetiva que le transmite la titularidad” (“La herencia en el derecho romano ......”. Cit: pág 40).

${ }^{26}$ El acto de aceptación podía referirse a la herencia civil, "hereditas”, o a la herencia pretoria, “bonorum possessio”, que consiste en la posesión de las cosas hereditarias concedida por el Pretor. Ésta podía ser conferida de conformidad con el testamento, "bonorum possessio secundum tabulas", o en ausencia de éste, "bonorum possessio sine tabulis o abintestato", o contra lo dispuesto en el testamento, "bonorum possessio contra tabulas".

El sistema pretorio es seguido todavía en la época imperial y es en las constituciones que precedieron a Justiniano cuando comienza a borrarse la distinción entre hereditas y bonorum possessio.

${ }^{27}$ Expresión latina, ad ire hereditatem, significa, acudir o aproximarse a la herencia. De ahí que se hable en los textos romanos de aditio o de adquisitio, o el derecho de adir, que proviene de la palabra latina adire, aditio, que significa "ir hacia". 
voluntario fallecía antes de adir la herencia, la vocación, el llamamiento a heredar, no se transmitía a sus herederos ("hereditas delata, nondum adquisita, non transmittitur ad heredes" ${ }^{\prime 28}$ ). Sin embargo, tal principio sufre importantes derogaciones en el curso del derecho histórico romano hasta llegar a afirmarse con Justiniano (siglo VI d.C.), la norma contraria permitiéndose así algunos casos de sucesión en la delación. Son las llamadas transmissiones ${ }^{29}$.

Aparece así, el sistema de adquisición de la herencia que conocemos en la actualidad, conocido bajo la denominación de sistema latino-romano, o de adquisición por aceptación y que por los heres extranei se podía expresar de varias formas:

a) mediante la pura y simple declaración de aceptar, hecha de forma expresa, si bien no era preciso que estuviera revestida de ninguna solemnidad, que era la "aditio" en sentido estricto, o aditio nuda voluntate,

b) la "cretio" ${ }^{30}$, que era una declaración solemne ${ }^{31}$, hecha de forma verbal, sólo ante testigos, "cretis verbis", de querer aceptar la herencia, que podía ser perfecta o imperfecta ${ }^{32}$, se tenía que realizar cuando el testador así se lo hubiera impuesto al sucesor y dentro de un plazo determinado ${ }^{33}$.

${ }^{28}$ Cfr C. 6, 30, 7; C. 6, 51, 1, 5.

No obstante, de los textos romanos se deducen algunas excepciones a esta regla concedida para casos particulares (vid VOLTERRA: Op. cit.: pág 705. Cita pp nº 36).

${ }^{29}$ Algunas de ellas eran las siguientes: ex capite in integrum restitutionis, que es la más clásica, ex capite infantiae (introducida por Teodosio II y Valentiniano III); Theodosiana o ex iure sanguinis, y Iustiniana o ex iure deliberandi.

${ }^{30}$ Sin embargo, en el derecho clásico no fue necesaria para adir la herencia a menos que hubiere sido impuesta por el testador el cual fijaba también un plazo (ordinariamente de cien días) dentro del cual se tenía que realizar.

Se aplicó todavía en el siglo IV de la era cristiana y fue abolida (para las herencias deferidas a los "filii in potestate") por TEODOSIO y HONORIO en el año 407, y de forma definitiva, por JUSTINIANO (siglo VI d. C.) (C. I. 6, 30, 17).

Sobre la cretio, vid entre otros: ARIAS RAMOS: Op. cit.: Pág 852 y ss; FUENTESECA: Derecho privado romano. Madrid. 1978. Pág 566; IGLESIAS: Derecho romano. Cit: Pág 590 y ss; PACCHIONI: Manual de Derecho Romano. Traducción de Isidoro Martín Martínez y Antonio Reverte Moreno. Librería Santaren. Valladolid. 1942. Pág 307; VOLTERRA: Op. cit.: Pág 710.

${ }^{31}$ Según GAYO $(2,166)$ y ULPIANO $(22,28)$, se empleaba esta fórmula pero en la sucesión testada: "Quod me P. Maevius testamento suo heredem instituit, eam hereditatem adeo cernoque". Se desconoce cual era la fórmula que se empleó en la sucesión ab intestato.

${ }^{32}$ Respecto de la primera, cretio perfecta, tenía lugar cuando el testador desheredaba al instituido en el caso de que no aceptase ("nisi creverit exheres esto"), y en el caso de la segunda, cretio imperfecta, cuando no disponía nada en el testamento para el caso de no aceptación, pero, en este caso, el testador solía designar un sustituto al heredero (GAYO 2, 178; ULPIANO 22, 34).

${ }^{33}$ Por regla general, era de cien días (GAYO 2, 170), contados a partir de la muerte del testador independientemente del hecho de que el heredero tuviese conocimiento o no de la apertura de la sucesión, o de su posibilidad de llevar a cabo la adición, o de la existencia de condiciones que dejaran en suspenso la delación (cretio continua), o solo se contaban los días en que el heredero podía realizar la adición, partiendo de aquel en que tenía noticia de la delación (cretio vulgaris). 
No obstante, en los textos de la Compilación Justinianea, la aditio se coloca en lugar de la cretio, como declaración expresa, escrita o verbal, pero ya no solemne, hasta que es abolida definitivamente por Justiniano (C. 6, 30, 17), contraponiéndose a la pro herede gestio, o simple manifestación tácita de voluntad.

c) Y si no se hubiere establecido la cretio, se podía también aceptar a través de un acto cualquiera, incluso de forma tácita, sin solemnidad alguna, pero que implicara comportarse como tal heredero -tamquam heres-, o que se tratase de actos de señorío o de gestión patrimonial sobre el patrimonio hereditario sin necesidad de entrar en la posesión material de la herencia, a lo que se le atribuyó el efecto de que el delado adquiriera el título de heredero por cuanto se consideró como manifestación tácita de voluntad y que se conoció como, "pro herede gestio" (GAYO 2, 167).

En caso contrario, si el heres extranei no quería adir la herencia, podía rechazar dicho llamamiento a través de la repudiación, o "repudiatio", que podía realizarse de cualquier modo, expreso o tácito, por el que se diese a entender la voluntad de no querer heredar pero que, en el caso de que existiese "cretio" impuesta por el testador, bastaba con dejar transcurrir el plazo sin haber declarado la voluntad de aceptar, ante lo cual el llamado pierde su derecho a la herencia y se entendió repudiada la delación sucesoria, "praetermittere hereditatem" (dejar pasar, dejar de lado, omitir, pasar en silencio, la herencia) (IGLESIAS ${ }^{34}$ ).

Este es el sistema sucesorio que rige en la actualidad, entre otros y como más representativos, en los ordenamientos jurídicos, italiano (art. 459 Codice de 1942: "L'eredità si acquista con l'accettazione. L'effetto dell'accettazione risale al momento nel quale si è aperta la successione."), y, en nuestra opinión, así como de un amplio sentir de la doctrina y de la jurisprudencia, el español (art. 988 y ss CC), tal y como se expondrá y analizaremos detenidamente más adelante, en este mismo capítulo, si bien no faltan quienes propugnan y defienden la vigencia del sistema germano.

\section{2-2.- Sistema germano.}

El derecho sucesorio germánico ${ }^{35}$, tanto en sus orígenes como en su mecánica de funcionamiento, fue totalmente contrario al romano, aunque no dejan de presentar

${ }^{34}$ Derecho romano. Instituciones de derecho privado. Cit: Pág 619 y ss.

$35 \mathrm{Al}$ amparo de esta expresión, se hace referencia a la existencia de toda una pluralidad de ordenamientos de diferentes pueblos bárbaros o de derechos populares (volksrechte), ya que no se puede decir que existiera un derecho germánico único que fuera común a todos los pueblos indogermanos, aunque sí se puede apreciar la existencia de una serie de rasgos o características que son comunes a todos ellos (ESPINAR LAFUENTE: La herencia legal y el testamento. Barcelona. 1956. Pág 38). 
cierta similitud uno y otro porque, al igual que ocurrió en Roma, como consecuencia de la gran importancia y protagonismo que tuvo la familia en las sociedades de los primitivos pueblos germánicos, la sucesión aquí también tuvo un marcado carácter eminentemente familiar, si bien, con cariz diferente, ya que se concibió como un mecanismo de transmisión del patrimonio a favor de todo el colectivo del grupo familiar sobre la base de una idea de solidaridad.

Así, la transmisión de patrimonio hereditario se fundó en el principio de cohesión familiar nacido al amparo de la vieja comunidad germánica o propiedad en mano común -"Gesammteigentum" o "Gemeinschaft zur gesammtem Hand"-, cuyo objeto perteneció a la colectividad o grupo familiar sin ninguna división ideal de cuotas. De ahí que se considerase que los bienes pertenecían, no tanto al individuo, sino a la comunidad familiar. Y ello porque, así como en Roma la familia fue un grupo social que revistió caracteres de tintes casi políticos y era una unidad colectiva de soberanía que estaba bajo la potestas del pater, los pueblos germanos se basaron en la sippe como grupo natural, de sangre y tierra, "Blut und Boden", como el núcleo en torno al cual giró la sucesión mortis causa ${ }^{36}$.

De ello se derivaron toda una serie de consecuencias que marcaron de manera muy profunda el sistema sucesorio germano como fueron: el predominio de la sucesión legal, la exclusión de la desheredación, el predominio de los vínculos de sangre, el sistema de parentelas, la ausencia del derecho de representación, la pluralidad de sucesiones, la renuncia a las sucesiones futuras, o la existencia de un derecho hereditario.

Sin embargo, a diferencia de lo que ocurrió en el derecho romano donde prevaleció la sucesión testada, y, por tanto, voluntaria, sobre la intestada o legal, en el sistema germano sucedió lo contrario, prevalece la sucesión legal, que tenía carácter forzoso o necesario, sobre la voluntaria. De ahí que, entre los primitivos pueblos germanos, se desconociese el testamento y la única sucesión que había fue la

${ }^{36}$ En este sentido, manifiesta NUÑEZ LAGOS (“El derecho sucesorio ante la tradición española y el Código Civil”. RGLJ. T. XXI. Madrid. 1951. Pág 390 y ss.), lo siguiente:

"La sangre y la tierra engendran solidaridad: solidaridad entre los parientes, solidaridad con la tierra. ....... Todos tienen una participación en el patrimonio, todos son titulares de la propiedad o, tal vez, se puede decir mejor que el grupo aparece titular en común. Copropiedad en común: "zur gesamten Hand". La transmisión hereditaria es más bien un fenómeno automático de acrecimiento, y la sucesión en las deudas es un fenómeno semejante al de solidaridad de las obligaciones. El hecho de la muerte de un partícipe deja a la comunidad intacta, y todos los fenómenos sucesorios se producen automáticamente ope legis". "El derecho a todos los bienes de una sucesión existe perfecto por y desde el fallecimiento del causante, ope legis, y de modo automático, sin necesidad de aceptación ni acto alguno del heredero, y subsiste hasta que, antes del término de su caducidad o prescripción, se produzca la repudiación de la herencia que, en su caso, tiene un juego resolutorio y retroactivo". 
legítima en la que los únicos herederos que sucedían fueron los familiares del causante. No obstante, el heredero no era designado por éste, sino que venía determinado por una relación de sangre conforme a los principios, "solus Deus heredem facere potest" y, "heredes gignuntur, non scribuntur"37. Así, apunta GARCíA VALDECASAS ${ }^{38}$, que, en ella, "la adquisición de la herencia se produce por ministerio de la ley sin contar para nada con la voluntad el sucesor".

Por ello, al tener carácter forzoso la sucesión, los bienes no se adquirían por la aceptación del sucesor, sino por el solo hecho de la delación o simple hecho de la muerte sin necesidad del concurso, incluso ni tan siquiera conocimiento, del heredero, según el principio de que el muerto mismo es quien inviste al heredero: "der Tote erbt den Lebendigen", que luego se ha visto reflejado en la versión francesa "le mort saisit le vif", en el latín medieval en la expresión, "mortus aperit oculos viventis", u otras como, "il morto impossessa el vivo", "mortuus facit vivum possessorem sine ulla adprehensione", o la máxima, "El Rey ha muerto, viva el Rey" (ROCA SASTRE ${ }^{39}$ ).

De ello toma su origen el rasgo que, podríamos definir, como, el más característico y definitorio del sistema sucesorio germano, cual es el hecho de que, la muerte del causante unida al llamamiento o delación, provoca por sí sola, de manera automática, ipso iure, por ministerio de la ley ${ }^{40}$, desde el mismo instante en que aquella se produce, la transmisión y adquisición de la herencia a favor de sucesor, sin necesidad de declaración expresa alguna de aceptación por su parte para que dicha adquisición se produzca ya que tiene lugar de forma sincrónica con la delación y que se conoce con el nombre de, "anfall" (GARCíA VALDECASAS ${ }^{41}$ ).

${ }^{37}$ CASTRO LUCINI: Temas de derecho sucesorio. Artes Gráficas Iberoamericanas S.A. Madrid. 1987. Pág 261.

38 “La adquisición de la herencia en el derecho español”. RDP. Febrero. 1944. Pag. 96.

39 "La adquisición y la repudiación de la herencia en el derecho común y en el derecho foral”. Cit: Pág. 2.

40 Sin embargo, una institución que atenuó las consecuencias de la adquisición ipso iure de la herencia en el derecho germano es la "Dreisigste” (GARCÍA VALDECASAS: Op. cit.: Pag. 99.).

Se trataba de un período de treinta días, a contar del de la muerte, en el que no se podía realizar ningún acto que turbara la paz de la casa mortuoria. En este lapso de tiempo, el heredero no podía exigir que la viuda saliera de la casa del difunto, lo que no impedía que la gewere perteneciere al heredero y no a la viuda, como tampoco desvirtuaba el principio básico de la adquisición hereditaria: es solo en el ejercicio de sus derechos en lo que se veía limitado el heredero. Tampoco se le podía exigir al heredero en ese tiempo la división de la herencia, ni el pago de las deudas hereditarias.

${ }^{41}$ Op. cit.: Pag. 96. 
Así, en el régimen jurídico actual del $\mathrm{BGB}^{42}$, el solo hecho de la delación da lugar a la transmisión mortis causa de los bienes del causante al sucesor y a que éste adquiera la herencia, invistiéndole así con el carácter y condición de heredero. Ello significa que, desde el mismo instante en que se produce el fallecimiento del causante y se abre la sucesión, tiene lugar la delación y, de forma automática, ope legis, la adquisición de la herencia, sin necesidad de que el sucesor tenga que manifestar su voluntad de aceptar o tenga que realizar acto alguno para poder adquirir. Incluso, la atribución o adquisición de la herencia se produce sin que el sucesor conozca el hecho del fallecimiento del causante (§ 1922 BGB). En consecuencia, el traspaso de bienes se produce del causante al sucesor, sin solución de continuidad, ipso iure, desde el preciso instante en que aquel fallece, sin que exista situación de yacencia, vacancia alguna, transitoriedad o indeterminación, tanto en la titularidad como en la posesión de los bienes de la herencia. El sucesor es heredero desde el mismo momento del fallecimiento del causante sin necesidad de que tenga que realizar acto o declaración alguna de voluntad por su parte.

Ahora bien, aunque la herencia se adquiere sin necesidad de acto volitivo alguno por parte del sucesor, la sucesión, pese a su automatismo, no se le impone al heredero en contra de su voluntad ${ }^{43}$, porque, si quiere, puede rechazar la herencia manifestando su voluntad de repudiar (§ 1942-1 BGB). De ahí que la adquisición de la herencia no sea definitiva, sino meramente provisional o temporal, hasta que no expire o transcurra el plazo que se le concede al ya heredero para poder repudiar.

La repudiación actúa a modo de condición resolutoria de la adquisición que se produjo de la herencia en el momento del fallecimiento del causante a resultas de la delación porque enerva y destruye dicha adquisición con efecto retroactivo al momento de la apertura de la sucesión (§ 1953 BGB), y se entiende que el declarante nunca fue llamado a la misma. Se puede realizar tan pronto como se produzca la muerte del causante ( $§ 1946$ BGB), en un plazo de seis semanas que comienza desde que el sucesor tiene conocimiento de la adquisición provisional y de la causa del llamamiento o desde la notificación de la disposición, o en un plazo de seis meses si el causante ha tenido su último domicilio solamente en el extranjero al comienzo del plazo, o si el heredero, al comienzo del plazo, se encuentra en el extranjero ( $§ 1944$ BGB). Y si el heredero dejare transcurrir el plazo, se tendrá la herencia por aceptada (§ 1943 BGB).

${ }^{42}$ En él se regula el derecho de sucesiones en el Libro quinto, desde el parágrafo 1922, y la aceptación y de la repudiación de la herencia -Annahme und Ausschlagung der Erbschaft-, a partir del parágrafo 1942.

${ }^{43}$ Vid LACRUZ BERDEJO: Notas al "Derecho de Sucesiones" de Binder. Ed. LABOR. Barcelona. 1953. Pág 177 y ss. 
En lo que se refiere a sus requisitos: ha de ser un acto puro (§ 1947 BGB), e indivisible, por cuanto no puede recaer solo sobre una parte de la herencia ( $§ 1950$ BGB), y se ha de realizar mediante declaración ante el tribunal de testamentarías que será redactada por éste o públicamente autenticada (§ 1945 BGB).

La delación tiene un doble efecto: uno de carácter automático que se produce siempre, aun en contra de la voluntad del llamado porque tiene lugar sin necesidad del concurso de su voluntad incluso aun desconociendo el hecho de la sucesión, que es la adquisición de la herencia desde el mismo instante en que se produce la apertura de la sucesión, y otro voluntario, o discreccional, la facultad que concede al ya heredero, si no quiere serlo, de poder repudiar la herencia dentro del plazo legal y así enervar, con efecto retroactivo al momento del fallecimiento del causante, la adquisición de la herencia que se produjo de forma automática al abrirse la sucesión.

Sin embargo, ello no obsta ni impide para que el sucesor, en su caso, si quiere, declare que acepta la herencia, lo que podrá realizar tan pronto como se produzca la muerte del causante (§ 1946 BGB). Aceptación que actuaría a modo de ratificación de la adquisición que, de forma provisional, se produjo en el momento de la apertura de la sucesión, por lo que vendría a confirmarla, al tiempo que excluye, ya de manera definitiva, la posibilidad de poder repudiar la herencia (§ 1943 BGB). De ahí que, por otro lado, desde otro punto de vista, la aceptación tendría también un valor negativo porque lleva consigo una renuncia del derecho a repudiar, mas no de concreta y efectiva adquisición de los bienes que integran la herencia que ya se habría producido desde el mismo momento de producirse el fallecimiento del causante, mientras que la repudiación que, en su caso, haga el heredero tendría una función positiva ya que sirve para perder o destruir lo que ya se ha adquirido y rechazar definitivamente la posibilidad de llegar a ser heredero (LACRUZ BERDEJO, SANCHO REBULLIDA ${ }^{44}$ ).

Aquí el sucesor adquiere la posesión y la propiedad de los bienes desde el fallecimiento del causante a través de la Gewere (o saissine del derecho francés), y no tenía que verificar acto alguno de aprehensión posesoria de los bienes pues queda investido, sin más, de todo cuanto lo estaba el causante en el momento de la defunción. "Le mort saisit le vif, sans aprehension de fait", pues el heredero se viste íntegramente de la herencia (ROCA SASTRE ${ }^{45}$ ).

\footnotetext{
${ }^{44}$ Derecho de Sucesiones. I. Cit: Pág 54.

45 “La adquisición y la repudiación de la herencia en el derecho común y en el derecho foral”. Cit: Pág. 2.
} 
Como expone ROCA SASTRE ${ }^{46}$, en este sistema, el supuesto de hecho o factum que determina la adquisición de la herencia está integrado por dos elementos que vienen a coincidir en un mismo momento: a) la apertura de la sucesión provocada por el hecho de la muerte del causante o, en su caso, declaración de fallecimiento, y b) la vocación o llamamiento del sucesor, de los que se deriva la consecuencia jurídica prevista por el Derecho objetivo cual es la adquisición de la herencia.

El sistema germano tiene la gran ventaja, o parte positiva, de que resuelve el tránsito mortis causa de los bienes del causante a los herederos de forma instantánea o inmediata a haberse producido el fallecimiento de aquel al hacer adjudicación de los mismos a los sucesores desde ese momento, sin necesidad de esperar a que se produzca la aceptación, lo que evita toda situación de transitoriedad o indeterminación en la titularidad de los bienes, al tiempo que proporciona seguridad y certidumbre, lo que no ocurre en el sistema romano donde, al no existir ese automatismo en el tránsito mortis causa de los bienes, se produce una inseguridad e incertidumbre que no se resuelve hasta que no se produzca la aceptación por parte del sucesor.

\section{2-3.- Sistemas actuales ${ }^{47}$.}

Apunta CÁMARA LAPUENTE ${ }^{48}$ que, cabe agrupar en la actualidad los diversos ordenamientos jurídicos existentes en el ámbito del Derecho de Sucesiones ${ }^{49}$, en los Estados miembros de la Unión Europea, en cuatro grandes familias:

46 “La adquisición hereditaria en el derecho comparado”. Cit: Pág. 424.

${ }^{47}$ Bajo este epígrafe, aludimos a cuáles son los sistemas que existen en la actualidad en orden a la transmisión de la herencia desde el punto de vista de su activo, no así desde el punto de vista del pasivo, respecto del cual, y en opinión de CAMARA LAPUENTE, "la mayoría de los Códigos actuales recogen el principio de la responsabilidad ultra vires (Austria, Bélgica, España, Francia, Grecia, Italia, Países Bajos), se acoge igualmente la posibilidad de limitar la responsabilidad bien a los bienes de la herencia, bien a su valor, mediante algunos mecanismos formales centrados en la aceptación a beneficio de inventario. En la práctica, es el sistema habitual. Algunos sistemas, pese a la declaración inicial de responsabilidad personal del heredero, son más favorables a la responsabilidad intra vires, como Alemania, donde la posible aceptación no prejuzga la responsabilidad hasta un momento posterior ( $\S$ 1942 BGB), y existen varios procedimientos distintos de liquidación colectiva del pasivo (§ 1975 BGB). Inglaterra establece directamente el principio de responsabilidad intra vires” "¿Derecho Europeo de Sucesiones?. Un apunte”. Capítulo 41. En Derecho Privado Europeo. Coordinador Sergio Cámara Lapuente. COLEX. Madrid. 2003. Pág 1226).

${ }^{48}$ Op. cit.: Pág 1195.

${ }^{49}$ CÁMARA LAPUENTE, apunta dos razones que, en su opinión, se han convertido en tópico, para justificar la postergación que sufre el Derecho de Sucesiones en el debate que se está llevando a cabo, en el ámbito de la Unión Europea, dentro del derecho privado, en ramas como es el derecho contractual y patrimonial o el derecho de familia, lo que justifica la ausencia de grupos de investigación europeos dedicados a la obtención de reglas o principios sobre el fenómeno sucesorio: "la escasa incidencia de las reglas de la sucesión mortis causa en la consolidación del mercado interior y su infranqueable apego a las longevas tradiciones jurídicas y a factores culturales y sociales de sesgo social” (Op. cit.: Pág 1185). 
a) Sistemas latino-romanos, al que pertenecen países como: Francia ${ }^{50}$, Bélgica, Luxemburgo y Países Bajos, por un lado, y España e Italia, por otro;

b) Sistemas germánicos, entre los que se encuentran: Alemania, Austria, Grecia $y$, extraordinariamente, Suiza;

c) Sistemas nórdicos o escandinavos, formado por: Suecia y Finlandia, por un lado, y Dinamarca, por otro, junto con Noruega e Islandia, si bien, estos dos países no forman parte de la Unión Europea;

d) Sistemas anglosajones, formado por: Inglaterra, Gales e Irlanda.

A los anteriores sistemas, cabría añadir los países del este europeo después de las ampliaciones de la Unión Europea acaecidas en los años $2004^{51}$ y $2007^{52}$, lo que, en opinión de CÁMARA LAPUENTE ${ }^{53}$, "llevaría a reconsiderar las posibles afinidades entre sí, para construir una categoría propia en el ámbito sucesorio, de los ordenamientos vigentes en países antiguamente socialistas".

ROCA SASTRE ${ }^{54}$, por su parte, y en lo que se refiere a la adquisición de la herencia, apunta la existencia en los ordenamientos jurídicos civiles actuales de tres regímenes o sistemas diferentes ${ }^{55}$ :

- dos de carácter extremo, llamados también sistemas de adquisición directa, dentro de los que se distinguen, a su vez, otros dos: de adquisición directa e inmediata, que sería el sistema germano, y en el que basta la delación para poder adquirir, y de adquisición directa y diferida, que sería el sistema latino-romano, en que la adquisición sólo se produce por la aceptación, expresa o tácita, de la delación, de efectos retroactivos al momento de la apertura de la sucesión y que hasta que no se produzca, se produce el fenómeno o situación de la herencia yacente, y

\footnotetext{
${ }^{50}$ No obstante su incardinación aquí no es la más adecuada porque, como veremos más adelante en este mismo capítulo, punto 2-3-1-1, el sistema sucesorio francés, se considera, más bien, mixto, o intermedio entre el germano y el latino al tomar reglas de uno y otro.

${ }^{51}$ Con fecha 1 de mayo de 2004, se incorporan: Estonia, Letonia, Lituania, Polonia, República Checa, Hungría, Eslovaquia, Eslovenia, Malta y Chipre.

${ }^{52}$ En fecha 1 de enero de 2007, se incorporan: Rumania y Bulgaria.

53 Op. cit.: Pág 1195.

54 “La adquisición hereditaria en el derecho comparado”. Cit: Pág. 422 y ss.

55 CAMARA LAPUENTE, por su parte, coincide con la misma clasificación, solo que distingue dentro del sistema de adquisición directa, dos sistemas (Op. cit.: Págs 1195, 1225 y 1226):

a) de transmisión directa e inmediata o ipso iure,

b) de transmisión por aceptación, “aditio hereditatis”, o diferida,

c) de transmisión por decisión judicial,

d) de transmisión por persona interpuesta, indirecta o diferida.
} 
- un tercer sistema, mixto o intermedio, o sistema de adquisición fiduciaria.

A los anteriores, hay que añadir un cuarto sistema, llamado de adquisición directa por investidura, que es una variante del primero.

Con una visión de futuro y "ante la disparidad de soluciones sobre la transmisión, no ya solo del activo, sino también del pasivo de la herencia -apunta CAMARA LAPUENTE $^{56}$ citando a LELEU ${ }^{57}$-, se ha realizado alguna propuesta doctrinal para crear, por Ley uniforme, un modelo basado, en cuanto a la transmisión del activo, en el modelo francés, y en cuanto a la transmisión del pasivo, en el modelo alemán".

\section{2-3-1.- Sistema o régimen de adquisición directa.}

Este sistema se caracteriza por el hecho de que el sucesor adquiere la condición de heredero y la propiedad de la herencia que le ha sido deferida desde el momento del fallecimiento del causante directamente de él, sin necesidad de que intervenga autoridad, funcionario o persona alguna en el proceso de cambio o tránsito de los bienes de unas manos a otras. El traspaso mortis causa de los bienes deferidos se produce del causante al sucesor de forma directa, de tal manera que hay una continuidad jurídica de aquel a éste, y las legislaciones que lo siguen adoptan, más bien, el criterio de la sucesión en la persona que de sucesión en los bienes.

Dentro de él se pueden distinguir, a su vez, dos sistemas según que la adquisición de la herencia se produzca por el solo hecho de la delación, o en virtud de la aceptación que son, respectivamente, los sistemas germano y romano, ya vistos.

En lo que se refiere a la posesión del caudal relicto, ROCA SASTRE ${ }^{58}$ distingue en este sistema de la adquisición directa, a su vez, tres sistemas:

a) de adquisición ipso iure, que se corresponde con el sistema de adquisición en virtud de la delación. En él, la posesión de los bienes se adquiere por el sucesor, por ministerio de la ley, desde el mismo momento de la muerte del causante.

${ }^{56}$ Op. cit.: Pág 1226. ERPL. 6 (1998). Pág 176 y ss.

58 “La adquisición hereditaria en el derecho comparado”. Cit: Pág 430 y ss.

Para un estudio más completo acerca de la adquisición hereditaria de la posesión, véase, entre otros: ROCA SASTRE: “La adquisición hereditaria de la posesión”. RGLJ. CI. 1953. Número extraordinario. Pág 333 y ss. Publicado también en Estudios sobre sucesiones. T. I. Madrid. 1981. Pág 167 y ss; CALVO MEIJIDE, A: La posesión en el derecho hereditario. Tesis doctoral publicada en edición facsímil por el Servicio de Reprografía de la Editorial de la Universidad Complutense de Madrid. 1990. 
b) De adquisición por autoridad propia, que es el propio de aquellos países en que rige el sistema romano de adquisición de la herencia. El sucesor, pese a tener o gozar de la posesión jurídica, ha de utilizar algunos medios o realizar algunos actos que la Ley establece para poder adquirir dicha posesión como situación o realidad de hecho sometida a su señorío.

c) De adquisición por investidura judicial, es aquel en que el sucesor ha de dirigirse a la autoridad judicial para que sea ésta quien le ponga en posesión de los bienes del causante. Es el sistema que rige en Austria.

\section{2-3-1-1.- Sistema de delación.}

Su prototipo por excelencia lo constituye el sistema sucesorio germano antes expuesto, o alemán actual $y$, junto a él, se puede incluir aquí el sistema sucesorio francés, instaurado desde el año 1804 por el Code de Napoleón ${ }^{59}$, si bien le separa de

${ }^{59}$ La regulación de esta materia en el derecho civil francés está notablemente influenciada por el pensamiento de POTHIER a través de su obra Traté des Successions, publicada en el año 1775.

Su texto ha sido modificado por la Ley n ${ }^{\circ}$ 2001-1135, de 3 diciembre de 2001 (JO $\mathrm{n}^{\circ}$ 281, de 4 diciembre de 2001), y de manera más profunda, por la Ley $n^{\circ}$ 2006-728, de 23 junio de 2006, de reforma en materia de sucesiones y liberalidades ( $\mathrm{JO} \mathrm{n}^{\circ}$ 145, de 24 de junio de 2006), que da nueva redacción a los capítulos IV, V y VI, del Título I, Libro III.

El nuevo capítulo IV, de distribución totalmente diferente, con una mejor sistemática, respecto del texto derogado, comprende cuatro Secciones: la primera, relativa a disposiciones generales (arts 768 a 781); la segunda, a la aceptación pura y simple (arts 782 a 786); la tercera, a la aceptación a beneficio de inventario (arts 787 a 803); y la cuarta, a la “renonciation”, o repudiación, de la sucesión (arts 804 a 808). Ya su epígrafe, “De l'option de l'heritier”, es diferente porque antes, esta materia, que se localizaba en el capítulo V, se titulaba, “De l'acceptation et de la repudiation des successions”, lo que es loable porque aglutina en una sola palabra, “option” u opción, las dos declaraciones del heredero.

El texto actual incorpora algunas novedades respecto del derogado, o reformado. Así:

a) emplea el término "retroactip" para referirse a dicha retroactividad, a diferencia de la redacción anterior del artículo 777 que utilizaba el verbo "remonter" -remontar, subir-, que era una palabra de significado algo confuso aquí aplicado porque daba a entender que la declaración del sucesor remontaba, subía, al día de la apertura de la sucesión, es decir, retrocedía, se volvía hacia atrás, a ese momento, lo que se interpretaba en el sentido de que tenía carácter retroactivo a ese instante, pero no lo decía de forma nítida, había que entenderlo así. En este sentido, ya decía el artículo 785 en su redacción anterior, actual artículo 805, que, “L'héritier qui renonce est censé n'avoir jamais été héritier” -el heredero que renuncia se supone que nunca ha sido heredero-, lo que daba a entender el carácter retroactivo de la declaración.

b) Por otro lado, emplea este término, "renonciation", o renuncia, para referirse a la declaración de rechazo del "héritier”, o heredero, a la herencia. Y además, lo hace de forma unívoca o uniforme, tanto en el epígrafe de la sección $4^{\mathrm{a}}$ del capítulo IV, como después en los preceptos que lo integran (arts 804 a 808). Pero, no emplea el término “répudiation”, o repudiación, que sí lo hacía, en cambio, de forma expresa en el epígrafe del antigüo capítulo V -“De l'acceptation et de la répudiation des successions”-, aunque después, en su sección $2^{\mathrm{a}}$, decía, “De la renonciation aux successions”, lo que, al contraponer uno y otro término, planteaba el debate de la confusión entre renuncia y repudiación. Ahora, esta colisión, al menos en teoría, no existe al suprimirse el epígrafe del antigüo capítulo V y optar por el empleo unitario del término "renonciation", o del verbo "renoncer", en la regulación de esta declaración del "héritier".

Entonces, ante ello cabe preguntarse, por un lado: ¿se puede deducir que el legislador francés trata de terminar con el enfrentamiento, y consiguiente polémica, que hasta entonces existía entre uno y otro término?, y, por otro: ¿considera la repudiación de la herencia como una renuncia?, porque, antes se producía la colisión entre ambos términos, lo que inducía a confusión, ahora ya no. 
aquel alguna diferencia porque sigue, más bien, un sistema que se podría calificar de mixto, ya que contiene preceptos inspirados, unos en el sistema germano y otros en el sistema romano.

Entre el sistema sucesorio francés y el germano existe una gran similitud porque la adjudicación y adquisición de la herencia se produce, tanto en uno como en otro, de forma automática desde el mismo momento de la apertura de la sucesión por el solo hecho de la delación, lo que, por otro lado, responde a la idea, proveniente del Droit coutumier, de que solo la ley hace herederos. No obstante, el "héritier" no está obligado a heredar porque podrá emitir su declaración de "renonciation", sancionando la máxima del Derecho francés, "il ne se porte héritier qui ne veut", "renonciation", que tendría la función de rechazar dicha adquisición patrimonial y la condición de heredero, y es como si el "héritier" nunca hubiere sido llamado a la herencia como tal heredero, y, al igual que en el sistema alemán, si manifestare su declaración de aceptación, ésta consolidaría o ratificaría la adquisición ya realizada y la condición de heredero.

Así, el tenor del artículo 724, párrafo $1^{060}$, que es aplicación de la regla "le mort saisit le vif', nos da a entender, en principio, que la adquisición es automática desde el

En este sentido, tratando de salir al paso, TROPLONG, comentarista del Code, entendió que la diferencia era irrelevante desde el momento en que abstención, repudiación y renuncia tienen el mismo valor o son equiparables entre sí (Des donations entre vifs et des testaments ou commentaire du titre II, livre III du Code Napoleón. Bruxelles. A. Labroue et compagnie. 1855).

Desde el punto de vista legal, del tenor del actual artículo 805, párrafo $1^{\circ}$, se desprenden dos consideraciones:

$1^{\text {a) }}$ sanciona la presunción legal de que, a resultas de su declaración, al “héritier”, o heredero, nunca se le ha tenido como tal, lo que da a su declaración un valor de repudio al tiempo que un efecto retroactivo porque entiende que en ningún momento lo ha sido. Es como si su llamamiento no se hubiese efectuado,

$2^{\mathrm{a}}$ ) no obstante lo anterior, emplea al principio el término "héritier" para referirse al declarante dando a también a entender que, en el momento de emitir su declaración de "renuncia", se le considera por la ley como tal "héritier", o heredero -igual se puede apreciar en el texto del epígrafe del capítulo IV cuando reza "De l'option de l'heritier"-, salvo que se entienda que se emplea este término de forma impropia, al igual que sucede en nuestro Código Civil en numerosas ocasiones.

Con lo cual, de la misma manera que sucede en el derecho germano, su declaración de "renonciation", destruye, "borra”, o deja sin efecto la condición de "héritier” que se entiende adquirida, de forma instantánea, incluso desconociendo su condición de sucesor, desde el momento de la apertura de la sucesión, así como la adquisición que, de forma provisional y automática, se produce de la herencia, lo que es equiparable a una repudiación. Por ello, pese a emplear el término "renonciation” se puede decir que sí que estamos ante una verdadera y propia declaración de repudio.

${ }^{60}$ De nueva redacción por Ley $n^{\circ}$ 2001-1135, de 3 diciembre de 2001 (art. 18): “les héritiers désignés par la loi sont saisis de plein droit des biens, droits et actions du défunt”.

Después de su entrada en vigor, si bien se mantiene el sistema automático de adquisición de la herencia que viene rigiendo desde la entrada en vigor del Code, la novedad está en que el llamamiento a los herederos se hace con independencia de su filiación al desparecer, desde este momento, todo vestigio de discriminación que por razón de filiación existía hasta entonces en el derecho sucesorio francés en el que se distinguía entre hijos legítimos y adulterinos, al disponer en su artículo 733, también de nueva redacción por tal ley, que, "la loi ne distingue pas entre la filiation légitime et la filiation naturelle pour déterminer les parents appelés à succéder”. Como consecuencia de ello, se da nueva redacción al párrafo primero de dicho artículo 724 desapareciendo la alusión que a los mismos se hacía. 
instante de la defunción, momento en que la herencia ha sido deferida, incluso antes de que se tenga conocimiento de esta circunstancia. Sin embargo, según el artículo 776 en su redacción actual ${ }^{61}$, con precedente en el anterior $777^{62}$, la opción ejercida tiene efecto retroactivo al día de la apertura de la sucesión. Así, al ser necesaria la declaración del sucesor para poder adquirir y darle efecto retroactivo, hace que el derecho sucesorio francés se sitúe, más bien, en el ámbito de los sistemas de adquisición por aceptación, al igual que sucede en el derecho germano.

En este sentido, como apunta ROCA SASTRE ${ }^{63}$, debe de calificarse, en realidad, al sistema francés, de mixto, "debido a que contiene preceptos inspirados unos en el sistema germánico, y otros, en el sistema romano, formando con esta mezcla de elementos dispares un conjunto heterogéneo que da lugar a dudas y a interpretaciones completamente distintas".

Otros ordenamientos en los que se sigue el sistema de delación lo constituyen el sistema sucesorio de países como: Suiza, Grecia, Turquía, Dinamarca, Finlandia, Islandia, Noruega y Suecia, o países influidos por el Code de Napoleón: Bélgica, Holanda, Luxemburgo, Rumania, Méjico, Brasil, Chile, República Argentina, Colombia, Venezuela, Perú, y prácticamente los países de toda Iberoamérica.

\section{2-3-1-2.- Sistema de aceptación.}

Es contrapuesto al sistema de delación germano porque en él, y aquí es donde radica su especialidad, al tiempo que principal diferencia que lo separa del mismo, la delación por sí sola no es suficiente para que se produzca la adquisición de la herencia ya que, indefectiblemente, es necesaria la declaración de voluntad de aceptación por parte del sucesor, requisito que actúa como presupuesto esencial e imprescindible, conditio sine qua non, para que dicha adquisición pueda tener lugar.

El sistema tipo del mismo lo constituye el sistema latino-romano, al que antes hemos aludido, encarnado, hoy día, principalmente, en el derecho italiano ${ }^{64}$ y derecho

${ }^{61}$ De nueva redacción por la Ley n ${ }^{\circ}$ 2006-728, de 23 junio de 2006: “les héritiers désignés par la loi sont saisis de plein droit des biens, droits et actions du défunt”.

62 Disponía que, "I'effet de l'acceptacion remonte au jour de l'ouverture de la succession".

63 "La adquisición y la repudiación de la herencia en el derecho común y en el derecho foral”. Cit: Pág. 8.

${ }^{64}$ Así, según el artículo 459 del actual Código Civil italiano de 1942, "l'eredità si acquista con l'accettazione. L'effetto dell'accettazione risale al momento nel quale si è aperta la successione”. Y, en el supuesto de que el llamado no quisiere ser tal sucesor, tendrá que repudiar, en cuyo caso se considera como si nunca hubiere sido llamado a la sucesión (art. 521: "Chi rinunzia all'eredità è considerato come se non vi fosse mai stato chiamato”). Luego, el fallecimiento de la persona solo produce la apertura de la sucesión y concede al sucesor la facultad de decidir acerca de la delación que le ha sido deferida. 
español. También rige en otros países como: Portugal ${ }^{65}$, Cuba, Filipinas, Puerto Rico y algunos países de América latina.

\section{2-3-2.- Sistema o régimen de adquisición fiduciaria.}

O sistema anglosajón, propio y característico del derecho inglés, y que es radicalmente distinto al que rige en el resto de los países europeos. Rige en él después de la reforma introducida en el año 1925 por la Administration of Estates Act, y tiene sus orígenes en la vieja fórmula "le mort saisit son seigneur" de que el patrimonio de una persona muerta solo puede obtenerse por concesión de autoridad.

Se caracteriza ${ }^{66}$ por el hecho de que la transmisión o tránsito de los bienes del causante a sus sucesores y consiguiente adquisición por parte de éstos tanto de aquellos como de la condición de heredero, no se realiza de forma directa sino indirecta y diferida, a través de persona interpuesta, de un intermediario que se constituye en pieza básica y fundamental de todo el proceso sucesorio en torno a la cual gira todo el mecanismo hereditario ${ }^{67}$. Dicho intermediario puede serlo: un "executor", o persona instituida por el propio causante en su testamento, un "personal representative", o persona designada por un Tribunal en defecto de testamento, o un "administrator cum testamento anexo", que es una persona designada por el Tribunal si no lo designa el testamento o el designado renuncia.

Dicho intermediario queda investido de la propiedad y posesión de los bienes relictos del causante, tanto muebles como inmuebles, y los administra no en provecho propio, sino a modo de fiduciario. Otra de sus funciones es liquidar la herencia y hacer entrega del remanente a los sucesores. Así, su misión es "purgar" los bienes del difunto de las deudas que los gravan. Su papel se asemeja al del administrador de una quiebra. El sucesor adquiere un patrimonio ya liquidado (residue), después de haberse pagado las dudas y los legados. Los herederos no responden, en ningún caso, de las deudas de la herencia y si después de haberse distribuido todos los bienes apareciere

${ }^{65}$ El Código Civil actualmente vigente, de 1966, regula el sistema de adquisición de herencia en el Título I del Libro V. Después, en el capítulo IV, titulado “Aceitaçao da herença”, comprensivo de los artículos 2050 al 2061, regula la aceptación de la herencia, y en el capítulo V, titulado "Repudio da herença”, del artículo 2062 al 2067, la repudiación de la herencia.

En él, se sigue el sistema de adquisición de la herencia a través de la aceptación con efectos retroactivos al momento del fallecimiento del causante y utiliza el término "repudio" para referirlo exclusivamente a la repudiación, mientras que la "renuncia", se refiere a la renuncia traslativa a la que da un carácter de aceptación tácita de la herencia.

66 CAVANILLAS MÚGICA: “La herencia no aceptada: apuntes de derecho comparado”. En Libro-Homenaje al profesor Manuel Albaladejo García. T I. Colegio de Registradores de la Propiedad y Mercantiles de España. Servicio de Publicaciones. Universidad de Murcia. 2004. Págs 1004 y 1005.

${ }^{67}$ STEPHEN: Comentaries on the law of England. 1928. II. Capítulo XXXV. 
una nueva deuda, el acreedor sólo podrá hacerla efectiva contra los bienes de la herencia, en el estado y en las manos en que se encuentre en dicho momento. De ahí que se conciba en este sistema la herencia como un patrimonio en liquidación siendo función del intermediario o ejecutor de últimas voluntades impedir la confusión de patrimonios entre el propio del causante y el del heredero.

En este sistema todo el proceso sucesorio mortis causa está bajo control judicial ya que los Tribunales confirman la validez del título testamentario del "executor" (grant of probate), nombran al "administrator" (grant of letters of administration) e, incluso, hasta que se produce este nombramiento, se ocupan de la posesión y administración de los bienes relictos.

Se observa así, cómo es un sistema en el que se pueden distinguir dos fases: una, de administración, que no es meramente conservativa e interina, sino liquidatoria o de purga de deudas y legados cuya responsabilidad recae sobre los bienes de la herencia, y otra, de distribución, o de transmisión a los herederos del remanente de los bienes. De lo que se deriva la consecuencia de que falta la situación de interinidad o de yacencia, que es característica, en el derecho continental, de la herencia no aceptada $^{68}$.

\section{2-3-3.- Sistema o régimen de adquisición directa por investidura.}

Es un sistema de adquisición por aceptación pero con la variante de que en él, para poder adquirir la herencia, se requiere, además de la aceptación expresa por parte de los herederos, la intervención judicial porque la transmisión sólo se produce a través de la decisión del Juez. Es el sistema actualmente vigente en Austria.

Se trata de un sistema que sigue al romano, si bien adopta un régimen propio en lo que se refiere a la forma de adquisición del título o condición de heredero por parte del sucesor y, consiguientemente, de la porción o cuota a que ha sido llamado.

En él, los sucesores, ya lo sean por testamento, por ley o por contrato sucesorio (las tres formas posibles de sucesión en este ordenamiento), tienen que acudir necesariamente a un Tribunal, llamado "de la sucesión", en petición de ser declarado heredero y de que se le adjudique la herencia. Acto seguido se incoa un procedimiento cuya finalidad es la de verificar, comprobar, determinar y declarar la cualidad o condición de heredero a favor de aquellos que así lo han solicitado y resulte justificado conforme las normas sucesorias y proceder, en su caso, a la respectiva adjudicación,

${ }^{68}$ Vid: CAVANILLAS MÚGICA: Op. cit.: pág 1005. 
atribución o entrega de los bienes hereditarios a que han sido llamados. Después el Tribunal emite una declaración judicial en la que se indican quienes son los herederos (de ahí que se la conozca como acto de investidura), y que sirve, al mismo tiempo, de atribución y entrega de los bienes hereditarios (Einantwortung). Es a partir de ese momento y no antes, cuando tiene lugar la concreta y efectiva la adquisición de los mismos, de tal manera que desde el momento de la defunción hasta que se produce dicha declaración judicial, la herencia se encuentra en una situación de yacencia entendiéndose, en este sentido, que los bienes, en esa situación, son poseídos por el difunto ( $\S 547$ ABGB). En ese intervalo, los llamados solo tienen una expectativa hereditaria. Dicha declaración pone fin a esa situación de interinidad en que se encuentra la herencia y consuma la transmisión de los bienes relictos y la efectiva toma de posesión de los mismos.

El parágrafo 797 del ABGB establece que nadie puede tomar posesión de la herencia por su propia autoridad. De ahí que el acto de la investidura judicial sea un acto básico y decisivo, de carácter esencial, en el proceso sucesorio para la efectiva adquisición del título de heredero.

No obstante, al formular su petición, los sucesores han de manifestar ante el Tribunal, su voluntad de ser declarados herederos (ya sea de forma pura y simple o a beneficio de inventario, no se admite la forma tácita) y se les adjudique la herencia. $Y$ si desean repudiar la herencia, basta con guardar silencio o abstenerse de aceptar ante el Tribunal, no siendo necesaria una declaración formal sobre ello.

Por otro lado, dicho procedimiento no tiene por finalidad la conservación y administración de los bienes de la herencia, como tampoco su liquidación -salvo en el caso de aceptación de la herencia a beneficio de inventario-, ni actúa como medio de salvaguardia o protección de los derechos de los acreedores, legitimarios y legatarios de la herencia, salvo petición especial y expresa. Su única finalidad es realizar el acto de investidura por medio del cual se pone fin a la situación de yacencia de la herencia, se adquiere el título o condición de heredero, y se adquiere de manera efectiva y real los bienes hereditarios, si bien, respecto de los inmuebles, es precisa su inscripción en el correspondiente Registro Público. 


\section{3.- EL SISTEMA ESPAÑOL DE ADQUISICIÓN DE LA} HERENCIA.

La cuestión de qué sistema, si romano o germano, rige en nuestro ordenamiento jurídico acerca de la adquisición de la herencia, tradicional, clásica e históricamente, ha suscitado un gran debate en nuestro derecho dentro de la doctrina, en el que se ha dirimido entre la vigencia de uno $u$ otro, dando lugar a una abundantísima literatura ${ }^{69}$.

La vigencia del sistema germano fue defendida, en su día, por GARCÍA VALDECASAS ${ }^{70}$, y la del sistema romano, por ROCA SASTRE ${ }^{71}$, que se pueden considerar las dos cabezas visibles o representativas de uno y otro sistema.

Sin embargo, se trata de un debate que se puede considerar estéril, como ha puesto de relieve, entre otros, LACRUZ BERDEJO ${ }^{72}$, quien ha tratado de restarle importancia al manifestar que, "el problema es de escasa importancia práctica puesto que los preceptos del Código Civil atienden a las cuestiones concretas que pudiera suscitar".

Igual creemos nosotros porque, tal vez, la polémica o problemática a que ha dado lugar se ha magnificado en exceso al tener un alcance más teórico que práctico ya que, en la realidad, en cuanto a efectos o resultados, uno y otro sistema se vienen a identificar o equiparar por el carácter retroactivo que tiene en el sistema romano la

${ }^{69}$ Así, entre otras muchas publicaciones relativas a ello:

ALBALADEJO: "La adquisición de la herencia en el derecho español”. ADC. 1955. Pág 3 y ss; CARRIÓN: “Aceptación tácita de la herencia. La petición de liquidación y el pago del impuesto sucesorio no significan aceptación tácita [Comentario a la STS (Sala 1ª) de 20 enero 1998 (RJ 1998, 57)]” RDP. Madrid. Diciembre 1999. Págs 877 a 892; CASADO IZQUIERDO: "La acción de petición de herencia”. AC. n 11/11-17 marzo 1996; GARCÍA VALDECASAS: Op. cit.: "La adquisición de la herencia en el derecho español”; GALVÁN GALLEGOS: La herencia: contenido y adquisición. La aceptación y repudiación de la herencia. La Ley-Actualidad. Madrid. 2000; "La indivisibilidad de la aceptación y repudiación de la herencia”. ADC. Tomo L. Fascículo IV. 1997. Pág 1817 y ss; GITRAMA: Op. cit.: Comentarios al Código Civil ....... T XIV. Vol 1º JORDANO FRAGA: La sucesión en el "ius delationis": una contribución al estudio en la adquisición sucesoria mortis causa. Ed. CIVITAS. Madrid. 1980; MARTÍN BLANCO: “La adquisición de la herencia en el Código Civil español”. RGLJ 1956. Pág 45; ROGEL VIDE: Op. cit.: "Renuncia y repudiación de la herencia”; ROYO MARTÍNEZ: Exposición elemental del Derecho civil español: Derecho sucesorio “mortis causa”. Sevilla. 1951; SÁNCHEZ ROMÁN: Estudios de Derecho civil. T. VI. Vol 2. Derecho de Sucesiones. 2a Ed. Madrid. 1910; VALVERDE: Tratado de Derecho Civil español. T. V. 4ª Ed. Valladolid. 1926.

${ }^{70}$ De entre sus obras merecen destacarse la ya citada: "La adquisición de la herencia en el derecho español” y, “De nuevo sobre la adquisición de la herencia”. RDP. T. XXXV. 1951. Pag. 991 y ss.

${ }^{71}$ De entre sus obras acerca de ello, véanse: la ya citada, "La adquisición y la repudiación de la herencia en el derecho común y en el derecho foral", o "La adquisición hereditaria en el derecho comparado”. Estudios sobre sucesiones. T. I. Madrid. 1981. Publicado también en Revista del Instituto de Derecho Comparado. № 1. Julio-diciembre de 1953. Págs 61 a 87.

${ }^{72}$ Elementos de Derecho Civil. T V. Cit: Pág 37. 
declaración del delado dimanante del ius delationis en su ejercicio al momento de la apertura de la sucesión (art. 989 CC).

Tal debate, desde otro punto de vista, ha dado lugar a que se plantee la relevante cuestión de cual es la función que tiene en nuestro sistema sucesorio la declaración de aceptación: si la de adquirir efectivamente la herencia, que sería la que tuviere si se admite la vigencia del sistema romano, o si la del sistema germano, que sería la de confirmar o ratificar la adquisición que se produjo a resultas de la delación, o a resultas de la defunción del causante y subsiguiente apertura de la sucesión.

El origen y razón de ser de la incertidumbre acerca de qué sistema, si romano o germano, rige en nuestro ordenamiento jurídico en orden a la adquisición de la herencia, a la luz de la normativa del Código Civil, así como de la distinta posición que al respecto se pudiere adoptar, está, a nuestro juicio, como sucede en tantos otros muchos casos, en el oscurantismo que ofrece dicho texto legal que, no sólo no dice de forma expresa, clara y terminante, cómo se adquiere la herencia, sino que es imprecisa, ambigua y vacilante, ya que da pie para encontrar argumentos a favor de la vigencia o aplicación tanto de uno como de otro sistema. Incluso podemos decir que es contradictoria si se contraponen entre sí los preceptos legales en los que se pueden fundamentar los argumentos sobre los que se apoya la doctrina para defender la vigencia de uno y otro sistema. No sucede lo mismo en las leyes sucesorias de Cataluña (artículo 411-5, de la Ley 10/2008, de 10 de julio, del libro cuarto del Código Civil, sobre sucesiones), o Aragón (art. 322, del $\mathrm{CDFA}^{73}$ ), que son más explícitos porque en ellos se subordina de forma expresa la adquisición de la herencia a la aceptación. O también en otros ordenamientos jurídicos actuales próximos al nuestro, como es el italiano, donde también de forma expresa se dice que, solo a través de la aceptación se adquiere la herencia: "L'eredità si acquista con l'accettazione" (art. 459).

No obstante, aunque la respuesta más convincente, y que se puede considerar mayoritaria, desde el punto de vista legal, doctrinal y jurisprudencial, según veremos a continuación, es la vigencia del sistema romano y necesidad de aceptación de la herencia para poderla adquirir, la cuestión no es ni pacífica, ni tranquila, ni sencilla, principalmente, en nuestra opinión, según ya hemos apuntado, como consecuencia de la imprecisión y ambigüedad que existe en el Código Civil.

73 Aprobado por Decreto Legislativo 1/2011, de 22 de marzo, del Gobierno de Aragón, por el que se aprueba, con el título de “Código del Derecho Foral de Aragón”, el Texto Refundido de las Leyes civiles aragonesas (BOA $n^{\circ}$ 63, de 29 de marzo de 2011). 
Haciendo una breve alusión a la polémica planteada, volviendo la vista atrás y remontándonos a las primeras décadas del siglo pasado, la postura que se mantenía por entonces dentro de la doctrina, seguida entre otros, por MANRESA, VALVERDE, CASTÁN TOBEÑAS, DE BUEN, TRAVIESAS o DE DIEGO, fue la de entender, casi con absoluta rotundidad, que el sistema de adquisición de herencia por el que se regía nuestro ordenamiento jurídico era el romano, de tal manera que era necesaria la declaración de aceptación de la herencia para adquirir la condición de heredero, o la de repudiación, en caso contrario, si no se quería ser heredero, retrotrayéndose los efectos de una y otra declaración al momento de la muerte del causante (art. 989 CC). No obstante, ya por entonces, DE DIEGO ${ }^{74}$ había reconocido que los artículos 609 , 661, 440 y 1006, que después tomará GARCIA VALDECASAS, parecen contener ciertas remembranzas germánicas de la transmisión hereditaria ipso iure.

Como tampoco faltaban autores como SÁNCHEZ ROMÁN ${ }^{75}$, que calificaban el sistema de "mixto", por el efecto retroactivo de la aceptación, sin reparar que lo mismo sucedía en Roma. En igual sentido y en términos semejantes, se manifestaba VALVERDE $^{76}$.

En este ambiente, GARCIA VALDECASAS, en el año $1944^{77}$, seguido después por algún autor, como ROYO ${ }^{78}$ o GITRAMA ${ }^{79}$, aunque éste con algunas matizaciones, plantea por primera vez en un artículo ${ }^{80}$, desviándose así de la postura que era mayoritaria en ese momento en la doctrina, la tesis de que nuestro Código Civil sigue el sistema germánico ${ }^{81}$, de tal manera que la adquisición de la herencia se produce por el solo hecho de la delación, sin necesidad de aceptación, sin perjuicio de que se pudiere repudiar, sobre la base, entre otros, por un lado, de los artículos 657, 661 que,

${ }^{74}$ Instituciones de Derecho civil Español. T III. Cit: Pág 346 y ss.

${ }^{75}$ Estudios de Derecho civil. T VI. Vol 2. Cit: Pág 21 y ss.

${ }^{76}$ Tratado de Derecho Civil español. T V. Cit: Pág 497 y ss.

${ }^{77}$ Con anterioridad a la tesis germanista de GARCIA VALDECASAS, la DGRN, con fecha 15 de marzo de 1918, emitió un informe en el que se decía que "nuestro sistema sucesorio se aleja del Derecho Romano en el punto fundamental de la aceptación de la herencia y que únicamente para repudiarla exige en el artículo 1008, el instrumento público o la declaración auténtica" (Vid ROCA SASTRE: "La adquisición y la repudiación de la herencia ......”. Cit: Pág 13 y ss.). Después, dicho informe es citado por una Real Orden de 16 de marzo de 1918 que estableció la no exigencia de escritura pública de aceptación de herencia para poder practicar en el Registro de la Propiedad inscripciones de títulos hereditarios, en contra de lo que solicitaron varios Colegios Notariales.

${ }^{78}$ Derecho sucesorio “mortis causa”. Cit: Pág 39.

${ }^{79}$ Op. cit.: Pág 29. Vid también: La administración de herencia en el derecho español. EDERSA. 1950. Pág 32, pero sin argumentar.

${ }^{80}$ Op. cit.: Pag. 89 y ss.

${ }^{81}$ Ya antes COSAK sostuvo que la adquisición de la herencia en nuestro derecho se producía, ipso iure, igual que en el derecho alemán: una vez fallecido el causante y producida la delación ("El derecho hereditario según los principios del Código Civil alemán comparados con los del derecho español”. RDP. 1923. Pág 300). 
para GARCIA VALDECASAS ${ }^{82}$, son fundamentales en orden a la adquisición de la herencia, y por otro, el artículo 440, que es, o actúa, a modo de complemento del aquellos ${ }^{83}$.

${ }^{82}$ Op. cit.: Pág 106 y ss.

${ }^{83}$ En su opinión, los citados preceptos son fundamentales en orden a la adquisición de la herencia $\mathrm{y}$, en base a ellos, tal adquisición, al igual que ocurre en el derecho germano, se produce de forma automática, ope legis, por el solo hecho de la delación, desde el momento de la muerte del causante sin necesidad de aceptación.

En su opinión, la aceptación "es una declaración de voluntad conforme con la adquisición de la herencia verificada al morir el causante y su sentido u objeto es el de hacer definitiva esa adquisición”, y no tendría otro efecto que hacer irrevocable la adquisición que, de forma provisional, de la herencia se ha producido a resultas de la delación en el instante del óbito del causante, así como el de concretar la responsabilidad del sucesor ante las deudas de dicha herencia. Mientras que, la repudiación, "es una declaración de voluntad por la que el heredero se despoja retroactivamente de su cualidad de tal, se desprende de la herencia antes adquirida; actúa, por tanto, como condición resolutoria de la adquisición hereditaria" (Op. cit.: Pág 110). Este sería el sentido de tales declaraciones "si queremos concordar ambas instituciones con los principios establecidos en los artículos 657, 661 y 440, sin desvirtuarlos".

No obstante lo anterior, reconoce que la objeción más seria a su tesis es la retroactividad de la aceptación que establece el artículo 989 CC, mientras que, en lo que se refiere a la repudiación, es un argumento favorable a ella (Op. cit.: Pág 111 y ss.), porque tal efecto se justifica por el hecho de que, al ser el sucesor heredero desde el mismo instante de la muerte del causante, la retroactividad se produce para deshacer dicha condición y se entenderá, en consecuencia, a resultas de dicha declaración, que no lo ha sido en ningún momento y, por tanto, no ha llegado a adquirir la herencia. De no haberse producido la adquisición, no tendría sentido el efecto retroactivo de su declaración.

Acerca de la expresión contenida en el párrafo primero del artículo 440, "se entiende transmitida", se interpreta en el sentido de que alude al traspaso ipso iure, por ministerio de la ley, de la posesión de los bienes hereditarios al heredero por el solo hecho de la muerte del causante (Op. cit.: Pág 107 y ss), sin necesidad de que se produzca la aprehensión material de los mismos, lo que, en palabras de GARCÍA GOYENA, es la denominada "posesión civilísima", "possessio artificialis", o "ficta possessio" por GARCÍA VALDECASAS (Op. cit.: Pág 108). Y, su párrafo segundo se entiende en el sentido de que el repudiante ya poseía los bienes de la herencia antes de su declaración y, por tanto, antes de la aceptación que, en su caso, hubiere emitido.

A propósito del artículo 661, que es el pilar más importante sobre el que se sostiene la tesis germanista que propugnó GARCÍA VALDECASAS, ALBALADEJO contra argumenta diciendo que, pese a su tenor literal y no obstante ser el único y verdadero argumento a favor de la adquisición ipso iure de la herencia porque, en su opinión, aparte de que los artículos 657 y 1006 tienen un valor neutro ("La adquisición de la herencia en el derecho español”. Cit: Págs 12 y 25).

En este sentido, ALBALADEJO, a propósito del mismo, entiende que, "en él no se quiere establecer que por el hecho exclusivamente de la muerte del causante le suceden los llamados a la herencia" (Comentarios al Código Civil ....... T XII. Vol 2. Cit: Pág 56 y ss).

Sigue manifestando que es preciso juzgar el tema en su conjunto, no solo por el hecho de la muerte y no solo por esas palabras porque de la regulación que la ley establece en su conjunto del fenómeno sucesorio y de su interpretación de forma sistemática, se obtiene la conclusión de que el espíritu del artículo es: partiendo de que el llamado acepte, sucede al causante por su muerte y desde ésta, es decir, porque murió, y desde entonces. "Todo lo que no sea admitir esto, sino empecinarse en que diciendo el artículo que se sucede por el solo hecho de la muerte, la sucesión se produce sin más, ........., es reducirse a una interpretación puramente literal, improcedente, desmentida por la futura regulación del tema, amén de rechazada tanto por la jurisprudencia como por la doctrina absolutamente dominante y, desde luego, por toda la actual”.

No obstante la crítica, ALBALADEJO añade otros presuntos argumentos que se podrían esgrimir a favor de la adquisición ipso iure de la herencia como serían: cuando el Código habla de heredero cuando aun no ha habido aceptación (arts 1001, 1004, 1005, 1006, 1012), o el tenor del artículo 1016, o el hecho de que exija más requisitos para la repudiación que para la aceptación de la herencia, o el silencio del llamado en el caso de interrogatio in iure (art. 1005), o la situación de yacencia de la herencia, o la retroactividad de la repudiación, etc. 
GITRAMA $^{84}$, entiende, en cambio, que el sistema que informa el Código Civil es un tanto ecléctico pero con preferencia germánica porque, según él, la aceptación es confirmatoria de la adquisición que se produce ".... por el hecho solo de su muerte" (art. $661 \mathrm{CC}$ ), si bien, de manera provisional ya que, desde entonces, se convierte en definitiva al tiempo que comporta la facultad de repudiar.

El Tribunal Supremo, por su parte, pese a su marcada posición romanista, según veremos más adelante, se ha pronunciado, no obstante, en numerosas sentencias a favor de la tesis de que la adquisición de la herencia se produce por ministerio de la ley o de forma automática a la muerte del causante sin necesidad de aceptación ${ }^{85}$.

Pero se trata de sentencias que, en palabras de ALBALADEJO, "lo ha dicho simplemente por repetir o parafrasear la letra del texto original, careciendo de todo propósito de decidir nuestro problema y normalmente sin ni siquiera plantearlo". Aunque, según ya apuntamos y luego veremos, el Tribunal Supremo se inclina más a favor de la vigencia de la tesis romanista en nuestro derecho como se puede observar, no solo por haber un mayor número de pronunciamientos que ha habido en este sentido, sino porque se trata de supuestos en los que así se ha manifestado de forma expresa al entrar a analizar a fondo la cuestión por razón de la litis planteada.

Sin embargo, mantener la vigencia en nuestro derecho del sistema germano de adquisición de la herencia, encuentra una fuerte oposición porque el sistema romano actúa como un gran contrapeso al tener fuertes y sólidos argumentos desde el punto de vista legal, como ahora veremos a continuación, así como un número considerable de seguidores dentro de la doctrina, además de una jurisprudencia muy consolidada.

${ }^{84}$ Op. cit.: Pág 29.

${ }^{85}$ SSTS 20 de marzo de 1916; 8 de abril de 1927; 18 de abril de 1934; 30 de mayo de 1958; 27 de enero de 1961; 9 de mayo de 1962; 13 de marzo de 1964. Citadas por ALBALADEJO en comentario al artículo 661 del Código Civil en Comentarios al Código Civil y Compilaciones forales. Pág 63.

En este sentido, también es de reseñar, la sentencia que el Juzgado de Primera Instancia $\mathrm{n}^{\circ} 3$ de Ciudad Real emitió en fecha 26 de noviembre de 1993, y en la que condenó a los padres del conductor de una motocicleta al abono de los daños causados por su hijo entendiendo que al haber fallecido éste sin descendientes, por virtud del juego de los arts 807 y 661 CC, aquellos eran herederos forzosos del mismo desde el instante mismo de la muerte sin solución de continuidad y sin necesidad de aceptación, decantándose así la sentencia de instancia por una concepción germanista de la transmisión de la herencia al heredero (así relatado por SAP Ciudad Real, de 30 de junio de 1994, AC 1994\1061). Dicha sentencia fue posteriormente revocada por el Audiencia al estimar el recurso de apelación interpuesto por los padres.

Incluso nos podemos encontrar con alguna sentencia, como la de 15 marzo 1994, de la Audiencia Provincial de Málaga (AC 1994\458), que defiende el carácter mixto, entre el romano y el germano, de nuestro sistema de adquisición de la herencia. 
Remontándonos a nuestros antecedentes históricos, aunque los textos legales hispanos anteriores a las Siete Partidas (año 1254), no dejan claro cual de los dos sistemas, romano o germano, rige en nuestro derecho, ya desde las mismas leyes alfonsinas (Partida 6, Título 6, Ley 11), a las que sigue el Ordenamiento de Alcalá (año 1348), nuestro derecho histórico y tradicional ha seguido sin variación desde entonces hasta nuestros días, más de siete siglos, con la salvedad del Proyecto de 1851 (arts 554, 820 y 821), de marcada tendencia germanista al seguir al Code francés, el sistema romano o de necesidad de aceptación para poder adquirir la herencia. En este mismo sentido, del tenor de la Base $1^{\text {a }}$ de la Ley de Bases de 11 de mayo de 1888 se desprende el propósito de que el Código Civil ha de recoger, con carácter general, en su elaboración, nuestro derecho tradicional.

Centrándonos en el Código Civil, analizando el texto de su articulado, son múltiples y variados los argumentos que, en nuestra opinión, se pueden obtener de él para invocar, con bastante rotundidad, la vigencia en nuestro ordenamiento jurídico del sistema romano de adquisición de la herencia, sin perjuicio de algún precepto que pudiere servir de fundamento para invocar la vigencia del sistema germano. Así:

A) Un primer argumento gira en torno al ius delationis en base a dos ideas:

$1^{\mathrm{a}}$.- la forma de cómo está configurado en nuestro derecho porque entraña o confiere al delado la doble facultad u opción de aceptar o repudiar la herencia. Si la herencia se adquiriese por el solo hecho de la delación sin necesidad de aceptación, como ocurre en el derecho germánico, no se le concedería la opción de aceptar por cuanto ésta sería innecesaria para poder adquirir, sin perjuicio de que tuviese, como en el derecho alemán, la función de ratificar la adquisición ya realizada, y solo tendría sentido la delación para el caso de repudiación.

El llamamiento a la herencia se concibe en nuestro ordenamiento jurídico, no como la atribución provisional o eventual de una titularidad hereditaria que se produce desde el momento del fallecimiento del causante, que se adquiere sin más, y de la que el llamado se puede despojar o desprender después, o dejar sin efecto, repudiando, sino como la facultad que tiene de poder optar entre adquirir y ser heredero, si acepta, o no serlo, si repudia.

Así, dada la función que cumple y tiene encomendado el ius delationis, permite hablar, tanto de la necesidad de aceptar para poder adquirir, como de repudiar para rechazar, la herencia. Lo que no sucede en el sistema germano, donde la repudiación 
solo tiene relevancia a los efectos de manifestar que no se quiere adquirir la herencia al ser innecesaria la aceptación para que tal adquisición se produzca.

$2^{\mathrm{a}}$.- Los presupuestos ${ }^{86}$ tan concretos y precisos que se exigen para la exteriorización y ejercicio del ius delationis (art. 991 y ss CC), y quienes son las personas que están facultadas para aceptar en supuestos especiales (herencia dejada a los pobres, a personas jurídicas, establecimientos públicos oficiales, etc).

El artículo 991, sobre el que se fundamenta el ius delationis en su ejercicio porque establece algunos de los presupuestos precisos para ello, en nuestra opinión, es inexplicable o no tendría cabida en un sistema de adquisición automática como lo es el germano. En este sentido, destaca la práctica ausencia, incluso, casi nula regulación que con este detalle hay en el BGB alemán sobre esta misma cuestión.

B) Siguiendo con el ius delationis pero examinando el régimen jurídico de las declaraciones de aceptación y repudiación, llama la atención el hecho de que el epígrafe de la Sección que encabeza el articulado que le da contenido se denomine así, "De la aceptación y repudiación de la herencia" ${ }^{\text {"7 }}$, lo que, en nuestra opinión, no es muy original porque lo más lógico hubiera sido rubricar dicha Sección con el siguiente epígrafe: "De la adquisición de la herencia"88, habida cuenta de que una y otra declaración del delado giran en torno a la adquisición aunque con significado diferente porque, no solo se trata de la adquisición de la herencia, sino que en él se regulan una y otra declaración relativas a dicha adquisición, sin perjuicio de que luego tengan efectos y consecuencias jurídicas distintas. No obstante, lo que sí es cierto es que el tenor del epígrafe nos da precisamente a entender que son dos las declaraciones que el delado puede emitir acerca de la oferta hereditaria que ha recibido: aceptar o repudiar.

${ }^{86}$ Acerca de los mismos y de su examen, véase más adelante, en este mismo capítulo, el punto número 4-3, al que nos remitimos.

${ }^{87}$ Igual se expresan otros textos legales de nuestro entorno al regular esta materia:

- Code francés: con anterioridad a la reforma introducida por la Ley n ${ }^{\circ} 2006-728$, de 23 junio de 2006, en materia de sucesiones y liberalidades, titulaba su Capítulo V, "De l'acceptation et de la repudiation des successions". Ahora, este Capítulo, que ha pasado al ser el IV, se titula "De l'option de l'heritier", aludiendo a las dos manifestaciones del sucesor.

- Codice italiano (Capítulo V, Título I, del Libro segundo, sobre las sucesiones).

- BGB alemán (Título primero, Sección segunda, del Libro V, sobre derecho sucesorio).

- En nuestro ordenamiento interno, el Capítulo IV, Título I, del Libro Tercero sobre Sucesiones, del Código del Derecho Foral de Aragón.

${ }^{88}$ Así se manifiesta el Título VI de la Ley 10/2008, de 10 de julio, del libro cuarto del Código civil de Cataluña, relativo a las sucesiones. 
Desde otro punto de vista, y en este mismo sentido, la normativa es muy amplia, ya que consta nada menos que de veintidós artículos (del 988 al 1009), estableciendo detalles muy precisos y concretos acerca de los presupuestos y requisitos que han de reunir dichas declaraciones de voluntad en su emisión así como las consecuencias jurídicas que se derivan de las mismas, lo que denota la gran importancia y trascendencia que tienen una y otra.

A propósito de ello, apunta LACRUZ con gran acierto que, "si fuera -como en el derecho alemán- una simple "renuncia al derecho de repudiar", ni los preceptos a ella relativos serían tan detallados, ni el plazo máximo para aceptar o repudiar serían tan largo. A lo que se añade la fuerza retroactiva de la repudiación, cosa inexplicable sin la admisión del sistema romano ...." 89 .

En esta misma línea de argumentación, destaca el gran número de artículos en los que se habla, a la vez, de aceptación y repudiación (arts 988, 989, 990, 991, 992, $993,994,997,1004,1005,1006,1007,1009,1010)$, pero entendemos que no se hace en el sentido de contraponer entre sí, de forma enfrentada, una y otra declaración y sí con un carácter descriptivo o informativo, es decir, de establecer reglas o normas que son de aplicación tanto a una como a otra declaración. Ello, en nuestra opinión, nos está dando a entender, sin entrar en el fondo del asunto a que se refiere cada artículo, que la declaración del sucesor puede consistir en una u otra manifestación.

Decimos esto porque, si se siguiese el sistema germano de adquisición de la herencia, no se estaría hablando constantemente de aceptación y repudiación al no ser necesaria aquella para adquirir, tal y como se observa en el BGB alemán.

C) Un argumento más a favor de la vigencia del sistema romano lo constituye el plazo tan excesivamente largo que se concede para el ejercicio de la delación ${ }^{90} 0$, dicho en otros términos y desde otro punto de vista, tal y como se expresa algún autor $\left(\right.$ ALBALADEJO ${ }^{91}$ ), la inexistencia de un breve plazo para la repudiación.

D) Ya examinando cada una de las dos opciones que entraña el ius delationis en su ejercicio, son varios los argumentos que podemos invocar a favor de la vigencia del sistema romano, tanto a propósito de la aceptación, como de la repudiación:

Así, en lo que se refiere a la primera, a la declaración de aceptación:

${ }^{89}$ Elementos de Derecho Civil. T V. Cit: Pág 38.

${ }^{90}$ En este sentido, nos remitimos al punto número 2-2 del capítulo siguiente donde se analiza la problemática que existe acerca del plazo de que se dispone para el ejercicio del ius delationis.

91 “La adquisición de la herencia en el derecho español”. Cit: Pág 30. 
a) destaca la constante alusión que, de forma tan reiterada, se hace a la misma en diferentes preceptos y de los que se infiere su necesidad y exigencia para poder adquirir la herencia (art 999 y ss CC).

Si la aceptación tuviese el mismo valor o función que en el derecho alemán, no tendría una regulación tan minuciosa y tan detallada, como tampoco se le daría tanta importancia. Ello contrasta con el sistema germano en el que esta declaración, aparte de que no es precisa para adquirir la herencia, la única función, valor o sentido que tiene es la de ratificar la adquisición ya realizada al tiempo que es expresión de renuncia a la repudiación de la herencia.

Desde otro punto de vista y en otro orden de argumentos, llama a atención el hecho de que, aunque del régimen del Código Civil se infiere la necesidad y exigencia de la aceptación para poder adquirir una herencia, no es menos cierto que, después, en consecuencia o coherencia con ello, se muestra preponderantemente favorable a la aceptación desde el momento en que rige un sistema de amplísima libertad de forma por cuanto se facilita su manifestación o exteriorización extraordinariamente al permitir que se pueda realizar de cualquier forma, tanto expresa como tácita, y ya sea verbal o escrita, a diferencia y en contraste con lo que ocurre con la declaración de repudiación que está sujeta a un sistema formalista (art. 1008 CC), y a la exigencia de unos presupuestos $^{92}$ y requisitos ${ }^{93}$ que, en ocasiones, no se dan en la aceptación.

b) Llama la atención la existencia de aquellos casos en los que la aceptación se impone ope legis, por ministerio de la ley, al ser la única opción que se tiene ante la oferta hereditaria desde el momento en que no se contempla en ellos la posibilidad de poder repudiar la herencia deferida, lo que daría lugar a los casos de adquisición ipso iure o automática de la herencia o imposición ex lege de la aceptación ${ }^{94}$ : cuando el sucesor sustrae u oculta algunos efectos de la herencia (art 1002 CC), o se hubiere producido en su contra una interpelación judicial y dejare transcurrir el plazo que le ha señalado el Juez para que manifieste si acepta o repudia (art 1005 CC), o cuando por su culpa o negligencia no se iniciare o concluyere el inventario (art 1018 CC), o cuando habiéndose reservado el derecho de deliberar no manifiesta al Juzgado si acepta o repudia la herencia (art 1019 CC).

92 Acerca de los mismos, nos remitimos al punto 4-2 de este mismo capítulo.

93 Acerca de ellos, nos remitimos al capítulo sexto donde se hace un análisis de los mismos.

${ }^{94}$ A propósito de ello, nos remitimos al punto número 2-6 del capítulo segundo, donde se hace referencia a aquellos casos en que el ius delationis sólo consiste en la posibilidad de poder aceptar la herencia. 
Si la aceptación no fuese necesaria, no se impondría ope legis. Sí podría haber lugar, en su caso, a otras consecuencias jurídicas pero no a dicha imposición.

c) Si no fuese necesaria la aceptación para adquirir la herencia, no se distinguiría, en nuestra opinión, entre aceptación expresa y aceptación tácita (arts 999 y 1000 CC).

Si rigiese el sistema germánico no se entraría a analizar o valorar el significado de dichos actos y entenderlos como equiparables a la aceptación por cuanto la adquisición de la herencia ya se habría producido ipso iure, por ministerio de la ley, en el momento del fallecimiento del causante $y$, en consecuencia, sería irrelevante la realización de los mismos por parte del sucesor porque ya no tendrían ninguna trascendencia jurídica en orden a la efectiva adquisición de la herencia.

Aquí, en cambio, en nuestro ordenamiento, en el régimen del Código Civil, su importancia se pone de relieve en el hecho de que es una de las formas que existen de adquirir la herencia (arts 999 y 1000 CC).

d) La posibilidad de poder aceptar la herencia amparándose en el beneficio de inventario (art. 998 y 1010 y ss CC), entendemos que es una razón más para fundamentar la vigencia del sistema romano porque es una forma de aceptación expresa de la herencia de la que se puede servir aquel sucesor que, desconociendo cual es la situación real de la herencia, se protege de las deudas de la misma y evita así asumir un riesgo o perjuicio en su patrimonio. En contraste a ello, en el derecho alemán se sigue otro sistema en lo que se refiere a la responsabilidad del heredero por las obligaciones del caudal relicto del causante (§ 1967 y ss BGB).

Frente a los argumentos anteriores a propósito de la declaración de aceptación que abundan en la vigencia del sistema romano en nuestro derecho, también nos los encontramos en torno a la declaración de repudiación.

Así, acerca del distinto papel que tiene en uno y otro sistema sucesorio, a diferencia de lo que sucede en el germano, en el que tiene un papel fundamental hasta el punto de que de ella depende la adquisición de la herencia porque tiene la función de dejar sin efecto la adquisición ya realizada con carácter retroactivo al momento de la apertura de la sucesión, por lo que actúa a modo de condición resolutoria de la misma, no sucede lo mismo en el sistema romano porque aquí, en realidad, lo que rechaza el delado es un llamamiento hereditario, no una adquisición que sólo puede tener lugar precisamente a través de la aceptación. 
En el sistema germano, la adquisición de la herencia depende única y exclusivamente de la repudiación porque para adquirir no es preciso aceptar ya que la adquisición se produce por el solo hecho de la delación, mientras que la repudiación tiene la consecuencia de dejar sin efecto tal adquisición. En cambio, en el romano, la adquisición, no solo depende de la declaración aceptación, sin la cual no tendrá lugar, sino también de la de repudiación, porque, si no se quiere adquirir, es preciso manifestarlo de forma expresa y solemne, y, hasta tanto en cuanto no se exteriorice y no haya prescrito el plazo de ejercicio del ius delationis, se podrá aceptar la herencia.

E) Uno de los argumentos de mayor peso, como también el más invocado por la doctrina, para justificar y defender la vigencia del sistema romano de adquisición de la herencia en nuestro ordenamiento jurídico, es el carácter retroactivo que tiene el ius delationis en su ejercicio ya que la declaración del delado produce efectos, no desde el momento en que se emite, sino desde el instante en que se produjo el fallecimiento de aquella persona de cuya sucesión se trate (art. 989 CC; art. 411-5, Ley 10/2008, de sucesiones, de Cataluña; art. 322, del CDFA).

La retroactividad no tiene sentido y es absolutamente inconcebible si la herencia se adquiriere y se es heredero desde el mismo momento en que se produce la muerte del causante, de forma automática, sin necesidad de aceptación, como sucede en el sistema germano, precisamente porque ya se ha adquirido y no hace falta declarar que se acepta. De ahí que, aquí, en el sistema germano, retroacción y adquisición automática, desde el punto de vista de la aceptación, son de todo punto incompatibles, incluso contradictorios e imposibles de armonizar entre sí: la retroactividad no puede existir porque, aunque se acepte, la adquisición ya se ha producido. Y, si se aceptare la herencia, la aceptación no hace más que confirmar la adquisición al tiempo que excluye la posibilidad de poder repudiar. Pero, sí tiene sentido en este sistema la retroacción cuando se trata de la repudiación porque esta declaración tiene el efecto de enervar la adquisición ya realizada, actuando a modo de condición resolutoria de la misma, destruyendo ésta con efectos retroactivos al día de la apertura de la sucesión.

En cambio, en el sistema romano, la retroacción sí tiene sentido y es, hasta cierto punto necesaria e imprescindible porque al manifestar el llamado su voluntad de aceptar, lo lógico es que lo sea no desde el momento en que realiza dicha declaración, sino desde el mismo instante en que se produjo el fallecimiento de aquella persona a quien va a heredar. Como tampoco tiene sentido dejar sin cubrir ese período de interinidad que hay entre el momento del fallecimiento y aquel en que se exterioriza la declaración de aceptar. Lo mismo podemos decir de su voluntad de repudiar. 
Por tanto, al dar el Código Civil, así como las leyes sucesorias de Comunidades Autónomas, a la declaración del llamado efectos retroactivos, demuestra que no se trata de un sistema automático de adquisición sino que tiene la opción de manifiestar su voluntad de ser o no heredero y después se concede a la misma efectos, no desde el momento en que se realiza, sino desde el mismo instante en que surgió la delación.

F) En directa y estrecha relación con lo que acabamos de exponer y como una consecuencia derivada de la misma, surge un nuevo argumento, otro de los más claros y rotundos junto con el anterior, al sentir mayoritario de la doctrina, a favor de la vigencia del sistema romano, cual es la situación de yacencia ${ }^{95}$ en que se encuentra la herencia desde el momento en que se abre el proceso sucesorio mortis causa hasta aquel en que se produce el ejercicio del ius delationis por parte del delado.

La existencia y admisión de esta situación de la herencia en el proceso sucesorio en nuestro ordenamiento no ha planteado ninguna duda, tanto a la doctrina ${ }^{96}$, a excepción hecha de los que defienden la tesis de que nuestro sistema de adquisición de herencia es el germano, como a la jurisprudencia ${ }^{97}$.

${ }^{95}$ En este momento, la herencia, no es ni se la puede considerar como vacante, porque la situación surge a resultas de la inactividad o falta de respuesta del sucesor acerca de la delación que le ha sido deferida al no haber ejercitado aun el ius delationis, pero se está a la espera de que lo haga (STS de 11 de abril de 2000, RJ 2967). El sucesor aun no se ha posicionado acerca de la delación que le ha sido deferida.

Después, esta situación desaparece si la herencia es aceptada, en cuyo caso, se dice que está adida, y si es repudiada, estará vacante, si bien, tanto en uno como en otro caso, una y otra declaración se retrotraen al momento del fallecimiento del causante (arts 989 CC; 411-9, Ley 10/2008, de sucesiones, de Cataluña; 324, del CDF de Aragón), con lo que se borra o desaparece esta situación de interinidad.

${ }^{96}$ Acerca de la misma, con carácter general, entre otros:

CAVANILLAS MÚGICA: Op. cit.: Págs 1003 y ss; HERNANDEZ DÍAZ-AMBRONA: La herencia yacente. Biblioteca de Derecho Privado n ${ }^{\circ}$ 61. J M ${ }^{\mathrm{a}}$ Bosch Editor S.A. Barcelona. 1995; “Algunos aspectos sobre la herencia yacente”. RDP. Junio 2002. Pág 460 y ss; MONJE BALMASEDA: La herencia yacente. Ed Dykinson. Madrid. 2001; ROMERO COLOMA: "En torno a la problemática de la herencia yacente”. RCDI. Año LXXIII. Nov-Dic. 1997. No 643. Pág 2217 y ss; SÁNCHEZ HERNÁNDEZ: La herencia yacente (vertiente personal y patrimonial). Ed Tirant lo Blanch. Valencia. 1997; SILLERO CROVETTO y SÁNCHEZ HERNANDEZ: "La herencia yacente ante los tradicionales y actuales sistemas germánico y romano de adquisición de la herencia”. RDP. Septiembre. 1995.

${ }^{97}$ Así, entre otras muchas: SSTS de 19 octubre 1963 (RJ 4142); 10 noviembre 1981 (RJ 4471); 20 mayo y 20 de septiembre de 1982 (RJ 2585, 4920); 12 de marzo de 1987 (RJ 1435): "la apertura de la sucesión de una persona se abre justamente en el momento de su muerte, en el cual su patrimonio se transmite en herencia yacente, que es aquel patrimonio relicto mientras se mantiene interinamente sin titular, y pasa a los herederos, con efectos desde el fallecimiento del causante, una vez determinado por medio de testamento, o en su defecto mediante la correspondiente declaración de herederos abintestato"; de 20 de marzo y 7 mayo de 1990 (RJ 1711, 3689); 21 de mayo de 1991 (RJ 3779); 31 de enero de 1994 (RJ 1994/643); 11 de abril de 2000 (RJ 2967).

SSAP Valencia, de 30 septiembre 1992, AC 1992/1287; Burgos (Sección 2a), de 14 julio de 1998, AC 1998/6163; Murcia (Sección 5ª), de 17 diciembre de 2002, JUR 2003\113530; Badajoz (Sección 3ª), de 12 diciembre de 2002, JUR 2003\78208; Auto AP Málaga (Sección 5a), de 29 octubre de 2002, JUR 2003\70997; SSAP Barcelona (Sección 16 ), de 22 febrero 2002, JUR 2002\136372: Murcia (Sección 3ª), de 20 febrero de 2002, JUR 2002\116306; Orense (Sección 2ª), de 30 noviembre de 2001, JUR 2002\23178; Las Palmas, de 8 de abril de 2005, JUR $2005 \backslash 132523$. 
Desde el punto de vista legal, y a diferencia de lo que sucede en el derecho italiano ${ }^{98}$ donde sí se regula de forma expresa, no ocurre lo mismo en nuestro Código Civil donde es una situación atípica. Sin embargo, ello no obsta para que en él nos encontremos con varios artículos de los que se puede inferir su admisión y existencia en nuestro derecho ${ }^{99}$.

G) Por último, la existencia del ius transmissionis (art 1006 CC) constituye, en nuestra opinión, una prueba más de la necesidad de que el sucesor necesariamente ha de aceptar o repudiar porque si la adquisición fuere automática sin necesidad de aceptación al fallecimiento del sucesor, se abriría la sucesión de éste pero ya integrado en su caudal hereditario los bienes que él adquirió en la herencia del primer causante de tal manera que los herederos de él, del sucesor, ya no tendrían necesidad de aceptar la herencia del primer causante para poderlos adquirir, como sucede en nuestro derecho, mientras que aquí, según dicho precepto, esa opción de aceptar o

${ }^{98}$ En su Codice civile la herencia yacente se regula a partir del artículo 528, que abre el capítulo octavo, “Dell'eredità giacente”, del Título Primero, Libro Segundo, “Delle successioni”.

99 Así:

a) el artículo 989, en el que se establece la retroactividad de la aceptación o repudiación de la herencia al momento del fallecimiento del causante. Difícilmente se puede hablar de retroactividad de dicha declaración si no existiese esta situación,

b) el artículo 1020, en que se provee, de conformidad con las reglas contenidas en los arts 790 y ss de la LEC, a la administración de la herencia cuando ésta tenga carácter provisional (ex art. 999 CC), o por parte del Juez cuando se ha incoado procedimiento de testamentaría o abintestato sin que haya aceptado el heredero, o durante todo el tiempo de formación del inventario y la deliberación del llamado (art. 1010 CC), hasta la aceptación o repudiación de la herencia,

c) el artículo 1934, que permite la prescripción a favor y en contra de la herencia "antes de haber sido aceptada y durante el tiempo concedido para hacer inventario y para deliberar".

No sucede lo mismo en las leyes sucesorias de Cataluña (art. 411-9, Ley 10/2008, de sucesiones, de Cataluña), o Aragón (art. 324, CDFA), donde, en redacción casi idéntica, se alude de forma expresa a la herencia yacente (en ésta se dice que tiene lugar, “desde la apertura de la sucesión hasta la aceptación del llamado la herencia carece de titular"), al tiempo que se alude a los actos puede realizar el heredero sin haber tomado dicho título ("actos de conservación, defensa y administración ordinaria de la herencia, incluidos la toma de posesión de los bienes y el ejercicio de acciones posesorias", añade la ley de Cataluña), si bien, se deja a salvo, tanto en una como en otra, quem dichos actos, "no implican por ellos mismos aceptación, salvo que con estos actos se tome el título o la calidad de heredero".

Como también se puede deducir de forma implícita su existencia a través de otros textos legales, como es, la Ley Hipotecaria cuando dispone en su artículo 20 párrafo 4 que, "no será necesaria la previa inscripción o anotación a favor de los mandatarios, representantes, liquidadores, albaceas y demás personas que con carácter temporal actúen como órganos de representación y dispongan de intereses ajenos en la forma permitida por las leyes”. O la LEC, que, en su artículo 6.1.4 establece que podrá ser parte en un proceso ante los tribunales civiles, "las masas patrimoniales o los patrimonios separados que carezcan transitoriamente de titular o cuyo titular haya sido privado de sus facultades de disposición y administración”, a lo que añade después en el artículo $7.5^{\circ}$ que, “comparecerán en juicio por medio de quienes, conforme a la ley, las administren”. Lo que viene a resolver ya de manera definitiva cualquier duda que hubiese acerca de la capacidad procesal de la herencia yacente.

Por otro lado, cabe señalar incluso la existencia en nuestro ordenamiento de algunos supuestos concretos que se pueden calificar de yacencia forzosa, como es el de la vocación sucesoria cuando esté sometida a condición suspensiva mientras esté en situación jurídica de pendencia, o cuando el heredero sea desconocido o se encuentre en ignorado paradero, o se suscite contienda judicial acerca del título o condición de heredero, o se haya ordenado la institución a favor de persona determinable pero aun no determinada (ROMERO COLOMA: Op. cit.: Pág 2219). 
repudiar pasa a sus sucesores para que hagan suya dicha declaración y puedan adquirir los bienes objeto de transmisión. En este sentido, en el derecho alemán, si el sucesor fallece antes de que transcurra el plazo para poder repudiar, este derecho pasa a sus herederos ( $§ 1952$ BGB), pero no hace falta que acepten la herencia del primer causante.

En contraste al régimen del Código Civil, la única, si no excepción, sí peculiaridad con la que nos encontramos es en el derecho foral de Navarra (Ley 315, párrafo $2^{\circ}$, de la CDCFN), en el que la herencia se entiende adquirida de manera provisional por el heredero desde el momento del fallecimiento del causante, pero con derecho a renunciarla o a aceptarla, lo que es una confirmación de la adquisición, por lo que, cuando se acepta, no hay propiamente una retroacción sino una ratificación de dicha adquisición, lo que es semejante al sistema germano.

Todo lo anterior, viene a corroborar la voluntad, podríamos decir incluso inequívoca, del legislador favorable a la vigencia del sistema romano en nuestro ordenamiento jurídico y que hacemos nuestra en base a los argumentos invocados.

Desde el punto de vista doctrinal, numerosos civilistas entienden que el sistema de adquisición de herencia más acorde con la regulación que se contiene en el Código Civil es el romano.

Así, para ROCA SASTRE ${ }^{100}$, que es, según ya hemos apuntado, uno de los más fervientes defensores de su vigencia en nuestro derecho, entiende que es el sistema que sigue o adopta el Código Civil, si bien con alguna impureza porque, "parece seguir el mismo sistema que el Código de Napoleón o el alemán y suizo, pero en el fondo no es así. Una mayor influencia del Derecho romano y la falta de precedentes consolidados de la saisine germánica han sido seguramente la causa de que los codificadores no quisieran seguir la orientación francesa imperante, de modo que se da el caso curioso de que con materiales legislativos algo semejantes, la doctrina es distinta en España que en Francia en punto al modo de adquisición hereditaria".

De igual manera, DíEZ-PICAZO y GULLÓN BALLESTEROS ${ }^{101}$, entienden que "nuestro sistema sigue básicamente las líneas del romano, no hay adquisición ipso iure de la herencia con poder de repudiación, sino poder de aceptarla o repudiarla".

100 “La adquisición y la repudiación de la herencia en el derecho común y en el derecho foral”. Cit: Pág 14 y ss.

${ }^{101}$ Sistema de Derecho Civil. Vol. IV. Cit: Pág 335. 
También VALLET DE GOYTISOLO ${ }^{102}$, con apoyo en la retroacción que otorga a las declaraciones del sucesor el artículo 989 CC, o el tenor del 991 CC, en base a los requisitos que exige para aceptar o repudiar. En igual sentido, PUIG BRUTAU ${ }^{103}$, quien se muestra partidario del sistema romano con apoyo en la literalidad de los artículos 988, 989, 998 y 1034 CC, LACRUZ ${ }^{104}$, o ALBALADEJO ${ }^{105}$.

MANRESA ${ }^{106}$, en cambio, mantiene una posición intermedia entre el sistema romano y germano al decir que: “.... de estos artículos -se refiere a los 657, 440, 988 y 989-, se deduce la doctrina de nuestro Código. Acogiendo un sistema mixto, considera necesaria la aceptación, pero retrotrae sus efectos al momento de la muerte del causante. La repudiación es una renuncia a la herencia solamente deferida, presumiéndose que no ha existido nunca llamamiento".

La jurisprudencia, por su parte, es proclive en proclamar la vigencia del sistema romanista, lo que se observa, tanto en el Tribunal Supremo ${ }^{107}$, como en las Audiencias Provinciales ${ }^{108}$, si bien, se puede ver en aquel sentencias que defienden la vigencia del sistema germano, o en la Dirección General de los Registros y del Notariado ${ }^{109}$, que se muestra también favorable a la vigencia del sistema romano de adquisición de la herencia en nuestro derecho.

${ }^{102}$ Panorama del Derecho de Sucesiones. II. Cit: Pág 424.

${ }^{103}$ Fundamentos de Derecho Civil. T. V. Vol $1^{\circ}$. Cit: Pág 159 y ss.

${ }^{104}$ Elementos de Derecho Civil. V. Cit: Pág 37.

105 "La adquisición de la herencia en el derecho español”. Cit: Págs 6, 10, 28 (aquí destaca como argumentos a favor de la adquisición por aceptación: el ius delationis, la retroactividad de la aceptación y la inexistencia de un breve plazo para la repudiación).

También en Comentarios al Código Civil ....... T XII. Vol 2º Cit: Pág 61 y ss, invoca varios argumentos a favor de que la herencia se adquiere por la aceptación.

${ }^{106}$ Op. cit.: Pág 343.

${ }^{107}$ Así, entre otras muchas: SSTS 25 de junio de 1946; 19 de noviembre de 1956 (RJ 4116); 5 de julio y 29 de noviembre de 1958; 12 de mayo de 1960 (RJ 2039); 19 de octubre de 1963 (RJ 4142); 10 de noviembre de 1981 (RJ 4471); 20 de mayo y 15 de junio de 1982 (RJ 2585 y 3426); 11 de noviembre de 1994 (RJ 8468); 27 de junio de 2000 (RJ 5909).

En ésta última sentencia, una de las más recientes, se afirma de manera expresa (Fdto Dcho $2^{\circ}$ ), lo siguiente: "En materia de adquisición de herencia, y con relación al régimen sucesorio del Código Civil, resulta incuestionable que rige el denominado sistema romano caracterizado porque no basta la delación hereditaria (apertura, vocación y delación) para ser titular del derecho hereditario, sino que además es preciso que el heredero acepte la herencia, lo que puede efectuarse de forma expresa o bien tácita. Producida la delación, el heredero -el llamado a heredar en concreto-, como titular del «ius delationis», puede aceptar o repudiar la herencia, pero en tanto no acepte, como se ha dicho, no responde de las deudas de la herencia, porque todavía no se produjo la sucesión -no es sucesor, sino sólo llamado a suceder-. Si acepta responderá incluso con sus propios bienes, salvo que la aceptación expresa tenga lugar con arreglo a lo prevenido para disfrutar del beneficio de inventario".

${ }^{108}$ SSAP Ciudad Real, 30 de junio de 1994 (AC 1061), Burgos, 14 de julio de 1998 (AC 6163); Asturias, 10 de junio de 1999 (AC 6058) y 28 de junio de 2001 (AC 2026); Cáceres, 26 de abril de 2001 (JUR 171113); Madrid, de 23 de abril de 2004 (AC 1718); Asturias, $n^{\circ}$ 226/2005 (Sección 5a), de 13 junio (JUR 2005\154580); Madrid, nº 260/2005 (Sección 11ª), de 9 junio (JUR 2005\173187).

${ }^{109}$ Así, entre otras, como más reciente, RDGRN de 3 de febrero de 1997, RJ 853. 


\section{Sistema de adquisición de los legados.}

No obstante todo lo anterior, hay que puntualizar que lo dicho hasta aquí hemos de entenderlo referido al sistema de adquisición que rige cuando se trata de llamamientos hechos a título universal porque la cuestión que se plantea es si se puede aplicar a los llamamientos hechos a título particular.

Acerca del ejercicio del ius delationis en materia de legados, llama la atención, como ha puesto de relieve la doctrina en reiteradas ocasiones, la ausencia en el Código Civil de preceptos referidos a ello, salvo los artículos 888, 889 y 890, que sí hablan de aceptar y repudiar, porque, el artículo 988 y siguientes, relativos a la aceptación y a la repudiación, tal y como se rubrica la Sección que lo encabeza, se refiere a la herencia, de lo que se puede deducir, en principio, que dicha normativa sólo sería aplicable a los llamamientos hechos a título universal.

SÁNCHEZ ROMÁN ${ }^{110}$, así lo entendió porque para él, los artículos 988 a 1009 del Código Civil se refieren solo a la herencia y no a los legados, "cuya aceptación y renuncia se regulan por las disposiciones especiales de los artículos 888, 889 y 890", si bien, en lo que se refiere a la forma, entiende que tendrá que ser expresa, pero no solemne.

De igual manera piensa OSSORIO MORALES ${ }^{111}$, pero no da razones que lo justifiquen, y entiende que la Sección a la que dan contenido dichos artículos, se refiere solo a la herencia, no pudiendo ser aplicable a los legados, si bien admite que, como nadie puede ser legatario contra su voluntad, los legados son renunciables.

Tambien DÍEZ-PICAZO ${ }^{112}$ entiende que las normas del Código Civil relativas a la aceptación y repudiación de la herencia no son aplicables a los legados, silencio, que, para él, "es intencionado pues en otros temas importantes siempre se preocupa por extender al legatario el régimen que establece para el heredero (arts 794 y ss, 789, 987, etc)". Ahora bien, "aunque el Código sólo dedica a la aceptación y repudiación de los legados preceptos fragmentarios, pueden sin dificultad considerarse aplicables por analogía, en concepto de supletorios, los dictados en relación con la herencia que no se refieran a la capacidad o forma de manifestar estas declaraciones de voluntad". Pero, no dice por qué.

\footnotetext{
110 Op. cit.: Pág 1326.

${ }^{111}$ Manual de Sucesión Testada. Instituto de Estudios Políticos. Madrid. 1957. Pág 362.

112 Sistema de Derecho Civil. Vol. IV. Cit: Págs 431 y 432.
} 
En cambio, ALBALADEJO ${ }^{113}$, siguiendo a $\mathrm{GANGI}^{114}$, se muestra partidario de la aplicación analógica de los referidos preceptos (art. 988 y ss CC), en cuanto lo permita la diversidad del objeto de ambas formas de suceder y, particularmente, lo relativo a la retroacción de los efectos de la aceptación, o repudiación, al tiempo de la apertura de la sucesión. Así, cita como aplicables en materia de legados, los artículos 989, 990, $991,997,999,1000,1001,1005$, y en lo que se refiere a la capacidad, entiende que debe de regirse, según él, por la exigida para aceptar donaciones.

En nuestra opinión, cierto es que la regulación en el Código Civil en este punto deja bastante que desear porque no nos dice de manera expresa si es precisa la aceptación para su adquisición, como tampoco si, en el caso de su repudiación, es o no aplicable la norma del artículo $1008^{115}$. Pero, no es menos cierto que, aunque se trata de una forma de suceder que es distinta a la sucesión universal o a título de heredero, el del legatario es un derecho que emana o procede de la herencia y, además, de la directa voluntad del causante, al igual que cuando se trata de un llamamiento voluntario, por lo que, sin perjuicio de las diferencias que hay entre uno y otro título sucesorio y de la respectiva forma de suceder, entendemos que las normas contenidas en los artículos 988 a 1009 pueden ser, en su caso, aplicables a los legados, por vía analógica, con carácter supletorio, en todo aquello que éstos no estén especial y expresamente regulados, y además, siempre que no haya una disposición expresa que impida o prohíba su aplicación a los mismos, o sea contraria a dicha aplicación, o se trate de alguna disposición que sea de específica aplicación a una u otra forma de suceder como ocurre, según veremos a continuación, a propósito de la adquisición (art. 881 y concordantes del Código Civil).

Acerca del sistema que rige en nuestro ordenamiento en relación a los legados, del tenor de los artículos 881, 882, 883, 885 y 888, parece deducirse que el legatario capaz, cuando se trata de legados puros y simples ${ }^{116}$, adquiere el legado sin

${ }^{113}$ Comentarios al Código Civil y Compilaciones Forales. T XII. Vol 1º. Arts 858 a 891 del Código Civil. EDERSA. Madrid. 1981. Pág 388 y ss.

${ }^{114}$ I legati nel diritto civile italiano con riguardo alla giurisprudenza, al diritto romano ed alle moderne legislación. Parte generale. Vol 1. 2a Ed. Padova. CEDAM. 1933. Pág 299.

${ }^{115}$ En relación a ello, nos remitimos al punto número 2 del capítulo sexto, donde, al tratar de los requisitos que se exigen de manera objetiva para la repudiación, examinamos la observancia de la forma en la declaración, tanto en los llamamientos a título universal como a título particular.

${ }^{116}$ En el caso de que se tratare de legados sometidos a condición suspensiva, habrá que estar o esperar a su cumplimiento (art. 759 CC) para que dicha adquisición se produzca, como también, en su caso, su repudiación o aceptación por parte del legatario. No sucede lo mismo si se trata de legados que hubieren sido instituidos bajo término suspensivo porque, en ellos, de conformidad con el artículo 799 CC, al haber certeza de que el término va a llegar, no solo se podrá repudiar, o aceptar, antes de que éste se cumpla, sino que, si falleciere el legatario antes de que se verifique su cumplimiento, no habrá impedimento para que adquiera derecho al legado y lo transmita a sus herederos. 
necesidad de aceptación, de manera automática, por ministerio de la ley, desde el mismo momento en que se hubiere producido el fallecimiento del causante, salvo que lo repudie, que así tendrá que hacer si no quiere dicho legado para evitar que se produzca la adquisición del mismo, repudiación que, por otro lado, no podrá hacer en el caso de que lo haya aceptado, ya sea de forma expresa o tácita ${ }^{117}$.

La cuestión que planteamos puede parecer vanal, o la podríamos obviar, pero entendemos que tiene interés precisamente por razón de la importancia que en estas adquisiciones mortis causa tiene la declaración de repudio que es análoga en su función a la que tiene en el sistema germano.

Así, dado el régimen del Código Civil, la aceptación no es necesaria para adquirir el legado pero, si se hace, no sólo confirma la adquisición ya realizada y que tuvo lugar, de manera provisional, en el momento de producirse la apertura de la sucesión, sino que automáticamente se excluye la posibilidad de poderlo repudiar. Mientras que, la repudiación, no solo se precisa para rechazar el legado, sino que es necesaria para evitar que se suponga aceptado y porque destruye con efecto retroactivo, al momento de abrirse la sucesión, la adquisición realizada.

La adquisición hay que entenderla como automática en el sentido de que es instantánea a la muerte, o que tiene lugar acto seguido a que ésta se haya producido, sin necesidad de aceptar, lo que no quiere decir que sea definitiva porque el legatario siempre tendrá la posibilidad de poder repudiar, en tanto en cuanto no la haya aceptado antes, expresa o tácitamente. En este sentido, apunta GUTIERREZ JEREZ $^{118}$, que habría que hablar, más bien, de una adquisición preventiva porque nos encontramos ante una situación jurídica transitoria, o de pendencia, supeditada, o que está a la espera de su posible repudiación, o en su caso, aunque no sea necesaria para adquirir, de aceptación expresa.

De ahí que, por un lado, si el legatario no acepta de forma expresa, o tácita, el legado deferido a su favor, la adquisición se produciría "si no lo repudia antes de que se extinga el derecho que la ley le concede como base de la delación hereditaria: el derecho a repudiar para no adquirir, que denominamos ius repudandi" (GUTIERREZ

117 Esta ausencia de claridad, contrasta con otros Códigos, como es el italiano, el cual, en su artículo 649, manifiesta que, "el legado se adquiere sin necesidad de aceptación salvo la facultad de repudiar".

118 “La adquisición y la renuncia de los legados”. En Libro-Homenaje al profesor Manuel Albaladejo García. T I. Colegio de Registradores de la Propiedad y Mercantiles de España. Servicio de Publicaciones. Universidad de Murcia. 2004. Pág 2325. 
JEREZ ${ }^{119}$ ) y, por otro, pero en sentido inverso, podrá repudiar el legado siempre y cuando no lo haya aceptado previamente, o no haya prescrito el plazo de que dispone el legatario para poder ejercer el ius repudiandi.

El ius delationis, así, en el caso de los legados ${ }^{120}$, sería una delación atípica porque se trataría de un derecho que solo tiene un sentido, el negativo, ius repudiandi, o como dice GUTIERREZ JEREZ ${ }^{121}$, "un derecho a repudiar para no adquirir", quien defiende la existencia de un verdadero ius delationis en el legado aunque solo sea materializado en el ius repudiandi, porque solo consiste, o atribuye al legatario, la posibilidad de repudiar ya que la declaración de aceptación es innecesaria para que tenga lugar la adquisición de legado, sin perjuicio de que, aun así, se quiera manifestar por su parte dicha aceptación para confirmar la adquisición ya realizada.

Sin embargo, no faltan autores en nuestra doctrina que, en su opinión, existe una aceptación presunta del legado por entender que, "el legado se adquiere sin necesidad de aceptación porque ésta se presume" (SÁNCHEZ ROMÁN ${ }^{122}$ ), a lo que GARCÍA RUBIO ${ }^{123}$, contesta manifestando que no está justificado hablar de una aceptación presunta, en primer lugar, "por la inexistencia en nuestro derecho sucesorio de un tercer tipo de aceptación que pudiera colocarse al lado de la expresa y la tácita" y, en segundo lugar, "porque se basa en un sofisma según el cual la falta de renuncia al legado implica la aceptación del mismo, cuando en realidad es una circunstancia puramente negativa a la que, en principio, no se le atribuye valor negocial alguno".

De igual opinión a SANCHEZ ROMÁN es GUTIERREZ JEREZ ${ }^{124}$, para quien, "al tratarse de una disposición particular, al legatario le basta para adquirir la no repudiación libre y consciente durante un plazo determinado: el correspondiente a la acción para reclamar su derecho", lo que le lleva a decir que estaríamos también ante un supuesto de "aceptación presunta con efectos definitivos".

119 Op. cit.: Pág 2324.

${ }^{120}$ Dentro de la doctrina española se ha discutido la existencia y aplicación del ius delatonis en los legados: JORDANO FRAGA (La sucesión en el ius delatonis. ........ Cit: Pág 347), lo admite, otros, como ALBALADEJO (Curso de Derecho Civil. T. V. Cit: Pág 48), lo niegan, en el sentido de que al producirse una adquisición automática del legado, nos aleja de la delación en su sentido más puro. Aunque, él mismo habla de adquisición provisional para referirse a la que corresponde al legatario.

${ }^{121}$ Op. cit.: Pág 2322. Después, en página 2324, manifiesta, siguiendo a JORDANO FRAGA, que la repudiación del legado no implica una renuncia como acto dispositivo al ius delationis, sino el ejercicio negativo de esa delación.

${ }^{122}$ Op. cit.: Pág 1250.

${ }^{123}$ La distribución de toda la herencia en legados (un supuesto de herencia sin heredero). Universidad de León. Servicio de Publicaciones. Ed. CIVITAS S.A. 1989. Pág 153.

${ }^{124}$ Op. cit.: Pág 2324. 
Ahora bien, sí será necesario o se exigirá que la aceptación del legado se haga de forma expresa cuando se quiera o se trate de una aceptación parcial del mismo ${ }^{125}$, que aquí sí se permite a diferencia de la sucesión a título universal o de heredero (arts 889 y 890 CC). Y, por otro lado, si no es necesaria la aceptación por parte del legatario de la cosa legada para que se produzca la adquisición de la misma, sí lo es, en cambio, la entrega del legado (arts. 882, 883, 885, 886, $1025 \mathrm{CC})^{126}$, pero que actúa, no a modo de requisito esencial para que se produzca la adquisición, sino como complementario para la efectividad del legado ${ }^{127}$.

A la repudiación del legado se refiere el artículo 888 del Código Civil al señalarlo como uno de los supuestos en que no tiene efecto, al tiempo que determina cuáles son las consecuencias que de ello se derivan. Sin embargo, en él no se emplea de forma expresa el término repudio, sino que dice: "el legatario no quiera .... admitir el legado", expresión que plantea el interrogante de cual es su significado y que, en nuestra opinión, hemos de entender en el sentido de repudiación, o ejercicio del ius repudiandi, porque si lo que verdaderamente quiere el legatario es no admitir, o no aceptar, el legado y desentenderse de él, lo que tiene que hacer es repudiarlo. Después, los dos siguientes artículos, 889 y 890, también se refieren al repudio de un legado, si bien, en ellos ya se emplea de forma expresa dicho término.

En definitiva, la adquisición de un legado, al decir del sentir mayoritario de la doctrina y el nuestro, se asemeja o coincide básicamente con el sistema sucesorio germano, de adquisición ipso iure, porque no hace falta la aceptación por parte del legatario para que se produzca la adquisición del legado, sino que ésta tiene lugar por el solo hecho de la delación, desde el mismo momento de la muerte del testador (art. $881 \mathrm{CC}$ ), lo que no obsta para que se pueda repuair por el legatario y sin perjuicio, por otro lado, de la necesidad de entrega por parte del heredero ${ }^{128}$. En este precepto, el

125 Véase en este sentido, el punto número 2-2 del capítulo cuarto, donde, al tratar de la indivisibilidad de la declaración del delado desde el punto de vista del objeto, se hace una alusión a la misma en relación a los legados.

${ }^{126}$ No obstante, existen numerosos supuestos en que quiebra la necesidad de entrega como es, aquel en que el legatario ya posee la cosa legada con anterioridad a la muerte del causante, en cuyo caso no será necesario el hecho o acto material de la entrega de la cosa legada (STS 3 de junio de 1967 -RJ 2982-); que sea el propio testador quien autorice al legatario a tomar posesión por sí mismo de la cosa legada (STS 26 de octubre de 1928; Res DGRN de 19 de noviembre de 1952 -RJ 2816-; 25 de mayo de 1971 -RJ 3402-); por existir conflicto de intereses o contienda judicial entre los herederos a cerca de la herencia, el legatario puede pedir del Juez la entrega ejerciendo las acciones legales pertinentes (STS 30 de noviembre de 1990 -RJ 9220-); cuando el legado se ordena en pago de la legítima y el heredero ha sido instituido en cosa cierta y determinada (SAP Asturias n 280/2001, de 16 mayo -JUR 2001\213665-).

127 RDGRN de 19 de mayo de 1947, RJ 1044; SAP Asturias nº 162/2001 (Sección 6 6), de 22 marzo (AC 2001\638).

${ }^{128}$ Vid, a propósito de la entrega de un legado, la Res DGRN de 13 de abril de 2009 (BOE nº 109, de 5 de mayo de 2009). 
artículo 881, es muy reveladora la expresión que en él se contiene de que el legatario “.... adquiere derecho ...." ${ }^{129}$, porque no se emplea a propósito de las adquisiciones a título universal donde se habla de aceptación o repudiación (cfr art 988 y ss CC). No dice que sea precisa la aceptación para que se produzca la adquisición, a diferencia de lo que sucede en las que tienen lugar a título universal. Lo que viene a significar que, ya desde el mismo momento del fallecimiento del causante tiene una titularidad concreta sobre lo que se le legó y que le faculta, además, para pedir su entrega al heredero o al albacea (art. 885 CC). Como tampoco, para pedir la entrega, el artículo exige que, previamente, se tenga que haber aceptado el legado.

Ello se corrobora por la circunstancia de que, en el caso de que el legatario falleciere sin haber adquirido el legado, siendo éste puro, según el tenor del artículo $881 \mathrm{CC}$, lo "transmite" a sus herederos, pero no como legado del testador, sino, como apunta ALBALADEJO ${ }^{130}$, como bien que ya forma parte de la herencia que el legatario deja a sus sucesores.

Y, desde el punto de vista formal, la declaración de repudiación del legatario se ha de realizar de forma solemne porque, en nuestra opinión, según veremos más adelante $^{131}$, ha de estar sujeto a la norma del artículo 1008 CC.

\section{4.- LA ACEPTACIÓN DE LA HERENCIA.}

\section{4-1.- Concepto.}

Aunque el objeto de nuestra tesis es la declaración de repudiación de la herencia, ello no obsta para que nos detengamos, siquiera de forma breve, en su antítesis, la aceptación, dado que sin ella, en nuestro ordenamiento jurídico, no hay adquisición de la herencia al seguirse el sistema romano. Además, una y otra

${ }^{129}$ Esta expresión viene a superar la distinción proveniente del Derecho romano, de "dies legati cedit a morte testatoris" o "dies cedens", y "dies legati venit adita hereditate" o "dies veniens". Aquel, expresaba el momento en que nacía el derecho a adquirir el legado que lo era al fallecer el testador, y éste, el momento de la adición de la herencia por el heredero instituido y se adquiría el legado.

Esta distinción era consecuencia de la exigencia de que, para adquirir el legado, era preciso que el instituído heredero hubiese aceptado la herencia, pues solo eran eficaces las disposiciones testamentarias, y entre ellas los legados, desde que aquel era heredero, y no lo era, sin la aceptación. Sin embargo, hoy, en el derecho moderno, al no ser ya precisa la aceptación de la herencia para que tengan vigor las disposiciones testamentarias ordenadas por el causante, ya no tiene sentido seguir manteniendo esa distinción (Vid: ALBALADEJO: Comentarios al Código Civil .......... T XII. Vol 1º. Cit: Pág 275; GUTIERREZ JEREZ, Op. cit.: pág 2317).

${ }^{130}$ Comentarios al Código Civil .......... T XII. Vol 1º . Cit: Pág 277.

131 En este sentido, nos remitimos al punto número 2 del capítulo sexto, donde examinamos la observancia de la forma en la declaración, tanto en los llamamientos a título universal como a título particular. 
declaración, repudio y aceptación, comparten caracteres, salvo alguna diferencia que separa a aquella de ésta en cuanto a la forma, y los presupuestos precisos para su ejercicio, como ahora veremos.

Son muy variadas las definiciones que ha dado la doctrina a propósito de la aceptación de la herencia porque dependen del diferente criterio o punto de vista que se adopte, al igual que sucede, como luego veremos, con la repudiación.

En nuestra opinión, es "aquel acto en virtud del cual el llamado a la herencia entra a formar parte del proceso sucesorio mortis causa, adquiere el título o condición de heredero y, con ello, los bienes, porción o cuota a que hubiere sido llamado, al tiempo que excluye o rechaza la posibilidad de poder repudiar"132.

Esta será, efectivamente, la intención deliberada, consciente y directa del delado cuando dice que acepta: adquirir la herencia, la condición o título de heredero, así como aquella porción o cuota de bienes del causante a que ha sido llamado. $\mathrm{Y}$, además, no solo lo dice de forma expresa, sino que lo hace con el propósito conseguir esa finalidad. La declaración de aceptación tiene así la función de permitir que el delado se posicione frente a la herencia y se incorpore a ella como sujeto activo de la misma ya con la condición de heredero del causante.

Pero, la declaración de aceptación de la herencia no solo es posible realizarla de forma expresa, sino que también se puede manifestar a través de una conducta, un comportamiento, o la comisión de un acto cuya ejecución no se puede realizar si no se tiene, previamente, el título o condición de heredero, o a través de él, y, como éste no se tiene, dicha ejecución implica de forma implícita, o viene a significar, por razón de la naturaleza y trascendencia del acto, la intención, presunta o indirecta, a la vez que, en muchas ocasiones, involuntaria, por parte del delado, de adquirir la herencia porque no sea esa su intención deliberada y consciente cuando lo realiza, dando lugar así a los llamados supuestos de aceptación tácita, de cuyo examen nos ocuparemos más adelante al examinar las clases de aceptación.

132 No obstante, hay otros efectos o consecuencias jurídicas de los que nos ocuparemos, más adelante, en este mismo capítulo, en el punto 4-4, al exponer cuales con los efectos de la aceptación.

Definición que no sería la misma si hubiésemos de referirla al sistema germano por cuanto, en él, la declaración de aceptación tiene un sentido, una función y un significado diferente. Así, se puede entender como tal: “aquella declaración de voluntad por medio de la cual, el ya heredero, confirma o ratifica la adquisición ya realizada en el momento de la apertura de la sucesión y excluye la posibilidad de repudiar por lo que es, al mismo tiempo, expresión de una renuncia a la repudiación”. 


\section{4-2.- Presupuestos.}

El ius delationis exige, con carácter previo a su ejercicio y para que éste después pueda tener lugar, de forma inexcusable, la concurrencia, o cumplimiento, de una serie de presupuestos, que podemos clasificar en objetivos y subjetivos, que, además, unos y otros, se han de cumplir de forma conjunta o simultánea.

\section{4-2-1.- Objetivos.}

Los llamamos así porque son ajenos o externos a la persona del delado ya que no dependen de él, tanto en el hecho de su producción, como porque tienen lugar o se manifiestan fuera del círculo o ámbito de su esfera personal o particular y, además, se predican con carácter general respecto de todo sucesor.

A ellos se refiere el artículo 991 del Código Civil, que confirma los precedentes de nuestro derecho histórico ${ }^{133}$ en este punto, y que son: el hecho del fallecimiento de la persona de cuya sucesión se trate y la existencia de una vocación sucesoria.

\section{4-2-1-1.- El hecho de la muerte del causante.}

Es preciso que la persona de cuya sucesión se trate haya fallecido. No existe proceso sucesorio mortis causa ${ }^{134}$, sino desde el momento en que tiene lugar la muerte de la persona, o se emite, en su caso, el auto judicial de declaración de su fallecimiento por parte del Juez (art. 196 CC).

${ }^{133}$ Así: Digesto, Libro 29, Título 2, Ley 19; Partidas 6, 6, 14; artículo 823 del Proyecto de 1851; artículo 1001 del Anteproyecto, del que es copia literal (STS de 31 de mayo de 1930 -RJ 1834-).

${ }^{134}$ No obstante, acerca del mismo, en lo que no se pone de acuerdo la doctrina es en establecer cuales son las fases, etapas o momentos que se desarrollan en su desenvolvimiento ya que incluso pueden variar según el diferente sistema sucesorio ante el que estemos. Así:

LACRUZ BERDEJO (Elementos de Derecho Civil. T V. Cit: Pág 35 y ss), excluye de la sucesión, en sentido estricto, la liquidación, división y adjudicación de la herencia, y entiende que el proceso sucesorio está formado por las siguientes fases: a) apertura de la sucesión, b) vocación a la herencia, c) delación de la herencia y, d) adquisición o investidura. en el mismo sentido ALBALADEJO y DÍEZPICAZO.

En opinión de CASTÁN TOBEÑAS (Derecho Civil Español Común y Foral. T. VI. Vol 1. Cit: Pág 130 y ss), la sucesión comprende las siguientes fases: a) la apertura de la sucesión, b) delación o vocación de la herencia, c) la opción o decisión del heredero y, d) la adquisición de la herencia.

Según ROCA SASTRE (“La designación, la vocación y la delación sucesorias”. Estudios sobre Sucesiones. Madrid. Instituto de España. 1981. Pág 132): el fenómeno sucesorio se desenvuelve a través de dos fases: la primera, de carácter transitorio, se abre con la delación y da lugar a la situación de herencia deferida, y la segunda, de carácter definitivo, se abre con la aceptación, dando lugar a la situación de herencia o sucesión adquirida, con la que queda consumado dicho proceso sucesorio. A ello añade, como presupuesto necesario para que aquella se produzca, que tenga lugar la previa designación o determinación del heredero. Por lo que, la delación presupone la vocación y ésta, la designación. 
Es el momento en el que coinciden todos los ordenamientos jurídicos actuales, también la doctrina y el Tribunal Supremo ${ }^{135}$, al señalar tal circunstancia como el punto de partida o arranque de la sucesión mortis causa ${ }^{136}$.

Así, vida de la persona, no existe otra cosa más que su patrimonio y es a partir de la muerte cuando ya se puede hablar, en sentido propio y jurídico, de sucesión mortis causa. Ya la propia expresión lo dice, sucesión por causa o derivación de la muerte.

Tampoco hasta este instante se podrá hablar de herencia ${ }^{137}$, o de vocación, o de delación, por lo que, en consecuencia, el ius delationis no nace ni existe, sino desde ese momento y, sólo desde este instante, se podrá aceptar o repudiar la herencia por parte del delado ${ }^{138}$.

Sin embargo, desde el punto de vista legal, el Código Civil solo dice de forma expresa que sea la muerte el momento de la apertura de la sucesión a propósito de la declaración de fallecimiento (art. 196 CC). No así cuando trata de las sucesiones en el Título III del Libro III, que, en nuestra opinión, sería, lógicamente, el lugar más idóneo y apropiado para ello por ser la sede de su régimen jurídico a partir del artículo 657,

135 En este sentido, es doctrina abundante y reiterada, que el momento en que se produce la transmisión mortis causa de los bienes al heredero lo es la muerte del causante siendo éste y no otro, ni antes, el instante en que se produce la apertura de la sucesión.

Valga, entre otras muchas, la STS de 7 de mayo de 1990 -RJ 3689-, que cita otras anteriores sobre esta misma cuestión, y manifiesta lo siguiente: “como tiene declarado esta Sala en Sentencias de 19 de octubre de 1963 (RJ 1963\4142) y 25 de junio de 1965 (RJ 1965।3939), tales preceptos (artículos 657, 658, 659 y 661 del Código Civil) vienen a señalar el momento en que la sucesión se transmite con referencia al heredero, dado que, como pone de manifiesto la Sentencia de 12 de marzo de 1987 (RJ 1987\1435), la apertura de la sucesión de una persona se abre justamente en el momento de su muerte".

${ }^{136}$ Así se infiere de los artículos 657, 661, 758, 991 CC; si bien, en Aragón -art. 321.1 CDFA-, y Cataluña -art. 411-5, Ley 10/2008-, se dice de forma expresa.

${ }^{137}$ Precisamente, respecto de ella, no se pude saber cual es su composición y elementos que la componen si no es a partir del momento en que se produce el hecho del fallecimiento, que es el instante en que se conoce y se puede determinar con precisión cual es el patrimonio que el de cuius deja a sus sucesores a los efectos de establecer el contenido de aquella. Ni tan siquiera en vida de una persona se puede saber qué bienes son los que forman, o van a formar, parte de la misma (cfr art. 659 CC). Se ignora cual va a ser el contenido del derecho sucesorio de cada sucesor. Incluso existirán algunos derechos, titularidades y contratos que son intransmisibles por cuanto se extinguirán a resultas de la defunción.

Luego, mal o difícilmente se puede hablar, en vida de una persona, de sucesión mortis causa, porque sería un contrasentido, de herencia, y menos aun de ejercer el ius delationis por parte del llamado porque éste aun no ha nacido y por falta del objeto a que se refiere. Ya dijeron los clásicos: “viventi nulla est hereditas", o "viventis non datur hereditas".

Incluso GAYO (D. 50.16.24) definió la herencia del siguiente modo: "Nihil est aliud hereditas quam successio in universum ius quod defunctus habuit" -la herencia no es otra cosa que la sucesión en todo el derecho que el difunto tuvo-. En igual sentido, JULIANO (D. 50.17.62).

${ }^{138}$ De ahí que, en vida del causante, el futuro legitimario carece de legitimación activa para poder impugnar, en su caso, aquellos actos que aquel hiciere y que perjudicaren sus derechos legitimarios por cuanto "la condición de heredero exige para su consolidación que se produzca el fallecimiento del causante” (STS 28 de febrero de 2004, RJ 1447). También publicada en Diario LA LEY, AÑO XXV. Número 6010. Martes, 4 de mayo de 2004. 
aunque sí dice en éste que, "los derechos a la sucesión de una persona se transmiten desde el momento de su muerte"139. De ello se desprende que es el hecho de la muerte la circunstancia que determina la apertura del proceso sucesorio mortis causa, como también se alude a ella en otros muchos artículos para la determinación de los derechos que surgen a propósito o como consecuencia de la sucesión mortis causa (arts. 440, 658, 659, 661, 759, 784, 799, 881, 882, 991, 1006 CC). En este sentido, y en coherencia con ello, el Código Civil prohibe en su artículo 1271 la posibilidad de poder celebrar cualquier clase de acto, pacto o contrato, sobre herencia futura, aun no deferida o no abierta, es decir, todo tipo de pacto sucesorio, como, de igual manera, no permite la renuncia a la legítima futura (art. $816 \mathrm{CC})^{140}$.

Así pues, sólo a partir de este momento o desde que se emita, en su caso, el auto judicial de declaración de fallecimiento, se desarrolla el proceso previsto por la ley para que la sucesión mortis causa despliegue sus efectos jurídicos, de tal manera que, la muerte, actúa a modo de conditio iuris o presupuesto sine qua non, no solo para que tenga lugar la transmisión de los bienes y derechos que integran el patrimonio de una persona a resultas de su fallecimiento, sino para el ejercicio del ius delationis.

Por su parte, manifiesta ROCA SASTRE que, "la muerte de la persona origina la apertura de su sucesión y el inicio del fenómeno sucesorio correspondiente, del que se vale el Derecho para mantener el principio de continuidad de las relaciones jurídicas relictas por el difunto, mediante regular su destino, a base de colocar como alter ego a otro u otros sujetos en el lugar dejado vacante por el finado"141.

Ahora bien, en vida del causante se pueden producir algunos actos que después condicionarán y determinarán el desarrollo de la sucesión como es: la designación del sucesor, o de los sustitutos, por parte del causante en su testamento, o incluso la misma partición que en él hiciere inter vivos de la herencia (art. 1057 CC), pero no por ello entendemos, en contra de la opinión de algún autor ${ }^{142}$, que tal designación o partición haya que considerarlas ya como fases del proceso sucesorio y partes

${ }^{139}$ Mucho más explícito era el Proyecto de 1851 que, en su artículo 550, decía textualmente: “la apertura de la sucesión tiene lugar desde la fecha de la muerte del causante”.

${ }^{140}$ Más adelante, en el punto número 4-1 del capítulo cuarto, nos ocuparemos más en detalle de estas dos instituciones, los pactos sucesorios y la posibilidad de renuncia a la legítima futura, a propósito de los límites de la repudiación, al que nos remitimos.

141 “La designación, la vocación y la delación sucesorias”. Cit: Pág 131.

${ }^{142}$ Así para VALLET DE GOYTISOLO (Panorama del derecho de sucesiones. II. Cit: Pag 14), el proceso se inicia incluso antes de que se abra la sucesión con la designación o nombramiento del sucesor por parte del causante en su testamento, a la que sigue la delación, llamamiento o vocación hereditaria, después tendría lugar la adquisición y, finalmente la división y adjudicación de los bienes. 
integrantes del mismo, aunque sí son circunstancias que después se han de tener necesariamente en cuenta por cuanto van a influir en el desarrollo del mismo.

No obstante, en aquellas Comunidades Autónomas en que han venido rigiendo, tradicional e históricamente, normas de derecho foral, se admite la posibilidad de poder celebrar actos, pactos o contratos sobre la herencia antes del fallecimiento de la persona a través de la sucesión contractual y de instituciones jurídicas muy diversas $^{143}$, por lo que el proceso sucesorio se puede iniciar, incluso desarrollar, ya en vida de una persona. En este sentido, cabe apuntar que, en el derecho foral navarro (Leyes 155 y 156, de la CDCFN), existe la peculiaridad de que es posible la renuncia, o transacción, sobre la herencia futura siempre que se haga mediante escritura pública, en cuyo caso, el renunciante queda excluido de la sucesión deferida por la ley, si bien, podrá aceptar las disposiciones que en su favor ordenare el causante.

\section{4-2-1-2.- Existencia del derecho a heredar o vocación sucesoria.}

El segundo presupuesto objetivo que se exige es la existencia del derecho a heredar (art. 991 CC), representado por la delación, en cuanto llamamiento, y por la vocación, como título justificativo de la misma. Así, no se podrá repudiar, o aceptar, la herencia de quien, además de no estar cierto del hecho de su muerte, no se tenga derecho a ella porque no haya sido llamado a la misma.

Tener "derecho a la herencia" significa que la persona tiene que haber sido llamada a la sucesión, ya sea por el causante a través de testamento, ya sea por la ley en caso de sucesión intestada, o a través de "heredamiento", en el caso de Cataluña (art. 411-3, Ley 10/2008, de Sucesiones), o de pacto, en el caso de Aragón (art. 317.1, CDFA), llamamiento o vocación de la que nace el ius delationis que atribuirá al llamado la facultad u opción de repudiar o de aceptar.

${ }^{143}$ Así, en las siguientes Comunidades Autónomas:

- Aragón: arts. 317.1, 377 y ss (Título II del Libro Tercero del CDFA).

- Baleares: instituciones como las donaciones universales (art. 8 y ss CDCFIB), la "definición" (art. 50 CDCFIB), o los pactos sucesorios (art. 72 y ss CDCFIB).

- Cataluña: donde la sucesión contractual (Título III de la Ley 10/2008, de 10 de julio: art. 431-1 y ss), gira en torno a los pactos sucesorios (art. 431-1), "los heredamientos" (artículo 431-18), las donaciones mortis causa (artículo 432-1), o los pactos de renuncia a la legítima futura (art 451-26); o ya fuera del ámbito sucesorio, las compras con pacto de sobrevivencia.

- Galicia: arts $181.2^{\circ}, 209$ y ss, de la LDCG de 2006.

- Navarra: Leyes 149, 155, 156, y 172 a 183, del CDCFN.

- País Vasco: arts 27, y 74 y ss, de la LDCF. 
De ello se deriva la circunstancia de que este presupuesto presupone o engloba el anterior porque el derecho a heredar no nace sino desde el momento de la muerte de aquella persona de cuya sucesión se trate. Lo que implica, además, por otro lado, tener, según el título sucesorio, una relación de parentesco con el causante y que esté determinada legalmente ${ }^{144}$.

Así, el ius delationis no existe sin una vocación o llamamiento sucesorio previo al ser una consecuencia derivada del mismo. Es una relación de causa a efecto. De ahí que difícilmente se podrá ejercer por parte de quien, aun sabiendo que ha fallecido el de cuius, lo hace en la creencia de que tiene derecho a su herencia y luego ocurre que la vocación es inexistente porque no se ha producido. En consecuencia, sin vocación, no hay delación, como tampoco derecho sucesorio, por lo que, sin él, nadie se puede pronunciar sobre una herencia a la que no ha sido llamado.

ALBALADEJO ${ }^{145}$, en este sentido, analizando la expresión "tener derecho a la herencia", entiende que significa o se usa en el sentido de "estar instituido por el causante", o "ser pariente con derecho a sucederle abintestato". "Cosas que en rigor, generan el verdadero "derecho a la herencia", cuando muere el causante". "Y que el requisito de "la muerte de la persona", sobraría si aquella expresión, "tener derecho a la herencia", se utilizase en sentido estricto o riguroso (pues no se tiene derecho a la herencia sino desde que se muere el causante).Con lo que, entonces, el primero englobaría el segundo".

Ahora bien, ¿qué consecuencias jurídicas se derivan en el caso de que faltare o no se observare el cumplimiento de cualquiera de estos presupuestos por parte del eventual sucesor?. Dado el tenor literal en que se expresa el artículo 991 CC, tanto uno como otro, tienen, en nuestra opinión, carácter esencial en el ejercicio del ius delationis, por lo que su no cumplimiento, o no existencia, de cualquiera de ellos daría lugar a que la declaración emitida por parte de quien pretendiere repudiar, o en su caso aceptar, aquella herencia a que hubiere sido llamado, sería totalmente ineficaz, no produciría ningún efecto jurídico y se tendría por no realizada ${ }^{146}$.

${ }^{144}$ Así, la Audiencia Provincial de Valencia, en su sentencia, núm. 80/2005 (Sección 8ª), de 21 febrero (JUR 2005\84942), negó capacidad para poder repudiar a la hija la herencia de su padre porque, en el momento de efectuar dicha declaración, aun no había sido inscrita su condición de hija no matrimonial del causante en el Registro Civil.

145 “La repudiación de la herencia”. AC. N 36/3-9. Octubre 1994. Pág 737 y ss.

${ }^{146}$ En este sentido, nos remitimos a lo que exponemos en el capítulo décimo donde se analizan las causas de ineficacia de la repudiación y las consecuencias jurídicas que de las mismas se derivan. Más en concreto, al punto número 3-1-2, donde se alude al incumplimiento de estos dos presupuestos. 


\section{4-2-2.- Subjetivos.}

A ellos se le unen otros que afectan ya de forma más personal y directa, de manera particular, de ahí su carácter subjetivo, al futuro sucesor, y que son: que tenga la certeza del fallecimiento del causante y de su derecho a la herencia (art. 991 CC).

El delado ha de tener constancia, por sí mismo, porque así lo sepa por su propio conocimiento personal y directo, de ese hecho, de la defunción del causante, de tal manera que lo que no puede hacer, por el riesgo que para él supone de incurrir en un caso de error, aunque sea involuntario, es dar por cierta y verdadera esa circunstancia al dar credibilidad o fiarse de meros rumores, presunciones, o noticias difundidas por terceros o por cualquier medio, de que el causante de la sucesión a la que él cree que es, o va a ser llamado, ha fallecido y no por él mismo ${ }^{147}$.

Se trata de una certeza subjetiva y personal del sucesor pero de la que no se le exige que aporte ningún tipo de prueba acerca de la misma, como sería, como más fehaciente, el correspondiente certificado de defunción expedido por el Registro Civil, que sería, indudablemente, la prueba más decisiva e indubitada a través de la cual se podría obtener esa certeza de manera irrefutable. No obstante, el sucesor sí que ha de poner de su parte toda la diligencia debida para tener esa certidumbre porque sino se podría producir un supuesto de error y la subsiguiente ineficacia de la declaración.

En este sentido, tan ineficaz es la repudiación, o aceptación, de la herencia de una persona viva y que el sucesor realiza porque cree que la puede exteriorizar, o porque cree que ya ha muerto, como la de aquel que ya ha muerto pero que tiene noticia de este luctuoso hecho sólo por una sospecha o por meros rumores o suposiciones sin haberse cerciorado de forma personal, directa e indubitada, por él mismo, de la circunstancia del fallecimiento. Así, la declaración se ha de manifestar, no sólo con pleno conocimiento y consciencia de lo que se hace, sino también con la certeza y seguridad de que es cierto y real el óbito de aquel a quien se va a heredar.

Después, ya como requisito particular, se le exige al sucesor capacidad ${ }^{148}$ para poder ejercer el ius delationis que puede variar según sus circunstancias personales.

147 ALBALADEJO (“La repudiación de la herencia”. Cit: Pág 739), subraya la exigencia de este requisito y cita los antecedentes históricos del artículo 991 que abundan todos en ese sentido: Digesto, 29, 2, 23, Digesto 29, 2, 19; Digesto 29, 2, 93, Digesto 29, 2, 17. Partidas 6, 6, 14; art. 823, Proyecto de 1851.

${ }^{148}$ En este sentido, nos remitimos al capítulo sexto donde se hace un análisis más detenido de la misma. 


\section{4-3.- Clases.}

En nuestro ordenamiento jurídico, y a diferencia de lo que sucede en el caso de la repudiación, que es eminentemente formalista por cuanto, como luego veremos ${ }^{149}$, ha de ser siempre expresa y estar sujeta a una serie de formalidades o requisitos (art. 1008 CC), en lo que se refiere a la aceptación, de conformidad con lo preceptuado en el Código Civil (arts 998, 999 y 1000), lo que también sucede en las leyes sucesorias de diferentes Comunidades Autónomas, podemos decir que rige un sistema de amplia libertad, hasta el punto de que se puede realizar de cualquier manera, dada la amplia variedad de formas a través de las cuales se puede exteriorizar y de posibilidades que puede ofrecer, verbal o escrita, pública o privada, incluso por medio de actos o comportamientos, de muy variada índole, que, por razón de su trascendencia y significado, se reputan aceptación, dando lugar a la denominada aceptación tácita.

En este respecto, manifiesta el artículo 998 CC que, "la herencia podrá ser aceptada pura y simplemente, o a beneficio de inventario", y aquella, a su vez, según el artículo 999 CC, puede hacerse de forma expresa o tácita.

Aceptación expresa es aquella que tiene lugar cuando el delado manifiesta de forma directa y abierta que acepta la herencia del causante.

Aceptación tácita es, según el tenor del párrafo $3^{0150}$ del artículo 999 CC, “..... la que se hace por actos que suponen necesariamente la voluntad de aceptar, o que no habría derecho a ejecutar sino con la cualidad de heredero"151. Sin embargo, su tenor es confuso, ambiguo y abstracto, porque no aclara suficientemente o no dice cuáles son unos y otros actos, ni tampoco qué es lo que se ha de entender por tácita aceptación de una herencia. Tan solo se limita a dar una descripción de la misma pero lo hace en términos muy generales, aunque, tal vez, otra cosa no podía hacer el legislador ya que esta modalidad de aceptación, dada la gran infinidad o multiplicidad de formas, actos o comportamientos a través de los cuales se puede manifestar, lo

${ }^{149}$ Véase el capítulo cuarto en el que se hace un análisis de los caracteres, así como el capítulo sexto, donde, al examinar los requisitos objetivos de la repudiación, se examina la forma que debe revestir en su exteriorización esta declaración.

150 Este precepto procede sustancialmente del Derecho Romano (Instituta, libro 2º Título XIX, párrafo 7, “de heredum qualitate et differentia”, con arreglo al que "obrar como heredero es obrar como dueño, porque los antiguos decían herederos significando dueños”), y de las Partidas (la Ley 11, Título VI, Partida Sexta, sobre "en que manera deue el heredero tomar la heredad", se refiere a que "se puede fazer por fecho: maguer non lo diga paladinamente”) (STS de 12 de julio de 2006, RJ 8445).

${ }^{151}$ Más explícita se manifiesta la ley Ley 10/2008, de 10 de julio, de sucesiones, en su artículo 461-5, en el que se citan una serie de actos que se reputan de aceptación tácita de la herencia.

O el artículo 349.3 del CDF de Aragón: “es la que tiene lugar mediante actos del llamado que suponen necesariamente la voluntad de aceptar o que no podría realizar si no fuera heredero”. 
que ha planteado la dificultad, no ya solo de decir en qué consiste, sino fundamentalmente de calificar o de valorar los actos a través de los cuales se puede exteriorizar, a los efectos de precisar si es, significa o constituye por parte de quien los realiza, aceptación de una herencia ${ }^{152}$.

En este sentido, ha sido el Tribunal Supremo (entre otras, STS de 12 de julio de 1996 -RJ 5887-, y 27 de junio de 2000 -RJ 5909-) ${ }^{153}$, quien, se ha preocupado de aclarar el sentido del artículo $999 \mathrm{CC}$, al decir que son: "actos claros y precisos que revelen la voluntad inequívoca de aceptar la herencia. Ha de tratarse de hechos que no tengan otra explicación, pues lo que importa es la significación del acto, en cuanto indica la intención de hacer propia la herencia y no de cuidar el interés de otro o eventualmente el propio para después aceptar". En igual sentido se ha manifestado de manera reiterada la Dirección de los Registros y del Notariado a través de sus resoluciones ${ }^{154}$.

También la jurisprudencia, de manera totalmente casuística, se ha preocupado de precisar cuando se está o no ante un supuesto de tácita aceptación de una

${ }^{152}$ Los casos de aceptación tácita se trata de supuestos en los que, ya lo deja entrever el artículo 999, el único título legítimo válido que faculta para la realización de los mismos es el de heredero, porque son de tal naturaleza o entidad en relación a la herencia que implican una injerencia directa en ésta, tanto en lo que se refiere a su gestión, como en el destino de los bienes. Solo el que ya tiene el título formal de heredero y, por tanto, ha aceptado la herencia, se entiende que puede realizarlos, si bien, en estos casos, dicho título expresamente no se ha adquirido porque no se ha aceptado de forma directa y abierta la herencia, incluso puede que cuando se realizan ésta no sea voluntad o intención deliberada, consciente o directa del llamado adquirir la condición de heredero, hacer la herencia como propia y los bienes que le han sido deferidos. Pero, dado su significado y naturaleza, y la trascendencia jurídica que de ellos se deriva, su ejecución implica o entraña, indefectible e inevitablemente, de forma implícita, aceptación porque de otra manera no se pueden realizar. El único título legítimo válido que faculta para su realización y en virtud del cual se pueden ejecutar es el de heredero y, por tanto, llevan consigo de forma intrínseca, en sí mismos, la adquisición de la herencia, incluso aunque el delado no lo quiera o realice tales actos sin esa intención o propósito.

153 Dirección jurisprudencial que proviene de otras sentencias más antiguas que le preceden, como las de 21 abril 1881; 8 julio 1903; 17 febrero 1905; 12 febrero 1916; 6 de julio de 1920; 23 abril 1928; 13 de marzo de 1952, RJ 808; 27 de abril y 23 de mayo de 1955, RJ 1554, 1707; 16 junio 1961, RJ 2367; 14 marzo 1978, RJ 957; 15 junio 1982, RJ 3426; 24 noviembre 1992, RJ 9367; 20 de enero de 1998, RJ 57. Así como en alguna posterior a ellas: STS 12 de julio de 2006, RJ 8445.

También es recogida esta doctrina en la jurisprudencia de Tribunales Superiores de Justicia. Entre otros, el de Cataluña (Sts 29 de enero de 1996 -RJ 6248-; 3 de diciembre de 1998 -RJ 1999/629-; 19 de julio de 2001 -RJ 2002/1402-).

Igualmente en numerosas sentencias de Audiencias Provinciales: Tarragona, 23 de octubre de 1998 -AC 2084-, y 24 de enero de 2002, Sección 3a, -AC 889-; Las Palmas, 11 de enero de 1999 -AC 3114-; Avila, 1 de febrero de 1999 -AC 3734-; Lleida (Sección 2a), 15 de octubre de 1999; Auto AP Baleares, 29 de marzo de 2001, JUR 2001\179234; Baleares, 24 de enero de 2002 -JUR 2002\97982-; Madrid (Sección 14ª), 24 de mayo de 2000 -JUR 2000\216461-).

154 Resoluciones de 25 mayo 1895, 21 mayo 1910; 21 enero 1993, RJ 445; 10 diciembre 1998, RJ 10483; 25 febrero 1999, RJ 743. 
herencia. Así, hay numerosas y abundantísimas sentencias ${ }^{155}$, ya desde principios del siglo pasado hasta nuestros días, en las que se examina, no ya tanto la intención del delado en la ejecución de ciertos actos o la finalidad que persigue en la realización de los mismos, sino el significado, valor y trascendencia jurídica que tienen en relación a la sucesión a que ha sido llamado, dando lugar a supuestos que se han considerado por parte de los Tribunales como de aceptación tácita porque se interpreta que son demostrativos de aceptación de una herencia, incluso aun cuando no sea esa la voluntad consciente y deliberada del sucesor cuando los realizó por cuanto no se pueden realizar si no es con el título o condición de heredero.

\footnotetext{
${ }^{155}$ Esta jurisprudencia se inicia a principios del siglo pasado y podemos citar, entre otras muchas, las siguientes: ostentar ante la Administración el título de heredero (STS 18 de junio de 1900); haber reconocido un débito de la herencia (RGRN 21 de mayo de 1910); prestar la conformidad a operaciones particionales (RDGRN 8 de mayo de 1918); vender bienes hereditarios o cobrar créditos de la herencia (STS 6 de junio de 1920); actos que realice el heredero en los que disponga gratuita o onerosamente de los bienes hereditarios (STS 6 de diciembre de 1926); el otorgamiento de escritura de apoderamiento (STS 23 de abril de 1928); el hecho de solicitar del juzgado la declaración de heredero abintestato (SSTS 23 de abril de 1928; 23 de mayo de 1955, RJ 1707; 31 de diciembre de 1956 RJ 1957/120; 14 de marzo de 1978, RJ 957); interponer reclamaciones o demanda relativa a los bienes de la herencia (SSTS 7 de enero de 1942, RJ 4; y 13 de marzo de 1952, RJ 808); hacer gestiones sobre bienes hereditarios (STS 23 de mayo de 1955, RJ 1707); pago con bienes hereditarios de una deuda de la herencia (STS 16 de junio de 1961, RJ 2367); el ejercicio de acciones relativas a los bienes relictos como es la partición de la herencia (STS 14 de marzo de 1978, RJ 957); la disolución de una sociedad con asistencia a la Junta General de todos los accionistas (STS 10 de noviembre de 1981, RJ 4471); el cobro de créditos hereditarios (STS 15 de junio de 1982, RJ 3426); actos acreditan que mantenía la condición de propietario de los bienes heredados y, además, presentó escritos para la liquidación de los impuestos de derechos reales (STS 15 de noviembre de 1985, RJ 5611); asumir la totalidad del patrimonio causante, ejercer actos significativos, declararlo en confesión judicial, presentar instancia y pagar los derechos sucesorios (STS 4 de junio de 1987, RJ 4028, Fdto 2º); gestionar bienes de la herencia (STS 25 de junio de 1990, RJ 4891); instar ante servicios oficiales la calificación de ganancial de la finca discutida (STS 20 de noviembre de 1991, RJ 8415); la impugnación de la validez del testamento de la causante en el que excluía al demandante de la herencia (STS 24 de noviembre de 1992, RJ 9367); el pago de deudas contra el caudal hereditario, cesación y cierre de la empresa del causante (STS 12 de julio de 1996, RJ 5887 -con precedente en otras sentencias de la misma Sala, de 15 junio 1982 -RJ 3426-, que sintetiza la jurisprudencia precedente sobre esta misma cuestión; de 13 marzo 1952 -RJ 808- y 27 abril 1955 -RJ 1554-); la aceptación expresa de una herencia en la que, por el ius transmisionis, se contiene la aceptada tácitamente (STS 10 de octubre de 1996, RJ 7551); la mera presentación de la demanda en que se ejercita acción declarativa del dominio sobre un bien de la herencia supone una clara aceptación tácita (STS 9 de mayo de 1997, RJ 3879); poseer los bienes de la herencia en concepto de usufructuario y no de propietario (STS 20 de enero de 1998, RJ 57); el hecho de realizar actos que exceden de la mera conservación y/o administración de la herencia como es ordenar a corta y tala de árboles de una finca del causante o ser condenado por un delito de alzamiento de bienes al disponer de una finca perteneciente al patrimonio hereditario del finado, son actos que constituyen aceptación tácita de la herencia (SAP Avila, 1 de febrero de 1999, AC 3734); el ejercicio de la acción de reclamación de cantidad (SAP Palencia, 22 de noviembre de 1999, AC 2415); disponer de los fondos existentes en una cuenta bancaria que parcialmente pertenecía al causante (SAP Badajoz, 14 de enero de 2000, AC 2879); la gestión de los bienes de la herencia por los hijos del fallecido y la continuación de ellos en el negocio de alquiler de vehículos automóviles (SAP Palencia, 10 de octubre de 2000, AC 2255); venta a un tercero de los derechos procedentes de la herencia (SAP Madrid, de 23 de septiembre de 2003, Sección 14a , JUR 20031257046). Como también se entendió que hubo aceptación tácita de la herencia en el requerimiento notarial que se hizo instando a que se retirase de un piso determinados objetos (SAP Tarragona, 24 de enero de 2002, Sección $3^{\mathrm{a}}$-AC 889-); o la realización por los herederos del cuaderno particional (STS 12 de julio de 2006, RJ 8445).
} 
En este sentido, tiene establecido que, hay aceptación cuando se trata de actos positivos, en el sentido de que han de consistir en una actividad, en un dar o un hacer respecto de los cuales, atendiendo a su naturaleza, al significado o trascendencia que tienen respecto de la herencia, se puede entender o presumir que hay una voluntad de aceptar porque no se pueden ejercer si no es con el título o condición de heredero. $Y$ además de positivos, añade GITRAMA ${ }^{156}$, han de ser inequívocos, "de modo que sólo pensando y obrando en heredero podían ser y fueron realizados". Como también, el hecho de no mostrarse parte en el procedimiento judicial incoado al efecto respecto de la sucesión de que se trate, lo ha resuelto de manera negativa al entender que no significa ni prejuzga en el delado aceptación ${ }^{157}$.

Pero, el Código Civil admite a continuación, en el último párrafo del artículo 999, poder realizar actos "de mera conservación", y actos "de administración provisional", entendiendo que, "no implican la aceptación de la herencia, si con ellos no se ha tomado el título o la condición de heredero". Lo que, lejos de aclarar dudas acerca de qué se ha de entender por aceptación tácita de la herencia, añade, si cabe, más ambiguedad porque no dice ni aclara cuales son tales actos, ni menos aun, en qué consisten ya que, dada su naturaleza y la amplia variedad de formas a través de los cuales se manifiestan o pueden consistir, ofrecen una gran analogía o semejanza con una tácita aceptación de la herencia. En este sentido, para que no se entienda como tal, se ha de tratar, ante todo, de actos que, por razón de su naturaleza e importancia, así como por su ejecución, no pueden entrañar ni significar para quien los realiza, como dice el precepto, aceptación de la herencia, ni intención de adquirir a través de ellos la condición de heredero. También aquí la jurisprudencia se ha ocupado de decir, en alguna ocasión, aunque sea de manera circunstancial, cuando estamos ante un acto de conservación y/o de administración ${ }^{158}$.

${ }^{156}$ Comentarios al Código Civil T XIV. Vol 1º. Cit: Pág 200.

157 Así, "el hecho de recibir notificaciones de diligencias judiciales y adoptar una postura pasiva ante las mismas, no supone actuación alguna por parte de las coherederas" (SAP Avila, 1 de febrero de 1999 -AC 3734-).

En este mismo sentido, se manifestó la SAP de Madrid en su sentencia de 23 de abril de 2004 (AC 1718): "no puede entenderse que hubo aceptación tácita por el mero hecho de dejar pasar el tiempo sin aceptarla, pues la aceptación y repudiación no está sujeta a otro plazo que el previsto en el artículo 1005 CC, como dijo la Sentencia del Tribunal Supremo de 15 de noviembre de 1985 (RJ 5611), y para valerse de él es preciso que el tercero interesado ejercite acción judicial reclamando al llamado a la herencia para que se pronuncie en uno u otro sentido, tal como así lo recuerda la sentencia apelada, circunstancia que no ha concurrido en el caso presente".

158 Así, constituye un acto que excede de la mera conservación y administración provisional de la herencia que implica, al mismo tiempo, la aceptación tácita de la misma, el hecho de encargar uno de los coherederos la corta y tala de árboles de una finca perteneciente al causante (SAP Avila, 1 de febrero de 1999, AC 3734). 
Siguiendo con la aceptación tácita de la herencia, el Código Civil, después, en su artículo $1000 \mathrm{CC}$, establece, a título meramente enunciativo ${ }^{159}$, una serie de supuestos en los que se contemplan actos cuya ejecución da lugar a que se sobreentienda o presuma ex lege, y además, iuris et de iure, al no admitirse prueba en contrario, tácita aceptación de una herencia por parte de su autor. De estos supuestos, nos interesan aquí los contemplados en los números $2^{\circ}$ y $3^{\circ}$, que se refieren a actos que se califican por el Código Civil como de renuncia. Tal interés se justifica porque, a la vista de dicho término y el tema que nos ocupa, se nos plantean tres interrogantes interrelacionados entre sí: por un lado, si se trata de una renuncia, ¿ante qué clase de renuncia estamos? -abdicativa o extintiva, preventiva o declarativa, recognoscitiva o traslativa-, siguiendo la clasificación de ROCA SASTRE ${ }^{160}$, por otro, dependiendo de la categoría o calificación que se les dé, de renuncia, ¿se pueden tratar de casos de aceptación, tácita, de la herencia?, y tambien nos planteamos, si se puedan calificar como una forma de repudiación, habida cuenta de la relación que hay entre ésta y la renuncia, según analizaremos y expondremos más adelante ${ }^{161}$.

Finalmente, puntualizar que, la denominada aceptación a beneficio de inventario (art. $1023.1^{\circ} \mathrm{CC}$ ), no es, o no consiste, propiamente en una forma de aceptación, sino que es una medida de protección que se concede al sucesor ante las consecuencias que para él se puedan derivar acerca de la oferta hereditaria que ha recibido. Así, todo sucesor puede aceptar la herencia de forma pura y simple y pedir después, dentro de los plazos y formalidades establecidas por la Ley (art. 1010 y ss CC), dicho beneficio incluso aunque el testador se lo haya prohibido (art. 1010 in fine CC).

De ahí que se ha de distinguir, más exactamente, desde un punto de vista más técnico y estricto ${ }^{162}$, entre:

${ }^{159}$ En nuestra opinión, no supone o encierra en su formulación un sistema de numerus clausus ya que la realidad y la jurisprudencia nos han venido demostrando desde hace muchos años, como hemos visto hace un momento, que hay infinidad de actos que constituyen aceptación tácita de una herencia.

${ }^{160}$ Derecho Hipotecario. T II. BOSCH. Barcelona. 1979. Pág 151 y ss.

Del estudio de las diferentes clases de renuncia, nos ocupamos en el capítulo tercero, punto número 3-1, al que nos remitimos.

${ }^{161}$ Desde un punto de vista sistemático, tal vez éste sería el lugar más idóneo o apropiado para su examen dado que estamos tratando en este momento las diferentes clases que hay de aceptación de la herencia. Sin embargo no lo vamos a hacer aquí, sino que el estudio y análisis más detenido de estos dos supuestos lo vamos a dejar para más adelante (véase el punto número 7 del capítulo tercero), una vez que hayamos examinado la institución jurídica de la renuncia y sus clases, así como las analogías o semejanzas, y las diferencias, que existen entre ella y la repudiación, y el concepto de ésta, porque será entonces cuando tengamos más elementos de juicio para hacer dicho análisis.

${ }^{162}$ LACRUZ BERDEJO y SANCHO REBULLIDA: Derecho de Sucesiones. I. Cit: Pág 122. 
a) aceptación pura y simple sin solicitud simultánea de beneficio de inventario, que puede ser expresa o tácita y,

b) aceptación pura y simple con solicitud simultánea de beneficio de inventario, que habrá de ser siempre expresa.

\section{4-4.- Efectos.}

Las consecuencias o efectos que se derivan de la aceptación, expresa, o táctita, de la herencia por parte del sucesor, son muy variados y de diversa índole, ya que se producen en diferentes órdenes o ámbitos, no solo respecto a él, sino también frente a la propia herencia y demás sujetos implicados en ella: cosucesores, sustitutos designados por el causante y acreedores.

Tales efectos podrían enumerarse así:

a) el sucesor adquiere la condición o título de heredero y sucede al causante en la misma posición jurídica que éste tuvo en vida, de tal manera que entra y ocupa su mismo lugar en la misma situación, condición, posición y estado en que éste dejó su patrimonio. El sucesor se subroga en todos los bienes, derechos y obligaciones del difunto (arts 659 y 661 CC), así como acciones, relaciones jurídicas activas y pasivas, incluídas las contractuales, de que éste era titular en el momento del fallecimiento y que son se extingan con su muerte (art. 1257 párrafo $1^{\circ} \mathrm{CC}$ ) (in omne ius defuncti).

b) Hace suyos los bienes, porción o cuota que le hayan sido deferidos, aquellos a que hubiere sido llamado por el testador, o por la ley.

c) Desde el momento de la aceptación, puede entrar en la posesión y disfrute de los bienes y derechos que integran el patrimonio del causante tal y como fue relicto por éste, con todos los frutos, accesiones, mejoras, incluso menoscabos o deterioros no abonables ni imputables a terceras personas.

d) Asume distinta responsabilidad por razón de las deudas del causante según haya aceptado la herencia, si pura y simplemente, o a beneficio de inventario (art. 998 y concordantes $\mathrm{CC})^{163}$.

${ }^{163}$ De igual manera en Cataluña: art. 461-14 y ss, Ley 10/2008, de 10 de julio, del libro cuarto del Código civil de Cataluña, relativo a las sucesiones. 
e) La aceptación tiene efectos retroactivos ${ }^{164}$ al momento del fallecimiento del causante (art. $989 \mathrm{CC}$ ), de tal manera que se entiende producida y despliega sus efectos, no desde el momento en que se realiza, sino desde el instante en que se ha producido el fallecimiento de la persona a quien se sucede.

Como consecuencia de la retroactividad, por un lado, la adquisición de la porción o cuota a que ha sido llamado el sucesor se entiende producida desde ese mismo instante de la muerte del causante y, por otro, cesa o desaparece la situación de interinidad o de yacencia que, en su caso, se encontraba la herencia.

f) La aceptación excluye, o precluye, y elimina de manera definitiva la posibilidad de repudiar la herencia en un momento posterior en el caso de que después, el ya sucesor, se retractase o arrepintiese de ello, ya que el ius delationis sólo se puede ejercer una sola vez y, como consecuencia de ello, se agota y extingue.

Una y otra declaración son, no ya solo antitéticas, antinómicas, o incompatibles entre sí, sino excluyentes, porque su ejercicio, además de agotar el ius delationis, supone de forma automática la imposibilidad de poder emitir después la declaración de signo contrario.

g) La aceptación, si se ha emitido cumpliendo con todos los presupuestos y requisitos exigidos para su ejercicio, tiene carácter irrevocable ${ }^{165}$ (art. $997 \mathrm{CC}$ ), una vez realizada no se puede destruir o dejar sin efecto, en un doble sentido:

a') el ya heredero no se puede desdecir después, en un momento posterior, manifestando ahora que quiere repudiar,

b') como tampoco puede ser invalidada o impugnada salvo que adolezca de alguno de los vicios que anulan el consentimiento o aparezca un testamento del causante que modifique sustancialmente la vocación sucesoria (art. 997 CC) ${ }^{166}$.

h) Todos los llamamientos sucesivos que hubiere hecho el causante en su testamento a favor de otras personas en concepto de sustitutos respecto del sucesor

\footnotetext{
164 Acerca de la retroactividad como característica del ius delationis, véase el capítulo cuarto donde se analiza más en detalle.

165 Del examen de esta característica del ius delationis, nos ocupamos en el punto número 1 del capítulo cuarto donde se analiza más en detalle.

${ }^{166}$ Acerca de estas causas de impugnación de la declaración del delado, así como de los demás supuestos de ineficacia de la misma, nos remitimos a cuanto se expone en el capítulo décimo, donde se hace un exhaustivo examen de las mismas.
} 
aceptante quedarían inoperantes y los designados no podrían ejercer su respectivo ius delationis ya que su potencial derecho a la herencia se ha frustrado definitivamente.

i) Se excluye el derecho de acrecer entre los coherederos respecto de la cuota o porción de herencia que a él le ha correspondido (art. 981 y ss CC).

j) Surge ya el "derecho hereditario" propiamente dicho. Desde este momento el heredero está facultado para ejercitar todas las acciones que estime pertinentes para proteger su derecho y que podemos dividir en dos bloques:

a') acciones que correspondían al causante en vida y que el heredero ejercita como propias del difunto,

b') acciones que nacen del título sucesorio y que el heredero ejercita como suyas propias. A su vez, dentro de éstas, podemos distinguir:

a") acciones universales, que protegen el derecho hereditario en su configuración unitaria como son: acción de petición o reclamación de herencia, o actio petitio hereditatis, y el interdicto de adquirir la posesión de la herencia (art. 250.1.1 ${ }^{\circ}$ LEC),

b") acciones particulares, que se conceden al heredero en defensa de facultades concretas: aquellas que protegen la legítima (actio ad suplendam legítima, o acción de suplemento de legítima -art. 815 CC-, y acción de reducción de donaciones inoficiosas -arts. 636, 654 y concordantes CC-); y la actio familiae erciscundae, acción de partición de herencia (art. 1051 CC).

A ello habríamos de añadir la garantía hipotecaria de la anotación preventiva en el Registro de la Propiedad (arts. 42.6º 46, 49.1, 57, 68.1 LH, y 146, 206.10, 209 RH).

k) El ya heredero puede inscribir en el Registro de la Propiedad el título de herencia (testamento, contrato sucesorio, declaración abintestato, acta de notoriedad), en tanto en cuanto se refiera o afecte a bienes inmuebles o a derechos reales (arts 14, 16, 28, 49 LH y concordantes RH).

I) Nace la situación de comunidad hereditaria entre los llamados que hayan aceptado la herencia que se prolongará hasta el momento en que se verifique la partición de la misma y se proceda a la posterior adjudicación de los bienes que la integran entre los herederos, momento en que se produce su disolución. 
Ignacio Sánchez Cid. 


\title{
Capítulo 2: EL SUCESOR Y LA DELACIÓN.
}

\begin{abstract}
1.- La vocación sucesoria. 2.- La delación. 2-1.- Examen del "ius delationis". 2-2.- Plazo para el ejercicio del ius delationis. 2-3.- La transmisión de la delación. 2-4.- El abandono de la delación. 2-5.- ¿Es obligatorio el ejercicio de la delación?. 2-6.- Cuando la delación sólo consiste en la aceptación. 3.- La pérdida de la facultad de repudiar en el caso del artículo 1002 del Código Civil. 3-1.- Qué se entiende por "perder la facultad de renunciarla". 3-2.- Empleo equívoco del término "heredero". 3-3.- Qué se ha de entender por "sustaer u ocultar algunos efectos de la herencia". 3-4.- En qué momento han de producirse los hechos. 3-5.- ¿Puede el sucesor, pese a la sanción, manifestar su voluntad de repudiar?.
\end{abstract}

\section{1.- LA VOCACIÓN SUCESORIA.}

El mero hecho del fallecimiento de una persona y sea cual fuere el sistema sucesorio ante el que estemos, no es suficiente para que tenga lugar la transmisión mortis causa de su patrimonio a sus sucesores, como tampoco para que éstos puedan ejercer el ius delationis, sino que es preciso que se haya producido previamente su llamamiento a la herencia. Esto es, tenga lugar su cita o emplazamiento a la misma, lo que se conoce más comúnmente y en términos jurídicos como, vocación ${ }^{167}$, que se puede realizar de diferentes formas ${ }^{168}$ y que dependerá de la ley que, en cada caso sea aplicable, diferente según la respectiva vecindad civil del difunto.

${ }^{167}$ Vocación, proviene de la palabra latina vocatio, que significa invitación o llamada, término que, a su vez, proviene del verbo voco, llamar, convocar.

${ }^{168}$ La determinación de cual sea el derecho aplicable en cada caso a la vocación es fundamental para después fijar los títulos en virtud de los cuales se defiere la sucesión (Vid: FONT SEGURA: "La sucesión hereditaria en Derecho interregional”. ADC. Tomo LIII. Fascículo I: Enero-marzo 2000. Pág 69 y ss). 
Su importancia y trascendencia en el proceso sucesorio se pone de relieve en el hecho de que, desde el momento en que se produce ese llamamiento a la herencia, va a nacer, o se va a derivar, la delación ${ }^{169}$, que es el ofrecimiento de la herencia a las personas que han sido llamadas a ella y que les va a conceder la facultad u opción de pronunciarse sobre la misma a través del ejercicio del ius delationis.

Ahora bien, así como la vocación depende, de la voluntad del causante o del parentesco, según que la sucesión sea testada, intestada, o por pacto en el caso de sucesión contractual, la delación siempre depende de la ley.

En este sentido, tal y como establece el artículo 9.8 CC, "la sucesión por causa de muerte se regirá por la ley nacional del causante en el momento de su fallecimiento, cualquiera que sean la naturaleza de los bienes y el país donde se encuentren”. De ahí que, en principio, la ley aplicable al llamamiento es la ley personal en el momento de la defunción y será la que después rige el fondo de la sucesión.

Sin embargo, si el causante ha dispuesto de sus bienes a través de un acto de última voluntad, o pacto sucesorio, con sujeción a una ley nacional, o personal, que es diferente de aquella que tuviere en el momento de su defunción, aquellos, acto y pacto, conservan su validez, sin perjuicio de las legítimas, que se ajustarán a la ley nacional del momento del fallecimiento. Lo que es de gran importancia en nuestro Derecho interregional habida cuenta de las diferencias que hay por razón del mismo pero que puede dar lugar a que haya de aplicarse de forma acumulativa, al permitirlo así el artículo 9.8 CC, dos leyes: la de la vecindad civil del causante del momento de su defunción y la que él tenía en el momento de disponer de sus bienes por testamento o por pacto. Tal circunstancia puede llevar consigo, como apunta FONT SEGURA, que la ley aplicable a la sucesión hereditaria vea contradichos principios esenciales en los que se fundamenta su ordenación (tal sería el caso de colisión entre la ley común y la ley catalana como sucede en los casos que él pone).

Por otro lado, dada la variedad legislativa que existe, nos encontramos con diversas formas de deferirse la sucesión que será distinta en función, lógicamente, de la ley personal del causante en el momento de su defunción. Así, la sucesión se defiere:

- en el ámbito del Código Civil (arts. 658, 912.1º): por testamento y, a falta de éste, por disposición de la ley;

- en Aragón (art. 317.1, CDFA): por pacto, por testamento y por disposición de la ley;

- en Baleares: en Mallorca y Menorca, por testamento, por ley y por vía contractual (arts 6 y 7 CDCFIB); mientras que en Ibiza y Formentera: por testamento, por pacto y por disposición de la ley (art. 69 CDCFIB);

- en Cataluña (art. 411-3, Ley 10/2008, de 10 de julio): los fundamentos de la vocación sucesoria son el heredamiento, el testamento y lo establecido por la ley. La sucesión intestada solo puede tener lugar en defecto de heredero instituido, y es incompatible con el heredamiento y con la sucesión testada universal;

- en Galicia (art. 181 de la LDCG): por testamento, por cualquiera de los pactos sucesorios admisibles conforme a derecho y por disposición de la ley; legal;

- en Navarra (Ley 300 de la CDCFN): por testamento, por pacto y, en su defecto, por sucesión

- en el País Vasco (art. 27 de la LDCF): por testamento, por ley, pacto sucesorio, capitulaciones matrimoniales o escritura de donación.

169 Es un término que el Código Civil no emplea pero sí habla de “deferir” (arts 658, 913), que significa presentar u ofrecer, y se conoce más común y propiamente con el término de "ius delationis", "ius adeundae vel repudiandi hereditatis" o, simplemente, “ius adeundi" (D. 50, 16, 151: "Delata hereditas dicitur quam quis possit adeundo consequi”).

También se puede admitir o inferir la existencia de la delación en el artículo 1006, al establecer la transmisibilidad del derecho de aceptar o de repudiar la herencia, o “ius transmissionis”. 
A propósito de la vocación sucesoria, manifiesta ROCA SASTRE que, “.... es el surtir efectos jurídicos la designación de heredero a partir de la apertura de la sucesión y la delación es uno de estos efectos, consistente en atribuir el derecho a suceder a favor del heredero designado. .... es la entrada en vigor o actuación jurídica de la designación de heredero hecha por el causante (fundada en la relación de parentesco, con designación en último lugar del Estado), cuyo entrar en eficacia jurídica tiene lugar en el momento de abrirse la sucesión, siempre que el designado exista y sea capaz de suceder"170.

Desde el punto de vista legal, la vocación es un momento del proceso sucesorio del que sí se hace eco el Código Civil en algunos artículos $(1007,1009)$, pero que incurren en la incorrección de emplear y aplicar el término heredero a quien todavía en realidad no lo es porque, partiendo de la consideración, según ya hemos visto, de que en nuestro ordenamiento jurídico rige el sistema romano de adquisición de herencia, sólo a través de la aceptación se produce tal adquisición, así como el título o condición de heredero ${ }^{171}$. De ahí que algunos autores emplean, en este momento o fase de la sucesión, para designar al llamado, términos como, "sucesor eventual" (LACRUZ BERDEJO) o, "heredero presunto" (ROCA SASTRE). Así, en nuestra opinión, se pueden distinguir tres términos que atienden a tres momentos distintos:

a) hablaríamos de, llamado, cuando estamos ante una persona que solo tiene ante sí un llamamiento a resultas de la apertura de la sucesión pero que aun no se ha producido por estar sujeta dicha vocación a un plazo o a una condición suspensiva.

No obstante, como apunta LACRUZ BERDEJO, se pueden considerar a, "todos aquellos cuya relación con el causante supone una expectativa más o menos lejana de llegar a ser sus herederos testamentarios, o abintestato, son llamados en el momento mismo de la muerte, como lo prueba el que, desde ese momento, pueden transmitir su vocación hereditaria eventual (cfr arts 657 y 1006 CC), así como su legitimación para pedir la fijación de un término al heredero para que acepte o repudie"172.

170 “La designación, la vocación y la delación sucesorias”. Cit: Pág 139 y ss.

${ }^{171}$ En cambio, sí se podría emplear dicho término y no sería una incorrección jurídica si estuviésemos en el sistema germano, porque, en él, la vocación sucesoria atribuye como efecto inmediato la delación, la cual implica por sí misma la adquisición de la herencia y la condición de heredero al llamado sin necesidad de aceptación.

Pero, sí lo sería cuando se tratar de identificar a quien solo es, de momento, un llamado a la sucesión, nos plantea el interrogante de si podría, o no, dar pie a presuponer o entender que la herencia se adquiere antes o sin necesidad de aceptación, acorde al sistema germano. Nosotros entendemos que no. Que se trata, de una incorrección jurídica, de una forma impropia de designar al sucesor.

${ }^{172}$ Elementos de Derecho Civil. V. Cit: Pág 36. 
b) Hablaríamos de vocado, cuando la vocación ya existe, es actual, lo que tiene lugar cuando el llamamiento es puro o se ha cumplido la condición o plazo suspensivo a que, en su caso, estuviere sujeto. Ahora, al ser ya el llamamiento real y efectivo, uno y otro término, llamado y vocado, vendrían a coincidir y significar lo mismo.

c) Y, hablaríamos de delado, cuando el llamado, o vocado, ya es titular del ius delationis y tiene la facultad actual de decidir de forma inmediata y pronunciarse sobre la herencia que se le ha deferido, aceptando o repudiando.

Pero, dado que la atribución del ius delationis al sucesor, de no existir condición o término suspensivo, se produce desde el mismo instante en que tiene lugar la vocación, delado y vocado vendrían a coincidir y significar lo mismo, por lo que se podrían emplear uno y otro indistintamente, aunque el término delado, sería más específico y concreto porque se ajustaría a la verdadera situación en que se encuentra el sujeto, al tiempo que lo identificaría de forma más propia, estricta y técnica frente a la herencia por ser la delación la consecuencia jurídica derivada de la vocación.

Y, por otro lado, la vocación, no sólo puede ser diferente en función de la distinta clase que adopte, sino que puede fracasar o se puede frustrar respecto de un sucesor por múltiples motivos: porque, en el momento de abrirse la sucesión, el designado no exista porque hubiere premuerto al causante, o no esté individualmente determinado (cfr, art 769 y ss CC), o no sea capaz de heredar ${ }^{173}$, o repudie la herencia, o fallezca antes de que se cumpla la condición a que estuviere sujeto su llamamiento ${ }^{174}$ o de ejercer el ius delationis, o que prescriba el plazo para el ejercicio de la actio petitio hereditatis o acción de petición de herencia ${ }^{175}$.

${ }^{173}$ Mención especial merece el supuesto de que se trate de un llamamiento deferido a favor del concebido y no nacido (nasciturus), o de quien ni tan siquiera está aún concebido (concepturus), porque, hasta que no se tenga la certeza de que uno y otro tienen personalidad jurídica (arts 29 y 30 CC), no podrá tener lugar el llamamiento a su favor, ya que, al no ser aun personas, ni tan siquiera tendrán capacidad para poder suceder, encontrándose la herencia mientras tanto, respecto de ellos, en una situación jurídica de pendencia, de yacencia. Situación que cesa cuando adquieran esa condición o se tenga la certeza de que ya no la podrán alcanzar por haberse producido un aborto o porque la criatura hubiese fallecido muerta. Además, en el caso del concepturus, se ha de dar primero la circunstancia de que sea concebido y después, a que llegue a nacer vivo.

$174 \mathrm{Si}$ el sucesor fallece en el intervalo comprendido entre la apertura de la sucesión y el cumplimiento de la condición, aunque sobreviva al testador, no transmite a sus sucesores derecho alguno respecto de esa herencia (art. $759 \mathrm{CC}$ ).

${ }^{175}$ En estos casos, según las circunstancias, se suspende la partición de la herencia en el caso de que el llamamiento se haya hecho a favor del concepturus o del nasciturus (art 959 y ss CC), o se produce el llamamiento a favor de otro u otros sucesores a través de distintos mecanismos o instituciones como son: el derecho de transmisión (art 1006 CC), el derecho de representación (art. 924 y ss CC), las sustituciones hereditarias (art 774 y ss CC), el acrecimiento (art 981 y ss CC), o la sucesión intestada (art $\left.912,3^{\circ} \mathrm{CC}\right)$. 


\section{2.- LA DELACIÓN.}

De la vocación nace la delación, de tal manera que ésta presupone aquella, pero no al revés. No obstante, la vocación no tiene sentido sin la delación porque ésta es el ofrecimiento que se hace de la herencia a los llamados y en virtud del cual les va a conceder la oportunidad de pronunciarse sobre la oferta hereditaria que han recibido, pudiendo aceptarla o repudiarla. La vocación señala el quantum y el lugar del sucesor, y depende de la voluntad del causante o del parentesco, mientras que la delación depende de la ley al ser ésta quien la realiza y supone poner la herencia a disposición del llamado para que se manifieste acerca de la misma $\left(\operatorname{LACRUZ}^{176}\right)$.

ALBALADEJO ${ }^{177}$ define la delación como, "la atribución originaria a un sujeto del derecho de suceder a otro mortis causa" o, "el poder de suceder mortis causa al causante". Se trata de, añade, "un poder jurídico actual -y no eventual- y concreto de hacer propia la herencia -o parte de ella- a la que se es llamado".

Para el sucesor entraña sustancialmente la atribución del ius delationis, lo que le confiere la posibilidad de aceptar o repudiar la herencia. Pero, le atribuye, además, otras facultades ${ }^{178}$ como son: poder defender su facultad adquisitiva sobre la herencia yacente frente a terceros de peor o inexistente derecho sucesorio que el suyo; administrar la herencia yacente y realizar actos de conservación para impedir la dispersión o deterioro del patrimonio hereditario mientras se decide sobre su eventual adquisición siempre que no impliquen tomar con ello el título o condición de heredero (art. 999 pfo $4^{\circ} \mathrm{CC}$ ); realizar un inventario del patrimonio con el objeto de examinar cual es su estado o situación para después deliberar acerca del mismo (art. 1010 CC).

Por otro lado, acerca de la delación y de su relación con la vocación, se plantea por parte de la doctrina la discusión de si se puede separar de ésta, en el sentido de si son términos o actos equivalentes entre sí, o si prevalece uno sobre el otro. A este respecto, DOMINGUEZ REYES ${ }^{179}$, plantea tres grupos de teorías o posiciones doctrinales:

176 Derecho de sucesiones. Parte General. Cit: Pág 157.

177 “La sucesión iure transmissionis”. ADC. 1952. Separata. Pág 7 y ss; "La adquisición de la herencia en el Derecho español”. ADC. 1955. Pág 28.

178 JORDANO FRAGA: Los acreedores del llamado a una sucesión "mortis causa", ante el ejercicio por éste del “ius delationis”. Colegio de Registradores de la Propiedad y Mercantiles de España. Centro de Estudios Registrales. Madrid. 1996. Pág 19.

179 “Vocación y delación de la herencia”. RCDI. Julio-agosto 2000. No 660. Pág 2287 y ss; También LACRUZ BERDEJO: Derecho de sucesiones. Cit: Pág 156, se hace eco de las posiciones que se adoptan. 
A) Teoría positiva: se caracteriza por admitir la separación y/o diferenciación entre vocación y delación. Siguen esta teoría numerosos autores italianos como, BETTI, TRABUCCHI, RUGGIERO, CARIOTA FERRARA, BARBERO, MESSINEO, ANDREOLI, para quienes la vocación es la llamada que se realiza a favor del sucesor que implica la posibilidad de suceder pero no de que sea efectivo heredero, mientras que la delación es el ofrecimiento que se hace de la herencia o puesta a disposición de la misma a los sucesores, lo que supone la concreta y efectiva adquisición o atribución de la misma. Esta posición de distinguir y separar la vocación de la delación es mayoritaria dentro de la doctrina española (LACRUZ BERDEJO ${ }^{180}$, VALLET DE GOYTISOLO, DIEZ PICAZO y GULLÓN, CAPILLA, PUIG PEÑA). En igual sentido, la jurisprudencia del Tribunal Supremo ${ }^{181}$.

B) Teoría negativa: seguida por autores como NICOLO, IOFRIDA, COVIELLO o CICU. Su postura es negar la distinción entre vocación y la delación, y entienden que una y otra se vienen a equiparar. La primera, representa el aspecto subjetivo de la sucesión e implica el llamamiento, mientras que la delación, es el aspecto objetivo, es el momento en que la herencia se pone a disposición del sucesor.

C) Teorías intermedias: a su vez, dentro de ellas podemos distinguir, por un lado, la posición de aquellos que dan prevalencia a la delación sobre la vocación (para BARASSI la delación atribuye la condición de heredero teniendo lugar en el momento de la apertura de la sucesión) y, por otro, la de quienes destacan la vocación sobre la delación ya que no hay verdadera y propia adquisición si no hay previamente un Ilamamiento a dicha sucesión (BRANCA, SANTORO PASSARELLI).

En este sentido, acerca de la cuestión planteada, sucede que la vocación y la delación son dos actos que, aunque desde un punto de vista meramente teórico o conceptual, se pueden llegar a distinguir y diferenciar entre sí, en la práctica, no solo suelen coincidir, sino que se confunden y compenetran ya que, la mayoría de las veces, tienen lugar o se producen a la vez, de forma simultánea, o en un espacio muy corto de tiempo, de manera muy próxima el uno al otro, de tal manera que son difíciles de diferenciar o de separar entre sí $^{182}$. Al tiempo en que se produce la vocación, tiene, o puede tener lugar la delación y nace el derecho de los sucesores para que manifiesten si aceptan o repudian esa sucesión a la que han sido llamados.

${ }^{180}$ Derecho de sucesiones. Parte General. Cit: Pág 157.

${ }^{181}$ SSTS 9 junio 1964, RJ 3216; 12 mayo 1990, RJ 3916; 27 junio 2000, RJ 5909.

182 GARCIA-BERNARDO LANDETA: "Designación "mortis causa", vocación hereditaria y adquisición automática”. RDN. No XXIV. abril-junio 1959. Pág 81 y ss. 
A este respecto, en opinión de LACRUZ, "son dos fenómenos que se producen en el proceso sucesorio determinado por la apertura, y no puede decirse que sean dos aspectos del mismo fenómeno. Lo que sí ocurre es que la delación presupone a la vocación, aunque no al contrario"183. Mientras que, para ROCA SASTRE, la vocación es la "entrada en vigor o actuación jurídica de la designación de heredero hecha por el causante en el testamento", y la delación de la herencia consiste en "atribuir el derecho a suceder a favor del heredero designado"184.

No obstante todo lo anterior, es cuestión admitida por la doctrina sin reserva o discusión alguna el hecho de que la vocación es en todo caso necesaria ya que es el título o fundamento en virtud del cual es llamado todo sucesor a la herencia del causante. No podemos decir lo mismo de la delación porque, según ya vimos en el capítulo anterior al tratar de los diferentes sistemas sucesorios de adquisición de la herencia, actúa de distinta manera y tiene diferente función según uno u otro sistema.

\section{2-1.- Examen del "ius delationis".}

Se trata de un derecho que no se adquiere por el sucesor como si se tratase de un elemento patrimonial más de la herencia, ex patrimonio hereditatis, sino, ex lege, de forma automática, por ministerio y disposición de la ley, además, con carácter ex novo, ya que se confiere por la ley directamente a cada uno de los llamados, de forma originaria $^{185}$ e in tuitu personae, a título particular o individual, como una consecuencia directa e inmediata derivada de la vocación, de tal manera que cada uno de ellos es titular de su respectivo ius delationis y que, en el caso de ser varios, cada uno de ellos podrá ejercitar por sí solo y con independencia de los demás (art. 1007 CC). Y, es un derecho que se adquiere por el sucesor sin necesidad del concurso de su voluntad, al margen y con independencia de la misma, extinguiéndose, entre otras causas, por el ejercicio exclusivo y excluyente de una de las dos facultades que lo integran, ya sea en sentido positivo, por la aceptación, o en sentido negativo, por la repudiación.

${ }^{183}$ Derecho de sucesiones. Parte General. Cit: Pág 157.

184 “La designación, la vocación y la delación sucesorias”. Cit: Pág 140.

${ }^{185}$ Ahora bien, en el caso de sucesión a través del derecho de transmisión, la adquisición del ius delationis proveniente de la sucesión del primer causante por parte del transmisario, no se produce de forma originaria o directa, sino de manera derivativa (JORDANO FRAGA: "La sucesión en el "ius delationis”......". Cit: Pág 315 y ss.), a través de la previa aceptación de la herencia de su causante o transmitente, de tal manera que la única opción que tiene el transmisario de poder hacer suyo dicho ius delationis y adquirir la herencia que es objeto de transmisión, es aceptar previamente la herencia de su causante.

Después, el transmisario, una vez que ha aceptado la herencia de éste, puede, con la misma libertad aceptar o, en su caso, repudiar la herencia que es objeto del derecho de transmisión. Mas, si lo que decide es repudiar la herencia a que él ha sido llamado directamente, por su propio derecho, esto es, la de su causante o transmitente, pierde toda opción respecto de la herencia del primer causante, ya que el ius delationis forma parte de dicha herencia. 
Por otro lado, pese a ser un valor o elemento patrimonial más de la herencia del causante junto con los demás bienes, derechos, acciones y pasivo que forme parte de la misma (está implícito y es inseparable de ella) ${ }^{186}$, es un derecho de carácter $u$ origen extrapatrimonial en el sentido de que no se trata de un derecho ni de una atribución que realiza el causante a favor de sus sucesores, sino que toma su origen en la ley y es consecuencia directa e inmediata derivada de la vocación.

Desde otro punto de vista, y acerca de su naturaleza ${ }^{187}$, el ius delationis no confiere al llamado el título o condición de heredero, sino de heredero electo, presunto, potencial o posible, que solo alcanzará o adquirirá de forma efectiva si acepta la herencia ${ }^{188}$, mientras que, si repudia, la rechaza. Así, se considera por la inmensa mayoría de la doctrina ${ }^{189}$ como un derecho subjetivo porque su titular tiene una situación de poder concreto en virtud del cual puede exteriorizar una declaración de voluntad que entraña la facultad: bien de adquirir aquello a que ha sido llamado, ante lo que tendrá que aceptar, bien de rechazarlo, ante lo que tendrá que repudiar ${ }^{190}$.

186 La RDGRN de 20 de septiembre de 1967 (RJ 4367), considera el “ius delationis” como un elemento o derecho más que integra la masa hereditaria del causante.

${ }^{187}$ Acerca de la naturaleza del ius delationis, se han mantenido otras tesis:

a) como mera expectativa jurídica, o mera posibilidad del nacimiento o adquisición de un derecho, pero no es admisible porque concede la posibilidad actual y efectiva del ejercicio de un derecho,

b) una facultas adquirendi, o reflejo de la capacidad de obrar de la persona en su aspecto negocial (DE CASTRO: Derecho Civil de España. Ed. CIVITAS. Madrid. 1984. Pág 605), o emanada de la personalidad del sujeto e incluida en el marco de los derechos a la libertad personal como manifestación de la libertad negocial (HERNÁNDEZ VALDEOLMILLOS: “La transmisión del ius delationis”. Libro Homenaje a Juan B. Vallet de Goytisolo. Junta de Decanos de los Colegios Notariales de España. Vol IV. Madrid. 1988. Pág 480).

c) un poder de la voluntad concedido a un sujeto en particular sobre un objeto concreto y determinado (VON THUR: Parte General del Derecho Civil. Traducción de Roces. 2 ${ }^{\text {a }}$ ed. Madrid. 1927. Pág 21).

${ }^{188}$ En este sentido, el confusionismo del Código Civil es manifiesto porque emplea en numerosas ocasiones el término heredero de manera impropia ya que a quien se está refiriendo, en realidad, es al presunto o eventual sucesor, de ahí que más propiamente habría que hablar de llamado, vocado o delado, sobre todo cuando aun no ha sido ejercitado el ius delationis.

Así, en unos artículos se está refiriendo a quien aun no ha aceptado la herencia y, por tanto, a quien solo es sucesor (arts 758, 759, 766, 799, 800, 801, 1000, 1001, 1002, 1004 a 1007, 1010, 1014 a 1016, 1018, 1019, 1022, 1023, 1024, etc), mientras que en otros se refiere a quien ya realmente es heredero por haber tomado este título o condición a resultas de haber aceptado ya la herencia (arts 858, 859, 863, 864, 867, 876, 886, 906, 981, 984, 1003, 1034, 1051, etc).

189 Así, entre otros muchos: ALBALADEJO: “La sucesión iure transmissionis”. Cit: Pág 922; LACRUZ BERDEJO: Derecho de Sucesiones. Parte General. Cit: Pág 158; GARCÍA-BERNARDO LANDETA: Op. cit.: Pág 80 ; ROYO MARTÍNEZ: Op. cit.: Pág 59; O’CALLAGHAN: Compendio de Derecho Civil. T. V. Cit: Pág 36.

${ }^{190}$ En este sentido, el Tribunal Supremo, refiriéndose a las consecuencias que de la delación se derivan, manifiesta, en la sentencia de 27 de junio de 2000 (RJ 5909) que, "producida la delación, el heredero -el llamado a heredar en concreto-, como titular del «ius delationis», puede aceptar o repudiar la herencia, pero en tanto no acepte, como se ha dicho, no responde de las deudas de la herencia, porque todavía no se produjo la sucesión, no es sucesor, sino sólo llamado a suceder. Si acepta responderá incluso con sus propios bienes, salvo que la aceptación expresa tenga lugar con arreglo a lo prevenido para disfrutar del beneficio de inventario". En igual sentido, SAP Oviedo 10 junio 1999 (AC 1999\6058). 
Se considera también como un derecho de apropiación o de adquisición que pertenece a la categoría de los denominados "derechos potestativos", o "derechos de poder jurídico" (DE CASTRO ${ }^{191}$ ), al ser de ejercicio voluntario, ya que su titular, dependiendo sólo de su voluntad, puede hacer uso del mismo para producir efectos jurídicos; "derechos de formación"; "derechos de modificación" porque con su decisión puede influir sobre una situación jurídica preexistente modificándola, extinguiéndola 0 creando otra nueva de forma unilateral, solo con su voluntad, o "derechos de caracterización jurídica"192.

\section{2-2.- Plazo para el ejercicio del "ius delationis".}

A diferencia de lo que sucedió en el Derecho Romano en que el ius delationis tuvo una duración ilimitada ya que el sucesor no tenía plazo en cuanto a su ejercicio, el derecho común se inclinó a lo contrario, a limitarlo y señalar un plazo o período de tiempo dentro del cual el llamado a la herencia tenía que manifestar si aceptaba o repudiaba.

Así se recogió en nuestro derecho histórico, en la legislación de Partidas, pero después no se ha visto reflejado en el Código Civil porque, a diferencia de lo que sucede en otros Códigos Civiles de nuestro entorno donde sí se hace referencia a ello ${ }^{193}$, en él no se establece de forma expresa cual es el plazo de que dispone el sucesor para dicho ejercicio ${ }^{194}$, lo que ha dado lugar, por un lado, como sucede en tantos otros casos en los que hay un vacío legal, a que la doctrina haya elucubrado y mantenido diversas posturas acerca de cual es ese plazo y, por otro, a que este vacío

191 Op. cit.: Pág 605.

192 ALBALADEJO: "La sucesión iure transmissionis". Cit: Pág 923; LACRUZ BERDEJO: Derecho de Sucesiones. Parte General. Cit: Pág 104; HERNANDEZ GIL: Lecciones de Derecho sucesorio (resumen de explicaciones de Cátedra). Madrid. 1969. Pág 105; ROYO MARTÍNEZ: Op. cit.: Pág 59; ROGEL VIDÉ: Op. cit.: Pág 326.

${ }^{193}$ Así, en el derecho italiano (art. 480 Codice), o del derecho francés (art. 780.2 Code: "La faculté d'option se prescrit par dix ans à compter de l'ouverture de la succession”, desde la Ley n ${ }^{\circ}$ 2006-728 de 23 junio de 2006), donde, tanto en uno como en otro, el derecho a aceptar la herencia prescribe a los diez años.

En cambio, en el derecho alemán, para aceptar no hay plazo habida cuenta de que no es precisa la aceptación para ser heredero y adquirir la herencia, mientras que el plazo de que se dispone para poder repudiar es de seis semanas contadas desde el momento en que el heredero tiene conocimiento de la adquisición provisional y de la causa del llamamiento (§ 1944 BGB).

${ }^{194}$ El Proyecto de 1851, siguiendo en lo esencial al Código Civil francés, estableció que "el derecho para aceptar o renunciar la herencia, no habiendo tercero que inste, se prescribe por el mismo tiempo que las otras acciones reales" (art. 835). Sin embargo, este artículo no ha pasó después al texto del Código Civil.

En cambio, en el derecho catalán se establece expresamente que el sucesor tiene un plazo de 30 años para aceptar o repudiar (art. 461-12, Ley 10/2008, de 10 de julio, del libro cuarto del Código civil, relativo a las sucesiones, con precedente en los derogados artículos, $28.1^{\circ}$ del Código de Sucesiones de 1991, y 275 de la Compilación).

De igual plazo dispone el sucesor en el derecho foral navarro (Ley 324). 
legislativo sea, tal y como expusimos en el capítulo anterior, uno de los argumentos que se esgrimen para defender la existencia en nuestro ordenamiento jurídico del sistema romano de adquisición de la herencia.

Sin embargo, dada la amplitud del plazo de que disponía el sucesor para aceptar la herencia y habida cuenta de la situación de inseguridad y de incertidumbre que se producía en el proceso sucesorio ante la ausencia de un titular hereditario, ya desde el Derecho Romano se arbitraron medios para evitar dicha situación, lo que se ha visto después reflejado en nuestro derecho en la interrogatio in iure, o interpellatio in iure, a que se refiere en Código Civil (arts. 1004 y 1005), que son los dos únicos supuestos en los que se delimita de forma concreta, en aquel, el plazo a partir del cual se puede dirigir acción contra el sucesor para que se manifieste sobre si acepta o repudia la herencia y, en éste, el plazo de que dispone después para que se pronuncie.

Pero, fuera de estos dos supuestos, excepcionales, por otro lado, es donde se plantea la cuestión de, ¿hasta cuando puede ser ejercitado el ius delationis?, ¿tiene el sucesor un plazo máximo para su ejercicio y, por ende, para repudiar la herencia?, o, por el contrario, puede mantener su decisión de manera indefinida en el tiempo sin pronunciarse en uno $u$ otro sentido, sin repudiar, ni aceptar, lo que ha dado lugar a posiciones varias dentro de la doctrina.

Así, un amplio y mayoritario ${ }^{195}$ sector dentro de la doctrina, y que se puede considerar como el más aceptado, defiende que el plazo de que dispone el sucesor para repudiar, o aceptar, una herencia es el de treinta años.

El argumento central de su tesis se basa en poner en conexión el ius delationis con el plazo de la acción que tiene el sucesor para poder reclamar los bienes que él se crea con derecho a ellos y formen parte de una herencia, acción de reclamación o de petición de herencia, o actio petitio hereditatis ${ }^{196}$.

${ }^{195}$ Así, entre otros: DÍEZ-PICAZO-GULLON BALLESTEROS: Sistema de Derecho Civil. Vol. IV. Págs 538 y 558; GITRAMA: Op. cit.: Pág 361; PUIG BRUTAU: Fundamentos de Derecho Civil. T. V. Vol 1ํ. Cit: Págs 211 y 212.

${ }^{196}$ No está regulada de forma expresa en el Código Civil, aunque sí se hace eco de ella en su articulado (arts 192, 1016 y 1021).

Acerca del plazo de su ejercicio, y a diferencia de lo que ocurrió en alguno de nuestros textos históricos [La Partida 6, 14, 7, señaló la prescripción de la petición de herencia a los diez o veinte años según que el heredero estuviese en el lugar o fuera de él, frente al poseedor con justo título y buena fe, y de treinta años contra el poseedor de mala fe (VALLET: Panorama de derecho de sucesiones. II. Cit: Pág 651). Ya antes, en la Constitución del Emperador Teodosio II, del año 424 (Código Teodosiano 7, 39, 3), se establece que las acciones que recaen sobre una universalidad tienen una prescripción de treinta años], el Código Civil no dice de forma expresa cual es su plazo su prescripción, que sí lo hacen otros Códigos extranjeros como es el italiano, en el que se establece que es imprescriptible (art. 533), o la propia ley de 
Ello presupone, no la identificación, porque son diferentes entre sí ya que cada una de ellas responde a una finalidad y cometido diferentes, pero sí la interconexión y situación en un plano de simultaneidad de las dos acciones, del ius delationis y de la actio petitio hereditatis o de reclamación de los bienes de la herencia, porque difícilmente se puede ejercitar ésta si antes la herencia no ha sido aceptada por cuanto se carecería de legitimación para ello, de lo que resultaría que el plazo para repudiar, o aceptar, implicaría el mismo plazo para reclamar $^{197}$.

Ahora bien, el dies a quo de su prescripción no es, según la jurisprudencia ${ }^{198}$, el de la defunción del causante, sino, "aquel en que el poseedor aparente empieza a poseer los bienes hereditarios "animo suo", es decir, exteriorizando la intención de hacerlos propios titulándose dueño de los mismos, comportándose como tal y negando a los demás el carácter de heredero que invocan", que es el instante en que se produce el supuesto de hecho que da lugar al nacimiento de dicha acción. No obstante, si se diere la circunstancia de que tal supuesto de hecho surge o se produce, bien antes de que se haya abierto la sucesión ${ }^{199}$, bien antes de que se pueda ejercer válidamente el ius delationis porque se diere la circunstancia de que estuviere sujeto en su ejercicio a una condición suspensiva, habida cuenta de que sólo en el caso de que se aceptare la herencia se estaría legitimado activamente para dicho ejercicio, en nuestra opinión, el plazo de prescripción se contaría desde ese momento (la apertura de la sucesión o el cumplimiento de la condición) y no desde que se produjo el motivo que dio lugar al ejercicio de la acción.

Sucesiones de Cataluña de 1991, donde se fija el plazo de treinta años contados desde el fallecimiento del causante (art. 64 in fine). En este sentido, al ser una acción naturaleza real, dado el objeto que a través de la misma se reclama, una herencia, y que, además, es susceptible de que pueda ser ejercitada frente a cualquiera que posea los bienes hereditarios sin tener título o derecho para ello, el plazo que establece el Código Civil cuando se trata del ejercicio de acciones reales sobre bienes inmuebles es el de treinta años (art. 1963), y la herencia, entendida como un conjunto de bienes y de obligaciones (universitas), no es en sí misma un inmueble, es una universalidad.

${ }^{197}$ Acerca de este argumento, de relacionar el ius delationis con la acción de petición de herencia, disiente ALBALADEJO porque entiende que se trata de dos acciones distintas que no se pueden confundir: en una se le concede al sucesor un plazo para que diga si acepta o repudia (en este sentido, como veremos más adelante, en su opinión, el plazo de que dispondría el sucesor sería de quince años por aplicación del artículo 1964 CC), mientras que, en la otra, al que ya es heredero por haber aceptado, pero que aun no posee la herencia, se le da otro plazo distinto para que la reclame de quien la tenga, de lo que se deriva la consecuencia de que una y otra tienen distinto plazo en cuanto a su ejercicio ("Comentario a la Sentencia del Tribunal Supremo de 27 de noviembre de 1992”. CCJC. n ${ }^{\circ}$ 31. Enero-marzo 1993. Pág 90).

198 SSTS de 25 enero de 1962, RJ 562; 23 diciembre 1971, RJ 5401; STSJ Cataluña, de 23 de mayo de 1996, RJ 6255.

${ }^{199}$ Tal sería el caso de que, en vida del causante, el sujeto frente al que se dirige dicha acción pretendiere ostentar algún derecho sobre los bienes como puede ser a través de una detentación en precario, incluso con tolerancia o aquiescencia del dueño, o que fuere mero depositario de los mismos porque hubiere confiado en él el causante para su guardia o custodia. 
De lo anterior resultaría la consecuencia, o la regla, de que, el plazo del que dispone el delado para poder ejercer el ius delationis sería el de treinta años contados a partir del momento en que se produce la apertura de la sucesión, esto es, la muerte del causante, o desde que se pueda ejercer y haya nacido legal y válidamente a la vida jurídica en el caso de que estuviere sujeto a una condición suspensiva.

También para LACRUZ ${ }^{200}$ el plazo para ejercer el ius delationis, es el mismo que para poder reclamar la herencia, de treinta años, ya que, “..... el mismo tiempo durará el derecho a aceptar contados desde que al heredero ...... se le ofreció la herencia, es decir, desde que pudo manifestar eficazmente su voluntad de querer ser heredero".

De igual manera opina ROCA SASTRE MUNCUNILL ${ }^{201}$, para quien, dado que en nuestro derecho no existe de forma expresa un plazo para repudiar, o aceptar, la herencia, ni para utilizar el beneficio de inventario o derecho de deliberar, se podrá realizar dicha declaración mientras no prescriba la acción para reclamar la herencia ${ }^{202}$.

Por su parte, tanto el Tribunal Supremo y Superiores de Justicia, como algunas Audiencias, de manera reiterada ${ }^{203}$, también han entendido que el plazo del que dispone el sucesor para poder reclamar los bienes de la herencia es el de treinta años contados a partir del momento de la muerte del causante que será, en consecuencia, el mismo plazo del que dispone para el ejercicio del ius delationis y manifestar si acepta o repudia la herencia a que se ha sido llamado.

200 Elementos de Derecho Civil. T. V. Cit: Pág 77.

${ }^{201}$ Derecho de Sucesiones. T. III. Cit: Pág 473.

202 Así se deduce, según él, del artículo 1016 del Código Civil, también 192 y 1021, el cual lo prevé para el beneficio de inventario y el derecho de deliberar, con las excepciones de que:

a) el heredero tenga en su poder todos o parte de los bienes de la herencia (art. 1014 CC), en cuyo caso, dispone del plazo de 10 o 30 días según que resida o no en el lugar donde hubiese fallecido el causante de la herencia y contados desde el siguiente a aquel en que supiere ser tal heredero,

b) el heredero haya sido requerido o interpelado judicialmente para aceptar o repudiar (art. 1015 CC en relación con el 1005 CC), que tendrá el que señale el Juez que no podrá exceder de 30 días.

203 Entre otras muchas:

SSTS 30 de marzo de 1889; 18 de mayo de 1932 -RJ 1056-; 12 de abril de 1951 -RJ 1012-; 12 de noviembre de 1953 -RJ 2918-; 6 de marzo de 1958; 25 de octubre de 1963 -RJ 1056-; 12 de noviembre de 1964 -RJ 5093-; 14 de marzo de 1968 -RJ 1738-; 23 de diciembre de 1971 -RJ 5401-; 2 de junio de 1987 -RJ 4024-; 10 de abril de 1990 -RJ 2712-; 27 de noviembre y 20 de junio de 1992 -RJ 5410 y $9597-$.

STSJ de Navarra, no 13/1994, de 14 junio (RJ 5513): "Establecido en treinta años por las leyes 38.1 y 324 del Fuero Nuevo el plazo prescriptivo de la acción de petición de herencia, el fundamental problema que el motivo de casación plantea es el relativo al inicio de su cómputo que, arregladamente a lo prevenido en el artículo 1969 del Código Civil, ha de referirse al día en que pudo ejercitarse”.

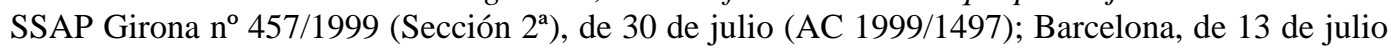
de 2004, JUR 2004\218515; Las Palmas núm. 2/2006 (Sección 4ª), de 12 de enero (AC 2006/687). 
Frente a dicha postura, para un sector también amplio de la doctrina ${ }^{204}$, donde hay que buscar respuesta a la cuestión planteada es en la regla del artículo 1016 $\mathrm{CC}^{205}$, referido al plazo de que dispone el sucesor para aceptar la herencia a beneficio de inventario o con el derecho de deliberar si no se hubiere presentado contra él ninguna demanda y si no estuviere en ninguno de los casos a que se refieren los dos artículos anteriores, 1014 y 1015.

No obstante, hay que hacer abstracción de la casuística que en él se contiene, del ámbito o supuesto para el que dicha acción está previsto, así como del diferente momento de partida para el inicio del cómputo de una y otra: en el ius delationis lo será el momento del fallecimiento del causante, mientras que en la acción de petición, será después, en un momento posterior, cuando el derecho del sucesor (ya heredero, por cuanto para ejercitar dicha acción ya tiene que haber aceptado previamente la herencia), ha sido perturbado, violentado o lesionado, cuando el poseedor aparente, ya sea porque no tiene título o el que invoca no es lícito o válido, comienza a poseer todos o parte de los bienes de la herencia animo suo y niega el carácter de herederos a quienes lo invoquen. Luego, según esta dirección doctrinal, el sucesor podrá repudiar, o aceptar, la herencia en tanto en cuanto no haya prescrito aquella, la acción de petición o de reclamación de herencia. Así, el plazo de que dispone para el ejercicio del ius delationis será el mismo que tiene para poder reclamar los bienes de la herencia que le hubieren sido deferidos.

ALBALADEJO ${ }^{206}$, no está de acuerdo con ello y dice que "la mala inteligencia por algunos del artículo 1016 del Código Civil introduce confusión" ya que, comentando el tenor literal del citado precepto, "no puede significar lo que dice, ya que se delibera antes de aceptar, luego no cabe aceptar con el derecho de deliberar; se querrá decir que, en el caso del artículo, se puede pedir plazo para deliberar y aceptar o no luego".

${ }^{204}$ Así, entre otros: JORDANO FRAGA, para quien, del artículo 1016 resulta que el plazo (de caducidad) para el ejercicio del "ius delationis", ..., coincide con el plazo -de prescripción-, de la acción de petición de herencia -o sea, según interpretación doctrinal y jurisprudencial más seguida, de treinta años- (La sucesión en el "ius delationis". Cit: Págs 73 y 74); ESPÍN CANOVAS: Manual de Derecho civil español. Vol. V. Cit: Pág 68; SCAEVOLA: Código Civil. Comentado y concordado. Tomo XVII. Instituto Editorial REUS. Madrid. 1944. Cit: Pág 536; ROYO MARTÍNEZ: Op. cit.: pág 275; CASTÁN TOBEÑAS: Derecho Civil Español Común y Foral. T. VI. Vol 1. Cit: Págs 158 y 434; PUIG BRUTAU: Fundamentos de Derecho Civil. T. V. Vol 1ํ. Cit: págs 212 y 351; GITRAMA: Op. cit.: pág 361.

${ }^{205}$ En él se hace alusión a la prescripción pero de una forma muy incidental, aparte de que contiene algunas imprecisiones porque se refiere impropiamente al heredero, que no es tal porque en este momento aun no tiene esa condición por cuanto aun ha aceptado, por lo que no se le puede aplicar una acción, de reclamar la herencia, cuyo ejercicio, bien presupone la previa aceptación de la herencia, bien una aceptación tácita de la misma.

Por otro lado, no se prevé en él qué sucede si transcurre el tiempo previsto para que prescriba la facultad de optar entre aceptar y repudiar.

206 “Comentario a la Sentencia del Tribunal Supremo de 27 de noviembre de 1992”. Cit: Pág 90. 
Para él, el verdadero sentido del artículo 1016 es que, "se refiere no al supuesto de aceptación, sino al de petición del beneficio de inventario, aun después de ser heredero puro y simple. Lo cual sólo quiere decir que tal heredero aún puede limitar su responsabilidad al activo hereditario, convirtiéndose en heredero a beneficio de inventario. Ello porque el beneficio de inventario es simplemente un medio de limitar la responsabilidad y perfectamente independiente de la aceptación, aunque, claro, sólo puede darse cuando haya aceptación -o, en general, adquisición-, pues si no, no puede haber responsabilidad, y es, por tanto, innecesario limitarla".

Para ALBALADEJO ${ }^{207}$, la solución más acertada ante la ausencia de norma específica es aplicar al ejercicio del ius delationis el plazo general de prescripción de quince años de que trata el Código Civil en el artículo 1964 para las acciones personales que no tenga señalado plazo especial de prescripción.

ROCA SASTRE ${ }^{208}$, por su parte, sostiene que el plazo de que dispone el sucesor para aceptar la herencia es de cuatro años pero no por el argumento anterior sino por aplicación analógica de los artículos 1299 y 1301 del Código Civil, y 14.3 del Reglamento Hipotecario. De igual manera, también entienden que el plazo a aplicar es el de los cuatro años, O'CALLAGHAN ${ }^{209}$ y GALVÁN GALLEGOS ${ }^{210}$.

Todo lo dicho con anterioridad habrá que entenderlo referido al ejercicio del ius delationis cuando se trata de llamamientos hechos a título universal, porque, en el caso de los realizados a título particular, o de legado, nos planteamos la cuestión de si rige o no el mismo plazo. Recordemos que aquí solo se trataría de la facultad de repudiar, o ius repudiandi, habida cuenta de que, en nuestro ordenamiento jurídico, según el sentir mayoritario dentro de la doctrina, no es precisa la aceptación para que se produzca la adquisición del legado ${ }^{211}$.

Acerca de ello, GUTIERREZ JEREZ ${ }^{212}$, entiende que "la acción correspondiente al legatario y que marcará la duración temporal del ius repudiandi, es la actio ex testamento, que prescribe a los quince años contados desde que el legatario pudo ejercitarla, con arreglo a lo dispuesto en el artículo 1964. Se trata, en consecuencia, de

\footnotetext{
${ }^{207}$ Anotaciones de Derecho español al Derecho de Sucesiones. Parte General, de CICU. Cit: Pág 356; “Comentario a la Sentencia del Tribunal Supremo de 27 de noviembre de 1992”. Cit: Pág 91.

${ }^{208}$ Anotaciones al Derecho de Sucesiones de Kipp. Tomo V. Vol 2º . BOSCH. Casa Editorial S.A. Barcelona. 10ª Ed. 1976. Pág 41.

${ }^{209}$ Compendio de Derecho Civil. T. V. Sucesiones. EDERSA Madrid. 1987. Pág 49.

210 "Los plazos para repudiar la herencia”. AC. nº 20/15-21 mayo 1995. Pág 375.

${ }^{211}$ En este sentido, nos remitimos a cuanto exponemos en el punto número 3 del capítulo anterior donde aludimos al sistema de adquisición de los legados en nuestro derecho.

${ }^{212}$ Op. cit.: Pág 2325.
} 
una acción personal, no personalísima, como lo acredita la aplicabilidad del artículo 1001 a los legados. Transcurrido dicho plazo, se extinguiría por prescripción el derecho a repudiar, entendiéndose definitivamente adquirido el legado".

Nosotros, por nuestra parte, entendemos que el plazo de que dispone el sucesor para poder repudiar una vocación sucesoria, y tanto se trate de llamamientos hechos a título universal como a título particular, es el de treinta años, porque no deja de ser un contrasentido o una paradoja que se establezca por ley este plazo (art. 1963 CC), para el caso de que, tratándose de bienes inmuebles, se pretenda reclamar su dominio respecto de quien los poseyere porque carezca de título legítimo para ello, mientras que para poder repudiar, o en su caso, aceptar, se dispusiese de un plazo inferior.

Si así fuere y el sucesor pretendiere realizar dicha reclamación, se encontraría en la situación contradictoria, y no menos extraña o anómala, de que no la podría realizar porque, por un lado, aunque estuviere en plazo para poder reclamar, ya no podría hacerlo al haber prescrito su ius delationis y, por otro, porque el ejercicio de la acción de petición de herencia presupone para su legitimación activa, necesariamente, la previa aceptación de esa herencia, que no ha realizado, y que, además, ya no podrá hacerlo, porque, aunque lo pretendiese en ese momento, ya habría prescrito el plazo establecido para ello. Sólo tiene la actio petitio hereditatis y la puede ejercitar quien ya ha aceptado la herencia y se crea con derecho a los bienes de la misma. Si a través de dicha acción lo que se reclaman son bienes de la herencia, lógicamente, sólo le compete y puede hacerlo quien ya forma parte de ella que lo será sólo quien ha aceptado. De ahí que, en lo que no se haya producido la aceptación, el delado no es sujeto beneficiario de la herencia, por lo que, en tanto en cuanto no acepte, no puede reclamar nada, y no está legitimado activamente para el ejercicio de esta acción.

Por otro lado, mal puede reclamar el sucesor aquello sobre lo que previamente no se ha manifestado. No deja de ser una contradicción que quien pretende reclamar aquello que se cree con derecho a ello, antes no ha aceptado lo deferido a su favor. $Y$, desde otro punto de vista, el que puede lo más, puede lo menos, en el sentido de que, frente a una acción que tiene por objeto pedir o reclamar lo que se cree que es de uno, o de la herencia si se formulare la reclamación a favor de la comunidad de herederos, frente a quien lo tiene sin derecho o sin título legítimo para ello, está la sola declaración de voluntad de aceptar que no concede u otorga más que el título o condición de heredero con, eso sí, toda la trascendencia jurídica que ello implica. 


\section{2-3.- La transmisión de la delación.}

Dado que el ius delationis se defiere con carácter in tuitu personae, a favor del delado, cabe plantearse si, una vez que le ha sido deferido, puede o no disponer de él y celebrar algún pacto o contrato sobre el mismo por acto inter vivos, a título oneroso o gratuito, incluso por via mortis causa, a favor de alguno de los demás cosucesores o incluso de un tercero.

En este sentido, el Código Civil admite (art. $1006 \mathrm{CC}^{213}$ ), que el ius delationis se puede transmitir por vía mortis causa a través del conocido derecho de transmisión, transmisión de la delación, o ius transmissionis ${ }^{214}$, lo que se produce ope legis, por ministerio de la ley, de forma automática, sin necesidad de que el causante haga acto alguno de disposición mortis causa en su testamento para que tenga lugar cuando haya fallecido alguno de sus sucesores sin haber ejercitado el ius delationis. Igual sucede en las leyes sucesorias de las Comunidades Autónomas ${ }^{215}$, así como en la práctica totalidad de los ordenamientos jurídicos de nuestro entorno ${ }^{216}$.

\footnotetext{
${ }^{213}$ Este artículo se complementa con el 881 CC en el que se hace referencia a la transmisión de los legados.

${ }^{214}$ Es una institución desconocida en el derecho romano clásico dado el carácter personalísimo del llamamiento porque no se admitía una aceptación que no fuese por el mismo heredero llamado (hereditas delata, nondum adquisita, non transmittitur ad heres. Cfr C 6, 30, 7; C 6, 51, 1, 5). No obstante, fue evolucionando y transformándose hasta admitir numerosas excepciones que llegaron a desvirtuar y dejar sin efecto la regla general prohibitiva, culminando en Justiniano con la sanción de la norma contraria permisiva del ius transmissionis. Así, se distinguieron en la época romano bizantina, hasta cuatro clases distintas de transmisiones que hicieron del ius delationis, una aplicación casi excepcional del mismo: transmissio ex capite in integrum restitutionis, transmissio ex capite infantiae, transmissio Theodosiana o ex iure sanguinis, transmissio Iustiniana o ex capite iuris deliberandi que por su extraordinaria amplitud comprendió a las demás dando lugar al moderno "ius transmissionis" (IGLESIAS: Derecho Romano. Instituciones de Derecho Privado. Cit: Pág 609).

La terminología que se ha utilizado para denominarla es muy variada, ya que no hay unanimidad en la doctrina. Así, se habla de: sucesión en el "ius delationis" (JORDANO FRAGA), o de sucesión "iure transmissionis" (ALBALADEJO; MONSERRAT VALERO), o "sucesión por derecho de transmisión" (GARCÍA GARCÍA), y no faltan quienes hablen de transmisión del "ius delationis" (HERNÁNDEZ VALDEOLMILLOS).

Nosotros aquí, por entender que se trata de una modalidad de sucesión que se produce por la transmisión del "ius delationis" y por razones de agilidad en la expresión, nos referiremos a ella hablando de derecho de transmisión o "ius transmissionis", lo que no quiere decir que estemos en contra de otras expresiones o formas de identificarlo, si bien, hemos de decir que hay algún supuesto, como ocurre en los casos de vocación eventual, en que se produce esta modalidad de sucesión aun cuando falte la delación o ésta esté indeterminada de forma transitoria pero que está supeditada o condicionada a que tenga lugar y exista después, en un momento posterior. En otro caso, si la delación no se produce, la transmisión del "ius delationis” no tendrá valor ni efecto jurídico alguno. De ahí que GARCÍA GARCÍA prefiera hablar de "sucesión por derecho de transmisión" y critique la expresión sucesión en el "ius delationis" (La sucesión por derecho de transmisión. Ed CIVITAS. Madrid. 1996. Pág 30).

${ }^{215}$ Así, en: Compilación de Derecho Civil foral de Navarra (Leyes 180 y 317), en Cataluña, Ley10/2008, de 10 de julio, (arts 461-13 y 427-17, en relación al legado) y, en Aragón (art. 354 CDFA).

${ }^{216}$ Así, en: Francia (arts 774 y 775 del Code, después de la Ley no 2006-728, de 23 junio de 2006); Italia (art. 479 Codice Civile bajo la rúbrica "Trasmissione del diritto di accettazione"); Portugal (art. 2031 del Código Civil de 1966); Suiza (art. 569 del ZGB); Austria (parágrafo 809 del ABGB).
} 
No obstante, lo que sí puede hacer el causante, en la eventualidad de que se produzca esta circunstancia es, a través de diversas fórmulas ${ }^{217}$, que los bienes que hubiesen correspondido a dicho sucesor se encaucen o dirijan a solo determinado/s heredero/s u otras personas que él designe, sobre lo que HERNÁNDEZ VALDEOLMILLOS plantea varias hipótesis ${ }^{218}$. Como tampoco habría lugar al derecho de transmisión en el caso de que procediere, en su caso, el derecho de representación (art. 924 y ss CC).

Distinto es el supuesto, más problemático, que es el que aquí nos interesa, de si es posible su transmisión por acto inter vivos, a título oneroso o gratuito, incluso por vía de sucesión mortis causa por parte del delado, a través del testamento, incluso, asignándolo o atribuyéndoselo a alguno de sus sucesores por vía de legado.

Sea cual fuere la vía empleada, inter vivos o mortis causa, en nuestra opinión y al sentir unánime de la doctrina, su ejecución, en cualquier caso, por aplicación del espíritu que adorna y caracteriza el artículo 1000 CC, entrañaría una manifestación de aceptación tácita de la herencia porque el ius delationis se defiere con carácter in tuitu personae por parte del causante, o de la ley, al delado, a resultas de la vocación que se ha realizado a su favor, por lo que es absolutamente personal e intransferible, sin

No obstante, solo se admite, o es posible, en aquellos ordenamientos jurídicos de corte o tradición romana en los que se exige obligatoriamente la aceptación para que se produzca la referida adquisición. No sucede así en los ordenamientos de adquisición automática de la herencia, como es el alemán, donde no es necesaria la aceptación para ser heredero y adquirir los bienes deferidos.

${ }^{217}$ Así, puede ordenar de manera expresa en su testamento la designación de un sustituto vulgar para este supuesto, disponer que los bienes que hayan de ser deferidos al delado hagan tránsito a otras personas distintas de aquellas que fueren sucesores de éste, como pueden ser: sus coherederos con derecho de acrecer o los sucesores abintestato de su propia herencia. Inluso, llegado el caso, podría hasta prohibirlo expresamente.

218 “La transmisión del ius delationis”. Libro Homenaje a Juan B. Vallet de Goytisolo. Junta de Decanos de los Colegios Notariales de España. Vol IV. Madrid. 1988. Pág 475 y ss:

1.- puede el primer causante instituir a su heredero bajo la condición suspensiva de que acepte la herencia de forma que si fallece sin aceptar (ni repudiar), tal hecho tenga el mismo valor que si hubiera repudiado, sustituyéndolo por un segundo heredero, añadiendo así, al amparo de la libertad de testar, un nuevo supuesto de sustitución vulgar por la vía de institución condicional.

2.- Puede el testador prohibir el ius transmissionis ordenando, por ejemplo, que si el instituido fallece sin aceptar ni repudiar, no transmita derecho alguno a sus herederos con lo que se abriría la sucesión abintestato por frustración total del testamento.

3.- Puede el testador suprimir radicalmente el derecho de transmisión ordenando que en caso de fallecer el heredero sin aceptar no haga tránsito su derecho a ningún otro heredero, ni siquiera por el llamamiento de los herederos intestados del propio testador.

Al amparo del principio de que la voluntad del testador es ley de la sucesión y su conexión con la interpretación del testamento y el favor testamenti, HERNÁNDEZ VALDEOLMILLOS entiende que en todos los casos anteriores, u otros similares, la verdadera voluntad del testador ha sido la de instituir herederos condicionales sobre la base de atribuir a la aceptación el valor de una condición positiva potestativa cuyo incumplimiento produce idéntico resultado práctico que la repudiación, con lo cual el ius transmissionis se traslada al campo de la sucesión intestada y en el caso extremo del Estado quedaría inoperante por falta de transmisarios. 
perjuicio de que se pueda ejercer por medio de apoderado ${ }^{219}, y$, por tanto, sólo él, de forma única y exclusiva, y no otro, puede hacer uso de esta facultad. Y si el delado lo cediese a favor de otra persona, lo que estaría haciendo es dejar en manos del cesionario la opción que el ius delationis lleva consigo. Pero, además, dado el carácter absolutamente personalísimo de la delación, hace que el acto no se podría realizar y, si se admite, se estaría disponiendo de un derecho que forma parte de manera implícita de la herencia ya que de ella no se puede desligar, ni separar, ni ejercer de forma autónoma o independiente, lo que implicaría estar aceptando, de forma tácita, la herencia. Si él quiere transmitir aquello que se le defiere a través de la vocación lo que tiene que hacer es aceptar la herencia y luego transmitirlo por el título que quiera.

En este sentido, el Código Civil solo admite la transmisión, como ya hemos apuntado, en el caso de que el delado falleciere sin haber hecho uso del mismo, en los términos de establecer que, "pasa a los suyos el mismo derecho que él tenía" (art. 1006 CC). Es decir, la misma opción en que consiste y no otra diferente, de aceptar o repudiar, pero no de ceder esa opción, ni menos aún, de transmitir, a través del mismo, a otra persona, los bienes deferidos. $\mathrm{Y}$ lo permite por estar aun intacto el ius delationis al no haberse ejercitado.

De igual manera sucedería si el delado trata de transmitir la delación por vía de sucesión mortis causa, a título particular, asignándolo o atribuyéndoselo a alguno de sus sucesores por vía de legado. Ésta es una hipótesis que ha sido tratada por varios autores y que admite sin reservas ROCA SASTRE para quien, "no hay dificultad alguna en que este ius delationis corresponda a un legatario del heredero fallecido, cuando así lo haya dispuesto éste"220. Otros, como ALBALADEJO ${ }^{221}$ o VALLET $^{222}$, también lo admiten aunque no sin ciertas reticencias y con distintos argumentos, pero sin que ello constituya una forma de aceptación tácita de la herencia. En igual sentido, HERNANDEZ VALDEOLMILLOS ${ }^{223}$.

En sentido contrario y opuestos a tal posibilidad, se manifiestan LACRUZ y SANCHO, quienes entienden que, “..... el llamado a una herencia puede ordenar, a su vez, que tal herencia pase a uno solo de sus sucesores universales, o un legatario,

${ }^{219}$ En este sentido, nos remitimos al punto número 3 del capítulo cuarto donde tratamos el carácter personal y apoderable de la repudiación.

220 “El derecho de transmisión” Estudios de Derecho privado. Vol II. Sucesiones. Madrid. 1948. Pág 295.

${ }^{221}$ Curso de Derecho Civil. T. V. Cit: Pág 46.

${ }^{222}$ Panorama del Derecho de Sucesiones. II. Cit: Pág 397 y ss.

223 "La transmisión del ius delationis". Libro Homenaje a Juan B. Vallet de Goytisolo. Junta de Decanos de los Colegios Notariales de España. Vol IV. Madrid. 1988. Pág 477. 
pero entonces ya no dispone del ius delationis, sino de una herencia definitivamente adquirida, porque, por el solo hecho de realizar tal asignación singular, la herencia se entiende aceptada. Así se deduce del artículo 1000,10 CC, que considera adida la herencia cuando el heredero la vende, dona o cede a un extraño, a todos sus coherederos o a alguno de ellos ....."224.

En nuestra opinión, compartiendo la posición y las palabras de LACRUZ y SANCHO, entendemos que no sería posible dicha disposición del ius delationis, sin que ello implique o signifique una aceptación tácita de la herencia porque, aparte del carácter personal que tiene el llamamiento en la persona del sucesor por parte del causante, y pese a no estar tipificados tales actos en el artículo 1000 del Código Civil, el delado, a través de ellos, lo que está haciendo, en realidad, es decidir y disponer sobre el destino de la porción o cuota sucesoria que a él le ha sido deferida, con carácter in tuitu personae, por parte de su de cuius. Si ello fuere posible, él, lo que estaría haciendo, al igual que sucede en la transmisión inter vivos, es decidir quien, en su lugar, va a ser el beneficiario o destinatario de la disposición mortis causa deferida a su favor. Luego, en realidad, está decidiendo sobre aquello que le ha sido deferido, lo que supone, aunque, tal vez, no sea esa su voluntad deliberada y consciente, influir en el destino de esos bienes porque supone una injerencia en el traspaso o movimiento de los bienes previsto por el causante, incluso una forma de frustrar, o de burlar, su voluntad, porque el adquirente no es un sucesor, ni está designado por el testador. A mayores, el ejercicio de la opción que entraña el ius delationis es personal e intransferible, absolutamente indisponible. La vocación, y subsiguiente delación, solo única y exclusivamente le corresponden al sucesor.

Por otro lado, la transmisión, inter vivos o mortis causa, por vía de legado, del ius delationis, impide, en nuestra opinión, que se pongan en marcha, en su caso, los mecanismos legales previstos para el caso de repudiación (sustitución, derecho de acrecer o apertura de la sucesión intestada), porque éstos han sido previstos para el sucesor designado por el causante y no para el adquirente ${ }^{225}$.

${ }^{224}$ Derecho de Sucesiones. I. Cit: Pág 72.

${ }^{225}$ Así, pensemos por un momento que es posible la disposición mortis causa del ius delationis y que después el cesionario o adquirente del mismo decide repudiar. En este caso, ¿a quien sustituyen los sustitutos previstos por el causante?: ¿al cedente?, él no es quien ha repudiado, ¿al cesionario?, él no es a quien el testador previó un sustituto para el caso de repudiación y sí al cedente. Luego, la cláusula de sustitución prevista por el causante quería frustrada.

Incluso podemos entender o interpretar que cuando el delado realiza alguno de estos actos lo hace porque no quiere posicionarse acerca de la delación que le ha sido deferida y para que no quede abandonada hace cesión de la misma a otra persona. De ahí que tal acto de disposición signifique o entrañe, en nuestra opinión, una forma tácita de aceptar la herencia. 
En comentario común a ambos casos, aunque el delado ciertamente no ejerce la opción que le concede el ius delationis, lo cierto es que la disposición del mismo, sea por acto inter vivos, a título oneroso o gratuito, o por acto mortis causa, pese a no ser supuestos o hipótesis que estén recogidos de forma expresa en el artículo 1000 del Código Civil, entendemos que habría que considerarlos implícitamente incluidos dentro de su ánimus o ratio porque, lo que verdaderamente está dando a entender dicho precepto es que, la realización de cualesquiera actos de disposición por parte del llamado sobre el derecho de adir o no la herencia, implican una aceptación tácita de la misma porque se trata de actos que no se puedan ejecutar sin el título o condición de heredero, lo que implica aceptación, y entrañan "actos de señor" (STS de 20 de enero de 1998, RJ 57). En este sentido, dado que el precepto no encierra un sistema de numerus clausus, y solo recoge supuestos de disposición inter vivos, ha de ser interpretado de forma amplia o extensa y entender también comprendidos en él, no solo los actos que expresamente cita, sino también cualesquiera otros semejantes, no ya solo inter vivos, sino actos mortis causa como pudieren ser los aquí examinados.

\section{2-4.- El abandono de la delación.}

La delación va indefectible e implícitamente unida, de forma automática y sin que lo pueda evitar o impedir el sucesor, a la vocación sucesoria que a él se le ha dirigido, de la cual aquella emana y tiene su origen por ministerio y disposición de la ley, mas no por la voluntad del causante, lo que se produce como una relación de causa-efecto, de forma inseparable, de tal manera que sin vocación no hay delación.

No obstante, se ha planteado la doctrina la cuestión de si el ius delationis es renunciable y, por ello, susceptible de abandono. Es decir, ¿puede el vocado manifestar que abandona el ius delationis, que se desentiende totalmente de él, haciendo caso omiso del mismo como si la vocación no se hubiere producido a su favor, de tal manera que se desvincula de la oferta hereditaria que ha recibido?, lo que implica tanto la opción de repudiar como de aceptar la herencia. Y, además, sin hacer cesión o transmisión del mismo a otra persona, al igual que si se tratase de la renuncia, abdicativa, de cualquier otro derecho. Lo que, al fin y a la postre, viene a significar, en realidad, una forma de renunciar a la herencia o de quererla rechazar, cuando resulta que es precisamente la repudiación el medio, en sentido estricto, técnico, propio y jurídico, por no decir que el único, del que dispone el sucesor para rechazar la herencia a que ha sido llamado si esa era su voluntad real cuando abandonó el ius delationis. 
En principio, se puede entender como un acto en virtud del cual el delado manifiesta no querer la herencia, al igual que en la repudiación, cuando en realidad va más allá porque lo que quiere es desentenderse totalmente de ella, no quiere saber nada, como si nunca se hubiese producido la delación a su favor, de tal manera que no quiere repudiarla, como tampoco aceptarla. Por tanto, no ejerce ninguna de las dos opciones, dejando abandonada la delación.

¿Es ello posible?, haciendo un juego de palabras con el objeto de nuestra tesis, ¿se puede repudiar el ius delationis?. Y, por otro lado, ¿es posible dicha renuncia sin que ello implique o signifique un acto de repudiación, propiamente dicha, de la herencia?.

Algo que parece de todo punto lógico y evidente es el hecho de que, si se admite la renuncia al ius delationis, ésta no se puede entender, en modo alguno, como una repudiación de la herencia porque ésta, la repudiación, en un sentido propio y estricto, solo, única y exclusivamente, puede tener lugar a través del ejercicio en sentido negativo del ius delationis ya que en eso consiste la manifestación de dicho ejercicio.

Todo lo más se podría llegar a entender, en su caso, como un acto asimilable a la repudiación por razón de los efectos y consecuencias que de la misma se derivan como ahora veremos, pero sin que implique una repudiación propiamente dicha. Otra cosa distinta es que sea admisible la renuncia a la delación en sí misma considerada, lo que significa rechazar, tanto la posibilidad de repudiar, como de aceptar, la herencia. Así, pues, la renuncia, o el abandono, del ius delationis comprendería la doble facultad u opción de repudiar o aceptar, mientras que la repudiación de la herencia significa y consiste en el ejercicio en sentido negativo del ius delationis. Luego, aquel sería, no ya solo diferente a éste, sino más amplio y por ello, totalmente distinto uno del otro. No obstante, la cuestión planteada no es ni pacífica ni sencilla como lo demuestra el hecho de la división que se observa acerca de ello en la doctrina.

Así, para HERNÁNDEZ VALDEOLMILLOS ${ }^{226}$, el ius delationis es un derecho irrenunciable porque, “... su renuncia implicaría la destrucción de la facultad de aceptar la herencia sin haberla repudiado y, en su reverso, la destrucción de la facultad de repudiarla sin haberla aceptado, lo cual nos llevaría al absurdo jurídico de la paralización del proceso sucesorio". Después, con apoyo en esta tesis, entiende que el ius delationis no es un verdadero derecho subjetivo como tampoco un derecho

\footnotetext{
${ }^{226}$ Op. cit.: Págs 479 y 480.
} 
potestativo pues, en rigor, no hay tales derechos y prefiere calificarlo de facultad jurídica (facultas adeundi vel repudiandi).

ROGEL VIDE ${ }^{227}$, por su parte, también entiende que el ius delationis, por su propia naturaleza, es irrenunciable. A lo que él añade: "lo mismo sucede con la facultad de aceptar o de repudiar. Respecto de esta última, lo único que cabe es ejercitarla -aceptando o repudiando-, o no ejercitarla, absteniéndose simplemente". En igual sentido, según él cita, se manifiesta FERRI ${ }^{228}$.

En cambio, JORDANO FRAGA ${ }^{229}$, sí admite dicha renuncia porque siendo la delación hereditaria una oferta de adquisición, "la voluntad del llamado titular solo se despliega o, aceptando o repudiando, o absteniéndose".

ALBALADEJO ${ }^{230}$, también admite la renuncia al ius delationis como si se tratase de cualquier otro derecho subjetivo. Si bien, es cierto que, tanto la repudiación como la renuncia al ius delationis, conducen al mismo resultado: a la no adquisición de la herencia, pero por caminos diferentes: el de no adquirirla, por renunciar al ius delationis, y el de no adquirirla por, usando el ius delationis en sentido negativo, repudiando dicha herencia. En defensa de su tesis, se apoya en los siguientes argumentos:

$1^{\circ}$.- la regla general de la renunciabilidad de los derechos que admite el artículo 6.2 del Código Civil, y así de sus expectativas,

$2^{\circ}$.- en que quita dudas sobre la sucesión, que es lo que la ley quiere cuando impide tanto la aceptación de la herencia condicional como la aceptación o repudiación condicionales,

$3^{\circ}$.- no se ve por qué va a impedirse a quien no es sólo que no quiere la herencia y la repudiaría en su día, sino que no quiere saber nada de aquella sucesión y hasta desea desentenderse del derecho a ella.

Sin embargo, aunque reconoce que, si bien desde un punto de vista teórico, el argumento es impecable, después, en la práctica, dará lo mismo una renuncia al ius delationis que una repudiación de la herencia, ya que, en la realidad, una y otra se

${ }^{227}$ Op. cit.: Pag 252.

${ }^{228}$ Rinunzia e rifiuto nel diritto privato. Milano. A. Giuffrè. 1960. Pág 113.

${ }^{229}$ La sucesión en el "ius delationis" .......... .Cit: 165.

230 "La sucesión iure transmissionis”. Cit: Pág 27. También en, “La repudiación de la herencia”. $A C n^{\circ}$ 36/3-9. Octubre 1994. Pág 743. 
vienen a equiparar o identificar. Por ello, "una de dos: o se equiparan ambas, o, si no, hay campo abierto para que quepa hacer como una lo que no se puede como otra".

Pero ALBALADEJO ${ }^{231}$ no solo lo admite, sino que señala, al menos en teoría, hasta otras cinco posibles formas distintas de rechazar el sucesor la delación que le ha sido deferida atendiendo al momento y a las circunstancias en que puede manifestar su declaración de rechazo o repudio a la misma. No obstante, dependiendo de cuando sea ese momento y de cómo se haya realizado, alguna de estas formas se podrá calificar, en su caso, como de repudiación, en el sentido propio del término, y, por tanto, según y cómo, será o no verdadera repudiación, y si se puede llegar a entender o no alguna de ellas, en lo que aquí nos interesa, como una forma de renuncia a la delación pero sin que constituya una repudiación de la herencia.

Primera: que el futuro sucesor manifieste en vida del causante su voluntad de repudiar:

esta hipótesis no es admisible en nuestro Código Civil desde el momento en que, en vida del causante, no se permite la celebración de ningún acto, pacto o contrato sobre la herencia futura, esto es, sobre una sucesión que todavía no esté abierta (art. 1271 pfo $2^{\circ} \mathrm{CC}$ ). Además, hay que estar, en este mismo sentido, a lo dispuesto en los artículos 991 CC, del que se deriva la doble circunstancia o exigencia de la apertura de la sucesión y del derecho a heredar para que se produzca la delación hereditaria, y 816 CC, que prohíbe toda renuncia o transacción sobre la legítima futura.

Por tanto, esa forma de repudio no es admisible en los territorios de derecho común en que rige el Código Civil. No obstante, en algunas Comunidades Autónomas, aquellas de tradición foral, sí se admite en su derecho propio no ya solo la renuncia sobre herencia futura ${ }^{232}$, sino la celebración de distintos actos, pactos o contratos sobre herencias aun sin deferir a través de distintas instituciones jurídicas.

Segunda: que el ya sucesor, por haberse producido el hecho del fallecimiento del causante, manifieste su voluntad de repudiar por ser su vocación pura:

modalidad que puede revestir, a su vez, según ALBALADEJO, dos formas:

a) que el sucesor renuncie al derecho a heredar: sería aquel supuesto en que lo que hace el sucesor, en realidad, es renunciar, en el sentido propio del término, a su

231 “La repudiación de la herencia”. Cit: Pág 714 y ss.

${ }^{232}$ Así: Aragón: art 399 (sobre "Pactos de renuncia”), del CDFA. Baleares: Mallorca (arts 50 y 51 CDCFIB); Ibiza y Formentera (art 72 CDCFIB). Navarra: Leyes 155 y 156 CDCFN. 
derecho a la herencia que ya ha adquirido porque ha habido previa declaración de aceptación. El sucesor hace dejación o abandono de su derecho a heredar. Lo renuncia sin más.

Se trataría, no de una repudiación, que no puede tener lugar porque ya se ha aceptado, sino de una renuncia a su derecho hereditario que ya forma parte de su patrimonio, como sería la de cualquier otro derecho subjetivo del que él fuese titular.

De ahí que esta forma de renuncia no se puede entender ni como una forma de repudiación propiamente dicha, ni como una renuncia al ius delationis, y menos aun como una modalidad de renuncia de las contempladas en el artículo $1000 \mathrm{CC}$, sino de la renuncia de un derecho que ya forma parte de su patrimonio.

b) que renuncie, optando por no suceder, haciendo uso de ese derecho a heredar: en este caso, el sucesor, una vez producida la delación y, a la vista del ius delationis, opta o decide por no suceder manifestando su voluntad de repudio.

En este caso, lo que en realidad hace el sucesor es repudiar la herencia, en el sentido propio y estricto del término, y no renunciar al ius delationis.

Tercera: que el ya sucesor manifieste su voluntad de repudiar pese a pender su vocación de una condición:

se trata de aquel supuesto en que, estando ya abierta la sucesión, la vocación o llamamiento del sucesor está aun pendiente para su efectividad de un acontecimiento futuro y objetivamente incierto, por lo que no se sabe si será efectivamente llamado a la sucesión ya que ello dependerá de que se cumpla, o no, la condición, según que ésta sea positiva o negativa (arts 1117 y 1118 CC). Así, al estar pendiente la vocación hereditaria del cumplimiento de dicha condición, el sucesor no puede realizar acto alguno de disposición no ya solo sobre la delación sucesoria o ius delationis, sino, lógicamente, sobre el mismo derecho hereditario. Solo si se cumple la condición, podría rechazar la delación y, en caso contrario, nunca llegaría a nacer su vocación a la herencia como tampoco la delación. Su posición o situación sería equiparable a pretensión de rechazo en vida del causante que vimos en primer lugar.

Pero, esta modalidad de rechazo, dado el tenor del artículo 991 CC, sería imposible de realizar en tanto en cuanto su derecho a heredar no exista y sea cierto. 
Cuarta: que el ya sucesor, teniendo a su favor una expectativa actual por estar sujeta a un término, manifieste su voluntad de repudiar:

esta hipótesis sería equiparable a la anterior, si bien, dado que aquí existe la certeza de que la delación va a tener lugar en todo caso, ya se sepa el momento (término determinado), o no (término indeterminado), el sucesor tendría de esperar a que dicho término se cumpliera para poder aceptar o repudiar el llamamiento que le ha sido deferido. No obstante, dado el tenor de los artículos 784, relativo a la sustitución fideicomisaria, y 799 CC, relativo al término suspensivo en la institución de heredero, sí sería factible dicha repudiación desde el momento de la apertura de la sucesión.

Ahora bien, en comentario común a estas dos últimas hipótesis, hay que decir que una y otra quedan inoperantes o sin virtualidad alguna desde el momento en que se admita la posibilidad de renuncia al ius delationis por parte del sucesor porque, sin necesidad de esperar a que se cumpla la condición o el término, podrá renunciar al ius delationis. De esta forma resuelve o despeja la incógnita y la incertidumbre que pende en ese momento sobre la vocación y delación sucesorias, al no esperar a que llegue el momento señalado para su cumplimiento, lo que equivaldrá, en realidad, en palabras de ALBALADEJO ${ }^{233}$, a una repudiación anticipada de la herencia.

Quinta: que el sucesor, después de haber adquirido el título o condición de heredero, manifieste su voluntad de repudio:

en este caso, como ya hemos argumentado más arriba, no existirá repudio propiamente dicho, sino renuncia, puesto que como ya es heredero, significa que ya habido previa aceptación de la herencia, lo que excluye la posibilidad de repudiación al ser una y otra declaraciones incompatibles entre sí. Entonces, lo que sería objeto de renuncia es aquello que ya se adquirió a resultas de la aceptación que bien puede ser un bien concreto y determinado o al derecho hereditario.

En nuestra opinión, cierto es que el ius delationis no es un derecho que forma parte del patrimonio personal del sujeto que es llamado a la herencia porque no está incorporado al mismo y sí, en cambio, es parte integrante del acervo hereditario, un elemento patrimonial más del mismo junto con aquellos otros activos y pasivos que lo formaren, pero se trata de un derecho que se tiene u ostenta en virtud de la vocación sucesoria, que nace como consecuencia de la misma por disposición de la ley, cuyo único titular es el mismo llamado y que solo él está facultado para su ejercicio. De ahí

233 “La repudiación de la herencia”. Cit: Págs 743y ss. 
que, en tanto en cuanto el ius delationis concede la posibilidad de poder aceptar o repudiar la herencia a que se ha sido llamado, sí sería admisible la renuncia abdicativa del mismo, como si se tratase de cualquier otro derecho subjetivo que ya formare parte del patrimonio del llamado y estuviere incorporado a él, porque la ley no prohíbe de forma expresa dicha renuncia, como tampoco, entendemos, entraría en el ámbito del artículo 6.2 del Código Civil al no ser contraria al interés u orden público, ni causar perjuicio a tercero.

Un argumento más que se podría esgrimir a favor de la renunciabilidad del ius delationis, lo constituye el hecho de que la ley no obliga a ejercer la delación (art. 988 $\mathrm{CC}$ ), que es libre, lo que significa que a nadie se le puede obligar a manifestarse en uno u otro sentido.

Por otro lado, también sería posible, en nuestra opinión, dicha renuncia al ius delationis porque, por razón de los efectos y consecuencias jurídicas y prácticas que de la misma se derivarían, éstas sean idénticas o análogas a las de una repudiación propiamente dicha en virtud del ejercicio en sentido negativo del ius delationis. Una y otra decisión por parte del llamado conducirían y llevarían al mismo resultado, al abandono de la herencia, aunque por diferente vía, como decía ALBALADEJO, en el primer caso, a través de la actitud activa de repudio, mientras que, en el segundo, a través de una actitud pasiva de abandono y, por ello, en realidad, será lo mismo, tanto renunciar al ius delationis como repudiar la herencia deferida.

Pero aquí, nos surge una duda: a resultas o como consecuencia de la renuncia al ius delationis, ¿se pondrían en marcha los mismos los mecanismos previstos que para el caso de la repudiación de la herencia: llamamiento del sustituto, acrecimiento $\mathrm{y}$, en último término, apertura de la sucesión abintestato?, porque, en realidad, no ha habido repudiación propiamente dicha dado que el ius delationis no se ha ejercitado. En nuestra opinión, sí, porque renunciar al ius delationis es, en definitiva, un "no querer", que sería lo mismo que repudiar. En este sentido, el artículo 774 Cc, al tratar de la sustitución vulgar, emplea la expresión, "no quieran", lo que se ha interpretado como una repudiación, pero es una expresión dentro de la cual se puede comprender también la renuncia al ius delationis porque, no se quiere una herencia, tanto cuando se la repudia en virtud del ejercicio en sentido negativo del ius delationis, como cuando se renuncia a éste, ya que, desde el punto de vista de sus efectos y de las consecuencias prácticas que se derivan de una y otra figura, ambas son las mismas, conducen al mismo resultado y se vienen a identificar. 
No obstante, entre la renuncia al ius delationis y la repudiación de la herencia sí hay, en nuestra opinión, alguna diferencia importante: por un lado, aquella consiste en el no ejercicio del ius delationis y se produce como consecuencia del abandono o dejación que se hace del mismo por parte del llamado, mientras que la repudiación consiste en su ejercicio en sentido negativo; y, por otro lado, a través de la renuncia, se excluye al mismo tiempo, en virtud de un solo golpe o acto, la posibilidad de aceptar y de repudiar la herencia, mientras que, a través de la repudiación, no solo se rechaza la herencia, sino que se ejercita el ius delationis y se excluye la posibilidad de poder aceptar. Aunque después, las consecuencias jurídicas que se derivan de una y otra, se vienen a equiparar porque ambas dan lugar a la puesta en marcha de los mismos mecanismos para proveer acerca del destino mortis causa de aquello que se le defirió al sucesor y que renunció a su ius delationis.

\section{2-5.- ¿Es obligatorio el ejercicio de la delación?.}

Ante la oferta que el delado ha recibido a resultas de la vocación sucesoria, ¿puede adoptar una actitud de silencio respecto de la delación que le ha sido deferida, de tal manera que no renuncie al ius delationis, como se analiza en el punto anterior, sino que permanezca inactivo, adopte una actitud pasiva, no lo ejerza, se abstenga, no diga nada, ni acepte, ni repudie?, incluso ni tan siquiera realice acto posesorio alguno en relación a los bienes de la herencia, como tampoco actos de conservación o de administración (art. 999 CC), no se pronuncie ni se manifieste en ningún sentido sobre la oferta hereditaria que ha recibido, permanezca en silencio, lo que no significa que renuncie o abandone el ius delationis. ¿Es ello posible?.

Planteado en otros términos: si no renuncia o abandona al ius delationis, ¿es obligatorio su ejercicio?, de tal manera que se tiene que manifestar en uno u otro sentido, si no quiere aceptar, ¿ha de repudiar? y, si no repudia, ¿ha de aceptar?, o puede guardar silencio y dejar la oferta sucesoria que ha recibido olvidada 0 , abandonada a la suerte o destino que resulte de las normas del testamento, o de la ley. Y, si ello es posible, ¿cómo se interpreta el silencio?, ¿qué valor jurídico tiene?.

El silencio del sucesor no se plantea en aquellos $\operatorname{casos}^{234}$ en que se le ha concedido un plazo concreto y determinado para el ejercicio del ius delationis ya que la ley lo resuelve de manera expresa imponiendo la aceptación "ex lege" de la herencia. El problema se plantea en aquellos supuestos en que sí hay un momento inicial, que

${ }^{234}$ Así sucede cuando ha habido una interpelación previa, o "interrogatio o interpellatio in iure”, al sucesor (arts. 1004 y 1005 CC) o cuando éste se ha reservado el derecho de deliberar (art. 1019 CC). 
será cuando la delación ya se pueda ejercitar porque la vocación ya estuviere deferida y fuere un llamamiento puro, o se hubiere cumplido la condición suspensiva a que estuviere sujeto, pero no hay un momento final o, al menos, el plazo es temporalmente indefinido.

En aras de la buena fe, de que se resuelva la situación de incertidumbre, incluso de inseguridad jurídica en que se encuentra la herencia, de los intereses que subyacen en el ámbito de un proceso sucesorio en diferentes órdenes: de los demás sucesores, de otras personas llamadas a la sucesión (sustitutos, fideicomisarios, sucesores abintestato, transmisarios, etc), de los propios acreedores (tanto los que lo fueren de la herencia como los particulares del sucesor), como por razón de la propia seguridad de tráfico jurídico, lo suyo, lo más propio, lógico y normal, es que el delado se manifieste en uno $u$ otro sentido, que repudie o acepte la vocación que le ha sido deferida y no mantenga una actitud de silencio, y tanto más si no tiene o no existe ninguna razón o motivo que justifique no declarar en uno u otro sentido.

A este respecto, hemos de tener en cuenta que, según el artículo 988 del Código Civil según el cual, "la aceptación y la repudiación de la herencia son actos enteramente voluntarios y libres" ${ }^{235}$, de lo que se deriva una doble consecuencia: por un lado, son declaraciones de voluntad que, en sí mismo consideradas, en el momento en que se exteriorizan, el delado puede actuar con total y absoluta libertad para decidir en uno u otro sentido, si acepta o repudia, según estime o tenga por conveniente, por lo que no puede estar, en modo alguno, condicionado por ninguna circunstancia que limite dicha voluntad (cfr. art. 997 CC) y, por otro, que es el que aquí nos interesa, dado el tenor del precepto, la ley no obliga, ni a aceptar, ni a repudiar, la herencia.

Pero, este carácter libre puede ser interpretado o leído en otro sentido: no es obligación del delado aceptar si lo que ha decidido es no repudiar, como tampoco es una obligación repudiar, si lo que ha decidido es no aceptar. Son dos declaraciones de voluntad que, aunque sean antitéticas u opuestas entre sí en el sentido de que, la exteriorización de una excluye automáticamente la posibilidad de emitir la otra, entendemos que ello no quiere decir, en modo alguno, que si no se quiere una se tenga que exteriorizar o manifestar necesaria y obligatoriamente la otra. En este sentido, el Código Civil, al igual que ocurre en otras leyes sucesorias de nuestro entorno, en ningún momento impone de forma obligatoria o imperativa el ejercicio del

235 Del carácter libre de la repudiación, junto con los demás que adornan esta declaración de voluntad, ya trataremos más adelante en el capítulo cuarto. 
ius delationis, de tal manera que se tenga que ejercitar en uno u otro sentido: si no se acepta, se tenga que repudiar y, si no se repudia, se tenga que aceptar.

En el sistema romano, en nuestro ordenamiento jurídico, de la misma manera que la aceptación no se hace para decir, o hacer saber, que no se quiere repudiar, sino para manifestar que se quiere ser heredero, la repudiación no se hace tampoco para evitar que la herencia se tenga por aceptada, sino para expresar el rechazo que se hace a la vocación sucesoria que se ha recibido. No es una obligación, ni un deber jurídico, ser heredero, pero si se quiere ser, hay que aceptar, y si no se quiere ser tal heredero, hay que repudiar. Pero ello, no para evitar que se produzca o se presuma, tanto en uno como en otro caso, el efecto contrario, sino porque, sólo se es heredero si se acepta y, no se es heredero sólo si se repudia. Las declaraciones de aceptación y repudiación no son interdependientes ni están relacionadas entre sí en el sentido de que el hecho de no emitir una de ellas supone o implica necesariamente que se tenga que emitir la otra, o se presuma que se quiere la declaración de signo contrario. Es decir, al igual que la ausencia de aceptación no significa repudiación, la ausencia de repudiación no significa aceptación. Así, de la misma manera que no se le impone al delado la herencia contra su voluntad (salvo los casos de aceptación "ex lege"), menos aun sin el concurso de su voluntad, incluso aun cuando no exista ninguna causa o motivo que justifique que no pueda o no quiera aceptar, tampoco, en este caso, se le impone o se presume la repudiación ${ }^{236}$.

De ahí que, a la vista de lo expuesto, en nuestra opinión, no es obligatorio el ejercicio del ius delationis por parte del sucesor, de tal manera que, sin renunciar a él, no diga absolutamente nada, no repudie ni acepte, no se manifieste en ningún sentido y mantenga una actitud de silencio o de inactividad en relación al mismo.

Ahora bien, ello no obsta ni impide para que, en este caso, y, tal vez, aquí con más motivo, proceda la interpelación a que se refieren los artículos 1004 y 1005 del Código Civil, en cuyo caso, ya no tendrá más remedio que manifestarse en uno u otro sentido, dentro del plazo que a tal efecto le señale el Juez, si no quiere que se le imponga por ley la aceptación de la herencia.

${ }^{236}$ En cambio, en el sistema germano, no ocurre lo mismo porque en él, la adquisición de la herencia se le impone al delado, no solo sin necesidad del concurso de su voluntad, sino ignorando él el hecho de la delación, por cuanto dicha adquisición se produce, ope legis, de manera automática desde el mismo instante en que se produce la delación sin necesidad de aceptación y sin perjuicio de que repudie dentro del plazo legal si no quiere ser tal heredero. 
El valor o significado que tiene el silencio en el ámbito del derecho ha sido interpretado de varias formas, tanto por la doctrina, que ha elaborado diversas teorías $^{237}$, como por la jurisprudencia, que resuelve respondiendo de manera positiva llegándolo a entender como expresión de una declaración de voluntad cuando concurren determinadas circunstancias o requisitos ${ }^{238}$. Pero, ello se ha planteado, de forma casi exclusiva, en el campo de las obligaciones y contratos, no así en el de la sucesión mortis causa que ha sido tratado en pocas ocasiones por la jurisprudencia.

\footnotetext{
${ }^{237}$ En este sentido, pero tratándose del valor que tiene el silencio como declaración de voluntad en el ámbito contractual, DIEZ PICAZO (Fundamentos de Derecho Civil Patrimonial. Vol I. Ed CIVITAS. Madrid 1996. Pág 149), expone tres teorías:

$1^{\text {a }}$.- Teoría negativa: según la cual, el que guarda silencio no declara nada. No puede decirse que callando se manifieste ninguna voluntad (qui tacet non utique fatetur). El silencio, en rigor, más que una declaración de voluntad es una omisión de declaración.

$2^{\mathrm{a}}$.- Frente a la posición negadora de dar algún valor al silencio, se observa que hay casos en los cuales el silencio constituye un tácito asentimiento o una tácita aquiescencia a lo declarado o manifestado por otra persona (qui tacet consentire videtur). El que calla otorga. El que calla parece consentir.

$3^{\text {a }}$.- Una tercera posición intermedia mantenida por STS 14 de junio de 1963 (con precedente en la doctrina sentada, en su día por la de 21 de octubre de 1941, y corroborada aquella por otras posteriores de 13 de febrero de 1978 y 12 de octubre de 1982), según la cual el silencio puede ser considerado como una declaración de voluntad contractual cuando, dada una determinada relación entre dos personas, el modo corriente de proceder implica el deber de hablar, de manera que si el que puede y debe de hablar no lo hace, se ha de reputar que consiente en aras de la buena fe. El silencio puede ser considerado como declaración en todos aquellos casos en que la buena fe impone un deber positivo de manifestación de una repulsa (qui siluit cum potuit et debuit loquere consentire videtur).

${ }^{238}$ Así, entre otras muchas:

STS de7 de julio de 1990 (RJ 5782): "Puede considerarse como manifestación de voluntad el silencio cuando el que calla debe hablar, no adoptando una actitud meramente negativa en el curso de las relaciones jurídicas que le ligan con la otra parte, pues no cabe callar cuando se debe hablar, induciendo a error (cfr. SSTS 1. 14 junio 1963 [RJ 1963|3057] y 2 junio y 10 octubre 1982 [RJ 198215560])".

STS de 28 de junio de 1993 (RJ 4791): "El consentimiento tácito, en su carácter meramente negativo del silencio, sólo adquiere relevancia jurídica cuando de antemano es tenido en cuenta por la ley para significarle un cierto efecto, bien sea procesal -confesión judicial-, o sustantivo -tácita reconducción, elevación de la renta arrendaticia-, o cuando de la mera voluntad privada surgen relaciones en cuyo curso acaecen hechos que hacen precisa, para puntualizar los derechos derivados, una manifestación de voluntad que se omite; siempre que se den los requisitos a que se refiere la STS 24 noviembre 1943 (RJ 1943|1292), el silencio absoluto no es productor de efectos jurídicos más que en el caso de que la ley o voluntad de las partes se lo reconozca o conceda previamente, pudiendo hablarse de un silencio cualificado sólo cuando se junte a hechos positivos precedentes, a una actividad anterior de la parte que guardó silencio o a particulares situaciones subjetivas u objetivas que sirvan como elemento útil para tener por hecha la manifestación de una determinada voluntad (cfr. STS 24 enero 1957 [RJ 1957|367])".

STS de 29 de febrero de 2000 (RJ 812): "el silencio puede equivaler al asentimiento cuando quien calla viniera obligado a manifestar su voluntad contraria según las exigencias de la buena fe entre las partes o los usos generales del tráfico (SS. 24-11-1943 [RJ 1943|1292], 24-1-1957 [RJ 1957|367], 14-61963 [RJ 1963|3057] y 2-2-1990 [RJ 19901652], entre otras)".

SAP Cantabria (Sección 4a), no 262, de 23 de abril de 2001 (AC 20011852): "Por lo que al silencio como declaración tácita de voluntad se refiere, hemos de considerar que, si bien el silencio como tal no constituye en sí mismo una declaración de voluntad, integrado en un conjunto de circunstancias puede adquirir la significación de tal. La jurisprudencia, basándose en el criterio que encierra el viejo aforismo «qui tacet consentire videtur, si loqui debuisset ac potuisset», ha señalado que el silencio puede constituir una declaración tácita de voluntad, si se produjo, en el ámbito de determinadas circunstancias, y eran en definitiva generadas, en relación a esas circunstancias, de la confianza ajena (cfr. STS 17-111995 [RJ 1995, 8734])".
} 
Ciñéndonos al ámbito de la sucesión mortis causa, el silencio del delado se puede plantear en: si entenderlo como una forma o manifestación de aceptación, tácita, de la herencia, o si como un supuesto de repudiación, y si no se puede calificar como ninguna de las dos, ¿estaríamos ante un caso de abandono o derelicción de los bienes deferidos $y$, como tal, una forma de renuncia de los mismos?.

Acerca de la primera opción, nos remitimos a cuanto ya expusimos más arriba a propósito de la aceptación tácita de la herencia y entendemos que no.

Y, acerca de la segunda opción, en principio, a través del mismo, se puede apreciar una actitud que denota, no ya apatía, pasividad o indiferencia, sino abandono, más bien rechazo porque expresa no querer hacerse cargo de los bienes sucesorios ya que, en el supuesto de querer la vocación sucesoria, o ser heredero, lo lógico es que hubiera aceptado de forma expresa, o habría entrado en posesión de los bienes, o habría realizado en relación a ellos cualquier acto o un comportamiento que entrañe una aceptación tácita de los mismos, como también, de igual manera, en el supuesto de no haber querido ser tal heredero, lo lógico y normal es que hubiera repudiado. Pero, tampoco dice de forma expresa y abierta querer repudiar. En definitiva, no quiere saber absolutamente nada de la delación deferida a su favor. No se trataría de una repudiación por acción, pero, ¿se podría hablar de una repudiación "por omisión”, y por ello, una forma tácita de repudiación de la herencia por inactividad del sucesor?.

Difícilmente se puede calificar o entender como repudiación la actitud de silencio del delado porque esta interpretación está totalmente en contra del sistema formalista que tiene y caracteriza a la repudiación de la herencia en nuestro derecho que ha de ser siempre expresa y formal ${ }^{239}$ (art. $1008 \mathrm{CC}$ ), ya que la ley no la presume. No cabe la repudiación tácita. En consecuencia, el silencio del delado no se puede entender o interpretar como un supuesto de repudiación tácita de la herencia ${ }^{240}$.

${ }^{239}$ Acerca de este carácter, véanse el capítulo cuarto, y el punto número 2 del capítulo sexto, a los que nos remitimos.

${ }^{240}$ En este sentido, en contraste a ello, para el caso de adquisición de la herencia, y al objeto de dar más facilidades para que se produzca y de dar cobertura legal a cualesquiera actos que realizare el delado sobre la herencia de su causante, se adopta un sistema amplio y se admite la aceptación tácita de la herencia que se puede expresar a través de todo un sinfín de manifestaciones.

En cambio, en el supuesto de la repudiación, dado que para el delado supone perder la posibilidad de poder enriquecerse y ver aumentado su patrimonio con el consiguiente perjuicio económico, además de razones de seguridad jurídica para el proceso sucesorio y todos los sujetos implicados en el mismo, se justifica el hecho de que rija un sistema más estricto y restringido, y se adopten más cautelas en su celebración. De ahí que sólo se admita, al igual que ocurre en los demás ordenamientos jurídicos actuales, la repudiación de forma expresa, formal y solemne. No hay sistema legal alguno en el que se admita una repudiación tácita de la herencia. 
En este sentido, el Tribunal Supremo, en sentencia de 8 de febrero de 2000 (RJ 2423), con precedente en otra anterior de 4 de febrero de 1994 (RJ 909), manifestó que, "incluso el mero transcurso del tiempo, vigente la acción, no es suficiente para deducir una conformidad que entrañaría renuncia, nunca presumible [Sentencias de 3 marzo 1986 (RJ 1094), 25 abril 1986 (RJ 2002), 15 octubre 1986 (RJ 5791), 16 octubre 1987 (RJ 7292) y 5 marzo 1991 (RJ 1718)]".

Por otro lado, se puede observar que, el Código Civil, ante el silencio del delado, impone la aceptación de la herencia y no la repudiación. Así sucede en varios casos: en la interpelación al sucesor (arts 1004 y $1005^{241}$ ), o cuando se reserva el derecho de deliberar (art. 1019), o cuando sustrae u oculta efectos de la herencia (art. 1002), o por cuando por su culpa o negligencia no empieza o termina el inventario (art. 1018). Se observa, en consecuencia, hacia la repudiación, una postura legal muy restringida en el sentido de admitirla únicamente cuando se manifiesta de forma clara, expresa y solemne por parte del delado.

Entonces, si concluimos que el no ejercicio del ius delationis por parte del delado, no constituye, o no se puede entender, desde un punto de vista jurídico, estricto o técnico, como un supuesto de repudiación, tampoco de aceptación tácita, de la herencia, ¿cabría entender que se trata, o estamos, ante un supuesto de dejación o abandono y, como tal, un caso de renuncia, abdicativa, de la herencia, equiparable al abandono de la delación que ya examinamos en el punto anterior?. Ciertamente, como consecuencia de la actitud del sucesor, los bienes a que él fue llamado quedan, no ya solo desatendidos, sino abandonados, al tiempo que dejados a la suerte de una situación de indeterminación, interinidad o provisionalidad, incluso de incertidumbre, porque no se sabe qué es lo que va a ser de ellos, lo cual denota en un sentido amplio pero impropio, rechazo, y como tal, repudio por parte del delado. En este sentido, ya se califique de renuncia, ya se califique de repudio, impropio, lo cierto es que esta actitud del delado, una vez prescrito el plazo de que dispone para ejercer el ius delationis, pierde todo derecho que tuviere sobre la herencia, de lo que se derivarían los mismos e idénticos efectos que si se tratase de una repudiación expresa. Por ello, desde un punto de vista práctico y ateniéndonos a las consecuencias que de ello se

${ }^{241}$ En este mismo supuesto, en Aragón (art. 348.2, CDFA), y en Navarra (Ley 315 de la CDCFN), el silencio implica aceptación, si bien con la diferencia de que, en Navarra, el sucesor adquiere, de manera provisional, la herencia, sin perjuicio de poder renunciar después mientras no se haya aceptado expresa o tácitamente.

No ocurre lo mismo en Cataluña (art 461-12 punto 3, Ley10/2008, de 10 de julio, del libro cuarto del Código civil relativo a las sucesiones), donde, una vez vencido el plazo fijado por el juez sin que el llamado haya aceptado la herencia en escritura pública o ante el juez, se entiende que la repudia, salvo que sea un menor de edad o un incapaz, en cuyo caso se entiende que la acepta a beneficio de inventario. 
derivarían, se podría equiparar, el silencio, a la repudiación, porque una y otra conducen a una misma situación o resultado, sin perjuicio de las diferencias técnicas y jurídicas que, por un lado, adornan y, por otro, separan a una y otra figura.

Por tanto, igual valdría, o nos llevaría a resultados análogos, si bien por caminos diferentes al tratarse de tres figuras o supuestos distintos, la renuncia o abandono del ius delationis, su no ejercicio, como repudiar la herencia. Daría lo mismo cualquiera de las tres hipótesis, sin perjuicio de las diferencias que hay entre ellas como ha quedado apuntado.

\section{2-6.- Cuando la delación solo consiste en la aceptación.}

Aunque el ius delationis confiere al delado la posibilidad de repudiar, o aceptar, la herencia, existen toda una serie de supuestos en los que queda reducido a solo la posibilidad de aceptar, con la especialidad de que se le impone de manera forzosa u obligatoria al no ser ni tan siquiera necesario que se declare para que se produzca la adquisición de la herencia ya que ésta se le impone ipso iure, por ministerio de la ley.

De ello se deriva la consecuencia de que, en estos casos, la libertad de ejercicio (art. 988 CC) que caracteriza el ius delationis en su ejercicio no existe. Se trata de supuestos en los que el delado no tiene, o no le queda más opción que la de ser heredero porque, no solo se le impone por disposición e imperativo legal la aceptación y subsiguiente adquisición de la herencia, sino que no tiene, en modo alguno, la posibilidad de poder repudiar. Son los denominados casos de aceptación ex lege, que ALBALADEJO ${ }^{242}$ califica de discutidos o discutibles.

Se pueden distinguir en ellos, a nuestro criterio, dos hipótesis:

a) que la aceptación se imponga por razón de los sujetos que han sido llamados a la herencia ${ }^{243}$.

242 “La repudiación de la herencia”. Cit: Pág 722; “La adquisición de la herencia en el derecho español”. Cit: Pág 6.

${ }^{243}$ Tal es el caso de las herencias deferidas a favor del alma (art. 747 CC), o las dejadas a favor de los pobres (arts 992 párrafo $2^{\circ} \mathrm{CC}$ ), o en el caso de la sucesión intestada deferida a favor del Estado (art. 956 CC); de la Generalitat de Cataluña (art. 442-12, Ley 10/2008, de 10 de julio, del libro cuarto del Código civil relativo a las sucesiones); de la Diputación Foral del País Vasco (art. 73, LDCF); de la Diputación Foral de Navarra (Leyes 304 n 7 y 307 párrafo último de la CDCFN); Comunidad Autónoma de Aragón o, en su caso, Hospital de Nuestra Señora de Gracia o Provincial de Zaragoza, aunque no se dice nada en el actual Texto Refundido de las Leyes civiles aragonesas, aprobado por Decreto Legislativo 1/2011, sí en el anterior artículo 202, de la Ley de sucesiones de 1999. 
Se trata de supuestos en los que la adquisición se impone de manera forzosa $u$ obligatoria porque no se contempla por la ley posibilidad de poder repudiar ${ }^{244}$. De ahí que, en estos casos, la aceptación de la herencia sea obligatoria.

b) Que la adquisición de la herencia se imponga sin necesidad de que se declare la voluntad de aceptar por parte del sucesor porque se le priva de la facultad de poder repudiar, en unas ocasiones por su silencio, en otras, a modo de sanción por razón de la conducta que ha tenido respecto de aquella, la herencia. Así:

a') cuando el delado ha sido interpelado judicialmente para que manifieste si acepta o repudia y no lo ha hecho dentro del plazo o término que a tal efecto le haya concedido el Juez, plazo que no podrá pasar de treinta días. En este caso, si lo dejare transcurrir sin hace ninguna manifestación, "se tendrá la herencia por aceptada" (art. 1005 CC).

b') Cuando por culpa o negligencia del llamado, no se principiare o concluyere el inventario en plazo y forma (art. 1017 CC), o se haya reservado el derecho de deliberar (art. 1010 pfo $2^{\circ} \mathrm{CC}$ ), y en el plazo de treinta días contados desde el siguiente a aquel en que hubiese concluido el inventario no haya manifestado al Juzgado si acepta o si repudia la herencia (art. 1019 pfo $1^{\circ} \mathrm{CC}$ ). En estos casos, "se entenderá que la acepta pura y simplemente" (arts. 1018 y 1019 pfo $2^{\circ} \mathrm{CC}$ ).

c') En el supuesto de que trata el artículo 1002 del Código Civil, en que al sucesor se le impone la adquisición forzosa de la herencia, a título de heredero puro y simple, al despojársele de la facultad de poder repudiar por su conducta desleal como consecuencia de haber sustraído u ocultado algunos efectos de la herencia.

Acerca de este último supuesto y dado el interés que, a nuestro juicio, suscita por lo singular y excepcional de la sanción que en él se establece, las particulares circunstancias o requisitos que se tienen que dar para que tenga lugar su aplicación y las consecuencias jurídicas que de ella se derivan, según veremos a continuación, nos vamos a detener en él, haciendo un examen más en profundidad del mismo.

${ }^{244}$ No obstante, acerca de posibilidad de la repudiación de la herencia deferida a favor de los pobres, véase, en el capítulo sexto, el punto número 1-1-2-5, y en el caso de la herencia ordenada a favor de sufragios y obras piadosas, el 1-1-2-6, a los que nos remitimos. 


\section{3.- LA PERDIDA DE LA FACULTAD DE REPUDIAR EN EL CASO DEL ARTÍCULO 1002 DEL CODIGO CIVIL.}

La razón de ser o fundamento que justifica este precepto ${ }^{245}$ según el cual, "los herederos que hayan sustraído u ocultado algunos efectos de la herencia, pierden la facultad de renunciarla, y quedan con el carácter de herederos puros y simples, sin perjuicio de las penas en que hayan podido incurrir"246, obedece a la voluntad de imponer una sanción civil a aquel sucesor que ha tenido una conducta desleal respecto a la herencia a que ha sido llamado cuando, tal vez, amparándose en la situación de desprotección o de desamparo en que se pueda encontrar el patrimonio del causante, o aprovechándose de la situación de ventaja o privilegio que tenga respecto de ciertos bienes o derechos porque ya obran en su poder por algún motivo, se apropia de ellos para sí, los sustrae u oculta, cuando resulta que han de formar parte del acervo hereditario, con el consiguiente daño o perjuicio para la herencia, demás sucesores $u$ otras personas interesadas en dicha sucesión, como pueden ser los acreedores o los legatarios.

Se trata de sancionar la comisión de un acto ${ }^{247}$, no ya tanto por razón de su naturaleza, índole o importancia, incluso relevancia y trascendencia económica o patrimonial para la herencia, sino porque, en sí mismo considerado, entraña o significa un gesto, un comportamiento de ingratitud, de deslealtad o desconsideración por parte del sucesor, no ya solo contra la herencia y demás personas interesadas en la sucesión, sino respecto del causante, su honra o memoria. Obviamente, éste, al haber fallecido ya no podrá proceder o actuar contra dicho sucesor. De ahí que sea la ley quien se encargue de castigar dicho comportamiento ${ }^{248}$ con una sanción que, como ahora veremos, es de gran trascendencia para el sucesor por cuanto le "inviste" forzosa y necesariamente con el carácter o la condición de heredero puro y simple, sin

${ }^{245}$ Con antecedentes en la legislación de Partidas: leyes $9^{\mathrm{a}}$ y 12 del Título VI, Partida $6^{\mathrm{a}}$, y en los artículos 832 del Proyecto de 1851 y 1014 del Anteproyecto de 1882-1888, con el que coincide en su redacción.

${ }^{246}$ En términos análogos se manifiesta el artículo 461-8 de la Ley10/2008, de 10 de julio, de Cataluña, relativo a las sucesiones: "el llamado que haya sustraído u ocultado bienes de la herencia pierde la facultad de repudiarla y deviene heredero puro y simple, aunque manifieste la voluntad de repudiar la herencia de acuerdo con los requisitos establecidos por el presente libro".

O el Código Civil italiano a través de su artículo 527: "I chiamati all'eredità, che hanno sottratto o nascosto beni spettanti all'eredità stessa, decadono dalla facoltà di rinunziarvi e si considerano eredi puri e semplici, nonostante la loro rinunzia”.

${ }^{247}$ Véase más adelante, en este mismo capítulo, el punto número 3-3 en el que se analiza la expresión "sustraer u ocultar algunos efectos de la herencia" donde se hace un estudio más exhaustivo de qué actos serían subsumibles en el ámbito del artículo 1002 CC.

${ }^{248}$ Lo mismo ocurre en los casos de incapacidad para poder suceder por causa de indignidad del artículo 756 y ss CC. 
posibilidad de poder repudiar, y con una responsabilidad, en consecuencia, ilimitada frente a las deudas de la herencia (art. 1003 CC), lo que tiene especial relevancia si se trata de una herencia deficitaria. No obstante, se trata de una sanción que, a nuestro juicio, como ahora veremos, no es todo lo eficaz que sería de desear.

Así, cuando se produce el hecho fáctico de que trata el artículo, el derecho o la facultad de poder repudiar la herencia no existe para aquel sucesor que ha tenido ese comportamiento respecto a la misma por cuanto se le priva de esa opción por la ley y se le impone por ésta, de forma obligatoria, la aceptación-adquisición de esa herencia, porque le "inviste" de la condición de heredero, y además, de forma pura y simple.

En este sentido, la Audiencia Provincial de Tarragona, en su sentencia de 23 de octubre de 1998 (AC 2084), manifestó que, "se trata de un supuesto de aceptación «ex lege» de la herencia como sanción civil por la conducta del llamado a ser heredero, con independencia de que éste tuviera intención de aceptar o no la herencia, y que, además, le priva de la posibilidad de acogerse al beneficio de inventario, pues queda como heredero puro y simple, en concordancia con lo preceptuado en el art. 1024 del mismo Código".

Creemos, por ello, que las consecuencias de la sanción que impone el precepto van incluso más allá de imponer ex lege una aceptación pura y simple de la herencia porque, en realidad, lo que se produce para el sucesor es la privación de la posibilidad misma del ejercicio del ius delationis ${ }^{249}$, ya que, no solo no puede optar entre aceptar o repudiar la herencia al privársele de la facultad de repudiar, sino que ni tan siquiera puede después aceptar de manera libre y voluntaria, lo que, por otro lado, si no contradice lo preceptuado por el artículo 988 CC que sanciona la libertad de ejercicio del ius delationis, sí constituye una excepción al mismo, por cuanto se le impone, de manera forzosa e imperativa, por ministerio y disposición de la ley, la aceptación pura y simple de la herencia, y la atribución, en consecuencia, de la condición de heredero de esta naturaleza con los efectos que de ello se derivan (art. 1003 CC). En este sentido, manifiesta, con acierto, ROGEL VIDE ${ }^{250}$ que, "la posición de heredero puro y simple de quien haya escondido o sustraído bienes hereditarios no difiere nada de aquel que haya asumido voluntariamente la cualidad de heredero mediante aceptación expresa o tácita".

249 O’CALLAGHAN, en comentario al artículo 1002, Comentario del Código Civil. Secretaría General técnica del Ministerio de Justicia. Madrid. 1993. Pág 2377, opina lo contrario: “No se produce una privación del derecho a repudiar, sino que es una aceptación directa impuesta por la Ley. Hay una atribución de la herencia, como si fuera una aceptación impuesta “ex lege””.

250 Op. cit.: Pág 345. 
Además de lo anterior, se deriva también para el sucesor la consecuencia de que tampoco puede instar, en su caso, la solicitud del beneficio de inventario a su favor porque esta "investidura" lleva también consigo la imposibilidad de poder pedir dicho beneficio, o la pérdida del mismo en el supuesto de que ya lo hubiere solicitado, (cfr art. 1024,10 CC y SAP de Tarragona, de 23 de octubre de 1998 -AC 2084-), por lo que queda, de manera ya definitiva, como heredero puro y simple, y con una responsabilidad ilimitada frente a las deudas de la herencia. Consecuencias que, posiblemente, exceden de las expectativas, intención o previsión que tuviese, en un principio, el delado ante la oferta hereditaria que se le ha hecho. En este sentido, si él no tuviere la intención de aceptar la herencia y sí de repudiarla, no sin antes haberse aprovechado o beneficiado de la misma al sustraer u ocultar bienes o derechos, sí que se puede entender como una verdadera sanción o castigo a su comportamiento. Pero, también puede ocurrir, apunta HERNÁNDEZ $\mathrm{GIL}^{251}$, según el caso, que incluso le pueda beneficiar si la herencia es de saldo positivo, o como decimos, le perjudique si el pasivo es superior al activo.

No obstante, como apuntamos, la sanción que impone el artículo 1002 es, en nuestra opinión, incompleta o poco eficaz, o al menos, no lo todo eficaz que sería de desear porque lo suyo hubiese sido, no investir al sucesor como heredero puro y simple, que incluso hasta puede salir favorecido si se trata, como apuntamos, de una herencia beneficiosa, sino apartarle totalmente de la misma como si de un caso de indignidad se tratase, y obligarle, además, lo que el Código Civil no exige, a la devolución de aquello que sustrajo u ocultó para su incorporación al acervo hereditario y evitar así, por otro lado, a los demás sucesores tener que entablar un proceso judicial, ya sea civil o penal, para poder recuperar los bienes o derechos sustraidos.

Pero, pasemos a analizar dicho precepto porque, dado el tenor del mismo, tanto por lo que dice y cómo lo dice, como por lo que calla, se plantean, en nuestra opinión, varias cuestiones o interrogantes que consideramos de interés y pasamos a exponer.

\section{3-1.- Qué se entiende por "perder la facultad de renunciarla".}

Una cuestión que nos plantea el artículo 1002 es el significado que tiene, o ha de dársele, al término renunciar, porque no habla de repudiar. Cierto es que, en principio, se puede pensar que se trata de una cuestión puramente semántica o terminológica, pero nos plantea el interrogante de si uno y otro término, renuncia y repudiación, son

${ }^{251}$ Lecciones de Derecho sucesorio (resumen de explicaciones de Cátedra). Cit: Pág 104. 
equivalentes y significan lo mismo y, si así fuere, a qué clase de renuncia se refiere, habida cuenta de las diferentes clases que existen de la misma ${ }^{252}$.

En este sentido, aunque del examen comparado, más detenido y en profundidad de la repudiación y la renuncia nos vamos a ocupar en el próximo capítulo, aquí, sin perjuicio de ello y dada la cuestión que debatimos, adelantamos que, en nuestra opinión, el término renuncia ha de entenderse como equivalente a repudiación en su modalidad de renuncia preventiva u obstativa, habida cuenta de las características o circunstancias en que ésta consiste porque la renuncia a que se refiere el precepto es a una vocación adquisitiva, esto es, a aquello a lo que se está llamado, al igual que sucede en la repudiación.

Así, la expresión "pierden la facultad de renunciarla" entendemos que se ha de interpretar en el sentido de, "pierden la facultad de repudiarla" porque, en realidad, a lo que se está refiriendo el precepto, o lo que nos está queriendo decir (lo que es su espíritu), es que, como consecuencia de los hechos cometidos por el delado, lo que no puede hacer y, además, no puede ocurrir, es que se aproveche de la herencia a que ha sido llamado sustrayendo u ocultando bienes de la misma o que quede para sí de forma ilícita, irregular o fraudulenta con algún efecto del acervo hereditario, el que más le interese o uno de gran valor, y después, una vez conseguido, repudie la herencia.

No obstante lo anterior, en otro orden de argumentos, llama la atención el hecho que el Código Civil se queda ahí, solo en eso, en privar al delado de la facultad de repudiar la herencia, pero no le exige, como debería ser y que, además, es de gran relevancia, la devolución de los objetos que se apropió porque no impide la posibilidad de que se quede con los bienes que sustrajo u ocultó al guardar silencio sobre ello. Pero, sí estará obligado a dicha devolución cuando así sea condenado a ello en virtud de una sentencia civil firme si prospera con éxito el ejercicio de alguna de las acciones dimanantes del derecho hereditario que ejerciere, en su caso, contra él, cualquiera de los demás sucesores, como puede ser: la acción de petición de herencia o actio petitio hereditatis, el interdicto de adquirir la posesión de la herencia (art. 250.1.1ํ LEC), el ejercicio de una acción reivindicatoria, o también a resultas de una sentencia penal firme si la sustracción u ocultación fuere constitutiva de delito y hubiese dado lugar a un proceso de esta naturaleza. Igual sucede en la ley de sucesiones de Cataluña que también guarda silencio sobre ello y no se obliga al sucesor a devolver los bienes que

252 En este sentido, acerca de las clases de renuncia (abdicativa o extintiva, traslativa, o a la preventiva u obstativa), así como de su estudio, nos remitimos al punto número 3-1 del capítulo tercero, donde nos ocupamos de ello. 
sustrajo u ocultó por lo que no se ve privado de ellos, sino que, en principio, se los puede quedar (otra cuestión es que tenga o no derecho a ellos), por lo que devendría, o podría devenir, en propietario de aquello que ocultó o sustrajo, como apunta ROGEL VIDE ${ }^{253}$, con la posibilidad, al menos teórica, de que pudiere realizar actos de disposición sobre los mismos, salvo que, como apuntamos, en virtud de sentencia civil o penal firme sea condenado y obligado a su devolución, pero esto será, no como consecuencia de dicho precepto, sino del ejercicio de la correspondiente acción civil o penal ante los Tribunales de Justicia.

No ocurre lo mismo en el derecho civil francés porque el artículo 778, antiguo 792, del Code, además de privar al sucesor de la facultad de repudiar, le impide tener participación alguna en los bienes sustraídos u ocultados, es decir, le priva de ellos y no los puede adquirir.

Ahora bien, el sucesor que ha actuado con pleno conocimiento y consciencia en la ejecución del acto, incluso, tal vez, de manera deliberada, dolosa, y no por mera negligencia o ignorancia, a sabiendas de que retenía en su poder algún efecto de la herencia sin título jurídico válido que le legitimase para ello, o lo hubiese sustraído, u ocultado, se encuentra con la dificultad o el obstáculo para que pueda llegar a adquirir efectivamente su propiedad y disponer de los mismos, por lo que se le podría reputar poseedor de mala fe respecto de dichos bienes (art. 433 CC: "se reputa poseedor de buena fe al que ignora que en su título o modo de adquirir exista vicio que lo invalide. Se reputa poseedor de mala fe al que se halla en el caso contrario"), en consecuencia, no se le podría reputar poseedor en concepto de dueño y, al faltar esta exigencia (art. 447 CC), adolecería, en su caso, de título jurídico válido a los efectos de adquirir el dominio, así como también para la usucapión o prescripción adquisitiva de los bienes sustraídos u ocultados, de conformidad con lo dispuesto en el artículo 1950 y ss CC (STS 10 de noviembre de 1955, RJ 3107).

\section{3-2.- Empleo equívoco del término "heredero".}

Otra de las cuestiones que suscita, en nuestra opinión, el artículo 1002 es el empleo de forma impropia, por no decir que incorrecta, del término "herederos" para referirse a quien comete los hechos que motivan su aplicación, porque si el sujeto que realiza alguno de estos actos ya tiene efectivamente esa condición o título, es porque ya ha aceptado la herencia, se derivaría la consecuencia de que la sanción que en él se contempla ya no podría ser objeto de aplicación, carecería de sentido, por cuanto la

${ }^{253}$ Op. cit.: Pág 345. Cita a pie de página nº 205. 
facultad de repudiar ya no la tiene al haberla agotado o consumido por exclusión, además de que su decisión sería irrevocable (art. 997 CC).

Así, el supuesto de hecho a que se refiere el artículo 1002 ha de entenderse referido al "llamado", o "delado", esto es, al sucesor que aun no ha ejercitado el ius delationis. En este sentido, la ley catalana de sucesiones, 10/2008, con precedente en la anterior de 1991, habla de llamado, término que también se puede entender como vocado o delado ${ }^{254}$ (art. 461-8).

Ahora bien, cabe, evidentemente, la posibilidad de que quien sustrae u oculta bienes de la herencia sea ya un heredero. Mas, en este caso, las consecuencias que se producen son muy diferentes como analizaremos más adelante (punto número 3-4).

\section{3-3.- Qué se ha de entender por "sustaer u ocultar algunos efectos de la herencia".}

El tenor del precepto habla de "sustraer u ocultar", sin embargo, dado su significado gramatical y las distintas formas o comportamientos a través de las cuales se pueden manifestar, así como la posible existencia de otros muchos actos que se pueden subsumir en ellos, o hacerlos asimilables, según veremos ahora, entendemos que es preciso adoptar una postura amplia porque, si se interpretasen de forma estricta o restringida, podrían quedar fuera del mismo numerosos supuestos que pueden ser merecedores de la sanción que en él se establece.

Por ello, se plantea, en nuestra opinión, la necesidad de precisar cual es su sentido y alcance, así como determinar qué actos del delado se pueden incluir en el supuesto de hecho del artículo 1002 y que podrían suponer la comisión del ilícito en él tipificado.

Así, el comportamiento del sucesor puede consistir:

a) en "sustracción" que, según la Real Academia de la Lengua, es o consiste en "hurtar, robar fraudulentamente", a lo que podemos añadir el hecho de aprovechar o tomar para sí, incluso con engaño, algo que ha de formar parte de la herencia por disposición de la ley, ya sea en el sentido de guardarlo y quedarse con él, ya en el de gastarlo o consumirlo, lo que implica una conducta activa en el sucesor. Así, además del hurto y el robo, se pueden incluir al amparo de este término la comisión de actos

${ }^{254}$ Vid MEZQUITA GARCÍA-GRANERO: Comentarios a los artículos 16 a 37 del Código de Sucesiones de Cataluña, en Comentarios al Código de Sucesiones de Cataluña: Ley 40/1991, de 30 de diciembre. BOSCH. Casa Editorial. Barcelona. 1994. Pág 81. 
delictivos como: la falsificación, la estafa, la apropiación indebida, el alzamiento de bienes, etc, cuando se hubieren cometido sobre bienes o derechos de la herencia,

b) en "ocultación", que consiste en esconder, disfrazar o encubrir algún bien o derecho, callar o negar su existencia, o el hecho de no incluirlo en el inventario, lo que sería, de alguna manera, ocultarlo y significaría una conducta pasiva ${ }^{255}$.

Pero, además de los dos casos anteriores, el ilícito se puede entender, o se ha de entender, en nuestra opinión, en un sentido mucho más amplio y comprender también todo acto que implique o signifique por parte del sucesor una conducta desleal para con la herencia a que ha sido llamado, de tal manera que suponga un fraude, un engaño, una estafa o una intención de aprovecharse en beneficio propio de cualquiera de los bienes o derechos que la integran. Así, se podrían subsumir aquí, actos como: causar un perjuicio a la herencia o a cualquier interesado en la sucesión; falsificar, suponer, alterar u ocultar títulos de propiedad, documentos contables o facturas comerciales con la intención de disminuir el activo o incrementar el pasivo de la herencia; simular o negar la existencia de una deuda frente al activo; fingir un crédito para aumentar el pasivo ${ }^{256}$; ocultar cierta cantidad de dinero, alhajas u objetos que obraban en su poder y que pertenecían al causante (MANRESA ${ }^{257}$ ); el ingreso en la propia cuenta bancaria, pocos meses antes del fallecimiento del causante, de un talón por importe de 3.000 .000 de pesetas cuya procedencia no se pudo justificar al partir de la apreciación por parte del Tribunal de instancia de una donación o enriquecimiento injusto (SAP de Tarragona, de 23 de octubre de 1998 -AC 2084-); el hecho de ser condenado uno de los sucesores por un delito de alzamiento de bienes al disponer de una finca perteneciente al patrimonio del finado, ya que ello supone la sustracción de un bien del acerbo hereditario (SAP de Avila, de 1 de febrero de 1999 -AC 3734-).

En este sentido, ROGEL VIDE ${ }^{258}$ y MANRESA ${ }^{259}$, tratando de precisar el alcance y significado del acto de sustracción u ocultación de los bienes, y en lo que se refiere a su significado o calificación desde el punto de vista jurídico, entienden que en ellos no hay propiamente un acto de aceptación expresa o tácita de la herencia, como tampoco es un acto de heredero, ni acto de señor, sino, sencilla y llanamente, actos de hurto o de estafa por parte de quien los realiza que, en ocasiones, son reveladores de un

${ }^{255}$ Vid O’CALLAGHAN, en comentario al artículo 1002, Comentario del Código Civil. Cit: Pág 2377.

${ }^{256}$ LACRUZ BERDEJO, SANCHO REBULLIDA, LUNA SERRANO y otros: Elementos de Derecho Civil. T. V. Sucesiones. DYKINSON. Madrid. 2001. Pág 68.

${ }^{257}$ Op. cit.: Pág 419.

${ }^{258}$ Op. cit.: Pág 345.

${ }^{259}$ Op. cit.: Pág 418. 
propósito perverso de enriquecerse en provecho y beneficio propio pero en perjuicio de otro, y sin perjuicio de que tenga después, incluso, la intención de aceptar la herencia, o incluso, de repudiarla.

Acerca de su naturaleza, el Tribunal Supremo, en sentencias de 4 de abril de 1903 y 20 de noviembre de 1907, estableció que es preciso que el llamado proceda maliciosamente y con el propósito de lucrarse o de perjudicar los intereses de la sucesión. Ahora bien, si el sucesor ha obrado no con malicia, de forma dolosa, sino por culpa o negligencia, ignorando que aquello que obra en su poder pertenecía a la herencia del causante y lo retiene en su poder, o entiende que le pertenecía en virtud de algún título o derecho aunque no sea válido, no habría comportamiento punible y no actuaría la sanción del artículo 1002 (MANRESA ${ }^{260}$ ).

Por su parte, la ya citada SAP de Tarragona, de 23 de octubre de 1998 (AC 2084) manifestó que, "la sustracción significa el aprovechamiento para sí, tomar para sí algo de la herencia; la ocultación esconder un bien o callar sobre su existencia. La doctrina viene incluyendo en el indicado precepto los supuestos en que, aun cuando la sustracción u ocultación hubiera tenido lugar en vida del causante, se retienen los efectos o bienes de la herencia una vez producido su fallecimiento, momento en el que se producirá propiamente la ocultación o sustracción de bienes pertenecientes a la herencia, y será aplicable la sanción".

Se trata de actos que, por otro lado, como consecuencia de los mismos, se produce una disminución, resta o merma del activo del haber hereditario, lo que lleva consigo una disminución de capacidad del mismo para hacer frente al pasivo de la herencia con el consiguiente perjuicio para los demás sucesores y acreedores de la herencia.

SÁNCHEZ ROMÁN, citado por MANRESA ${ }^{261}$, entiende, por su parte, en este sentido, que no se deben comprender "los casos de consumir, malgastar, menoscabar o perder por negligencia o defecto de conservación las cosas hereditarias", siendo discutible el caso de no colacionar teniendo obligación de hacerlo, y a sabiendas.

En nuestra opinión, en comentario a SÁNCHEZ ROMAN, la inclusión, o no, de tales casos como supuestos de hecho que dan lugar a la aplicación del precepto, entendemos que exige, además, examinar y valorar, en su caso, la circunstancia de si el sucesor ha actuado de mala fe, de manera deliberada y consciente, de tal manera

${ }^{260}$ Op. cit.: Pág 419.

${ }^{261}$ Op. cit.: Pág 418. 
que él sabía que con su actuación causaba un daño o perjuicio a la herencia. Porque, si no fuese así, al no existir intencionalidad en su comportamiento, difícilmente se podrían incluir en el ámbito del precepto tales hechos, habida cuenta de que quien sustrae u oculta, o realiza cualesquiera otros actos a los que antes hemos aludido, no lo hace de buena fe, sino a sabiendas de lo que hace y para qué lo hace.

Desde otro punto de vista, no serían actos ilícitos que entrasen dentro del ámbito de este precepto, los "actos conservatorios o de administración provisional que no impliquen aceptación si con ellos no ha tomado el título o condición de heredero" (art. 999 in fine CC), o los de carácter posesorio, o los que impliquen aceptación tácita de la herencia por parte del sucesor (ROGEL VIDE ${ }^{262}$ ).

En otro orden de argumentos, y a propósito de la comisión de estos hechos, nos planteamos la siguiente cuestión, no tratada por el Código Civil y que entendemos de vital importancia, cual es el hecho de si es preciso que exista una condena, en virtud de sentencia civil o penal firme, por razón de los hechos a que se refiere el artículo 1002 CC, para que proceda la pérdida de la facultad de repudiar, como también que se imponga dicha sanción en virtud de, y a través de, una sentencia judicial. Porque, nos preguntamos, ¿y si no se llega a probar de manera efectiva e indubitada que ha existido sustracción u ocultación de bienes de la herencia por parte del sucesor?, ¿o si el sucesor, sea, o no, conocedor de la sanción que se le puede imponer, se arrepiente y devuelve aquello que tenía en su poder antes de que se inicien contra él acciones civiles o penales por razón de los hechos cometidos y devuelve los bienes al acervo hereditario?, ¿o si la sustracción u ocultación no se llega a consumar y se trata de un acto tan solo intentado?, ¿o si el sucesor retiene o conserva en su poder algún bien o derecho en virtud de un título que él cree justo, legítimo y válido, o incluso en garantía del pago de una deuda ${ }^{263}$ a modo de derecho de retención, dando lugar a un pleito que, en el momento de fallecer el causante, aun no se ha resuelto y ocurre que después se falla en contra del sucesor?, en este caso, ¿dicha retención es tipificable en el supuesto de hecho del artículo 1002 CC?.

En este sentido, entendemos que sería preciso, aunque el Código Civil no lo establezca de forma expresa, para que el sucesor pierda la facultad de poder repudiar y quede investido en la condición de heredero puro y simple del causante, que se declare probada, en virtud de sentencia civil o penal firme, la sustracción u ocultación de bienes o efectos de la herencia de que se le acusa, o que aquel acto por el que ha

\footnotetext{
262 Op. cit.: Págs 343 y 344.

${ }^{263}$ Arts $453.1^{\circ}, 1600,1730,1780$ CC.
} 
sido juzgado ha significado una conducta o comportamiento desleal para con la misma, y ello lleve consigo, a resultas de ello, incluso en el mismo fallo judicial, la imposición de la sanción del artículo 1002 CC. A ello hemos de añadir que, además, se ha de dar la circunstancia de que el Juez ha de determinar si, a resultas de las pruebas practicadas en el proceso, ha existido en el sucesor el ánimus o intención de cometer tales actos con la intención o el propósito deliberado y consciente de quedarse con ese bien o derecho, lo que es otro de los requisitos o circunstancias que se han de valorar a la hora de imponer dicha sanción. Y si así se considera probado por parte del Juez, entendemos que ésta sería la única forma o el único medio de que existiese una prueba fehaciente e indubitada de la irregularidad cometida por parte del sucesor. Se trata simplemente de una cuestión de prueba y, solo en este caso, procedería, en debida forma, la aplicación de dicho artículo.

\section{3-4.- En qué momento han de producirse los hechos.}

La cuestión, que puede parecer baladí, entendemos que tiene su interés porque dependiendo de cuando, en qué momento, se haya producido el hecho que dar lugar a la sanción del artículo 1002 CC, puede suceder que no se pueda aplicar, o incluso, ya no tenga sentido y sea totalmente inoperante.

En principio, examinando el tenor del precepto se puede entender que tales actos se tienen que cometer una vez que se ha producido el fallecimiento del causante ya que, por un lado, en él se habla de "heredero", aunque, como ya hemos apuntado, hay que entenderlo más exactamente como sucesor o delado, de lo que se deduce que el autor de los hechos ha de ser alguien que en el momento de cometerlos tenga esa condición, no haya ejercitado aun el ius delationis, y, por otro, al hablar de "efectos de la herencia"264, da a entender que ha de tratarse, porque el Código Civil no

${ }^{264}$ Otro de los silencios del Código Civil es el hecho de que no dice qué bienes o derechos pueden ser objeto de sustracción o de ocultación, pero hemos de entender o interpretar dicho término en el sentido más amplio posible. Así, puede serlo cualquier elemento patrimonial, activo o pasivo, que, por disposición de la ley, haya de formar parte del caudal hereditario: bienes, derechos, acciones, créditos, deudas, obligaciones, cargas, etc.

Dado que el precepto se refiere a sustraer y ocultar -actos que se pueden considerar como equivalentes a hurto, robo, engaño o estafa-, parece estar pensando en bienes muebles ya que éstos, dada su naturaleza, son los que se constituyen en el objeto propio y característico de estos actos ilícitos. Sin embargo, también puede tener por objeto bienes inmuebles como puede ocurrir cuando el sucesor trata de aprovecharse de la falta o insuficiencia de titulación de una propiedad; o el falseamiento del título de propiedad para evitar que una propiedad forme parte de la herencia y así pueda ser objeto de apropiación por su parte o, en su caso, de traba o embargo por parte de los acreedores; o de su no inscripción en el Registro de la Propiedad; o de las deficiencias o excesos de cabida; o de modificación de los linderos que hay para pretender una superficie distinta, de una mayor cabida si es a su favor; o del hecho de ser administrador, arrendatario o poseedor de dicho bien y pretende apropiarse del mismo, o se trata de los denominados bienes inmuebles por destino (art. $334 \mathrm{n}^{\circ} 4^{\mathrm{o}}, 5^{\circ}, 6^{\circ}, 7^{\circ}$ y $9^{\circ} \mathrm{CC}$ ). 
distingue, de cualesquiera efectos que ya forman, o deban de formar parte, del acervo hereditario. Todo lo cual nos lleva, en principio, a la conclusión de que tales actos parece que han de producirse una vez que se haya abierto la sucesión, o más exactamente, en el momento de formalizarse el inventario que sería el instante en que se procede a la determinación y cuantificación del activo y del pasivo partible de la herencia a los efectos de establecer después el activo neto y la respectiva porción o cuota de cada heredero.

Sin embargo, cabe plantearse si es posible que estos actos se hayan cometido incluso en vida del causante por parte de quien después será su sucesor y tengan, lógicamente, después relevancia en el futuro proceso sucesorio.

Acerca de ello, es cierto que el Código Civil no lo dice, pero la comisión de tales actos en vida del causante ${ }^{265}$ puede también llevar consigo la aplicación de la sanción del artículo 1002 porque, si los efectos sustraídos u ocultados debían de formar parte de la herencia y después, en el momento de hacer el inventario, no aparecen o se desconoce su paradero y existencia, obviamente, no pueden formar parte del mismo y se produce, no ya solo un fraude, sino un perjuicio para los demás sucesores por cuanto no pueden ser tenidos en cuenta al hacerse dicho inventario, como tampoco podrán, lógicamente, ser objeto de reparto entre ellos. Pero, será en este momento de la formación del inventario cuando tenga relevancia el hecho porque puede incluso suceder que el sucesor se arrepienta y proceda a la devolución de los efectos sustraídos antes de su confección, en cuyo caso es discutible la imposición de la sanción del artículo 1002 CC.

Cosa bien distinta de la anterior es que se trate de bienes o derechos que, siendo de la titularidad y pertenencia del causante, obran, en vida de éste, en poder del sucesor, incluso se detentan y poseen con su conocimiento, consentimiento y beneplácito (que sea depositario de los mismos porque se los ha confiado para su guarda, cuidado y custodia, se trate de una detentación en precario con tolerancia del difunto, o una retención por parte del sucesor en garantía del pago de alguna deuda que tuviere contra el causante), pero, en este caso, al producirse tales actos con la permisibilidad del causante, no cabría hablar de sustracción u ocultación de los mismos por parte del sucesor y no habría ilicitud en ese momento. Ahora bien, si después, al practicarse el inventario de la herencia, esos bienes o derechos que detenta el sucesor y que han de formar parte del activo hereditario, los mantiene en su poder sin título legítimo jurídico válido que le faculte para poseerlos o retenerlos en su

${ }^{265}$ Así lo reconoció la SAP de Tarragona de 23 de octubre de 1998 (AC 2084). 
poder y no hace entrega de los mismos, o no da noticias de su existencia a los demás sucesores o albaceas y los oculta, entonces es cuando entendemos que surgiría el ilícito tipificado en el artículo 1002 CC.

Por tanto, la tipicidad de los hechos que dan soporte a la sanción del artículo 1002 CC, hay que referirla, en nuestra opinión, al momento en que se procede a la confección del inventario de la herencia porque es ese el momento en el que se puede decir propiamente que se produce el hecho de la sustracción u ocultación, si bien, el acto del que nace ese hecho puede tener lugar, tanto antes como después del fallecimiento del causante porque, aunque el bien o derecho sustraído u ocultado se detente por el sucesor, incluso con la tolerancia, permiso o autorización del causante, en vida del mismo, después tiene la obligación de proceder a su entrega o devolución si no tiene título jurídico válido a su favor que legitime, después de la apertura de la sucesión, la retención, posesión o titularidad de ese bien o derecho a su favor.

Otra circunstancia o requisito, además del anterior, que, a nuestro juicio, tiene su relevancia e importancia y que ha de ser tenido en cuenta para que se pueda aplicar el artículo 1002 CC y despliegue toda su efectividad con las consecuencias jurídicas que del mismo se derivan, es el momento en que se descubre, si antes o después del ejercicio del ius delationis, el hecho de la sustracción u ocultación de aquel bien o derecho que debía haber formado parte de la herencia, o la comisión del acto que signifique conducta desleal o demostrativa de ingratitud, sea cual fuere el instante en que se haya cometido, si en vida del causante o después de su fallecimiento. Porque, cabe plantearse si el artículo 1002 tiene la misma virtualidad en el caso de que los hechos a que se refiere, se descubran o se cometan después de dicho ejercicio, o incluso después de haberse realizado las operaciones de partición y adjudicación de los bienes entre los herederos, hasta el punto de que, como ahora veremos, la sanción del artículo puede quedar totalmente inoperante. Así, podemos distinguir varias hipótesis:

a) si los hechos, sea cual fuere el momento en que se hubieren producido, se descubren antes de haber ejercido el ius delationis, es cuando tiene verdadera efectividad la sanción que contempla el artículo 1002 CC porque, al no haberse aun manifestado acerca de la vocación que ha recibido, su posición se definiría por la ley y es cuando queda, tal y como en él se sanciona, como "heredero puro y simple".

Este sería el momento, podríamos decir que, ideal, o más idóneo, para que la sanción tenga plena eficacia. 
b) Pero, si el sucesor ya ha aceptado o repudiado, al haberse definido ya su situación en la herencia, las consecuencias son diferentes, si bien, es preciso distinguir según se haya decidido por una u otra. No obstante, es preciso tener en cuenta que, en cualquier caso, sea cual fuere la declaración del sucesor, repudio o aceptación, su decisión es irrevocable (art. 997 CC). Aún así:

a') si el sucesor ha repudiado, como consecuencia de ello, desde entonces ha dejado de formar parte del proceso sucesorio al haberse autoexcluido del mismo. Desde este instante es lo mismo que si nunca hubiese sido llamado a la sucesión o estuviésemos ante un extraño a la herencia. Podemos decir incluso que el sujeto ya no es ni tan siquiera un sucesor, eventual o futuro, porque ha dejado de serlo.

En este caso, la sanción del artículo 1002 ya no tiene sentido y pierde toda su virtualidad y eficacia por cuanto ya no se le podrá imponer, aunque sea por ley, la condición de heredero puro y simple al ser la declaración de repudiación irrevocable (sí se podrá declarar ineficaz por otra causa pero no por ésta -art. 997 CC- ${ }^{266}$ ), lo que, por otro lado, no le exime, ni le libera de la responsabilidad civil o penal en que, en su caso, haya podido incurrir por razón del ilícito cometido, así como, además, se le imponga, en su caso, la obligación de restituir lo que tiene en su poder indebidamente.

b') Y, si su voluntad ha sido la de aceptar la herencia, a resultas de ello, no solo ha adquirido la condición de heredero y los bienes porción o cuota que le han sido deferidos, sino que con su declaración ha excluido la posibilidad de repudiar. En este caso, además de la irrevocabilidad de la declaración, tampoco tendría aplicación la sanción del artículo 1002 de privarle de una facultad que ya no tiene.

Ahora bien, es preciso distinguir:

a") si ha aceptado la herencia de forma pura y simple, su manifestación, al ser irrevocable (art. 997 CC) no se modifica, si bien, su posición, respecto de la herencia, sería la misma que si se le impusiere la sanción del artículo 1002, la de heredero puro y simple. Luego, el resultado es el mismo, además de que la sanción no se le podría imponer.

b") Mientras que, si ha aceptado a beneficio de inventario, aunque el Código Civil no lo diga de manera expresa, existe unanimidad en la doctrina en entender que pierde dicho beneficio, tal y como manifiesta el artículo 1024 CC en su no

${ }^{266}$ Acerca de la ineficacia de la declaración de repudiación, sus causas y consecuencias, véase el capítulo décimo. 
$1^{\circ}$, "si a sabiendas dejare de incluir en el inventario alguno de los bienes, derechos o acciones de la herencia" y, consecuentemente, no se podrá aprovechar de la utilidad que a él le pueda reportar quedando así, definitivamente, como heredero puro y simple de la herencia, con la consiguiente confusión de patrimonios entre el suyo propio y el que reciba de la herencia, y la asunción de responsabilidad ilimitada respecto de las deudas existentes en la misma, si el comportamiento que ha tenido ha sido deliberado y consciente, a sabiendas de lo que estaba haciendo.

En este caso, sí que tiene plena eficacia la sanción del artículo 1002 CC porque, a resultas de aplicar el número $1^{\circ}$ del artículo 1024 CC, se llega al mismo resultado.

Ahora bien, si ha actuado de buena fe y lo tenía en su poder en la creencia de que ese bien o derecho le pertenecía y no hay intención dolosa, entendemos que seguiría conservando dicho beneficio, sin perjuicio de que, si hubiere lugar a ello, tuviese que hacer entrega o devolución del mismo al acervo hereditario.

Por otro lado, tanto en uno como en otro caso, el sucesor no está libre de responsabilidad en que hubiese incurrido por razón del hecho cometido, tanto desde el punto de vista civil como penal, para con los demás sucesores y personas interesadas en la sucesión, hasta el punto de que puede ser obligado, en su caso, si la correspondiente sentencia dictada en su contra así lo establezca, a la devolución de aquello que sustrajo u ocultó y/o a que les indemnice por razón de los daños y perjuicios que por su actuación se hubieren producido o causado. En este punto o momento, si la partición de la herencia todavía no se ha realizado, se estaría aún a tiempo de incluir el bien o derecho de que se trate en el inventario junto con los demás elementos patrimoniales que integren la herencia del causante. $\mathrm{Y}$, si ya se hubiere hecho la partición de la herencia entre los herederos, entraríamos en otro ámbito distinto cual es el de la posible rescisión de la partición (art. 1073 y ss CC), si la sustracción o ocultación de bienes de la herencia puede ser causa para invalidar la partición de una herencia, o a una ampliación de la partición si los bienes son recuperados.

Así, a la vista de todo lo expuesto, para que tenga plena efectividad la sanción del artículo 1002 CC, es preciso, con independencia de cual sea el momento en que los hechos se hayan cometido, si antes o después del fallecimiento del causante, que se hayan descubierto siempre antes de que el sucesor haya ejercitado el ius delationis, porque, si fuere después, las consecuencias, según hemos visto, son 
diferentes de cómo lo haya hecho: si ha repudiado, la sanción ya no tiene sentido por cuanto no se le puede privar de algo que ya no tiene, mientras que si ha aceptado de forma pura y simple, esta decisión se equipara a la sanción del artículo 1002, por lo que ésta no tiene ninguna eficacia jurídica pese a que se han producido la sustracción u ocultación, y si ha aceptado la herencia a beneficio de inventario, en este caso, de conformidad con lo dispuesto en el artículo $1024.1^{\circ} \mathrm{CC}$, pierde los beneficios que a él le pudiere reportar ese derecho y queda con el carácter o la condición de heredero puro y simple, lo se equipara a la regla del artículo 1002.

Nosotros, aquí, en otro orden de argumentos, nos preguntamos si no hubiese sido más efectivo a los efectos de imponer una sanción más eficaz en la comisión de estos hechos, haber declarado, ope legis, indigno al sucesor de suceder al causante (art. 756 CC), porque no deja de ofrecer cierta analogía o semejanza la gravedad de los mismos con los que son o constituyen causa de dicha indignidad. No deja de ser, incluso paradójico, que un sucesor que haya sustraído u ocultado algún efecto de la herencia, o haya realizado cualquier otro acto que suponga un daño o perjuicio contra la misma, después se le "castigue" con ser sujeto perceptor de los bienes de esa herencia, de la que se ha hecho desmerecedor de la misma por su comportamiento, al investirle con la condición de heredero puro y simple de la misma cuando, se puede dar la circunstancia, de que él así decide ejercer el ius delationis, en cuyo caso, la sanción quedaría totalmente enervada. Como también puede suceder que a él le proporcione un beneficio cuando se trate de una herencia beneficiosa porque apenas tenga deudas, e incluso se dé la circunstancia de que, tal vez, por paradójico que pueda resultar, él tuviese, por el motivo que sea, la intención de repudiar y ahora se le "obligue" a suceder al causante, con lo cual se le "premia" su acto.

De ahí que lo suyo, probado el comportamiento del sucesor, así como la malicia o mala fe con que ha actuado, y que se puede calificar como un acto de ingratitud o de deslealtad, principalmente para con la persona, honra o memoria del causante, así como contra la herencia y demás personas interesadas en la sucesión, es que, no solo se le privase del ius delationis, sino que fuese apartado de toda participación en la sucesión, ni tan siquiera fuese investido de heredero puro y simple, y se le impusiese una sanción análoga a la que entraña una indignidad o una desheredación. Así, ¿por qué no tipificar esta conducta como un supuesto más de indignidad del artículo 756 CC, o una desheredación "ex lege", además de obligarle a la restitución de aquello que sustrajo u ocultó, así como a que indemnice a los demás sucesores y acreedores por razón de los daños y perjuicios que, en su caso, les hubiere causado?. 
3-5.- ¿Puede el sucesor, pese a la sanción, manifestar su voluntad de repudiar?.

¿Puede el sucesor, pese a haber sido privado de la facultad de repudiar por sustraer u ocultar bienes o derechos de la herencia, manifestar su voluntad de repudio porque él lo que no quiere realmente es suceder al causante?.

Esta hipótesis ya se contemplaba en el derogado artículo 24 de la ley catalana de sucesiones de 1991, actual artículo 461-8 de la ley 10/2008, según el cual: "el llamado que haya sustraído u ocultado bienes de la herencia pierde la facultad de repudiarla y deviene heredero puro y simple, aunque manifieste la voluntad de repudiar la herencia de acuerdo con los requisitos establecidos por el presente libro". De lo que se deriva que no podrá repudiar y será, aun contra su voluntad, heredero puro y simple del causante porque, aunque él no lo quiera, así será.

Sin embargo, en el Código Civil no se dice nada al respecto. Acerca de ello, en nuestra opinión, dado que en virtud de lo dispuesto en el artículo 1002 se le priva o despoja de la facultad de repudiar, desde el momento en que se le impone esta sanción, dicha declaración, en el caso de que la realizare, sería inexistente dado que carece de esa facultad, por lo que no tendría ningún valor ni trascendencia jurídica al haber ya sido privado de ella por ley, por lo que sería totalmente ineficaz. Es como si nunca la hubiese llegado a manifestar. Su declaración actuaría totalmente en el vacío.

Recordemos, en este sentido, lo ya comentado más arriba, que, en nuestra opinión, al imponérsele al sucesor la condición de heredero puro y simple de la herencia, en realidad, se le está privando del ius delationis por cuanto él ya no tiene la opción de poder decidir acerca de la oferta hereditaria que ha recibido. Luego, no solo no puede repudiar, ni aceptar al imponérsele obligatoria e imperativamente la condición de heredero puro y simple del causante.

A mayor abundamiento, a resultas de la aplicación de la sanción del artículo 1002, ya tendría la condición de heredero puro y simple del causante, y esta atribución es definitiva e irrevocable, al igual que lo es el ejercicio, por su parte, del ius delationis. En consecuencia, por este motivo, tampoco podría repudiar.

Por tanto, es de todo punto impensable y absolutamente inconcebible, no que el sucesor, sino, el ya heredero, por disposición de la ley, porque ya lo es desde el momento en que se le aplica la sanción del artículo 1002 CC, pueda manifestar su voluntad de repudiar. 
SEGUNDA PARTE: LA REPUDIACIÓN. 


\section{Capítulo 3: LA REPUDIACIÓN DE LA HERENCIA. ORÍGENES Y DEFINICIÓN.}

1.- Antecedes históricos. 1-1.- En el derecho romano. 1-1-1.- El acto de la "repudiatio" o repudiación. 1-1-2.- Institución de heredero bajo la condición "si volet". 1-1-3.- Concesión del "ius o beneficium abstinendi".-2.- En el derecho germánico. 1-3.- En el derecho español. 2.- Problemática y delimitación de su concepto. 3.- La renuncia. 3-1.- Clases de renuncia. 3-2.- Concepto de renuncia. 4.- La repudiación, ¿es una renuncia?. 5.Diferencias que separan a la repudiación de renuncia. 6.- Definición de la repudiación. 7.- La repudiación y los casos de renuncia del artículo 1000 del Código Civil. 7-1.- La renuncia del número $2^{\circ}$. 7-2.- La renuncia del número $3^{\circ}$.

La repudiación es una declaración de voluntad que, si bien, en esencia, significa el rechazo por parte del delado a la herencia que se le ha deferido, la función que ha desempeñado en el proceso sucesorio mortis causa, tanto en las diferentes épocas y regímenes jurídicos sucesorios que han existido a lo largo de la Historia, como en los actuales sistemas latino y germánico, no ha sido siempre la misma.

\section{1.- ANTECEDENTES HISTÓRICOS.}

\section{1-1.- En el derecho romano.}

A lo largo de varios siglos, la sucesión mortis causa se configuró como un sistema forzoso de adquisición porque el heres, como ya expusimos en el capítulo primero, por el solo hecho de la delación, que tenía lugar en el mismo instante en que se producia el fallecimiento del pater, además de ocupar su lugar, sucedía de forma automática, sin necesidad de realizar declaración alguna de voluntad por su parte, y 
no ya solo sin saberlo, sino, incluso, en contra de su voluntad porque adquiría la herencia sin que lo pudiese evitar -de ahí su nombre de necessarii ${ }^{267}$.

Sin embargo, con el paso del tiempo, se distinguieron hasta tres formas distintas de rechazar la herencia: en el caso de los heredes extranei, a través de la "repudiatio" $\mathrm{y}$, en el de los heredes necesarii, de dos maneras: cuando el causante instituye al sucesor en el testamento bajo la condición suspensiva "si volet", y por medio del derecho concedido por el Pretor denominado, "ius o beneficium abstinendi".

\section{1-1-1.- El acto de la "repudiatio" o repudiación.}

El sucesor voluntario, o heredes extranei, ante la delación sucesoria tenía la opción: bien de aceptar, si quería adquirir los bienes a los que fue llamado por vía de sucesión mortis causa, bien de repudiar, en caso contrario, si no los quería.

La repudiación, o repudiatio ${ }^{268}$ como se la conoció más comúnmente en el Derecho Romano, era "aquel acto en virtud del cual el sucesor voluntario manifestaba no adir la herencia que le había sido deferida a su favor". No obstante, en este sentido, apunta $\mathrm{BIONDI}^{269}$ que, en el Derecho clásico, quien no quisiese aceptar la herencia no necesitaba realizar acto expreso alguno de renuncia, ni tan siquiera en el caso de fijación del spatium deliberandi, ya que el mero transcurso del tiempo sin hacer ninguna declaración tenía el mismo valor que la repudiación. Así, para no adquirir la herencia, bastaba simplemente con no realizar la aditio.

También se emplearon otros términos para denominar la repudiación, tales como "repellere"270, "spernere"271 u "omittere", o "praetermittere hereditatem"272. En este sentido, hace observar ROGEL VIDE ${ }^{273}$ que, aunque los términos son empleados de forma indistinta, es necesario distinguir entre, "repudiare hereditatem", que implica la voluntad de renunciar, y "omittere hereditatem", que implica simplemente la no realización de la aceptación. Si bien, a continuación, hace constar que no se habla en las fuentes clásicas, de "hereditatem renunciare", ni de "renunciatio".

${ }^{267}$ Acerca de esta categoría de herederos, véase en el capítulo primero la cita a pie de página no 22.

${ }^{268}$ Vid IGLESIAS: Derecho Romano. Instituciones de Derecho Privado. Cit: Pág 625.

${ }^{269}$ Diritto ereditario romano. Parte generale. Milán. 1954. Págs 293 y 294.

En igual sentido PACCHIONI: Manual de Derecho Romano. Cit: Pág 317.

${ }^{270}$ Proviene del verbo latino "repello, repuli, repulsum”, que significa, rechazar, alejar.

${ }^{271}$ Deriva del verbo latino "sperno, sprevi, spretum”, que significa, apartar, alejar, rechazar, echar, desdeñar, despreciar.

${ }^{272}$ Que significaba dejar pasar, desaprovechar, despreciar, omitir, pasar en silencio.

${ }^{273}$ Op. cit.: Págs 227 y 228. 
La repudiación, al igual que la aceptación, presuponía, en su ejercicio, el hecho de la muerte de la persona (D 29, 2, 27: hereditas viventis non datur), la existencia de la delación de la herencia, la certeza de este derecho (D 29, 2, 23: in repudianda hereditate vel legado certus esse debet de suo iure is qui repudiat), que el llamado exista en el momento del fallecimiento del de cuius, si bien, se admitió que estuviere solo concebido en el momento de producirse la delación, que tuviere capacidad jurídica para poder suceder y conozca tanto el hecho de la muerte del causante como la noticia de su llamamiento sucesorio (D 29, 2, 23).

En cuanto a sus caracteres, la repudiatio tenía carácter indivisible, ya que tenía que comprender la totalidad de la atribución patrimonial que a resultas de la delación le correspondiese al sucesor -en consecuencia, no era admisible una repudiación parcial-; un acto puro, porque no se podía realizar bajo condición ni a término y, una vez realizada, no solo excluía la posibilidad de poder aceptar después, sino que era irrevocable, si bien, por excepción, se admitió, en el caso de herencia deferida a favor de un menor y para el caso de repudiación, que, en su nombre, hubieren hecho sus

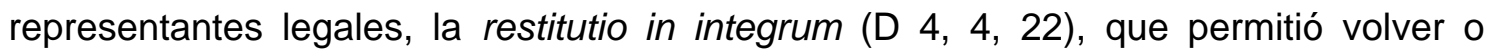
reponer las cosas al estado o situación anterior a la repudiación, pero, en este caso, el restituido es considerado como si hubiese adquirido la herencia asumiendo los derechos y las cargas que llevase consigo la delación deferida a su favor.

Acerca de su irrevocabilidad, es en el Derecho justinianeo (C 6, 31, 4), con precedente en una Constitución imperial de finales del siglo III d. C., principios del IV (entre los años 299 y 304), cuando así se afirma de forma expresa esta característica: "Sicut maior vigint quinque annis, antequam adeat, delatam repudians successionem, post quaerere non potest, ita quaesitam renuntiando nihil agit". Es el primer texto, al decir de ROGEL VIDE ${ }^{274}$, en el que parece que se utilizan de forma indistinta, los términos renuncia y repudiación, lo que no sucedió en el Derecho romano clásico, que, en opinión de TROPLONG ${ }^{275}$, ha llevado a que, en la actualidad, no se haga ninguna distinción entre abstención, repudiación y renuncia.

Por otro lado, se regía, en orden a su validez, por los mismos requisitos y principios que la aceptación ${ }^{276}$ y no estaba sujeta en su realización a ninguna forma 0 solemnidad (cfr D 29, 2, 95; GAYO 2, 169), de ahí que se pudiere manifestar por cualquier acto de voluntad, de forma expresa o tácita.

${ }^{274}$ Op. cit.: Pág 230.

275 Des donations entre vifs et des testaments ou commentaire du titre II, livre III du Code Napoleón. Bruxelles. A. Labroue et compagnie. 1855. Pág 284

${ }^{276}$ Vid IGLESIAS: Derecho Romano. .......... Cit: Pág 625. 
En cuanto al tiempo, en principio, el sucesor no tenía plazo para ello. No obstante, si había hecho uso del "spatium deliberandi" para deliberar y recabar información acerca de la situación y contenido de la herencia, tenía que manifestar necesariamente en un plazo de cien días si aceptaba o no, pero, si al término del plazo no decía nada, se entendía que repudiaba la herencia. Más tarde, ya en el Derecho Justinianeo, no solo se amplió el plazo a nueve meses o un año, según lo concediese el Juez o el Emperador, sino que se invirtió la presunción del Pretor, entendiéndose aceptada la herencia si el heredero no decía nada (C. I. 6, 30, 22, 13 a-14 b) ${ }^{277}$.

$Y$, en lo que se refiere a las consecuencias que de ella se derivaban, el sucesor repudiante quedaba definitivamente excluido de la sucesión con efectos retroactivos al momento del fallecimiento del causante (GAYO 2, 169), y se consideraba como si la herencia nunca le hubiere sido deferida. Después, si la herencia era testada, había que estar a la sustitución vulgar (substitutio vulgaris), o designación de un heres substitutus, que sería llamado en lugar del repudiante, si así se hubiere previsto u ordenado por el causante en su testamento. En su defecto, y en el supuesto de que existieren más sucesores, procedía en su favor el acrecimiento de la porción o cuota repudiada y, en último término, la apertura de la sucesión intestada. Y si se trataba de una sucesión intestada, la repudiatio daba lugar al acrecimiento, en todo momento, siempre que hubiere varias personas llamadas a la herencia y, por su falta, la herencia se defería a los siguientes sucesores por razón de orden y de grado.

Una diferencia que existió entre el Derecho clásico y el Justinianeo está en que, en éste, se estableció que, tanto la abstención como la repudiación, producían el mismo efecto de resolver el derecho a la herencia con la consiguiente pérdida de todo derecho a la misma.

Finalmente indicar que no puede ser confundida la repudiatio con otra institución poco conocida que fue la, "in iure cessio hereditatis" ${ }^{278}$, y que consistió en que el heredero llamado ab intestato, siempre que no fuese heres necessarius, podía, antes de la adición de la herencia, ante el Magistrado y en provecho de otra persona, ceder a ésta dicha herencia a través de una "enajenación" de la delación o "traspaso" del derecho a la herencia. El cesionario emprendía una petición de herencia contra el presunto heredero $a b$ intestato que no se podía oponer, ante lo que el Magistrado adjudicaba la herencia al demandante.

\footnotetext{
277 Vid IGLESIAS: Derecho Romano. .......... Cit: Pág 593.

${ }^{278}$ Acerca de ella, vid, entre otros: IGLESIAS: Derecho Romano. Cit: Pág 608.
} 


\section{1-1-2.- Institución de heredero bajo la condición "si volet".}

Ante el rigor y automatismo ipso iure que existía en la adquisición de la herencia para los heredes sui, y con el ánimo o intención de atenuar las consecuencias tan desfavorables que de ello se pudieren derivar para su propia persona y patrimonio al responder ultra vires hereditatis, se concedió al causante la posibilidad, o el recurso, de que instituyera al sucesor en el testamento bajo la condición "si volet"279 -si quiere-, (D 28, 7, 12), de tal manera que cuando se establecía dicha condición, la adquisición de la herencia ya no era automática y obligatoria desde el mismo instante en que se produjere la delación, sino que se hace depender de la voluntad del llamado por cuanto ello se le faculta para poder asumir o rechazar el título de heredero.

Así, cuando se establecía dicha cláusula, la decisión de ser o no heredero va a depender exclusivamente de la voluntad del sucesor, por lo que podrá rechazar la herencia, lo que hasta entonces era totalmente imposible que pudiera suceder. Solo si se cumple la condición, solo si quiere el sucesor, es heredero. Y, en caso contrario, no. De ahí que se tratare de una condición suspensiva potestativa. Mientras no se cumpliere la condición no se produciría la adquisición de la herencia.

Ello significa que, desde este instante, el automatismo y obligatoriedad en la adquisición de la herencia que hasta entonces existía y caracterizaba a la sucesión mortis causa en el caso de los heredes sui desaparece, porque, a resultas de su inclusión en el llamamiento por parte del causante, la delación sucesoria va a depender ya únicamente de la voluntad del llamado.

\section{1-1-3.- Concesión del "ius o beneficium abstinendi"280.}

Otro de los recursos que se instrumentaron a favor de los heredes sui, pero solo a los efectos de evitar o atenuar las consecuencias que se pudieren producir en su contra a resultas de una herencia dañosa, dada la responsabilidad ultra vires hereditatis que asumían, fue la concesión, ya al final de la República, en época de Cicerón (siglo I a. C.), a través del Edicto del Pretor, del denominado "beneficium

${ }^{279}$ La fórmula que se empleó fue la siguiente:

"Titius, si volet, heres esto, in necesario conditionem faciunt, ut, si nolit, heres non existat: nam in voluntaria heredis persona frustra adduntur, cum, etsi non fuerint addita, invitus non efficetur heres".

${ }^{280}$ Este derecho solo se concedió a los heredes sui y no a los heredes necessarii, o esclavos, quienes sí se vieron protegidos por el Pretor a través del beneficium separationis en virtud del cual no respondían frente a los acreedores de su difunto patrón con los bienes que hubieren adquirido del mismo después de quedar manumitidos por él a resultas de su fallecimiento. 
abstinendi"281, también conocido como "potestas abstinendi" (GAYO, Institutiones II, 162-163), "facultas abstinendi" (D 29, 2, 57), o "ius abstinendi" (D 28, 5, 87), o derecho de desentenderse de la herencia por un acto de voluntad.

Merced a él, los sui que mantuvieren una actitud de apartamiento respecto del proceso sucesorio, "inmiscere se hereditati" -sin tomar parte, intervenir o inmiscuirse en la herencia-, no respondían con su propio patrimonio frente a los acreedores del causante por razón de las deudas de éste por lo que se evitaba el rigor ante las mismas de su responsabilidad ultra vires, si bien conservaban nominalmente la condición de heres (D 38, 17, 20; y 29, 2, 12).

No obstante, los acreedores podían demandarlo ante el Magistrado -interrogatio in iure-, con la finalidad de que manifestase si aceptaba o no la herencia. Y si respondía negativamente, la ejecución sobre el patrimonio hereditario se realizaba "nomine defuncti".

En cuanto a su realización, no era necesaria ninguna formalidad para servirse de dicho beneficio, siendo suficiente con abstenerse de realizar cualquier acto de administración, goce o disposición de los bienes hereditarios (OURLIAC y DE MALEFOSSE ${ }^{282}$.

En lo que se refiere a sus efectos, se equiparó a los de la repudiatio pero solo desde el punto de vista patrimonial al quedar libre, al igual que en ésta, de toda responsabilidad por razón de las deudas hereditarias porque, pese a ello, el hijo seguía siendo considerado como heredes sui, ya que conservaba ciertos derechos de carácter extrapatrimonial que se derivaban del régimen de la herencia familiar y de los cuales no podía ser desposeído al ser su derecho sucesorio una concesión del ius civile. Sin embargo, ya en la época del Derecho justinianeo, el ejercicio del ius abstinendi dio lugar a que cesara ipso iure la condición de heredero del suus $\left(\right.$ VOLTERRA $\left.^{283}\right)$.

Por otro lado, a resultas de su ejercicio, la atribución patrimonial que había quedado abandonada podía ser adquirida por los sustitutos, los demás sucesores si hubiere derecho de acrecer entre ellos, o los herederos intestados o, en su caso, por los fideicomisarios.

${ }^{281}$ ARIAS RAMOS: Op. cit.: Pág 850; MANRESA: Op. cit.: Pág 340; PACCHIONI: Op. cit.: Pág 312; VOCI: Istituzioni di diritto romano. Milano. A Giuffrè. 1948. Pág 422.

${ }^{282}$ Histoire du Droit privé. III. Presses universitaires de France. Paris. 1968. Pág 356.

283 Op. cit.: Pág 709. 
$\mathrm{Y}$, otra diferencia que lo separaba de la repudiatio es que, a diferencia de ésta, que era irrevocable, el "beneficium abstinendi" se podía perder si, una vez obtenido, el sui se inmiscuía en las operaciones de la herencia.

\section{1-2.- En el derecho germánico.}

En sus orígenes, tal y como ya expusimos en el capítulo primero, a propósito del mismo cuando tratamos los sistemas de adquisición de la herencia, y de manera muy análoga a como ocurrió en el Derecho romano, la transmisión mortis causa de la herencia, así como la adquisición de ésta, tuvo un carácter forzoso o necesario ya que se producía ipso iure y de forma automática, desde el mismo momento en que se produjo la muerte del causante, por el solo hecho de esta circunstancia, a favor de los miembros del grupo familiar.

El fallecimiento de la persona, no solo determinaba quien era el heredero por cuanto éste venía establecido por una relación de sangre conforme a los principios "solus Deus heredem facere potest" y "heredes gignuntur, non scribuntur"284, sino el traspaso automático, desde ese mismo instante, a su favor de la herencia. El solo hecho de la delación, o "anfall" ${ }^{285}$, término que no significaba la posibilidad de ser heredero, sino que atribuía de forma inmediata dicha cualidad, provocaba la adquisición mortis causa ante lo que el sucesor quedaba investido con esta condición y le atribuía directamente la cualidad de heredero que, además, no podía rechazar por cuanto no tenía la posibilidad de poder repudiar. La delación no atribuía ninguna opción al sucesor de poder aceptar, o repudiar, sino sólo la atribución instantánea de la herencia. No había necesidad de una aditio para tener que adquirir ésta.

No impedía esta adquisición ni tan siquiera la circunstancia de que se desconociese el hecho del fallecimiento del causante, o que el sucesor estuviere ausente o se hallare en paradero desconocido, ya que obtenían la propiedad y la posesión, Gewere, al menos de una forma ideal, como consecuencia de la adquisición provisional de la herencia que producía el solo hecho de la delación, o "anfall".

Sin embargo, con el paso del tiempo, se llegó a admitir que, si el sucesor no quería suceder mortis causa, podía manifestar su voluntad en contra y expresar su decisión de repudiar la herencia. Así, en contraste a la declaración de aceptación que no era necesaria para adquirir, sí lo era en cambio la de repudiación para expresar la voluntad de rechazo. La repudiación era obligatoria e imprescindible para evitar que se

\footnotetext{
284 CASTRO LUCINI: Cit: Pág 261.

${ }^{285}$ GARCÍA VALDECASAS: Op. cit.: Pag. 96.
} 
produjere dicha adquisición mortis causa. Como consecuencia de ello, no solo se rechazaba la herencia, sino que se destruía con efecto retroactivo al momento de la apertura de la sucesión la adquisición que de la misma se había producido en ese instante a favor del sucesor. En este sentido, la adquisición era provisional hasta que no transcurriese el plazo concedido al heredero para poder repudiar. También, como consecuencia de ello, se recurrió a la ficción de considerar, una vez realizada la repudiación, que el repudiante nunca llegó a ser heredero.

De ahí que, hoy, en el derecho alemán, la repudiación tiene la función, no solo de manifestar que no se quiere ser heredero, sino que sirve para destruir o dejar sin efecto, con carácter retroactivo al momento del fallecimiento del causante, la adquisición que, de forma provisional, se produjo a favor del sucesor por el solo hecho de la delación. Esta declaración se puede realizar tan pronto como se produzca la muerte del causante (§ 1946 BGB), en un plazo de seis semanas que comienza desde el momento en que el sucesor tiene conocimiento de la adquisición provisional y de la causa del llamamiento o desde la notificación de la disposición (§ 1944 BGB), o en un plazo de seis meses si el causante ha tenido su domicilio en el extranjero, teniéndose la herencia por aceptada si el heredero deja transcurrir dicho plazo (§ 1943 BGB).

$\mathrm{Y}$, en cuanto a sus efectos, se tendrá por no ocurrida con la muerte del causante la adquisición provisional a favor del repudiante y la herencia se defiere a favor de aquel que estaría llamado si éste no hubiese vivido al tiempo de fallecimiento del causante (§ 1953 BGB).

\section{1-3.- En el derecho español.}

Con anterioridad a las Leyes de las Siete Partidas de Alfonso X el Sabio (año 1254), poco se sabe acerca del sistema sucesorio mortis causa español, así como, en consecuencia, de la forma de adquisición de la herencia.

Los textos legales anteriores no aluden a ello, ni distinguen entre sucesión legítima y sucesión testamentaria, como tampoco a la necesidad de tener que aceptar para adquirir mortis causa, o de repudiar si no se quiere adquirir, lo que da a entender, manifiesta LOPEZ GOMEZ ${ }^{286}$ que, por influencia del derecho germánico, regiría un sistema, recogido en el Fuero Real (año 1255) y algunos Fueros municipales, de transmisión legal de la herencia en el que no era precisa la voluntad del sucesor para

${ }^{286}$ Tratado teórico legal del derecho de sucesión, según los precedentes históricos del derecho de Castilla y el Código Civil y las especialidades forales. T. II. Valladolid. Establecimiento tipográfico de Hijos de J. Pastor. 1891. Pág 125. 
poder adquirir. De la misma opinión es GITRAMA ${ }^{287}$, para quien, dado que los cuerpos legales hispanos anteriores a las Partidas parecen no referirse ni a la aceptación ni a la renuncia de la herencia, da pie a imaginar que nuestro sistema sucesorio mortis causa de adquisición de herencia sería de corte germánico. En consecuencia, se sucedería de forma instantánea a la muerte del causante por el solo hecho de la delación y sin necesidad de que el sucesor aceptare la herencia. MANRESA ${ }^{288}$, de igual manera, apunta que los textos de nuestro derecho histórico anteriores a las Partidas no hablan, ni de aceptación, ni de repudiación, hasta que éstas copiaron el sistema romano, que luego reformó el Ordenamiento de Alcalá (año 1348), al basarlo en nuevos principios dando a la institución el carácter que reviste en los tiempos modernos.

El historiador GARCIA-GALLO ${ }^{289}$, por su parte, también se hace eco de esta oscuridad. En su opinión, los estudios de la historia del derecho español, referidos al período comprendido entre los siglos VIII al XIII, ante la inexistencia de códigos y compilaciones legales y ausencia de una ciencia jurídica que presentase una síntesis del sistema jurídico o analizase las instituciones, han encontrado gran dificultad en el estudio de las mismas, sobre todo en la época de la Alta Edad Media que es la más olvidada, la que está en su mayor parte sin estudiar. Sin embargo, es, a su juicio, la más decisiva porque en ella se forjaron la mayor parte de las instituciones que han llegado hasta nosotros. En este sentido, GARCíA-GALLO expone y relata cual fue el panorama del derecho de sucesiones en la época de la Alta Edad Media en el derecho español y los problemas que en ella se plantearon al analizar el concepto de successio, la condición de heres, el concepto de testamentum, el acto mortis causa, o la hereditas, al tiempo que cita a numerosos autores ${ }^{290}$ que a través de sus obras han contribuido con gran mérito a conocer, si quiera de manera parcial o fragmentada, esta rama del derecho privado.

Es en el texto de las Partidas, como antes apuntábamos, donde se empieza a definir nuestro sistema sucesorio mortis causa al adoptarse en él, por influencia del derecho justinianeo, el sistema romano de adquisición de la herencia a través de la aceptación y, por tanto, es el primer texto legislativo del derecho histórico español en

287 Op. cit.: Pág 23.

${ }^{288}$ Op. cit.: Pág 345.

289 "El problema de la sucesión mortis causa en la alta Edad Media española". AAMN. Tomo X. Año 1959. Pág 249 y ss.

${ }^{290}$ Op. cit: Pág 252 y ss: SALVADOR MINGUIJÓN, MARTÍNEZ MARINA, ENRIQUE DE GAMA BARROS, ANDRÉS GONZÁLEZ PALENCIA, MIGUEL SANCHO IZQUIERDO, ENRIQUE LUÑO PEÑA, JOSÉ MALDONADO, RAFAEL GIBERT, LACOSTE, ROMERO VIEITEZ, D’ORS, LOPEZ FERREIRO, etc. 
el que se trata de establecer la primera regulación de nuestro sistema sucesorio mortis causa. No obstante, dice MANRESA que, "bien pronto frente a este sistema se estableció el que pudiéramos llamar propiamente nacional, introduciéndose en el siglo XIV con la publicación del Ordenamiento de Alcalá, la reforma más radical en esta materia que a la sazón pueda esperarse"291.

Según las Partidas, para que tuviere lugar la sucesión mortis causa, y siguiendo los precedentes del Digesto ${ }^{292}$, era preciso el fallecimiento del causante, la existencia cierta del derecho a heredar ${ }^{293}$, esto es, la delación de la herencia, que si estuviere sometida a condición, no existía hasta que ésta se cumpliere, y después capacidad para poder heredar por parte del sucesor ${ }^{294}$, a quien también se le exigió que tuviese conocimiento cierto del hecho de la muerte del causante ${ }^{295}$. Estos eran los presupuestos que, ya por entonces, se establecieron para poder aceptar o repudiar la herencia. Así, para que se produjere la aditio, fue requisito necesario la aceptación de la herencia ${ }^{296}$ que, a su vez, podía ser pura y simple o a beneficio de inventario ${ }^{297}$, y además libre, ya que nadie podía ser obligado a aceptar una herencia por lo que se estableció la repudiación. Por otro lado, se distinguen en las Partidas las mismas categorías de herederos que existieron en el derecho sucesorio romano: suyos, necesarios y voluntarios o extraños ${ }^{298}$, que son análogas en cuanto a las personas a que se refieren en él. En este sentido, sanciona ya el sistema de legítimas a la que llama "parte debita iure naturae" ${ }^{\text {"299. }}$

La aceptación de la herencia tenía que ser un acto puro ${ }^{300}$, no sometido a condición, y demás indivisible e irrevocable ${ }^{301}$. No obstante, tratándose de un menor de veinticinco años y en consideración a su edad, a él se le concedió el "beneficio de restitución", que le dio la posibilidad de acceder, mediante la aditio, a la herencia en el caso de que antes la hubiere repudiado ${ }^{302}$.

${ }^{291}$ Comentarios al Código Civil español. T. V. (arts 609 a 743) 6a Ed. Corregida, aumentada y puesta al día por P. MARÍN PÉREZ. Instituto Editorial REUS. Madrid. 1951. Pág 214.

${ }^{292}$ Libro XXIX, título II, ley 23.

293 Ley 14, título 6 ${ }^{\circ}$, Partida $6^{\text {a. }}$

${ }^{294}$ Ley 13, título 6 ${ }^{\circ}$, Partida $6^{\text {a. }}$.

${ }^{295}$ Ley 14, título $4^{\mathrm{o}}$, Partida $6^{\mathrm{a}}$.

${ }^{296}$ Ley 11, título 6 ${ }^{\circ}$, Partida $6^{\mathrm{a}}$.

${ }^{297}$ Leyes 15 y 5, título 6 ${ }^{\circ}$, Partida $6^{\mathrm{a}}$.

${ }^{298}$ Ley 21, título $3^{\circ}$, Partida $6^{\mathrm{a}}$.

${ }^{299}$ Ley 17 , título $1^{\circ}$, Partida $6^{\text {a }}$.

${ }^{300}$ Ley 15, título $6^{\mathrm{o}}$, Partida $6^{\mathrm{a}}$.

${ }^{301}$ Ley 18, título $6^{\circ}$, Partida $6^{\mathrm{a}}$.

${ }^{302}$ Ley 18, título $6^{\circ}$, Partida $6^{\mathrm{a}}$. 
Apenas un siglo después, en el año 1348, en las Cortes que se celebraron en Alcalá de Henares a iniciativa del rey Alfonso XI, se aprueba el Ordenamiento de Alcalá que introduce importantes novedades en varias materias, entre otras, el sistema sucesorio instaurado por la legislación de las Partidas y que suponen una superación del formalismo del derecho romano ya que rompen, en algunas cuestiones, con el derecho hasta entonces vigente como fueron: admitir la validez del testamento aunque no contenga institución de heredero (Ley primera y única del título XIX) o suprimir la incompatibilidad entre la sucesión testada e intestada, dándole así, ya por entonces, el carácter que reviste en los tiempos actuales.

Las Leyes de Toro (año 1505), mencionan el sistema de adquisición y repudiación instaurado por las Partidas pero sin afectar en lo esencial al mismo. Su contribución al derecho de sucesiones se concreta en dos cuestiones: la mejora a título de legado (Ley XXI), y la capacidad de la mujer para repudiar (Ley LIV).

Después, hasta mediados del siglo XIX, en que se inicia el proceso de elaboración del Código Civil, no se produce noticia o hecho alguno de relevancia acerca del sistema de adquisición y repudiación de herencia. Así, a lo largo de seis siglos, desde las Partidas hasta este momento, en nuestro sistema sucesorio, no hay adquisición de la herencia sin aceptación de la misma por parte del llamado, como, de igual manera, si no se quiere ser heredero es preciso repudiar.

Es en el Proyecto de 1851 cuando se produce el primer intento de giro o de cambio porque el tenor de su artículo 554 ("los herederos suceden al difunto por el solo hecho de su muerte, no sólo en la propiedad, sino también en la posesión"), que sigue al artículo 724 del Code francés, según el cual: "Les héritiers ...... sont saisis de plein droit des biens, droits et actions du défunt", se inclinaba claramente por el sistema germánico de adquisición de la herencia, artículo que después ha tenido su reflejo en el actual artículo 661 cuyo tenor literal es sustancialmente idéntico.

Mas tarde, los redactores del Código Civil siguen fundamentalmente los precedentes del Code de Napoleón ${ }^{303}$, pero del que le separan algunas diferencias importantes, y regula esta materia de forma conjunta del artículo 988 al 1009, que dan contenido a la Sección $4^{\mathrm{a}}$ ("De la aceptación y repudiación de la herencia"), del Título III, del Libro III.

303 Antiguos artículos 774 a 792. Hoy, su regulación, que se inicia en el artículo 768, ha sido recientemente modificada por la Ley $n^{0}$ 2006-728, de 23 junio de 2006, de reforma en materia de sucesiones y liberalidades ( $\mathrm{JO} \mathrm{n}^{\circ}$ 145, de 24 de junio de 2006), que da nueva redacción a los capítulos IV, V y VI, del Título I, Libro III. 
A la regulación del Código le antecede ${ }^{304}$ el Proyecto de 1851 (arts 820 a 840) y el Anteproyecto de 1882-1888 (arts 988 a 1021, cuyo contenido, al decir de ROGEL VIDE $^{305}$, coincide prácticamente con los artículos del Código Civil, salvo los $n^{\circ} 833$, 995, 1000, 1001 y 1006, que son de nuevo cuño), a lo que habríamos de sumar, el Código Civil mexicano de 1870 (arts 3936 y ss) -a su vez influenciado por el Proyecto español de 1851 y el Código Civil portugués de 1868-, muchos de cuyos artículos son transcritos al Anteproyecto de 1882 y de aquí pasan al Código Civil actual.

En el texto del Código Civil se observa el mismo confusionismo del Code francés porque, según ya vimos en otro momento ${ }^{306}$, si bien, por un lado, del tenor de los artículos 440, 657 y 661, parece desprenderse la vigencia del sistema germánico, por otro, se puede mantener la vigencia del sistema romano, según se aprecia, entre otros, del artículo 989, que sigue al antiguo $777^{307}$ del Code francés, hoy 776 ('L'option exercée a un effet rétroactif au jour de l'ouverture de la succession"), y que declara la retroactividad de los efectos de las declaraciones aceptación y repudiación de la herencia al día de la apertura de la sucesión que es propio y característico del sistema romano, lo que es de todo punto incompatible con el carácter automático del sistema germano de adquisición de herencia.

Además de la normativa del Código Civil, es preciso tener en cuenta también las leyes sucesorias de algunas Comunidades Autónomas como Cataluña (art. 411-5 de la Ley 10/2008, relativa a las sucesiones), o Aragón (art. 322, CDFA), en las que se sigue, según ya expusimos en el capítulo primero, y de acuerdo con su respectiva tradición histórica, un sistema de adquisición y repudiación de herencia análogo al del Código Civil. Sin olvidar, la peculiaridad o especialidad que hay en la Comunidad Autónoma de Navarra, donde, de conformidad con la Ley 315, párrafo $3^{\circ}$, de su Fuero Nuevo, la herencia se entiende adquirida por el heredero desde el momento del fallecimiento del causante, si bien, de manera provisional, por cuanto, si no quiere ser efectivamente heredero, tiene la facultad de repudiarla, lo que dará lugar a que quede sin efecto dicha adquisición, como también puede, en su caso, aceptarla, declaración que actuaría a modo de confirmación o ratificación de dicha adquisición, lo que hace del ordenamiento jurídico navarro un sistema semejante al germano.

${ }^{304}$ Sobre los antecedentes del Código Civil, vid, entre otros: GITRAMA: Op. cit.: Pág 22 y ss.

305 Op. cit.: Pág 237.

${ }^{306}$ Véase en el capítulo primero, el punto número 3, donde se analiza el sistema de adquisición de herencia español.

${ }^{307}$ En él, sólo se hacía referencia de forma expresa al carácter retroactivo de la aceptación, mas no de la repudiación:"L'effet de l'acceptation remonte au jour de l'ouverture de la succession”.

Hoy, después de la reforma introducida por la Ley n ${ }^{\circ}$ 2006-728, de 23 junio de 2006, se alude en el nuevo artículo 776, a una y otra al hablar de "option exercée". 


\section{2.- PROBLEMÁTICA Y DELIMITACIÓN DE SU CONCEPTO.}

Hasta aquí, en todo cuanto antecede, hemos empleado el término repudiación, incluso podríamos decir que con cierta insistencia y reiteración, lo cual puede parecer que ya damos por sentada la aptitud o idoneidad de este término para expresar la negativa de quien ha sido llamado a una herencia, manifiestar su voluntad de rechazo a la misma y no querer, en consecuencia, llegar a ser heredero, así como aquello que le correspondiere por razón de dicho llamamiento. Sin embargo, como ahora veremos, el uso de dicho término, así como su significado, no es, en absoluto, pacífica ni incontrovertible, sino, más bien, polémica, conflictiva y llena de dudas.

En sí mismo considerado, el sentido de la palabra repudiación, no es ni claro ni preciso, entre otros motivos, porque existen otros términos que, ya desde el punto de vista gramatical, tienen cierta semejanza o similitud y que, pese a no significar lo mismo, inducen a confusión al ser muy parecidos entre sí, incluso semánticamente, como son: rechazo, abandono, desistimiento, pero, sobre todo, el término renuncia, con el que, tradicional y clásicamente, ha tenido una gran analogía. Como también, es la institución con la que mayor conflicto o enfrentamiento ha tenido a la hora de definir y precisar el significado que tiene el acto de rechazo a la herencia, en el sentido de si el repudio es o no una manifestación de renuncia.

El uso indiscriminado de uno y otro término ha dado lugar a una incorrección jurídica y una imprecisión terminológica que viene desde hace ya varios siglos lo que ha provocado una gran confusión en esta materia. Así, en un sentido convencional, usual, vulgar o coloquial, para manifestar que no se quiere una herencia, es muy frecuente oir o decir en el lenguaje cotidiano de la calle: "he renunciado a la herencia", en la creencia, equívoca, de que se está rechazando cuando lo que se está haciendo, en realidad, son verdaderas renuncias, traslativas, que equivalen a una aceptación tácita de la misma. Incluso, muy pocas veces se emplea el término repudiación.

Entonces, al hilo de lo anterior, cabe plantearse la siguiente cuestión: ¿es lo mismo decir: "repudiación de la herencia" que, "renuncia de la herencia"?, ¿una y otra expresión tienen el mismo significado?, sobre todo, cuando es el propio Código Civil quien alimenta esta confusión a través de su articulado. Así sucede en los números $2^{\circ}$ y $3^{\circ}$ de su artículo 1000 , de cuyo examen nos ocuparemos al final de este capítulo, donde emplea el término "renuncia" para referirse a determinados actos y entender, en relación a los mismos, cuando se entiende aceptada tácitamente una herencia. Actos respecto de los cuales se plantea, a su vez, la cuestión de si son o no verdaderos 
supuestos de renuncia, en el sentido estricto y propio del término, incluso si son supuestos de repudiación, dada la similitud que existe entre ésta y aquélla. Igual se observa en otros artículos como son, el 833, que habla de "renunciar a la herencia" y, el 890, que emplea el término "repudiar", refiriéndose a los legados.

En este sentido, queremos dejar apuntado, como punto de partida, en relación a la cuestión planteada, que las expresiones, "repudiación de la herencia" y "renuncia de la herencia", son totalmente distintas y no significan lo mismo porque, conforme iremos viendo a través de los argumentos que más adelante se expondrán, desde el punto de vista jurídico y técnico, se trata de dos actos que, no solo son totalmente diferentes entre sí en lo que se refiere a su concepto y los presupuestos necesarios para su exteriorización, sino que, precisamente por razón de esa diferencia, tienen un significado, unos efectos y unas consecuencias jurídicas y prácticas muy distintas entre sí. Aunque, paradójicamente, como luego veremos, la repudiación no deja de ser una forma o manifestación de renuncia, una institución que se aproxima a alguna de ellas, si bien la cuestión que se debate es en cual se puede catalogar o calificar.

El uso de los términos repudiación y renuncia como análogos o semejantes a lo largo de la Historia por parte de la doctrina, las leyes, la jurisprudencia, en el Derecho comparado, en el ámbito de la sucesión mortis causa, ha llevado a una identidad, mejor dicho, falsa identidad, entre uno y otro, lo que ha causado una gran confusión terminológica y de significado, sobre todo desde el punto de vista jurídico, lo que justifica la gran dificultad que ha habido, y hay, para tratar de diferenciarlos entre sí, hasta el punto de que gran parte de la doctrina llega a considerar a la repudiación como una modalidad de renuncia y se hayan llegado a emplear, en consecuencia, como equivalentes, aunque de forma errónea, las expresiones antes apuntadas: "repudiación de la herencia" y "renuncia de la herencia".

En este sentido, la doctrina se ha esforzado, no sin éxito, en distinguir entre repudiación y renuncia ${ }^{308}$, llegando a realizar un estudio comparativo entre ellas y justificando sus diferencias, aunque no han faltado quienes han llegado a entender que son esencialmente idénticas, o que no hay base suficiente para su distinción y que ésta resulta artificiosa (CANO MARTÍNEZ DE VELASCO ${ }^{309}$ ). Incluso se trata, como ha llegado a manifestar GITRAMA ${ }^{310}$, de un caso de "pulcritud semántica".

\footnotetext{
${ }^{308}$ Entre ellos muchos destacan, y valgan por todos ellos, NOVOA SEOANE: "La repudiación y la renuncia de la herencia”. RDP. 1919; ROGEL VIDE: Op. cit.: Pags 221 y ss, y 323 y ss.

${ }^{309}$ La renuncia a los derechos. BOSCH. Casa Editorial. S.A. Barcelona. 1986. Pág 296.

310 Op. cit.: Pág 7.
} 
Como punto de partida en nuestro estudio y a modo de introducción, nos puede servir el significado que da a ambos términos el diccionario de la Real Academia Española $^{311}$, que, en nuestra opinión, puede sernos de utilidad porque son muy aproximados al que uno y otro tienen, o se les da, ya en un sentido jurídico, estricto o técnico. Así, según dicha institución, la repudiación significa, "rechazar algo, no aceptarlo", y la renuncia, "hacer dejación voluntaria, dimisión o apartamiento de una cosa que se tiene o del derecho y acción que se puede tener. No querer admitir o aceptar una cosa. Despreciar. Abandonar".

Pero, en un sentido ya más específico, NOVOA SEOANE ${ }^{312}$, en un principio y, más tarde, ROGEL VIDE ${ }^{313}$, que son quienes, entre otros, han realizado en nuestra doctrina un estudio comparativo de los vocablos, "renuncia" y "repudiación", llegan a la conclusión de que son diferentes y no se pueden confundir ya que, "la repudiación es un acto de nolición porque implica no querer y el que repudia no llega nunca a ser heredero, mientras que la renuncia implica una volición en principio y una dejación después". En cambio, "se renuncia a lo que se tiene; se repudia lo que se puede tener y no se quiere". Ello ya nos pone de relieve, a priori, el distinto significado que tiene uno y otro término.

En este mismo sentido, CANO MARTíNEZ DE VELASCO ${ }^{314}$, resalta también la contraposición que existe entre los términos repudiación y renuncia al manifestar que, "tampoco constituye renuncia el rechazo de todo un patrimonio", lo que se denomina "repudio" o "repudiación", y solo tiene lugar respecto del patrimonio mortis causa. Cuando lo que se cede es una parte alícuota del patrimonio de una persona viva por decisión de ésta, el beneficiario de la renuncia traslativa, ¿puede rechazar o repudiar?. Lo correcto es decir que, en su caso, rechaza no repudia, ya que hay que reservar el concepto repudiación para cuando la delación la hace la ley por haber muerto el transferente (sucesión mortis causa). No obstante, cuando se ocupa después de la renuncia en el derecho de sucesiones y al tratar de la definición de repudiación, manifiesta que: "se ha pretendido distinguir la repudiación de la herencia de la renuncia a ella, pero tal discriminación no tiene base suficiente $y$, por ello, resulta artificiosa" $^{315}$. Sin embargo, frente a los términos renuncia y repudio, distingue otros, ya apuntados antes, como, "abandono" y "rechazo". Éste, el rechazo, "es un negocio

\footnotetext{
311 Vid. Vigésima primera edición. Madrid. 1992.

312 Op. cit.: Pág 146.

313 Op. cit.: Pag 223.

314 Op. cit.: Pág 16.

315 Op. cit.: Pág 296.
} 
jurídico unilateral y recepticio por el que se declara no aceptar una oferta o no querer que el derecho objeto de ésta ingrese en el patrimonio del rechazante" ${ }^{316}$, mientras que, el repudio, "es el rechazo de un patrimonio o de parte del mismo, es decir, del negocio jurídico dirigido al Juez de la testamentaría o del abintestato o al oferente de no querer que los derechos, obligaciones y cargas constitutivos de aquel se añadan a los propios del patrimonio del repudiante".

LUIGI FERRII $^{317}$, en la doctrina italiana emplea también, en sentido contrapuesto, dos términos, "rinunzia" y "rifiuto", referido éste a la repudiación.

A la vista de lo anterior, y ante la dificultad con que nos encontramos, para decir qué es o en qué consiste la repudiación, así como para precisar cual es su significado y naturaleza en orden a su diferenciación, en particular con la renuncia, vamos a detenernos antes, si quiera por breves instantes, en analizar ésta, lo que nos servirá de base y apoyo para después poder llegar al concepto de la repudiación, así como a establecer las posibles analogías y diferencias que existen entre una y otra. En este sentido, entendemos que no es posible dar un concepto preciso de la repudiación, como tampoco comprender cual es su sentido y significado, si no vemos previamente qué se entiende por renuncia, así como sus modalidades y caracteres que la adornan.

\section{3.- LA RENUNCIA.}

Dada la gran variedad de formas que puede revestir y la multitud de situaciones jurídicas tan heterogéneas y distintas a través de las cuales se puede manifestar, la renuncia se puede prestar a confusión no ya solo con otras instituciones jurídicas como son: el "abandono", la "remisión o condonación de deudas", la "cesión de un crédito", la "excusa", el "aquietamiento", el "allanamiento", el "desistimiento", la "abdicación", el "abandono de la acción" ${ }^{18}$, sino también, con la "repudiación", con la que tiene una gran proximidad por razón de la semejanza o identidad que tienen entre sí una y otra institución, no solo desde el punto de vista fonético, gramatical o semántico, sino por razón de los efectos o consecuencias jurídicas que se derivan de una y otra, además de la cuestión que ya hemos dejado planteada de si la repudiación es o no una forma o manifestación de renuncia. página 51.

316 Op. cit.: Pág 49. Después se ocupa más en detalle del estudio de su concepto a partir de la

${ }^{317}$ Rinunzia e rifiuto nel diritto privato. Milano. A. Giuffrè. 1960.

${ }^{318}$ Vid CANO MARTÍNEZ DE VELASCO: Op. cit.: Pág 11 y ss. Más en detalle, págs 17 y 18; 46 (aquí la distingue del "no uso", o de "promesa de no ejercitar un derecho", o del "aquietamiento a una pretensión injusta”). 
A la renuncia se refiere el Código Civil, con carácter general, en el número 2 de su artículo 6, pero no existe en todo el texto legal una regulación unitaria de la misma, tampoco la define en ningún precepto, ni dice qué es o en qué consiste la renuncia de derechos, aunque sí aplica dicho término no solo a estos, sino también a las acciones y a determinados cargos o funciones ${ }^{319}$. En cambio, sí se ocupa de poner requisitos a su ejercicio o límites a su validez como son, el interés, el orden público ${ }^{320}$ y el perjuicio a tercero ${ }^{321}$, como también utiliza el término renuncia en innumerables preceptos ${ }^{322}$, incluso podríamos decir que de forma indiscriminada, como si se tratase de un término unívoco, de significado unitario, cuando resulta que, desde el punto de vista jurídico, tiene diferentes sentidos con un contenido muy diverso y una trascendencia jurídica distinta en unos casos y otros ${ }^{323}$, como ahora veremos al tratar de sus clases, lo que induce a una extraordinaria confusión. Igual sucede en el ámbito de la sucesión mortis causa en las relaciones del sucesor con la herencia, cuando se emplea como equivalente o análogo a la repudiación, ya que, unas veces se trata de verdaderos casos de repudiación y no de renuncia ${ }^{324}$, y otras se habla expresamente de repudiación, ya en sede de adquisición de la herencia (Sección cuarta, Libro III, Título III: art 988 y ss CC) $)^{325}$.

${ }^{319}$ Así: el albacea (art. 899 CC), la sociedad (art. 1705 CC), o el mandato (art. 1732,2 CC).

${ }^{320}$ Como, las leyes que regulan el estado y capacidad de la persona, las que se refieren a la organización de la propiedad y del crédito territorial, las del derecho de familia, las normas relativas a la legítima o solemnidades de los testamentos. Vid en este sentido: CABANILLAS SÁNCHEZ: Comentarios al Código Civil y Compilaciones Forales. T I. Vol 1. EDERSA. Madrid. Pág 759 y ss.

${ }^{321}$ Estaría prohibida la renuncia de aquellos derechos que lesionen de manera presente o actual el derecho de otra persona, pero no la que suponga un perjuicio posible, futuro o hipotético.

${ }^{322}$ Entre otros muchos: art 23 b, sobre nacionalidad; art 151, sobre alimentos; art $271.3^{\circ}$, relativo al tutor en relación a los bienes del pupilo; art 513.4 ${ }^{\circ}$, sobre usufructo; art 546, en materia de servidumbres; arts 646 y 652, sobre la acción de revocación de donaciones; art 766, heredero que renuncia a la herencia; art 816, renuncia sobre la legítima futura; arts 899, 900, 910 y 911, en relación al albacea; art 928, acerca del derecho de representación; art 1000, $\mathrm{n}^{\circ} 2^{\circ}$ y $3^{\circ}$, renuncia de la herencia; art 1002, pérdida del derecho de renunciar si se sustraen u ocultan efectos de la herencia; art 1102, relativo a la exigencia de responsabilidad por dolo; art $1280-4^{\circ}$, relativo a la exigencia de documento público; art 1705, renuncia de un socio a la sociedad civil; arts 1732, 1736 y 1737, acerca del mandato; art 1815, sobre la renuncia general de derechos y la transacción; art $1831.1^{\circ}$, sobre renuncia al beneficio de excusión en la fianza; art 1935 y 1937, relativo a la prescripción.

${ }^{323}$ Vid CABANILLAS SÁNCHEZ: Op. cit: Pág 734 y ss.

${ }^{324}$ Entre otros: art 766, heredero que renuncia a la herencia; art 816, renuncia sobre la legítima futura; art 833, sobre la repudiación de la herencia y la aceptación de la mejora; art 890, relativo a la repudiación del legado; art 1000 número 3, inciso segundo; art 1002, pérdida del derecho de renunciar si se sustraen u ocultan efectos de la herencia.

${ }^{325}$ Vid: art. 166, sobre la herencia deferida a los hijos por los padres; arts 988 a 994; art 997, a propósito de su irrevocabilidad; art 1001, sobre repudiación de la herencia por parte del heredero en perjuicio de sus acreedores; arts 1004 y 1005, en el caso de interpellatio in iure al sucesor; art 1006, a propósito del "ius transmissionis"; art 1007, cuando habla de la libertad para aceptar y/o repudiar cuando hay pluralidad de herederos; art 1008, referido a la forma; art 1009, en el caso de pluralidad de delaciones; art 1019, a propósito del derecho de deliberar; art 1022, o del beneficio de inventario; art 1033, acerca de los gastos causados para hacer uso del derecho de deliberar. 
Para abordar mejor esta dualidad de términos y tener una mejor comprensión de los mismos, vamos a ver, alterando el orden de exposición que hubiera sido más lógico desde un punto de vista sistemático cual sería, tratar primero su concepto y después sus manifestaciones, lo hagamos al revés, ver en primer lugar cuáles son las diferentes clases de renuncia que hay, y después, una vez delimitada o calificada cada una de ellas, cual es o se puede considerar verdadera y propia renuncia, al tiempo que de manera concreta tratemos de precisar su concepto.

\section{3-1.- Clases de renuncia.}

Muy posiblemente, una de las circunstancias que más ha contribuido a la confusión que tradicional e históricamente ha existido entre la renuncia y la repudiación, así como la imprecisión que hay en el empleo de uno y otro término, provenga de las distintas y muy variadas manifestaciones que existen de aquella, y a la gran heterogeneidad y diversidad que presenta en el tráfico jurídico.

Así, siguiendo a ROCA SASTRE ${ }^{326}$, que es quien ha formulado, tal vez, la clasificación ${ }^{327}$ que ha suscitado el mayor interés y ha tenido una gran trascendencia y repercusión en nuestro derecho acerca de la renuncia porque ha sido una de las más seguidas y más generalmente aceptadas, podemos distinguir las tres siguientes clases según que se refiera: a algo ya adquirido (renuncia abdicativa, o extintiva), a algo controvertido o dudoso (renuncia recognoscitiva, o traslativa), o a algo solo deferido (renuncia preventiva, u obstativa, declarativa o impeditiva) ${ }^{328}$ :

a) renuncia abdicativa, o extintiva, que, en opinión mayoritaria de la doctrina ${ }^{329}$, en puridad, sería la verdadera y propia renuncia frente a las otras dos modalidades que lo serían en sentido impropio ${ }^{330}$.

${ }^{326}$ Derecho Hipotecario. T II. Cit: Pág 151 y ss.

327 Otra clasificación: CANO MARTÍNEZ DE VELASCO: subjetiva y objetiva; independiente y dependiente; abstracta y casual; total y parcial; renuncia declaración y renuncia emanación; legítimas e ilegítimas; lícitas e ilícitas (Op. cit: Pág 63 y ss).

${ }^{328}$ Sobre esta misma clasificación: CANO MARTÍNEZ DE VELASCO: Op. cit: Págs 61 y 62.

${ }^{329}$ DÍEZ-PICAZO (Sistema de Derecho Civil. Vol. I. Cit: Pág 466); ROGEL VIDE (Op. cit.: Pag 246); CASTÁN TOBEÑAS (Derecho Civil Español Común y Foral. T. I. Vol 2. REUS S.A. Madrid. 1982. Pág 100); FERRI (Op. cit.: Pág 26); CAPILLA RONCERO, LOPEZ y LOPEZ, ROCA i TRÍAS, y otros: Derecho Civil. Parte general. TIRANT LO BLANCH. Valencia 1995. Pág 552.

${ }^{330}$ A su vez, dentro de esta modalidad de renuncia, DíEZ-PICAZO (Sistema de Derecho Civil. Vol. I. Cit: Pág 467), distingue un subtipo conocida como liberatoria, y que consiste sustancialmente en "un abandono de la titularidad de un derecho subjetivo para liberarse del cumplimiento de ciertas obligaciones a que está sujeto el renunciante precisamente por ser titular”. Tal es el supuesto, que él mismo cita, de la renuncia del artículo $395 \mathrm{CC}$, en el que se contempla la posibilidad de que el comunero se exima de la obligación de contribuir a los gastos de conservación de la cosa o derecho común renunciando a la parte que le pertenece en el dominio. Se trataría del caso de renuncias en el caso de 
A través de ella, el sujeto, a resultas de dicho acto, no sólo se despoja de un activo que forma parte de su patrimonio y del que es, en consecuencia, su titular, sino que se desentiende totalmente de él porque no lo transmite a ningún otro sujeto, lo deja abandonado, se convierte en una "res nullius", de tal manera que para él se extingue y lo pierde, si bien, puede ser adquirido después por cualquiera a través de las normas de la ocupación.

Acerca de ella y de sus caracteres, la DGRN en la Resolución de 3 de agosto de 1944 (RJ 998), manifestó que, "la naturaleza jurídica de la renuncia abdicativa pone de manifiesto que ésta es un acto de carácter absoluto, eminentemente voluntario y unilateral".

b) Renuncia recognoscitiva, o traslativa: llamada así porque a través de ella lo que hace el titular es separar de su esfera jurídica un derecho controvertido o dudoso pero señalando una persona que lo adquiere ${ }^{331}$.

Se difiere de la anterior en que, a través de ella ${ }^{332}$, el sujeto hace una verdadera enajenación o cesión de un derecho que a él le pertenece y forma parte de su patrimonio, en forma de renuncia (per modum renuntiationis), razón por la cual se habla también de renuncias traslativas (in favorem). De ahí que, en este caso, "en realidad, no hay aquí una verdadera renuncia, sino de un negocio patrimonial traslativo, para cuya eficacia es imprescindible el consentimiento del favorecido" (DÍEZ-PICAZO ${ }^{333}$ ). Como dice CARIOTTA FERRARA ${ }^{334}$, citado por ROGEL VIDE ${ }^{335}$, "la renuncia traslativa no existe; el adjetivo es incompatible con el sustantivo".

obligaciones ob rem o propter rem, cuya característica radica en la concreción del sujeto obligado de una manera mediata, indirecta, pues lo será sólo quien ostente la titularidad de un derecho subjetivo (cfr. arts 395 y 544 CC). Son obligaciones conexas con esa titularidad y surgen derivadas de la misma.

A propósito de esta categoría, otros, como BONET CORREA ("La renuncia exonerativa y el abandono liberatorio en el Código Civil”. RGLJ. 1961. Sept. Pág 241 y ss), hablan de renuncia exonerativa y abandono liberatorio.

${ }^{331}$ GITRAMA, al referirse a ella, la llama impropia o modal (Op. cit.: Pág 224).

332 En este sentido y distinguiendo esta modalidad de renuncia respecto de la traslativa, la SAP de Zaragoza, de 2 de diciembre de 2004 -JUR 2005\35181-, manifestó que “es constante la doctrina jurisprudencial que distingue entre renuncia propia o abdicativa, que ocurre cuando se desiste del derecho con ámbito de eficacia sólo personal, y la renuncia impropia o traslativa que es aquella en la que la renuncia se hace en favor de otra persona, (supuesto previsto en el art. 1000 CC), figura esta última que implica cesión, y que tiene identidad propia, de tal modo que no puede ser confundida sin más con la donación, y menos cuando de derechos expectantes se refiere. Otra cosa es que la renuncia traslativa sea una renuncia impropia, que supone una cesión de derechos que han de haber sido previamente adquiridos por el renunciante, y que al ser una transmisión «inter vivos» a título gratuito haya que acudir al régimen de las donaciones, en cuanto sea de aplicación, para dar solución a las cuestiones que pueda plantear".

333 Sistema de Derecho Civil. Vol I. Cit: Pág 466.

${ }^{334}$ El negocio jurídico. Traducción y notas de ALBALADEJO. Madrid. 1956. Pág 112. 
Desde el punto de vista de los sujetos, también se diferencia de la anterior, en que, en ésta, en la renuncia traslativa, intervienen dos sujetos: el titular actual, quien transmite, cede o dispone del derecho, y el titular futuro, quien lo adquiere. Luego, hay un cedente y un cesionario 0 , un transmitente y un transmisario. Mientras que en aquella, la renuncia abdicativa, sólo interviene un solo sujeto, el titular del mismo. Al no haber cesión o transmisión a otro sujeto, únicamente actúa el renunciante.

Por otro lado, lo que, en realidad, encierra o se desarrolla a través de esta figura es un negocio entre dos sujetos en el que uno de ellos cede y el otro adquiere, pero no hay, en absoluto, abandono, ya que, aquello sobre lo que se "renuncia", no deja, en ningún momento, de pertenecer a un patrimonio, no queda abandonado, ya que pasa de las manos del titular actual, transmitente o cedente, al titular futuro, cesionario, transmisario o adquirente, quien sucede a aquel sin solución de continuidad.

Como manifestaciones de esta modalidad de renuncia estarían el contrato de transacción y los negocios de disposición (ROCA SASTRE), a lo que podríamos añadir, los supuestos de los números $1^{\circ}, 2^{\circ}$, e inciso inicial del número $3^{\circ}$, del artículo 1000 del Código Civil, que examinaremos más adelante en este mismo capítulo.

Acerca de esta modalidad de renuncia, la DGRN, en Resolución de 5 de febrero de 1996 (RJ 1024), a propósito de un caso de aceptación tácita del artículo 1000, entendió que, "la denominada renuncia traslativa no implica propiamente una renuncia, sino una cesión de derechos que, precisamente para ser cedidos, han de ser previamente adquiridos. Este es el sentido que ha de darse al enunciado del artículo 1000 del Código Civil". Ahora bien, en este supuesto, dado que el sujeto titular no puede realizar esta enajenación o cesión si no ha adquirido previamente ese derecho o está ya incorporado a su patrimonio, por esa circunstancia, no se podría hablar de renuncia propiamente dicha. Si acaso, tan solo en un sentido impropio y ausente de todo tecnicismo, se podría hablar en esta modalidad como tal, de renuncia.

Sólo en un sentido impropio, a la vez que inadecuado, se podría hablar en este caso de renuncia porque el sujeto titular no puede realizar esta enajenación o cesión si no ha adquirido previamente ese derecho o está ya incorporado a su patrimonio. Por esta circunstancia, no se podría hablar de renuncia propiamente dicha. Si acaso, solo en un sentido impropio y ausente de todo tecnicismo, se podría hablar de renuncia.

335 Op. cit: Pág 246. 
c) Y, la renuncia preventiva, también obstativa, declarativa o impeditiva, tiene lugar, según ROCA SASTRE, cuando el sujeto separa de su propia esfera jurídica de voluntad el "derecho a adquirir otro derecho". Rechaza o rehúsa a hacer suyo, o a adquirir, un derecho que aun no está incorporado a su patrimonio y que pretende entrar en él (non uti ocassione adquirendi), lo que dependerá de la decisión del sujeto. Como dice LOPEZ y LOPEZ ${ }^{336}$, "es la anticipada voluntad de no ejercer un determinado poder jurídico que aun no se tiene".

En el caso de que tenga lugar ese rechazo, no por ello se produce para quien lo realiza un empobrecimiento o perjuicio porque su patrimonio permanece inalterable ya que no sufre ninguna disminución, tampoco ningún aumento, a diferencia de lo que sucede en la renuncia abdicativa en la que sí se produce una pérdida. Simplemente, es un negarse a adquirir. Es una "omissio adquirendi", dice ROCA SASTRE.

"En general -dice ROCA SASTRE-, la renuncia preventiva tiene lugar en todos los casos en que manifiesta su voluntad de no aceptar la persona cuya aceptación constituye la conditio iuris para que se opere a su favor la adquisición a la cual está aquella llamada". Y cita, entre otros casos, como manifestaciones de esta forma de renuncia: la repudiación de la herencia, legados y legítimas cuando la sucesión es causada -al que sigue aquí O'CALLAGHAN ${ }^{337}$-, así como la renuncia de donaciones y las ofertas de adquisición ${ }^{338}$.

Sin embargo, ROGEL VIDE ${ }^{339}$ no comparte la tesis de ROCA, disiente de su postura y entiende que, "en la llamada renuncia preventiva a la herencia, no se renuncia derecho alguno, se ejercita una facultad consistente en aceptar o en repudiar la herencia deferida". "Si como el mismo ROCA dice, no hay renuncia al ius delationis, $y$, en consecuencia, no hay renuncia abdicativa, tampoco es de recibo el término renuncia preventiva". "El "non uti occassione adquirendi" no provoca empobrecimiento; no implica abandono de un derecho perteneciente a la propia esfera jurídica; no es, en fin, renuncia en sentido técnico, es repudiación". A lo que añade a continuación: "para la mayoría de los autores ${ }^{340}$ la llamada "renuncia preventiva" no es verdadera renuncia, dado que no hay extinción del derecho subjetivo por una disposición de su titular, porque ese derecho no formaba parte de su patrimonio".

\footnotetext{
${ }^{336}$ Op. cit.: Pág 553.

337 “La renuncia a la legítima”. Libro homenaje a Roca Sastre. Junta de Decanos de los Colegios Notariales de España. T. III. Madrid. 1977. Pág 328.

${ }^{338}$ Derecho Hipotecario. II. Cit: Pág 151.

339 Op. cit: Pag 250.

${ }^{340}$ Cita a FERRI, DÍEZ-PICAZO y GULLÓN BALLESTEROS, PUIG BRUTAU.
} 
En nuestra opinión, no le falta razón a ROGEL VIDE porque la repudiación, en realidad, es el ejercicio del "ius delationis" en su aspecto negativo ya que no tiene ninguna otra manera de ser o de manifestarse por cuanto proviene o deriva de él. Pero también, desde el punto de vista de lo que significa, no es menos cierto que, en sí misma considerada, supone o entraña la pérdida de poder adquirir aquello a lo que se ha sido llamado, de la misma manera que la aceptación supone el efecto contrario, lo que hace que se asemeje a la renuncia preventiva.

Acerca de la misma se ha planteado la cuestión de si es o no verdadera renuncia porque, en sentido técnico, no la hay para quien la realiza porque no sufre la pérdida de ningún derecho ya que, aquello a lo que renuncia, no forma parte de su patrimonio por cuanto está fuera de su esfera jurídica y personal, es ajeno a él. Se trata, además, de un derecho que le es extraño, pero que le es ofrecido y es llamado al mismo para que lo adquiera. Decisión que depende solo de él, mas decide rehusarlo, manifiesta no quererlo o no aceptarlo. Como tampoco hay ninguna abdicación porque no se produce el abandono de ningún derecho. Ni es una renuncia a una expectativa y sí a un derecho que ya es efectivo y que le faculta para adquirir otro derecho.

De ahí que, en nuestra opinión, no se pueda hablar, en este caso, respecto de la renuncia abdicativa, de una renuncia en sentido estricto. En este mismo sentido, LOPEZ y LOPEZ ${ }^{341}$ entiende que, "sólo de manera impropia cabe decir que en estas hipótesis nos encontramos ante la figura de la renuncia".

Otros autores (DÍEZ-PICAZO y GULLÓN ${ }^{342}$, FERRI ${ }^{343}$ ), también entienden que la "renuncia preventiva" no es verdadera renuncia porque en ella no hay extinción del derecho subjetivo por una disposición de su titular ya que recae sobre un derecho que no forma parte del patrimonio del renunciante.

Por su parte, ROGEL ${ }^{344}$, ya en comentario común a las diferentes categorías, entiende que la verdadera y propia renuncia es aquella, la abdicativa, opinión que compartimos. A lo que añade; "las restantes "renuncias" han de ser, así, excluidas del concepto". Para CASTÁN, igualmente, ya que para él, la renuncia es "un acto de disposición por virtud del cual el titular del derecho hace dejación o abandono del mismo, pero sin transmitirlo a otra persona".

\footnotetext{
341 Op. cit.: Pág 553.

342 Sistema de Derecho Civil. Vol I. Cit: Pág 467.

343 Rinunzia e rifiuto nel diritto privato. Cit: Pág 25.

${ }^{344}$ Op. cit: Pags 244, 246 y 250, entre otras.
} 


\section{3-2.- Concepto de renuncia.}

A la vista de lo anterior y de la gran multiplicidad de formas y de manifestaciones que puede revestir la renuncia, se puede entender la gran dificultad que la doctrina ha tenido en definirla. En este sentido, aunque se puede dibujar una línea unitaria de pensamiento o un denominador común en todas ellas al ver en la renuncia un acto de carácter abdicativo o extintivo del bien o derecho que es objeto de la misma para su titular, después cada autor la define de diferente manera al tiempo que la enfoca desde un punto de vista distinto haciendo énfasis en uno u otro aspecto o le da su propio matiz o puntualización.

Así, para CABANILLAS SÁNCHEZ ${ }^{345}$, es, "la declaración unilateral de voluntad que determina la pérdida o el abandono de la titularidad de un derecho subjetivo, facultad o acción". A lo que añade que, "el efecto inmediato y típico de la renuncia es la abdicación en la titularidad del derecho. Se trata por consiguiente, de un caso de pérdida o abandono del derecho, que es una figura opuesta a la adquisición del derecho". CANO MARTÍNEZ DE VELASCO, en la misma línea de pensamiento, entiende que la renuncia "es un acto jurídico por el que se extingue un derecho para su titular en virtud de una disposición de su voluntad emanada o declarada a tal fin"346.

DÍEZ-PICAZO y GULLÓN BALLESTEROS ${ }^{347}$, califican la renuncia como "un negocio jurídico de carácter dispositivo que produce para su titular sobre el derecho subjetivo al que se refiere, la extinción o pérdida del mismo". En semejantes términos, de considerarlo como un negocio jurídico extintivo se manifiesta O'CALLAGHAN ${ }^{348}$.

Para ROCA SASTRE ${ }^{349}$, "es la declaración jurídica de voluntad por la cual el sujeto separa de su propia esfera jurídica un derecho subjetivo, expectativa, facultad, pretensión, beneficio, seguridad, garantía o posición jurídica".

ALBALADEJO ${ }^{350}$, por su parte, la define como, "el acto por el que el titular hace dejación voluntaria del mismo: no se trata de que lo transmite a otra persona sino de que simplemente se desprende de él".

345 Op. cit: Págs 739 y ss, y 767.

${ }^{346}$ Op. cit.: Pág 49

${ }^{347}$ Sistema de Derecho Civil. Vol. I. Cit: Pág 465.

${ }^{348}$ Op. cit.: Pág 312.

${ }^{349}$ Derecho Hipotecario. II. Cit: Pág 150.

${ }^{350}$ Derecho civil. I, Introducción y parte general. Vol. 1 Introducción y derecho de la persona. Librería BOSCH. Barcelona. 1975. Pág 367. 
En la doctrina extranjera, BETTI ${ }^{351}$, entiende la renuncia como un acto de disposición que produce la pérdida de un derecho del que se deriva la extinción del mismo, y de ahí que tal acto tenga carácter abdicativo, en contraposición a aquellos otros supuestos en que el acto de disposición también conlleva la pérdida del derecho pero la correlativa adquisición de ese mismo derecho por parte de otro. Después, al clasificar el negocio jurídico por razón de su contenido, reiterando dicho concepto, entiende la renuncia como un negocio de disposición meramente abdicativo y contrapuesto a la enajenación como negocio traslativo, si bien, tanto en uno como en otro, la disminución patrimonial consiste en la pérdida o limitación de un derecho subjetivo por parte del disponente ${ }^{352}$. CARIOTA FERRARA ${ }^{353}$, también entiende que la renuncia es un negocio jurídico unilateral que es consecuencia del ejercicio de la facultad de disposición por parte de su titular y que produce en éste la pérdida de ese derecho.

En nuestra opinión, la renuncia es "aquel acto jurídico que tiene lugar cuando una persona se desprende, de forma libre y voluntaria, de una cosa o derecho, del que es su titular y forma parte de su patrimonio, de tal manera que hace dejación o abandono del mismo pero sin transmitírselo a otra persona y, en consecuencia, queda sin titular actual, al tiempo que se produce para ella su pérdida o extinción".

El Tribunal Supremo, por su parte, a través de una jurisprudencia muy reiterada y abundante ${ }^{354}$, define la renuncia como, "la manifestación de voluntad que lleva a cabo su titular por cuya virtud hacen dejación del mismo, sin transmitirlo a otra persona, aunque pueda producirse de forma expresa o tácita, ha de ser clara, terminante e inequívoca, con expresión indiscutible de criterio de voluntad determinante de la misma, sin que sea posible deducirla de expresiones equívocas o dudosas, debiendo aparecer de actos concluyentes que demuestren de forma indubitada la voluntad renunciativa". De forma más abreviada como, "manifestación de voluntad que lleva a cabo el titular de un derecho por cuya virtud hace dejación del

${ }^{351}$ Teoría general del negocio jurídico. Traducción y concordancias con el Derecho español por A. Martín Pérez. Editorial Revista de Derecho Privado. Madrid. 1959. Pág 27.

352 Op. cit.: Pág 213.

353 Il negozio giuridico nel diritto privato italiano. Napoli. Morano Editore. (¿?). Págs 22, 23 y 137.

354 Así, entre otras muchas: SSTS 17 noviembre 1931, de 13 junio 1942 (RJ 767), 11 noviembre 1959 (RJ 3986), 20 diciembre 1960 (RJ 4104), 4 octubre 1962 (RJ 3790), 10 diciembre 1966 (RJ 5711) y 4 octubre 1968 (RJ 4088); 4 de mayo de 1976 (RJ 1989); 26 de septiembre de 1983 (RJ 4680); 24 de mayo y 18 de octubre de 1984 (RJ 2502 y 4896); 3 de marzo, 25 de abril, 11 de junio y 16 de octubre de 1986 (RJ 1094, 2002, 4278 y 7292); 7 de julio de 1988 (RJ 5559); 27 de febrero de 1989 (RJ 1405); 24 de octubre de 1991 (RJ 7863,7864 y 7865), que son reiteradas por las inmediatamente posteriores de ese mismo año, de 28 de octubre (RJ 7872, 7873, 7874); 31 de octubre (RJ 7879, 7880, 7881); 8 de noviembre (RJ 8149, 8150, 8151) y 11 de noviembre (RJ 8722, 8723 y 8724); 28 enero 1995 (RJ 178). 
mismo sin transmitirlo a otra persona" (STS 5 de abril de 1997, RJ 2640). O también, "es aquella manifestación de voluntad personal, clara, terminante, inequívoca y sin condicionamiento alguno, por virtud de la cual el titular de un derecho hace dejación del mismo" (STS de 30 de mayo de 1995, RJ 4025). En otra posterior de 30 de octubre de 2001 (RJ 8139), reiterando jurisprudencia anterior a ésta de la misma Sala ${ }^{355}$, manifiesta que, "la renuncia supone una declaración de voluntad, recepticia o no (según los casos y supuestos en que se produzca), dirigida al abandono o dejación de un beneficio, cosa, derecho, expectativa o posición jurídica".

\section{4.- LA REPUDIACIÓN, ¿ES UNA RENUNCIA?.}

A la vista de cuanto antecede, ¿el acto de la repudiación es una forma o manifestación de renuncia?. Yendo al punto de partida o momento en que la repudiación se ha de manifestar, tengamos en cuenta las siguientes consideraciones:

a) la repudiación es una facultad que solo se tiene cuando se ha sido llamado a una herencia y a través del ius delationis que, por otro lado, no forma parte del patrimonio del sucesor, sino que es un elemento patrimonial más de la herencia del causante, además, de ser un acto, como luego veremos, que tiene un perfil jurídico muy propio y unas características también muy definidas.

b) Cuando se manifiesta, no es preciso hacer mención expresa de qué bienes son objeto de repudio porque cuando se emite siempre comprende la totalidad de los bienes, porción o cuota que se hubiere deferido a favor del sucesor dado el carácter indivisible ${ }^{356}$ que tiene la declaración de voluntad (art. 990 CC).

c) En el momento de hacer la declaración, estos bienes no forman parte del patrimonio del repudiante, sino que se encuentran en una situación de indeterminación o de transitoriedad -de yacencia-, porque han dejado de ser del difunto y están a la espera de ser adquiridos por los sucesores que han sido llamados a la sucesión, y

d) es una declaración que, a resultas de ella, los bienes no quedan en absoluto abandonados, ni se hace transmisión o traspaso de ellos a favor de ninguna persona, sino que es el causante, o la ley, quien provee acerca su destino a través de distintas instituciones jurídicas como son: la sustitución, el acrecimiento o la sucesión intestada.

\footnotetext{
${ }^{355}$ Sentencias, entre otras, las de 26 de septiembre de 1983 (RJ 4680), 16 de octubre de 1987 (RJ 7292), y 5 de mayo de 1989 (RJ 3588).

${ }^{356}$ Acerca de esta característica y de las peculiaridades que ofrece, véase el punto número 2 del capítulo cuarto, al que nos remitimos.
} 
Entonces, se puede decir que la repudiación, ¿es una renuncia?. La repudiación, si no es, en realidad, una forma o manifestación de renuncia, ya sea abdicativa, ya sea traslativa o preventiva, como numerosos autores se han esforzado en ver, sí ofrece una gran analogía con esta última. Incluso podríamos decir que la renuncia tiene cierta fuerza atractiva sobre la repudiación ya que, aquélla, entendida en un sentido muy amplio, puede llegar a englobar o comprender a la repudiación. Se podría afirmar, en principio, que, la renuncia es el género, mientras que, la repudiación es la especie.

Como consecuencia de ello, dentro de nuestra doctrina, numerosos autores no dudan en situar la repudiación dentro de alguna de las tres categorías de la renuncia, esgrimiendo para ello diferentes razonamientos o argumentos, lo que va a depender del diferente punto de vista o criterio que se adopte.

Así, para ROCA SASTRE, seguido por ROCA-SASTRE MUNCUNILL y O'CALLAGHAN ${ }^{357}$, la repudiación de la herencia implicaría una verdadera renuncia preventiva, u omissio adquirendi, también renuncia obstativa, declarativa o impeditiva. En este sentido, argumenta ROCA SASTRE diciendo que se trata de aquel supuesto en que al existir "una vocación adquisitiva a nuestro favor, la oferta, el llamamiento o vocación en sí, parece constituir por sí sola, un derecho subjetivo (el ius adeundae hereditatis o delationis), y por consiguiente más bien se esté frente a un caso de renuncia abdicativa". Pero, "cree que hay base para no entenderlo así, ya que el instituido que repudia, no renuncia el ius delationis, sino a la herencia misma" ${ }^{358}$.

No obstante, recordemos aquí la postura contraria de ROGEL VIDE ${ }^{359}$ respecto de la renuncia preventiva, para quien no existe como tal, aquí, en el caso que nos ocupa, ya que, según él, el sucesor no está renunciando a ningún derecho, sino que "se ejercita una facultad consistente en aceptar o repudiar la herencia deferida". A lo que añade: "si como el mismo ROCA dice, no hay renuncia al "ius delationis", $y$, en consecuencia, no hay renuncia abdicativa, tampoco es de recibo el término "renuncia preventiva". El "non uti occassione adquirendi" no provoca empobrecimiento; no implica abandono de un derecho perteneciente a la propia esfera jurídica; no es, en fin, renuncia en sentido técnico, sino repudiación". ROGEL ${ }^{360}$, también critica dicha tesis por dos motivos:

\footnotetext{
357 “La renuncia a la legítima”. Cit: Pág 328.

${ }^{358}$ Derecho Hipotecario. II. Cit: Pág 150 y ss.; Derecho de Sucesiones. T. III. Cit: Pág 449.

${ }^{359}$ Op. cit.: Pag 250.

${ }^{360}$ Op. cit.: Pag 251.
} 
a) "Antes de la aceptación no se tiene todavía la titularidad del patrimonio hereditario y, por consiguiente, el llamado que repudia no abandona algo que ya tenía, sino que se limita a no adquirir algo que había sido puesto a su disposición", y

b) "respecto del ius delationis, la repudiación no implica en modo alguno abandono, sino ejercicio de un poder o facultad inserto en el mismo: el de optar por aceptar o repudiar una herencia".

LACRUZ BERDEJO ${ }^{361}$, por su parte, no duda en calificar también abiertamente de renuncia a la repudiación al manifestar que, "la repudiación es una renuncia, concretamente la declaración unilateral por la que el llamado a una herencia manifiesta en la forma dispuesta por la Ley su voluntad de no ser heredero", ya que "extingue en el llamado la facultad de aceptar que no podía serle retirada (no es como una oferta contractual, revocable hasta la aceptación), y mediante cuyo ejercicio se adquiere la herencia". "En todo caso, el llamado se depoja, mediante ella, de algo que ya tenía -la facultad de aceptar- y cuyo valor pecuniario asciende al importe del caudal líquido"362.

Tambien AZZARITI y MARTÍNEZ ${ }^{363}$, califican abiertamente la repudiación de la herencia como una renuncia extintiva o abdicativa del ius delationis. Al igual que nuestra doctrina, GITRAMA ${ }^{364}$, para quien la repudiación es "arquetipo de la renuncia abdicativa".

Para $\mathrm{BETTI}^{365}$, cuando la renuncia a la herencia se hace de manera pura y simple, aunque ésta aproveche a otros sucesores -que será una consecuencia ocasional o indirecta derivada de la misma-, no es de ninguna manera traslativa. Pero, "si dicha renuncia se produce a favor de determinados herederos o a favor de todos los llamados pero contra compensaciones, o a título de donación, entonces tiene el valor sustancial de enajenación de la herencia, pero precisamente por eso no es renuncia, sino que presupone o implica según ley, aceptación de la herencia".

En una línea diferente de pensamiento y empleando otros argumentos, DíEZPICAZO y GULLÓN BALLESTEROS ${ }^{366}$, entienden que la repudiación de la herencia

361 Derecho de Sucesiones. Parte general. Cit: Pág 309; LACRUZ-SANCHO: Derecho de Sucesiones. I. Parte general. Cit: Pág 138.

362 Derecho de Sucesiones. I. Parte general. Cit: Pág 138.

${ }^{363}$ Successioni per causa di morte e donazioni. $7^{\mathrm{a}}$ Ed. Padova. CEDAM. 1979. Pág 122.

364 Op. cit.: Pág 224.

365 Teoría general del negocio jurídico. Cit: Pág 214.

${ }^{366}$ Sistema de Derecho Civil. Vol. IV. Cit: Pág 542. 
es la contrapartida de la aceptación y consiste en, "la declaración de voluntad del llamado a una herencia de no ser heredero y de no adquirir por ende los bienes hereditarios". A lo que añaden que, "como nada habría llegado a adquirir, respecto de los bienes y derechos hereditarios no hay en puridad renuncia, sino voluntad de no adquirir (omissio adquirendi)".

ROGEL VIDE ${ }^{367}$, de nuevo, disiente de las posiciones anteriores de calificar la repudiación de la herencia como una modalidad de renuncia en cualquiera de sus manifestaciones y entiende que la repudiación no es más que el ejercicio del ius delationis en su vertiente o aspecto negativo, esto es, el sucesor lo que hace es manifestar que no quiere aceptar, adir la herencia a que ha sido llamado y, por consiguiente, de tomar la cualidad o condición de heredero. Precisamente de lo que se preocupa ROGEL de una manera constante es, como él dice, de "reducir el campo de la renuncia al terreno que le es propio eliminando de su ámbito figuras que poco o nada tienen que ver con ella", e identifica la repudiación a "la declaración de voluntad de no aceptar la herencia", cuya tradición se remonta al Derecho romano clásico ${ }^{368}$. Así, para él, la repudiación, al igual que la renuncia, se trata de "un negocio jurídico unilateral, no recepticio e irrevocable, omisivo, solemne, acto legítimo"369, características éstas que junto con las demás que adornan la repudiación ya veremos más adelante.

Nosotros, por nuestra parte, entendemos que difícilmente se puede calificar a la repudiación de renuncia abdicativa por un doble motivo:

$1^{\circ}$.- la renuncia abdicativa solo puede tener lugar respecto de bienes o derechos de los que ya somos titulares y están plenamente incorporados a nuestro patrimonio, lo que no ocurre en la repudiación que se refiere o tiene por objeto una porción o cuota de la herencia que aun no forma parte del patrimonio por cuanto ello solo puede tener lugar a través de la aceptación. $\mathrm{Y}$, si ya está incorporado a nuestro patrimonio es porque se ha aceptado, en cuyo caso, ya no se podrá repudiar.

Precisamente por la repudiación se rechazan y se impide que entren en dicho patrimonio esos bienes. En caso contrario, de ser aceptados, se produce su adquisición e ingreso en el patrimonio y si nos queremos desprender de ellos después, entonces, ahora sí, tendremos que renunciar, lo que constituirá un caso de renuncia abdicativa, o traslativa, pero ya no podremos repudiarlos.

\footnotetext{
${ }^{367}$ Op. cit.: Pag 250 y ss.

${ }^{368}$ Op. cit.: Pag 223.

${ }^{369}$ Op. cit.: Pags 253 y 334.
} 
$2^{\circ}$.- A resultas de la renuncia abdicativa, el bien o derecho queda abandonado, sin un titular actual, ya que no se hace transmisión del mismo a otra persona ni se obtiene por ello nada a cambio y, como res nullius, puede ser adquirido por cualquiera a través de la ocupación.

En cambio, como consecuencia de la repudiación, no se puede decir, en modo alguno, que haya dejación o abandono de los bienes sucesorios porque, aparte de que se encuentran, en ese momento, transitoriamente, sin titular actual por encontrarse la herencia yacente, la ley pone en marcha de forma instantánea los mecanismos previstos para cubrir la vacante que se ha producido.

Como tampoco, en nuestra opinión, se puede calificar la repudiación como una forma de renuncia recognoscitiva o traslativa porque, en ésta, se dispone de un bien o derecho controvertido o dudoso a favor de otro sujeto que lo adquiere, lo que, por un lado, presupone la previa adquisición de ese derecho por parte del renunciante para poder disponer de él $y$, por otro, lo que se hace es una verdadera enajenación o cesión de ese bien o derecho. En la repudiación, ni existe un derecho controvertido o dudoso, como tampoco se dispone, ni puede existir una previa adquisición del derecho -precisamente lo que se manifiesta a través de la repudiación es no querer adquirir-, ni se transmite. Solo se expresa un rechazo o un no aceptar la delación sucesoria.

Entonces, ¿se puede considerar como una modalidad de renuncia preventiva?. Ciertamente es la manifestación de renuncia en que, tal vez, mejor encaja, o a la que más se asemeja. Recordemos aquí las palabras de ROCA SASTRE ${ }^{370}$ para quien se trata de un supuesto en que al existir "una vocación adquisitiva a nuestro favor, la oferta, el llamamiento o vocación en sí, parece constituir por sí sola, un derecho subjetivo (el ius adeundae hereditatis o delationis), y por consiguiente más bien se esté frente a un caso de renuncia abdicativa". Por lo que, "cree que hay base para no entenderlo así, ya que el instituido que repudia, no renuncia el ius delationis, sino a la herencia misma".

Si entendemos por repudiación aquella declaración de voluntad en virtud de la cual el delado manifiesta que no quiere ser heredero respecto de la sucesión a que ha sido llamado y no adir, en consecuencia, los bienes, porción o cuota que le fueron deferidos a su favor, resulta que, por la repudiación, en realidad, se impide el nacimiento y consiguiente adquisición de un derecho a nuestro favor, aquel al que hemos sido llamados. No se trata del ejercicio de un derecho del que ya seamos

${ }^{370}$ Derecho Hipotecario. II. Cit: Pág 150 y ss; Derecho de Sucesiones. T. III. Cit: Pág 449. 
titulares y hagamos dejación voluntaria del mismo -lo que descarta la figura de la renuncia abdicativa-, como tampoco se trata de un derecho controvertido del que se hace, al mismo tiempo que su abandono, señalamiento o indicación de una persona que lo haya adquirido -lo que descarta la figura de la renuncia recognoscitiva o traslativa-, sino que, "lo que se produce es un rechazo a la oferta legal de adquisición en que consiste la delación hereditaria. Como tal rechazo no se refiere a un único derecho, sino al conjunto de ellos, que, como patrimonio o parte alícuota del mismo, se ofrece al sucesible, por lo que se da es la repudiación o repudio de una declaración para adquirir una herencia" (CANO MARTíNEZ DE VELASCO) ${ }^{371}$. Ya antes que esto, en su opinión "lo característico de aquel -se está refiriendo al Derecho de Sucesiones-, consiste en que los derechos, junto con las obligaciones, se adquieren sin que otro los pierda, ya que no los puede perder quien, por haber muerto, ya no existe. Este último dato o matiz determina que en el Derecho de Sucesiones no exista renuncia de derechos, pues, siendo ésta dejación de los mismos por su titular es imposible que los abandone quien ya ha fallecido".

Así, habida cuenta de que el momento en que se ha de producir el repudio a la herencia por parte del sucesor es aquel en que ésta está en situación de deferida, a resultas del mismo, lo que se produce es el rehúse o rechazo a la adquisición de un derecho que podía haber llegado a entrar en nuestro patrimonio según como sea nuestra decisión. En realidad, lo que hace el delado es ejercitar la opción que le concede la delación de poder adquirir o rechazar un derecho. Él no renuncia a nada de lo que es suyo y forma parte de su patrimonio, sino que rechaza aquello a lo que ha sido llamado y, en consecuencia, impide que entre en él.

Luego, si queremos aproximar la repudiación a alguno de los tipos de renuncia antes expuestos, o incluso encajarla en alguno de ellos, la modalidad a la que más se asemeja, o con la que tiene más analogía, y podría estar en más consonancia, sería, a nuestro juicio, con la renuncia preventiva por consistir, como dice ROCA SASTRE, en una omissio adquirendi, aunque, bien entendido, que la repudiación no deja de ser nunca expresión del ejercicio en sentido negativo del ius delationis del que deriva y tiene su origen, aunque después los efectos o consecuencias que de la misma se derivan se asemejen a los de una renuncia preventiva.

${ }^{371}$ Op. cit.: Pág 295. 


\section{5.- DIFERENCIAS QUE SEPARAN A LA REPUDIACIÓN DE LA RENUNCIA.}

No obstante lo anterior, existen numerosas diferencias que separan una y otra institución y que, de alguna manera, ya han quedado expuestas o perfiladas en todo cuanto antecede.

En nuestra opinión, la diferencia esencial, que podríamos incluso calificar como sustancial o de fondo, radica en el hecho de que la repudiación consiste, como bien dice ROGEL VIDÉ ${ }^{372}$, en la manifestación del ejercicio del ius delationis en su aspecto negativo y es, en consecuencia, expresión de rechazo, no solo a aquello a lo que fue llamado el sucesor y que, por tanto, no es suyo, luego, no está ni forma parte de su patrimonio, sino también a la adquisición de la cualidad o condición de heredero, al tiempo que se hace sin determinar el destino de esos bienes y sin recibir nada a cambio de ello.

Otras diferencias que separan a la renuncia de la repudiación son las siguientes ${ }^{373}$ :

a) la renuncia propiamente dicha es un negocio jurídico de carácter abdicativo en cuya virtud se produce la separación, dejación o abandono de una cosa o derecho por parte de su titular, que forma parte de su patrimonio, de tal manera que se desprende de él y queda abandonado pero sin hacer cesión o transmisión del mismo a otra persona, produciéndose para él su pérdida o extinción.

En cambio, la repudiación tiene por objeto, o recae, sobre bienes que no son del repudiante, no forman parte de su patrimonio, sino de la herencia a los que estaba él llamado a través de la delación. Precisamente, a resultas de su declaración, lo que hace el sucesor es rechazar o impedir que entren en su patrimonio. De ello se deriva la consecuencia de que, desde el punto de vista del objeto, no hay para el repudiante pérdida alguna de bienes en su patrimonio porque aquellos a los que estaba llamado, no son suyos, como tampoco los adquiere si no es a través de la aceptación. Como tampoco se produce, a resultas de la repudiación, la pérdida de ningún derecho por cuanto el patrimonio del declarante no sufre ninguna merma o disminución, permanece inalterado. Más bien, lo que sucede es que impide la entrada en dicho patrimonio de aquellos bienes, porción o cuota de la herencia a que él fue llamado.

\footnotetext{
${ }^{372}$ Op. cit.: Pag 250 y ss.

${ }^{373}$ Vid ROGEL VIDE: Op. cit.: Pag 253 y ss.
} 
En este sentido, y desde otro punto de vista, así como en la renuncia, abdicativa, existe un perjuicio para el renunciante ya que su patrimonio sufre la disminución o pérdida de aquello a lo que renuncia o él se desprende por cuanto lo separa, extrae o saca del mismo, no ocurre lo mismo en la repudiación porque el delado, a resultas de ella, no sufre ninguna merma o baja en su patrimonio, aunque sí es cierto que, a causa de ella, lo que se produce es un no enriquecimiento del mismo, ya que impide que aumente al rechazar la atribución patrimonial que entraña la repudiación a la vocación hereditaria y que sí habría tenido lugar caso de haber aceptado.

No obstante, este extremo, en nuestra opinión, conviene ser matizado porque, aunque no se produzca a resultas del repudio la salida efectiva de ningún elemento patrimonial del declarante, se podría decir que le causa una pérdida aunque con un significado diferente a la renuncia en el sentido siguiente: en la renuncia abdicativa, la pérdida es activa, porque, como consecuencia de ella, se produce una merma o resta en el activo patrimonial con la consiguiente pérdida de valor por cuanto aquello a lo que se renuncia sale del mismo y deja de formar parte de él. En cambio, en la repudiación, se puede decir que la pérdida es pasiva, en el sentido de que, si bien no hay salida de bienes del patrimonio, se frustró la posibilidad de obtener una ganancia que se habría producido en el caso de haber aceptado, por cuanto los bienes hubiesen entrado en el patrimonio del sucesor.

b) A diferencia de la renuncia que se puede realizar de forma tácita, como puede ser a través del no ejercicio de un derecho dentro de plazo o por actos de su titular que denoten su voluntad o intención de renunciar a un derecho, la repudiación siempre ha de ser expresa, nunca tácita, y de manera formal o solemne 374 (art. 1008 CC).

c) La renuncia puede someterse al elemento accidental de la condición o término suspensivo. No ocurre así en la repudiación, al igual que en la aceptación, en que el Código Civil prohíbe en su artículo 990 que se sometan a cualquier elemento accidental. Son declaraciones de voluntad que han de hacerse de forma pura ${ }^{375}$.

d) Los efectos de la renuncia se producen desde el momento en que tiene lugar. Por el contrario, en la repudiación, al igual que en la aceptación, los efectos se retrotraen al fallecimiento de la persona a quien se hereda (art. $989 \mathrm{CC})^{376}$.

\footnotetext{
${ }^{374}$ Acerca de la forma en la repudiación, véase en el capítulo sexto, el punto número 2, y para el caso de su incumplimiento, el punto número 3-1-5 del capítulo décimo, al tratar de la ineficacia.

${ }^{375}$ Del examen de este carácter, ya nos ocuparemos en el capítulo cuarto, al que nos remitimos.

${ }^{376}$ Acerca de la retroactividad de la declaración, véase el capítulo cuarto, al que nos remitimos.
} 
e) La renuncia tiene en su ejercicio los límites que establece el artículo 6.2 del Código Civil por lo que no puede ser contraria al interés o al orden público, ni puede causar perjuicio a tercero.

En el caso de la repudiación, nos planteamos el interrogante de si aqui rige dicho artículo, con las limitaciones que implica, por la circunstancia de si estamos, o no, ante una verdadera renuncia de un derecho porque, cuando se declara la voluntad de repudiar, ¿el delado está renunciando a algún derecho?. Partiendo de la consideración de que la repudiación es una modalidad de renuncia preventiva, y que el ius delationis lo que concede al llamado a la herencia es la opción o la facultad, de aceptar o de repudiar, la oferta hereditaria que ha recibido, lo que está haciendo, en realidad, es ejercer, en sentido negativo, un derecho, pero no renunciando a él. Luego, en un sentido propio, estricto y jurídico, la repudiación no es subsumible en el ámbito del artículo 6.2 CC porque entendemos que no se está renunciando a ningún derecho, sino, ejercitando un derecho o una facultad, una de cuyas manifestaciones se asemeja a una renuncia. De ahí que en su ejercicio no regirían las limitaciones que en dicho artículo se contienen ${ }^{377}$.

No obstante, aun así, cabría plantearse la hipótesis de si estos mismos límites rigen en la repudiación como ejercicio de un derecho. La repudiación es un acto no ya solo enteramente libre (art. 988 CC), por cuanto nadie puede ser obligado a ello ${ }^{378}$, sino que se puede decir que no es contrario ni a la moral, ni al orden público, pero, ¿causa perjuicio a tercero?, porque las consecuencias que de ella se derivan afectan a diferentes personas como son $^{379}$ : los cosucesores, porque si hubiese cláusula de sustitución ordenada por el testador para este supuesto, se ven privados de la porción o cuota repudiada, mientras que, en caso contrario, accederían a ella a través del derecho de acrecer; los acreedores también se pueden ver afectados, ya sean los de la herencia ${ }^{380}$, porque ya no tendrán a su alcance el patrimonio privativo del sucesor para poder satisfacer los derechos de crédito que tuvieren contra aquella, ya sean los particulares del repudiante, que se ven privados de la posibilidad de poder dirigirse

${ }^{377}$ En igual sentido, BAYOD LOPEZ: La llamada aceptación de la herencia por los acreedores. Artículo 1001 del Código Civil. Ed Tecnos. Madrid. 1998. Pág 48 y ss.

${ }^{378}$ No obstante, no olvidemos que existen algunos supuestos, de los que ya nos hemos ocupado en el punto número 6 del capítulo anterior, donde se impone ex lege la aceptación-adquisición de la herencia al no admitirse la posibilidad de poder repudiar, al que nos remitimos.

${ }^{379}$ Nos remitimos, en este sentido, al capítulo séptimo, donde se analizan los efectos de la repudiación en relación a los sujetos interesados en la herencia, y al capítulo noveno, relativo a los efectos en relación a los acreedores.

${ }^{380}$ A propósito de los efectos que la declaración de repudio tiene hacia ellos, véase en el capítulo noveno, el punto número 1 , al que nos remitimos. 
contra aquellos bienes, porción o cuota a que fue llamado su deudor, si bien, tienen a su favor, para este caso, en defensa de sus respectivos derechos de crédito, la acción que les concede el artículo 1001 CC $^{381}$; o incluso los mismos sucesores del repudiante, que puede ser la estirpe del causante, por cuanto ellos se verán privados de poder adquirir en el futuro aquello que fue objeto de repudio y que, en el devenir normal de las sucesiones, habrían llegado a heredar.

f) La renuncia es impugnable, en su caso, por parte de los acreedores del renunciante a través de las acciones subrogatoria y revocatoria o pauliana del artículo 1111 del Código Civil en el supuesto de que aquella se hubiera realizado en fraude de sus derechos.

En cambio, la repudiación, realizada conforme a derecho es irrevocable ${ }^{382}$ (art. 997 CC), sin perjuicio de que pueda ser ineficaz ${ }^{383}$, y que los acreedores particulares del repudiante tienen la defensa que les otorga el artículo 1001 CC.

g) Otra diferencia entre renuncia y repudiación está en sus efectos. Producida la renuncia, el derecho, la cosa u objeto a que se refiere, queda abandonado, sin titular actual: si son bienes muebles, son res nullius y susceptibles de ocupación (art. 609 y ss CC), y si son inmuebles, se consideran bienes mostrencos y pasan a ser propiedad del Estado ${ }^{384}$.

Efecto totalmente distinto tiene lugar a resultas de la repudiación porque, una vez producida ésta, la porción o cuota a que ha sido llamado el repudiante no se puede decir, en modo alguno, que queda abandonada y pueda ser adquirida por cualquiera, sino que da lugar a que se pongan en marcha las instituciones previstas por la ley para que se cubra la vacante producida: ya sea el llamamiento del sustituto previsto u ordenado, en su caso, por el causante en su testamento (art. 774 y ss CC), el acrecimiento a favor de los coherederos (art. 981 y ss CC) y, en último término, la apertura de la sucesión abintestato (arts. $912.3^{\circ}$ y 986 CC).

${ }^{381}$ De su examen ya nos ocuparemos más en detalle en el punto número 3 del capítulo noveno, a propósito del examen de los efectos que la repudiación tiene hacia ellos.

${ }^{382}$ De este carácter de la repudiación, su significado y trascendencia, ya nos ocuparemos en el capítulo cuarto, punto número 1 , al que nos remitimos.

${ }^{383}$ Véase, en este sentido, el capítulo décimo, dedicado todo él a la ineficacia de la declaración de repudio, sus causas y sus consecuencias.

${ }^{384}$ El artículo 17 de la Ley 33/2003, de 3 de noviembre, del Patrimonio de las Administraciones Públicas, dispone que: "Pertenecen a la Administración General del Estado los inmuebles que carecieren de dueño". Esta Ley derogó la 89/1962, de 24 de diciembre, de bases del Patrimonio del Estado y su Texto articulado aprobado por Decreto 1022/1964 de 15 de abril. Aquella, en su artículo 21 ya disponía: "Pertenecen al Estado como bienes patrimoniales los inmuebles que estuviesen vacantes y sin dueño conocido". 


\section{6.- DEFINICIÓN DE LA REPUDIACIÓN.}

De todo lo anterior, se puede entender la dificultad con que nos encontramos para decir qué es, o qué se entiende, por repudiación de la herencia, dada la gran semejanza que tiene con la renuncia, a lo que se añade el hecho de ser antítesis de la aceptación, circunstancia ésta de la que es difícil abstraerse a la hora de definirla.

Por otro lado, como señala ROGEL ${ }^{385}$, se pueden distinguir en la repudiación dos aspectos o perspectivas: una dinámica, que nos lleva a analizar el carácter negocial del acto de la repudiación y, una estática, que entraña estudiar el poder o la facultad de repudiar.

Acerca del primero, dado que tiene su origen en la voluntad humana, se plantea cómo calificar la repudiación, al igual que la aceptación, si es un hecho, un acto y si, dentro de éste, es un negocio jurídico. En este sentido, la declaración de voluntad que se emite por parte del sucesor en ejercicio del ius delationis se realiza con la concreta y específica finalidad de producir o conseguir un determinado efecto o consecuencia jurídica en relación a la herencia cual es, en el caso de la repudiación, el rechazo a la misma, y, de la aceptación, su adquisición. De lo que se derivaría la consecuencia de que, una y otra, constituyen un acto que merece el calificativo de negocio jurídico porque, siguiendo a DE CASTRO ${ }^{386}$, se trata de, "una declaración de voluntad que tiende a la lícita autorregulación de intereses que el derecho tutela reconociéndola como base y fundamento para la producción de los efectos que el ordenamiento jurídico dispone que tengan lugar en congruencia con lo que, a tenor de la declaración, se puede considerar querido por el declarante". En este sentido, la calificación y consideración de la declaración de voluntad del delado en ejercicio del ius delationis como negocio jurídico, hoy día, es admitida, sin ningún género de dudas, por la inmensa mayoría de la doctrina ${ }^{387}$, dado que se emite por parte del declarante con una determinada finalidad o intencionalidad y sin la cual no lo podría conseguir, cual es, ser o no heredero.

385 Op. cit.: pág 223.

386 El negocio jurídico. Ed. CIVITAS. Madrid. 1985. Edición facsímil de la edición original publicada en el año 1971 por el Instituto Nacional de Estudios Jurídicos. Pág 21 y ss.

387 Así, entre otros muchos:

ALBALADEJO: Anotaciones de Derecho español al Derecho de Sucesiones, Parte General, de CICU. Cit: Pág 434; CANO MARTÍNEZ DE VELASCO: Op. cit: Pág 41; DÍEZ-PICAZO: "La aceptación de la herencia por los acreedores del heredero”. ADC. XII-1 1959. Pág 129, nota 7; GITRAMA: Op. cit.: Pág 50 y ss; ROGEL VIDE: Op. cit.: Pág 334; RIVAS MARTÍNEZ: Derecho de Sucesiones Común y Foral. Cit: Pág 623; ROYO MARTÍNEZ: Op. cit: Pág 293. 
Sin embargo, algunos como DíEZ-PICAZO ${ }^{388}$, entienden que, "esta discusión teórica no es más que un reflejo de la polémica sobre distinción entre acto y negocio jurídico, porque lo cierto es que las reglas relativas a esta última figura conceptual (vicios de al voluntad como ejemplo más relevante), se aplican a la aceptación o repudiación si se entendiesen como actos jurídicos".

En este sentido, también desde el punto de vista legal, la repudiación se puede decir que es considerada como un negocio jurídico desde el momento que el Código Civil, refiriéndose a la aceptación y la repudiación, habla de acto en su artículo 988.

De la calificación como negocio jurídico se van a derivar toda una serie de consecuencias de gran importancia jurídica y práctica como es el hecho de que esta declaración de voluntad se va a someter a un determinado régimen jurídico en lo que se refiere a cuestiones como: capacidad, consentimiento, vicios de la voluntad, forma, clases de ineficacia y sus consecuencias.

Así, la declaración de voluntad que se emite en ejercicio del ius delationis, da origen a la celebración de un negocio jurídico que, por otro lado, y sin perjuicio del examen más detenido que hagamos en el próximo capítulo de los caracteres de la repudiación, se caracteriza, entre otras notas, por ser un acto inter vivos porque, aunque se trate de una declaración de voluntad que se emite a resultas o como consecuencia de la delación que surge por la muerte del de cuius, produce sus efectos en vida del declarante, al tiempo que es unilateral porque procede de una sola parte, se basta por sí sola para que produzca efectos y no requiere el concurso de otra voluntad que lo acepte y dé lugar a su perfección, y es no recepticio porque no se dirige, ni se tiene que dirigir, a ningún sujeto determinado, como tampoco necesita ser puesta en conocimiento de nadie ni notificada, para que sea válida y eficaz y produzca plenos efectos jurídicos.

Ya pasando a definir la repudiación, son muy variadas y dispares las que nos encontramos en la doctrina. Las diferencias radican en el distinto criterio o punto de vista que se adopte, como ahora vamos a ver, hasta el punto de que cada autor da la suya propia, si bien, se puede observar que son muy numerosas las que se han formulado tomando como referencia, bien la renuncia, bien la aceptación, lo que es hasta cierto punto inevitable, inlcuso lógico, habida cuenta de que, una y otra son manifestación, en sentido inverso, del ejercicio de un mismo derecho, el ius delationis. En este sentido, aunque se emplean indistintamente los vocablos repudiación y

${ }^{388}$ Sistema de Derecho Civil. Vol IV. Cit: Pág 533. 
renuncia, que es la terminología más utilizada y a la que se recurre con mayor frecuencia por la doctrina, también se emplean expresiones muy diversas como: "acción de repudiar", "no aceptación", "no admisión", "acción de renuncia", o verbos como, rehusar, repeler, rechazar o renunciar a adquirir, etc, lo que viene a demostrar que esta declaración del delado es un acto jurídico que se puede enfocar desde distintos puntos de vista y admite diferentes formas de ser descrito y definido.

Así, es denominador común bastante generalizado, por ser manifestación del ejercicio en sentido negativo del ius delationis, dar un concepto de la repudiación en el que se habla de, "no aceptación", "no asunción", o "no adquisición de la herencia". Tal es el caso de autores como: ALBALADEJO ${ }^{389}$, ROGEL VIDE ${ }^{390}$, FERRI ${ }^{391}$, DÍEZPICAZO $^{392}$, HERNÁNDEZ GIL ${ }^{393}$, como también se aprecia en la jurisprudencia (RDGRN de 25 de noviembre de 1942, RJ 1399).

Otros, tomando como referencia la aceptación pero en un sentido diferente, emplean en su definición, dada su antítesis a ella, términos como, "contraria" (MANRESA $\left.{ }^{394}\right)$, "contrapartida", o "antónimo" (GITRAMA $\left.{ }^{395}\right)$.

También hay numerosas definiciones que acentúan el carácter de rechazo hacia la herencia que entraña la repudiación, como es el caso de, VALVERDE ${ }^{396}$, para quien la repudiación es, "la manifestación que hace el llamado a la herencia de no admitirla", o CASTÁN TOBEÑAS 397 , es "el acto en virtud del cual el llamado a la sucesión declara formalmente que rehúsa la herencia a su favor deferida". En la misma línea de pensamiento nos encontramos a ROYO MARTíNEZ ${ }^{398}$ o RIVAS MARTÍNEZ ${ }^{399}$. En igual sentido, y en términos idénticos se manifiestó la Audiencia Provincial de Jaén en su sentencia de 26 de mayo de 1997 (AC 1051), al decir que, "la repudiación es el acto por virtud del cual el llamado a la sucesión declara formalmente que rehúsa la herencia a su favor deferida".

389 “La repudiación de la herencia”. Cit: Pág 716.

390 Op. cit: Pag 223.

${ }^{391}$ Rinunzia e rifiuto nel diritto privato. Cit: Pág 25 y ss.

392 "La aceptación de la herencia por los acreedores del heredero”. Cit: Pág 128; Sistema de Derecho Civil IV. Cit: Pág 536.

${ }^{393}$ Lecciones de Derecho sucesorio (resumen de explicaciones de Cátedra). Cit: Pág 100.

394 Op. cit.: Pág 406.

395 Op. cit.: Pág 49.

396 Tratado de Derecho Civil español. T. V. Valladolid. 1926. Pág 516

${ }^{397}$ Derecho Civil Español Común y Foral. T. VI. Vol 1. Cit: Pág 177.

${ }^{398}$ Derecho sucesorio “mortis causa”. Cit: Pág 293.

399 Derecho de Sucesiones Común y Foral. Cit: Pág 623. 
Tampoco faltan quienes, como LACRUZ BERDEJO ${ }^{400}$, que no dudan en calificar abiertamente de renuncia a la repudiación al manifestar que, "la repudiación es una renuncia, concretamente la declaración unilateral por la que el llamado a una herencia manifiesta en la forma dispuesta por la Ley su voluntad de no ser heredero". En este mismo sentido, se pronunció la Audiencia Provincial de Jaén en la sentencia de 18 enero de 2000 (Sección 2a) -AC 2000/612-, según la cual, “la repudiación o renuncia a la herencia, negocio contrario a la aceptación, «omissio adquirendi» consiste en la declaración de voluntad unilateral, expresa y formal del llamado a la herencia renunciando a adquirirla, con la consecuencia de dejar intacto y sin efecto la delación producida a favor del repudiante, dando lugar, en consecuencia a una nueva delación".

CANO MARTÍNEZ DE VELASCO ${ }^{401}$, no toma como referencia ni la aceptación, ni la renuncia, sino que da una definición descriptiva de la misma al manifestar que, "es un negocio jurídico solemne dirigido al Juez de la testamentaría o del abintestato, manifestando la voluntad de no querer que los derechos, obligaciones y cargas, constitutivos de la herencia, se añadan a los propios del patrimonio del repudiante".

Para ROCA SASTRE MUNCUNILL ${ }^{402}$, es "aquel acto por el cual el llamado a la herencia, por testamento o abintestato, manifiesta su voluntad de no ser heredero, de forma que en su virtud es Ilamado otro posible heredero".

$Y$, no faltan quienes se manifiestan de forma diversa, empleando diferentes expresiones, como también, de forma simultánea, varias a la vez.

Por nuestra parte, definimos la repudiación como, "aquel acto en virtud del cual el llamado a una sucesión, ya sea testada o intestada, manifiesta de forma unilateral y solemne, su voluntad de rechazar el llamamiento o atribución patrimonial que le ha sido deferido y, por consiguiente, no adir la herencia y no tomar el título o condición de heredero o, en su caso, de legatario" 403.

400 LACRUZ-ALBALADEJO: Derecho de Sucesiones. Parte general. Pág 309; LACRUZSANCHO: Derecho de Sucesiones. I. Parte general. Pág 138.

401 Op. cit: Pág 296.

${ }^{402}$ Derecho de Sucesiones. T III: Cit: Pág 449.

${ }^{403}$ El concepto de repudiación en el sistema sucesorio germano es diferente habida cuenta de la distinta función que tiene porque, a través de ella, el sucesor no solo manifiesta la voluntad de rechazo a la herencia, sino que deshace la adquisición que, de forma provisional, se produjo a su favor desde el mismo momento en que se produjo la delación, esto es, desde que tuvo lugar el fallecimiento del causante, al tiempo que elimina definitivamente, en su caso, la posibilidad, en su caso, de aceptar, en el supuesto de que el sucesor lo pretendiere hacer. 
No obstante, para una correcta y más exacta delimitación de qué es y en qué consiste la repudiación de la herencia, dada su proximidad o semejanza con la renuncia, podemos hacer las siguientes consideraciones o puntualizaciones:

$1^{\text {a }}$ - la repudiación, solo, única y exclusivamente tiene lugar, cuando la persona que ha sido llamada a una sucesión ejerce en sentido negativo el ius delationis deferido a su favor, ante lo que manifiesta no adir la herencia, no querer llegar a ser o tomar la cualidad o condición de heredero y, consecuentemente, no adquirir los bienes, porción o cuota que en virtud de la vocación sucesoria le han sido deferidos.

$2^{\mathrm{a}}$.- Cualquier acto que, en relación a los bienes de la herencia, se hiciere por parte del llamado, tales como: a) renunciar, en el sentido propio y técnico del término, al derecho hereditario en situación de herencia indivisa, b) los actos de renuncia a que se refiere el artículo 1000 CC (salvo el supuesto previsto en el inciso segundo del número $3^{\circ}$ ), que constituirían manifestaciones de aceptación tácita de una herencia y que examinaremos a continuación, o c) la renuncia que se hiciere de forma expresa de todo o parte de los bienes de la herencia después de haberlos adquirido a resultas de la aceptación y le hubieren sido adjudicados por la partición, todos ellos constituirían, en nuestra opinión, no manifestaciones de repudiación y sí, en cambio, actos de renuncia, sin perjuicio de cómo sea ésta después, si abdicativa, o traslativa.

$3^{\mathrm{a}}$.- En el caso de la renuncia, ésta tiene siempre por objeto un bien o derecho que es de la titularidad o pertenencia del renunciante y forma parte de su patrimonio, lo que presupone, tratándose de bienes sucesorios, que, en relación a ellos, ha tenido que existir previa aceptación de los mismos porque, de otra manera, no se podrían haber adquirido e incorporado al patrimonio del sucesor. Todo lo contrario sucede en la repudiación porque, a través de ella, se rechaza, que no se renuncia, algo a lo que, bien es cierto que se tiene derecho, pero que aun no ha entrado en el patrimonio del repudiante.

$4^{\mathrm{a}}$.- Desde el punto de vista del sujeto, cuando se realizare un acto de renuncia abdicativa en relación a los bienes sucesorios, no se haría en la condición de delado, y sí en el de heredero, por cuanto se estaría renunciando a algo que ya se ha adquirido a resultas de la aceptación. Mientras que, en el caso de repudiación, sería lo contrario, se haría en el título de delado y no en el de heredero, que precisamente se rechazó con el repudio. 
Así, si el llamado a una sucesión no quiere adir la herencia que le ha sido deferida y sí rechazar aquello a que fue llamado a través de dicho título sucesorio, desentendiéndose de ello sin hacer cesión o transmisión a otra persona de tal manera que sea el propio causante, o la ley, quien a través de los mecanismos sucesorios previstos para ello (sustitución, derecho de acrecer o apertura de la sucesión intestada), sea quien determine el destino de esos bienes, lo que tendrá que hacer es repudiar, ejercitar en sentido negativo el ius delationis. Pero, si lo que quiere hacer es desprenderse de esos bienes, sin llegar a adquirirlos de manera efectiva, haciendo cesión de ellos de forma gratuita, u obteniendo algo a cambio, a modo de contraprestación, entonces lo que puede hacer es, bien renunciar a través de alguno de los supuestos a que se refieren los números $2^{\circ}$ y $3^{\circ}$, inciso $1^{\circ}$, del artículo 1000 , en cuyo caso estaríamos ante un supuesto de aceptación tácita, o también desprenderse de ellos después de haberlos adquirido, en consecuencia, después de haber aceptado, como puede ser a través de un acto de renuncia que, bien puede tener lugar, ya de manera abdicativa mediante su dejación o abandono sin transferirlo a otra persona, lo que sería una renuncia propiamente dicha, bien de manera traslativa haciendo cesión o transmisión de los mismos, ya sea ésta a título oneroso, o a título gratuito, que sería una renuncia impropia.

\section{7.- LA REPUDIACIÓN Y LOS CASOS DE RENUNCIA DEL ARTÍ́CULO 1000 DEL CÓDIGO CIVIL.}

Al tratar más arriba en el punto número 2 de este capítulo de la delimitación del concepto de repudiación, habíamos dejado planteada la cuestión de si la realización de alguno de los casos a que se refiere el Código Civil en los números $2^{\circ}$ y $3^{\circ}$ de su artículo 1000 constituye un verdadero supuesto de renuncia y, en consecuencia, si se pueden llegar a considerar como una forma de repudiación, al ser ésta una modalidad o manifestación de la misma, o si, como dice el precepto, hay que tenerlos como casos de aceptación, tácita, de la herencia.

En comentario general al referido artículo, LACRUZ BERDEJO ${ }^{404}$ califica estos supuestos de "aceptación por cesión del ius delationis". Pero, dicha calificación, a nuestro juicio, no es muy acertada o afortunada porque cuando el delado realiza cualquiera de aquellos actos, en realidad, él no está disponiendo o cediendo el ius delationis porque, sencillamente, no puede lo hacer. $Y$ ello, porque desde un punto de

${ }^{404}$ Derecho de Sucesiones. I. Cit: Pág 125; también en: Derecho de sucesiones. Parte General. Cit: Pág 292. 
vista técnico y jurídico, su ejercicio no puede ser, en modo alguno, objeto de cesión dado que se trata de un derecho que deriva o proviene de la vocación sucesoria que a él se le confiere con carácter in tuitu personae, siendo su ejercicio personalísimo ${ }^{405}$, solo del propio sucesor, sin posibilidad alguna de que pueda ceder a otra persona esa facultad, a excepción hecha del ius trasmissionis (art. 1006 CC). De ser factible, significaría tanto como investir al cesionario como nuevo sucesor del causante, como así sucede a través del ius transmissionis, y que sea él después quien repudie, o acepte, una delación que, a él personalmente, no se le ha deferido. Además, es equívoca, y hasta inviable o imposible de que se produzca en los términos planteados porque, si a través de la cesión, como dice LACRUZ, se está aceptando, de forma tácita, la herencia por parte del sucesor-cedente, ello significa que, a través de este acto, estaría adquiriendo su porción o cuota sucesoria. Entonces, cabe preguntarse, ¿qué es lo que se cede o adquiere realmente el cesionario?, porque, si el acto de la cesión, no solo implica aceptación y adquisición, sino que supone ejercicio y extinción del ius delationis, éste se habrá consumado, lo que nos lleva a un imposible: el cesionario no adquiriría nada precisamente porque ya lo habría adquirido el cedente a través de dicho acto. En este sentido, a nuestro juicio, la cesión del ius delationis implica o significa aceptación tácita de la herencia.

Como veremos más adelante al examinar cada uno de los supuestos de hecho que dan contenido a sendos números, a excepción del recogido en el inciso segundo del $n^{\circ} 3$ que sí se considera por la doctrina, salvo alguna opinión en contra, como un caso de verdadera y propia repudiación, observamos cómo, a través de ellos, de lo que está disponiendo, en realidad, el delado, es de su porción o cuota sucesoria. Después, el adquirente, destinatario o cesionario, como consecuencia de estos actos, deviene en titular de esa porción u cuota a que fue llamado el delado-cedente, pero lo que no tiene, en modo alguno, es la opción de repudiar, o aceptar, que entraña el ius delationis por cuanto éste ya se extinguió. Opción que, recordemos, es personal e intransferible del delado como consecuencia de la vocación que con carácter in tuitu personae se ha realizado en su favor.

El artículo 1000 CC, entendemos que emplea el término renuncia en un sentido impropio porque, salvo el supuesto contemplado en el segundo inciso del número $3^{\circ}$, no se trata de casos de renuncia en el sentido estricto y técnico del término, esto es,

${ }^{405}$ Véase a propósito de esta característica, el punto número 3 del capítulo cuarto.

Ver tambien, en este sentido, el punto número 3 del capítulo anterior, relativo a la transmisión de la delación y el punto número 4-3 del capítulo primero, donde se alude a ello a propósito de las clases que hay de aceptación de la herencia. 
de renuncia abdicativa o extintiva, sino de renuncia traslativa, como lo califica la doctrina ${ }^{406}$, ya que a través de esos actos (una donación, en el caso del número $2^{\circ}$, y una transmisión onerosa, en caso del apartado $3^{\circ}$ inciso primero), el sucesor no hace realmente una dejación o abandono de aquello a lo que fue llamado, sino transmisión o cesión a favor de otra u otras personas que adquieren y devienen en titulares de ello.

Por otro lado, es preciso puntualizar que tales supuestos, aunque, en principio, parece que consisten en la realización de un solo acto, se puede decir que, a través de ellos, en realidad, se realizan dos porque, de forma implícita, conllevan la ejecución de una "doble transmisión", ya que los bienes que forman parte del acervo hereditario pasan del causante al cesionario, no de una forma directa, sino por medio del delado, quien actua como vehículo o medio de transmisión al ser éste el sujeto llamado a los mismos y quien después los transmite o hace llegar al cesionario o adquirente. Ahora bien, pero para que ello sea posible, es preciso que el delado haya adquirido previamente aquello que es objeto de disposición por cuanto no se puede transmitir más derechos que los que se tienen, y la adquisición de aquello que se cede, en este caso, no se ha producido por cuanto no ha aceptado la herencia, al menos de forma expresa. Y como la transmisión no puede tener lugar si no tiene el título o condición de heredero, al no haber habido una previa aceptación expresa por parte del delado, ha de entenderse que estamos ante supuestos que son expresión, o entrañan, de forma implícita, en su realización, una aceptación tácita de la herencia porque no se pueden ejecutar si no es con el título o condición de heredero. De ahí que, en consecuencia, en la ejecución de cualesquiera de estos casos, se pueda, o se deba de hablar, en nuestra opinión, de "aceptación, tácita, de la herencia y transmisión del derecho hereditario". Y decimos del derecho hereditario, que no del ius delationis como antes hemos comentado en la crítica a LACRUZ, porque lo que realmente es objeto de cesión es aquello a lo que el sucesor, o cedente, ha sido llamado, si bien, desde este instante, se subrogaría en la posición de aquel y podría ejercer las acciones a que hubiere lugar al igual que si hubiese sido él quien hubiese aceptado la herencia ${ }^{407}$.

A la vista de lo expuesto hasta aquí, podemos decir, a modo de conclusión provisional, que no se trata de casos que hayan de considerarse como supuestos de renuncia, en sentido estricto, por cuanto tienen un carácter traslativo al haber un

406 BETTI: Teoría general del negocio jurídico. Traducción y concordancias con el Derecho español por A. Martín Pérez. Editorial Revista de Derecho Privado. Madrid. 1959. Pag 214; CARIOTTA FERRARA: El negocio jurídico. Madrid. 1956. Pág 112; DÍEZ-PICAZO y GULLÓN: Sistema de Derecho Civil. Vol I. Cit: Pág 466 y ss; GITRAMA: Op. cit.: Pág 224; ROCA SASTRE: Derecho Hipotecario. T II. Cit: Pág 117; ROGEL VIDE: Op. cit.: Pag 246.

${ }^{407}$ Véase acerca de ello el punto número 4-4 del capítulo primero. 
adquirente de los bienes, incluso a título oneroso, de ahí que el término renuncia se emplee de forma impropia, como tampoco se pueden considerar, en modo alguno como casos de repudiación, y sí, por tratarse de casos de renuncia en sentido impropio, de aceptación tácita de la herencia.

No obstante, sin perjuicio de ello, antes de entrar en el análisis de los supuestos contemplados en los números $2^{\circ}$ y $3^{\circ}$, en comentario común a todo el precepto, y en lo que se refiere a la casuística que en él se contiene, un breve apunte: en nuestra opinión, no solo no ayuda a clarificar el significado de la aceptación tácita, sino que contribuye, creemos, si cabe, a aumentar aun más esa confusión por varios motivos:

a) formula, a nuestro juicio, a título meramente enunciativo, ya que no supone o encierra un sistema de numerus clausus, una serie de actos cuya ejecución por parte del delado da lugar a que se sobreentienda o presuma por la ley, iuris et de iure, al no admitirse prueba en contrario, tácita aceptación de una herencia.

En este sentido, la realidad nos ha venido a demostrar, que existen múltiples formas de aceptar de forma tácita una herencia ${ }^{408}$.

b) Es reiterativo en su casuística porque repite supuestos de renuncia (números $2^{\circ}$ y $3^{\circ}$, en el caso de renuncia gratuita), aunque con diferentes destinatarios en uno y otro caso, pero que se podían haber agrupado bajo un mismo número.

c) Como consecuencia de lo anterior, es imperfecto en su formulación ya que los apartados que lo componen han de complementarse recíprocamente entre sí (así sucede en el caso del número $3^{\circ}$ que lo será con el número $2^{\circ}$ si se hiciere la renuncia de forma gratuita a favor, no de todos, sino de algunos de sus coherederos).

De ahí que, desde un punto de vista lógico y sistemático, lo suyo habría sido reunir en un solo número el supuesto de disposición a título gratuito, sea cual fuere el número de destinatarios o de beneficiarios. En igual sentido, opina GITRAMA ${ }^{409}$.

En relación a uno y otro supuesto, el Tribunal Superior de Justicia de Cataluña, en sentencia de 29 de enero de 1996 (RJ 6248), dispone que: "Los apartados segundo y tercero del artículo 1000 se refieren al caso de haber instituido el testador de modo simultáneo una pluralidad de herederos y por eso prevé los efectos de la renuncia a su

\footnotetext{
408 Véase en este sentido, la cita a pie de página número 155, en la que se citan numerosísimas sentencias donde se recogen un sinfín de actos realizados por parte del delado que se han considerado por parte de los Tribunales como supuestos de tácita aceptación de una herencia.

${ }^{409}$ Op. cit.: Pág 227.
} 
cuota hereditaria hecha por cualquiera de los coherederos a favor de los otros". A lo que añade: "Por consiguiente, la aplicación del artículo 1000 del Código Civil .... exige, de modo inexcusable, que una pluralidad de personas vengan llamadas de modo simultáneo a una misma herencia, lo que origina la llamada delación solidaria, que se traduce en un llamamiento solidario de todos los coherederos a la herencia y a una delación conjunta a favor de todos los instituidos". De lo que se puede obtener la conclusión de que el número $2^{\circ}$ del artículo 1000 no es aplicable a aquellos supuestos de institución de heredero único con designación de sustituto vulgar para el caso de premoriencia, como era el caso de autos.

\section{7-1.- La renuncia del número $2^{\circ}$.}

A su tenor ${ }^{410}$, entiéndese tácitamente aceptada la herencia: "Cuando el heredero la renuncia, aunque sea gratuitamente, a beneficio de uno o más de sus coherederos".

Ante todo, comentar que no estamos propiamente ante un heredero, sino ante un sucesor que aun no ha ejercitado su ius delationis porque, si realmente fuese un heredero, ya habría aceptado y, en consecuencia, ya no estaríamos, como dice el precepto, ante un caso de aceptación tácita de la herencia.

En este caso, lo que uno de los sucesores realiza, en realidad, es un negocio jurídico que encierra una verdadera transmisión porque dispone de aquello que a él se le ha deferido a favor de uno o más, no de todos, los cosucesores, o incluso ya herederos. En consecuencia, difícilmente se puede hablar de renuncia propiamente dicha, porque de aquello de lo que dispone, no lo abandona, ni se desentiende de ello, sino que lo transmite a favor de persona/s determinada/s. Lo que da pie a calificar el acto de renuncia traslativa. En este sentido, si el llamado dispusiese a favor de todos los demás cosucesores de forma conjunta, sea, o no, con asignación de porción o cuota, y mediante precio, esto es, de forma onerosa, supuesto aquí no contemplado, entendemos que sería de aplicación el inciso primero del número $3^{\circ}$ de este mismo artículo. En igual sentido, así lo entiende también GITRAMA ${ }^{411}$.

Así, se trata de un acto que, dadas las circunstancias como se ejecuta, no puede tener lugar si no se detenta el título o condición de heredero. Luego, estaríamos ante un supuesto de aceptación tácita de la herencia porque sólo la previa adquisición del título de heredero legitimaría su ejecución pero que, al no tenerlo en ese momento por no haber aun aceptado, su realización lleva consigo, de forma implícita, incluso

\footnotetext{
${ }^{410}$ Vid sobre el mismo: SAP Málaga (Sección 6a ${ }^{\mathrm{a}}$ ), de 20 de diciembre de 2000 (JUR 2001195285).

${ }^{411}$ Op. cit.: Pág 225.
} 
involuntaria en el delado por cuanto, tal vez, esa no fue su intención cuando lo ejecutó, la adquisición de lo que se le defirió. De ahí que su ejecución implica necesariamente aceptación, tácita, porque no se puede ejecutar si no se es heredero. De ello se deriva la circunstancia de que, al no haber aceptación previa la herencia, no ha habido adquisición ni entrada en el patrimonio del disponente de aquello de lo que se dispone. Por ello, difícilmente se puede renunciar a algo, o transmitir, que no se tiene o no se ha adquirido antes, como tampoco, en otro orden de argumentos, como consecuencia de la disposición, se produce abandono alguno, rasgo carácterístico de la renuncia, porque hay un adquirente. Luego, estaríamos ante un supuesto de renuncia traslativa.

De igual manera, el Código Civil francés, en su actual artículo $783^{412}$, con precedente en el modificado artículo $780,1^{\circ}$, reputa aceptación tácita, aunque pura y simple, toda cesión, a título gratuito u oneroso, hecha por un sucesor de todo o parte de sus derechos sucesorios ${ }^{413}$.

Por otro lado, esta disposición se puede realizar, dada la dicción del precepto, tanto a título oneroso, percibiendo a cambio alguna contraprestación del adquirente, como a título gratuito ${ }^{414}$, de forma lucrativa, sin recibir nada a cambio, pero ello, no significa, en modo alguno, que estemos ante una donación propiamente dicha. En este sentido, así lo califica GITRAMA, porque "lo que aquí trata el Código es un negocio jurídico traslativo" ${ }^{\prime 15}$. En nuestra opinión, aquí no hay una donación porque, para que se trate de una verdadera liberalidad, ha de suponer, en este caso para el delado, una pérdida o una disminución patrimonial que aquí no existe porque aquello de lo que él dispone, no ha llegado a entrar en su patrimonio ya que no ha aceptado la herencia. El delado, eso sí, deja de enriquecerse o pierde la posibilidad de aumentar el activo de su patrimonio, pero no por ello sufre la pérdida patrimonial alguna, que es el rasgo esencial y característico de la donación. Su patrimonio sigue inmutable ya que no ha

412 "Toute cession, à titre gratuit ou onéreux, faite par un héritier de tout ou partie de ses droits dans la succession emporte acceptation pure et simple.

Il en est de même:

$1^{\circ}$ De la renonciation, même gratuite, que fait un héritier au profit d'un ou de plusieurs de ses cohéritiers ou héritiers de rang subséquent;

$2^{\circ}$ De la renonciation qu'il fait, même au profit de tous ses cohéritiers ou héritiers de rang subséquent indistinctement, à titre onéreux”.

${ }^{413}$ La novedad de la nueva regulación está en que, en el anterior artículo $780.1^{\circ}$, distinguía entre “donation, vente ou transport” -donación, venta o cesión-, mientras que ahora, sólo habla de cesión, lo que habrá de entenderse en un sentido amplio, si bien, establece que puede ser tanto a título oneroso como gratuito, lo que antes no decía. Después, los dos supuestos a que alude, son los mismos que en el texto modificado.

${ }^{414}$ Así lo entendemos pese a que en el supuesto no se diga porque, según su tenor: “aunque sea gratuitamente”, lo que da a entender que puede ser también a título oneroso.

415 Op. cit.: Pág 224 
sufrido ninguna merma o disminución. Luego, difícilmente se puede hablar aquí de una donación en un sentido propio, sin perjuicio de que esa sea, en realidad, la intención del delado, hacer una donación. Pero, en puridad, y en un sentido técnico, no cabría hablar, como tal, de una donación, de ser un acto que entrañe una liberalidad con la consiguiente pérdida patrimonial para quien la realiza.

Este es, por otro lado, el supuesto que con más frecuencia se produce en la práctica en la creencia de que se rechaza una herencia cuando, en realidad, se está disponiendo de aquello a lo que se es llamado a favor de otra u otras personas.

\section{7-2.- La renuncia del número $3^{\circ}$.}

Según su tenor, entiéndese aceptada la herencia: "Cuando -el sucesor- la renuncia por precio a favor de todos sus coherederos indistintamente ${ }^{416}$; pero, si esta renuncia fuere gratuita y los coherederos a cuyo favor se haga son aquellos a quienes debe acrecer porción renunciada, no se entenderá aceptada la herencia" ${ }^{417}$.

En él, se distinguen dos supuestos que se corresponden respectivamente con los incisos primero y segundo:

a) en el primero, el delado ceda su cuota a título oneroso, por precio, percibiendo algo a cambio, siendo beneficiarios todos los demás sujetos que han sido llamados junto con él a la herencia, de forma indistinta, sin asignación o distribución de porciones o cuotas por parte del sucesor.

Este caso es análogo al contemplado en el número 2 de este mismo artículo, si bien, con la diferencia de que, en éste, los beneficiarios son, no uno o varios, sino todos los demás cosucesores que han sido llamados junto con él a la herencia. Por otro lado, al hacerlo por precio, impide que se puede calificar el acto de renuncia, en sentido estricto, esto es, abdicativa, y sí traslativa, por lo que habrá que entender que tal acto implica en su ejecución, implícitamente, una aceptación, tácita, de la herencia.

${ }^{416}$ De igual manera, tanto en Aragón (art. 350.1 a, CDFA), como en Cataluña (art. 461-5, letra b, Ley 10/2008, sobre sucesiones), se considera también en este caso que no existe renuncia y sí aceptación, tácita, de la herencia por parte del llamado. Igual sucede en el Codice civile italiano (art 519, $2^{\circ}$ ).

417 También en Aragón se entiende como no aceptada la herencia cuando el llamado renuncia gratuitamente a ella en favor de todas las personas a las que se defiere la cuota del renunciante (art. 350.3 CDFA). Igual en Cataluña, la Ley 10/2008, sobre sucesiones, en su artículo 461-6, nº 2, lo entiende como un caso de repudiación de la herencia.

A propósito de este supuesto vid: SAP de Álava, de 7 de febrero de 1995 (AC 1995\395). 
b) En el segundo, el delado realiza de igual manera dicho acto, a favor de todos los demás sujetos llamados a la herencia, también de forma indistinta, pero con la diferencia de hacerlo a título gratuito, sin percibir nada a cambio y, además, se da la circunstancia de que entre ellos se dan los requisitos precisos para que pueda tener lugar, en su caso, el derecho de acrecer $^{418}$.

Aquí concurren toda una serie de circunstancias que lo hacen diferente, no ya del anterior, sino de los demás del mismo artículo, y que van a dar lugar a que se llegue a considerar como un caso de verdadera repudiación de la herencia, tanto por parte de la doctrina, aunque no faltan voces discordantes que opinen lo contrario, como de la jurisprudencia, porque el resultado del mismo es exactamente igual que si el renunciante hubiese repudiado esa misma porción o cuota de la herencia. Estas circunstancias o requisitos, serían los siguientes:

$1^{\mathrm{a}}$.- la disposición se realiza por parte del disponente, a título gratuito, sin recibir nada a cambio.

$2^{\mathrm{a}}$.- Es beneficiario, el colectivo formado por todos los demás sucesores que hubieren sido llamados junto con el disponente a la sucesión y no personas concretas y determinadas, uno o varios, que él elige o decide, como ocurre en los casos de los números $1^{\circ}$ y $2^{\circ}$, si no que la renuncia se realiza de forma indistinta, genérica $o$ indeterminada a favor de todos ellos, sin asignar o indicar porciones o cuotas y sin especificar cual es el sujeto destinatario de la misma.

$3^{a}$.- Se ha de dar, además, la circunstancia de que, entre los destinatarios de la atribución han de concurrir los presupuestos necesarios para que entre ellos se dé el derecho de acrecer (art. 981 y ss CC), de tal manera que, si no se da este requisito, aunque la disposición se haga a favor de todos ellos, de forma indistinta, a los efectos de entender el acto como un posible caso de repudiación de herencia, ya no tendría esta consideración.

Este presupuesto entendemos que es necesario e imprescindible que exista para que, cuando se proceda a distribuir la porción o cuota "renunciada" entre los beneficiarios de la misma, el resultado sea exactamente el mismo que el que resultaría de aplicar las normas, testamentarias o legales a que hubiere lugar, en su caso, en el supuesto de que el "renunciante" la hubiera repudiado.

${ }^{418}$ Este párrafo, según señala ROGEL VIDE (Op. cit.: Pág 336), aparece por primera vez en la redacción definitiva del Código Civil. Proviene, parece ser, del artículo 938 del Código Civil italiano ya que no estaba ni en el Proyecto de García Goyena, ni en el Anteproyecto de 1882-1888. 
No obstante, una puntualización que entendemos de gran importancia: aunque el Código Civil no lo diga, es preciso que, cuando se realiza tal acto, no exista en la sucesión, testamentaria ha de ser, cláusula de sustitución vulgar porque sino, ante su ejecución, tendría preferencia el llamamiento de los sustitutos frente el derecho de acrecer, en cuyo caso serían éstos los beneficiarios del acto y no los demás cosucesores. Más exactamente, la "renuncia" no se podría realizar, salvo que se dé la circunstancia de que los beneficiarios del acto sean los mismos sujetos designados como sustitutos del renunciante. Y ello, porque, lo que no puede suceder es que, como consecuencia de la "renuncia", resulten perjudicados los sustitutos designados por el causante ya que sino sería una forma de burlar o frustrar la voluntad del causante, cuando no de incumplirla. Ahora bien, la cláusula de sustitución sería de aplicación, lógica y evidentemente, sólo si la hubiere previsto el causante para el caso de repudiación de la herencia, dada la similitud, por no decir identidad, que existe entre el repudio y el acto de que tratamos. $Y$ si se da la circunstancia de que, el causante, al ordenarla, no previó la hipótesis del repudio y sí otras, como la premoriencia y/o la incapacidad, entonces sí que, en nuestra opinión, tendría lugar el reparto de la porción o cuota entre renunciada todos los demás sucesores de conformidad con las normas del derecho de acrecer. De no ser así, si el de cuius no contempló la sustitución para el caso de repudio, entendemos que sería tanto como establecer una sustitución vulgar ex lege en un supuesto para el que él no lo previó.

$4^{\mathrm{a}}$.- La "renuncia" se ha de hacer de forma genérica o indeterminada, es decir, sin que exista una previa, simultánea o posterior distribución, reparto o asignación en porciones de la cuota renunciada entre los beneficiarios de la misma. Reparto, que se hará después entre todos ellos al aplicar las reglas del acrecimiento ${ }^{419}$.

Acerca del supuesto que tratamos, para MANRESA ${ }^{420}$, "sería la verdadera $y$ propia renuncia, por su carácter extintivo, que la Ley autoriza al heredero. El sucesor abdica su derecho sin condiciones ni reservas, lo abandona en absoluto y la Ley cuida

419 En este sentido, acerca de la concurrencia de estos requisitos, así se manifestó la Audiencia Provincial de Asturias en su sentencia de 29 enero de 2004 (Sección $4^{\mathrm{a}}$ ) -AC 2004/20-, para quien, el $\mathrm{n}^{\mathrm{o}}$ $3^{\circ}$ del artículo 1000 CC, "exige claramente la concurrencia de dos requisitos: la gratuidad de la renuncia y que se haga a favor de quienes tengan derecho de acrecer. De este modo, aunque la renuncia se haga gratuitamente y a favor de todos los coherederos, no podrá considerarse renuncia y sí aceptación, si estos últimos no eran los legalmente llamados a la sucesión en defecto del renunciante, es decir, si carecían del derecho de acrecer. Sólo se considerará renuncia cuando el destino de los bienes y derechos hereditarios es el mismo que el que se produciría a través de la simple repudiación. Pero no cuando ésta se establezca a favor de alguien, aunque sea un coheredero, que implique un cambio de rumbo de los bienes relictos, distinto del que venía establecido por testamento o por Ley”.

${ }^{420}$ Op. cit.: Pág 401. 
de adjudicarlo a quien corresponda". Según él, la ley equipara este acto a una verdadera renuncia extintiva y no lo considera como una donación por cuanto ésta requiere aceptación: la renuncia es un acto unilateral que no requiere aceptación por parte de las personas a quienes beneficie, por lo que su forma y efectos deben seguir las reglas de ésta y no las de las donaciones.

ALBALADEJO ${ }^{421}$, por su parte, manifiesta que, "solo se considera que hay repudiación cuando el llamado que se desentiende de la herencia lo hace sin nada a cambio y dejando que aquélla siga el mismo curso que habría seguido de no ser llamado él".

De igual manera, para ROGEL VIDE ${ }^{422}$, se está en presencia de una verdadera repudiación "porque el llamado no hace otra cosa que manifestar expresamente querer las mismas consecuencias que se derivarían de la repudiación por obra de la ley". En igual sentido, ROYO MARTÍNEZ ${ }^{423}$.

En la misma línea de pensamiento, la DGRN, en Resolución de 3 de agosto de 1944 (RJ 998), con precedente en una de 12 de noviembre de 1910, manifestó que, "el párrafo $3^{\circ}$ del artículo 1000, en su final, niega a la renuncia no traslativa el carácter de aceptación de herencia y a los renunciantes el de herederos". De igual manera, el Tribunal Supremo, por su parte, en sentencias de 18 de mayo de 1962 (RJ 2753) y 22 de enero de 1973 (RJ 3139), entendió que, en este caso, estamos ante un supuesto de renuncia pura y simple.

ROCA SASTRE ${ }^{424}$, en cambio, entiende que se trata de una verdadera y propia renuncia preventiva u omissio adquirendi, en que el llamado a la herencia rechaza el llamamiento o sin más hacer suyo el derecho deferido.

En nuestra opinión, este supuesto es un acto equiparable a una repudiación de la herencia porque, dadas las circunstancias como se realiza, el resultado o los efectos que de él se derivan son exactamente los mismos que si se tratase de una verdadera y propia repudiación por lo siguiente:

a) el disponente hace dejación o abandono de aquello que le corresponde sin que haya un destinatario concreto por cuanto lo hace de forma abstracta, genérica o indeterminada a favor del conjunto de todos los demás sujetos llamados a la sucesión,

\footnotetext{
421 “La repudiación de la herencia”. Cit: Pág 753.

422 Op. cit: Pág 336.

${ }^{423}$ Derecho sucesorio “mortis causa”. Cit: Pág 293.

${ }^{424}$ Derecho de Sucesiones. T. III. Cit: Pág 471.
} 
b) lo hace de forma gratuita, sin recibir nada a cambio, y sin decir ni disponer nada acerca del destino de la cuota renunciada,

c) a ello hemos de añadir la circunstancia de que, los destinatarios van a resultar favorecidos, no como haya dispuesto el renunciante, sino con sujeción a las mismas reglas que, en su caso, hubiesen sido de aplicación como si efectivamente se hubiere producido la repudiación de la porción o cuota que se ha renunciado, de tal manera que ésta va a tener el mismo destino que hubiese establecido el testamento o la ley para el caso de repudiación.

En otro orden de argumentos, y acerca del ámbito de este número $3^{\circ}$ del artículo 1000, ALBALADEJO ${ }^{425}$ amplía la casuística del mismo al entender que igual efecto se produce si dicha renuncia se hace a favor de todos los que, no siendo coherederos, serían llamados en defecto del renunciante, como serían los sustitutos vulgares o los herederos abintestato del causante. En igual sentido, ROGEL VIDE ${ }^{426}$, también entiende que estamos ante un caso de repudiación cuando la renuncia se haga a favor de los sustitutos, si los hay, o de los herederos legítimos o abintestato, si no hay sustitutos ni coherederos con derecho de acrecer. También MANRESA ${ }^{427}$ admitió que no existía aceptación de la herencia, además de estos casos, cuando se realizase dicha renuncia a favor de quienes por virtud del acrecimiento debiera de corresponder la porción del que renunció. A lo que añade que, al producir los mismos efectos que una renuncia extintiva absoluta, ha de hacerse en la forma que ordena el artículo 1008 CC.

A los anteriores, añadimos por nuestra parte el supuesto de que igualmente estaríamos ante un caso de repudiación si se realizare la renuncia a favor de todos los demás coherederos y se diere la circunstancia de que se hubiere ordenado por parte del causante una cláusula de sustitución recíproca entre ellos, de tal manera que son ellos mismos los que se sustituyen entre sí en el caso de que se produjere alguna vacante en sus respectivas cuotas, porque se daría la coincidencia de que los destinatarios de la renuncia son los mismos sujetos sustitutos que asumirían la cuota repudiada.

No obstante, la propuesta de ALBALADEJO y de ROGEL, también la nuestra, sugiere algunos comentarios, cuando no matizaciones: 436.

${ }^{425}$ Anotaciones de Derecho español al Derecho de Sucesiones, Parte General, de CICU. Cit: Pág

\footnotetext{
${ }^{426}$ Op. cit.: Pág 337.

427 Op. cit.: Pág 401.
} 
a) partiendo de la premisa de que, cuando queda vacante alguna porción o cuota de la herencia y existe en la sucesión una cláusula de sustitución vulgar, son los sustitutos designados por el causante quienes tienen preferencia para ser llamados a la misma cuando se produce un hecho como el que tratamos, dicha cláusula tiene preferencia en su aplicación respecto de los cosucesores beneficiarios del acto, siempre y cuando, según ya hemos apuntado, se hubiese previsto por parte del causante como una de las hipótesis que dan lugar a su puesta en funcionamiento, el supuesto de repudiación.

En este caso, el acto de "renuncia" sí se podría realizar, pero serían beneficiarios de la porción o cuota "renunciada", no los demás cosucesores como pretendía el renunciante, sino los designados como sustitutos suyos por parte del causante. Y si pese a dicha cláusula, persistiere en su intención el renunciante, dicha "renuncia", tal y como él pretendía, no se podría llevar a cabo. De ahí que, la cláusula de sustitución constituya un obstáculo para el renunciante en su deseo de favorecer a los demás cosucesores ya que no puede, en modo alguno, ser infringida o incumplida por ser expresión de la voluntad del causante, que es ley en su sucesión, por lo que tendrá que ser observada, dada la casuística para la que se previó. Precisamente esa es su función, y más cuando lo ha establecido el propio de cuius. De ahí que la existencia de dicha cláusula constituye, sino un obstáculo o impedimento, sí un condicionamiento importante para poder realizar el acto de renuncia de que tratamos.

La consecuencia que de ello se deriva es que el acto no puede, en modo alguno, ser utilizado por el renunciante como un instrumento de fraude, o para frustrar, o dejar sin efecto dicha cláusula al haber sido establecida por el causante. De ahí que, para que no sea infringida, solo se puede realizar dicho acto si se da la circunstancia de que sus destinatarios son los mismos sujetos que han sido designados como sustitutos suyos, en cuyo caso, no se trastocaría la voluntad del causante porque los destinatarios, al fin y a la postre, son los mismos. De no ser así, se produciría un solapamiento o enervación de la cláusula de sustitución por el acto del sucesor porque la dejaría sin efecto y, en la sucesión, es ley la voluntad del causante.

No obstante, aunque se cumpla la previsión del causante, eso sí, por vía diferente a la ordenada o establecida por él, lo cierto es que, de alguna manera, entendemos que la cláusula de sustitución queda enervada, o solapada, por dicho acto en el sentido de que los beneficiarios de la renuncia acceden a la porción o cuota renunciada, no como consecuencia de la puesta en vigor de dicha cláusula, sino por la forma como se ha realizado, o se tiene que realizar, la renuncia para que se equipare 
a una repudiación y produzca los mismos efectos que ésta, repudiación que, de haberse producido, entonces sí que habría dado lugar a que, de forma efectiva, se pusiese en marcha dicha cláusula.

b) Al hilo de lo anterior, dado que los sujetos beneficiarios de este acto han de ser los mismos sujetos sustitutos para que la cláusula no quede enervada y se cumpla la voluntad del causante, entendemos que su entrada o asunción en la porción vacante se produce, en realidad, no como consecuencia de la vocación en virtud de la cual han sido llamados por parte del causante, esto es, como tales sustitutos, sino por el acto de renuncia realizado a su favor por parte de quien ellos iban a sustituir ya que la ejecución de dicho acto ha sido precisamente el detonante que ha motivado que ellos hagan suya la porción del sucesor.

En resumen y conlusión, para que pueda producirse el acto de renuncia a que se refiere este inciso segundo del número $3^{\circ}$ del artículo 1000 , no solo es preciso que se haga a favor de todos los demás cosucesores que hubieren sido llamados junto con el renunciante a la herencia, de forma gratuita e indeterminada, esto es, sin hacer entre ellos división, distribución o reparto de la porción o cuota renunciada, sino que, además, se dé la coincidencia de que estos sujetos serían los mismos que resultaren beneficiarios en el caso de repudiación de esa misma cuota y según aplicación del mecanismo o institución a que hubiere lugar a resultas de dicho repudio en virtud de las reglas que sean aplicables en la sucesión de que se trate (sustitución, derecho de acrecer o sucesión abintestato), para que se dé el mismo resultado que a través de éstas, ya que son instituciones que no pueden resultar infringidas, alteradas o trastocadas por la decisión de un sucesor.

Ello nos lleva a la siguiente reflexión que va un poco más allá del mero resultado y que es, no de fondo, sino de forma: al tener que haber coincidencia de sujetos entre los destinatarios de la "renuncia" y los que resulten de la sustitución, acrecimiento o sucesión abintestato que fuere de aplicación, según los casos, en el supuesto de repudiación, ello nos lleva a la conclusión de que, se produce idéntico resultado, da lo mismo, tanto si el sucesor realiza el acto de que trata el inciso segundo del número $3^{\circ}$ del artículo 1000, como si repudia. 


\section{Capítulo 4: CARACTERES Y LÍMITES DE LA REPUDIACIÓN.}

Consideraciones generales. 1.- Acto irrevocable. 2.- Acto indivisible. 2-1.- La indivisibilidad desde el punto de vista del sujeto. 2-2.- La indivisibilidad desde el punto de vista del objeto. 3.- Acto personal y apoderable. 3-1.- Su ejercicio a través de apoderado. 3-2.- Los acreedores y el ejercicio de la delación. 4.- Límites de la repudiación. 4-1.- Los pactos sucesorios. 4-2.- La renuncia a la legítima futura.

\section{CONSIDERACIONES GENERALES.}

La repudiación, según hemos analizado en el capítulo anterior, es un acto que entraña la celebración de un negocio jurídico que, respecto de la renuncia, tiene sus analogías y diferencias, lo que nos ha servido, para precisar su concepto, modelar su perfil y establecer algunos de sus caracteres, pero hay otros ${ }^{428}$ que hacen de ella una declaración de voluntad singular y le dan una identidad propia.

${ }^{428}$ Acerca de los mismos, véanse, entre otras muchas publicaciones, las siguientes:

ALBALADEJO: Anotaciones de Derecho español al Derecho de Sucesiones, Parte General, de CICU. Cit: Pág 427 y ss; “La repudiación de la herencia”. Cit: Pág 717 y ss; CANO MARTÍNEZ DE VELASCO: Op. cit: Pág 298; GALVÁN GALLEGOS: La herencia: contenido y adquisición. La aceptación y repudiación de la herencia. Cit: Pág 73 y ss; GITRAMA GONZÁLEZ: Op. cit.: Pág 45 y ss; MANRESA: Op. cit.: Pág 345 y ss; PUIG BRUTAU: Fundamentos de Derecho Civil. T. V. Vol 1º. Cit: Pág 209 y ss; ROGEL VIDE: Op. cit.: Pág 334; RIVAS MARTÍNEZ: Derecho de Sucesiones Común y Foral. Cit: Pág 623; ROCA SASTRE MUNCUNILL: Derecho de Sucesiones. T. III. Cit: Pág. 449; ROYO MARTÍNEZ: Derecho sucesorio “mortis causa”. Cit: Pág 293; SILLERO CROVETTO: Comentario a los artículos 988 a 1034 del Código Civil, en Jurisprudencia civil comentada (Tomo I). Dirección: Pasquau Liaño. Ed. COMARES. Granada. 2000. Pág 1677. 
En este sentido, la repudiación y la aceptación, al ser declaraciones de voluntad que emanan del ejercicio de un mismo derecho, el ius delationis, tienen unos mismos caracteres (art. 988 y ss), salvo alguna diferencia que separa a aquella, la repudiación, en cuanto a la forma, respecto de ésta, la aceptación.

Así, es una declaración de voluntad unilateral y no recepticia, expresa y solemne, de efectos retroactivos, de ejercicio libre y voluntario, puro, de disposición, irrevocable, indivisible, y que tiene carácter personal, si bien, es posible hacerlo por medio de apoderado:

\section{1.- Unilateral y no recepticia.}

O que procede de una sola persona, en el sentido, como dice ALBALADEJO ${ }^{429}$, de que, en el momento de su exteriorización, "no hay más parte que el repudiante". Es decir, a los efectos de su perfeccionamiento, basta la sola voluntad del delado para que la repudiación tenga por sí misma validez y eficacia jurídica ${ }^{430}$, de tal manera que, como ya hemos apuntado, no es necesario el concurso ni consentimiento de ninguna otra persona, ya fuere la de aquellos a quienes, en su caso, pudiere, si no afectar, sí perjudicar dicha declaración, de forma directa o indirecta, como pueden ser los sucesores de ulterior grado del repudiante, ya de aquellos que estuvieren interesados en la sucesión, como pueden ser los acreedores, ya sean de la herencia, ya del propio repudiante. No sucede lo mismo en la inmensa mayoría de los negocios jurídicos, como ocurre en los contratos, en los que sí es preciso tal concurso de voluntades (oferta y aceptación), entre las partes o sujetos que los celebran para su validez y perfeccionamiento (arts. 1258 y 1262 CC).

Así, es un acto no recepticio porque la declaración de repudio es válida y eficaz por sí sola desde el mismo momento en que se emite sin necesidad de que sea aceptada por nadie, ni aprobada por ninguna autoridad o funcionario, comunicada y/o notificada, o puesta en conocimiento de otro sujeto el hecho de su realización, como pudieran ser otras personas interesadas en la sucesión, tales como los albaceas, o a quienes de una forma directa o indirecta les pudiere afectar (sustitutos, cosucesores, sucesores abintestato, o herederos fideicomisarios).

429 "La repudiación de la herencia”. Cit: Pág 717.

${ }^{430}$ Ya en las Partidas (Ley 2, título 6º $6^{\circ}$ Partida 6 $6^{\mathrm{a}}$ ), se decía: "la aceptación de la herencia es un negocio jurídico unilateral y, por lo tanto, perfecto en virtud de la sola declaración de la voluntad del heredero, la cual no necesita encontrarse con otra voluntad". 
Este carácter se refuerza por el hecho de que, siendo varios los sujetos llamados a la sucesión, la declaración en ejercicio del ius delationis es individual y personal, de tal manera que cada uno de ellos emitirá la suya propia por sí y con independencia de los demás, y además, la de cada uno, sea en uno u otro sentido, no afecta ni vincula a la que hagan los demás (art. 1007 CC).

Desde el punto de vista legal, el Código Civil no dice nada acerca de la unilateralidad de la declaración que sí, en cambio, es proclamado expresamente por el artículo 343.1 del CDF de Aragón de 2011.

No obstante su carácter unilateral, el Tribunal Supremo, en la sentencia de 28 de marzo de 2003 (RJ 3038), llegó a afirmar que la emisión de esta declaración de voluntad, al tener la condición de negocio jurídico, da origen al nacimiento de una obligación para el sucesor. Así, manifiesta lo siguiente en su Fundamento de Derecho 40: "Dice la sentencia de esta Sala de 17 Oct. 1975 -RJ 3675-, que «los ordenamientos legislativos y la doctrina científica de nuestra Patria, admiten varios casos de obligaciones creadas por la voluntad unilateral, citándose por los autores, como ejemplo de ello, los arts. 1330 y 1887 del CC, los arts. 587 y 589 del CCom, las denuncias de los contratos y las obligaciones incorporadas a los títulos de crédito, a los que podemos añadir la aceptación y repudiación de herencia, que la doctrina califica como declaraciones de voluntad no recepticia, y cuya eficacia obligacional proclama nuestro Código en el art. 997, y ha sancionado la jurisprudencia en multitud de sentencias entre las cuales cabe citar las de 25 Abr. 1928, 6 Mar. 1944 -RJ 303-, 23 May. 1955 -RJ 1707- y 18 Sep. 1975»".

Ciertamente, llama la atención el hecho de que se diga que de esta declaración de voluntad nazca una obligación para el sucesor. Puede incluso parecer excesivo y que contradice o altera esa unilateralidad de la que estamos hablando, habida cuenta, como ya hemos comentado, de que no es preciso un concurso de voluntades para que nazca y se perfeccione. No obstante, igual sucede en aquellos casos de obligaciones creadas por la voluntad unilateral de una persona. En este sentido, para aclararnos esta afirmación y tratar de entender qué es lo que se quiere decir con ello, puede ayudarnos una sentencia anterior de 4 febrero de 1994 (RJ 909), citada por la de 2003, en la que, refiriéndose al artículo 997 del Código Civil, dice que: "el precepto civil dicho contempla otro aspecto general y común a la aceptación y repudiación de herencia, al representar efectivos y vinculantes negocios jurídicos como presupuesto de aplicación de la norma civil, para evitar las situaciones de temporalidad en los herederos y que no obstante su carácter no receptivo, han de asimilarse a los 
contratos y regirse por su normativa general". De ello se desprende, o se puede entender que, pese a su unilateralidad, la repudiación es una declaración que no puede abstraerse ni evitar la aplicación, en algunos de sus aspectos, de las normas que regulan las obligaciones y contratos, sobre todo en lo que se refiere a los efectos y consecuencias jurídicas de todo orden que de ella se derivan: pensemos en el caso de la repudiación en perjuicio de acreedores y los medios de defensa que estos tienen ante la misma (art. 1001 CC), o en lo relativo a las causas de su impugnación, como lo demuestra el artículo 997 del Código Civil al referirse a los supuestos de ineficacia cuando dicha declaración adoleciere de algunos de los vicios que anulan el consentimiento o apareciese un testamento desconocido.

En consecuencia, pese a su carácter unilateral, no puede abstraerse ni impedir que le sean de aplicación, en su caso, y en algunos de sus aspectos, las normas de las obligaciones y de los contratos.

No obstante lo anterior, ALBALADEJO ${ }^{431}$, por su parte, entiende que, si bien lo normal es que la repudiación se realice por medio de un acto unilateral del llamado, cabe también la posibilidad de que se haga por pacto que podría ser de dos maneras:

a) obligándose el repudiante con otro de los llamados a la sucesión a realizar (a cambio de algo o gratuitamente) aparte, el acto unilateral repudiatorio, o

b) celebrando un pacto, también a cambio de algo o gratuitamente, en el que se incluyese ya la repudiación.

Ahora bien, a ello añade que, "ambos casos caen bajo el ámbito del artículo 1000 del Código Civil", luego, tanto en uno como en otro, no se trataría propiamente de una verdadera repudiación y sí de un supuesto de aceptación tácita de la herencia. Solo la habría cuando el repudiante la realiza sin designar beneficiario o cuando lo hace desentendiéndose de su porción hereditaria y deja que sean las normas por las que se rija la sucesión, testamentarias o legales, las que establezcan su destino.

\section{2.- Es una declaración expresa y solemne.}

A diferencia de la aceptación, que se puede hacer de cualquier forma, incluso de manera tácita a través del comportamiento y actitud del sucesor (arts 999 y 1000 CC), es característica de la declaración de repudiación el hecho de que ha de ser siempre

431 “La repudiación de la herencia”. Cit: Pág 754. 
expresa $^{432}$, nunca se presume ${ }^{433}$, porque no se puede manifestar de forma tácita, deducida de actos del sucesor de los que se pueda inferir o entender la voluntad de repudiar ya que, si su voluntad es no querer la herencia a que ha sido llamado, entonces ha de decir, siempre, en cualquier caso, de forma expresa, que la repudia.

Este carácter expreso y solemne de la repudiación viene declarado en el artículo 1008 CC al disponer que, "la repudiación de la herencia deberá hacerse en instrumento público o auténtico, o por escrito presentado ante el Juez competente para conocer de la testamentaría o del abintestato" ${ }^{\prime 434}$, de tal manera que, la forma 0 solemnidad es manera de ser del negocio, "forma dat esse rei", un requisito esencial de la misma, y su infracción o inobservancia, da lugar a su nulidad ${ }^{435}$.

Circunstancias de muy diversa y variada índole justifican que la repudiación sea una declaración de voluntad que no se pueda emitir de cualquier forma. Así, la propia naturaleza del acto de que se trata, el significado y trascendencia que tiene por cuanto supone para quien la realiza la no adquisición de un derecho, la necesidad de tener una mayor certeza o seguridad en la situación creada por la repudiación (DíEZPICAZO, GULLÓN BALLESTEROS ${ }^{436}$ ), la repercusión que tiene para la propia herencia y los intereses que hay en juego de los demás sucesores que concurren a la sucesión o de las personas que tengan a su favor alguna expectativa de futuro sobre la misma (futuros sucesores del sucesor, sustitutos, coherederos con derecho de acrecer, herederos fideicomisarios), y de los acreedores, ya sean de la propia herencia como particulares del sucesor, así como por exigencias de la seguridad en el tráfico jurídico, hacen que la repudiación sea una declaración de voluntad que, no solo se ha de manifestar de forma expresa, sino que su exteriorización ha de revestir necesariamente una forma "solemne", lo que constituye otra de sus particularidades, al tiempo que es, a la vez, es un rasgo que la diferencia de la aceptación y un requisito esencial de la misma, sin el cual no puede existir.

${ }^{432}$ En relación a ello se debate la cuestión de, qué valor jurídico tiene el silencio del sucesor cuando no repudia ni acepta la herencia. Si no dice nada, ¿se puede entender que repudia?.

Acerca de ello, nos remitimos a lo ya expuesto en el punto número 5 del capítulo segundo, donde se examina el valor del silencio a propósito de si es o no obligatorio el ejercicio de la delación.

${ }^{433}$ Así de dice de forma expresa en el artículo 804 del Code francés: "La renonciation à une succession ne se présume pas".

${ }^{434}$ En este sentido: en Cataluña (art 461-6.1, Ley10/2008), y en Aragón (351 CDFA).

${ }^{435}$ En este sentido, nos remitimos al punto número 2 del capítulo sexto, donde se analiza la forma como requisito objetivo que se ha de observar al emitir la declaración de repudio y las diversas modalidades que puede revestir.

${ }^{436}$ Sistema de Derecho Civil. Vol. IV. Cit: Pág 542. 


\section{3.- De efectos retroactivos.}

De la retroactividad, que ha sido proclamada por la jurisprudencia ${ }^{437}$, se ocupa el artículo $989 \mathrm{CC}^{438}$, a cuyo tenor, tiene lugar desde "el momento de la muerte de la persona a quien se hereda" ${ }^{439}$, o mejor tendría que decir, "de aquella persona de cuya sucesión se trate", que sería más correcto, porque, en sentido estricto y desde un punto de vista técnico y jurídico, solo "se hereda" y se es heredero, si se acepta la herencia. Precepto que, por otro lado, está en concordancia con otros del Código Civil (arts. 440, 657 y 661), en los que se establece que es la muerte de la persona el momento en que se produce la transmisión mortis causa del patrimonio a sus sucesores.

A resultas de la retroactividad, se considera que el delado nunca ha sido llamado a la sucesión y la vocación realizada a su favor es como si nunca hubiere existido. En este sentido, así lo declaran de forma expresa Códigos como son el Codice italiano (art. $521^{440}$ ), o el Code francés (art. $805^{441}$ ). De ahí que haya de entenderse que el presunto sucesor, no ha llegado a ser, ni menos aun, se le ha considerado heredero, incluso aunque hubiese realizado en relación a dicha herencia actos posesorios, detentatorios, de conservación o de administración provisional que, por otro lado, no constituyen, o no pueden constituir, aceptación de la herencia (art. 999 párrafo $4^{\circ} \mathrm{CC}$ ).

${ }^{437}$ Así, entre otras: SSTS de 22 de diciembre de 1978 -RJ 4477-; 19 de diciembre de 1984 -RJ 6138-; 11 de noviembre de 1994 -RJ 8468-.

${ }^{438}$ Sigue los precedentes del Proyecto de 1851 (art. 821), el Proyecto de 1882, del que copia el texto de su artículo 999 con la única diferencia de que sustituye el término "la fecha" que emplea éste, por "al momento".

En términos idénticos, se manifiesta el artículo 343.1 del CDF de Aragón.

En Navarra, la Ley 315, párrafo $3^{\circ}$, del Fuero Nuevo de Navarra, solo alude a la repudiación porque, como ya comentamos en su momento, a propósito de la adquisición de la herencia en nuestro ordenamiento jurídico, la herencia, en Navarra, se entiende adquirida de manera provisional por el heredero desde el momento del fallecimiento del causante, pero con derecho a renunciarla, o a aceptarla, lo que es una confirmación de la adquisición, por lo que cuando se acepta no hay propiamente una retroacción sino una ratificación de dicha adquisición.

En Cataluña, la Ley10/2008, relativa a las sucesiones, solo proclama de forma expresa la retroactividad respecto de la aceptación (art. 411-5), pero, lógicamente, igual efecto tendrá la repudiación.

La retroactividad está también recogida en otros Códigos Civiles de nuestro entorno, como el francés (art. 776 en su redacción actual) o el italiano (art. 521), así como en la práctica totalidad de los Códigos Civiles latinoamericanos que reproducen, en parecidos términos, la fórmula del Código Civil español (Vid MANRESA: Op. cit.: Pág 350).

${ }^{439}$ La circunstancia de la muerte, viene determinada por la hora, fecha y lugar en que se ha producido el fallecimiento, que se acreditará a través de la certificación de la inscripción de defunción practicada en el Registro Civil (arts 81 LRC).

Tratándose de una declaración de fallecimiento, la sucesión se abrirá en la fecha que conste o se entienda sucedida la muerte legal de la persona (arts 195.2 y 196.1 CC).

${ }^{440}$ Según su tenor: "chi rinunzia all'eredità è considerato come se non vi fosse mai stato chiamato" -quien renuncia a la herencia es considerado como si nunca hubiese sido llamado-.

441 "L'héritier qui renonce est censé n'avoir jamais été héritier" -el heredero que renuncia se considera que nunca ha sido heredero-. 
Como consecuencia del repudio, se frustra la delación y se pone en marcha una nueva vocación y delación a favor de otra u otras personas, si bien, ello dependerá del diferente mecanismo o institución que sea de aplicación, en su caso, sustitución vulgar, el derecho de acrecer o, en último término, apertura de la sucesión intestada.

Por otro lado, este carácter retroactivo de la declaración del delado, es uno de los argumentos más importantes que se invocan, tanto por parte de la jurisprudencia, como por todos aquellos que defendemos la vigencia en nuestro ordenamiento jurídico del sistema sucesorio romano de adquisición de la herencia ${ }^{442}$.

\section{4.- De ejercicio libre y voluntario.}

Por definición, un presupuesto básico y fundamental sobre el que descansa la esencia y naturaleza de cualquier negocio jurídico lo constituye la libertad de decisión y la autonomía privada e individual que tiene la persona, circunstancias que han de presidir la gestación y posterior exteriorización de la declaración de voluntad que le da vida al ser el pilar central y básico sobre el que descansa o se fundamenta. Igual sucede a propósito de la repudiación.

En este sentido, voluntad y libertad, es un binomio de términos que, en muchas ocasiones, están íntimamente entrelazados entre sí en el ámbito de persona, así como en la celebración de los contratos y demás negocios jurídicos (cfr arts 1255 y 1258 CC), y que, aplicados, en este caso, a la sucesión mortis causa, como apunta GITRAMA $^{443}$, aparecen combinados en el artículo 988 CC cuando se trata del ejercicio del ius delationis. Este precepto, con precedente en el artículo 820 del Proyecto de 1851 y en texto casi idéntico al de éste -"la aceptación y repudiación de la herencia son actos libres y voluntarios"-, manifiesta que: "la aceptación y repudiación de la herencia son actos enteramente voluntarios y libres" 444 .

${ }^{442}$ Recordemos que, en el sistema germano, la declaración de repudio también tiene carácter retroactivo, pero con la peculiaridad o especialidad de que hace desaparecer la adquisición que, de forma provisional, se produjo a resultas del fallecimiento del causante (§ 1953.1 BGB), lo cual constituye una diferencia que la separa del romano, donde sólo se rechaza la vocación sucesoria, mas no una adquisición provisional de la herencia que no existe. Igual que en el sistema germano sucede, recordemos, en Navarra (Ley 315), donde "la herencia se entiende adquirida por el heredero desde el fallecimiento del causante".

No ocurre lo mismo respecto de la aceptación porque, al no ser necesaria para poder adquirir, caso de emitirse, no tiene carácter retroactivo porque lo que hace, en realidad, es ratificar la adquisición provisional que se produjo al fallecimiento del causante. De ahí que en este sistema no exista la situación ínterin o de provisionalidad, que existe en el sistema romano y que despararece cuando se manifiesta el delado.

443 Op. cit.: Pág 55.

444 En términos idénticos se manifiestan la Ley10/2008, de 10 de julio, sobre sucesiones (artículo 461-1), el Fuero Nuevo de Navarra (Ley 315), y el CDF de Aragón (342.1). 
Esta característica se puede entender, en nuestra opinión, en un doble sentido, o puede tener un doble significado:

a) nadie, ningún sucesor mortis causa, de la misma manera que no puede ser obligado a repudiar, ni a aceptar, la herencia a la que ha sido llamado, tampoco se le puede impedir o prohibir que lo haga ${ }^{445}$,

b) el hecho de que, la exteriorización de la declaración de voluntad, al igual que sucede en la celebración de cualquier otro acto, contrato o negocio jurídico ${ }^{446}$, se ha de emitir de forma totalmente libre, voluntaria y espontánea, de tal manera que sería susceptible de ser impugnada si adoleciese de algunos de los vicios que anulan el consentimiento (error, violencia, coacción, miedo, dolo -cfr arts. 997 y 1265 CC-) ${ }^{447}$.

Esta libertad viene después corroborada por el artículo 1007 CC para el caso de que hubiere varios sucesores en una misma sucesión, porque “....... podrán los unos aceptarla y los otros repudiarla"448. A lo que añade después, a continuación, para el caso de aceptación: "De igual libertad gozará cada uno de los herederos para aceptarla pura y simplemente o a beneficio de inventario". En este caso, las respectivas declaraciones de voluntad de cada uno de los sucesores, son, no ya solo libres, sino, además, autónomas e independientes entre sí, de tal manera que la declaración de voluntad de unos no condiciona ni limita las que hagan los demás en uno u otro sentido, lo que incide, por otro lado, según veremos más adelante, en la indivisibilidad de la declaración. Cada uno es libre de repudiar, o de aceptar, por sí solo y con independencia de lo que hagan los demás. Libertad que no se altera por el hecho de que trate de varios coherederos llamados a una misma porción o cuota de la herencia (PUIG BRUTAU ${ }^{449}$ ).

${ }^{445}$ No sucedió lo mismo en el derecho romano en el caso de los heres necessarii, a quienes se les obligaba a suceder porque, no es que no pudiesen repudiar, es que ni tan siquiera se contaba con el concurso de su voluntad para aceptar ya que adquirían, ipso iure, de forma automática, por ministerio de la ley. No se contemplaba la posibilidad de poder repudiar.

En este sentido, nos remitimos al punto número 2-1 del capítulo primero, donde se hace referencia al sistema romano de adquisición de la herencia, y al punto número 1-1 del capítulo tercero, donde se exponen las diferentes formas que se admitieron de repudiación de la herencia en el derecho romano.

${ }^{446}$ Así, en otros casos: cfr. art. 73-5 CC, que declara nulo el matrimonio contraído por coacción o miedo grave; arts 441 y 444, a propósito de la adquisición de la posesión; arts 673 y 674 CC, sobre nulidad del testamento otorgado con violencia; arts 1265 y 1301 y ss CC, relativo al consentimiento en los contratos.

${ }^{447}$ Véase, en este sentido, el capítulo décimo en el que se analizan más en detalle y en profundidad las diferentes causas o supuestos que pueden dar lugar por esta causa a la ineficacia de la repudiación, al que nos remitimos.

${ }^{448}$ Igual sucede en Cataluña: art 461-1.2, Ley10/2008, de 10 de julio.

${ }^{449}$ Fundamentos de Derecho Civil. V. 1º. Cit: Pág 233. 
La libertad de que goza todo sucesor permite, por otro lado, que ni tan siquiera sea preciso, desde un punto de vista material y formal, que, siendo varios los sucesores, emitan su declaración de voluntad de manera simultánea, al mismo tiempo, si bien, pueden ponerse de acuerdo para hacerlo al unísono, en un mismo acto o comparecencia que incluso puede ser el mismo documento, o también por separado, cada uno por su cuenta. Recordemos aquí el carácter no recepticio de la declaración porque no es requisito necesario para la validez y eficacia de la repudiación que ésta tenga que ser notificada o comunicada a nadie. Como también puede cada uno de ellos hacerlo en cualquiera de las formas prevenidas en el artículo 1008 CC.

No obstante, la libertad de poder repudiar no es absoluta porque quiebra en toda una serie de supuestos ${ }^{450}$ : unos, por razón del sujeto llamado, otros, a modo de sanción por la conducta del sucesor, en los que el ius delationis se reduce a solo la aceptación al imponerse ex lege la adquisición de la herencia, privando así al llamado de la posibilidad de repudiar la herencia. Sin embargo, ello no obsta para que, aun así, se considere a la declaración de voluntad del delado como un acto libre y voluntario porque se trata de casos en los que se dan unas circunstancias especiales que, de alguna manera, justifican la restricción de dicha libertad.

\section{5.- Puro.}

Así lo declara el artículo $990 \mathrm{CC}^{451}$ cuando dice que "...... no podrá hacerse ......, a plazo, ni condicionalmente"452, es decir, la declaración del sucesor se ha de emitir de forma incondicionada (MANRESA) ${ }^{453}$, no puede estar sometida a ninguno de los elementos accidentales del negocio jurídico (condición, término o modo).

La única excepción que admite la ley, pero tratándose de una aceptación, en que puede ponerse una condición, es en el caso de que se quisiere atender el pago de las deudas hereditarias solo con el importe de los bienes de la herencia o hasta donde éstos alcancen (arts. 998, 1010 y 1023 CC) (MANRESA) ${ }^{454}$.

${ }^{450}$ En este sentido, nos remitimos al punto número 2-6 del capítulo segundo, donde se exponen los supuestos en que se impone por ley la adquisición de la herencia, al punto número 3 del mismo capítulo, referido al examen del supuesto de que trata el artículo 1002 del Código Civil en que se priva al sucesor de la posibilidad de repudiar la herencia, y al capítulo sexto, puntos números 1-1-2-5, en el caso de la herencia deferida a favor de los pobres y, 1-1-2-6, en el caso de la herencia ordenada a favor de sufragios y obras piadosas.

${ }^{451}$ Con precedente en la Ley 15, título 6 $6^{\circ}$, Partida $6^{\text {a }}$ y en el artículo 822 del Proyecto de 1851.

${ }^{452}$ En igual sentido se manifiesta el artículo 461-2.1 de la Ley10/2008, de sucesiones de Cataluña; Ley 315, último párrafo, del Fuero Nuevo de Navarra, o el artículo 343.2 de la CDF de Aragón de 2011.

${ }^{453}$ Op. cit.: Pág 352.

${ }^{454}$ Op. cit.: Pág 352. 
No obstante, si pese a la dicción del artículo 990 CC, se diere la circunstancia de que el sucesor somete su declaración a condición o término, devendría en ineficaz por causa de nulidad total y absoluta de la misma ${ }^{455}$, sin posibilidad de convalidación 0 subsanación. Así lo entiende la doctrina ${ }^{456}$ por distintos motivos:

a) por el hecho de que quien emite así su declaración de voluntad lo hace no por capricho, sino para limitar o circunstanciar los efectos de su volición, ya que, de no ser así, lo habría hecho de forma pura,

b) por aplicación analógica del artículo 1116 CC, que declara nulas las obligaciones que dependan de una condición imposible, contraria a las buenas costumbres o prohibida por la ley, y

c) por aplicación directa y conjunta de los artículos $6,3^{\circ}$ y 990 CC, que prohíbe repudiar a plazo o condicionalmente.

Este carácter es también subrayado por el Tribunal Supremo ${ }^{457}$.

\section{6.- De disposición.}

La repudiación y la aceptación de la herencia han sido consideradas por parte de la doctrina como actos de disposición ${ }^{458}$, no solo por la naturaleza del acto, sino también por las consecuencias que de ellas se derivan. En este sentido, manifiesta GITRAMA ${ }^{459}$, que se tiene como acto de disposición: a la aceptación por aplicación de la tesis romanista (adquirir lo que todavía no era del adquirente), y la repudiación, en base a la tesis germanista (deshacerse de lo que ya era del repudiante).

${ }^{455}$ Véase en el capítulo décimo, el punto número 3-2-2, donde se analiza este supuesto al tratar de las causas de ineficacia de la repudiación.

${ }^{456}$ Así, entre otros:

LACRUZ BERDEJO: Derecho de sucesiones. Parte General. Cit: Pág 283; ALBALADEJO: Derecho civil. V. Derecho de sucesiones. Vol. 1. Cit: Pág 209; PUIG BRUTAU: Fundamentos de Derecho Civil. T V. Vol 1․․ Cit: Pág 229; O’CALlAGHAN: Compendio de Derecho Civil. T V. Sucesiones. EDERSA. Madrid. 1987. Pág 2355; GITRAMA: Op. cit.: Pág 84 y ss.

${ }^{457}$ Entre otras, como más recientes: SSTS de 28 de marzo de 2003 (RJ 3038); 11 de junio de 2004 (RJ 3830).

${ }^{458}$ Decía el profesor Clemente de Diego (Curso elemental de Derecho Civil español, común y foral. T III. Parte especial. Madrid. 1923. Pág 140), a propósito de las facultades dominicales que, "el derecho de disponer consiste en la afirmación clara, manifiesta y directa de esa superioridad del sujeto de la propiedad, en cuya virtud ésta es medio ofrecido a aquel para que haga de ella o en ella lo que quisiere, según Dios o según fuero". Definición que pude ser aquí aplicable al caso de la declaración dimanante del ejercicio del ius delationis. Citaba a continuación como formas particulares de su ejercicio, o facultades derivadas de este derecho, las de enajenar, gravar, limitar, transformar y destruir.

Y, según el diccionario de la Real Academia, disponer significa, "ejercitar en las cosas facultades de dominio, enajenarlas o gravarlas, en vez de atenerse a la posesión y disfrute”.

${ }^{459}$ Op. cit.: Pág 98. 
Desde el punto de vista legal, se desprende esa calificación del tenor del artículo 992 CC al exigir para su realización, en lo que se refiere a la capacidad del delado ${ }^{460}$, "tener la libre disposición de los bienes" ${ }^{461}$, lo que supone equiparar esta declaración de voluntad a actos de disposición como son la enajenación o el gravamen, y exigir para aquellos la misma capacidad que para éstos.

Así, la repudiación, desde el momento en que supone rechazar aquello a lo que el sucesor ha sido llamado, entraña, a nuestro juicio, una "omissio adquirendi" o una manifestación de renuncia, luego, una forma de disponer de los bienes hereditarios porque a resultas de la declaración se decide rechazarlos y se impide que entren en el patrimonio. Disposición que, en cierta medida, aunque sea en un sentido figurado, se asimila, a una enajenación. De ahí que, en consecuencia, después se exija la misma capacidad que para poder realizar ésta.

De igual manera, la aceptación también se asimilaría a un acto de disposición, si cabe, con mayor razón que la repudiación porque entraña adquisición, en consecuencia, querer unos bienes y ser heredero, y después, ya en cuanto a sus efectos, aunque con distinto alcance, adquirir distinta responsabilidad en lo que se refiere a las deudas de la herencia, según ésta haya sido aceptada.

De forma más específica, la repudiación se caracteriza por otras notas que, por su relevancia y por algunas particularidades que ofrecen, analizamos más en detalle a continuación.

\section{1.- ACTO IRREVOCABLE.}

Del carácter unilateral y no recepticio de la declaración de repudio se deriva otra característica, definitoria de la misma, incluso consustancial a su esencia y naturaleza, cual es su irrevocabilidad, recogida de forma expresa por el artículo $997 \mathrm{CC}^{462}$, y que se refuerza con el principio que rige en nuestro ordenamiento jurídico de que todo negocio jurídico es, en general, y como tesis de principio, definitivo e irrevocable, salvo los casos exceptuados por ley.

\footnotetext{
${ }^{460}$ Acerca de la misma, para el ejercicio del ius delationis, nos remitimos al capítulo sexto donde se analiza al tratar de los requisitos subjetivos de la repudiación.

461 No sucede lo mismo en el derecho francés donde la aceptación se equipara a un acto de administración desde el momento en que basta tener esta capacidad para poderla realizar, mientras que para la repudiación se exige tener la libre disposición.

${ }^{462}$ Igualmente así lo sancionan, en Cataluña, el artículo 461-1.3, de la Ley10/2008, de 10 de julio, relativa a las sucesiones, la Ley 315, último párrafo, del Fuero Nuevo de Navarra, o el artículo 343.1 de la CDF de Aragón de 2011.
} 
Significa que la declaración de voluntad emitida en ejercicio del ius delationis, una vez exteriorizada, es definitiva e inamovible, de tal manera que no se puede deshacer o invalidar después pretendiendo realizar una declaración de voluntad de signo contrario, salvo vicio del consentimiento u otra causa que la hiciere susceptible de ser impugnada ${ }^{463}$.

Esta característica ha sido proclamada por el Tribunal Supremo, a través de su jurisprudencia, de manera inveterada, rotunda, clara y expresa, como hizo a través de la sentencia de 15 de noviembre de 1985 (RJ 5611), al decir que, "la aceptación de la herencia, al igual que ocurre con la repudiación, una vez realizada es irrevocable", con precedente en otras ${ }^{464}$, y ratificada en fallos posteriores ${ }^{465}$.

La irrevocabilidad se justifica en el hecho, o principio, de que, la ley no consiente que de modo temporal se asuma la cualidad de heredero, y ello en base al axioma o máxima del Derecho romano, "semel heres, semper heres", ya recogido en textos de nuestra legislación histórica (Ley 18, en relación con la 11, título 6º Partida 6ª) ${ }^{466}$.

Por su parte, CANO MARTÍNEZ DE VELASCO ${ }^{467}$, refiriéndose con carácter general a la irrevocabilidad de los derechos, apunta que, por razón de su no receptividad, solo es revocable aquella declaración de voluntad que va dirigida a otro, al que se efectúa la revocación, lo que también se puede predicar respecto de la declaración de repudiación de la herencia.

Sin embargo, cuando hablamos de la irrevocabilidad es preciso acotar el sentido y significado de esta característica porque, además, del ya descrito, tiene otro diferente que, en nuestra opinión, es de gran relevancia y trascendencia.

463 Véase en el capítulo 10, el punto n $n^{\text {4 }}$-1 relativo a la ineficacia de la repudiación por causa de anulabilidad por vicios del consentimiento.

464 SSTS de 23 de mayo de 1955 (RJ 1707); 16 de junio de 1961 (RJ 2367); 12 de mayo de 1981 (RJ 2048).

465 SSTS de 27 de noviembre de 1992 (RJ 9597); 4 de febrero de 1994 (RJ 909); 28 de marzo de 2003 (RJ 3038): “la norma de irrevocabilidad de la aceptación y de la repudiación de la herencia es una norma imperativa cuya aplicación no puede ser eludida por la parte una vez emitida la declaración de voluntad en que consiste, ni puede ser dejada sin efecto por actos o declaraciones de voluntad en contrario, cualquiera que sea la proximidad en el tiempo entre estos actos o declaraciones de voluntad y la repudiación de la herencia, y que el artículo 997 no establece distinción alguna a este respecto; de acuerdo con el texto legal, la eficacia de la repudiación de la herencia solo se ve alterada por la impugnación fundada en la existencia de algún vicio del consentimiento o en la aparición de un testamento desconocido ......” (FJ 4 ${ }^{\circ}$ ); 11 de junio de 2004 (RJ 3830).

466 Así, entre otras: SSTS de 23 de mayo de 1955 (RJ 1707); 4 de febrero de 1994 (RJ 909); 28 de marzo de 2003 (RJ 3038).

${ }^{467}$ Op. cit.: Pág 300. 
En concreto nos referimos al hecho de que, la declaración de repudio, si se ha emitido o exteriorizado conforme a derecho, cumpliendo con todos los presupuestos y requisitos de validez y eficacia exigidos por la ley ${ }^{468}$, goza de plena eficacia jurídica y está revestida de una presunción de veracidad iuris et de iure ${ }^{469}$, que es cuando se puede hablar propiamente de la irrevocabilidad de la declaración. Esta exigencia, entendemos que es presupuesto esencial y básico, no solo para que exista verdadera y propia repudiación, y surta los efectos que le son propios, sino para que se pueda decir que la repudiación es irrevocable. De ello se va a derivar, además, que es, inatacable o inimpugnable, de tal manera que no se puede pretender instar la declaración de su invalidez, ni tan siquiera por el propio sujeto que la emitió porque no se puede retractar de su decisión, como tampoco dejarla sin efecto ya que sería, por otro lado, ir contra sus propios actos.

Ahora bien, en el supuesto de que se hubiere exteriorizado incumpliendo, o cumpliendo de forma parcial o incompleta, algunos de esos presupuestos o requisitos exigidos por la ley para su validez y eficacia, no es que sea revocable, es que es jurídicamente ineficaz, más bien, susceptible de ser impugnada o invalidada, en diferente grado y con distinto alcance, según la clase o causa de vicio, defecto o irregularidad de que adoleciere, de lo que se van a derivar diferentes consecuencias jurídicas según el hecho o circunstancia que lo hubiere motivado ${ }^{470}$. De ahí que haya que distinguir dos términos, irrevocabilidad e ineficacia, porque, si bien, en principio, parecen no tener relación, en nuestra opinión, sí tienen que ver el uno con el otro pero que, además, no se pueden confundir, en el sentido siguiente: la irrevocabilidad, sólo se puede predicar, como antes hemos apuntado, respecto de la declaración que sea

468 Acerca de los mismos, nos remitimos al capítulo sexto, donde se hace un análisis de ellos.

469 En este sentido, pero analizada esta cuestión desde otro punto de vista, una vez que se ha emitido la declaración, ocurre que ha precluido el momento para el ejercicio del ius delationis y éste no se podrá volver a ejercer otra vez, lógicamente, en sentido contrario, para pretender ahora aceptar la herencia, o simplemente deshacer la repudiación ya realizada, dejándola sin efecto.

El ius delationis solo se podrá ejercitar una vez en uno de los dos sentidos, opciones o facultades en que consiste, de aceptación o repudio, y, una vez ejercitado en uno u otro, se extingue y agota. Ha desaparecido. Dicho con otras palabras, la repudiación y la aceptación son, no ya solo declaraciones antitéticas u opuestas entre sí, una respecto de la otra, por razón de su significado, sino que se excluyen mutuamente [Vid STS de 27 de noviembre de 1992 (RJ 9597), comentada por ALBALADEJO en CCJC. $\mathrm{N}^{\circ}$ 31. Enero-marzo 1993. Pág 73 y ss.], en el sentido de que, si ya se ha manifestado una de ellas, se extingue de forma automática la posibilidad de poder realizar la otra.

El ius delationis comprende o entraña esta doble facultad y se extingue por el ejercicio exclusivo y excluyente de una de las dos: o se acepta, o se repudia. Si se acepta, ya no se puede repudiar y, al revés, si se repudia, ya no se podrá aceptar. Como tampoco se podrá aceptar y/o repudiar de forma simultánea (art. 990 CC) (GALVÁN GALLEGOS: “El destino de la herencia repudiada”. RDP. Octubre. 1995. Pág 900. Cita a pie de página $n^{\circ} 4.9$ ). Exteriorizar o manifestar una de ellas supone automáticamente excluir o cerrar la posibilidad de poder manifestar la otra, aunque solo sea para invalidarla o dejarla sin efecto.

${ }^{470}$ En este sentido, nos remitimos al capítulo décimo donde será objeto de examen la ineficacia de la repudiación y sus causas. 
plena y jurídicamente perfecta, válida y eficaz, en cuyo caso, no se podrá impugnar o invalidar porque se ha exteriorizado conforme a derecho, mientras que, en caso contrario, si adolece de algún vicio, defecto o irregularidad, o existe ausencia de alguno de los presupuestos esenciales para su válida emisión conforme a derecho, no se puede decir que sea revocable, que sería una incorrección desde un punto de vista técnico y jurídico, sino ineficaz, pudiendo incluso ocurrir que llegue a ser nula de pleno derecho dependiendo de la circunstancia que hubiese motivado la ineficacia.

Por tanto, la irrevocabilidad sólo se puede predicar para el caso de repudiación perfecta y, en el supuesto de que adoleciere de algún vicio o defecto que la haga ineficaz con arreglo a la ley, o ausencia de algún presupuesto esencial, aparte de que sería imperfecta, no se puede decir que sea revocable y sí, en cambio, ineficaz o susceptible de ser impugnada con diferente alcance y consecuencias, según el vicio o defecto de que adoleciere, ya sea como un supuesto de anulabilidad (art. 997 CC), ya de nulidad radical total y absoluta o de pleno derecho (art. $6.3 \mathrm{CC}$ ), ya que difícilmente se puede revocar algo que incluso se puede llegar a decir que no existe.

En este sentido, el artículo 997 del Código Civil, después de declarar la irrevocabilidad en su inciso primero, a continuación, en el segundo, permite la impugnación de la declaración del delado, "cuando adoleciese de alguno de los vicios que anulan el consentimiento o apareciese un testamento desconocido". Aunque de su estudio y análisis nos vamos a ocupar más adelante en detalle, en el capítulo décimo al examinar la ineficacia de la declaración, aquí, entendemos que conviene aclarar y precisar, por lo que acabamos de exponer, que, a nuestro juicio, en el caso de que se dieren algunas de las circunstancias que en él se mencionan, no se trata de supuestos que constituyan una excepción a la irrevocabilidad, sino de casos que hacen que dicha declaración sea susceptible de ser invalidada con arreglo a la ley. Por tanto, no son casos de revocación de la declaración y sí de impugnación de la misma. Dicho en otros términos, si se dieren algunas de las circunstancias del artículo 997 CC, no se puede decir, en modo alguno, que, en estos casos, la declaración del delado sea revocable y sí, en cambio, susceptible de ser impugnada con arreglo a derecho. Igual cabe decir, con más motivo, en el caso de que se hubiere infringido algún precepto legal de carácter imperativo o prohibitivo (art $6.3 \mathrm{CC}$ ), porque mal se puede revocar aquello que es nulo habida cuenta de que la ley lo tiene por no realizado o celebrado.

En otro orden de argumentos, el ius delationis no se puede entender, incluso no tiene sentido, sin esta característica porque, de no ser así, si fuese una declaración que se pudiese revocar y cambiar de sentido tantas cuantas veces lo desease o le 
interesase a los sucesores, el proceso sucesorio, la herencia, los derechos y la posición jurídica de todas aquellas personas que, directa o indirectamente, estuvieren afectadas o involucradas en la misma, incluso la propia voluntad del causante, así como el destino mortis causa de sus bienes, estarían expuestos de forma permanente a una peligrosa situación de inseguridad jurídica y de incertidumbre porque quedarían en manos de la voluntad y libre albedrío o el deseo caprichoso y arbitrario del delado, quien, dependiendo de las circunstancias que rijan en la sucesión y de sus intereses, podría cambiar de opinión o de voluntad a su antojo y conveniencia.

No obstante esta característica, hay dos supuestos respecto de los cuales se nos plantea el interrogante de si constituyen una excepción a dicha irrevocabilidad, o una anomalía que existe en relación a la misma, y que son:

a) los casos del artículo 1009 CC, en los que se contempla la hipótesis de que una persona sea llamada a una herencia a través de varios títulos sucesorios o varias delaciones porque, en ellos, cabe la posibilidad de que, después de haber repudiado la herencia en virtud de una delación, surja otra posterior en la misma sucesión, a través de otro título sucesorio diferente, por medio de la cual, el ya repudiante, tiene la oportunidad de volver a manifestarse sobre la misma herencia pero con la posibilidad, esta vez, si es su deseo, de poderlo hacer en sentido contrario al anterior ${ }^{471}, y$

b) la declaración de "aceptación" de la herencia a que alude el artículo 1001 del Código Civil, que, en su caso, hicieren los acreedores del repudiante, para evitar así que resulten perjudicados como consecuencia de la repudiación de la herencia por parte de su deudor y que les permite proceder a la ejecución de aquellos bienes que a éste le hubiesen correspondido caso de haber aceptado. En este sentido, surge la cuestión de si, a resultas de la misma, queda revocada, la declaración de repudio que motivó el nacimiento de dicha acción. Sin embargo, una respuesta adecuada a esta y otras cuestiones nos exige analizar la naturaleza y efectos de dicha acción que haremos más adelante ${ }^{472}$.

Finalmente, dada la posibilidad que existe, según veremos más adelante, de que el ius delationis se pueda ejercer, no personalmente por parte del delado, sino a través de apoderado a quien se haya otorgado poder especial y bastante para el caso, nos

471 Quede solo aquí planteado porque de su examen nos vamos a ocupar más en detalle en el próximo capítulo, en el que se analiza la repudiación por parte del delado en el caso de que tuviere a su favor una pluralidad de delaciones.

472 Véase en este sentido, en el capítulo noveno, el punto número 3, dedicado todo él al examen del artículo 1001 y la problemática que plantea. 
surge el interrogante de, en qué momento se produce la irrevocabilidad de la declaración $^{473}$ : si, una vez otorgado el poder sin necesidad de que el apoderado haya hecho uso de la facultad que le ha sido conferida, o si después de haberla ejercitado.

$\mathrm{Y}$, ya en el ámbito del derecho comparado, recordemos que, en el derecho francés, existe la especialidad, en comparación con el nuestro, de que la declaración de repudiación es revocable porque, el sucesor, en lo que no haya prescrito el derecho a aceptar (el plazo es de diez años -art. 780 Code-), y los herederos del grado siguiente no hayan aun aceptado la herencia, puede retractarse de su declaración y volver a aceptar (artículo $807^{474}$, con precedente en el 790 en su redacción anterior). Con lo cual, se trataría de una declaración cuya eficacia definitiva está supeditada a esta circunstancia y, por ello, sí sería revocable aunque de forma condicional.

\section{2.- ACTO INDIVISIBLE.}

Manifiesta el artículo 990 CC, cuyos antecedentes y orígenes se remontan a Las XII Tablas del Derecho Romano ${ }^{475}$, después recogidos en textos legales de nuestro

${ }^{473}$ El dilema surge porque se da la circunstancia, o el hecho, de que existen dos momentos, que incluso difieren entre sí por un período más o menos largo en el tiempo, el uno respecto al otro, en los que hay sendas actuaciones en relación a la repudiación de la herencia: un primer momento, aquel en el que el delado otorga a favor de quien va a ser su apoderado el correspondiente poder concediéndole dicho mandato, con lo cual, ya en este instante el sucesor se pronuncia y adopta una decisión en un determinado sentido, de repudio, acerca del ejercicio del ius delationis y así lo hace constar en el referido poder. Y, un segundo momento, aquel en que el apoderado, haciendo uso de la facultad que le ha sido concedida y en cumplimiento del mandato recibido, manifiesta y exterioriza la voluntad de su representado de repudiar la herencia, que es realmente el instante en que podemos decir tiene lugar la repudiación porque es el momento en que se emite y hace efectiva.

474 “Tant que la prescription du droit d'accepter n'est pas acquise contre lui, l'héritier peut révoquer sa renonciation en acceptant la succession purement et simplement, si elle n'a pas été déjà acceptée par un autre héritier ou si l'Etat n'a pas déjà été envoyé en possession. Cette acceptation rétroagit au jour de l'ouverture de la succession, sans toutefois remettre en cause les droits qui peuvent être acquis à des tiers sur les biens de la succession par prescription ou par actes valablement faits avec le curateur à la succession vacante”. -Hasta que no prescriba el derecho de aceptar contra el que no ha adquirido, el heredero puede revocar su renuncia aceptando la sucesión pura y simplemente, si aún no ha sido aceptada por otro heredero o si el Estado no ha tomado ya posesión. Esta aceptación se retrotrae al día de la apertura de la sucesión, sin embargo cuestiona los derechos que pueden ser adquiridos por un tercero sobre los bienes de la sucesión por prescripción o por actos válidamente hechos con el curador de la sucesión vacante-.

${ }^{475}$ En él, no sólo no fue posible la repudiación parcial cuando el llamamiento fuere a la totalidad de la herencia, sino también cuando se llamara al mismo sucesor a varias partes de la misma, porque no se le permitía que repudiara unas y aceptara otras. La aceptación de alguna de las partes a que fue llamado, se hacía extensivo a todas las demás (“Hereditas pro parte adiri nequit” -DIGESTO 29, 2, 1-2 y 10-: la herencia no se puede adir parcialmente).

Así, rigió la regla de que la herencia debía de ser aceptada tal como era deferida, no podía aceptarse "por parte", tanto si hubiese sido llamado a toda la herencia como a una porción solamente: "quid totam hereditatem adquirere pocest, is pro parte eam sciendo adire non potest. Sed et si quis ex pluribus partibus in eiusdem heereditate institutus sit, non potest quasdam parte repudiare, quas agnoscere". DIGESTO, “de adquirir, vel omitt, hered”, fragmentos 1-2 (XXIX, II). Citado por MANRESA (Op. cit.: Pág 353). 
derecho histórico ${ }^{476}$, que, "la aceptación o la repudiación de la herencia no podrá hacerse en parte .....", norma también sancionda en otros textos legales ${ }^{477}$ y en códigos civiles europeos ${ }^{478}$.

Tal expresión, "no podrá hacerse en parte", que sanciona el carácter indivisible que tiene la declaración que emana del ejercicio del ius delationis, en principio, parece simple: la herencia no se puede repudiar, o aceptar, por parte del sucesor en solo una parte de la misma, es decir, de forma parcial o fragmentaria, sino que se tiene que referir a la totalidad de aquello a lo que ha sido llamado, de tal manera que no puede dividir su declaración, repudiar, o aceptar, solo una parte de los bienes que le han sido deferidos y, en consecuencia, paralelamente, aceptar, o repudiar, el resto.

Pero, esta norma es, a nuestro juicio, manifiestamente insuficiente porque, dado su tenor literal, plantea numerosas dudas y da lugar a distintas interpretaciones, sobre todo cuando el llamamiento a la herencia es plural, supuesto, por otro lado, muy frecuente, bien desde el punto de vista de los sujetos, cuando son varios los llamados, bien en cuanto al objeto, aquello a lo que se es llamado, ya cuando hay un solo título sucesorio de vocación a favor del sucesor que comprenda varias porciones o cuotas de la herencia, ya una pluralidad de títulos a favor de una misma persona que pueden recaer, a su vez, bien sobre distintas porciones o cuotas de la herencia -"ex pluribus portionibus"-, bien sobre una misma porción o cuota, o sobre la herencia en su totalidad, supuestos en los que la indivisibilidad ha suscitado una mayor problemática.

Ahora bien, aunque el término indivisibilidad haya permanecido invariable en cuanto a su enunciado a lo largo de todas las épocas, como pone de relieve GALVÁN GALLEGOS $^{479}$, no tiene el mismo significado ni la misma función hoy, en el derecho actual, al que tuvo o cumplió en tiempos pasados. Y ello, porque el fundamento que justificaba en el Derecho Romano y en Las Partidas la no parcialidad de la repudiación, no es aplicable al régimen del Código Civil que elaboró un sistema sucesorio basado en principios distintos a los que imperaban en aquel al evolucionar el concepto de heredero hacia una menor radicalidad de las consecuencias que suponía

${ }^{476}$ Criterio que recogería la legislación de Partidas: "Seyendo algunt home rescebido por heredero en parte cierta, maguer él non sepa quanta es, bien puede entrar en la herencia, solamiente que la entre con entencion de la haber quanto quier que sea" (Partida VI, Título VI, Ley XV), y después el artículo 822 del Proyecto de 1851, aunque sólo referido a la repudiación.

477 Así en: Cataluña (art 461-2.1, Ley10/2008, sobre sucesiones; Aragón (art. 345.1 CDFA).

478 Así: art. 769 del Code francés; § 1950 del BGB alemán; arts 475 y 520 del Codice civile italiano de 1942.

479 “La indivisibilidad de la aceptación y repudiación de la herencia”. ADC. Tomo L. Fascículo IV. 1997. Pág 1818 y ss. 
ser llamado a la universalidad de la herencia y convertirse en continuador de las relaciones jurídicas del causante ${ }^{480}$.

Así, a diferencia de lo que sucedió en el Derecho Romano, en el que la indivisibilidad se justificó y fundamentó en el carácter universal del llamamiento y en la designación y función que desempeñó el heres respecto de la herencia, hoy, en la actualidad, dicho carácter o condición ha cambiado totalmente ya que, en los territorios de derecho común, aquellos en que rige el Código Civil, ha sido derogado (cfr. arts $658,764,912.2^{\circ}, 986 \mathrm{CC}$ ), aunque aun quedan algunos vestigios de ello en el propio Código, como sucede en el caso de que sea una sola persona la instituida heredera sin determinación de cosa ni de cuota, en cuyo caso, se entiende llamada al todo, o cuando se instituye indistintamente a varias personas, sin perjuicio de la recíproca comprensión que entre ellas suponga tal concursus $\left(\mathrm{VALLET}^{481}\right.$ ), como también hay ordenamientos actuales, como es el derecho sucesorio catalán o balear, en que la institución de heredero tiene un carácter universal.

Acerca de ello, apunta VALLET ${ }^{482}$ que, no hay que confundir la "universalidad del título de heredero", a la que alude el Código Civil en sus artículos 660 ("llámase heredero el que sucede a título universal ...."), y 661 ("los herederos suceden al difunto .... en todos sus derechos y obligaciones"), con la "universalidad del heredero escrito o testamentario", porque, de no haber dispuesto el causante totalmente de la herencia a través de su testamento, dicho heredero testamentario sucederá conjuntamente con los que lo sean abintestato. Ser heredero, es ser sucesor universal, lo que significa, en principio, adquirir un patrimonio concebido como una universalidad o universitas ius. Es decir, se adquiere un todo ideal sin atender a su contenido ni a los elementos que lo componen, por lo que no puede ser dividido si no es en partes alícuotas. Concepción universal que responde a una idea de seguridad jurídica con la finalidad de conseguir el objetivo y finalidad del proceso sucesorio mortis causa, pero que se rompe en el caso de que, ante la insuficiencia de la delación testamentaria, sea preciso abrir la intestada, lo que no afecta a la "universalidad del título de heredero" del que participan, tanto el heredero instituido en el testamento, como el abintestato. Por otro lado, la palabra heredero en el derecho positivo actual no es sacramental en la institución, ni positiva (art. $768 \mathrm{CC}$ ), ni negativamente (art. $660 \mathrm{CC}$ ), como tampoco lo es la expresión de la cosa o cuota asignada. De ahí que habrá que estar a la voluntad

\footnotetext{
${ }^{480}$ Véase en este sentido, en el capítulo primero, el punto número 2-1, donde se analiza dicho sistema sucesorio y la importancia y función que tuvo el heres en la sucesión, al que nos remitimos.

${ }^{481}$ Panorama de derecho de sucesiones I. Cit: Pág 97 y ss.

482 Panorama de derecho de sucesiones I. Cit: Pág 103.
} 
o intención del testador y considerar la regla del artículo 768 como interpretativa de la misma y complementaria de la consignada en el párrafo $2^{\circ}$ del artículo $668 \mathrm{CC}$, lo que lleva a VALLET ${ }^{483}$ a rechazar la universalidad de la institución de heredero como fundamento de la indivisibilidad de la aceptación y la repudiación de la herencia y buscar otro, "al aceptar el Código Civil la institución sólo en parte de la herencia y la concurrencia, en ese caso, con los herederos intestados con el llamado testamentariamente en parte". De ahí que se incline a "la presuposición legal de que es la voluntad del testador lo que puede justificar tanto la indivisibilidad de la aceptación o la repudiación, como la posibilidad de repudiar la herencia y aceptar el legado o la mejora, o viceversa, de rechazar éstos y aceptar aquella".

A nuestro juicio, la idea de la universalidad de la institución de heredero no deja de ser un argumento que sería válido y admisible como fundamento de la indivisibilidad de la declaración del delado en el caso de heredero único porque, al ser él el único receptor y destinatario de los bienes del causante, es el supuesto en que ciertamente se puede decir que se produciría una continuidad en esa universalidad dado el paso que se produce del patrimonio de las manos del causante a las del heredero. En este caso, se reunirían, a la vez, la universalidad de la institución de heredero y la universalidad del patrimonio porque, en relación a éste, tan solo habría un cambio de titular, mas no en su composición, que permanecería inalterable, y seguiría siendo uno y el mismo. Mientras que, siendo varios los herederos, esa unidad que caracteriza al patrimonio en vida de su titular, el causante, de manera inevitable, al tiempo que de forma lógica y necesaria, se rompe o desaparece desde el momento en que, los bienes que lo integran se van a repartir entre los sucesores aunque sea en partes alícuotas, según la voluntad del testador o las normas legales, formando, a su vez, nuevos y distintos patrimonios. Igual ocurre en el caso de que la institución de heredero no agote la totalidad de los bienes que integran el patrimonio del causante y estos se tengan que deferir por vía intestada, en cuyo caso, unos irían a parar a manos de los herederos testamentarios, y otros, a manos de los herederos abintestato.

Frente a la anterior posición, no falta la clásica de otros, como MANRESA ${ }^{484}$, que sostienen que el fundamento de la indivisibilidad de la declaración del delado está en "la continuación de la personalidad jurídica del difunto que, aunque corresponda a varios, es siempre única e indivisible", y ello porque "el testador o la ley, al conferir la

\footnotetext{
483 Panorama de derecho de sucesiones I. Cit: Págs 110 y 111.

484 Op. cit.: Pág 354.
} 
cualidad de heredero, designan un sucesor en todos los derechos y obligaciones del causante, escogen un representante de su personalidad. Si se acepta la representación se admite toda, no una parte de la misma; si se renuncia, no se admite nada, no se quiere representar". En su opinión, lo esencial es la sucesión en la persona, mientras que la sucesión en los bienes es lo secundario, por lo que no hay que hablar de cuotas o partes separadas de bienes. A lo que añade, "nuestro Código, al hablar de la herencia y no de cada cuota, y al no establecer excepción alguna, parece aceptar ese fundamento y en la doctrina que de él se desprende". En igual sentido se manifiestan ROCA SASTRE ${ }^{485}$, O' CALLAGHAN ${ }^{486}$ o GITRAMA ${ }^{487}$.

Desde una perspectiva distinta, GARCÍA GOYENA, refiriéndose a la repudiación, fundamentó la indivisibilidad en que ello significaba "un desaire o afrenta al testador", lo que daba lugar a que perdiese otros posibles llamamientos hereditarios del mismo causante, como eran los legados (art. 839 Proyecto de 1851), o la mejora hecha en testamento (art. 665 Proyecto de 1851). En este sentido, la repudiación se entiende como un acto de menosprecio, de ingratitud, de falta de aprecio o de respeto a la voluntad y memoria del causante, porque se rechaza aquello a lo que éste nos asignó en vida, pero no es más que un argumento de carácter ético o moral que es suficiente para fundamentar desde un punto de vista técnico y jurídico la indivisibilidad. Lo que no obsta para que, aun así, se pueda seguir considerando, como tal, un acto de agravio o de ingratitud para con el causante aunque desde el punto de vista jurídico sea lícito, o al menos no es ilícito, desde el momento en que no está sancionado.

Ciertamente, hoy día, la idea de la continuidad sucesoria de la personalidad del difunto, de ser su representante, como fundamento de la indivisibilidad, es difícil de admitir porque la finalidad de la sucesión mortis causa no es la continuación del de cuius más allá de su muerte por parte de, o a través de, sus herederos, como tampoco la de su personalidad que se extinguió a su fallecimiento (art. 32 CC) sino, la transmisión del patrimonio de que era titular en el momento de su defunción. La sucesión mortis causa, hoy se concibe como un medio o instrumento, no de sucesión

${ }^{485}$ Anotaciones al Derecho de Sucesiones de Kipp. Tomo V. Vol 2º . Cit: Pág 52.

${ }^{486}$ Comentario del Código Civil. Cit: Pág 2354.

${ }^{487}$ Para él (Op. cit.: Pág 74), la asunción del todo o de la nada por parte del sucesor, es una consecuencia de dos principios que considera básicos en derecho de sucesiones:

a) la idea de la continuidad sucesoria de la personalidad del difunto por el heredero. El objeto del llamamiento a heredar es indivisible, e indivisible debe ser la aceptación lo mismo que la repudiación. La herencia es una unidad patrimonial en la sucesión a título universal.

b) La teoría clásica del patrimonio que considera a éste como una universalidad de Derecho. El heredero adquiere la universitas iuris como unidad objetiva y consolida, o rechaza, su adquisición mediante un único acto. 
en la persona, sino de sucesión en los bienes y derechos que integraban el patrimonio de una persona en el momento de su fallecimiento (cfr arts 657, 659, 660, 661 CC).

Así, en el derecho actual, en nuestra opinión, la indivisibilidad se justifica o se fundamenta, tal y como apuntan, entre otros, VALLET ${ }^{488}$ o GALVAN GALLEGOS $^{489}$, en la voluntad del testador, que es de donde toma toda su razón de ser, porque, no solo es el causante el que decide quien va a ser llamado a su herencia, sin perjuicio de los herederos forzosos (art. 807 y ss CC) sino, a qué y cómo se va a producir ese llamamiento, en qué porción, cuota o fracción, así como su contenido, de tal manera que, en el caso de que fueren varios los sujetos llamados, cada uno con su propio ius delationis, a cada uno de ellos le podrá atribuir o asignar, si es su voluntad, una porción o cuota diferente en la medida y manera que tenga por conveniente (art. 763 $\mathrm{CC}$ ). Así, cuando la vocación sucesoria proviene de la voluntad del testador, las posibilidades son múltiples. De ahí que, la existencia de una pluralidad de títulos sucesorios, o de uno solo, a favor del mismo sucesor, a una pluralidad de cuotas, no sólo es posible porque el testador puede actuar con total y absoluta libertad para establecer, si es su deseo, llamamientos diferentes o independientes a porciones o cuotas distintas, sino que puede incluso alterarlo, tanto en el sentido de manifestar que las cuotas son separables, aunque de por sí no lo sean, como declararlas no separables pese a que de por sí lo fueren. En este caso, cuando en la sucesión haya varios títulos sucesorios a favor del mismo sucesor que recaen sobre diferentes porciones o cuotas de la herencia, se puede entender, o presumir, que la voluntad del causante ha sido la de establecer distintas vocaciones o llamamientos separados, distintos e independientes entre sí, por lo que el sucesor es libre, en principio, de aceptar unos y repudiar otros. Mientras que, si el llamamiento es único a varias porciones o cuotas, se puede entender, en principio, que ha sido su voluntad hacer una única vocación ${ }^{490}$, por lo que el delado solo podrá emitir una única declaración comprensiva de todas las cuotas que le hubiesen sido deferidas.

En este sentido, no ocurre lo mismo en el derecho sucesorio catalán o balear, donde la condición de sucesor tiene carácter universal respecto de la sucesión, lo que condiciona o modifica el carácter de indivisibilidad de la declaración del sucesor y su designación agrupa o absorbe todas las delaciones como si fueren una sola. No obstante, cierto es que, el hecho de que se cumpla, o no, después la voluntad del causante, va a depender también del factor o de la voluntad del sucesor porque, sin

\footnotetext{
${ }^{488}$ Panorama de derecho de sucesiones I. Cit: Pág 111.

489 “La indivisibilidad de la aceptación y repudiación de la herencia”. Cit. Pág 1821.

490 No obstante, véase en este sentido, en el capítulo quinto, el punto número 2.
} 
perjuicio de que su decisión de heredar, es libre y voluntaria y se puede manifestar en uno u otro sentido, de aceptar o repudiar (arts. 988 y 1007 CC), dicha decisión, en todo caso, ha de coincidir con lo que el testador, o la ley, le han ofrecido. Por ello, lo que no puede hacer el sucesor, en modo alguno, es desvirtuar o dejar sin efecto la voluntad del causante manifestada en el testamento al ser éste el instrumento por el que éste "dispone para después de la muerte" de los bienes (art. $667 \mathrm{CC}$ ), de lo que se deriva su naturaleza imperativa, o de ser norma con rango de ley, en el destino mortis causa de los mismos, o la distribución que resulte de las normas legales, de tal manera que ha de respetar lo querido por el testador o dispuesto por la ley.

De ahí que, para poder entender el carácter indivisible de la repudiación, es preciso tener en cuenta circunstancias de vital importancia en la sucesión, como son: el título o fundamento de vocación en virtud de la cual se es llamado a la herencia (heredero, legatario, sustituto, derecho de acrecer, sucesor fideicomisario, legitimario, mejorado, transmisario, etc, a lo que se añade la posibilidad, frecuente, por otro lado, de la combinación de algunos de ellos entre sí), la posible existencia de una pluralidad tanto de títulos como de cuotas, la extensión y contenido del llamamiento, etc. Todo ello da lugar a que la indivisibilidad en el ejercicio del ius delationis dé lugar no solo muy diversas hipótesis o supuestos, como veremos a continuación, sino a que planteé una extraordinaria complejidad que, entendemos, es preciso abordar para su mejor comprensión desde dos puntos de vista, como luego haremos: del sujeto del título sucesorio y del objeto de la vocación.

En otro orden de argumentos, la indivisibilidad es una norma o regla que, como apunta GITRAMA ${ }^{491}$, es de carácter imperativo, o de derecho necesario, frente a la que no cabe voluntad en contrario, tanto respecto del causante, en el sentido de que éste no puede dispensar de ello al sucesor o pactar con éste la divisibilidad de la declaración del ius delationis en su ejercicio, como respecto del propio sucesor, ya que éste no puede modificar ni disgregar o separar el contenido u objeto de la vocación, mas sí podrá renunciar a su ejercicio ${ }^{492}$.

Por otro lado, desde otro punto de vista, admitir la divisibilidad en la declaración del sucesor, sería tanto como ir en contra del espíritu de la sucesión mortis causa basada en la voluntad del testador, si es ésta por la que se defiere la sucesión, al ser

491 Op. cit.: Pág 82.

492 De la posibilidad de renunciar el sucesor el “ius delationis”, ver en el capítulo segundo el punto número 4, donde se plantea la cuestión de si se puede o no rechazar la delación. 
su testamento el título preferente para determinar la delación hereditaria ${ }^{493}$. $\mathrm{Y}$, en otro orden de argumentos, supone dejar en manos del sucesor el destino mortis causa de los bienes porque quedaría a su libre capricho y albedrío aceptar unos y repudiar otros, lo que, por otro lado, traería consigo alterar, modificar o ir en contra de la voluntad del causante, lo que, en cierta medida desnaturalizaría y truncaría el proceso sucesorio en lo que se refiere al destino de los bienes establecido a través del testamento, o por la ley, en el caso de sucesión abintestato.

\section{2-1.- La indivisibilidad desde el punto de vista del sujeto.}

La indivisibilidad de la repudiación, tradicional y clásicamente, se ha venido refiriendo, o planteando, en relación al objeto de la vocación, esto es, a aquello a lo que es llamado el sucesor.

Sin embargo, entendemos que también tiene su perspectiva desde el punto de vista subjetivo, porque, a nuestro juicio, es preciso hacer alguna puntualización ya que, a diferencia de lo que sucede si hay un único heredero en la sucesión, en el que no se plantean, en principio, dudas en la aplicación del precepto, no ocurre lo mismo cuando son varios los sucesores llamados en los siguientes términos.

La indivisibilidad no impide que cada sucesor pueda decidir libre y voluntariamente lo que estime conveniente, aceptar o repudiar, respecto de la delación que le fue deferida sin que le afecte o condicione la decisión de los demás, en cuyo caso, la indivisibilidad se predicaría sólo respecto de la declaración individual de cada uno de ellos en el ejercicio de su ius delationis y referido a su propio llamamiento.

En este sentido, recordemos el carácter individual de la declaración, por lo que, siendo varios los sucesores llamados, y al ser un acto totalmente libre y voluntario (art. 988 CC), de igual libertad goza cada uno de ellos para aceptar y/o repudiar de forma individual, con independencia y por separado respecto de los demás (así resulta de lo dispuesto en el artículo 1007 CC). Ello significa que las respectivas declaraciones de voluntad de cada uno de los sucesores llamados a la sucesión son, no ya solo libres, sino totalmente autónomas e independientes entre sí, de tal manera que la declaración de cada uno de ellos no limita, ni condiciona o determina la que hagan, en su caso, los demás en uno u otro sentido. Cada uno de los sucesores, en relación a su propia delación, es libre de decidir lo que quiera, de repudiar o de aceptar, por sí solo y con independencia de lo que manifiesten los demás.

493 GALVAN GALLEGOS: “La indivisibilidad de la aceptación y repudiación de la herencia”. Cit: Pág 1822. 


\section{2-2.- La indivisibilidad desde el punto de vista del objeto.}

Atendiendo al objeto de la vocación, la indivisibilidad de la declaración se ha de entender, a priori, como ya hemos apuntado, en el sentido de que, el sucesor no puede fraccionar o dividir la porción o cuota de herencia a que ha sido llamado, sino que ha de recaer, o se tiene que referir, a la totalidad de aquello que le ha sido deferido mortis causa por virtud de la vocación ${ }^{494}$. Así, o se acepta todo, o se repudia todo. Lo que no puede hacer el sucesor es repudiar una parte de los bienes, porción o cuota que le han sido deferidos y el aceptar resto, o al revés. Es decir, su declaración ha de ser total y completa. De ahí que no puede disgregar, dividir o separar el contenido de la porción o cuota a que ha sido llamado por el testador, o por la ley, en virtud de la vocación sucesoria y a través de esa delación, aceptando una parte y repudiando la otra ${ }^{495}$.

${ }^{494}$ Cabe incluso plantearse si el concepto de indivisibilidad es aquí igual al que se predica en el caso de las obligaciones de esta naturaleza.

Si en éstas se entiende como tal, aquella obligación que es susceptible de ser cumplida por partes en el momento de su ejecución sin que se altere su esencia o naturaleza, en cierta medida, late aquí la misma idea en el caso de la declaración que ha de emitir el delado en el ejercicio del ius delationis porque la esencia de esta característica radica o consiste en que dicha declaración ha de respetar la voluntad del causante, o de la ley, relativo al destino mortis causa de los bienes, en el sentido de que no puede, en modo alguno, alterar el contenido de los lotes, porciones, cuotas o distribución que se hubiere hecho de los mismos en el testamento o resulte de la aplicación de las normas legales. El delado tendrá que emitir su declaración ateniéndose a aquel o a éstas. De ahí que la divisibilidad o indivisibilidad de la declaración dependa, no ya tanto de la naturaleza de los bienes, como sucede en algunos supuestos en el caso de las obligaciones, sino de la voluntad del testador o de la ley.

${ }^{495}$ La regla del artículo 990 CC hay que referirla al caso de los llamamientos hechos a título universal porque, en los realizados a título particular, sí se admite la posibilidad, en algunos supuestos, de que se pueda producir una divisibilidad, o una repudiación parcial, del legado.

No obstante, se trata de casos en los que se da la especialidad o peculiaridad de que, aunque en ellos existe un único título sucesorio del que se derivaría una sola delación y una sola declaración, dado el contenido del objeto del llamamiento, la ley admite un fraccionamiento, o división, en la declaración del delado.

Así, ello se puede producir:

a) cuando se trata de un legatario beneficiario de un solo legado (art. 889 CC): en este caso, la especialidad se produce cuando el legado ordenado en testamento contiene una parte a título oneroso y otra a título gratuito.

De ello se deriva la consecuencia de que podrá libremente aceptar una parte del legado y repudiar la otra si las dos son iguales (onerosas o gratuitas), mientras que si solo una de ellas es onerosa, no podrá repudiar ésta y aceptar la otra, la gratuita. Pero lo que sí podrá, entendemos, interpretando a sensu contrario el artículo, aunque será muy extraño que así lo haga, es que acepte la parte onerosa y repudie la parte gratuita.

Después, sigue el artículo 889 CC diciendo que, "si muriese antes de aceptar el legado dejando varios herederos, podrá uno de éstos aceptar y otro repudiar la parte que le corresponda en el legado". Ello es consecuencia de la libertad que existe entre cosucesores a que se refiere el artículo 1007 CC. Sin embargo, si el legatario fallece antes de aceptar el legado dejando un único sucesor, se aplicará la regla anterior: podrá éste aceptar una parte del legado y repudiar la otra si las dos son iguales, onerosas o gratuitas.

b) Cuando se trata de un legatario que sea beneficiario de varios legados (art. 890, $1^{\circ}$ CC): aquí, la especialidad se produce cuando los legados son distintos: unos onerosos y otros gratuitos, en cuyo caso: "el legatario de dos legados, de los que uno fuere oneroso, no podrá renunciar éste y aceptar el otro". 
No obstante lo anterior, puede decirse que el significado que encierra la expresión del artículo 990 CC, “.... no podrá hacerse en parte ....”, constituye, ya desde antiguo, un verdadero enigma porque, al no decir nada más el texto legal ni ser complementado por ningún otro precepto, es manifiestamente insuficiente ante la amplísima variedad de hipótesis o supuestos que se pueden producir si tenemos en cuenta, por un lado, la gran variedad de títulos sucesorios a través de los cuales se puede producir la vocación o llamamiento a la herencia, y subsiguiente delación, su origen, cómo se han producido ${ }^{496} \mathrm{y}$, por otro, la posibilidad de que ese llamamiento puede ser no a una, sino a varias porciones o cuotas de la herencia, referidos todos ellos al caso de que el destinatario del título/s sea el mismo sucesor, lo que puede suceder tanto si fuere él solo en la herencia como si son varios los sucesores.

Ya entrando en el examen de la problemática que plantea la indivisibilidad desde el punto de vista del objeto, cuando el llamamiento comprende varias porciones o cuotas de la herencia, o una sola, incluso la totalidad de la misma, a través, no de uno, sino de varios títulos sucesorios, sucede que, dada la amplia y variada pluralidad que pudiere existir, tanto de títulos como de cuotas o porciones, como consecuencia de la combinación de unos y otros, se pueden producir varios supuestos o hipótesis ${ }^{497}$ :

A) que haya un único título sucesorio que comprenda varias porciones o cuotas de la herencia, o

B) que haya una pluralidad de títulos o llamamientos que puede tener por objeto:

Ahora bien, "si los dos son onerosos o gratuitos, es libre para aceptarlos todos o repudiar el que quiera". Aquí, se aplica idéntica solución que en el caso anterior: podrá aceptar un legado y repudiar el otro si son de la misma o idéntica naturaleza: onerosos o gratuitos, mientras que si son distintos, no podrá repudiar el oneroso y aceptar el gratuito. Sí, lo contrario, aunque, como ya hemos comentado, resultará, en nuestra opinión, extraño.

Y, distintos de los anteriores, son aquellos supuestos en que: el llamamiento a título particular a que hubiere sido llamado el sucesor, concurre con el título universal, de heredero, dando lugar al “prelegado" (art. 890 párrafo $2^{\circ} \mathrm{CC}$ ); aquel en que el sucesor, al tiempo que es heredero del causante lo es también mejorado de él (art. 833 CC); o aquel en que, siendo legitimario del causante, recibe de éste, además, por vía de legado, la mejora. Pero, de estos supuestos ya trataremos en el capítulo siguiente dado que en ellos se produce la especialidad, o peculiaridad, de que al concurrir varios títulos sucesorios sobre el mismo sucesor, surge la cuestión de si es o no divisible su declaración en el sentido de si ha de emitir una sola que sea comprensiva de los distintos títulos sucesorios que se le hubieren deferido, o si puede hacer declaraciones distintas, separadas, de tal manera que pueda incluso aceptar un título y repudiar el otro.

${ }^{496}$ Acerca de la vocación y delación sucesorias, sus diferentes clases o modalidades y los efectos o consecuencias que se derivan de las mismas según cómo se hayan originado o establecido, véase en el capítulo segundo, el punto número 1, al que nos remitimos.

497 Vid GALVAN GALLEGOS: "La indivisibilidad de la aceptación y repudiación de la herencia”. Cit. Pág 1824 y ss. 
a) una misma porción o cuota de la herencia, o ésta en su totalidad, lo que puede suceder en diferentes casos:

a') cuando el sucesor es llamado por testamento y abintestato, de forma sucesiva, por la ley ${ }^{498}$,

b') porque sea llamado por vía intestada más de una vez,

c') porque quien repudie lo haga en la condición de transmisario, si bien, aquí, se pueden producir, a su vez, dos hipótesis ${ }^{499}$ :

a") que después de repudiar sea llamado de nuevo a la herencia objeto de transmisión pero ahora como sucesor abintestato de la misma, o

b") que después del repudio vuelva a ser llamado de nuevo a la herencia, esta vez, como sustituto a resultas de su propia repudiación.

En comentario común a los dos anteriores casos que se producen al amparo de esta hipótesis, en todos ellos, los distintos títulos sucesorios surgen, no de forma simultánea, sino sucesiva.

b) Distintas porciones o cuotas de la herencia, iguales o desiguales entre sí, "ex pluribus portionibus", lo que puede obedecer a:

a') que el llamamiento se haya producido, a la vez, de forma simultánea, a través del título testado e intestado,

b') que el testador haya instituido al sucesor en varias cuotas distintas entre sí a través de títulos diversos (a título de heredero, a título de legatario, sustituto, legitimario, mejorado, fideicomisario), títulos que pueden ser: coetáneos o simultáneos entre sí porque se produzcan dos o más al mismo tiempo, al haber nacido en el mismo instante (prelegatario -art. 890.2 CC-, heredero y mejorado -art. 833 CC-, legitimario y mejorado, etc), que hayan nacido de forma sucesiva (heredero y sustituto, legatario y sustituto, etc), o que haya nacido uno después de haberse extinguido el anterior.

c') en el caso de que se dé el derecho de acrecer entre cosucesores.

498 LACRUZ, cita en este supuesto el caso de que se llame por testamento a la herencia al hijo único, el cual a su vez es legitimario y heredero abintestato (Derecho de sucesiones. Parte General. Cit: Pág 177).

499 De su estudio más en detalle, dadas las particulares circunstancias en que tiene lugar la sucesión por virtud del ius transmisssionis, nos vamos a ocupar en el último punto del siguiente capítulo, al que nos remitimos. 
Por su parte, ALBALADEJO, en este sentido, señala aquí varios supuestos en los que se pueden producir las hipótesis que venimos planteando, al tiempo que da respuesta al interrogante de cuando el sucesor puede aceptar o repudiar ante las distintas delaciones que ha recibido ${ }^{500}$.

En todos los supuestos anteriores, el interés o el atractivo que puedan ofrecer se suscita, no ya tanto por la complejidad y diversidad de las situaciones que en sí mismo encierran, sino en la cuestión de si el sucesor puede o ha de emitir una sola declaración de voluntad que sea comprensiva de todas las cuotas que le han sido deferidas a través del único título sucesorio por el que ha sido llamado a la sucesión (caso de la letra $A$ ), o si, en los casos de la letra $B$ ), cada uno de los títulos sucesorios puede llevar consigo su propia declaración individual de repudio, o aceptación, -una declaración para cada una de las delaciones-, de tal manera que, en este supuesto, cada una de las declaraciones sería autónoma, distinta e independiente respecto de las demás o si, por el contrario, ha de emitir una sola declaración que sea única o comprensiva de todos los títulos que se hubieren ordenado a su favor, de tal manera que una sola declaración comprenda o se refiera a todos los títulos a la vez, como si fueran uno solo y, por tanto, en aplicación del artículo 990 CC, sería indivisible respecto de todos ellos (si aceptare, se entendería que acepta todas las porciones que le hubiesen sido deferidas, y si repudiare, que las repudia todas). En este caso, se puede hablar de una divisibilidad de la declaración del sucesor en el sentido de que podrá hacer tantas cuantas declaraciones o llamamientos se hubieren hecho a su favor, de lo que se deriva la consecuencia de que podrá repudiar unas porciones o cuotas y aceptar otras, lo cual no obsta para que cada una de las declaraciones, en sí misma considerada, siga siendo indivisible en lo que se refiere al objeto del título en virtud del cual se haga por aplicación de lo dispuesto en el artículo 990 CC.

Planteado en otros términos, se debate la cuestión de si se puede o no aceptar la herencia a través de una segunda delación después de que haya habido una previa repudiación por parte del delado. Es decir, ante el hecho de que el sucesor tenga ante

500 "La repudiación de la herencia”. Cit: Pág 719:

a) que el sucesor que haya sido instituido como tal en más de una porción o cuota de herencia, ya sean iguales o desiguales entre sí, en cuyo caso, podrá renunciar a unas y aceptar otras, y viceversa,

b) que el sucesor sea beneficiario de varias porciones que hayan sido designadas cada una de ellas de forma separada, en que podrá renunciar unas y aceptar otras,

c) que el sucesor sea al mismo tiempo sustituto vulgar de otro heredero, en cuyo caso, podrá aceptar el título hereditario que le ha sido deferido a él personalmente y repudiar el de sustituto, o al revés,

d) que el sucesor sea al mismo tiempo heredero y legatario, en que podrá renunciar la herencia y aceptar el legado, o renunciar éste y aceptar aquélla (art. 890 CC), sin embargo, aquí, respecto del legado, no hay propiamente delación, sino adquisición, con la facultad de renunciarlo. 
sí, de forma simultánea o sucesiva, dos o más títulos sucesorios en virtud de los cuales, y a través de cada uno de ellos, tenga la opción de aceptar o de repudiar la herencia, se plantea la cuestión de si la declaración de voluntad de repudiación que, en su caso, haga respecto de uno de los títulos sucesorios que le han sido deferidos, en aquel que primero se le ofrezca o tenga derecho a ejercitar, afecta o repercute en el otro, o en los sucesivos, de tal manera que le impida o condicione su declaración de voluntad en éstos, o si, por el contrario, son independientes entre sí.

Sin embargo, vamos a dejar aquí tan solo planteadas estas hipótesis porque, dada su complejidad y la amplitud de su contenido, entendemos justificado, a la vez que necesario, que le dediquemos un estudio y análisis de las mismas de forma especial y expresa en el próximo capítulo, referido todo él al ejercicio de la repudiación cuando se da el supuesto de que exista una pluralidad de títulos sucesorios o de cuotas, o ambos a la vez, a favor del mismo sucesor. Además, a ello se añade la circunstancia de que, en algunos de estos casos, es aplicable la norma contenida en el artículo 1009 del Código Civil porque en él se recogen algunos de los supuestos que pueden dar origen a dicha pluralidad, como es el caso del sucesor que sea llamado a la sucesión a través de dos títulos distintos, por vía testada e intestada, aunque, como veremos, es insuficiente porque es muy incompleto e impreciso, ya que, aparte de no resolver de forma satisfactoria las hipótesis que en él se regulan, hay más casos en que se puede producir tal dualidad y que no se recogen en él.

No obstante, hoy en el derecho actual, tanto la primera hipótesis, que un heredero sea llamado a varias porciones o cuotas de la misma herencia a través de un solo título sucesorio, como la segunda, que ese llamamiento a varias porciones o a toda la herencia, se haga por medio de una pluralidad de llamamientos deferidos a favor del mismo sucesor, no es posible que se produzca en aquellos sistemas $u$ ordenamientos jurídicos en que rige un principio de universalidad de la institución de heredero, como sucede en Cataluña y Baleares, porque en ellos, el carácter universal que tiene el título de heredero en la sucesión no lo permite ya que los unificaría, dando lugar, en principio, a la indivisibilidad de la repudiación, o de la aceptación, de la herencia ${ }^{501}$.

${ }^{501}$ VALLET: Panorama de derecho de sucesiones I. Cit: Pág 113. 


\section{3.- ACTO PERSONAL y APODERABLE.}

Desde otro punto de vista, el ius delationis se caracteriza porque en su ejercicio es personalísimo, en el sentido de que, el hecho material de la exteriorización de la declaración de voluntad a través de la cual se manifiesta, sólo, única y exclusivamente le compete al sucesor, de tal manera que sólo él la puede realizar por ser quien ha sido llamado a la sucesión y como destinatario o beneficiario de la disposición mortis causa ordenada a su favor por el testador o por la ley. Carácter personal que se acentúa aún más por el hecho de que es un acto cuyo ejercicio depende de su libre y espontánea voluntad (art. $988 \mathrm{CC}$ ), libertad que justifica que sea sólo él quien esté facultado para decidir acerca de la oferta hereditaria que ha recibido. Además, dado que de esta decisión depende la adquisición de la condición de heredero, lo lógico es que sea el mismo sujeto a quien va dirigida tal oferta quien lo manifieste. De ahí que sea sólo el sucesor quien tenga la facultad exclusiva de dicho ejercicio.

Ello es consecuencia también del carácter in tuitu personae que tiene la vocación en el sucesor, que se hace en contemplación y en consideración a él, sobre todo cuando proviene de la voluntad del causante. Por tanto, se trata de un derecho que es inherente a él, quien es el único que está legitimado directa y activamente para su ejercicio, si bien, ello no obsta para que, pueda, en su caso, hacerlo a través de otra persona $^{502}$, por medio de representante o apoderado.

Sin embargo, este carácter personalísimo tiene en nuestro ordenamiento jurídico la excepción, que no por ello lo desvirtúa, de dos supuestos en los que dicho ejercicio no se lleva a cabo por parte del propio beneficiario de la disposición sino por un tercero, una persona que es, además, ajena al proceso sucesorio. En concreto son:

a) el caso de la herencia deferida a los pobres, en el que dicho ejercicio se hará “... por la persona que haya designado el testador, en su defecto por los albaceas, $y$, si no los hubiere, por el Párroco, el Alcalde y el Juez municipal (hoy Juez de Paz)" (artículos 749 y 992 párrafo $2^{\circ} \mathrm{CC}$ ) ${ }^{503} \mathrm{y}$,

b) la herencia en que el testador ordene alguna disposición para sufragios y obras piadosas en beneficio de su alma (artículo $747 \mathrm{CC})^{504}$, que se hará por parte del albacea designado por el causante en el testamento.

\footnotetext{
${ }^{502}$ Vid, entre otros, GITRAMA: Op. cit.: Pág 59 y ss.

503 En Cataluña, vid, art 428-3.2, de la Ley10/2008, y en Aragón, art. 473 CDFA de 2011.

${ }^{504}$ En Cataluña, vid, art 428-3.1, de la Ley10/2008, y en Aragón, art. 473 CDFA de 2011.
} 
Estos casos no dejan de ser algo singular y que podríamos calificar o denominar como, ejercicio del ius delationis por tercero, ya que es una persona ajena a la sucesión mortis causa y, además, no beneficiario de la atribución patrimonial, quien lo ejerce con la peculiaridad de que no lo hace para él, en provecho o beneficio propio, sino para otro ${ }^{505}$. Se trata de dos supuestos que, en nuestra opinión, constituyen, como decimos, una excepción al carácter in tuitu personae que tiene el ius delationis en su ejercicio por parte del sucesor.

\section{3-1.- Su ejercicio a través de apoderado.}

El ejercicio del ius delationis por medio de representante está admitido por el Código Civil en los casos de representación legal ${ }^{506}$, y no lo prohíbe o impide en los de representación voluntaria, lo que posibilita que se pueda llevar a cabo, en su caso, por medio de apoderado.

En este caso, para que sea plenamente válido y eficaz y surta todos los efectos que le son propios, es preciso que el apoderado actue por medio de un poder que ha de ser especial, bastante y expreso (art. 1713 párrafo $2^{\circ} \mathrm{CC}$ ) ${ }^{507}$, individualizado y específico para la sucesión concreta de que se trate, no siendo válido el concedido con carácter general para repudiar, o aceptar, herencias. En este sentido, recordemos que, tanto del Tribunal Supremo ${ }^{508}$, como, sobre todo, de la Dirección General de los Registros y del Notariado ${ }^{509}$, tienen establecido que los poderes se han de interpretar de forma restrictiva.

${ }^{505}$ A propósito de estos dos supuestos, al margen de la especialidad que ofrecen, se plantea en ellos la problemática de si es posible o no poder repudiar la herencia, cuestión ésta que ya analizaremos más adelante, en el capítulo sexto, puntos números 1-1-2-5, relativo a la herencia deferida a los pobres, y 1-1-2-6, sobre la herencia deferida a favor de sufragios y obras piadosas, al tratar de los requisitos subjetivos que se exigen para poder repudiar la herencia.

${ }^{506}$ En el supuesto de los menores de edad (art. 166 CC); o del incapaz (art. 271,4 ${ }^{\circ} \mathrm{CC}$, en el caso de tutela); de la herencia deferida a favor de personas jurídicas (art. 993 CC); o del ausente (art. 185 CC).

507 Así, la Audiencia Provincial de Málaga, en su sentencia no 1053/2004 (Sección 5a), de 27 septiembre (JUR 2004\292455), entendió que al tratarse la repudiación de un acto de disposición, no basta el poder otorgado en términos generales.

${ }^{508}$ Así, entre otras: Sentencia de 6 de marzo de 1943 (RJ 306).

${ }^{509}$ Resoluciones, entre otras, de 20 de marzo 1899; 23 de febrero de 1929; 23 de enero de 1943 (RJ 117), 15 de diciembre de 1953; 18 de noviembre de 1960 (RJ 3384); 5 de diciembre de 1961; 6 de noviembre de 1962 (RJ 4309); 29 de septiembre de 1965 (RJ 3984); 29 de septiembre de 1983 (RJ 7024); 24 de octubre de 1986 (RJ 6069); 18 de octubre de 1989 (RJ 7049); 1 de junio de 1999 (RJ 4191): “la interpretación de los poderes debe hacerse restrictivamente por los peligros que pueda representar para el apoderado, cuya voluntad ha de ser clara al respecto, y no permitiendo que se amplíe el poder a casos distintos de los comprendidos en su texto, singularmente cuando se trate de actos que tiendan a disminuir el patrimonio del poderdante", además de que, "en la cuestión del ámbito de las facultades representativas conferidas al apoderado debe regir el criterio de interpretación estricta, de manera que no puede en principio extenderse el mandato a casos distintos de los comprendidos en su texto". 
Por otro lado, el mero hecho de otorgar el poder por parte del sucesor no implica o significa que ya, desde ese mismo instante, se haya ejercido el ius delationis sin tener que esperar a que el apoderado haga uso del mismo, de tal manera que, si se hubiere otorgado con la facultad de repudiar, ello ya implique su voluntad de no ser heredero, o si fuere de aceptación, de serlo, lo que permite que el sucesor pueda cambiar su decisión hasta el momento en que el apoderado haga uso de la facultad que le ha sido conferida.

En este sentido, el otorgamiento del poder solo revela un propósito, una intención, un deseo, pero no la decisión firme e irrevocable de repudiar, o aceptar, porque requiere como complemento que el apoderado, siguiendo las instrucciones del sucesor, exteriorice, en su nombre, dicha declaración de voluntad ${ }^{510}$, que será el instante en que realmente se ejerza el ius delationis. Dado que hasta este momento no existe frente a terceros, sólo de forma ínterin o provisional, es lo que permite que el poder pueda ser revocado y dejado sin efecto por el sucesor ${ }^{511}$, o conferido a otra persona, o incluso puede que el delado cambie de opinión, de tal manera que si, en un principio, lo concedió para repudiar, después lo modifique para ahora aceptar, o al revés. De ello, se derivan, por otro lado, dos consecuencias:

$1^{\mathrm{a}}$.- solo desde el momento en que el representante ha ejercido la facultad que le ha sido otorgada, la decisión del delado es efectivamente irrevocable y ya no podrá, él, de forma unilateral, dejarla sin efecto, lo que no impide ni obsta para que pueda instar, en su caso, si hubiere lugar a ello, su declaración de ineficacia. La irrevocabilidad de la declaración sólo es posible desde el momento en que se ha exteriorizado por parte del apoderado, que es el instante en que realmente se ejerce. Nunca antes.

$2^{\mathrm{a}}$.- No obstante lo anterior, a los efectos de su posible ineficacia, será preciso atender, no solo al instante en que se ejerce la facultad concedida por parte del apoderado, sino al momento en que se ha otorgado el poder, porque puede suceder que el delado no tenga capacidad para ejercer el ius delationis.

\section{3-2.- Los acreedores y el ejercicio de la delación.}

Toda delación supone para su titular una oferta adquisitiva y la posibilidad de ver aumentado el caudal de su patrimonio ya que, a través de la misma, podrá adquirir

${ }^{510}$ Vid GITRAMA: Op. cit.: Pág 61.

511 En este caso, no sería correcto, ni técnica, ni jurídicamente, hablar de revocación de la declaración de repudio, sencillamente porque dicha declaración aun no ha nacido, no existe. Mas sí de revocación del mandato (art. 1733 CC), revocabilidad que se funda en el carácter in tuitu personae que lo caracteriza (STS de 6 de octubre de 1989, RJ 6891), y en la propia voluntad del delado-mandante. 
aquellos bienes que provienen del causante, además, de forma gratuita, sin necesidad de tener que realizar contraprestación alguna o entrega de bienes a cambio de ello por tratarse de una adquisición a título lucrativo, lo que, por otro lado, desde el punto de vista de su responsabilidad frente al pago de deudas, tiene una gran importancia por cuanto ello dará lugar a que se produzca una mayor solvencia frente a los acreedores.

De ahí, en consecuencia, que sea lógico el interés de éstos en la decisión que adopte el delado sobre la oferta sucesoria que ha recibido, y tanto los de la propia herencia, como los particulares suyos, por cuanto afecta, de forma directa a su solvencia económica y patrimonial y, subsiguientemente, a que vean o no aumentadas las posibilidades de poder cobrar los créditos que tuvieren, unos contra la herencia, otros contra dicho deudor. No obstante, en el caso de los acreedores de la herencia, ello tiene como contrapunto la diferente responsabilidad que asuma el delado según como acepte la herencia, si de forma pura y simple, o si a beneficio de inventario.

En este sentido, y dado el carácter personal del ius delationis en su ejercicio, se plantea la cuestión de si los acreedores están facultados para poderlo ejercer a través de la acción subrogatoria del artículo 1111 del Código Civil.

Acerca de ello, es opinión mayoritaria dentro de la doctrina ${ }^{512}$ que no es posible la sustitución o suplantación del delado en el ejercicio de la delación por parte de los acreedores a través de dicha acción ${ }^{513}$. Así, JORDANO FRAGA ${ }^{514}$ entiende que la respuesta es negativa a la vista de "los principios generales que delimitan el ámbito material de la acción subrogatoria y los principios específicos de la adquisición que inspiran la adquisición hereditaria en nuestro derecho $y$, de forma particular, el modo concreto en que recíprocamente se limitan en él, la libertad de opción del delado (art. 988 CC), y el interés de sus acreedores (revocatoria, arts 1001 y 1005 CC)".

512 Así, entre otros muchos autores:

ALBALADEJO: Anotaciones de Derecho español al Derecho de Sucesiones, Parte General, de CICU. Cit: Pág 348 y ss; CRISTOBAL MONTES: La vía subrogatoria. TECNOS. Madrid. 1995. Pág 187; DIEZ-PICAZO: “La aceptación de la herencia por los acreedores del heredero”. Cit: Págs 182y 183; DIEZ-PICAZO/GULLON: Sistema de Derecho Civil. Vol IV. Cit: Pág 536; GITRAMA: Op. cit.: Pág 243 nota 41; LACRUZ/SANCHO: Elementos de Derecho Civil. T. V. Pág 101.

513 Los acreedores, de ejercer el ius delationis, lo que harían, con toda seguridad, no es precisamente repudiar la herencia, por cuanto les perjudica y sí aceptarla, ya que, los que lo fueren de la herencia, perderían la posibilidad de poder dirigirse contra los bienes particulares del delado para cobrar los créditos que tuvieren contra aquella, e igualmente, los acreedores suyos particulares, porque no se podrían dirigir contra aquellos bienes de la herencia a que hubiere sido llamado su deudor para cobrar los créditos que tuvieren contra él, siempre y cuando, lógicamente, ello no hiciese peor la situación patrimonial del deudor, como sería en el caso de tratarse de una herencia deficitaria que estuviese gravada de forma excesiva con numerosas deudas y cargas.

${ }^{514}$ Los acreedores del llamado a una sucesión "mortis causa", ante el ejercicio por éste del "ius delationis". Colegio de Registradores de la Propiedad y Mercantiles de España. Centro de Estudios Registrales. Madrid. 1996. Págs 30 y 33 y ss. 
Ahora bien, los acreedores no por ello se encuentran totalmente indefensos porque, antes del ejercicio del ius delationis, tienen a su favor la interpelación judicial de que trata el artículo 1005 CC, a través de la cual pueden compeler al deudor a que, dentro del plazo que a tal efecto le conceda el Juez, manifieste si repudia, o acepta, la herencia, bajo el apercibimiento de que si no lo hace se tendrá la herencia por aceptada. Sólo a través de la interrogatio in iure pueden, al menos, conseguir que su deudor se pronuncie acerca de la delación que le ha sido deferida y evitar, por otro lado, una posible situación de silencio que dilataría su pronunciamiento respecto de la oferta hereditaria que se le ha hecho.

Precisamente, dado el tenor del artículo 1005 CC existe, a nuestro juicio, una razón legal que impide a los acreedores que puedan subrogarse en el ejercicio del ius delationis. Y ello, porque de dicho precepto se pueden obtener dos conclusiones: sólo al delado es a quien le compete dicho ejercicio, y a nadie más, y que, cualquier otra persona, incluso los demás sujetos llamados a la misma sucesión, así como también, en este caso, los acreedores, con anterioridad a dicho ejercicio, lo único que podrán hacer es dirigirse al Juez al objeto de plantear dicha interpelación, pero lo que no sustituirle o suplantarle en el ejercicio de la delación. Lo mismo ocurre cuando el delado se hubiere reservado el derecho de deliberar y no manifiesta, en el plazo de los 30 días siguientes a la conclusión del inventario, si acepta o si repudia (art. 1019 CC). Sólo en estos casos es la ley quien decide por él ante su silencio, pero después de haber concedido al llamado la oportunidad de manifestarse.

A ello hemos de añadir otra razón más que, en nuestra opinión, justifica la imposibilidad del ejercicio de la delación por parte de los acreedores del delado y es la circunstancia, ya apuntada más arriba, de que el carácter personalísimo que tiene el ius delationis en su atribución al delado está fundamentado en el hecho de que se hace in tuitu personae, en consideración y en contemplación a él, a su persona, ya sea por parte del causante, ya sea por la ley, de lo que se deriva la consecuencia de que sólo él está facultado o legitimado activamente para su ejercicio.

Después, pero esto ya es otra cuestión, los acreedores particulares del delado, si éste ha ejercido el ius delationis y su decisión ha sido la de repudiar, tendrán, a su favor la acción que les concede el artículo 1001 del Código Civil del que nos ocuparemos más adelante en el capítulo noveno. 


\section{4.- LÍMITES DE LA REPUDIACIÓN.}

El ius delationis, en su ejercicio, en el momento de su emisión, se ha de sujetar obligatoria y necesariamente a una serie de presupuestos y requisitos ${ }^{515}$ para que se pueda considerar válido a efectos legales y surta los efectos jurídicos que le son propios, lo que, ya de por sí, constituye una limitación en dicho ejercicio desde el momento en que su inobservancia o incumplimiento puede llevar consigo la ineficacia de la declaración ${ }^{516}$.

Abordamos aquí, a continuación, por un lado, los pactos sucesorios ya que la celebración de los mismos en algunas de sus modalides, y por otro, la renuncia a la legítima futura, entendemos que suponen una limitación en el ejercicio del ius delationis.

\section{4-1.- Los pactos sucesorios.}

Los límites a la repudiación para el sucesor existen incluso ya en vida del causante porque, en este momento, por un lado, el artículo 1271 CC proscribe totalmente la celebración sobre la herencia futura de todo contrato cuyo objeto no sea otro que el de, "practicar entre vivos la división de un caudal y otras disposiciones particionales, conforme a lo dispuesto en el artículo 1056", y por otro, como manifiesta el artículo 991 CC, no se puede repudiar, o aceptar, una herencia sin estar cierto del fallecimiento de la persona a quien se va a heredar y de su derecho a la herencia, lo que presupone, no solo que la sucesión mortis causa esté abierta y, por tanto, se haya producido el fallecimiento de la persona de cuya sucesión se trate, sino una vocación y una delación sucesoria que, en ningún caso, existen si no hay proceso mortis causa. Uno y otro precepto constituyen un obstáculo, podríamos decir que, insalvable, para poder ejercitar el ius delationis dimanante de la herencia de una persona en vida de ella, lo que ya es un límite aunque sea temporal.

Aquel, el artículo $1271 \mathrm{CC}$, entendiendo su tenor en un sentido amplio, veta la posibilidad de poder celebrar sobre la herencia futura toda clase de actos, pactos, contratos y negocios jurídicos de carácter sucesorio, sea cual fuere su naturaleza y contenido, de entre los cuales estaría, entre otras, la posibilidad de poder repudiar la herencia, lo que cierra la puerta a la celebración, en los territorios de derecho común, de cualquier tipo de pacto sucesorio sobre la herencia que tuviere ese objetivo.

\footnotetext{
${ }^{515}$ De su examen nos ocuparemos en el capítulo sexto, al que nos remitimos.

${ }^{516}$ En este sentido, véase el capítulo décimo donde se analiza la ineficacia de la repudiación y sus causas.
} 
No obstante, dada la obsolescencia que tiene el Código Civil en numerosos aspectos y cuestiones en materia de sucesiones, ya desde hace años, se ha abierto en la doctrina el debate de introducir cambios en dicho texto legal para adecuar y poner en consonancia esta materia a las necesidades y exigencias de la sociedad actual, patrimonios familares, y del tráfico jurídico. Cambios entre los que está la posibilidad de poder celebrar pactos sucesorios, lo que conlleva plantearse la cuestión de qué consecuencias pueden entrañar su celebración en orden a la repudiación de la herencia y si suponen algún límite en el ejercicio del ius delationis.

Este régimen legal contrasta con el de aquellas Comunidades Autónomas en que han regido normas de derecho foral y en las que se admite la posibilidad de poder celebrar actos, pactos o contratos sobre la herencia en vida de una persona a través de la sucesión contractual y de instituciones jurídicas muy diversas ${ }^{517}$.

Igual sucede en el ámbito del derecho comparado $^{518}$, donde su existencia está plenamente admitida en algunos paises próximos al nuestro en los términos que establecen sus respectivas legislaciones.

517 Así:

- Aragón: art 377 y ss (Título II relativo a la sucesión paccionada, del Libro Tercero del CDFA).

- Baleares: instituciones como las donaciones universales (art. 8 y ss CDCFIB), la “definición” (arts 50 y 51, referido a Mallorca; art. 80, aplicable a Ibiza y Formentera, no así a Menorca, art. 65, CDCFIB), o los pactos sucesorios (art. 72 y ss CDCFIB).

- Cataluña: El derecho catalán ha conocido tradicionalmente los pactos sucesorios en forma de donación universal o heredamiento (arts. 411-7, 431-1 y ss, Ley 10/2008, sobre sucesiones). Estos pactos, como es sabido, eran el vehículo de transmisión intergeneracional de los patrimonios familiares, de base típicamente agraria, por medio de la institución de heredero único convenida en capítulos matrimoniales. Otras figuras dentro de los pactos sucesorios, son: las donaciones por causa de muerte (art. 432-1 y ss, Ley 10/2008, de 10 de julio), o la renuncia a la legítima futura (art. 451-26, Ley 10/2008, de 10 de julio).

- Galicia: arts 181.2º 209 y ss, de la LDCG de 2006.

- Navarra: Leyes 149, 155, 156 y 172 a 183, del CDCFN.

- País Vasco: arts 27, y 74 y ss, sobre pactos sucesorios, de la LDCF.

${ }^{518}$ En Francia, el artículo 1130 de Code admite que las cosas futuras puedan ser objeto de una obligación. No obstante, el párrafo $2^{\circ}$, después de decir que: “On ne peut cependant renoncer à une succession non ouverte, ni faire aucune stipulation sur une pareille succession, même avec le consentement de celui de la succession duquel il s'agit” -No se podrá no obstante renunciar a una sucesión no abierta, ni hacer ninguna estipulación sobre dicha sucesión, ni aún con el consentimiento de aquel de quien se trate la sucesión, más que en las condiciones previstas por la ley-, la reforma introducida por la Ley $n^{\circ}$ 2006-728, de 23 junio de 2006, sobre sucesiones, añade a continuación: “... que dans les conditions prévues par la loi”. -.... más que en las condiciones previstas por la ley-, lo que abre la puerta a la posibilidad de poder celebrar pactos sucesorios.

En el derecho italiano igualmente se admiten pactos de esta naturaleza en los términos que establecen los artículos 458, y 768 bis y ss (capítulo V bis, sobre pactos de familia, introducido por el artículo 2-1, de la ley, $\mathrm{n}^{\circ}$ 55, de 14 de febrero de 2006 sobre "Modifiche al codice civile in materia di patto di famiglia" -Gazzetta Ufficiale, $\mathrm{n}^{\circ}$ 50, de 1 de marzo de 2006-).

En el derecho alemán, la Sección cuarta del Libro V (§ 2274 y ss), está dedicada al contrato sucesorio. En él, se admiten, además, los denominados "pacta de non succedendo", que es un contrato concluido por el testador en vida, con su cónyuge, o un pariente, en virtud del cual se contempla la renuncia del aceptante a su derecho a la legítima (§ 2346), a un legado o a una donación (§ 2352). La 
DELGADO ECHEVERRIA ${ }^{519}$, ante una futura reforma del derecho de sucesiones, se plantea en este sentido, entre otros objetivos, la conveniencia de ampliar la libertad de disposición del causante, opinión que compartimos, lo que entrañaría, entre otras medidas, admitir instrumentos distintos del testamento unipersonal como serían: el testamento mancomunado, al menos entre cónyuges, las donaciones mortis causa, o la posibilidad de poder celebrar pactos sucesorios.

Su postura favorable a admitir los pactos sucesorios en el Código Civil ${ }^{520}$, le lleva a plantear tres cuestiones: suprimir el párrafo $2^{\circ}$ del artículo 1271 del Código Civil, establecer una regulación una pormenorizada de los mismos que propicie su celebración, y su admisión explícita con disposiciones a título particular. Después, el resultado de la encuesta que realizó compulsando la opinión de la doctrina, es abrumador $^{521}$, mayoritariamente favorable o positivo a favor de las tres cuestiones, siendo muy pocos los que se oponían. Lo que viene a demostrar que la doctrina ve con buenos ojos una reforma en esta materia.

renuncia, que se puede realizar, en su caso, en beneficio de un tercero determinado ( $§ 2350$ ), incluso puede ser anulada ( $\S 2351$ ), se concibe como un negocio de disposición abstracto que produce la pérdida del legítimo derecho sobre la herencia, lo que da lugar a la exclusión de la misma como si ya no se viviese al tiempo de la muerte del causante. No obstante, aunque no es conceptualmente esencial al pacto, el aceptante recibe una contraprestación (indemnización), si bien, su convenio se hace constar de forma independiente junto a la renuncia sucesoria abstracta, de tal manera que no puede reivindicarse en el ámbito del derecho de obligaciones en el caso de que la renuncia se haya vuelto superflua por la muerte prematura del renunciante, e igualmente, al revés, no puede reivindicarse la renuncia cuando la indemnización prometida no se ha efectuado.

En Suiza: artículo 494 de su Código Civil.

En Portugal: artículo 1700 y ss de su Código Civil.

${ }^{519}$ En las jornadas que celebró la Asociación de Profesores de Derecho Civil en su reunión del año 2006 en Santander, presentó una ponencia sobre, “Una propuesta de política del Derecho en materia de sucesiones por causa de muerte”. En ella, establece una serie de objetivos en la reforma de esta materia, así como saber cual era la opinión de los Profesores de Derecho Civil sobre la oportunidad de dicha reforma del Derecho de Sucesiones del Código civil y las materias o temas sobre los que parecería más necesario u oportuno introducir modificaciones legales con el fin de formular propuestas de política legislativa (Derecho de Sucesiones. Presente y futuro. Cit : Pág 13 y ss).

Ante ello, realizó una encuesta entre los miembros de la Asociación para conocer un estado de opinión sobre mútiples cuestiones que él planteaba cuyos resultados se han visto después reflejados en su "Propuesta de conclusiones” (Derecho de Sucesiones. Presente y futuro. Cit: Pág 145 y ss.).

${ }^{520}$ Sobre ellos, dice lo siguiente (Derecho de Sucesiones. Presente y futuro. Cit : Pág 134): “Creo que no hay ninguna razón de política legislativa basada en la moral, las buenas costumbres o de orden público para no admitir en el Código los pactos sucesorios. De hecho, fueron recogidos explícitamente hasta 1970 para determinar derechos sucesorios de los adoptados, otros preceptos del Código pueden entenderse como admisiones singulares (vgr. arts. 826 y 827, art. 1341.2) y los propició la Ley de reforma y desarrollo agrario". A lo que añade más adelante, "el Notariado español entiende que serían útiles para la transmisión de patrimonios empresariales ...; asi mismo, la Recomendación de la Comisión CE de 7 de diciembre de 1994 los sugiere para facilitar la transmisión de la pequeña empresa. Podrían prestar servicios entre cónyuges, para instituirse recíprocamente o, simplemente, para aumentar o disminuir los derechos sucesorios que la ley les reconoce; también entre parejas estables; o entre los progenitores en beneficio de sus hijos comunes (por ejemplo, como parte de los arreglos al divorciarse)".

${ }^{521}$ Derecho de Sucesiones. Presente y futuro. Cit : Págs 165 y 166. 
Tambien a favor de los pactos sucesorios se manifiesta SÁNCHEZ ARISTI ${ }^{522}$ para quien, quizás, su principal fundamento es que otorgan seguridad al heredero instituido dado su carácter irrevocable por la naturaleza contractual del pacto, en contraste con el carácter revocable del testamento, si bien, entiende que, "una primera opción de técnica legislativa habría consistido en limitarse a eliminar del artículo 1271 CC la prohibición de los contratos que tengan por objeto la herencia futura, sin agregar ninguna regulación específica sobre la materia". Sin embargo, "esta opción se ha desechado por considerar que, a la postre, podría generar una mayor inseguridad jurídica"523. Aun mostrándose favorable a los pactos sucesorios, entiende que las reticencias hacia los mismos en sistemas de Derecho Civil de inspiración romanista son profundas y hunden sus raíces en una larga tradición histórica, justificación de la prohibición que ha descansado en consideraciones de diverso orden ${ }^{524}$.

Pero, dejando al margen la innovación legal que supondría sancionar los pactos sucesorios en el ámbito del Código Civil y subsiguiente derogación de la norma del párrafo $2^{\circ}$ de su artículo 1271 que los prohíbe en la actualidad, así como las ventajas o bondades que ello puede suponer, la cuestión, ya planteada, que aquí viene al caso es la siguiente: una vez regulados los pactos sucesorios, qué incidencia tendrían en el ejercicio del ius delationis en el sentido de si constituirían una limitación al mismo en lo que se refiere a la declaración de repudiación de una herencia.

Acerca de ellos, SÁNCHEZ ARISTI ${ }^{525}$ parte en su propuesta de concebirlos como un tipo de negocios bilaterales $y$, por tanto, irrevocables de forma unilateral por cualquiera de las dos partes otorgantes -lo que sería una de sus peculiaridades más características-, de naturaleza tanto onerosa como gratuita, que, con carácter previo a la apertura de la sucesión, pueden tener un triple objeto: ordenar la institución, la renuncia o la disposición de derechos relativos a la herencia de una persona. De lo que resultan tres tipos de pactos sucesorios: los institutivos o de suceder, los

522 Op cit.: Págs 478, 484, 491.

${ }^{523}$ Ante ello, se muestra favorable a introducir una regulación sistemática y detallada de los pactos sucesorios en el Código Civil y hace la propuesta de añadir un nuevo Capítulo II bis (comprensivo de los artículos 911 bis hasta el 911 novies), al Título III del Libro III, bajo el epígrafe, "De la sucesión contractual", organizados en tres Secciones ("De los pactos sucesorios en general", "De los pactos sucesorios institutivos", "De los pactos sucesorios renunciativos y dispositivos”), además de la modificación incidental de otros artículos en coherencia o consonancia con aquellos. En su opinión, "incorporar al sistema del Código Civil la figura de los pactos sucesorios, propicia una vía de disposición de los bienes por causa de muerte alternativa al testamento, lo cual representa una mayor riqueza para el sistema en su conjunto".

${ }^{524}$ Op cit. Pág 480 y ss. 
renunciativos o de no suceder y los dispositivos o sobre la herencia de un tercero. Veamos los dos primeros que son los que aquí nos interesan ${ }^{526}$.

Los institutivos, que sería la modalidad más típica y de la que normalmente se habla cuando se trata de estos pactos, son aquellos por los cuales el causante de una herencia ordena, de acuerdo con otra persona y a favor de ésta, una o varias instituciones de heredero, o uno o varios legados, sobre bienes de su herencia ${ }^{527}$. El instituido por el pacto puede ser tanto uno de los otorgantes, que puede serlo el futuro sucesor, como ambos otorgantes recíprocamente, o incluso un tercero no interviniente en el negocio. Su eficacia está subordinada a la muerte del causante-instituyente y a la correlativa supervivencia del instituido. La consecuencia que se derivaría del pacto es que, después, al abrirse la sucesión, por un lado, se adquiriría de forma automática de la condición de heredero sin necesidad de tener que manifiestar querer aceptar la herencia, dado que esa aceptación ya se produjo en vida del causante de forma implícita a través del consentimiento por él prestado al contratar con el causante y, por otro, no podrá, en su caso, una vez abierta la sucesión, si lo pretendiere, repudiar la herencia ${ }^{528}$.

Esta modalidad de pacto puede inducirnos a pensar, en principio, que su celebración supone una limitación a la posibilidad de poder repudiar. Sin embargo, a nuestro juicio, lo que está haciendo el sucesor, en realidad, es ejercitar en vida del causante, y a través de contrato, el ius delationis en su aspecto o faceta positiva de aceptación de la herencia porque su consentimiento implica esta manifestación de voluntad, pero, con una doble peculiaridad: por un lado, tiene por objeto una herencia aun no deferida $y$, por otro, lo hace por medio de contrato, lo que supone la imposibilidad de poder dejar sin efecto después su declaración de forma unilateral dado el carácter irrevocable que tiene el consentimiento emitido al celebrar el pacto sucesorio ya que se hace de forma bilateral, de mutuo acuerdo, con el futuro causante.

${ }^{526}$ Son aquellos por los que los otorgantes realizan un acto dispositivo respecto de bienes pertenecientes a la herencia de una tercera persona, todavía viva, en el entendimiento de que se espera recibirlos de ella por título hereditario de tal modo que el causante no es nunca parte en este tipo de pactos. SÁNCHEZ ARISTI, reconoce que este tercer tipo de pactos no es de naturaleza sucesoria stricto sensu, pero entiende oportuno regularlos conjuntamente "a fin de evitar equívocos" ("Propuesta para una reforma del Código Civil en materia de pactos sucesorios”. Cit. Pág 492).

${ }^{527}$ En este sentido, en el Pais Vasco, el artículo 74 de la LDCF dispone que, mediante pacto sucesorio "se puede disponer la sucesión en bienes de los otorgantes, bien a título universal o particular, con las modalidades, reservas, sustituciones, cláusulas de reversión, cargas y obligaciones que se acuerden".

${ }^{528}$ En este sentido, en Cataluña, con precedente en el artículo 76 del Código de Sucesiones de 1991, así dispone el artículo 431-28.1, Ley 10/2008: "Una vez muerto el heredante, el heredero instituido en heredamiento no puede repudiar la herencia, salvo que se trate de una persona no otorgante del pacto, pero puede disfrutar del beneficio de inventario si manifiesta esta voluntad en el tiempo y la forma establecidos por el artículo 461-15. El tiempo debe contarse desde la muerte del heredante”. 
De ahí que el sucesor, al consentir, no solo está aceptando la herencia, sino que, al mismo tiempo, está excluyendo la posibilidad de repudiar después, incluso en vida del causante, por cuanto, dada la naturaleza contractual del pacto que ha celebrado, la declaración es irrevocable y no podrá, como apuntamos, deshacer o invalidar después de forma unilateral, sino que tendrá que ser de mutuo acuerdo, a través de un nuevo pacto, con el causante. En este sentido, manifiesta SÁNCHEZ ARISTI que ello "se conecta en definitiva con el principio pacta sunt servanda y con los preceptos sobre los que dicho principio se sustenta", salvo "que se produzca un nuevo concurso de voluntades de quienes otorgaron el pacto para dejarlo sin efecto por mutuo disenso", o incluso por decisión unilateral del instituyente "si los otorgantes hubieran acordado esa posibilidad, sometida, en su caso, a alguna causa concreta de revocación"529.

Los renunciativos, o pactos de non succedendo, son aquellos en virtud de los cuales uno de los intervinientes renuncia, antes de la apertura de la sucesión, a los derechos que le pudieran corresponder en la herencia de otro. La renuncia se puede celebrar de forma pura o condicional, total o parcial, y de forma gratuita u onerosa, incluso puede tener por objeto transigir sobre los derechos de dicha herencia ${ }^{530}$. De ahí que, en realidad, encierren un verdadero acto de disposición.

${ }^{529}$ Así lo contempla en la propuesta de redacción del artículo 911 sexies del Código Civil, donde señala varios supuestos de los cuales sólo sería de aplicación, al caso de repudiación, éste, señalado con la letra a). Los demás, no, porque sólo encajarían en el caso de renuncia ("Propuesta para una reforma del Código Civil en materia de pactos sucesorios”. Pág 517).

${ }^{530}$ En este sentido:

- en Aragón, pactos de renuncia son los otorgados entre el renunciante o renunciantes y la persona o personas de cuya sucesión se trate, y pueden referirse a todos los derechos sucesorios o a parte de ellos, establecerse a título gratuito u oneroso y sujetarse a condición (art. 399 CDFA).

- En el Pais Vasco, apunta IMAZ ZUBIAUR que, esta modalidad de pacto no está contemplado en la Ley 3/1992, de 1 de julio, acorde con el pacto sucesorio de institución que sería el prototipo, si bien, "nada impediría comprender que el propio art. $74 \mathrm{LDCF}$, cuando establece que mediante pacto sucesorio puede ordenarse la sucesión de sus otrogantes, incluye la posibilidad de que dicha ordenación se efectúe a través de un pacto negativo o de renuncia”. A lo que añade más adelante que, "en el Derecho de Tierra Llana, el pacto de non succedendo buscaría la renuncia anticipada por parte del los sucesores forzosos, ...., en aras, fundamentalmente, a otorgar al futuro causante una absoluta libertad de testar, que no de mera distribución ....”, y que "carecen de arraigo alguno en el sistema jurídico infanzón, a diferencia de lo que ocurre en otros ordenamientos”, derecho aragonés, legislación balear, u ordenamiento gallego (La sucesión paccionada en el Derecho Civil Vasco. Monográficos "La Notaría”. $\mathrm{N}^{\circ}$ 6. Col-legi de Notaris de Catalunya. Marcial Pons. Madrid-Barcelona 2006. Pág 236).

Por su parte, ASUA GONZÁLEZ, C.I., y otros, en su propuesta de un nuevo régimen sucesorio para el conjunto de la Comunidad Autónoma Vasca y así superar la diversidad legislativa que existe en la misma en derecho de sucesiones, proponen una modalidad de pacto de renuncia celebrado entre el causante, o instituyente, y el instituído en virtud del cual, éste abdica, en todo o en parte, sobre los derechos sucesorios que pudieran corresponderle en la sucesión del causante, pudiéndose establecer a títlo oneroso o gratuito y sujetarse a condición (Base $n^{\circ}$ 26) (Estudio sobre Derecho sucesorio Vasco. Bases para un nuevo régimen. Departamento de Derecho Civil. Servicio Editorial. Universidad del Pais Vasco. 2011. Pág 56). 
Esta modalidad de pactos, apunta SÁNCHEZ ARISTI ${ }^{531}$, que pueden otorgarse entre el renunciante y el causante o entre aquel y un sucesor del causante que se verá beneficiado con la renuncia, tienen una mayor virtualidad cuando tienen por objeto los derechos forzosos establecidos por ley de forma imperativa a favor de determinados herederos, no así los derechos testamentarios o los ab intestato que, si bien también pueden ser objeto de estos pactos, pueden ser neutralizados fácilmente por el causante sin necesidad de acudir a un pacto renunciativo. De ahí que solo tiene realmente razón de ser cuando tiene por objeto otorgar alguna ventaja o beneficio a algún legitimario o potencial heredero del causante, razón por la cual pueden concurrir en el otorgamiento del pacto dado el interés que tienen en la renuncia. O también, los derechos sucesorios recibidos de otra persona en virtud de un precedente pacto sucesorio institutivo ya que entonces, esos derechos, aunque todavía no consolidados en el patrimonio del instituido, se hallan constituidos a su favor de manera irrevocable.

En el Código Civil, esta modalidad de pactos sólo están contemplados, con la finalidad de prohibirlos, en la imposibilidad de poder renunciar anticipadamente a la acción de reducción de donaciones inoficiosas (art. 655, párrafo $2^{\circ}$ ), o a propósito del derecho a la legítima futura de un heredero forzoso (art. 816).

Ahora bien, para que el pacto de non succedendo entrañe, a nuestro juicio, una verdadera repudiación, sería preciso que cumpliera los siguientes requisitos:

a) que se trate de un acto realizado a título gratuito, esto es, sin que se reciba contraprestación alguna a cambio, se haga de forma desinteresada porque, en caso contrario, entendemos que estaríamos ante una renuncia traslativa,

b) se haga de forma pura, no condicional, ni a término,

c) ha de recaer sobre la totalidad de aquello que le vaya a corresponder al otorgante-sucesor en el futuro en el momento de deferirse la sucesión dado el carácter indivisibe de la repudiación que no se puede fragmentar, y

d) se haga sin designación de las personas a quienes vaya a ir aquello a lo que se repudió, de tal manera que sea la voluntad del causante, o las reglas aplicables a la sucesión de que se trate, según las circunstancias de la misma, las que determinen cual va a ser el destino de los bienes, porción o cuota, que ha sido objeto de repudio.

${ }^{531}$ Dos alternativas a la sucesión testamentaria: pactos sucesorios y contratos post mortem. Editorial Comares. Granada 2003. Págs 28 y 155 y ss. 
Cualquier otra clase de pacto renunciativo que no reúna las características de la repudiación, a nuestro juicio, no tendría la consideración, o no sería asimilable a una repudiación de herencia en el sentido propio, pero, sí se podría considerar como una forma de renuncia impropia y, como tal, de aceptación, tácita, de la herencia, al igual que ocurriría con la celebración de los denominados pactos sucesorios dispositivos.

En este supuesto, se da la peculiaridad de que el acto se realiza en vida de la persona de cuya sucesión se trate, lo que, no solo constituiría una importante novedad en el régimen del Código Civil, sino que rompe totalmente con el status o situación que existe en el régimen jurídico actualmente en vigor que no lo permite. Ello va a traer como consecuencia que, después, una vez abierta la sucesión, el repudiante ya no tendrá opción alguna sobre la herencia por cuanto ha quedado excluido de ella y no podrá manifestarse acerca de la misma al haberlo hecho ya en vida del causante.

Y, por otro lado, la celebración de estos pactos de non succedendo, en nuestra opinión, no desvirtuaría, en modo alguno, la regla del artículo 991 CC, que seguiría plenamente vigente, porque, fuera de este supuesto, no se podría repudiar la herencia hasta que no se abra la sucesión y no se tenga certeza del derecho a ella, salvo que, como decimos, se haga a través de esta modalidad de pacto sucesorio, en cuyo caso, sí sería posible. Así, su celebración no supondría infracción de dicha norma, que seguiría teniendo plena virtualidad, aunque, eso sí, constituirían una excepción a la misma porque, fuera de ellos, como decimos, no se podría repudiar.

\section{4-2.- La renuncia a la legítima futura.}

Una aplicación específica de la prohibición contemplada en el párrafo $2^{\circ}$ del artículo 1271 lo constituye, en relación a la legítima, el artículo 816 del Código Civil ${ }^{532}$,

532 Acerca de los antecedentes históricos de esta prohibición y de su evolución hasta nuestros días, ver, entre otros, O’CALLAGHAN: “La renuncia a la legítima”. Libro homenaje a Roca Sastre. Junta de Decanos de los Colegios Notariales de España. T. III. Madrid. 1977. Pág 344 y ss.

Precedente histórico inmediato del mismo lo constituye el artículo 646 del Proyecto de 1851 del que es copia casi literal del mismo.

De igual manera, ocurre en el derecho civil de Cataluña donde, el artículo 451-26 de la Ley 10/2008, sobre sucesiones, declara: "Son nulos los actos unilaterales, las estipulaciones en pacto sucesorio y los contratos de transacción o de cualquier otra índole otorgados antes de la muerte del causante que impliquen renuncia al derecho de legítima o que perjudiquen a su contenido", salvas las excepciones que en él se establecen. Así, "son válidos, si se otorgan en escritura pública: a) El pacto entre cónyuges o convivientes en unión estable de pareja en virtud del cual renuncian a la legítima que podría corresponderles en la sucesión de los hijos comunes y, especialmente, el pacto de supervivencia en que el superviviente renuncia a la que podría corresponderle en la sucesión intestada del hijo muerto impúber. b) El pacto entre hijos y progenitores por el que estos últimos renuncian a la legítima que podría corresponderles en la herencia del hijo premuerto. c) El pacto entre ascendientes y descendientes estipulado en pacto sucesorio o en donación por el que el descendiente que recibe de su ascendiente bienes o dinero en pago de legítima futura renuncia al posible suplemento". 
ya que, en su virtud, no se puede realizar sobre la misma, en tanto en cuanto se trate de legítima futura, esto es, la relativa a una sucesión aun no abierta o que, estando abierta, aun no se haya cumplido la condición o el plazo a que, en su caso, estuviere sujeta la vocación del legitimario, ninguna renuncia o transacción sobre la misma entre él y el causante ${ }^{533}$. Así, la regla del artículo 816 CC es una limitación al ejercicio del ius delationis al impedir su manifestación en vida del causante.

SÁNCHEZ ARISTI ${ }^{534}$, no obstante, puntualiza que, dado su tenor, sólo haría referencia a la renuncia pactada entre el legitimario y el causante, y nada dice de la realizada por un legitimario respecto a favor de otro, por lo que no podría concluirse la nulidad de la misma. Opinión que no compartimos porque, a nuestro juicio, dicho pacto entre colegitimarios, aunque del tenor literal del precepto puede entenderse, en principio, como no prohibido de forma expresa por él, entendemos que no estaría permitido por el propio tenor del párrafo $2^{\circ}$ del artículo 1271 cuando habla de "herencia futura" porque el legitimario estaría disponiendo a favor de otro colegitimario de un derecho futuro, que no existe de presente, sin perjuicio de que, dada su condición de heredero forzoso del causante, a él le va a corresponder en el día de mañana en la herencia de éste. La prohibición de los artículos 1271 y 816 CC no es por razón de los sujetos entre quienes se celebra el acto, sino por el objeto sobre el que recae.

No sucede lo mismo en el derecho aragonés donde, de conformidad con el artículo 492 CDFA, "la renuncia a la legítima puede hacerse tanto después como antes de la delación de la sucesión, y en este caso unilateralmente o como resultado de un pacto sucesorio" $\left(\mathrm{n}^{\circ} 1\right)$, exigiéndose, si se hace antes de la delación, la misma capacidad que se precisa para celebrar pactos sucesorios $\left(\mathrm{n}^{\circ} 2\right)$. A lo que añade después: "La renuncia a cualquier atribución patrimonial por causa de muerte procedente del ascendiente implica la renuncia a la legítima" $\left(\mathrm{n}^{\circ} 4\right)$.

${ }^{533}$ No obstante, dado su tenor, y aunque en él se hable solo de renuncia o transacción como actos relativos a la misma, hemos de entenderlo en un sentido general y amplio, esto es, también comprendidos en él cualesquiera otros actos que pudieren envolver una renuncia, sea en un sentido abdicativo o traslativo. De ahí que el ámbito de la prohibición del artículo 816 CC no sólo vendría referido al acto de renuncia propiamente dicho, sino también cualesquiera otros negocios jurídicos previos que, en su caso, se hubieren celebrado y a través de los cuales el legitimario pacta o se obliga a realizar dicha renuncia.

O’CALLAGHAN, en este sentido, refiriéndose a la transacción, entiende que este término va incluso más allá, porque para él, "el legislador piensa en ella como el más típico contrato relativo a la renuncia, o más aun, llama transacción a todo contrato sobre ella, cuando realmente puede ser una compraventa de derecho, permuta, aportación a sociedad, en realidad todo negocio dispositivo; en todo caso, aunque se limite a referirse a transacción, el Código civil prohíbe toda clase de contrato sobre la legítima no deferida por aplicación de la norma contenida en el artículo 1271" ("La renuncia a la legítima”. Cit. Pág 353).

En otro orden de argumentos, una vez más, se emplea el término "renuncia" de manera imprecisa porque, bien se puede entender que se está refiriendo al acto de renuncia como tal, bien a la repudiación pero empleado aquel término en un sentido impropio para referirse a ésta. Cualquiera de los dos sentidos, dado el espíritu y finalidad del precepto, se puede considerar comprendido dentro del mismo, de tal manera que, no solo estaría prohibida cualquier forma o manifestación de renuncia, en cualquiera de sus modalidades o manifestaciones, sino también la repudiación propiamente dicha.

${ }^{534}$ Op. Cit: Dos alternativas a la sucesión testamentaria: pactos sucesorios y contratos post mortem. Pág 158. 
Esta prohibición se fundamenta en diversas causas: en la naturaleza futura e indeterminada del objeto sobre el que recaen, en el carácter de derecho necesario que tienen las normas que regulan la legítima en nuestro ordenamiento jurídico, lo que hace que esté sustraída a la libre voluntad de las partes, o en el carácter esencialmente revocable de las disposiciones mortis causa.

Por otro lado, si antes vimos cómo la propuesta de DELGADO ECHEVERRIA de derogar el párrafo $2^{\circ}$ del artículo 1271 CC era secundada por una inmensa mayoría de la doctrina, aquí, en este caso, su propuesta de admitir la posibilidad de renunciar de forma anticipada a la legítima, es decir, derogar el artículo 816 CC $^{535}$, no encuentra tanto apoyo. En este punto, y según el resultado de la encuesta que él realizó, pese a que existe una opinión muy extendida en la doctrina de modificar el actual sistema legitimario del Código Civil, su iniciativa es rechaza claramente (pregunta 21), lo que después se ve reflejado en su "Propuesta de conclusiones" donde no hace mención a ello aunque sí a la necesidad de una reforma en profundidad del sistema legitimario del Código Civil ${ }^{536}$. En su opinión, "el rechazo a la posibilidad de renuncia anticipada de la legítima parece que está relacionado con una concepción "fuerte" de ésta, más que con una reflexión sobre la sucesión contractual".

No obstante, lo cierto es que, las normas de los artículos 1271, 816 y 991, o el 1674 CC, constituyen un obstáculo o impedimento infranqueable a la posibilidad de poder ejercer el ius delationis por parte del futuro sucesor en vida de aquella persona de cuya sucesión se trate. De ahí que, dado el tenor de los mismos, no sea lícita, so pena de nulidad total y absoluta, por infracción de una norma de derecho necesario, la realización de cualquier acto, no sólo de repudiación, sino cualquier otro, sea cual fuere la forma y denominación que recibiere o adoptare, por parte del futuro legitimario en vida del causante en relación al derecho sucesorio que, en su condición de heredero forzoso, fuese a percibir de él en su sucesión, una vez deferida la herencia. De lo que se derivaría la consecuencia de que, si a resultas de ello, el sucesor hubiese recibido, en su caso, algo a cambio, a título de contrapartida, compensación o contraprestación, tendría la obligación de devolverlo, al tratarse de un acto nulo de pleno derecho, por aplicación de la doctrina de los actos nulos (art. 1303 y ss CC).

${ }^{535}$ Derecho de Sucesiones. Presente y futuro. Cit : Pág 136.

${ }^{536}$ En este sentido, manifiesta lo siguiente: "Cabe sugerir la supresión de la legítima de los ascendientes, salvo atribuciones asistenciales, así como la reducción de la legítima de los descendientes y la generalización de su pago en dinero aun no hereditario. Con todo, debe notarse que una modificación sustancial del sistema legitimario, "núcleo duro" del Derecho de sucesiones, requiere particular estudio y amplio consenso, pues el valor simbólico de estas reglas en muy fuerte" (Derecho de Sucesiones. Presente y futuro. Cit : Pág 170). 
En este sentido, la referencia que se hace en el artículo 816 a la nulidad hay que entenderla como absoluta (SSTS de 10 de diciembre de 1896; 10 de julio de 2003 -RJ 4628-), in radice (STS de 9 de enero de 1958), con efectos retroactivos al momento en que se celebró el negocio jurídico de renuncia, y apreciable a instancia de cualquiera o de oficio aunque no necesita ser declarada judicialmente y es imprescriptible $\left(\mathrm{O}^{\prime} \mathrm{CALLAGHAN}^{537}\right.$ ). No opina lo mismo SÁNCHEZ ARISTI ${ }^{538}$, para quien tan solo se trataría de un caso de anulabilidad, subsanable por la falta de impugnación del renunciante, quien puede confirmar la renuncia con su comportamiento posterior.

La nulidad se justifica, por un lado, en el carácter de derecho necesario que tiene la regulación de la legítima, por lo que está sustraída a la libre determinación de las partes en relación a los derechos de los herederos forzosos (MARTíN PÉREZ ${ }^{539}$ ), y por otro, en ser una cuestión de orden público (art. 6.2 $\mathrm{CC}$ ), cuya negociación se sustrae también a la libre voluntad de las partes. O'CALLAGHAN ${ }^{540}$, por su parte, añade un factor humano y un factor jurídico: en lo que se refiere al primero, "está en el interés de la sociedad, y por tanto de la ley, de que no se renuncien a meras expectativas sobre herencias futuras, y por tanto derechos inseguros", y, en lo que se refiere al segundo, "descansa en el concepto de legítima, freno para la libertad de disposición mortis causa del testador y derecho que corresponde a los legitimarios por razón de proximidad familiar al causante, es decir, a la intangibilidad de la legítima ${ }^{541}$ que sirve de base a toda la regulación de la misma ......."

Por otro lado, esta norma del artículo $816 \mathrm{CC}$ hay que entenderla referida solo a lo que es la legítima estricta y no extenderla a la mejora, ya que los negocios jurídicos sobre ésta sí están admitidos por los artículos 826 CC, que declara válida la promesa de mejorar o no mejorar hecha por escritura pública en capitulaciones matrimoniales, y $827 \mathrm{CC}$, que permite pactar acerca de la mejora en capitulaciones o en contrato oneroso con un tercero. Ahora bien, si los pactos, renuncia, transacción o cualesquiera otros, sobre la mejora tienen lugar entre los herederos forzosos, sí que entraña un pacto sucesorio prohibido que entraría dentro del ámbito del artículo 1271 CC aunque su atribución dependa de la libre voluntad del causante (STS 13 de junio de 1903).

537 “La renuncia a la legítima”. Cit: Pág 352.

538 Op. Cit: Dos alternativas a la sucesión testamentaria: pactos sucesorios y contratos post mortem. Pág 158.

539 Comentario al artículo 816 CC, en Jurisprudencia civil comentada (Tomo I). Dirección: Pasquau Liaño. Ed. COMARES. Granada. 2000. Págs 1531 y ss.

540 "La renuncia a la legítima”. Cit: Pág 343.

${ }^{541}$ En este punto cita a FUENMAYOR: “Intangibilidad de la legítima”. ADC. 1948. Pág 46. 


\title{
Capítulo 5: LA REPUDIACIÓN EN EL CASO DE PLURALIDAD DE TÍTULOS Y/O DE CUOTAS.
}

\begin{abstract}
1.- Planteamiento, problemática y delimitación. 2.- La repudiación ante uno o varios títulos sucesorios y varias porciones o cuotas. 2-1.- La repudiación cuando hay un solo título y varias porciones o cuotas de la herencia. 2-2.- La repudiación cuando hay varios títulos y una o varias porciones o cuotas de la herencia. 3.- El artículo 1009 del Código Civil: delimitación del ámbito de su aplicación. 3-1.- Interpretación del párrafo primero y presupuestos para su aplicación. 3-2.- Interpretación del párrafo segundo y presupuestos para su aplicación. 4.- La repudiación en el caso de coexistencia de la sucesión testada e intestada. 4-1.- Que exista simultaneidad o compatibilidad entre ambas sucesiones. 42.- Apertura de la sucesión intestada porque la testada se frustre o sea insuficiente. 4-3.Apertura de la sucesión intestada por ineficacia de la testada o de la institución de heredero. 5.- La repudiación cuando coexisten otros títulos sucesorios. 5-1.- Que quien repudie como transmisario sea llamado después como sucesor abintestato. 5-2.- Que quien repudie como transmisario vuelva a ser llamado como sustituto a resultas de dicha repudiación.
\end{abstract}

\section{1.- PLANTEAMIENTO, PROBLEMÁTICA Y DELIMITACIÓN.}

Una de las características de la declaración del sucesor es, según veíamos en el capítulo anterior, su indivisibilidad, la cual, se puede plantear, también dejábamos apuntado, desde un doble aspecto o punto de vista:

a) subjetivo: referido al supuesto de que hubiere una pluralidad de sucesores en la sucesión y,

b) objetivo: relativo a la declaración del delado en atención al objeto de la vocación, aquello a lo que ha sido llamado. 
Ya por entonces, en relación al aspecto objetivo, apuntábamos la problemática que en él se producía en los términos de, si bastaba una sola declaración de voluntad, o varias, cuando el sucesor había sido llamado a varias porciones o cuotas de la herencia, que podían ser iguales o desiguales entre sí:

a) a través de un solo título sucesorio o llamamiento (es decir, una sola vocación y una pluralidad de porciones o cuotas),

b) a través de una pluralidad de títulos y que el llamamiento se hubiere producido: a distintas porciones o cuotas de la herencia, iguales o desiguales entre sí, -"ex pluribus portionibus"- (caso de una pluralidad, tanto de vocaciones, como de porciones o cuotas), a una misma porción o cuota o sobre la herencia en su totalidad (caso de pluralidad de vocaciones que recaigan sobre una sola cuota o la herencia en su totalidad).

Hipótesis, todas ellas, que, a nuestro juicio, inciden directamente en la indivisibilidad de la declaración, sobre todo, cuando el objeto es plural, tanto en el caso de la existencia de una sola delación, como si fueren varias, y que, dada la complejidad y problemática que encierran tales hipótesis, merecen, en nuestra opinión, un análisis más detenido, lo que es objeto del presente capítulo.

En un principio, en el primero de los dos supuestos apuntados, puede pensarse que si hay una única delación, proveniente de un único título sucesorio, aunque ésta comprenda varias porciones o cuotas de la herencia, el sucesor sólo puede emitir una declaración comprensiva de todo aquello que se le hubiere deferido, de tal manera que, si repudiare, se entiende que repudia todo, y si aceptare, que acepta todo. $Y$, en el segundo caso, cuando hay varios títulos, también pudiera pensarse que el sucesor tendrá derecho a exteriorizar tantas declaraciones de voluntad cuantas vocaciones tenga a su favor, cada una de ellas referida a aquello que tuviere por objeto, por lo que podría repudiar unas y aceptar otras, de forma independiente e indistinta cada una de ellas.

Sin embargo, tanto en uno como en otro supuesto, según vamos a ver ahora, la cuestión no es tan sencilla como a simple vista puede parecer, ya que habrá que tener en cuenta, por un lado, cómo se ha ordenado o establecido el título o fundamento de la vocación, por cuanto habrá que distinguir según cómo se ha deferido la sucesión, ya provenga de la voluntad del testador (art. $675 \mathrm{CC}$ ), ya de la ley, o ambos a la vez, y, por otro, en su caso, el tenor del artículo 1009 CC, dado que en él se contemplan dos normas que tienen como supuesto de hecho en su aplicación el llamamiento de un 
sucesor a la herencia a través de dos títulos sucesorios, testado e intestado, de los que derivarían sendas delaciones, por lo que sería, en principio, el precepto aquí aplicable en el caso que nos ocupa. No obstante, acerca del mismo, se da la circunstancia de que no resuelve de forma totalmente satisfactoria la compatibilidad de los dos títulos sucesorios y el subsiguiente ejercicio de la delación derivada de los mismos ya que se presta a diferentes interpretaciones como luego veremos, por lo que es confuso e impreciso y, además, manifiestamente insuficiente porque los supuestos en que puede haber pluralidad de títulos sucesorios son más de los reseñados en él, pluralidad que puede provenir de muy distintos orígenes, situaciones y circunstancias. Puede suceder, además, que unas arranquen o se produzcan en el mismo instante de la apertura de la sucesión, a la vez, de forma simultánea a este momento, y otras, en el devenir del proceso sucesorio, a lo largo de su desarrollo, en diferentes momentos, de forma sucesiva, uno después de otro.

A resultas de todo ello, es fácilmente comprensible que, no solo el ejercicio de la delación está condicionado por esa pluralidad de títulos o de cuotas en el caso de que la hubiere, sino que las consecuencias y efectos que tiene la declaración de repudio en estos casos por parte del sucesor proveniente de una de las delaciones sobre el resto de las que, en su caso, le han sido deferidas, son muy diversas. De ahí que, en estos supuestos, el ejercicio de la delación no consiste sólo en repudiar, o aceptar, sin más, sino que es una decisión cuya trascendencia se acrecienta cuando hay pluralidad de títulos sucesorios, o cuotas, a favor del mismo sucesor en los que el ejercicio de la delación que emana de cada uno de ellos, depende y está condicionada, en ocasiones, por toda una multiplicidad de factores o de circunstancias como veremos ahora a continuación.

\section{2.- LA REPUDIACIÓN ANTE UNO O VARIOS TÍTULOS SUCESORIOS Y VARIAS PORCIONES O CUOTAS.}

Cuando una persona es llamada a una sucesión mortis causa a través de un único llamamiento o título sucesorio que tiene por objeto una única porción o cuota de la herencia, o ésta en su totalidad, el ejercicio del ius delationis no ofrece ningún problema en lo que se refiere a su indivisibilidad porque el sucesor ha de exteriorizar su declaración de voluntad sin que pueda separar, disgregar o dividir el contenido de aquello a lo que ha sido llamado, de tal manera que, si acepta, acepta la porción o cuota en su totalidad, y si decide repudiar, la rechaza también en su totalidad. 
La dificultad surge cuando el llamamiento se produce, no a una porción o cuota de la herencia, sino a más de una, que, bien puede ser a través de un único título sucesorio, bien a través de varios, como sucede, entre otros casos: cuando hay varias instituciones otorgadas a su favor en el mismo testamento; o se instituye heredero a una persona en la mitad de la herencia y resulta ser heredero abintestato de la otra mitad (LACRUZ ${ }^{542}$ ); o cuando existe más de un testamento del mismo causante $\left(\right.$ GITRAMA $^{543}$ ) y resulta que todos ellos están interrelacionados por ser compatibles o complementarios entre sí, por lo que todos ellos han de ser tenidos en cuenta en su sucesión; o se trate de disposiciones testamentarias que estén condicionadas, relacionadas o sean interdependientes entre sí, unas respecto de otras, hasta el punto de que el beneficio o perjuicio que de alguna de ellas se pueda derivar u obtener esté en función del contenido de las demás ${ }^{544}$; o porque el testador exprese en el último testamento su voluntad de querer que el anterior/es subsista en parte y cuyas respectivas delaciones coincidan todas ellas sobre el mismo sucesor, lo cual, en cierto modo, por otro lado, unificaría el llamamiento a cuotas o porciones distintas $\left(V A L L E T^{545}\right)$; o que una misma persona haya sido instituída heredero por un único testamento, en varias porciones de herencia: a una mitad y, además, le deja 1/4 más $\left(A L B A L A D E J O^{546}\right)$. Éstas son, por citar, algunas de las hipótesis o supuestos, no ya más frecuentes, sino más típicos y característicos en los que se puede producir tal pluralidad de títulos y/o de cuotas, habida cuenta de que las sucesiones testada y abintestato son las dos formas o títulos sucesorios más frecuentes de deferirse mortis causa el patrimonio de una persona a resultas de su fallecimiento.

Pero, además de los anteriores, los supuestos aumentan por razón del origen del llamamiento, de la diferente forma como éste se ha producido: a título de heredero, de legatario, de sustituto, a través del derecho de acrecer, como sucesor fideicomisario, legitimario, mejorado, transmisario, etc, a lo que se añade la posibilidad, frecuente, por otro lado, de la combinación o simultaneidad de algunos de ellos entre sí.

\footnotetext{
542 Vid: LACRUZ BERDEJO y ALBALADEJO: Derecho de Sucesiones. Parte general Cit: Pág $175 \mathrm{y} \mathrm{ss}$

543 Op. cit.: Pág 306.

${ }^{544} \mathrm{Tal}$ es el caso de aquella herencia en que existe una propiedad sobre la que pesan numerosas deudas, cargas y gravámenes, y el propietario otorga testamento en el que instituye herederos de la misma a sus hijos.

Después, consciente de su testamento anterior y de que los sucesores puedan incluso repudiar la herencia dado lo gravoso que puede suponer para ellos la aceptación de la misma ya que ni tan siquiera les puede merecer la pena aceptarla a beneficio de inventario, otorga otro testamento posterior en el que tratando de compensarles por razón de esas cargas y gravámenes, o de incentivar o motivar su aceptación, se limita a atribuirles otro bien en compensación por ello diciéndolo, incluso, así, de manera expresa.

545 Panorama de derecho de sucesiones I. Cit: Pág 112.

${ }^{546}$ Curso de Derecho Civil. T. V. Sucesiones. Librería Bosch. Barcelona. 1979. Pág 87.
} 
El supuesto más normal y frecuente es aquel en que, si se defieren varias porciones o cuotas de la herencia a favor del mismo sucesor, haya también, igual número de vocaciones o títulos, tantos de éstos como de aquéllas. Pero, no siempre es así, porque puede suceder que ese llamamiento del sucesor a varias porciones o cuotas se haya realizado a través de una única vocación o título sucesorio ${ }^{547}$.

\section{2-1.- La repudiación cuando hay un solo título y varias porciones o cuotas} de la herencia.

Cuando existe un único título sucesorio que tiene por objeto varias porciones o cuotas de la herencia, dado que a favor del sucesor hay una sola vocación con su consiguiente delación, es lo mismo que si el título tuviese por objeto una sola porción o cuota de la herencia, y el delado sólo podrá emitir una única declaración de voluntad, de repudio o de aceptación, comprensiva de todo aquello a lo que ha sido llamado. De ahí que, si decide repudiar, repudiará todas las porciones o cuotas de la herencia que le hubiesen sido deferidas, y si decide aceptar, aceptará todas. Lo que no podrá hacer es, emitir tantas declaraciones de voluntad cuantas cuotas o porciones de la herencia le hayan sido deferidas, sino una sola proveniente de su única vocación o título, como tampoco podrá, en consecuencia, repudiar unas cuotas y aceptar otras, o al revés. La declaración, por razón de la indivisibilidad, ha de ser única, omnicomprensiva de todo aquello a lo que ha sido llamado sin que lo pueda separar, disgregar o dividir.

\section{2-2.- La repudiación cuando hay varios títulos y una o varias porciones o} cuotas de la herencia.

La problemática aquí es diferente porque el interrogante que se ha planteado la doctrina, cuando hay pluralidad de títulos que se refieran a una o varias cuotas de la herencia, a los efectos de la indivisibilidad de la declaración del delado, es saber cuando el llamamiento es único en relación al objeto y contenido del mismo, de tal manera que, si se entiende que hay un solo llamamiento, el sucesor sólo podría emitir una sola declaración de voluntad comprensiva de todo aquello a lo que hubiese sido llamado, por lo que, si aceptare, aceptaría todas las porciones o cuotas, mientras que, si repudiare, traería consigo el rechazo de todas ellas. $Y$, si se entiende que hay varios llamamientos, el sucesor puede emitir, o ha de emitir, tantas declaraciones cuantas sean aquellos, de lo que se derivaría la consecuencia de que podría aceptar unas porciones o cuotas y repudiar otras.

547 Vid GALVAN GALLEGOS: “La indivisibilidad de la aceptación y repudiación de la herencia”. Cit. Pág 1827. 
En este caso, a diferencia de lo que ocurrió en alguna etapa del Derecho Romano en que, tanto en el supuesto de que el llamamiento fuere a la totalidad de la herencia, como a varias partes de la misma, se rechazaba la aceptación o repudiación parcial por cuanto se tenía que hacer de manera total (Digesto 29, 2, 1-2 y 10), no sucede lo mismo en el derecho actual.

De forma particular, concreta y expresa, el Código Civil regula dos supuestos en los que se contempla la hipótesis que nos ocupa y que son: la concurrencia en un mismo sucesor de los títulos de heredero y mejorado, recogido en el artículo 833 ("el hijo o descendiente mejorado podrá renunciar a la herencia y aceptar la mejora"), y de heredero y legatario, o "prelegatario", en el artículo 890.2 ("el heredero que sea al mismo tiempo legatario, podrá renunciar la herencia y aceptar el legado, o renunciar éste y aceptar aquélla").

En ambos casos, se produce un concurso o pluralidad de delaciones, una simultaneidad de llamamientos a través de diferentes títulos ordenados por el testador a favor de un mismo sujeto, cada uno sobre diferentes porciones o cuotas de la herencia que, no solo son diferentes entre sí, sino independientes por razón de su contenido y naturaleza, lo que posibilita que el sucesor goce de total y absoluta libertad para poder ejercer cada uno de ellos de manera separada respecto del otro, lo que le permitirá, si es su deseo, aceptar uno de los llamamientos y repudiar el otro por cuanto no se interfieren, ni se limitan o condicionan entre sí. Se trata de supuestos en los que el llamado puede, no ya solo repudiar, o aceptar, los dos llamamientos, sino hacer declaraciones de signo diferente en relación a uno y otro, porque, dada la forma como se ha ordenado la disposición mortis causa, es voluntad del causante hacer distintos llamamientos a distintas porciones o cuotas de la herencia a través de diferentes títulos sucesorios. De ahí que, la ley, en el primer supuesto, permita que el sucesor pueda, en su caso, si es su voluntad, renunciar a la herencia y aceptar la mejora, o al revés, interpretado el artículo 833 a sensu contrario, repudiar ésta y aceptar aquella, y, en el segundo caso, de igual manera, podrá ser heredero y rechazar el legado, o al revés, ser legatario y rechazar la condición de heredero del causante. Alternativas que se fundamentan en la, presunta o expresa, voluntad del causante (cfr art. $675 \mathrm{CC}$ ).

Por otro lado, y acerca del párrafo $2^{\circ}$ del artículo 890, la norma en él contenida, cobra especial relevancia en aquellos casos en que, al tiempo que se designa a un heredero forzoso como sucesor a título universal, el causante le defiere su legítima por vía de legado porque, en este supuesto, la repudiación que, en su caso, hiciere de la 
herencia no implica la renuncia a la legítima, como tampoco al revés, si repudiare éste, el legado, en consecuencia, también la legítima, conserva los derechos sucesorios que le correspondieren por la vocación a título universal o de heredero.

Dentro de la problemática que comentamos, un supuesto que presenta, de alguna manera, cierta similitud con el que se recoge en este párrafo $2^{\circ}$ del artículo 890 $\mathrm{CC}$ y que nos merece una especial y particular atención, es aquel que tiene lugar cuando existe un legado y el legatario fallece sin haber hecho uso de su ius delationis, no ya sin haberlo aceptado -que no es necesario para adquirirlo conforme la doctrina del Código Civil (art. 881)-, sino, porque le sorprendió la muerte sin haberlo repudiado expresamente en el caso de que no lo quisiese, dando lugar al derecho de transmisión del mismo en favor de quienes sean sus respectivos sucesores. $Y$ ocurre que, después, éstos, en su condición de transmisarios, deciden aceptar la herencia de su causante, la del legatario-transmitente, pero, por el motivo que fuere, se plantean repudiar el legado que a éste le fue deferido proveniente de la herencia del primer causante. ¿Es ello posible?, ¿se puede emitir una declaración sobre el legado que sea independiente respecto de la herencia del legatario, de tal manera que sus sucesores pueden realizar, en su caso, dos declaraciones, una respecto del legado y otra sobre la herencia, distintas, separadas e independientes entre sí la una respecto de la otra? o, por el contrario, no puede realizar más que una sola declaración referida a la herencia que lleva implícito el legado, en cuyo caso, la repudiación o aceptación de aquella lleva consigo la del legado que le fue deferido al legatario-transmitente.

Sobre ello, la doctrina se mantiene dividida porque, autores como JORDANO FRAGA ${ }^{548}$, entienden que si nos inclinamos por la primera opción, estaríamos ante un supuesto de aceptación parcial porque los sucesores del legatario-transmitente suceden a título particular al primer causante y no a éste, que es su causante. Luego, la aceptación de la herencia del transmitente lleva consigo la del legado y no será posible, en su caso, aceptar aquella y repudiar éste. GETE-ALONSO ${ }^{549}$, en cambio, sí acepta esta hipótesis que califica de excepcional. Y otros, como GARCíA GARCÍA ${ }^{550}$, también admiten esta posibilidad y entienden que, pese a la dicción del artículo 990 CC, estaríamos, no ante un caso de aceptación parcial, sino de exclusión de unos bienes de la herencia.

${ }^{548}$ La sucesión en el "ius delationis": una contribución al estudio en la adquisición sucesoria mortis causa. Cit: Págs 350 y 351.

${ }^{549}$ Comentarios al Código Civil y Compilaciones Forales. T XXIX. Vol 3º. EDERSA. Madrid. 1986. Pag 287 y ss.

${ }^{550}$ La sucesión por derecho de transmisión. Ed. CIVITAS. Madrid. 1996. Págs 456 y 482, conclusión decimoséptima. 
En nuestra opinión, cierto es que se trata de un caso singular, pero entendemos que sí sería posible aceptar la herencia y repudiar el legado por dos motivos:

$1^{\circ}$.- de admitirse la segunda tesis, una sola declaración referida a la herencia que lleva implícito el legado, supondría, si no derogar, sí ir en contra del régimen del Código Civil en materia de legados, en el sentido de que se cercenaría la libertad de los transmisarios de poder repudiar el legado, porque, en otro caso, se les impone.

Para adquirir un legado, bien es cierto que no hace falta aceptarlo (art. 881 CC) pero, si no se quiere, ¿es preciso que se repudie para evitar que se suponga aceptado? ${ }^{551}$. Si esta es la opción que tenía el legatario-transmitente y que no ejerció, o no pudo ejercer, ¿por qué no van a gozar de la misma libertad sus sucesores?. Para ellos, no hay motivo para lo contrario, por lo que también regiría el mismo régimen de adquisición del legado que para su causante. Además, de no ser así, sería no solo modificar dicho régimen, sino imponer una aceptación ex lege del legado, o la imposibilidad de poderlo repudiar, lo que no deja de ser, sino una penalización a los sucesores del legatario-transmitente, sí una obligación o imposición. Aunque el legado se integre en la herencia del legatario-transmitente, por cuanto éste lo adquiere sin necesidad de que lo acepte, si bien de manera provisional al poderlo repudiar, que incluso ésta, tal vez, habría sido su decisión caso de haberla ejercido -en palabras de GUTIERREZ JEREZ ${ }^{552}$, el ius repudiandi sobre el mismo-, no por ello se sustrae a la normativa que rige en orden a su adquisición, que no se modifica cuando se produce un ius transmissionis sobre el mismo. Por tanto, los sucesores del legatariotransmitente entendemos que gozarían de la misma libertad que éste para repudiar el legado. Es definitiva, pasaría a ellos el mismo derecho que él tenía respecto del legado.

$2^{\circ}$.- Por razón de haber dos llamamientos, uno a título universal y otro a título particular, estaríamos ante un supuesto que, como decíamos, es muy semejante al del párrafo $2^{\circ}$ del artículo $890 \mathrm{CC}$, en que, el heredero que sea al mismo tiempo legatario, podrá renunciar a la herencia y aceptar el legado, o renunciar éste y aceptar aquella. Luego, los transmisarios estarían ante una opción que se podría considerar análoga o semejante a ésta y a la que se le podría aplicar por ello, entendemos, la misma regla.

${ }^{551}$ En este sentido, nos remitimos al punto número 3 del capítulo primero, donde, al final del mismo, después de analizar el sistema de adquisición de la herencia en nuestro ordenamiento jurídico, se hace una referencia al de los legados.

552 Op. cit.: Pág 2324. 
En este caso, si bien los transmisarios devendrían en sucesores de su causante respecto de los bienes de la herencia de éste, a resultas de la repudiación, no adquirirían lógicamente el legado, por lo que no entraría, ya de manera definitiva, en la herencia de su causante-legatario-transmitente, más exactamente, se extraería o quedaría excluido de la misma por cuanto se borraría, o se destruiría, esa adquisición provisional que de dicho legado se habría producido a favor del mismo.

Pero, dejando al margen estos supuestos a los que se da respuesta de forma expresa por parte de la ley, lo que le permite saber al delado a qué puede atenerse, se pueden producir otros en los que surge la dificultad de saber qué opción hay en el ejercicio del ius delationis cuando se da tal pluralidad de títulos y/o de cuotas porque se trata de situaciones atípicas a las que el Código Civil no da una respuesta para resolver la cuestión planteada ante la ausencia de normas o reglas sobre ello.

En este sentido, a diferencia de lo que ocurre en el derecho alemán, en el que se atiende al criterio, o regla, por disposición legal, de la forma cómo se ha hecho el llamamiento ${ }^{553}$, en nuestro derecho, la doctrina, ante la manifiesta insuficiencia del Código Civil en este punto, dejando al margen los supuestos ya apuntados, de los artículos 833 y $890.2^{\circ} \mathrm{CC}$, dado que las dos únicas normas que nos encontramos en él, es con los artículos 990 y 1009, acude al criterio de que exista o no lo que se ha denominado, "único fundamento de vocación", o "unidad o identidad de la causa", por VALLET, ROCA SASTRE ${ }^{554}$ o, lo que es lo mismo, en palabras de LACRUZ ${ }^{555}$ o de GITRAMA ${ }^{556}$, "el mismo fundamento en la vocación".

553 Vid VALLET (Panorama de derecho de sucesiones I. Cit: Pág 111): en él se distingue si el heredero es llamado en el mismo fundamento a partes diversas, o por distintos fundamentos de vocación, a distintas partes de la herencia, es decir, según se trate de un llamamiento a toda la herencia o parte de ella, hecho de una manera unitaria, o de llamamientos diferentes a una misma persona de diversas porciones hereditarias (BGB, §§ 1950 y 1951).

En el primer supuesto, la aceptación o repudiación son indivisibles, por lo que la declaración que se haga respecto de una parte vale también para las demás.

En el segundo, se subdistingue según que el llamamiento a las distintas porciones respondan a una misma causa o a causas distintas. De obedecer los llamamientos a una misma causa, la aceptación o la repudiación de una de las porciones hereditarias implica la de las otras, aunque hubieren sido deferidas más tarde (v. gr. por sustitución vulgar), mientras que si provienen de causas distintas, se podrán aceptar unas porciones y repudiar otras.

${ }^{554}$ Anotaciones al Derecho de Sucesiones de Kipp. Tomo V Vol 1º. Cit: Pág 53 y ss.

555 Derecho de sucesiones. Parte General. Cit: Págs 172, 175 y ss.

La doctrina alemana llama "fundamento de vocación”, a un supuesto de hecho al cual la ley une la consecuencia de que la persona que se encuentra en él puede ser heredero del fallecido. Y puede ser un determinado parentesco, que daría origen a la vocación intestada, o una declaración de voluntad, que daría origen a la vocación voluntaria o testada. En nuestro derecho a estas dos modalidades se refiere el Código Civil en los artículos 609 y 658.

556 Op. cit.: Pág 306. 
Siguiendo a VALLET ${ }^{557}$, se considera que hay "unidad o identidad de la causa", cuando los distintos llamamientos a favor del sucesor se han efectuado de alguna de las siguientes maneras: a) por un testamento, b) por varios testamentos ${ }^{558}$, c) por un contrato sucesorio, y d) por varios contratos sucesorios pactados con una misma persona.

En comentario a ello, a nuestro juicio, hay unidad en la vocación, o en la causa, cuando los diversos llamamientos que existen a favor del sucesor se diversifican o "reparten" entre títulos o fundamentos de vocación que son iguales o de idéntica naturaleza, de tal manera que, todos ellos, no solo tienen un mismo origen al provenir de una misma fuente, sino que, en la mayoría de las veces, se vienen a complementar entre sí, o servir de auxilio, unos a otros.

Habría "diversidad de causas" en los siguientes supuestos: a) cuando una parte de la sucesión se defiere por voluntad del causante y otra por disposición de la ley, b) si se llama a una parte por testamento y a otra por contrato sucesorio, c) si proceden de distintos contratos sucesorios convenidos por el causante con personas distintas, y d) si un heredero legítimo recibe porciones distintas por razón de su duplicidad de parentesco con el causante, o con una parte como cónyuge y otra como pariente.

En el primer caso, si se entiende que hay unidad de causa, la declaración del delado ha de referirse a todas las porciones que le hubiesen sido deferidas como si fuesen una sola. Mientras que, en el segundo, si los diversos llamamientos provienen de distintas causas, pueden aceptarse unas porciones y repudiarse otras, indiferente o indistintamente ${ }^{559}$.

Para LACRUZ ${ }^{560}$, "la cuestión de cuando hay vocación a participaciones diversas de la herencia, debe resolverse admitiendo que éstas existen cuando hay varios fundamentos de vocación eficaces, y fuera de esto debe aceptarse también la existencia de una pluralidad de partes hereditarias si el causante ha instituido a un coheredero en varias participaciones y las ha tratado en cuanto a los gravámenes de modo diferente".

${ }^{557}$ Panorama de derecho de sucesiones I. Cit: Pág 112.

${ }^{558}$ Se trataría de una delación hereditaria testamentaria doble, o múltiple, por pluralidad de testamentos, cuya coexistencia sólo es posible cuando el testador expresa en su último testamento su voluntad de que el/los anterior/es subsista/n en parte, lo que, en cierto modo, unificaría el llamamiento a cuotas distintas (Vid GALVAN GALLEGOS: "La indivisibilidad de la aceptación y repudiación de la herencia”. Cit. Pág 1827).

${ }^{559}$ Vid VALLET: Panorama de derecho de sucesiones I. Cit: Pág 112.

${ }^{560}$ Notas al "Derecho de Sucesiones" de Binder. Ed. LABOR. Barcelona. 1953. Pág 179. 
No obstante lo anterior, hemos de tener en cuenta que la independencia de los llamamientos realizados se puede ver alterada o modificada, en su caso, por la voluntad del testador, o el criterio interpretativo del artículo $675 \mathrm{CC}$, por cuanto puede en su testamento declarar separables o independientes las cuotas aunque de por sí no lo sean, o no separables los distintos llamamientos que, en principio, parezcan o puedan serlo ${ }^{561}$. De ahí que haya que estar, como apunta LACRUZ ${ }^{562}$, también en nuestra opinión, en cada caso concreto a la voluntad del causante porque habrá que presumir que es su voluntad hacer distintos llamamientos, o llamar a porciones o cuotas independientes, cuando en cláusulas distintas de un mismo testamento, o en varios, atribuye a un mismo heredero partes distintas de la herencia.

De igual manera piensa VALLET ${ }^{563}$, para quien, "si de la voluntad del causante resultare lo contrario, deberá respetarse, salvando el principio mediante entender que aquella voluntad presupone varios llamamientos alternativos: uno a la totalidad de lo dejado por ambos títulos, y otro u otros, por solo la institución contractual o por solo la testamentaria, o bien por cualquiera de las dos indistintamente".

Un caso que nos ha llamado la atención en relación a la cuestión que nos ocupa, no el ámbito del Código Civil, sino en la Ley 10/2008, de Sucesiones, de Cataluña, es la norma contenida en el número 2 de su artículo 461-2, según la cual, "Salvo que la voluntad del testador sea otra, se entiende que el llamado en cuotas diferentes que acepta cualquiera de ellas acepta también las otras, aunque le sean deferidas con posterioridad mediante sustitución vulgar o por cumplimiento de condiciones suspensivas". Esta norma se justifica por el hecho, ya comentado más arriba a propósito de la indivisibilidad de la declaración del delado, de que, cuando se produce este tipo de llamamientos, el carácter universal que tiene el título de heredero en la sucesión, al igual que sucede en Baleares, los unifica, dando lugar a la indivisibilidad de la repudiación, o de la aceptación, de la herencia, y el delado no podrá emitir más que una declaración, siendo ésta omnicomprensiva de todas las cuotas a que fuere llamado en la sucesión del causante, incluso aunque hubiese sido llamado a través de varios títulos sucesorios, lo que no sucede en el ámbito del Código Civil.

\footnotetext{
${ }^{561}$ Vid VALLET: Panorama de derecho de sucesiones I. Cit: Pág 111 y ss.

${ }^{562}$ Derecho de sucesiones. Cit: Pág 176.

${ }^{563}$ Panorama de derecho de sucesiones I. Cit: Pág 113.
} 


\section{3.- EL ARTÍCULO 1009 DEL CÓDIGO CIVIL: DELIMITACIÓN DEL ÁMBITO DE SU APLICACIÓN.}

A la vista de la casuística que venimos examinando, desde el punto de vista legal, al margen del artículo 990, el único precepto que nos encontramos en el Código Civil y que sería de aplicación a la misma para resolver la problemática que en estos casos se plantea, es con el artículo 1009, a cuyo tenor, "el que es llamado a una misma herencia por testamento y abintestato y la repudia por el primer título, se entiende haberla repudiado por los dos. Repudiándola como heredero abintestato y sin noticia de su título testamentario, podrá todavía aceptarla por éste"564.

Sin embargo, dicho precepto es manifiestamente insuficiente porque sólo se refiere al supuesto de ejercicio del ius delationis cuando se atribuye a un sucesor, en virtud de una pluralidad y concurrencia de títulos, testado y abintestato, la totalidad de la herencia o una cuota parte de ella. Es tambien oscuro y ambigüo en su tenor literal porque da lugar a más interrogantes que respuestas, ya que ni tan siquiera resuelve de manera adecuada las dos hipótesis que en él se contemplan, insuficiencia que va a dar lugar a que haya que aplicar otras normas sucesorias. De ahí que no sirva para resolver la amplia y compleja problemática que se plantea en otros casos en los que se produce, a resultas de otras circunstancias, esa pluralidad de títulos y/o de cuotas a que venimos aludiendo.

Parecida norma nos encontramos en otros textos sucesorios de nuestro ordenamiento jurídico ${ }^{565}$, aunque en algunos de ellos hay importantes diferencias en su contenido respecto del artículo 1009.

564 Con precedente en Digesto 29, 2, 17 y 77, y en la Ley 19, Título VI, Partida 6a que ya recoge esta norma. Este artículo es copia del artículo 840 del Proyecto de 1851. Se modificó después en el Anteproyecto de 1882, aunque finalmente se volvió a la redacción del Proyecto de GARCÍA GOYENA.

Mucho se ha escrito por parte de la doctrina acerca de este artículo. Así, entre otros:

ALBALADEJO: "La repudiación de la herencia”. Cit: Págs 751 y 752; GARCÍA GARCÍA: Op. cit.: Pág 244 y ss; GITRAMA: Op. cit.: Pág 303 y ss; LACRUZ BERDEJO: Derecho de sucesiones. Parte General. Cit: Pág 175 y ss; GALVAN GALLEGOS: "La indivisibilidad de la aceptación y repudiación de la herencia”. Cit. Pág 1834 y ss; MONSERRAT VALERO: “La sucesión "iure transmissionis", el concurso de delaciones en un mismo heredero y el impuesto de sucesiones". RCDI. Año LXX. Mayo-junio 1994. Nº 662. Pág 1059 y ss; SILLERO CROVETTO: Comentario al artículo 1009 CC en Jurisprudencia civil comentada (Tomo I). Dirección: Pasquau Liaño. Ed. COMARES. Granada. 2000. Pág 1699.

${ }^{565}$ Así, la Ley 316 de la Compilación de Derecho Civil Foral de Navarra reproduce dicho artículo en parecidos términos, al decir que, "el que renuncie a una herencia deferida por voluntad del causante quedará excluido de la sucesión legal de éste. El que renuncie a la sucesión legal renuncia también a la voluntaria, a no ser que ignorase el llamamiento".

En cambio, en el derecho civil catalán, el artículo 461-11 de la Ley 10/2008, de sucesiones, (con precedente en los artículos 256.1 de la Compilación de 1960 y 27 del Código de Sucesiones de 1991), 
Pasando ya a su análisis, en cada uno de los dos párrafos que lo integran, se contemplan sendos supuestos en los que se da la circunstancia de que son inversos entre sí porque, en el primero de ellos, trata de la repudiación del título testado al tiempo que hay una delación abintestato y, en el segundo, de la repudiación del título del intestado apareciendo después el testamentario.

Al hilo de ello, y a la vista de que en él se contempla la posibilidad de poder aceptar una herencia después de haberla repudiado, lo que constituiría, a nuestro juicio, ya habíamos apuntado, una excepción al principio de irrevocabilidad sancionado por el artículo 997 CC, la cuestión que en él se suscita y debate es la siguiente: si se trata de la atribución, a una misma persona, de la totalidad de una herencia, o una cuota parte de ella, por diversos fundamentos de vocación, o si regula una sucesión deferida, en parte por testamento y, en parte abintestato, en que corresponda de forma simultánea a un mismo sujeto dos porciones distintas, siendo llamado, a una de ellas, por el testador y, a la otra, por la ley.

A este respecto, tratando de aclarar su aplicación, y en comentario general al mismo, manifiesta LACRUZ ${ }^{566}$ que, "no es aplicable al caso de que correspondan a la vez a un heredero, en una sucesión, que se defiere por testamento o por contrato, o en parte por la voluntad del causante y en parte abintestato, dos distintas porciones, ambas asignadas por el causante o por la ley, o una disposición mortis causa y otra atribuída por la ley".

dispone que, "el llamado que repudia la herencia testamentaria puede aceptar la intestada, pero sujetándose a los legados, fideicomisos, condiciones y demás cargas que el testador haya impuesto”. A lo que añade, "la repudiación de una herencia en la creencia de que era intestada no perjudica al repudiante si ha sido llamado a la sucesión en testamento o pacto sucesorio". Esta segunda norma, en nuestra opinión, es confusa en su redacción si se la compara con la anterior del artículo 27, que era más clara, según la cual: "si el llamado repudia la herencia intestada con conocimiento de que es instituido heredero en testamento, se entenderá que ha repudiado la herencia testada; pero si lo ignoraba, la repudiación no le perjudicará". Vid, en este sentido: JOU I MIRABENT, L (coord.): Comentarios al Código de Sucesiones de Cataluña: Ley 40/1991, de 30 de diciembre. BOSCH. Casa Editorial. Barcelona. 1994. Pág 91 y ss.

De igual manera, en Aragón: "El llamado a una herencia por disposición voluntaria que sin ella estuviera también llamado por disposición de la ley, se entiende que si la repudia por el primer título la ha repudiado por los dos, salvo que en el mismo acto manifieste su voluntad de aceptar como heredero legal. En este último caso, quedará sujeto a las mismas modalidades, limitaciones y obligaciones impuestas por el disponente. Si el llamado repudia la herencia como heredero legal y sin noticia de su llamamiento voluntario, puede aceptarla todavía por éste" (344 CDFA).

Aquí vemos cómo, tanto en el derecho de sucesiones catalán como aragonés, se permite repudiar a la delación testada y aceptar a la intestada.

${ }^{566}$ Derecho de sucesiones. Parte General. Cit: Pág 175. 


\section{3-1.- Interpretación del párrafo primero y presupuestos para su aplicación.}

De su redacción, han surgido dos interpretaciones, contrapuestas entre sí, en qué se entiende cuando dice, el que es llamado "a una misma herencia" por testamento y abintestato, porque, ¿en qué consiste ese doble llamamiento a través de las dos sucesiones, testada e intestada?:

a) para unos, se trata de dos llamamientos simultáneos, que se producen a la vez, a un mismo tiempo, cada uno con su respectiva delación (uno por vía testada y otro por vía abintestato), en favor de un mismo sucesor.

De esta opinión es O'CALLAGHAN ${ }^{567}$, para quien, en el supuesto de que concurrieren en un mismo sujeto los dos títulos sucesorios, testado y abintestato, si repudia por el primero, se entiende repudiada toda la herencia, porque, según él, dado que el artículo 990 CC no permite aceptar en parte, ni repudiar en parte, lo que hace el artículo 1009 es imponer la sanción de una repudiación total.

Sin embargo, en nuestra opinión, no es aceptable este razonamiento porque, en el caso de que se trate de un llamamiento simultáneo, por distinto fundamento de vocación, a varias cuotas hereditarias, la independencia que hay entre cada uno de ellos permite aceptar unos y repudiar otros, por lo que el delado puede actuar con total libertad. Y, en el supuesto de que ese llamamiento simultáneo fuese a la misma cuota o participación, la sucesión testada tendría preferencia y prioridad sobre la intestada, dado que aquélla, por disposición legal, excluye a ésta (arts. 658.1, 912.1 CC), por lo que sólo podrá tener lugar un único fundamento de vocación. Una y otra serían absolutamente incompatibles entre sí, de manera simultánea, a un mismo tiempo, sobre una misma porción o cuota de la herencia y no podrían existir respecto de ésta porque la ley lo impide, dos llamamientos a la vez, uno por vía testada y otro por vía intestada.

De ahí que, para que existan dos llamamientos simultáneos respecto del mismo sucesor en la misma herencia, es preciso que necesariamente lo sea, al menos, a sendas porciones o cuotas, cada una con su respectiva delación. Y, en este caso, podría el sucesor libremente aceptar una vocación y repudiar la otra, de manera independiente, sin que se interfieran entre sí, puesto que serían dos llamamientos distintos, separados e diferentes entre sí, provenientes de distintos títulos sucesorios.

567 Comentario del Código Civil. Secretaría General técnica del Ministerio de Justicia. Madrid. 1993. Pág 2387. 
b) Para otros, en cambio, se trata de dos llamamientos sucesivos y subsidiarios en favor de un mismo sucesor respecto de la misma porción o cuota, de tal manera que se abre el segundo, el título intestado, después, a resultas o como consecuencia de la repudiación del primero, el título testado.

Según esta lectura u opinión, el designado como heredero testamentario repudia su porción o cuota por este título y, precisamente como consecuencia de ello, en una relación de causa-efecto, se abre, con carácter subsidiario o defectivo (art. 912.3 CC), respecto de lo que él ha repudiado, la vía intestada, resultando ser él mismo, por aplicación de las normas legales de ésta, quien vuelve a ser llamado a ello pero, esta vez, como sucesor abintestato del causante. El llamamiento, ahora, lo hace la ley, de forma sucesiva y supletoria, después del que hizo el testador, al haber quedado el suyo agotado y resultar estéril o frustrado, precisamente a resultas de su repudio, para deferir la porción o cuota repudiada.

Entonces, aplicando el tenor del inciso primero del artículo 1009 CC, resulta que, una vez que el delado ha repudiado la cuota o porción a que él estaba llamado por vía de la delación testada, no puede ahora volver a ser llamado a ella como sucesor abintestato de la misma. Se trata así de evitar que nazca a su favor la delación legal sucesiva, prevista para el caso de repudiación, en la que se le brindaría la posibilidad de volver a pronunciarse sobre la misma porción o cuota que él ya repudió a través de la delación testada. Además, se entiende, o se parte de la presunción de que, si ha repudiado es porque su voluntad realmente es la de no querer suceder al causante. Luego, no tiene sentido, es una incoherencia, algo incongruente, que ahora se le ofrezca la posibilidad u oportunidad de poder volver a emitir una declaración de voluntad sobre lo que él mismo ya repudió, y que ahora, si ha cambiado de opinión, por el motivo que fuere, lo acepte por vía intestada.

Después, ya en lo que se refiere a los efectos que de ello se derivan, una vez producida la repudiación, habría que llamar a los que fueren sucesores abintestato del causante del mismo grado que el renunciante, con exclusión de él, o los que lo fueren del grado o línea siguiente, según los sucesores que hubiese (cfr. arts 922 y 923 CC).

Ésta es la interpretación más acorde con los precedentes históricos del artículo que podemos encontrar en la legislación de Partidas ${ }^{568}$, y más extendida acerca de la lectura de este párrafo que hay dentro de la doctrina ${ }^{569}$.

${ }^{568}$ Ley 19, Título VI, Partida $6{ }^{\mathrm{a}}$. 
El fundamento de la imposibilidad de que vuelva a ser llamado el repudiante, ahora a través de la vía intestada, aparte de las razones arriba esgrimidas, radica, además, desde el punto de vista ético o moral, en el comportamiento o actitud, que se puede calificar de ingratitud o menosprecio, que ha tenido el sucesor hacia el causante por la decisión de repudiar su herencia precisamente a través de la propia vocación que le hizo a través del testamento. Se entiende que quien repudia una herencia lo hace porque efectivamente no quiere ser heredero del causante de la misma. De ahí que, al constituir su comportamiento un rechazo hacia su voluntad, un desaire, le hace ser merecedor de su exclusión, de no ser su sucesor. Incluso se puede entender, o nos podemos imaginar, que de haberlo sabido el causante, él mismo no lo volvería a llamar a su sucesión. Por ello, si después le es de nuevo deferido lo que él ya repudió, ahora por vía intestada, aparte de que el sucesor iría contra sus propios actos, sería un contrasentido, una contradicción, que volviese a tener la oportunidad de volver a pronunciarse sobre ello, incluso de poder aceptar, lo que sería totalmente contrario respecto de lo que ya declaró. El sucesor por su comportamiento ya no es digno de suceder a quien ya le ha dicho que no por causa de ingratitud hacia él ${ }^{570}$. En este caso, la imposibilidad de poder pronunciarse de nuevo sobre la herencia se puede decir que vendría justificada por el hecho de que se entiende que, como consecuencia de dicho repudio, rechazaría toda otra delación que se le defiriera, o se le vaya a deferir a su favor en el futuro. Luego, no tiene sentido que tenga una nueva posibilidad de volver a pronunciarse sobre la herencia, ahora a través de la sucesión intestada.

A los argumentos anteriores, se puede añadir una razón más para que el sucesor que repudia la delación testada no pueda volver a ser llamado, respecto de la misma porción o cuota repudiada, después por vía intestada: si así fuese, entendemos

569 Así, entre otros:

GITRAMA, para quien la expresión “a una misma herencia”, hace referencia a llamamientos sucesivos porque, "repudiada la herencia por el heredero testamentario y abierta en consecuencia, la sucesión abintestato, sea él mismo declarado heredero por ser el más próximo pariente del finado. Luego, en presencia del primer párrafo del artículo 1009, habrá que llamar a los demás parientes del mismo grado y no a él, y si era único en el grado, a los del grado posterior, sin sobrepasar el cuarto" (Op. cit.: Pág 305).

De igual manera, en palabras de LACRUZ, el artículo 1009 en su primer párrafo se refiere, “a la atribución, por dos títulos distintos, de una misma herencia o cuota de ella, y no es aplicable al caso de que correspondan a la vez a un heredero, en una sucesión que se defiere por testamento o contrato, o en parte por la voluntad del causante y en parte abintestato, dos distintas porciones, ambas asignadas por el causante o por la ley, o una disposición mortis causa y otra atribuida por la ley". A lo que añade después que, cuando habla de "una misma herencia”, se está refiriendo a llamamientos sucesivos, porque si son simultáneos, ya sea alguno por ley, ya todos por la voluntad del causante, mientras sean verdaderamente independientes entre sí, el sucesor es dueño de aceptar o de repudiar cada uno de ellos (Derecho de sucesiones. Cit: Pág 175).

También GALVAN GALLEGOS: “La indivisibilidad de la aceptación y repudiación de la herencia”. Cit. Pág 1835 y ss.

${ }^{570}$ Vid: GITRAMA: Op. cit.: Pág 306. 
que se dejaría en sus manos, a su libre albedrío y voluntad, el destino de la herencia por cuanto podría, no sólo ir en contra de la voluntad del causante, sino incluso frustrarla o dejarla sin efecto ya que, al forzar la apertura de la sucesión intestada, podría dar lugar incluso a otra distribución diferente de los bienes de la herencia sabedor de que en ésta rigen otras reglas diferentes, como también habría, en su caso, sucesores diferentes, incluso aquellos que el causante no llamó a su sucesión al otorgar testamento -tal es el caso de los hermanos y demás parientes colaterales-, y que ahora podrían llegar a sucederle. Sería una forma de desvirtuar o enervar el llamamiento hecho por el causante (GITRAMA ${ }^{571}$ ). Aparte de que no dejaría de ser un fraude o una burla, tanto para la voluntad del causante por el motivo antes indicado, como para la ley, por cuanto ésta prefiere y tiene establecido que prevalezca la delación testada sobre la intestada, incluso para la propia sucesión mortis causa del causante y todas las demás personas interesadas, directa o indirectamente, en ella.

En otro orden de argumentos, y en lo que se refiere a las circunstancias que han de concurrir para que proceda la aplicación de la regla del párrafo primero del artículo 1009 CC, entendemos que es preciso el cumplimiento de los siguientes requisitos:

$1^{\circ}$.- ha de tratase de una sucesión testada en la que no puede haber cláusula de sustitución respecto del repudiante, o que ya estuviere agotada si quien repudia es el sustituto, porque, de existir dicha cláusula y ésta se hubiere previsto u ordenado para el caso del repudio, una vez que éste se ha producido, sería llamado el sustituto designado por el causante, con lo que se excluye la sucesión abintestato.

$2^{\circ}$.- Tampoco ha de haber lugar, en su caso, a falta o por agotamiento de la cláusula de sustitución, al derecho de acrecer entre los demás cosucesores, si los hubiere, para que proceda la apertura de la sucesión abintestato (art. 912.3 CC) respecto de la porción o cuota repudiada, momento en el que serían llamados aquellos a que hubiese lugar de conformidad con las normas de la sucesión legal, de entre los cuales podrían encontrarse los restantes sucesores testamentarios.

Éstos, ahora, ya como sucesores abintestato del causante respecto de la porción o cuota repudiada, pueden libremente repudiarla, o aceptarla, por dos motivos: es una cuota diferente de la que se les defirió a ellos por vía testada y no son los "culpables" de la apertura abintestato de la sucesión, de lo que se deriva la consecuencia de que, con independencia de cual fuere su anterior manifestación, pueden decidir ahora libremente y aceptarla o repudiarla.

\footnotetext{
${ }^{571}$ Op. cit.: Pág 307.
} 
El sucesor repudiante, aunque, en principio, le correspondiere ser llamado en virtud de las normas de dicha sucesión, quedaría, por aplicación de este párrafo, excluido lógicamente del llamamiento intestado.

$3^{\circ}$.- El llamamiento testado e intestado ha de serlo a una misma porción o cuota de la herencia y no a porciones o cuotas diferentes porque, si así fuere, las delaciones serían independientes entre sí y el delado podría libremente aceptar unas y repudiar otras.

$4^{\circ}$.- Sendas delaciones dimanantes de las sucesiones, testada e intestada, han de ser a favor del mismo sucesor como consecuencia de las reglas que resulten aplicables a una y otra.

$5^{\circ}$.- Que el llamamiento abintestato se produzca de forma subsidiaria o sucesiva, en el sentido de que sea una consecuencia directa e inmediata, en una relación de causa a efecto, derivada del repudio de la delación testada por parte del sucesor ${ }^{572}$. Que sea él quien, a resultas de su propio repudio, haya dado lugar a la apertura de la sucesión intestada. Decimos esto porque, si se diere la circunstancia de que hubiere una segunda repudiación proveniente de otro sucesor, el primer repudiante, sí podría ser llamado a la porción o cuota repudiada por parte del segundo repudiante si así resulta de la aplicación de las normas legales de la sucesión intestada porque, no solo dicha vocación nace de otro título diferente, sino que él no ha dado lugar a la apertura de la sucesión intestada respecto de esta segunda poción o cuota repudiada, en cuyo caso, él tendría, a su favor, una nueva delación, en virtud de otro título diferente de aquel por el que se le defirió la porción que él repudió, ante lo que puede repudiar, o aceptar, esta otra cuota o porción de herencia.

Vemos así como el tenor del precepto es a todas luces insuficiente para poder resolver y dar respuesta a todos los casos que se pueden producir en los que la herencia de una persona se defiera, a la vez, a través de una y otra sucesión, testada e intestada, porque dicha simultaneidad de sucesiones puede tener, según veremos a continuación, en este mismo capítulo, un origen muy diverso.

572 Como ya hemos comentado, nunca el llamamiento sobre una misma porción o cuota se podrá producir de forma simultánea ya que tendría preferencia la delación testada sobre la intestada porque, para que se trate de un llamamiento simultáneo, unos por ley y otros por la voluntad del causante, es preciso que recaigan necesariamente sobre porciones o cuotas diferentes, en cuyo caso, las delaciones son, en su ejercicio, autónomas e independientes entre sí, de tal manera que el sucesor es dueño de aceptar o de repudiar, por separado y de forma independiente cada una de ellas. 
A propósito de esta hipótesis, no sucede lo mismo en el derecho alemán porque si se diere la circunstancia de que un sujeto fuese llamado a la sucesión como heredero por disposición por causa de muerte, si, sin dicha disposición estuviese llamado como heredero legítimo, puede repudiar la herencia como heredero instituido y aceptarla como heredero legítimo (§ 1948-1 del BGB).

\section{3-2.- Interpretación del párrafo segundo y presupuestos para su aplicación.}

El supuesto a que se refiere el párrafo segundo del artículo 1009 CC es inverso al primero porque en él, primero procede la apertura de la sucesión abintestato y después la testada, como consecuencia de la posterior aparición de un testamento causante, surgiendo así la pluralidad de delaciones o de títulos sucesorios que se contempla en dicho precepto.

Sin embargo, en este caso, el sucesor sí tiene la opción de volver a pronunciarse de nuevo sobre la misma herencia porque, aquí, "repudiándola como heredero ab intestato y sin noticia de su título testamentario, podrá todavía aceptarla por éste", lo que supone dar un tratamiento diferente respecto del supuesto del primer párrafo.

No obstante, pese al tenor del precepto, nos planteamos el interrogante de, si el mero hecho de la aparición del testamento deja sin efecto, de forma instantánea o automática, ope legis, la declaración de repudio realizada en virtud de la vocación intestada, de tal manera que es como si el delado no la hubiese realizado, y pueda aceptar ahora la herencia de su causante, o si es preciso instar su nulidad y, en este caso, ¿ante qué clase de nulidad estamos?. La respuesta a estos interrogantes, está condicionada por varias circunstancias.

En el orden fáctico de los hechos, abierta la sucesión intestada por inexistencia de la testamentaria, el sucesor decide repudiar la herencia -tal vez, en señal o como gesto de desaprobación, o rechazo, al comportamiento del causante por el hecho de que "no se haya acordado de él" instituyéndole como heredero en testamento porque así lo hubiesen hablado, o no le haya dejado el legado que le prometió u ofreció dado el comportamiento que tuvo con él en vida-. Pero, después del repudio, aparece un testamento, desconocido hasta entonces, como puede ser el caso de un ológrafo, que es el caso más frecuente y probable -un testamento abierto ya habría aparecido en el certificado de últimas voluntades-, del que, dado su carácter privativo, no se tenían noticias de su existencia y en el que el repudiante aparece instituido como heredero, ante lo que se plantea ahora, incluso en señal de gratitud y agradecimiento, al amparo de este artículo 1009, aceptar la herencia. El sucesor tendría así una segunda 
oportunidad de volver a pronunciarse sobre la herencia, pese a haberla repudiado con anterioridad, y podría aceptarla ahora, a través de la delación testada. En consecuencia, si aceptare, parece deducirse del tenor del precepto que su anterior declaración de repudiación quedaría invalidada, sin valor ni efecto alguno, y el sucesor devendría en heredero del causante.

El tenor literal de este segundo párrafo del artículo 1009 CC, en principio, parece claro y no deja lugar a dudas en su interpretación: la repudiación de la herencia inicialmente realizada al amparo de la delación intestada devendría ineficaz por la circunstancia sobrevenida de la posterior aparición del testamento y subsiguiente declaración de aceptación emitida a resultas de la delación proveniente del mismo. No obstante, conviene hacer algunas matizaciones:

\section{Primera.- El contenido del testamento.}

Una circunstancia que, a nuestro juicio, es de vital y trascendental importancia, y que, en cualquier caso, hay que examinar, valorar y tener muy en cuenta en cada caso, es el hecho de, si el testamento que ha aparecido, anula o no, en todo o en parte, la sucesión mortis causa abintestato ya abierta del causante ${ }^{573}$, o si son incluso compatibles entre sí.

Así, puede ocurrir que exista compatibilidad entre una y otra sucesión, en cuyo caso, la sucesión se deferiría, a la vez, a través de ambos títulos sucesorios, de lo que se derivaría, en consecuencia, la circunstancia, y la necesidad, de ver si la vocación dimanante del testamento que ha aparecido y cuya existencia se desconocía hasta ese momento, afecta o no a la del sucesor abintestato que repudió, en cuyo caso, puede suceder que la repudiación sea definitiva y ya no pueda aceptar.

Pero, si el testamento que ha aparecido basta y es suficiente para regular por sí solo de manera total y completa la sucesión mortis causa del causante, o deja totalmente sin efecto la delación abintestato por ser incompatible con ella ${ }^{574}$, la sucesión intestada quedaría totalmente invalidada, dada la prevalencia de aquella sobre ésta, por lo que la declaración del repudiante, así como la de todos los demás sucesores provenientes de la vocación y delación intestada, no tendría valor ni efecto

${ }^{573}$ Véase en este sentido, el punto número 5 del capítulo décimo, donde se analiza más en detalle y en profundidad la aparición del testamento como causa de ineficacia de la declaración de repudio, así como las distintas circunstancias que, en su caso, han de concurrir para que se produzca dicha ineficacia, al que nos remitimos.

574 Tal es el caso de que, a través del mismo, se instituye a otro sucesor, o más sucesores, o vuelve a ser llamado el mismo sucesor que repudió, ya sea a una porción o cuota diferente de la herencia, ya incluso a la misma porción o cuota que él rechazó. 
jurídico alguno. De lo que se derivaría la consecuencia de que podrían, o tendrían que emitir, en su caso, una nueva declaración de voluntad a resultas del ius delationis que emana de la vocación testamentaria, pudiendo ser incluso de signo contrario a la que emitieron a través de la delación abintestato. Ahora bien, en el caso del sucesor que repudió, es preciso, lógicamente, que sea llamado a la herencia por parte del causante a través de su testamento porque, de no ser así, ante la inexistencia de vocación testamentaria a su favor, aparte de que su declaración de repudiación queda sin efecto, ya no podrá manifestarse de nuevo sobre su herencia. Aunque, en este caso, ya no estaríamos ante la dualidad de títulos sucesorios de que trata el párrafo segundo de este artículo 1009.

Distinto es que el sucesor abintestato que repudió, ahora, en el testamento, fuese llamado a otro título diferente, como puede ser el particular de legatario, en cuyo caso, se produciría a su favor una nueva delación pero a una porción o cuota diferente de la herencia, y en virtud de un título o fundamento de vocación también diferente, en cuyo caso, al ser una pluralidad de vocaciones, no sólo distintas, separadas e independientes entre sí, sino que se refieren a otros bienes, las delaciones son autónomas e independientes entre sí, por lo que las declaraciones de voluntad que surjan provenientes de cada una de ellas, no se interfieren unas con las otras, de lo que resulta, por un lado, que la repudiación realizada al amparo de la vocación intestada seguiría siendo válida al no quedar afectada por la aparición del testamento $y$, por otro, el ahora legatario puede, si quiere, aceptar el legado -aunque su declaración no sea necesaria para adquirirlo-, o repudiarlo. Pero, en este caso, ya no estamos tampoco ante el supuesto de hecho a que se refiere este segundo párrafo del artículo 1009 CC porque es presupuesto esencial en su aplicación que los dos títulos sucesorios, testado y abintestato, deferidos a favor del mismo sucesor, recaigan sobre la misma cuota o porción de herencia.

Segunda.- La ineficacia del repudio no es automática.

Otra observación o apreciación que, a nuestro juicio, merece el párrafo es que, la ineficacia de la declaración de repudio realizada al amparo de la delación abintestato no es automática y, además, no siempre se tiene por qué producir ya que, pese a la aparición del testamento, puede ocurrir incluso que el repudio subsista y surta plenos efectos jurídicos. Y ello, por lo siguiente.

El artículo 1009 CC dice que, “.... podrá todavía aceptarla .....”, lo cual significa, o nos está dando a entender, dado que el término "podrá" denota voluntariedad y no 
imperatividad, es que el sucesor, si quiere y es su deseo, está aún a tiempo de poder aceptar pese a haber repudiado. Pero, lo que el precepto no dice, como tampoco da a entender, es que la repudiación sea ineficaz de forma instantánea y automática como consecuencia o por el mero hecho de la aparición del testamento.

En nuestra opinión, dicha ineficacia estaría suspensivamente condicionada a una doble circunstancia: por un lado, a la aparición del testamento y subsiguiente incompatibilidad del mismo con la delación abintestato y, por otro, a que, el sucesor, al amparo de la delación testada, acepte la herencia, porque, si su voluntad es, en cualquier caso, repudiar la herencia del causante, al haber ya repudiado, entendemos que no es preciso que haga uso de la delación testada porque la repudiación realizada, siendo válida y eficaz, es definitiva e irrevocable (art. 997 CC). Ahora bien, para ello es preciso que haya una total y absoluta identidad o coincidencia entre ambas delaciones, no ya en cuanto al sujeto, sino en cuanto al objeto, en el sentido de que el sucesor tiene que ser llamado exactamente a la misma e idéntica porción o cuota de la herencia a través de ambas delaciones, abintestato y testada, porque, si a través de la delación testada el sucesor es llamado a otro objeto, porción o cuota diferente de la herencia, necesariamente tendrá que manifestar su voluntad de repudio si no quiere suceder en aquello que le ha dejado el causante a través del testamento. Entendemos que resultaría absurdo repudiar algo que ya se ha repudiado. Pero, si hay identidad de objeto, y lo que quiere el sucesor, ahora, es aceptar la herencia, entonces sí que podrá, o tendrá que hacerlo a través de la delación testamentaria, en cuyo caso, como decimos, sí que devendría en ineficaz la declaración de repudio.

Tercera.- La buena o mala fe del sucesor.

El título testamentario, aunque no lo diga el precepto se deduce de su tenor, ha de surgir después de que el sucesor haya repudiado la herencia por vía intestada, por lo que se trata de un testamento del que se ignora totalmente su existencia hasta ese momento.

No obstante, puede ocurrir que el testamento ya exista en el momento de emitir dicha declaración, en cuyo caso, es preciso que el sucesor haya actuado de buena $\mathrm{fe}^{575}$, es decir, ignorando su existencia. En caso contrario, le perjudica y su declaración

575 Se actuaría de mala fe cuando el sucesor sí conoce la existencia de un testamento anterior, así como su contenido, como puede ser el caso de que tenga noticias de que el causante otorgó un testamento ológrafo porque él se lo reveló, o porque le ayudó a redactarlo, o incluso se lo confió para su custodia pero lo mantiene oculto y guarda silencio sin revelar su existencia, y después, como un gesto de desaprobación, desaire o desprecio al causante por no haberle, por ejemplo, dejado en su testamento un determinado bien o derecho, o no le haya mejorado, o le haya instituido heredero, decide repudiar la 
será definitivamente válida y eficaz por lo que no podrá, si es su deseo, aceptar ahora la herencia a través de la delación testada.

\section{Cuarta.- Eficacia del repudio.}

Entendemos que la declaración de repudio inicialmente emitida por parte del delado al amparo de la delación intestada, aunque quede invalidada después por la posterior aparición del testamento, de haberse emitido o realizado conforme a derecho, es, en principio, ab initio, en el momento de su exteriorización, jurídicamente válida y eficaz, y surte todos los efectos que le son propios.

De ahí que, en este caso, estaríamos, en sentido propio, estricto y técnico, ante un caso de ineficacia sobrevenida por causa de revocación a resultas de la aparición del testamento que deja sin efecto la vocación y delación intestada.

En cambio, para GITRAMA ${ }^{576}$, estamos ante, "una excepción a la irrevocabilidad que proclama el artículo 997 CC" porque el sucesor, en el caso de que aparezca un testamento instituyéndole el causante, según él, puede revocar su declaración.

Disentimos de esta opinión porque el sucesor no revoca su declaración, sino que es la aparición de testamento lo que enerva y deja sin efecto la vocación y delación intestada, en consecuencia, la declaración del sucesor. Hasta el instante en que aparece el testamento, la declaración de repudio, si se ha realizado conforme a derecho, cumpliendo todos los presupuestos y requisitos exigidos por la ley, produce todos los efectos y consecuencias jurídicas que le son propios, luego, es jurídicamente válida, perfecta y, por ello, irrevocable ${ }^{577}$. Pero, si después se da la doble circunstancia de que aparece un testamento del causante que deja sin efecto la vocación intestada y se produce la subsiguiente aceptación por parte del sucesor, la repudiación, desde ese mismo instante, deviene en ineficaz al quedar totalmente enervada la vocación (art. 991 CC), intestada, en este caso, de la que proviene la repudiación. De ahí que, no por ello entendemos que se pueda hablar de una excepción a la irrevocabilidad porque el repudio era perfecto e irrevocable, por lo que no cabe excepción alguna. Y sí, en cambio, de una ineficacia sobrevenida a resultas de la aparición del testamento lo que motiva su revocación.

herencia. En este caso, no se invalidaría la repudiación realizada por cuanto se hizo con pleno conocimiento de que ya existía ese testamento. Luego, no se podrá pretender impugnar, en base a ello, dicha declaración.

${ }^{576}$ Op. cit.: Pág 308.

${ }^{577}$ En este sentido, nos remitimos a cuanto se expone en el punto número 1 del capítulo anterior a propósito de la irrevocabilidad de la declaración. 
Además, puede incluso ocurrir que, cuando el sucesor emitió su declaración de repudio lo hizo, probablemente, en la firme convicción y creencia de que el destino mortis causa de los bienes del causante se deferiría a través de la sucesión intestada por ser la que estaba abierta en ese momento. Porque, es distinto que ya se conozca la existencia del testamento, en cuyo caso, el sucesor, actuando de buena fe, habría obrado en consecuencia a ello, no habría repudiado al amparo de una sucesión que se frustró por el testamento y sí ejercería el ius delationis proveniente de la delación testada. Pero, si el sucesor ignoraba, de buena fe, su existencia y manifestó su repudiación al amparo de la delación intestada creyendo que era ésta por la que se regía su derecho a la herencia, entonces estaríamos ante un error propiamente dicho, imputable a él aunque sea de forma involuntaria o negligente, porque, en el momento de emitir su declaración de voluntad, tendría que haber puesto toda la diligencia debida para saber cómo, por qué reglas (cfr. art. 991 CC), se iba a regir la sucesión del causante, y si existía o no testamento cuando él decidió repudiar la herencia. En este caso, las circunstancias son diferentes y entonces sí estaríamos hablando, no ya de una ineficacia sobrevenida, sino de un vicio de la voluntad impugnable por error al amparo del artículo 997 CC.

Por otro lado, en nuestra opinión, la norma del párrafo segundo del artículo 1009 $\mathrm{CC}$, es, hasta cierto punto, no ya solo lógica, sino vana e innecesaria, incluso absurda, porque, dada la preferencia o prioridad que tiene el título testado sobre el intestado (cfr arts. 658 y $912.1^{\circ} \mathrm{CC}$ ), la sucesión se ha de regir a través del aquel, por lo que quedaría invalidada la declaración del delado y éste se verá obligado a emitir una nueva declaración respecto de la herencia del causante en base a la delación testada. Pero, si el testamento solo sirve para regular de manera parcial la sucesión por resultar compatibles, respecto del sucesor que repudió, las dos delaciones, testada e intestada, entonces sí que tendría sentido dicha norma (habría a su favor un doble llamamiento a la herencia a través de dos títulos o fundamentos distintos de vocación), siempre y cuando, además, por un lado, cada una de las delaciones se refiera a diferente cuota o porción de bienes $y$, por otro, apareciese dicho testamento o desconociese su existencia, esto es, hubiese actuado de buena fe al tiempo de manifestar la declaración de repudio. De ahí que, si el repudiante intestado no ha sido instituido heredero en dicho testamento, no procede una nueva declaración sobre la herencia al no haber vocación testada a su favor. Basta y es definitiva la ya realizada. Mientras que si ha sido instituido, sí. 
La justificación o motivo, entre otros, en que se puede fundamentar o justificar esta permisibilidad o tolerancia al sucesor de poder aceptar la delación testamentaria de una sucesión después de repudiar la delación intestada, estaría en que, de esta manera, se le brinda la oportunidad de poder heredar, no porque lo diga la ley, sino en atención y correspondencia al llamamiento que le ha hecho el propio causante, como también es una forma de ensalzar su honra, memoria y voluntad, que es ley en la sucesión, y al hecho de dar prioridad o preferencia a la sucesión testada sobre la intestada al ser ésta secundaria o subsidiaria respecto de aquella. Lo contrario, no dejaría de ser, por otro lado, una forma de frustrar o de invalidar la voluntad del testador, incluso ignorar o ir en contra de la misma.

Y, si se diere el caso inverso, no tipificado en el artículo 1009 CC, que el sucesor hubiere aceptado la herencia del causante a través de la delación intestada y después apareciere un testamento que afectare su vocación abintestato, de igual manera podría, si él ahora quiere, y por el motivo que sea ${ }^{578}$, pese a que antes aceptó, repudiar ahora la herencia a través de la delación testada. Al haber quedado la intestada totalmente ineficaz, tendrá que emitir una nueva declaración, que podrá ser tanto de aceptación como de repudiación, porque tal declaración, además de ser libre y voluntaria (art. $988 \mathrm{CC}$ ), no está condicionada por la anterior por cuanto ésta es como si no la hubiere emitido, sin perjuicio de que, en su momento, fuese plenamente válida y eficaz hasta que apareció el testamento. Así, si fuere su voluntad, podría, pese a haber antes aceptado, repudiar ahora en base a la delación testamentaria.

No obstante, MANRESA ${ }^{579}$, entiende en este sentido que, si ya se hubiere aceptado la sucesión en virtud de la delación intestada, no podrá repudiar después por medio de la testada. De lo que disentimos por el motivo antes expuesto, porque, si como consecuencia de la aparición del testamento, resulta que queda totalmente invalidada la delación abintestato, el sucesor, al amparo de la testada, podrá y tendrá que emitir una nueva declaración de voluntad sobre la herencia del causante, y que puede ser, sea cual fuere la que hubiere emitido con anterioridad, según ya apuntamos, tanto de repudio como de aceptación.

578 Tal sería el caso de que el sucesor descubre, a través del testamento, que ha sido merecedor de un llamamiento por parte del causante que él considera insuficiente o no acorde con lo que esperaba de él porque le ha dejado una porción o cuota de bienes insignificante o un exceso de deudas o de cargas. Ahora, como reacción a ello, decide repudiar su herencia.

${ }^{579}$ Op. cit.: pág 446. 


\section{4.- LA REPUDIACIÓN EN EL CASO DE COEXISTENCIA DE LA SUCESIÓN TESTADA E INTESTADA.}

La concurrencia de los títulos sucesorios testado e intestado sobre un mismo sucesor respecto de la herencia a que ha sido llamado, si no es el más frecuente, sí es el más característico cuando hay una pluralidad de llamamientos sobre un mismo sujeto.

De la conjunción de ambos títulos sucesorios, se pueden producir varias hipótesis:

a) que, al abrirse la sucesión mortis causa, ésta se ordene a través de una delación testamentaria que sea suficiente y bastante por sí sola para deferir y regular, de manera total y completa, el destino de los bienes que integran la herencia.

En este caso, no procederá la apertura de la sucesión abintestato y todo se deferirá por vía de la testada según manifestó el causante en su testamento. En consecuencia, aquella, la sucesión intestada, no se llega a abrir en ningún momento por cuanto el testamento basta para regular la sucesión del causante.

b) Que no exista delación testada, bien porque el causante no haya otorgado testamento, bien porque después de haberlo otorgado resulte ineficaz (art. $912 \mathrm{n}^{0} 1^{\circ}$ CC: "cuando uno muere sin testamento, o con testamento nulo, o que haya perdido después su validez").

En este caso, el destino mortis causa de los bienes de la herencia se defiere en su totalidad conforme a las reglas de la sucesión intestada que tendría aquí carácter supletorio, subsidiario o defectivo respecto de la testada al no regir ésta, y el destino de los bienes de la herencia se deferiría en su totalidad conforme las normas legales de la sucesión abintestato.

c) Que sí exista delación testamentaria, pero que no baste o no sea suficiente para ordenar por sí sola, de forma total y completa, el destino mortis causa de todos los bienes de la herencia, bien porque no exista institución de heredero ${ }^{580}$, bien porque

${ }^{580}$ A diferencia del Derecho Romano en que la institución de heredero fue un requisito esencial en la validez del testamento [“caput et fundamentum totius testamenti”, decía GAYO (2,229), o MODESTINO, "sine heredis institutione nihil in testamento scriptum valet”], en nuestro derecho histórico, aunque las leyes de Partidas siguieron la doctrina justinianea sobre la institución de heredero, el Ordenamiento de Alcalá (Ley única del Título XVI), rechazó todo formalismo y admitió la validez de aquel testamento que no contuviere institución de heredero. 
la institución en él contemplada no contenga o no se refiera al todo el caudal hereditario (art. $764 \mathrm{CC}$ ), sino sólo a parte los bienes de la herencia (art. $912 \mathrm{n}^{\circ} 2^{\circ} \mathrm{CC}$ : "cuando el testamento no contiene institución de heredero en todo o en parte de los bienes, o no dispone de todos los que corresponden al testador"). En estos casos, a su vez, podemos de distinguir:

a') que el testamento no contenga institución de heredero, sin perjuicio de la validez de las demás disposiciones contenidas en él, hipótesis dentro de la cual, a su vez, puede suceder ${ }^{581}$.

a") que disponga solo de forma parcial de los bienes,

b") que disponga de todos los bienes pero distribuidos en legados de tal manera que éstos agotan la totalidad del caudal hereditario (art. 891 CC) ${ }^{582}$,

b') que el testamento sí contenga institución de heredero pero recaiga sólo sobre parte de los bienes de la herencia, porque si recayere sobre la totalidad de los bienes, toda la herencia se deferiría por las normas de la sucesión testada, que sería el supuesto, a).

581 No vamos a entrar aquí en el examen del principio de la necesidad o no de heredero en la sucesión, y sí solo dejar planteados una serie de supuestos donde, en principio, dado el tenor del artículo 921.2 ${ }^{\circ}$ CC, procedería, en principio, dado su tenor literal, la apertura de la sucesión intestada.

${ }^{582}$ Este es, sin duda, uno de los supuestos más discutidos en el que la falta de la institución de heredero ha planteado en la doctrina la polémica de si procede o no abrir la delación abintestato al amparo del artículo $912.2^{\circ}$ CC. Sin embargo, quede tan solo planteado como una hipótesis.

No obstante, y sin entrar a fondo en su examen, pese a que la dicción literal del artículo $912.2^{\circ} \mathrm{CC}$ así lo da a entender, GARCÍA RUBIO (Op cit: Pág 309 y ss), entiende, en base a argumentos de índole histórico, gramatical, sistemático y práctico, que, "nunca tendrá lugar la delación intestada si se ha distribuido toda la herencia en legados". Y apunta que ésta es la tesis sustentada tanto por el Tribunal Supremo (STS 21 de noviembre de 1950, -RJ 1686-), como por la DGRN (Res 30 de noviembre de 1916 -Col n 162, Tomo 138-).

En igual sentido opinamos nosotros, pese a que tan solo lo planteemos aquí como una hipótesis, al menos en teoría, subsumible en el ámbito del artículo $912.2^{\circ}$ CC, que no procede en este caso abrir la sucesión intestada, porque, efectivamente, si la totalidad del caudal hereditario se ha deferido por parte del causante, aunque sea a través de títulos ordenados de forma particular o individual, a favor de sujetos concretos y determinados, de tal manera que todos, absolutamente todos y cada uno los bienes que integran su herencia tienen un destinatario o sujeto perceptor de los mismos y ninguno de ellos queda vacante, sin destinatario o sujeto beneficiario del mismo, resulta inútil, incluso absurdo, abrir una sucesión a través de la cual se van a llamar a unos sujetos que no van a percibir nada porque, sencillamente, no hay nada que esté pendiente de repartir o de adjudicar. Y, si no van a heredar nada, no tiene sentido abrir la delación abintestato.

No piensa lo mismo ALBALADEJO (Comentarios al Código Civil y Compilaciones Forales. T XII. Vol $1^{\circ}$. Cit: Pág 395), para quien el artículo $912.2^{\circ}$ abre la sucesión intestada en dos casos: cuando el testador no nombró heredero, y cuando, aun habiéndolo nombrado, no dispuso a favor de él o del legatario de todos los bienes. Pero, en este caso, nos hacemos la misma pregunta: si el causante hizo, a través de su testamento, partición de todos y cada uno de los bienes que integraban su patrimonio a través de legados, ¿qué sentido tiene que se llame a la sucesión a unos herederos si ya no hay nada que heredar?, si ya no hay objeto en la sucesión?. 
En comentario común a los supuestos agrupados en la letra c), decir que se trata de casos en los que, salvo la excepción que acabamos de apuntar de que se distribuya toda la herencia en legados, la delación testamentaria es insuficiente porque no basta por sí sola, es incompleta, o se ha frustrado, para establecer el destino mortis causa de los bienes que integran la herencia. Ello obliga necesariamente a abrir la sucesión intestada para cubrir esta carencia de la testada y se ocupará de regular el destino de aquellos bienes no previstos por ésta lo que, por otro lado, da lugar a una compatibilidad ente ambas clases de sucesión porque las dos, testada e intestada, coexisten y se aplican a un mismo tiempo en un plano de igualdad, cada una sobre sus respectivos bienes, de tal manera que, una y otra, rigen de manera simultánea y con carácter principal entre sí, a un mismo tiempo. Cada una con sus propias reglas, van a regir, a la vez, el destino de los bienes de una persona con carácter autónomo e independiente una respecto de la otra: la testada, por un lado, va a marcar o regir el destino de aquellos bienes de la herencia a que se refiere el testamento conforme las normas contenidas en él y, por otro lado, la intestada, el destino de otros bienes distintos, el resto, conforme sus propias normas.

Por otro lado, en estos casos, una y otra sucesión no se interfieren, ni se mezclan, confunden o "molestan" entre sí, sino que coexisten y se complementan de forma mutua porque las dos, de manera conjunta, si bien, cada una con sus respectivas reglas y sobre diferentes bienes, van a determinar, de manera total y completa, el destino mortis causa del caudal relicto del causante.

d) También puede ocurrir que la delación testamentaria sea insuficiente o se frustre por otros motivos (art. $912 \mathrm{n}^{\circ} 3^{\circ} \mathrm{CC}$ : "cuando falta la condición puesta a la institución del heredero, o éste muere antes que el testador, o repudia la herencia sin tener sustituto y sin que haya lugar al derecho de acrecer" $\mathrm{y}, \mathrm{n}^{\circ} 4^{\mathrm{o}}$ : "cuando el heredero instituido es incapaz de suceder"), supuestos todos ellos en los que procede la apertura de la sucesión abintestato respecto de todos los bienes que integren la herencia de esa persona, o aquellos a que se refiere la porción o cuota afectada por cualquiera de los hechos anteriores.

En este caso, se da una subsidiariedad o aplicación supletoria, a la vez que sucesiva, de la sucesión intestada respecto de la testada, por defecto de ésta, por causa de haber resultado ineficaz para ordenar o regular el destino de los bienes, ya sea por inoperancia o frustración de la institución de heredero por el incumplimiento de la condición suspensiva que estaba sujeto, ya sea por premoriencia al causante (no obstante, para que proceda aquí la apertura de la sucesión intestada es preciso que 
no haya cláusula de sustitución prevista, ni proceda el derecho de acrecer), ya por repudiación del sucesor (cfr. arts 764, 766 y 986 CC), ya porque el instituido sea incapaz de suceder.

Pues bien, a la vista de todas las hipótesis anteriores, y ante la disyuntiva de, si ante una pluralidad de títulos deferidos a favor del sucesor, éste puede emitir una sola declaración de voluntad comprensiva de todos los llamamientos de que ha sido objeto, o si varias declaraciones, a cada llamamiento una declaración, cabe preguntarse, ¿en cuál, o cuáles, de dichas hipótesis se puede dar esta disyuntiva?.

En principio, dadas las circunstancias que concurren en cada una de ellas, entendemos que hay que estar ante alguna de aquellas a que se refieren las letras c) y d), porque solo aquí existe una aplicación, a un mismo tiempo, de las dos clases de sucesiones, testada e intestada, para deferir el destino mortis causa de los bienes del difunto. Si bien, a su vez, dentro de ellas: ¿a cual se aplica el párrafo primero del artículo 1009 CC?: ¿cuando existe simultaneidad o compatibilidad entre una y otra sucesión?, que sería el supuesto de la letra c) o, cuando la sucesión abintestato rige con carácter subsidiario, en defecto de la testamentaria, por causa de insuficiencia de ésta?, que sería el supuesto de la letra $d$ ).

Por otro lado, ante la coexistencia de una y otra clase de sucesión, partiendo de la circunstancia de que el sucesor ha repudiado el primero de los dos títulos sucesorios que le han sido deferidos, surge la cuestión de si, ante el segundo título, puede o no volver a pronunciarse sobre la misma herencia a través de la delación que emana del mismo. Que primero se abra la sucesión abintestato, aparte de que es más simple, no plantea apenas problema alguno, ya lo hemos tratado más arriba en el punto número 3-2. En cambio, que primero se abra la sucesión testamentaria y después la intestada, es más complejo dado que la casuística es más extensa y variada, y donde se plantea el verdadero problema de cómo ejercer el ius delationis ante una pluralidad de delaciones.

Se trata de aquellos supuestos en los que, una vez producido el fallecimiento de una persona, procede la ordenación de su sucesión conforme el testamento que ella otorgó. Pero después, por razón de distintos motivos, dicho testamento es insuficiente, o ineficaz, para regular de manera total y completa el destino mortis causa de sus bienes, lo que obliga a abrir la sucesión abintestato, de tal manera que se van a aplicar las dos sucesiones, bien a un mismo tiempo de manera simultánea, bien la intestada, de forma supletoria, por insuficiencia o ineficacia de la testada. 


\section{4-1.- Que exista simultaneidad o compatibilidad entre ambas sucesiones.}

Esta situación se produciría en aquellos supuestos a los que se refiere el artículo $912 n^{\circ} 2^{\circ}$ CC: "cuando el testamento no contiene institución de heredero en todo o en parte de los bienes, o no dispone de todos los que corresponden al testador".

En este caso, la apertura de la sucesión abintestato, y subsiguiente delación que se deriva de la misma, se produce, no solo con carácter subsidiario o defectivo, sino por causas que son totalmente ajenas a la voluntad de cualquier sucesor por cuanto ninguno de ellos ha dado lugar a que se produzca esta situación, como podría haber sido en el caso de repudiación de la delación testada. Luego, se puede decir, en términos coloquiales, que, ninguno de ellos "tiene culpa" de la apertura de la sucesión intestada por cuanto no ha sido provocada, ni directa, ni indirectamente por sucesor alguno, sino por la falta de previsión del causante que no dispuso de manera total y completa, a través de su última voluntad, del destino de todos los bienes que componen su caudal relicto. Ante ello, la ley, en su carácter o condición de subsidiaria o supletoria, cubre esta laguna con sus normas pero sin anular la voluntad del causante que la respeta y se mantiene, ya que no por ello queda enervada, por lo que se da esa simultaneidad o aplicación, de igual a igual, entre una y otra clase de sucesión, de lo que se deriva una compatibilidad entre ambos títulos sucesorios. Y, por otro lado, desde el punto de vista del objeto, de los bienes que integran el caudal relicto, unos se deferirán por vía de sucesión testada, otros por la intestada, por lo que cada delación recaerá sobre porciones, cuotas o bienes diferentes de la herencia.

Ante tales circunstancias, el sucesor que, en su caso, hubiere repudiado su porción hereditaria al amparo de la delación testada, entendemos que no le afecta la apertura de la sucesión abintestato en el caso de que fuere llamado a través de ella a la sucesión del causante porque, además, lo será a otra cuota o porción diferente de aquella que a él se le defirió a través del titulo testamentario. En consecuencia, podría perfectamente, a nuestro juicio, ejercer el ius delationis dimanante de la vocación abintestato con total y absoluta libertad, sin que le condicione, en modo alguno, la declaración de repudio que antes realizó al amparo de la delación testamentaria, por lo que podrá, si es su deseo, aceptar aquello que ahora se le defiera por vía intestada, pese a que antes hubiere repudiado lo que el causante de dejó por testamento. Una y otra declaración serían independientes entre sí y la primera no interferiría, ni condicionaría la segunda. 
De ahí que, en nuestra opinión, aquí, en este caso, no es aplicable la norma del artículo 1009 por un doble motivo: en primer lugar, porque estamos ante una pluralidad de delaciones que se producen de forma simultánea y, en segundo lugar, porque cada una de ellas tiene su respectiva porción o cuota. Una y otra sucesión, testada e intestada, son compatibles entre sí al tener por objeto diferentes cuotas o porciones de la herencia. Según veíamos más arriba, al tratar de las posibles interpretaciones de que ha sido objeto por parte de la doctrina, dicho precepto sólo procede en los casos de que se trate de llamamientos sucesivos y que, además, recaigan sobre la misma porción o cuota de la herencia que ya fue repudiada y de la que sea destinatario de la misma el mismo sucesor que la repudió.

Desde el punto de vista doctrinal, autores como, ALBALADEJO ${ }^{583}$, GITRAMA ${ }^{584}$, LACRUZ ${ }^{585}$ o VALLET ${ }^{586}$, entienden que la aceptación de la delación abintestato por parte del sucesor después de repudiar previamente la delación testamentaria, es válida cuando las dos vocaciones se producen o tienen lugar de forma simultánea o compatible, a un mismo tiempo, por causa de insuficiencia de la testada, de tal manera que las dos sucesiones rigen y se aplican en un plano de igualdad. Hay una situación de coexistencia entre las dos modalidades de sucesión a través de las cuales se va a establecer y regular, a la vez, de manera conjunta, el destino mortis causa de los bienes de una persona, si bien, cada una de ellas se va a referir a distintos bienes. Recordemos aquí lo que manifiesta LACRUZ para quien, "el artículo 1009 CC, al hablar de "una misma herencia", entiende referirse a llamamientos sucesivos y que en cuanto a los simultáneos, ya tenga lugar alguno por la ley, ya todos por la voluntad del causante, mientras sean verdaderamente independientes, el heredero es dueño de aceptar o de repudiar cada uno de ellos"587.

\section{4-2.- Apertura de la sucesión intestada porque la testada se frustre o sea} insuficiente.

Dado el carácter supletorio que tiene la sucesión abintestato respecto de la testada (cfr arts $658.1^{\circ}$ y $912.1^{\circ} \mathrm{CC}$ ), su puesta en marcha puede tener lugar cuando la testada no puede desplegar todos los efectos que, en principio, previó el causante

583 “La repudiación de la herencia”. Cit: Pág 752.

${ }^{584}$ Op. cit.: Pág 305.

Lo que él manifiesta es que la regla del artículo 1009 se aplicaría cuando el llamamiento es sucesivo. Luego, se puede entender, a sensu contrario, que no se aplicaría en este caso, en el de llamamiento simultáneo.

${ }^{585}$ Derecho de sucesiones. Cit: Págs 175 y 176.

${ }^{586}$ Panorama del Derecho de Sucesiones. I. Cit: Pág 113, citando a LACRUZ.

${ }^{587}$ Derecho de sucesiones. Cit: Pág 175. 
en el testamento al producirse toda una serie de circunstancias que son ajenas al mismo -aunque, en ocasiones, se pudieron prever y contemplar en él-, pero que, a resultas de ello, hacen que entre en funcionamiento la ley con carácter subsidiario o supletorio para regular el destino mortis causa de aquella parte de la herencia que se quedó sin la previsión testamentaria ordenada por el causante. Ello va a dar lugar a que se abra la sucesión legal y a que se produzca su simultaneidad o compatibilidad con la testada en lo que se refiere al resto de lo ordenado por el causante en su testamento. Se trata, por otro lado, de casos en los que la vocación prevista por el causante en su testamento se frustra o deviene en infructuosa y la hacen inoperativa o inútil.

Tales supuestos son aquellos a que alude el artículo $912 \mathrm{CC}$, en sus números $3^{\circ}$ ("cuando falta la condición puesta a la institución del heredero, o éste muere antes que el testador, o repudia la herencia sin tener sustituto y sin que haya lugar al derecho de acrecer"), y $4^{\circ}$ ("cuando el heredero instituido es incapaz de suceder"). En ellos, la apertura de la sucesión abintestato tiene un carácter diferente del que hemos visto en el supuesto anterior porque aquí se produce una aplicación supletoria o sucesiva de la misma respecto de la testada, por defecto de ésta, por causa de su insuficiencia, teniendo, en este caso, como decimos, un carácter subsidiario o defectivo.

En todo caso, en cualquiera de ellos, el llamamiento abintestato se va a producir sobre la misma porción o cuota de herencia que tuvo por objeto y la que se refirió la vocación testada que ha quedado enervada o se ha frustrado por cualquiera de las circunstancias antes indicadas pero, con una diferencia que es importante tener en cuenta: en los casos de premoriencia o incapacidad para suceder del delado, éste, obviamente, ya no puede volver a ser llamado a la sucesión abintestato del causante cuando se proceda a su apertura respecto de la porción o cuota que ha quedado vacante, en el primer caso, porque ya murió y, en el segundo, por prohibición legal, por lo que nunca podrá heredar en la misma, mientras que, en el caso de repudiación, sí podría, en principio.

Manifestada la repudiación, que es el supuesto que aquí nos interesa, no solo la sucesión testamentaria resulta frustrada, en todo o en parte, sino que, a resultas de ello, y en defecto de cláusula de sustitución prevista por el causante para este caso (art. 774 CC) y del derecho de acrecer, ya porque se trate de sucesor único, ya porque no se den los requisitos exigidos para ello por el Código Civil (art. 981 y ss), procede la apertura de la sucesión abintestato respecto de la porción o cuota de herencia que quedó vacante a resultas de la repudiación. Luego, sobre una misma porción o cuota 
de herencia va a ver, de forma sucesiva, una doble delación, primero testada, y después, intestada, si bien, se puede dar la circunstancia de que entre los sucesores abintestato del causante, como consecuencia de la aplicación de las normas legales, se encuentre el mismo sucesor cuya repudiación dio lugar a la apertura de la sucesión legal por ser el más próximo en grado.

Ante este nuevo llamamiento, ahora intestado, que se produce a favor del mismo sucesor cuya repudiación es la que lo ha provocado, la posición más extendida dentro de la doctrina y más generalmente aceptada, es la de entender que sí sería de plena aplicación y tendría todo su sentido la norma del párrafo $1^{\circ}$ del artículo 1009 CC que es precisamente la hipótesis que en él se contempla. En consecuencia, el repudiante, por aplicación del mismo, y pese a tener la condición de sucesor abintestato, no podrá ahora, a través de este título sucesorio, aceptar lo que ya antes previamente repudió.

La repudiación, en este caso, válidamente realizada al amparo de la delación testada es definitiva e irrevocable, y supone la separación y exclusión para siempre del sucesor de la herencia, sin que tenga posibilidad alguna de volver a ella, al menos, en aquello que él repudió, pero sí, en su caso, a otra porción o cuota diferente si se hubiere producido, por ejemplo, otro repudio por parte de otro sucesor, a través de la delación legal o intestada si fuere sucesor del causante a través de la misma.

En este caso, al producirse esta pluralidad de delaciones a favor de la misma persona y sobre una misma cuota a resultas de su propio repudio, para impedir que pueda volver a pronunciarse sobre ella a través de la nueva delación, es cuando el artículo 1009 CC despliega toda su eficacia. Norma que, por otro lado, sería, de alguna manera, una aplicación del carácter indivisible que proclama el artículo 990 CC del ejercicio del ius delationis, porque, de no ser así, el sucesor estaría haciendo, en diferentes momentos, dos declaraciones de voluntad, antitéticas y contradictorias entre sí, primero, de repudio y después, de aceptación, sobre una misma porción o cuota de la herencia, lo que, por otro lado, sería ir contra sus propios actos.

El espíritu del precepto, señala ALBALADEJO ${ }^{588}$, es que, "siendo preferente la delación testamentaria sobre la intestada, el efecto de la repudiación de aquella, es el omitir a ese repudiante en el llamamiento intestado subsiguiente, es decir, privarlo de él". Para GITRAMA ${ }^{589}$, si se repudia la designación hecha en testamento y después se anula éste con la consiguiente apertura de la sucesión legítima, se entiende que bajo

\footnotetext{
588 “La repudiación de la herencia”. Cit: Pág 752.

589 Op. cit.: Págs 306 y 307.
} 
ningún concepto quería heredar y, por ende, sigue considerándose repudiante. Y, si es al revés, sí podría aceptar por atención y respeto a la memoria del de cuius, por no desairarle, por delicadeza, ........, y que por ser primordial (art. 658,1 CC), hace que aquella repudiación sólo se refiriese a lo supletorio.

El planteamiento es, por otro lado, de cierta lógica ya que, si se repudia una herencia en virtud de un título testamentario que, por ende, proviene de la voluntad del causante, es porque ciertamente no se quiere ser heredero suyo. $Y$ si se abre después el título intestado, no tiene sentido permitir que el repudiante pueda ahora aceptar lo que antes ya dijo que no. En este sentido, la literalidad del artículo 1009 es bastante elocuente al presumirse iuris et de iure por la ley que si ha repudiado la herencia por la delación que le hizo el causante, habrá que entender que esa ha sido su voluntad y que no tiene ningún sentido que ahora ni tan siquiera se le brinde la oportunidad de volver a pronunciarse sobre la misma herencia a través del llamamiento que le hace la ley. Lo repudiado, repudiado está y el sucesor no puede ir contra sus propios actos.

Igual regla sería de aplicación para el caso de que quien da lugar a la apertura de la sucesión intestada a resultas de la repudiación es el sustituto designado por el causante en su testamento. En este caso, si es él quien repudia la herencia y, a resultas de ello, procede la apertura de la sucesión intestada y es llamado a la misma, ahora por derecho propio, como tal sucesor abintestato del causante, al ser él quien dio lugar a ello, no podría pretender aceptar aquello que él mismo repudió, ahora a través de la delación intestada. La repudiación es definitiva y queda apartado de la sucesión con todas las consecuencias inherentes a ello, no pudiendo acceder a la misma a través del titulo sucesorio abintestato.

\section{4-3.- Apertura de la sucesión intestada por ineficacia de la testada o de la} institución de heredero.

Un supuesto, que podríamos calificar de singular, es aquel que tiene lugar cuando después de haberse producido la repudiación de la herencia por el sucesor al amparo de la delación testada, se produce la invalidez de esta sucesión al haberse declarado la ineficacia del testamento ${ }^{590}$, dando lugar, en consecuencia, a la apertura

590 Aquí, las causas son múltiples porque puede tener lugar en aquellos casos en que se ha producido un vicio o defecto que es insubsanable que conlleva la ineficacia del mismo desde el momento en que se otorgó, tales como:

a) la existencia de defectos formales,

b) la concurrencia de vicios de la voluntad que den lugar a una declaración de voluntad no querida por el testador,

c) otorgar testamento bajo alguna forma no reconocida legalmente, 
de la intestada (art. $912.1^{\circ} \mathrm{CC}$ : “... o con testamento nulo, o que haya perdido después su validez"). Ahora bien, si la nulidad solo fuere parcial, podría darse el supuesto de concurrencia o compatibilidad entre la sucesión testada e intestada (art. $912 \mathrm{n}^{\circ} 2^{\circ} \mathrm{CC}$ ).

En estos casos, habría que plantear la cuestión, incluso con carácter previo, no ya de si el sucesor puede aceptar una herencia a través del título sucesorio intestado después de haberla repudiado por el testado sino, si es válido y tiene eficacia el ejercicio del ius delationis realizado sobre un testamento que, con posterioridad a ello, ha dejado de producir efectos, o más bien, nunca los llegó a producir, al haberse declarado su ineficacia en virtud de alguna de las causas que la ley establece.

Ciertamente, en este caso, la declaración de repudio, en sí misma considerada, habría que considerarla plenamente válida y eficaz de haberse emitido cumpliendo todos los presupuestos y requisitos legales, si bien, la razón o el motivo que provoca su ineficacia, no está en ella misma, sino en el origen o la fuente de la que emana: el título sucesorio y, subsiguientemente, si éste es ineficaz, también lo serán la vocación y delación que de él derivan. En consecuencia, cuando se produce un hecho de esta naturaleza se puede decir que es lo mismo que si dicha declaración nunca se hubiese llegado a emitir porque ha quedado invalidado el título del que procede.

Luego, el sucesor, en este caso, de resultar llamado a la herencia del causante, ahora, a través de la delación abintestato, a nuestro juicio, entendemos que sí podrá ejercer con total y absoluta libertad el ius delationis proveniente de la misma (art. 988 CC), y aceptar, o repudiar, dicha herencia.

d) la ausencia de capacidad para testar, etc.

Desde otro punto de vista, ya de manera casuística:

a) en el caso del testamento cerrado, cuando aparece rota la cubierta o quebrantados los sellos, o borradas, raspadas o enmendadas las firmas que lo autoricen (art. 742 CC),

b) testamentos en los que no se cumplen determinados requisitos posteriores a su otorgamiento que son necesarios para su validez definitiva: el testamento ológrafo que no se protocoliza en debida forma (art. 689 CC); el otorgado en peligro inminente de muerte (art. 700 CC) o en tiempo de epidemia (art. 701), que quedará ineficaz si pasaren dos meses desde que el testador haya salido del peligro de muerte, o cesado la epidemia, o cuando el testador falleciere en dicho plazo, también quedará ineficaz el testamento si dentro de los tres meses siguientes al fallecimiento no se acude al Tribunal competente para que se eleve a escritura pública, ya se haya otorgado por escrito, ya verbalmente (art. 703 CC); los testamentos otorgados sin autorización del Notario que resultarán ineficaces si no se elevan a escritura pública y se protocolizan en la forma prevenida en la Ley de Enjuiciamiento Civil (art. 704 CC); los testamentos militares (art. 716 CC), que caducarán cuatro meses después que el testador haya dejado de estar en campaña (art. 719 CC); el otorgado durante una batalla, asalto, combate y generalmente en todo peligro próximo de acción de guerra, podrá otorgarse testamento militar de palabra ante dos testigos, pero quedará ineficaz si el testador se salva del peligro en cuya consideración testó. Y si no se salvare, será ineficaz el testamento si no se formaliza por los testigos ante el Auditor de guerra o funcionario de justicia que siga al ejército, procediéndose después en la forma prevenida en el artículo 718 (art. 720 CC); o el caso del testamento marítimo, que caducará pasados cuatro meses, contados desde que el testador desembarque en un punto donde pueda testar en la forma ordinaria (art. 730 CC). 
Igual ocurriría en el supuesto de que se hubiese decretado la nulidad de la institución de heredero.

Por otro lado, y en este mismo sentido, el artículo 997 CC, después de proclamar la irrevocabilidad de la declaración del delado, admite su impugnación "cuando adoleciese de algunos de los vicios que anulan el consentimiento". Aplicando este precepto al caso que nos ocupa, el repudiante podría, además, en su caso, impugnar su declaración alegando error en la misma por cuanto la hizo sobre un testamento que creyó válido y veraz pero que después ha dejado de serlo, de lo que derivaría una declaración de voluntad inválida, o incluso, que ni tan siquiera ha llegado a nacer ante la ausencia de una delación válida y eficaz al no cumplir el testamento los requisitos exigidos, en su caso, por la ley, por lo que se podría entender que nunca la ha llegado a realizar. Así, impugnada con éxito su anterior declaración, el sucesor, quedaría en libertad para, ahora, decidir libre y voluntariamente lo que estime pertinente, como puede ser, si es su deseo, aceptar, ahora, por vía intestada, la herencia, o cuota de la misma, que antes repudió.

GITRAMA ${ }^{591}$ se plantea la hipótesis que venimos tratando pero referida, no a la repudiación, sino a la aceptación, en los términos de si, abierta después la sucesión intestada, sigue considerándose aceptante al sucesor o si podrá ahora repudiar la herencia al amparo de la delación abintestato. Responde entendiendo que sería impugnable dicha aceptación "por causa de error como vicio de consentimiento al tiempo de aceptar", por lo cual y, "por la libre voluntariedad de la aceptación y de la repudiación (artículo 988 CC) ......., ha de reconocerse plena libertad para el llamado para que, si lo desea, mantenga su aceptación y, si no, pueda repudiar; y ello si no son iguales las circunstancias en que se opera el llamamiento de una y otra sucesión, como puede ser la alteración de cuotas o la concurrencia de más llamados". Igual regla se podría aplicar también a la inversa, para el caso de que el sucesor hubiere decidido, pese a haber aceptado al amparo de la delación intestada, repudie ahora la herencia en la sucesión testada.

${ }^{591}$ Op. cit.: Págs 307 y 308. 


\section{5.- LA REPUDIACIÓN CUANDO COEXISTEN OTROS TÍTULOS SUCESORIOS.}

Ya apuntamos en otro momento a propósito de la indivisibilidad de la declaración del delado que, desde el punto de vista del objeto, se pueden producir en la sucesión mortis causa diversas hipótesis o supuestos en los que puede haber una coexistencia o pluralidad de títulos sucesorios que tengan por objeto una misma porción o cuota de la herencia, o ésta en su totalidad, a favor de un mismo sujeto pero que puede ser diversa en función de cómo se ha hecho el llamamiento.

Algunos de estos supuestos son, como ahora veremos, ciertamente un poco rocambolescos y, por ello, anómalos o extraños, porque, para que se produzcan, es necesaria la concurrencia de toda una serie de circunstancias de muy diversa índole.

De entre esas hipótesis, llama nuestro interés la que produce a resultas de la convergencia del título sucesorio que nace del ius transmissionis (art. $1006 \mathrm{CC}$ ), en la persona del transmisario, con otro como es el de sucesor abintestato, o sustituto, en los que se plantea la problemática ${ }^{592}$ que nos venimos planteando de, si se puede ejercer de nuevo el ius delationis después de una segunda delación al amparo de la norma del primer párrafo del artículo 1009 del Código Civil.

\section{5-1.- Que quien repudie como transmisario sea llamado después como} sucesor abintestato.

Manifestado por el transmisario, una vez aceptada la herencia de su causante o transmitente, la repudiación de la herencia, o aquella porción o cuota de la misma, que es objeto de transmisión, de no haberse previsto por el causante en su testamento, para este caso, cláusula de sustitución (art. 774 CC), en su defecto, sería de aplicación, si se dieren los requisitos legales exigidos para ello (art. 981 y ss CC), el derecho de acrecer entre los restantes cosucesores y, en último término, procedería la apertura de la sucesión abintestato (art. 912 n $3^{\circ} \mathrm{CC}$ ), a favor de quienes, según las normas de la misma fueren sucesores abintestato del causante.

Llegado este momento, de conformidad con dichas normas, se puede dar la circunstancia de que vuelva a ser llamado a aquello que fue objeto de repudio, ahora por vía intestada, porque así le corresponde por ley, y esta vez ya por derecho propio,

${ }^{592}$ Acerca de la misma, entre otros:

GARCÍA GARCÍA: Op cit: Pág 244 y ss; JORDANO FRAGA: La sucesión en el "ius delationis". Cit: Pág 293; MONSERRAT VALERO: Op. cit.: Pág 1059 y ss. 
el mismo sujeto que antes repudió en su condición de transmisario, de tal manera que se produce un nuevo llamamiento a su favor, un nuevo título sucesorio, por lo que vienen a coincidir en él, en momentos distintos, de forma sucesiva dos títulos sucesorios, primero, de transmisario y después, de sucesor abintestato ${ }^{593}$.

Entonces, dada la norma del párrafo primero del artículo 1009 CC, ¿podría dicho sujeto, pese a la repudiación anterior, aceptar ahora lo que él antes rechazó por vía testada a través del ius transmissionis?.

Siguiendo los postulados de la teoría clásica sobre quien sucede el transmisario, si a su causante o transmitente o si al causante originario, tenemos que, cuando él repudia la herencia transmitida, no lo hace ejerciendo un derecho propio, sino por vía indirecta, a través del ejercicio del ius delationis que había correspondido a su causante o transmitente y no a él, pero que hace suyo al aceptar la herencia de éste. En consecuencia, cuando ejerce este ius delationis y repudia, es como si en realidad lo ejerciera el mismo transmitente, pero no el transmisario.

En consecuencia, ¿la declaración de repudio de la herencia objeto del ius transmissionis en su condición de transmisario, obsta o impide el posterior ejercicio del ius delationis que sobre la misma tiene a su favor, ya como derecho propio, a través de la sucesión intestada, por aplicación de la norma del artículo 1009 CC?. En principio, pudiera pensarse que sí. Sin embargo, desde el punto de vista subjetivo, del declarante, en nuestra opinión, se produce un cambio importante.

Cuando, a resultas del repudio se abre la sucesión abintestato y el transmisariorepudiante es llamado a ella, ahora ya como sucesor directo y personal del primer causante porque así le corresponde por derecho propio de conformidad con las

${ }^{593} \mathrm{El}$ supuesto de que tratamos sería el siguiente:

A y B, marido y mujer, tienen un único hijo, C.

A, fallece habiendo otorgado testamento en el que lega a su hijo lo que por legítima estricta le corresponde e instituye única y universal heredera de todos sus bienes a su esposa, B.

$\mathrm{B}$, la esposa, que no puede superar la triste noticia del fallecimiento de su esposo, fallece al poco tiempo sin aceptar ni repudiar la herencia del marido dando lugar al "ius transmissionis" a favor de su hijo, C.

C, el hijo, heredero de su madre en virtud del testamento que ésta otorgó, acepta la herencia de ella, ante lo que hace suyo el "ius delationis" proveniente de la herencia de su padre. Después, el hijo, en ejercicio de dicho "ius delationis", renuncia a la herencia de su padre, dando lugar en ésta, dado que éste no ordenó cláusula de sustitución en su testamento (de haberse previsto, sería llamado el sustituto), a la apertura de la sucesión abintestato (art. 912.3 CC), por no haber lugar al derecho de acrecer por ser único sucesor.

Abierta la sucesión intestada en la herencia del padre, es llamado el hijo, C, ya por derecho propio, como primer sucesor abintestato del mismo por aplicación de las normas relativas a la misma.

Entonces, ¿puede C, el hijo, ahora, en su caso, aceptar la herencia del padre como sucesor abintestato del mismo después de haberla repudiado antes en su condición de transmisario?. 
normas que la rigen, estamos ante un sujeto que, desde el punto de vista jurídico, lo es en otra condición o título diferente: en un primer momento, como sucesor del que ha fallecido sin haber ejercitado el ius delationis, esto es, en la de transmisario, y, como tal, sucesor indirecto del primer causante en virtud del ius transmissionis al hacerlo a través del transmitente, y después, en un segundo momento, como sucesor abintestato del causante, ya por derecho propio, lo que hace de él un sucesor directo y personal suyo. Se produce así un cambio que, entendemos, trascendental y de gran relevancia jurídica: el sujeto, inicialmente transmisario, se apartó y quedó fuera de la sucesión por la repudiación, pero después, al abrirse la sucesión intestada, vuelve a ser llamado él de nuevo, esta vez personalmente, ahora ya como sucesor directo del causante, pasando a tener otra condición diferente, cual es la de sucesor abintestato personal suyo. En consecuencia, es un llamamiento que tiene una naturaleza distinta porque es directo y proviene de la propia ley, mientras que, en el caso del ius transmissionis, también proviene de la ley pero se ejerce de forma indirecta, a consecuencia de la previa aceptación de la herencia del transmitente, con lo cual es un llamamiento que se produce de forma derivativa y que, además, depende de la voluntad del propio transmisario al exigir inexcusablemente la previa aceptación, por su parte, de la herencia de su causante o transmitente.

En consecuencia, aunque se trate de la misma persona, entendemos que ahora estamos ante un sucesor distinto porque su llamamiento se hace en virtud de otro título sucesorio diferente de aquel por el que fue llamado a través de la vía testada. En este sentido, la posición jurídica y el modo de cómo accede a la primera herencia, primero, a través del ius transmissionis y, después, a través de la vía intestada, es totalmente distinto porque, en aquel, es un sucesor indirecto del primer causante, mientras que en ésta, es un sucesor directo y personal suyo que accede a su herencia en virtud de un derecho propio que a él le corresponde.

A la vista de ello, aunque haya identidad de objeto en uno y otro llamamiento, y partiendo de la circunstancia de que en cada uno de ellos los títulos jurídicos en virtud de los cuales se producen las delaciones son diferentes y la naturaleza de las instituciones es también diferente, es lo que da lugar a que, desde el punto de vista jurídico, en nuestra opinión, no haya identidad de sucesores, circunstancia ésta que, a nuestro juicio, es un presupuesto esencial que subyace en la norma del párrafo primero del artículo 1009 CC para que proceda su aplicación. Y por ello, en nuestra opinión, esta hipótesis quedaría fuera del supuesto de hecho a que se refiere y al sucesor no le sería de aplicación dicha prohibición, por lo que ahora podría, si es su 
deseo aceptar a través de la delación abintestato lo que él antes repudió como transmisario. Para que opere dicha prohibición, es preciso que el sucesor, tanto en la sucesión testada como intestada, sea llamado de forma sucesiva a la herencia directa y personalmente, por derecho propio, y en este caso, a nuestro juicio, no se da este requisito.

No obstante, así sería si siguiésemos los postulados de la teoría clásica porque, si aplicásemos los de la teoría de la doble capacidad o de la adquisición directa, dado que, según ella, el transmisario sucede directamente al primer causante y, por tanto, es su sucesor directo, la respuesta sería la contraria. Dado que, según esta teoría, al ser sucesor suyo, como a resultas de su repudiación y ante la ausencia de sustituto vulgar, ha sido preciso abrir la sucesión intestada (art. 912 n $3^{\circ} \mathrm{CC}$ ), sí que le sería de aplicación la prohibición del artículo 1009 CC por cuanto volvería a ser llamado como sucesor directo del primer causante y el transmisario no podría, ahora ya como sucesor intestado, aceptar la herencia que previamente repudió a través del ejercicio del ius transmissionis.

\section{5-2.- Que quien repudie como transmisario vuelva a ser llamado como sustituto a resultas de dicha repudiación.}

¿Quien ha repudiado la herencia a través del ius transmissionis puede volver a pronunciarse sobre ella como sustituto a resultas de la aplicación de la cláusula de sustitución prevista porque así fue llamado por el causante en su testamento ${ }^{594}$.

La repudiación de la herencia realizada por el transmisario da lugar a que entre en funcionamiento la sustitución prevista por el de cuius respecto del transmitente y, a resultas de ello, vuelve a ser llamado el transmisario pero ahora como sustituto porque así fue designado por el causante ${ }^{595}$. Paradójicamente, el transmisario, vuelve a entrar en la sucesión pero ahora como heredero directo y por derecho propio del primer causante, en la condición de sustituto a resultas de su propia repudiación, lo que hace que cambie sustancialmente su posición jurídica en la herencia.

594 Hipótesis que trata MONSERRAT VALERO y que admite al afirmar que, "también se deferiría al transmisario en el supuesto de que éste hubiera sido nombrado sustituto del transmitente en el testamento del primer causante” (Op. cit.: Pág 1059).

${ }^{595}$ Tal sería el supuesto en que se instituya como herederos a A, B, C y D. Y se da la circunstancia de que $\mathrm{D}$, que es hijo de $\mathrm{A}$, a su vez, ha sido designado sustituto suyo por el causante.

A, fallece sin ejercer el ius delationis, y D, transmisario, decide repudiar la herencia.

Producido el repudio, entraría en funcionamiento la cláusula de sustitución prevista en el testamento, ante lo que el sucesor D, sería de nuevo llamado a la herencia, si bien, ahora en su condición de sustituto. 
Entonces, reiterando argumentos ya expuestos, a nuestro juicio, tal repudiación no impide ni entorpece la posible aceptación posterior que, en su caso, pretendiese realizar ahora como sucesor directo del causante al haber sido llamado por él a su herencia en la condición de sustituto. En la condición de transmisario es, siguiendo los postulados de la teoría clásica en el ius transmissionis, sucesor indirecto del causante por cuanto a quien realmente sucede no es a éste sino a su propio causante o transmitente y, por tanto, la delación a través de la cual repudió no le fue deferida a él, sino a su causante, mientras que ahora ejerce un derecho que es suyo propio, que le corresponde a él, y la delación por medio de la cual puede volver ahora a pronunciarse sobre la misma herencia sí que es suya propia al haber sido deferida a su favor.

Ciertamente, no deja de ser una paradoja, pero ahora el transmisario es llamado a la sucesión en virtud de un título sucesorio diferente al igual que sucede en el supuesto anterior.

Distinto es que el transmisario después de repudiar aquello que ha sido objeto de transmisión, sea de nuevo llamado a la herencia como sustituto y decida de nuevo, por segunda vez, repudiar, dando lugar, ante la inexistencia del derecho de acrecer, a la apertura de la sucesión abintestato. De darse esta cadena de repudiaciones y si se da la circunstancia de que él, después, es de nuevo llamado a la sucesión pero ahora ya sucesor abintestato del causante, al ser quien, a resultas de su propia repudiación, ha dado lugar a la apertura de la sucesión intestada, entonces sí que estaríamos ante el supuesto de que trata la prohibición del párrafo $1^{\circ}$ del artículo 1009 CC y ya no podría volver a pronunciarse sobre la herencia del causante porque su repudio como sustituto sería definitivo, ante lo que quedaría totalmente apartado de la sucesión y su llamamiento a través de la delación intestada no se podría realizar. Además de que sería un absurdo y una contradicción que tuviese una tercera oportunidad de pronunciarse sobre una herencia que ya ha rechazado dos veces. 
Ignacio Sánchez Cid. 


\section{Capítulo 6: REQUISITOS DE LA REPUDIACIÓN.}

1.- Requisitos subjetivos. 1-1.- En el caso de que el sucesor sea una persona física. 1-11.- Regla general. 1-1-2.- Reglas especiales. 1-1-2-1.- En el caso del menor de edad no emancipado. 1-1-2-2.- En el caso del menor de edad emancipado. 1-1-2-3.- En el caso del concursado. 1-1-2-4.- En el caso del desaparecido y del declarado ausente. 1-1-2-5.En el caso de herencia deferida a los pobres. 1-1-2-6.- En el caso de herencia deferida a favor de sufragios y obras piadosas. 1-2.- En el caso de que el sucesor sea una persona jurídica. 2.- Requisitos objetivos. 2-1.- Forma documental o instrumental. 2-2.- Forma judicial. 2-3.- El artículo 1008 y la repudiación de los legados.

Ya vimos en el capítulo primero, a propósito de la aceptación de la herencia, cuáles eran los presupuestos que se exigen para poderla realizar y que, por extensión, también se predican, lógicamente, para el caso de repudiación al ser, una y otra, expresión del ejercicio del ius delationis. Presupuestos que se han de cumplir con carácter previo a dicho ejercicio, sobre los cuales éste se asienta y sin los cuales no podrá tener lugar, por cuanto sin ellos no se podrá ejercer de forma válida y eficaz la delación que ha sido deferida y que clasificábamos en, objetivos y subjetivos, referidos aquellos, al hecho de la muerte del causante y existencia de la vocación y delación sucesorias, y éstos, a la circunstancia de que el llamado tenga la certeza del hecho del fallecimiento del causante y de su derecho a la herencia.

A ellos se añade después, ya en el momento de la emisión o exteriorización de la declaración de voluntad, los requisitos, por un lado, de la capacidad personal que ha de tener el sucesor para poder ejercer el ius delationis y, por otro, la exigencia de tener que observar, en el caso concreto de la repudiación, una determinada forma o solemnidad al manifestar dicha declaración de voluntad. 


\section{1.- REQUISITOS SUBJETIVOS.}

\section{1-1.- En el caso de que el sucesor sea una persona física.}

\section{1-1-1.- Regla general.}

A modo de principio o de regla general, acerca de la capacidad que se exige a la persona física para el ejercicio del ius delationis, dispone el artículo $992 \mathrm{CC}^{596}$, en su inciso primero, que, "pueden aceptar o repudiar una herencia todos los que tienen la libre disposición de sus bienes"597. De lo que se infiere que, tanto la repudiación como la aceptación, como ya vimos más arriba, se consideran por la ley actos de disposición con las consecuencias jurídicas que de ellos se derivan. De ahí que se precise para su realización la misma capacidad que para estos ${ }^{598}$.

No obstante, dada la ambigüedad de la expresión, tener la "libre disposición de los bienes" ${ }^{\prime 599}$, creemos necesario analizar, si quiera de forma breve, su significado para saber qué capacidad se exige para ejercer de forma válida el ius delationis. En este sentido, aunque, puede parecer un juego de palabras, lo cierto es que no dice, o no exige, tener "toda la disposición" o, "la plena disposición", expresiones que tendrían un sentido diferente porque a través de ellas se podría entender que se refiere a todos los actos de la esfera jurídico patrimonial de una persona, mientras que la expresión del Código parece tener un ámbito distinto.

596 Tiene como precedente el artículo 824 del Proyecto de 1851 en el que se hablaba de la "libre administración de los bienes”, si bien, en el Anteproyecto de1882-1888, se cambia el texto y se exige en su artículo 1002 la "libre disposición de los bienes", que luego pasa a ser el actual 992.

${ }^{597}$ Algunas leyes sucesorias autonómicas contienen reglas dispares y fórmulas diversas acerca de la capacidad que, con carácter general, se exige para poder repudiar o aceptar la herencia.

Así, en Cataluña, “pueden aceptar y repudiar la herencia las personas con capacidad de obrar”, mientras que, en el caso de menores emancipados, habilitados de edad o sometidas a curatela, para repudiar, “deben de ser asistidos por las personas que complementen su capacidad” (art. 461-9.1, Ley 10/2008, sobre sucesiones), y “los padres o tutores necesitan la autorización judicial para repudiar las herencias deferidas a los hijos menores de edad o a las personas puestas en tutela” (art. 461-9.2, Ley 10/2008, sobre sucesiones).

En Aragón, la aceptación de la herencia es válida desde los 14 años cumplidos si no se estuviere incapacitado (art. 346.1 CDFA), mientras que, para la repudiación, se exige la intervención del padre y de la madre hasta la mayoría de edad (art. 346.1 y 3 CDFA), a lo que se añade la necesidad de autorización de la Junta de Parientes o del Juez si fuere menor de 14 años, estuviere incapacitado o sometido a autoridad familiar prorrogada o rehabilitada (art. 346.2 CDFA).

Por su parte, el Código Civil francés exige diferente capacidad para aceptar que para repudiar una herencia porque, para aquella, es suficiente tener la libre administración, mientras que, para ésta, se precisa tener la libre disposición de los bienes.

${ }^{598}$ Vid, entre otros, sobre ello, GITRAMA: Op. cit.: Pág 98 y ss.

${ }^{599}$ Expresión que se recoge en otros artículos del Código Civil. Así: art. 624, a propósito de la capacidad para realizar una donación; art. 1052, para pedir la partición de la herencia; art. 1160, para realizar válidamente el pago en las obligaciones.

También se observa en el Código de Comercio, a propósito del ejercicio del comercio, en su artículo 4, si bien, exige ser mayor de edad. 
Si acudimos a los preceptos del Código Civil relativos a la capacidad de las personas (arts 315, 322), vemos cómo, desde la mayoría de edad, se pueden realizar "todos los actos de la vida civil", tanto los más rigurosos o trascendentales como enajenar, gravar, limitar, transformar, transigir, destruir, y otros de menor rango como es la administración, "salvo las excepciones establecidas en casos especiales", esto es, los límites, restricciones o prohibiciones que lo impidan, en cuyo caso, ya no se tendría plena capacidad para poder realizar todos los actos de la vida civil, o aquel acto a que se refiere la limitación o prohibición de que se trate, en cuyo caso, no se tendría la libre disposición de los bienes. Como tambien, para referirse a la capacidad que se exige para la realización de distintos actos, contratos y obligaciones, o el desempeño de ciertos cargos o funciones, emplea diferentes expresiones, de significado muy diverso ${ }^{600}$, lo que crea una gran confusión y la dificultad de saber qué capacidad concreta es la que se exige y cual es su contenido.

Además, por otro lado, tiene declarado la jurisprudencia, de manera abundante y reiterada, que la capacidad de obrar en una persona se presume y existe en plenitud de la totalidad del contenido de las facultades que la integran y para todos los actos de la vida civil mientras no se demuestre lo contrario ${ }^{601}$, por lo que la libre disposición se presume siempre, al tiempo que la incapacidad ha de ser acreditada de modo fehaciente e indubitado ${ }^{602}$.

${ }^{600}$ Así, entre otros, en el artículo 241, a propósito de la capacidad para ser tutor, habla de "pleno ejercicio de derechos civiles"; art. 625, a propósito de la capacidad para aceptar donaciones: “todos los que no estén especialmente incapacitados por la ley para ello”; art. 662, relativo a la capacidad para poder testar: "todos, a quienes la ley no lo prohíbe expresamente"; 744, acerca de la capacidad para poder suceder: "los que no estén incapacitados por la ley"; 893, sobre el cargo de albacea: "el que no tenga capacidad para obligarse"; 1264, relativo al consentimiento en los contratos que habla de modificaciones e incapacidades especiales; 1457, acerca del contrato de compraventa, en el que habla de autorización para obligarse; 1931, a propósito de la prescripción.

${ }^{601}$ En este sentido, las resoluciones judiciales son innumerables. Así, entre otras muchas:

SSTS de 7 de febrero de 1967; 28 de junio de 1990 (RJ 4942) que, a su vez, cita otras de la misma Sala, de 10 de febrero de 1986 (RJ 520), de 10 de abril de 1987 (RJ 2549), de 26 de septiembre de 1988 (RJ 6860), de 20 de febrero de 1989 (RJ 1214). En igual sentido, STS de 19 de febrero de 1996, RJ 1413.

Res DGRN 20 de septiembre de 1993, RJ 6915; 24 de marzo de 1994, RJ 3191.

SSAP León, Sección 2a, de 19 noviembre de 1998 -AC 2073-; Alicante (Sección 7a), de 12 junio de 2001, JUR $2001 \backslash 237547$ ("la capacidad en las personas es una presunción que forma parte integrante, como tuvo ocasión de señalar, entre otras, la sentencia del TS de 20 de marzo de 1991 (RJ 2266), del derecho fundamental al libre desarrollo de la persona (art. 10.1 de la Constitución), presunción que sólo puede ser dejada sin efecto en virtud de sentencia judicial por las causas establecidas en la Ley”); Tarragona (Sección 3), de 15 abril 2002, JUR 2002/183938; Madrid de 10 de enero de 2003, JUR 2003/92878; Barcelona, de 29 de julio de 2005, JUR 2006/38029.

${ }^{602}$ Así, entre otras:

SSTS de 7 de febrero de 1967; 10 de abril de 1987 (RJ 2549); 18 de marzo de 1988, RJ 10355.

SSAP Cádiz, Sección $1^{\text {a }}$, de 2 octubre 2000, JUR 2001\19989; Zaragoza, Sección 5a, de 13 diciembre de 2000, JUR 2001\54410. 
A la vista de lo anterior, y tratando de dar una respuesta concreta acerca de la cuestión planteada, podemos decir que se puede disponer libremente de los bienes y, en consecuencia, se tiene capacidad para poder ejercer válidamente el ius delationis de la herencia a que se ha sido llamado (arts 988 y 992 CC), en plenitud de efectos jurídicos, desde que la persona es mayor de edad (arts 12 CE y 315 CC), y no tiene restringida la capacidad de obrar (art. 322 CC).

No obstante, en nuestra opinión, dado el tenor literal de ambos preceptos, arts 992 y 322 CC, entendemos que la regla de capacidad contenida en aquel, el artículo 992 CC, para el ejercicio del ius delationis, no añade nada nuevo ni distinto respecto de éste, del artículo $322 \mathrm{CC}$, solo que lo dice con otras palabras, al ser expresiones equivalentes, tener la "libre disposición de los bienes" y poder ejercitar "todos los actos de la vida civil salvo las excepciones establecidas en casos especiales", porque no se podrán realizar ciertos actos al no tener la libre disposición de los bienes cuando existen tales excepciones ${ }^{603}$.

${ }^{603}$ De entre las que pueden afectar a la capacidad de la persona, cobra especial relieve la que se deriva de la declaración judicial de incapacidad (arts 199, 200 CC).

$\mathrm{Al}$ no ser obligatoria o imperativa la incapacitación cuando una persona padece alguna de las causas que pudieren dar lugar a la misma, sino meramente potestativo o facultativo, posibilita la existencia de personas incapaces de hecho, que padecen alguna enfermedad o anomalía de carácter físico o psíquico, o algún tipo de trastorno mental o de minusvalía o discapacidad, pero que no han sido declaradas judicialmente incapaces. Ello nos lleva a plantear la cuestión de si estas personas tienen o gozan de capacidad frente al derecho para poder actuar por sí solas y si pueden, con plena validez y eficacia, ejercer el ius delationis que les ha sido deferido respecto de una sucesión.

En este sentido, es muy ilustrativa la sentencia del Tribunal Supremo de 28 junio 1990 (RJ 4942), ya que tuvo por objeto un caso de presunta incapacidad mental, no declarada judicialmente, a propósito del otorgamiento de un documento privado de renuncia a una herencia y en la que se pedía por la renunciante la nulidad de dicho documento por pretendida incapacidad mental en ese momento del otorgamiento. El Tribunal Supremo resolvió desestimando la pretensión de la actora por entender, entre otras razones, que, "la capacidad mental se presume siempre mientras no se destruya por una prueba concluyente en contrario, requiriéndose en consecuencia una cumplida demostración mediante una adecuada prueba directa -Sentencias de esta Sala de 10 de febrero de 1986 (RJ 520), 10 de abril de 1987 (RJ 2549), 26 de septiembre de 1988 (RJ 6860), 20 de febrero de 1989 (RJ 1214), entre otras-, por lo que no es posible que la referida presunción legal y jurisprudencial pueda ser destruida mediante otra presunción de las llamadas «de hombre» («presumptio hominis» o «presumptio facti»), contempladas en el artículo 1253 del Código Civil, como aquí pretende la recurrente”.

Por tanto, dado que la capacidad mental se presume siempre mientras no haya una prueba concluyente en contrarío (SSTS de 10 de febrero de 1986 -RJ 520-, y 19 de febrero de 1996 -RJ 1413-; SAP de Alicante núm. 597/2001 (Sección 6), de 8 noviembre AC 2002/284), como sería una sentencia judicial de incapacitación, habrá que entender, o presumir, que el enfermo mental no incapacitado, o presunto incapaz, tiene capacidad de obrar y que ésta es plena, sin restricciones (al menos por esta causa), por lo que podría, en principio, en nuestra opinión, ejercitar por sí mismo los derechos de que es titular al presumírsele iuris tantum que está en plenitud de facultades mentales y, por tanto, tendrá la libre disposición de sus bienes. En consecuencia, podrá repudiar la herencia que le hubiese sido deferida. Si bien, pese a ello, nada impide, aplicando la doctrina general de los actos, contratos y demás negocios jurídicos, que los actos realizados por él pueden ser objeto, en su caso, de impugnación, si bien, requiere la prueba de su ineptitud mental en el momento de la realización del acto. En este sentido, de la validez y eficacia de la declaración de voluntad emitida por un incapaz, esté o no incapacitado, nos vamos a ocupar en el capítulo diez, punto 4-3, al que nos remitimos. 
Sin perjuicio de ello, merecen especial atención por razón de algunas particularidades que se presentan en la repudiación, casos como: el menor de edad, sea o no emancipado, el concursado, el desaparecido y el ausente, o los supuestos específicos de que trata el Código Civil relativos a los pobres, sufragios y obras piadosas, de los que nos ocupamos más en detalle a continuación.

\section{1-1-2.- Reglas especiales.}

$\mathrm{Si}$, para poder ejercer válidamente el ius delationis es preciso que el sucesor sea mayor de edad y no tenga restringida su capacidad de obrar, hasta que no alcance dicha mayoría, podemos hablar de una incapacidad natural en la persona que exigirá la adopción de medidas especiales para poder cubrir esa ausencia de capacidad.

Así, hay supuestos que pueden suscitar interés por razón del sujeto a quien se puede deferir la herencia, como serían: el caso del nasciturus, del concepturus, y de fecundación asistida post mortem ${ }^{604}$, ya que plantean alguna dificultad en lo que se refiere al ejercicio del ius delationis dada la situación jurídica de pendencia en que se encuentran y la consiguiente incertidumbre acerca de su futuro como personas.

Por otro lado, el padecimiento de determinadas enfermedades o deficiencias físicas como sordera, ceguera, mudez o sordomudez, no suponen para quien las padece causa de incapacitación, como tampoco pérdida de aptitud o de idoneidad para poder ejercer los derechos y obligaciones de que se es titular. En estos casos, dado que se trata de emitir una declaración de voluntad y, en tanto en cuanto, la anomalía que se padezca no suponga una merma de sus facultades intelectuales y/o volitivas, más bien lo que se podría llegar a plantear, no es tanto una cuestión de capacidad, sino un problema de comunicación o de exteriorización de esa voluntad. Pero, al tenerse que hacer la declaración de repudio por escrito (art. 1008 CC), se podría realizar sin ningún género de dificultad y podría ejercitar por sí solo el ius delationis. Distinto es que la persona fuese, además de sordomuda, ciega, porque al no tener a través de sus sentidos ninguna forma de comunicación hacia el exterior, como tampoco desde el exterior hacia ella, salvo a través del tacto (a través del sistema de Braille), difícilmente podría aceptar o repudiar. En este caso, sería necesaria una declaración de incapacitación y proveerla del nombramiento de una persona que cuidase de su persona y de sus bienes a través de la cual se emitiría dicha declaración de voluntad.

${ }^{604}$ La posibilidad de que puedan ser llamados a la sucesión y su capacidad para poder suceder ha sido admitido desde el punto de vista legal en la legislación de algunas Comunidades Autónomas.

Así: en Navarra (Ley 154 CCDFN); Cataluña (art. 412-1, Ley 10/2008); Aragón (art. 325 CDFA).

También ha sido admitido por la jurisprudencia: SSTS de 29 de noviembre de 1935, 25 de abril de 1963 -RJ 1996-; 3 de abril de 1965 -RJ 1965-; 4 de febrero de 1970 -RJ 524-; 13 de diciembre de 1974; 29 de noviembre de 1985; 28 de noviembre de 1986 -RJ 6622-; 9 de febrero de 1998 -RJ 609-; Res DGRN de 2 de diciembre de 1986 -RJ 7883-; 29 de enero de 1988 -RJ 316-; o la SAP Valencia (Sección $7^{\mathrm{a}}$ ), de 23 de septiembre de 1998 -AC 1699-.

No sucede lo mismo en la doctrina donde ha habido autores que lo han negado en base a los artículos 29, 745, 750 y 758 CC, de los que se desprende la regla de que la capacidad para poder suceder o heredar se ha de apreciar en el momento de abrirse la sucesión, y como en ese momento el “concepturus” carece de existencia real, carecería de toda capacidad ya solo para poder heredar, tanto más para poder aceptar o repudiar. Otros, en cambio, lo han admitido: MATA DE ANTONIO ("Problemas prácticos en torno a la capacidad sucesoria del concepturus”. RDP. Septiembre-octubre 2003. Pág 658 y ss), DE CASTRO (Derecho Civil de España. Ed CIVITAS. Madrid. 1984. Pág 402), DIEZ PICAZO y GULLÓN BALLESTEROS (Sistema de Derecho Civil. Vol. IV. Cit: Págs 345 y 346).

Sin embargo, a través de alguna institución jurídica como son las sustituciones fideicomisarias (arts 781 y 787 CC), o la disgregación del usufructo y la nuda propiedad, sí se admite que el concepturus pueda ser llamado a una herencia. 
Dado que la condición de persona y la atribución de la personalidad se adquiere desde el mismo momento en que se nace con vida, una vez que se ha producido el entero desprendimiento del cuerpo del seno materno (artículo $30 \mathrm{CC}^{605}$ ), sin perjuicio de que al concebido pero no nacido “... se tiene por nacido por todos los efectos que le sean favorables, siempre que nazca con las condiciones que expresa el artículo siguiente" (art. 29 CC inciso segundo), entendemos que, con anterioridad a ello, sería de todo punto imposible repudiar la herencia que les hubiese sido deferida por quienes les representarían como ya si se hubiere producido su nacimiento, esto es, los padres, porque ello tropieza, por un lado, con el artículo 990 del Código Civil según el cual, "la aceptación o la repudiación de la herencia no podrá hacerse ....... condicionalmente", dado que la exigencia del artículo 30 de haber nacido vivo actuaría como tal, y, por otro, con el artículo 991 CC, que exige que el derecho a la herencia del sucesor sea cierto. En estos casos, su existencia depende del suceso futuro y objetivamente incierto de que llegue a nacer vivo, incluso antes, de ser concebido, en el caso del concepturus. De ahí que su derecho a la herencia sea incierto porque no se sabe en el momento de ejercicio del ius delationis si llegará a ser cierta su existencia. Cuando es llamado a una sucesión un nasciturus, o un concepturus, cierto es que se crea en su favor una expectativa jurídica que merece ser protegida, como lo demuestra el hecho de que, si fallece el padre estando el nasciturus en el vientre materno, se procede a suspender la partición de la herencia al tiempo que se pondrá ésta en administración (arts. 965 CC, y 797 y ss LEC), hasta que se resuelva la situación de incertidumbre que se ha creado, mas no por ello, entendemos, se podrá ejercer en su nombre el ius delationis por parte de sus progenitores por las exigencias de los artículos 990 y 991 del Código Civil al estar pendiente su existencia y por tener que esperar a que nazcan cumpliendo con los requisitos del artículo $30 \mathrm{CC}$, porque, ¿qué ocurriría si, una vez repudiada la herencia, no se produce la concepción, hay un aborto en fase de gestación o nace muerta la criatura?.

\section{1-1-2-1.- En el caso del menor de edad no emancipado.}

Cuando es llamado a una sucesión un menor de edad no emancipado, dado que por su situación personal sólo tiene capacidad jurídica, carece de la libre disposición de sus bienes exigida por el artículo 992 CC. Luego, obviamente, no tendrá la capacidad legal necesaria para poder él, por sí solo, repudiar, o aceptar, la herencia que le hubiese sido deferida. Ausencia de capacidad que se suple con la preceptiva intervención de sus representantes legales (los padres, o aquel de éstos que ejerciere

${ }^{605}$ De nueva redacción por la Disposición final tercera de la Ley 20/2011, de 21 de julio, del Regitro Civil. 
la patria potestad -arts. 154, 162, 166 CC-; o el tutor -arts 267 y $271.4^{\circ} \mathrm{CC}$-), que son a quienes le corresponde realizar, en su nombre, dicha manifestación.

En el primer caso, cuando el menor está bajo la potestad de los padres, éstos, por aplicación de lo dispuesto en el artículo 166 del Código Civil, no pueden decidir libremente según estimen o tengan por conveniente para los intereses del hijo respecto de la oferta sucesoria que ha recibido porque, en el caso de que optaren por repudiar la herencia o legado deferido a su favor, es necesaria, tal y como exige dicho precepto, la obtención de "previa autorización judicial"606, aparte de que no lo podrán realizar si no es, "por causas de justificadas de utilidad o necesidad, con audiencia del Ministerio Fiscal"607. Y si el Juez denegase la autorización solicitada por los padres para poder repudiar, "la herencia sólo podrá ser aceptada -por los padres- a beneficio de inventario". Y, si estuviere sujeto a tutela, el artículo $271.4^{\circ} \mathrm{CC}$ exige preceptivamente al tutor obtener previa autorización judicial "para aceptar sin beneficio de inventario cualquier herencia, o para repudiar ésta o las liberalidades".

No obstante, volviendo de nuevo al artículo 166 CC, manifiesta en su último párrafo que, "no será necesaria autorización judicial si el menor hubiese cumplido dieciséis años y consintiere en documento público", lo que, de forma singular, incluso excepcional, exceptúa a los padres de instar la pertinente autorización si el hijo consiente la repudiación ${ }^{608}$. No ocurre lo mismo, a nuestro juicio, si se tratase de un menor sometido a tutela porque, en este caso, sí que será necesaria, en todo caso, la autorización judicial que el Código Civil exige al tutor para poder repudiar porque en él no se contempla la posibilidad de que el tutelado pueda consentir en documento público como sucede en el caso de los padres y eximir, así, a su tutor de instar la

606 Una de las cuestiones que más se han debatido y tratado por la jurisprudencia acerca dicha autorización judicial es qué validez tiene el acto realizado por parte de los padres sin haberla obtenido previamente. Sin embargo, dejamos aquí planteada esta cuestión porque de ella nos vamos a ocupar más en detalle y de forma expresa, en el capítulo décimo, punto número 4-1-4, al que nos remitimos.

607 De igual manera:

- en Cataluña, "los padres o tutores necesitan la autorización judicial para repudiar las herencias deferidas a los hijos menores de edad o a las personas puestas en tutela" (art. 461-9.2, Ley 10/2008, sobre sucesiones) y, en los mismos términos, el art. 236-27.1, letra e), de la Ley Ley 25/2010, de 29 de julio, del libro segundo del Código civil de Cataluña, relativo a la persona y la familia, exige a los padres autorización judicial para renunciar las herencias o legados deferidos a los hijos,

- en Aragón, aunque un mayor de 14 años no incapacitado puede aceptar una herencia, "para repudiarla ....., aunque estén emancipados, necesitarán la debida asistencia”, esto es, la intervención de los padres (art. 346.1 y 3 CDFA). Mientras que, si fuere menor de 14 años, la repudiación le corresponde a sus representantes legales, además de que "necesitan autorización de la Junta de Parientes o del Juez" (art. 346.2 CDFA).

${ }^{608}$ En los mismos términos en Cataluña, donde la Ley 25/2010, de 29 de julio, del libro segundo del Código civil de Cataluña, relativo a la persona y la familia, establece en su artículo 236-30, letra a), que, "puede sustituirse la autorización judicial por el consentimiento del acto, manifestado en escritura pública, del hijo, si tiene al menos dieciséis años”. 
pertinente autorización judicial, por lo que éste ha de sujetarse siempre a la observancia de tal exigencia ${ }^{609}$.

Pero, centrándonos en la prestación de este consentimiento por parte del menor de 16 años, llama la atención por su valor, incluso el fundamento que tiene, y sobre lo que se han hecho diversos comentarios y apreciaciones por parte de la doctrina, si bien, un amplio sector (entre otros: BERCOVITZ ${ }^{610}$, URIBE SORRIBES ${ }^{611}$, o LOPEZ SAN LUIS ${ }^{612}$ ), coincide en señalar que tiene el valor de sustituir a la licencia 0 autorización judicial.

Así, a juicio de BERCOVITZ, "con esta excepción, se crea una figura intermedia entre el régimen general de la representación legal y la administración concedida a los progenitores y el régimen propio de la emancipación para determinados bienes (art. 323 CC)". Pero, a diferencia de lo que ocurre en la emancipación en que es el menor quien decide sobre la oportunidad de vender, gravar o enajenar, aunque después necesite la intervención de sus padres (arts 323 y 324 CC), aquí, la situación se invierte porque, en este caso, "son los progenitores los que han de tomar la decisión, pero necesitan el consentimiento del menor". Se trataría, por otro lado, de un sistema intermedio que, quizá, evita muchas emancipaciones, "que únicamente se producirían con el fin de poder disponer con mayor facilidad (sin necesidad de procedimiento judicial alguno) de determinados bienes del menor".

Por su parte, URIBE SORRIBES, en términos análogos, manifiesta que, "en estos casos, el límite que tiene la representación legal de los padres consistente en la necesidad de autorización judicial previa, se ve sustituido por el consentimiento del hijo", y coincide con BERCOVITZ en señalar que, evita tener que recurrir a la emancipación para que el menor pueda ejercitar el acto dispositivo por sí, con el consentimiento de los padres. A través de esta norma, añade URIBE, se llega al mismo resultado, con la diferencia de que, en este caso, "quien otorga el acto son los padres como representantes legales, aunque con el consentimiento del hijo".

LOPEZ SAN LUIS, en la misma línea de pensamiento, entiende que "el menor legitima la actuación de los titulares de la patria potestad en sustitución de la autorización judicial, .....".

${ }^{609}$ En el mismo sentido, LOPEZ SAN LUIS: La capacidad contractual del menor. Madrid. Dykinson. 2001. Pág 81. Cita a pie de página nº 116.

${ }^{610}$ Comentarios a las reformas del Derecho de Familia. Vol II. Ed. TECNOS. Madrid. 1984. Págs 1122 y 1123.

611 “La representación de los hijos”. AAMN. T XXV. Pág 276.

612 Op. cit.: Pág 81. 
Otros, en cambio, como GARCIA GARNICA ${ }^{613}$, no sin razón, entienden que, "esta norma ha sido criticada porque introduce un elemento perturbador en la lógica general del sistema de protección del menor ya que se refiere a los actos de renuncia de derechos del menor, así como enajenación y gravamen de sus bienes de mayor valor. Supone, en definitiva, un reconocimiento in peius de la capacidad natural del menor, incongruente con el sistema general". Y no le falta motivo porque ciertamente se trata de una norma que altera y trastoca el sistema de protección que la ley dispensa al menor al concederle una facultad que sólo se adquiere con la mayoría de edad. De ahí que después entienda que, "tal vez habría sido más acertado limitarse a admitir la posibilidad de confirmación por el hijo, al alcanzar la mayoría de edad, del acto realizado por sus padres sin autorización judicial, conforme a lo dispuesto en los artículos 1309 y siguientes del Código Civil, en lugar de admitir su renuncia a priori al control judicial de éstos". A lo que añade, "si bien, en todo caso, no podemos olvidar que esta renuncia podrá anularse en el caso de que el menor haya prestado un consentimiento viciado por error, dolo o violencia, conforme a las reglas generales".

A nuestro juicio, el hecho de dar tal relevancia al consentimiento del menor, es, sin duda alguna, algo verdaderamente anómalo y excepcional porque, no solo se tiene en cuenta su voluntad, lógicamente en atención a su edad y a su madurez intelectual, psíquica y volitiva -de ahí que se exija tener ya dieciséis años cumplidos ${ }^{614}$-, sino que se le da por la ley un valor de tal entidad y naturaleza que se considera suficiente como para llegar incluso a sustituir a la autorización judicial. Ahora bien, no deja de ser una actuación en la que los padres siguen en su función de representantes legales del menor porque, no por ello, dejan de actuar como tales, solo que la ley excepciona este caso de dicha representación legal en atención a las condiciones de madurez que el menor, normalmente, ya tiene a esa edad.

La prestación de este consentimiento por parte del menor entronca, directa e inevitablemente, con la cuestión de su eficacia jurídica frente al Derecho (cfr: arts 162, $164,165,166$ y 1261 a 1264 CC, y concordantes). Sin entrar en el fondo de la misma,

${ }^{613}$ El ejercicio de los derechos de la personalidad del menor no emancipado. Aranzadi. Cizur Menor (Navarra). 2004. Pág 37.

${ }^{614}$ El legislador fija o establece la edad de los dieciséis años en atención a las facultades intelectuales y volitivas, así como de discernimiento y consciencia que suele tener ya la persona a esta edad, y le viene a dar a su voluntad un valor análogo al de la persona ya plenamente capaz y responsable de sus actos. Por tanto, no es una edad aleatoria, sino establecida por razón de la madurez que ya tiene la persona en ese momento.

Recordemos que desde los dieciséis años el menor puede, entre otros actos: consentir la emancipación por concesión de los padres (art. 317 CC); solicitar el beneficio de la mayor edad (art 321 CC); o concertar su propio contrato de trabajo (art 7 letra b, RDLeg 1/1995, de 24 de marzo, por el que se aprueba el Texto Refundido del Estatuto de los Trabajadores). 
aunque sí lo abordaremos a propósito de la ineficacia ${ }^{615}$, es preciso relacionar la norma del artículo 166 con la contenida en el artículo $162.2 .1^{\circ} \mathrm{CC}^{616}$, en el que la ley permite que el menor pueda realizar por sí solo ciertos actos "de acuerdo con las leyes y con sus condiciones de madurez", lo vendría a ser la justificación o legitimación en que se fundamenta la posibilidad de poder prestar este consentimiento, y que, en palabras de JORDANO FRAGA, constituye una capacidad especial cuyo presupuesto básico es la "capacidad natural de entendimiento y juicio del menor"617. Capacidad natural de la que también se hacen eco otros autores ${ }^{618}$ y que permitiría, al tiempo que

${ }^{615}$ Vid, el punto número 3-1-3, del capítulo décimo, al que nos remitimos.

${ }^{616}$ En comentario a dicho precepto, MONTÉS PENADÉS entiende que en él se han entremezclado dos órdenes de conceptos: por una parte, los actos relativos a derechos de la personalidad y, por otro, actos que puede realizar por sí solo, en referencia a la ley y las condiciones de madurez (Comentarios a las reformas del Derecho de Familia. Vol II. Ed. TECNOS. Madrid. 1984. Págs 1085 y 1086).

Analizando los antecedentes del mismo (cita el texto que propuso DÍEZ-PICAZO a la Comisión General de Codificación y Proyectos de Ley de 1978 y 1979), entiende que las condiciones de madurez deben ser referidas a los derechos de la personalidad, y que la referencia a las leyes, ha de ponerse en relación con ese otro tipo de actos. En este punto cita URIBE, que llega a la misma conclusión (Op cit: Pág 261).

Así pues, en opinión de MONTÉS PENADÉS, habría realmente dos excepciones:

$1^{a}$.- actos relativos a derechos de la personalidad que el hijo está en situación de ejercitar por sí mismo de acuerdo con sus condiciones de madurez, y

$2^{\mathrm{a}}$.- otros actos que el hijo, de acuerdo con las leyes, pueda realizar por sí mismo. Lo que supone una remisión a lo que otros preceptos puedan establecer. Y aquí cita, entre otros: arts 124 CC (reconocimiento del hijo extramatrimonial); 164.4으 (actos de administración); 443 (adquisición de la posesión); 625 y 626 a contrario (aceptación de donaciones puras).

Al que añadiríamos el que aquí nos ocupa, como también, de gran relevancia, la posibilidad de reconocer su propio hijo si tiene capacidad para contraer matrimonio, y si no la tiene, con aprobación judicial (art. 121 CC).

URIBE, por su parte (Op cit: Pág 261), también pone de relieve la oscuridad del artículo 162 y llega a igual distinción que MONTÉS en orden a diferenciar en él dos clases de derechos.

JORDANO FRAGA, por su parte, justifica este y otros actos (entre los que cita: el otorgamiento del testamento desde los catorce años, salvo el ológrafo, la posibilidad de poder contraer matrimonio desde esa misma edad con dispensa del Juez, poder otorgar capitulaciones antes del matrimonio), diciendo que son casos en los que se rebaja el nivel general de capacidad "en atención a la propia naturaleza del acto y en función de los criterios de política legislativa que inspiren la regulación de las distintas instituciones. De ahí la variabilidad histórica de los supuestos de capacidad especial atribuida al menor que dependen, en definitiva, de la discrecionalidad del legislador" ("La capacidad general del menor”. RDP. 1984. Pág 896).

${ }^{617}$ Op. cit.: Págs 897 y 898.

A lo que comenta: "esta última dicción del precepto, la capacidad natural del menor no emancipado ("sus condiciones de madurez") no sólo opera como su necesario presupuesto al igual que en las restantes direcciones ya examinadas, sino que, a la vez, delimita el propio ámbito en el que al menor no emancipado se le reconoce por la ley capacidad (general) para actuar válidamente por sí. $Y$, en la medida en que se le reconoce una capacidad propia de actuar válidamente por sí, es esa misma medida en la que, en ese ámbito, se excluye la (innecesaria) intervención del representante legal.

De este modo, la capacidad natural se hace jurídicamente relevante y señala, en modo variable, según el propio desarrollo del menor, simultáneamente un ámbito de de válida actuación de menor y de correlativa exclusión del representante legal”.

${ }^{618}$ Así, entre otros: GOMEZ LAPLAZA (“Comentario a los artículos 1263 y 1264 del Código Civil”, en Comentarios al Código Civil y Compilaciones Forales. T XVII. T I.Vol 1º EDERSA. Madrid. 1981. Pág 169); LOPEZ SAN LUIS (Op. cit.: pág 79); GETE-ALONSO (La nueva normativa en materia de capacidad de obrar de la persona. Ed. CIVITAS. Madrid. 1985. Pág 43 y ss); CASTÁN TOBEÑAS (Derecho Civil Español Común y Foral. T. II. Vol 1. 2º REUS S.A. 14 Ed. Madrid. 1988. Pág 508). 
legitimaría, que el menor pueda, por disposición de la ley, realizar, no solo éste, sino otros muchos actos de su vida civil ${ }^{619}$, sin que por ello caigan en el ámbito de la anulabilidad. En este sentido, en nuestro ordenamiento jurídico, a diferencia de otros, como es el alemán donde se establece la edad de los siete años (parágrafo $104.1^{\circ}$ ), no se habla de una edad a partir de la cual se entiende que un menor de edad ya tiene capacidad natural.

No obstante, un comentario. No deja de llamar la atención el hecho que, el menor, pese a que carezca de capacidad para poder repudiar válidamente y con plena eficacia jurídica, por sí solo, aquella herencia a que hubiese sido llamado al amparo de lo dispuesto en el artículo 992 CC sí, en cambio, se admita que él pueda consentir en documento público que sus padres puedan repudiar esa herencia y éstos queden dispensados de solicitar la autorización judicial. Lo que no deja de ser una paradoja, algo anómalo o excepcional, como también, pueda él, por sí solo, otorgar un acto de gran trascendencia desde el punto de vista personal y jurídico patrimonial como es su propio testamento desde los catorce años de edad (arts. 662 y $663.1^{\circ} \mathrm{CC}$ ), salvo el ológrafo (art. $688 \mathrm{CC}$ ), y sin necesidad de que intervengan los representantes legales, cuando, además, se da la circunstancia de que el artículo 667 CC califica al testamento como un acto de disposición, lo mismo que lo es la repudiación ${ }^{620}$. Pero, volvemos de nuevo a lo mismo, se trata de actos que la ley permite, de forma excepcional, en atención a las condiciones de madurez del menor y sin que por ello cese la representación legal de los padres.

En otro orden de argumentos, dada la importancia y trascendencia del acto, está justificado el hecho de que deban de exigirse, apunta BERCOVITZ ${ }^{621}$, ciertas garantías en la prestación de dicho consentimiento, como es el hecho de que se deba de plasmar en documento público y que "habrá de concederse para cada acto y no es válido el concedido con carácter general". En este sentido, llama la atención que no se establezca por la ley ningún tipo de control o garantía de supervisión, ni antes, ni después de su otorgamiento, ni tan siquiera judicial, salvo el que, en su caso, haga el Notario que autorice el documento público en que conste el consentimiento del menor con carácter previo a su otorgamiento. Será entonces, en ese momento, cuando el

${ }^{619}$ En este sentido, vid por su amplitud, entre otros: GETE-ALONSO (Op. cit.: pág 29 y ss), y LOPEZ SAN LUIS (Op. cit.: pág 79 y ss). Tanto uno como otro se refieren, de forma sucinta, extensa y detallada, atendiendo a diferentes puntos de vista (esfera personal-familiar, situación personal, ámbito negocial patrimonial y patrimonio del menor), a toda una serie de supuestos de actuación personal y directa del menor.

${ }^{620}$ Véase en este sentido, el capítulo cuarto, al principio del mismo, al analizarse, desde un punto de vista general, los caracteres de la declaración de repudiación.

${ }^{621}$ Op. cit.: Pág 1122. 
Notario, en el ejercicio de su función (art. 194 RN de 1944), advertirá y hará saber al menor el significado, importancia y trascendencia del acto que va a consentir y otorgar. $\mathrm{Y}$, si se da la circunstancia de que el menor no lo comprendiere, aparte de que deberá ser instruido sobre este extremo por el propio Notario, o éste observase la posible existencia de algún vicio del consentimiento (como puede ser una coacción psíquica), pudiera darse la circunstancia de que el Notario no autorizara tal documento público, lo que puede constituir ya cierta garantía o salvaguardia en lo que se refiere a la libertad y consciencia o conocimiento en la prestación de ese consentimiento por el menor.

Por otro lado, y al hilo de la calificación o función que se da por parte de la doctrina al consentimiento del menor de sustituir a la autorización judicial, nosotros vamos un poco más allá y nos planteamos, dado el tenor del precepto, el interrogante de cómo se ha de entender, o qué valor dar a dicha sustitución: si se trata de una sustitución propiamente dicha, en el sentido de que la suple, es decir, autorización por consentimiento, de tal manera que, hasta los dieciséis años, se precisa autorización judicial, y después de dicha edad, en vez de ésta es preciso el consentimiento del hijo por lo que los padres, si deciden repudiar, tendrán que recurrir a él y no al Juez, o si lo que se quiere decir con ello es que, tanto el consentimiento como la autorización, tienen el mismo valor o equivalencia, de tal manera que, hasta los dieciséis años, se precisa autorización judicial, y después de dicha edad, tanto monta, monta tanto, la autorización como el consentimiento y éste vale lo mismo que aquella, ante lo que los padres tendrían, bien la autorización, bien el consentimiento del hijo, aquella en todo caso, o éste, si lo otorga, en cuyo caso, evita la autorización ${ }^{622}$.

Entendemos que, de darse la primera interpretación, estaríamos dando a dicho consentimiento un carácter obligatorio, y no ya tanto como presupuesto necesario para poder repudiar, al igual que sucede con la autorización, sino en el sentido de que se forzaría al menor a ello, a tener que consentir una repudiación que, de poder hacer él solo si ya fuere mayor de edad, probablemente no lo habría hecho y habría optado por la aceptación, lo que iría en contra del carácter libre y voluntario que caracteriza y ha de presidir la declaración del delado (art. 988 CC).

De ahí que, en nuestra opinión, el sentido que ha de dársele es el segundo porque, volviendo de nuevo al tenor del precepto, podemos observar que, al tiempo que establece la premisa de que el menor, para consentir, ha de tener dieciséis años

${ }^{622}$ En este sentido, en Cataluña, la Ley 25/2010, de 29 de julio, del libro segundo del Código civil, relativo a la persona y la familia, habla expresamente de sustitución en su artículo 236-30, letra a), al manifestar que, "puede sustituirse la autorización judicial por el consentimiento del acto, manifestado en escritura pública, del hijo, si tiene al menos dieciséis años”. 
cumplidos, después se manifiesta de modo condicional, dada la forma verbal que emplea, "consintiere", lo que, a nuestro juicio, denota voluntariedad y no imperatividad u obligatoriedad, como ocurriría si dijese que el menor ha de consentir. La autorización judicial no es necesaria si se dan las dos premisas: que el menor tenga dieciséis años cumplidos y consienta en documento público la repudiación. Es decir, el menor no estaría obligado a prestar dicho consentimiento si sus padres deciden repudiar la herencia a que él fue llamado, sino que es meramente potestativo o facultativo por su parte otorgarlo, como tambien puede guardar silencio, no decir nada, por lo que, ante su falta, tendrían que obtener la pertinente autorización judicial. Por tanto, teniendo el menor dieciséis años, valdría tanto el consentimiento como la autorización judicial y, a falta de aquélla, los padres, tendrán que solicitar ésta para poder repudiar. Distinto es que dijese: si el menor tiene dieciséis años cumplidos, ha de consentir la repudiación que hagan los padres, en cuyo caso, no será necesaria la autorización judicial ${ }^{623}$. De ahí que, en nuestra opinión, el consentimiento del menor es meramente potestativo por su parte y no es preceptivamente necesario para repudiar la herencia porque, en su defecto, si el hijo no lo otorga, incluso se niega a ello en el caso de que los padres se lo solicitaren, éstos han de recabar la autorización judicial.

Finalmente, al hilo de cuanto antecede, este supuesto nos da pie a plantear la cuestión de si, el menor no emancipado, fuera de la regla del último párrafo del artículo 166, carece en absoluto de capacidad para poder repudiar, o aceptar, o si, por el contrario, su voluntad tiene algún valor o trascendencia, aunque sea relativa, en orden a la opción que él tiene sobre la herencia a que ha sido llamado, sobre la base, por un lado, de esa capacidad natural de que goza ya a partir de cierta edad porque así se lo dan "sus condiciones de madurez" y que la propia ley le reconoce para poder realizar ciertos actos, y por otro, del hecho de que existan casos en que la jurisprudencia ha calificado de anulable el contrato celebrado por un menor de edad. El supuesto de que

${ }^{623}$ Nos planteamos la siguiente cuestión en la cual no vamos a entrar en el fondo de su examen porque se sale totalmente del objeto de nuestro estudio: qué ocurre si lo que hace el menor es comparecer ante Notario y manifiesta, no su consentimiento a la repudiación de la herencia, sino su aceptación a la misma dado que él no lo puede hacer por sí solo al ser aun menor de edad, y resulta que sus padres entienden que lo que procede, realmente, es lo contrario, repudiar la herencia porque entienden que es gravosa o perjudicial para los intereses de su hijo.

En este caso, ¿̇a decisión del hijo vincula a los padres?. Los padres, ¿necesariamente han de aceptar la herencia?, porque, recordemos que la decisión es de ellos pese a que necesiten del consentimiento del hijo (BERCOVITZ: Op. cit.: Pág 1122).

En principio, ante tal conflicto, diferencia de opiniones o de voluntades diferentes, y si los padres persisten en su actitud, a nuestro juicio, deberían recurrir al Juez y que sea él el que decida acerca de cual sería la decisión más apropiada a los intereses del menor.

Como también se puede dar la circunstancia, lo acabamos de apuntar, de que esa sería la intención o deseo del menor, aceptar la herencia si, siendo él ya mayor de edad, pudiese ejercer la delación por sí solo, ante lo que, precisamente por ese motivo y en señal de protesta o de rechazo a la intención de sus padres, se niega a otorgar dicho consentimiento. 
un menor no emancipado repudiare por sí solo la herencia a que ha sido llamado, es una hipótesis, a decir verdad, un tanto improbable, por cuanto, dado el carácter eminentemente formal que tiene la declaración de repudio, se hará ante Notario o el $J_{u e z}^{624}$, y éstos se lo impedirían, o no lo permitirían, por cuanto, aquel, el Notario, su función es valorar y apreciar la capacidad del otorgante (art. 145 RN de $1944^{625}$ ). Aun así, qué eficacia jurídica tendría, si nula o meramente anulable, dicha declaración de voluntad a la luz, por un lado, del artículo 992 CC a los efectos del ejercicio del ius delationis y, por otro, de los artículos 1261 a 1264 CC, relativos a la capacidad y el consentimiento para la celebración de los contratos. Ello incide directamente en la cuestión de la validez y eficacia de los actos, negocios jurídicos y contratos celebrados por menores no emancipados. Pero, de ello nos ocuparemos más adelante ${ }^{626}$ al examinar la ineficacia de la declaración de repudiación.

\section{1-1-2-2.- En el caso del menor de edad emancipado.}

Aquí, la problemática es diferente porque, dado que el menor goza de una, ya casi plena capacidad de obrar, a la luz del tenor del artículo 992 CC, nos plantea la duda de si tiene capacidad para repudiar por sí solo una herencia.

Al amparo de su régimen legal en materia de capacidad, se pueden plantear distintas posturas y obtener diversas respuestas:

a) estamos ante una persona que ya tiene una capacidad de obrar aunque sea limitada (cfr arts 323 y 324 CC), lo que parece entrar en colisión con el requisito de la libre disposición de los bienes que exige el artículo 992 CC.

${ }^{624}$ Nos remitimos, en este sentido, al punto número 2 de este capítulo donde se analiza, desde el punto de vista formal, la declaración de repudiación.

625 “La autorización o intervención del instrumento público implica el deber del notario de dar fe de la identidad de los otorgantes, de que a su juicio tienen capacidad y legitimación, de que el consentimiento ha sido libremente prestado y de que el otorgamiento se adecua a la legalidad y a la voluntad debidamente informada de los otorgantes e intervinientes”.

“Esto no obstante, el notario, en su función de control de la legalidad, no sólo deberá excusar su ministerio, sino negar la autorización o intervención notarial cuando a su juicio:

$2^{\circ}$ Todos o alguno de los otorgantes carezcan de la capacidad legal necesaria para el otorgamiento que pretendan”.

Sin embargo, la adveración hecha por el Notario de que el otorgante tiene capacidad no tiene valor de fe pública por cuanto puede ser desvirtuada por pruebas suficientes (SSTS 21 de marzo de 1952, RJ 504; 17 de marzo de 1961, RJ 959; 27 de marzo de 1963, RJ 2121; 10 de noviembre de 1969, RJ 5134; 4 de abril de 1984, RJ 1926; 4 de mayo de 1998, RJ 3230) Citadas por PASQUAU LIAÑO en comentario al artículo 1264, en Jurisprudencia civil comentada (Tomo I). Dirección: Pasquau Liaño. Ed. COMARES. Granada. 2000. Pág 2178.

${ }^{626}$ Véase, en el capítulo décimo, el punto número 4-2, donde analizamos qué eficacia jurídica tiene la declaración de repudio realizada por el menor de edad. 
En este sentido, ALONSO PEREZ ${ }^{627}$, cree que el menor emancipado sí puede aceptar herencias porque tiene "la libre disposición de sus bienes", aunque no la plena disposición de los mismos. Pero, no resuelve acerca de la repudiación.

b) Los artículos 323 y 324 CC no contemplan expresamente ni la repudiación ni la aceptación de una herencia como actos que el menor no pueda realizar por sí solo y para los que se le exija la intervención de sus padres, del cónyuge o del curador.

Entonces, al no prohibirlo expresamente el Código Civil se puede entender que lo permite y, en consecuencia, el menor emancipado podría por sí solo, sin necesidad del auxilio de nadie, repudiar aquella herencia que le hubiese sido deferida ${ }^{628}$.

c) Se trata de una persona que, al estar ya emancipada, su estado civil tiene aquí relevancia a los efectos de repudiación porque, según hemos visto en el supuesto anterior, el artículo 166 del Código Civil establece que, tratándose de un menor que ya tuviere dieciséis años pero que no esté emancipado, si éste consiente en documento público la repudiación, los padres están exentos de solicitar autorización judicial.

Luego, si se establece esta norma para el caso de que no esté emancipado, hay motivo para entender que, si ya lo está, podría el menor repudiar por sí solo el llamamiento sucesorio que le hubiese sido deferido sin necesidad del auxilio de sus padres, del cónyuge o del curador.

Así, vemos cómo, a la luz del Código Civil, la respuesta es más bien confusa ${ }^{629}$. De ahí que, desde el punto de vista doctrinal, nos encontramos con posturas muy diversas:

a) autores clásicos como MANRESA ${ }^{630}$, SCAEVOLA ${ }^{631}$, SÁNCHEZ ROMÁN ${ }^{632}$, DE DIEGO o VALVERDE, negaron que el menor emancipado pudiera aceptar o

627 "Estatuto jurídico del menor emancipado tras las recientes reformas del Derecho de familia". En La tutela de los derechos del menor. 1er Congreso nacional de Derecho Civil. Departamento de Derecho Civil de la Facultad de Derecho. Universidad de Córdoba. 1984. Pag 41.

${ }^{628}$ En este sentido, autores como GITRAMA (Op. cit.: Pág 112); LLEDÓ YAGÜE (Derecho de Sucesiones. Universidad de Deusto. Bilbao. 1991. Pág 48); CASTRO LUCINI (Op. Cit: Pág 627).

${ }^{629}$ En cambio, en Cataluña, el artículo 461-9 de la Ley 10/2008, de sucesiones, establece que, “los menores emancipados o habilitados de edad y las personas puestas en curaduría deben ser asistidos por las personas que complementan su capacidad”.

Y, en Aragón, ya vimos al tratar la regla general que el menor, aunque esté emancipado, “necesitará la debida asistencia” (art. 346.1 y 3 CDFA), es decir, intervención de sus padres, del tutor o de la Junta de Parientes, ya que no puede repudiar por sí solo.

${ }^{630}$ Op. cit.: Pág 370.

${ }^{631}$ Código Civil. Tomo XVII. Instituto Editorial REUS. Madrid. 1944. Pág 468.

${ }^{632}$ Estudios de Derecho civil. T. IV. Vol 3. Madrid. 1919. Pág 1768. 
repudiar libremente sin el consentimiento de sus padres o del curador, por lo que precisaba del auxilio legal para poder realizar estos actos,

b) ALBALADEJO ${ }^{633}$, O'CALLAGHAN, MUÑOZ, VALLET ${ }^{634}$, manifiestan que existe una incapacidad total para poder repudiar sin el consentimiento de sus padres 0 curador,

c) otros, como ROCA SASTRE, entienden que tiene capacidad para aceptar, pura y simple o a beneficio de inventario, por sí mismo, pero con la exigencia de la asistencia de sus padres o del curador para poder repudiar,

d) más permisivos, LACRUZ y SANCHO ${ }^{635}$ hablan de capacidad para poder aceptar a beneficio de inventario y para repudiar por sí mismo, siendo discutible su capacidad para aceptar de forma pura,

e) no faltan quienes como, DE CASTRO, BORREL y SOLER ${ }^{636}$ o SANTA MARÍA, entienden, invocando antecedentes históricos, que el menor emancipado tiene capacidad tanto para aceptar como para repudiar. En igual sentido la DGRN (RR de 7 de enero de 1907, 28 de mayo de 1971, 4 de noviembre de 1986).

f) ALONSO PEREZ ${ }^{637}$, por su parte, ya refiriéndose a la capacidad para poder repudiar, distingue con más detalle según cómo se realiza por parte del menor:

a') si se trata de una renuncia de los casos a que se refiere el artículo 1000 $\mathrm{CC}$, en sus números $2^{\circ}$ y $3^{\circ}$, o de renuncias impropias o traslativas que encubren verdaderas enajenaciones, si el objeto de la renuncia lo constituyen aquellos bienes a que se refiere el artículo $323 \mathrm{CC}$ (bienes inmuebles, establecimientos mercantiles o industriales u objetos de extraordinario valor), entonces estaremos ante los actos que le están vetados al menor emancipado a realizar por sí solo, en cuyo caso, necesitará el consentimiento de sus padres o del curador para poder realizar dicha renuncia,

b') pero, si se trata solamente de hacer efectiva de forma negativa el ius delationis, dado que tal derecho potestativo no está entre los actos enunciados en el artículo 323 CC, el menor emancipado estaría plenamente capacitado por sí mismo para repudiar no obstante la literalidad del artículo $992.1^{\circ} \mathrm{CC}$.

633 "La repudiación de la herencia”. Cit: Págs 724 y 725.

${ }^{634}$ Panorama del Derecho de Sucesiones. II. Cit: Pág 438.

${ }^{635}$ Elementos de Derecho Civil. T. V. Sucesiones. DYKINSON. Madrid. 2001. Pág 76.

${ }^{636}$ Derecho civil de Cataluña. V. "Sucesiones por causa de muerte". Barcelona 1944. Pág 425 y ss

637 "Estatuto jurídico del menor emancipado tras las recientes reformas del Derecho de familia". Cit: Pag 42. 
En nuestra opinión, el menor emancipado sí podría repudiar la herencia que le hubiere sido deferida porque:

a) pese a que se considere la repudiación como un acto de disposición, lo cierto es que el Código Civil no lo contempla en los artículos 323 y 324 como alguno de los actos que un menor emancipado no puede realizar por sí solo y que requiera el auxilio de alguna de las personas en ellos indicadas. Por otro lado, y en este mismo sentido, no se puede, ni considerar implícitamente incluído en ellos tal acto, como tampoco presumir la imposibilidad de poder repudiar, por cuanto las limitaciones a su capacidad habrán de entenderse de forma restrictiva.

Existen casos referidos a actos muy concretos en los que el Código Civil, con expresiones, eso sí, muy diversas y de significado variable, tales como: ser mayor de edad $^{638}$, estar en pleno uso de ejercicio de sus derechos civiles ${ }^{639}$, tener capacidad para obligarse ${ }^{640}$, o capacidad para contratar y disponer de los bienes ${ }^{641}$, está dando a entender que excluye de su ejecución, entre otros, al menor emancipado. Ello demuestra que las prohibiciones y limitaciones no se presumen, sino que, de una $u$ otra manera, han de establecerse de forma expresa.

b) Como consecuencia de lo anterior, la capacidad de obrar que el menor adquiere a resultas de la emancipación, le confiere la libre disposición y administración de los bienes y derechos en tanto en cuanto no exista limitación o prohibición expresa, lo que sería conciliable con la exigencia de la capacidad del artículo 992 CC. En este sentido, el Tribunal Supremo en su sentencia de 15 de diciembre de 1943 (RJ 1315), estableció que el requisito de la "libre disposición de los bienes" había de ser interpretado, no en un sentido rígido, sino flexible.

c) Si el Código Civil permite en el artículo 166 que el menor, con dieciséis años cumplidos y sin estar emancipado, puede consentir en documento público que sus padres puedan repudiar la herencia a que él le hubiere sido deferida dispensando a éstos de la exigencia de la autorización judicial, con mayor motivo podrá hacerlo él, por sí solo, ahora que ya está emancipado, porque, quien puede lo más, puede lo menos, ya que, si se le permite otorgar dicho documento sin estar emancipado -luego,

${ }^{638}$ Artículos 57, a propósito de los testigos que presencien la celebración del matrimonio civil, o 688, acerca del otorgamiento del testamento ológrafo.

${ }^{639}$ Artículos 241 y 291, acerca de la capacidad para ser tutor y curador.

${ }^{640}$ Artículos 181 y 184, no se dice pero dadas las funciones a que está llamado a cumplir así habrá que entenderlo a propósito del defensor del desaparecido y del representante del declarado ausente; 893, relativo a la capacidad del albacea.

${ }^{641}$ Artículo 624, acerca de la capacidad para poder donar. 
careciendo de capacidad de obrar, y sin perjuicio de que, después, al alcanzar la mayor edad, lo ratifique-, ahora que ya lo está, aunque no tenga capacidad de obrar plena, no solo nada impide que pueda otorgar dicho consentimiento, sino que incluso sea ya él mismo, personalmente, quien repudie.

\section{1-1-2-3.- En el caso del concursado.}

La Ley Concursal, 22/2003, de 9 de julio, no solo introdujo importantes novedades en materia de insolvencia frente a los acreedores en el ámbito mercantil terminando con la clásica distinción entre concurso y quiebra, sino que trajo consigo significativos cambios en lo que se refiere a la capacidad de obrar del comerciante individual al que se le concede un régimen de libertad más amplio que el derogado por dicha ley.

Hasta entonces, se distinguía entre incapacidad (antiguos arts. 1914 CC y 1161 LEC de 1881), para el caso del concurso de acreedores, e inhabilitación (art. 878 Cco), en el caso de la quiebra, lo que suponía una considerable restricción en el ámbito de su poder de actuación. Ahora, la ley 22/2003, distingue en su artículo 40, según cómo se haya calificado el concurso, si voluntario o necesario (art. 22.1 LC), con distintas consecuencias entre uno y otro en cuanto a la capacidad de obrar del concursado. Así:

a) cuando el concurso es voluntario, "el deudor conservará las facultades de administración y disposición sobre su patrimonio, quedando sometido el ejercicio de éstas a la intervención de los administradores del concurso, mediante su autorización o conformidad" ( $\left.\mathrm{n}^{\circ} 1\right)$,

b) y si el concurso se calificare de necesario, "se suspenderá el ejercicio por el deudor de las facultades de administración y disposición sobre su patrimonio, siendo sustituido por los administradores concursales" ( $\left.n^{\circ} 2\right)$.

En aquel, en el concurso voluntario, aunque el deudor mantiene sus facultades patrimoniales de administración y disposición, éstas están sometidas a la intervención de la administración concursal. Lo que equivale en la práctica a un control sobre sus actos que se plasma en la intervención de los administradores quienes habrán de dar su autorización o conformidad a los actos que él realice, lo que se podrá extender, en su caso, al ejercicio del ius delatonis por el deudor. No obstante, la administración del concurso puede elaborar una relación de actos u operaciones que por su natualeza o cuantía pueden estar exentos de esa previa y necesaria autorización (art. 44 LC), aparte de que las decisiones de los administradores están sometidas a la supervisión 
del Juez del concurso (art. 35,4 LC ${ }^{642}$ ). Como también, en el caso de colisión entre la decisión del concursado y la de los administradores, será el Juez quien decida.

Mientras que, en el concurso necesario, las consecuencias son más drásticas porque las facultades, tanto de administración, como de disposición, sobre los bienes residen en los administradores concursales. La limitación es mayor porque, en realidad, se produce una sustitución del deudor por los administradores.

Vemos así cómo la declaración de concurso incide, en mayor o en menor grado, tanto sobre las facultades de administración y de disposición de su patrimonio (art. 40.6 LC), como en lo que se refiere al ejercicio de acciones ante los Tribunales de Justicia (art. 54 LC), de lo que se deriva la consecuencia de que el concursado no podrá realizar por sí solo ningún acto, como tampoco ocupar ningún cargo, para el que se requiera la libre administración y disposición de sus bienes (arts 406, 893, 982, 1052 CC) (BERCOVITZ $\left.{ }^{643}\right)$.

A la vista de ello, dado que para el ejercicio del ius delationis el artículo 992 del Código Civil exige tener la libre disposición de los bienes, en nuestra opinión, se produce la especialidad o peculiaridad de que como el sucesor-concursado tiene afectada la libre disposición, en este caso, en el ejercicio de sus derechos, no podría libremente, por sí solo, decidir acerca de la repudiación de la herencia, sino que requeriría la intervención, en mayor o en menor grado, de los administradores del concurso, según cómo éste se hubiere calificado, ya que serían éstos a quienes les correspondería decidir sobre la oferta sucesoria que ha recibido el concursado, y más cuando su decisión afecta al contenido y valor de la masa patrimonial, que ésta aumente, en el caso de aceptar la herencia, con el consiguiente beneficio para los acreedores al ver éstos aumentadas las posibilidades de cobro de sus créditos por cuanto podrán hacerlos efectivos sobre los bienes que reciba su deudor de dicha herencia, o que se mantenga tal cual está, en el caso de la repudiación, por cuanto los bienes a que ha sido llamado no entran en su patrimonio con el consiguiente perjuicio para los acreedores al ver cómo no pueden dirigir sus reclamaciones contra dichos bienes para hacer efectivos sus derechos de crédito, sin perjuicio del derecho que les concede el artículo 1001 CC.

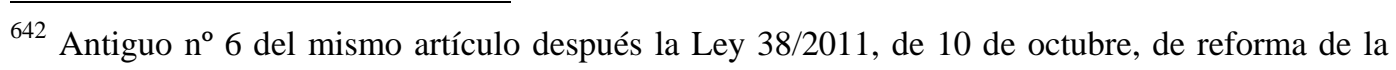
Ley 22/2003, de 9 de julio, Concursal (BOE $n^{\circ} 245$, de 11 de octubre de 2011).

${ }^{643}$ Comentarios a la Ley Concursal. Vol 1º. Ed TECNOS. Madrid. 2004. Pág 357 y ss. 


\section{1-1-2-4.- En el caso del desaparecido y del declarado ausente.}

Cuando se abre una sucesión mortis causa a la que es llamada una persona que en ese momento se encuentra en situación legal de ausencia, o desaparecida, tanto en una como en otra, en sí misma, no supone, en modo alguno, para ella causa de restricción o limitación de su capacidad de obrar, sino que ésta permanece intacta, porque, además, allí donde se encuentre, tendrá dicha capacidad ${ }^{644}$ y la podrá ejercer, en su caso, por lo que, si apareciese, podría, de no tener restricción por otra causa, ejercer el ius delationis. Pero, dada la situación en que se encuentra, de facto, no es que no pueda hacerlo, sino que lógica y evidentemente no lo hará porque, con toda probabilidad, ni tan siquiera sabrá que le ha sido deferida una herencia a su favor.

La herencia deferida a favor de aquella persona que se encuentre en alguna de estas situaciones plantea dos cuestiones, o especialidades, en relación al ejercicio del ius delationis: se ha de hacer a través de representante y demostrar la existencia del ausente o desaparecido.

Acerca de la primera, tanto en situación de ausencia no declarada, presunta o de hecho, como de ausencia legal, será su defensor o el representante, ya sea voluntario o legal, quien, en su nombre y por su cuenta, repudiará, o aceptará, la herencia que le hubiese sido deferida. Si bien, hemos de distinguir porque:

a) si se trata de un representante voluntario, habrá que estar, en todo caso, al contenido del poder que previamente le hubiese sido otorgado para ver si está facultado, o no, al amparo del mismo, para poder repudiar la herencia a que ha sido llamado su representado ${ }^{645}$. En caso contrario, ante la ausencia de concesión de esta facultad al apoderado, éste, lógicamente, no podría repudiar. Y si lo hiciere, la voluntad emitida sería totalmente ineficaz por ausencia o inexistencia de consentimiento.

b) Y si se trata del caso de un defensor o de un representante legal, entendemos que, para poder repudiar la herencia, necesitaría autorización judicial por analogía con el régimen que el Código Civil establece respecto de otros representantes legales como son los padres (art. $166 \mathrm{CC}$ ), o el tutor (art. $\left.271.4^{\circ} \mathrm{CC}\right)^{646}$.

\footnotetext{
${ }^{644}$ ALBALADEJO: “La repudiación de la herencia”. Cit: Pág 728; GITRAMA: Op. cit.: Pág 128.

${ }^{645}$ Vid, en este sentido, el punto número 3-1 del capítulo cuarto, relativo al ejercicio del ius delationis a través de apoderado.

${ }^{646}$ GITRAMA: Op. cit.: Págs 128 y 129.
} 
Y, acerca de la segunda cuestión, la repudiación de la herencia está supeditada a la exigencia de lo que dispone el artículo 190 del Código Civil, según el cual, "para reclamar un derecho en nombre de la persona constituida en ausencia, es preciso probar que esta persona existía en el tiempo en que era necesaria su existencia para adquirirlo"647 (SSTS 24 de noviembre de 1927, 9 de febrero de 1935, 21 de noviembre de 1943), lo que presupone que la desaparición de la persona se produjo antes de que se defiriese a su favor la herencia. Ello implica, tanto para el defensor como para el representante, la carga de la prueba de tener que demostrar que el desaparecido o el ausente vivían después, al momento de la apertura de la sucesión para poder ejercer en su nombre el ius delationis. Y, si no se puede demostrar, no podrían manifestarse sobre este extremo y la herencia seguirá el curso que por ley y según las normas que le fueren aplicables, le corresponda. En el caso contrario, de que la desaparición se hubiese producido después de deferirse la herencia, la prueba no consistiría más que en demostrar esta circunstancia y, por tanto, se entiende que, hasta ese momento, y en ese momento, la persona estaba viva y existía.

Esta importante apreciación se plantea por ALBALADEJO ${ }^{648}$, quien distingue según cual es el momento en que se ha producido la desaparición porque:

a) si ésta ha tenido lugar después de deferida la herencia, el defensor o representante no tendrá que probar la existencia del desaparecido precisamente porque éste ya existía en ese instante y solo tendrá que repudiar, o aceptar, caso de no haberlo hecho ya, lógicamente, el propio interesado, y

b) si la desaparición se produjo antes, entonces sí que será preciso demostrar la existencia del ausente o del desaparecido al momento de la apertura de la sucesión.

A este respecto, una de los medios que hay para demostrar que el desaparecido o el ausente está aun vivo es presentando, en su caso, una fe de vida o de estado expedido por el Registro Civil, al no haberse practicado todavía, hasta ese momento,

${ }^{647}$ El tenor literal del precepto aunque hable de reclamar, se puede también entender como ejercer, al tiempo que plantea la duda en su aplicación de, si solo se refiere al que ya está constituído en la situación legal de ausente, o si también se puede aplicar al desaparecido.

En este sentido, algún autor, como ALBALADEJO (Op. cit. La repudiación de la herencia. Pág 728 y ss.), entiende que se puede aplicar tanto a la persona respecto de la cual ya existe la declaración judicial de ausencia, como también a aquella que está solo desaparecida.

Nosotros, de igual manera, entendemos que sería de aplicación a uno y a otro, porque, tanto en uno como en otro caso, no se sabe ciertamente si esa persona existe o no. La situación de facto es la misma: incertidumbre en su existencia sin que se tengan noticias de ella, si bien, a medida que van pasando el tiempo, esa incertidumbre aumenta y las medidas de protección que, inicialmente son provisionales y muy limitadas, después son mayores y más amplias, pero no por ello la incertidumbre desaparece ni la exigencia de demostrar que esa persona existía.

648 "La repudiación de la herencia”. Cit: Pág 728 y ss. 
su inscripción de defunción o, en su caso, la declaración de fallecimiento (art. 363 y $364 \mathrm{RRC}$ ), lo que, por otro lado, constituye una presunción iuris tantum, como también puede ser a través de testigos o de cualquier otro medio por el que se demuestre de forma indubitada dicha circunstancia.

Pero, si no se probare la existencia del desaparecido o del ausente a la fecha de la delación, no habrá tal delación a su favor y, consecuentemente, tampoco posibilidad de repudiar, o aceptar, la herencia en nombre de ellos por aplicación del artículo 190 CC (además, para poder suceder a una persona, es preciso estar viva al tiempo de su defunción, o haberla sobrevivido siquiera por breves instantes -arts 759 y 766 CC-). En este punto, salvo que tratándose de una sucesión testada existiese en ella una cláusula de sustitución que previere la ausencia o la desaparición del sucesor, en cuyo caso sería llamado el sustituto, procedería, según el artículo 191 CC, un acrecimiento de la porción que le hubiere correspondido al ausente a favor de sus coherederos ${ }^{649}$ que “.... deberán hacer, con intervención del Ministerio Fiscal, inventario de dichos bienes, los cuales reservarán hasta la declaración del fallecimiento". No obstante, según el artículo 192 CC, ello "se entiende sin perjuicio de las acciones de petición de herencia $u$ otros derechos que competan al ausente, sus representantes o causahabientes. Estos derechos no se extinguirán sino por el transcurso del tiempo fijado para la prescripción"650.

Finalmente, en el supuesto de que el desaparecido o el ausente, apareciere después y siempre que no hubiere prescrito su derecho, podrá ejercer el ius delationis si no lo hubiese hecho ya su defensor o representante.

${ }^{649}$ Se ha planteado aquí la cuestión de si se aplica o no el derecho de representación en el caso de ausencia, esto es, si los nietos pueden heredar al abuelo estando el padre desaparecido o constituido legalmente en situación de ausencia. Lo que permitiría a estos después, en su caso, repudiar, o aceptar, la herencia de su abuelo.

En este sentido, el artículo 929 del Código Civil dice que "no podrá representarse a una persona viva sino en los casos de desheredación o incapacidad”. En este caso ocurre que el padre, no solo no está aún formalmente fallecido sino que se presume, iuris tantum, que está vivo aunque no se sepa donde está ni se encuentra, y además no se dan ninguno de los dos supuestos citados en el artículo: ni desheredación, ni incapacidad del sucesor. Luego, al no cumplirse ninguno de estos dos casos que establece el precepto, se daría la circunstancia de que al dolor de los hijos que produce la incertidumbre de no saber si su padre está o no vivo, se le une el hecho de que no sería posible aplicar el derecho de representación a su favor dada la dicción del artículo 929 CC, por lo que, pese a la ausencia del padre, no podrían suceder a su abuelo porque al abrirse la sucesión de éste, el padre no está aun formalmente muerto y no se da ninguno de los dos casos citados en dicho precepto solo previstos para el caso de estar vivo o, al menos, que no se pruebe que está muerto.

Sin embargo, el Tribunal Supremo en sentencia de 24 de noviembre de 1927 hizo una aplicación del derecho de representación en sentido negativo: se declararon herederos del causante a sus sobrinas como sus más próximos parientes ya que no se demostró la existencia del hijo del ausente al tiempo del fallecimiento de su padre y por carecer aquel de ascendientes y descendientes.

${ }^{650}$ La STS de 15 de octubre de 1963 (RJ 4122), reconoció estos derechos proclamados en este precepto. 


\section{1-1-2-5.- En el caso de herencia deferida a los pobres.}

El Código Civil contempla en el artículo 749 la posibilidad de que una persona en su testamento ordene o establezca que, todo o parte de los bienes que integran su herencia, sea a favor de los pobres ${ }^{651}$, lo que podrá hacer, bien designándolos de manera individual, en cuyo caso, no cabe duda alguna de su identidad, bien de manera genérica o indeterminada, sin identificación de las personas o de los pobres, con la posibilidad de que pueda intervenir un tercero (art. $671 \mathrm{CC}$ ).

Esta clase de disposición testamentaria, dado que el tenor del inciso segundo del artículo $992 \mathrm{CC}^{652}$, sólo alude a la aceptación de la herencia, que lo será por "las personas designadas por el testador para calificarlos y distribuir los bienes, y en su defecto a las que señala el artículo 749", que, además, ha de ser a beneficio de inventario, plantea el interrogante de si es posible que tales personas puedan repudiar las disposiciones deferidas a favor de los pobres. De ahí que sea, no ya discutible, incluso negado por la doctrina.

Ante ese silencio, ¿hay que entender que la prohibición se sobreentiende o presume y necesariamente se ha de aceptar y no se puede repudiar? o, ante el silencio legal, si no la prohíbe de forma expresa, ¿se puede entender o interpretar que la tolera o permite -de forma tácita-, por lo que, aun así, se puede repudiar?, porque, dado su tenor, parece que lo único que le preocupaba al legislador era la forma de aceptación, dado que solo hay una repudiación, expresa, y solo una forma en que se puede realizar, solemne (art. 1008 CC).

Por ello, para unos ${ }^{653}$, dado que el Código Civil solo habla de la aceptación, no es posible repudiar, y para otros ${ }^{654}$, dicho en otras palabras, no existe la facultad de repudiación.

${ }^{651}$ Tambien algunas leyes sucesorias autonómicas contemplan esta modalidad de disposición: Aragón (art. 473 CDFA). Cataluña (arts 428-3.2, 429-11, Ley 10/2008, sobre sucesiones).

652 STS de 25 de mayo de 1897: lo dispuesto en el artículo 992 CC es aplicable al caso de que por muerte del testador sin haber aceptado ni repudiado una herencia, recayese el derecho a ella de los pobres a quien aquel hubiera dejado la suya (se trataba de una señora que había destinado su herencia a dotar a doncellas pobres falleciendo sin ejercitar el "ius delationis" sobre la herencia de su madre). En este caso, el Tribunal Supremo, para evitar el embargo de los bienes de la testadora, extendió la regla de la aceptación a beneficio de inventario al ejercicio en sentido afirmativo del "ius delationis".

${ }^{653}$ MANRESA: Op. cit.: Pág 369; ALBALADEJO: “La repudiación de la herencia”. Cit: Pág 722; RIVAS MARTÍNEZ: Derecho de Sucesiones Común y Foral. Cit: Pág 631.

${ }^{654}$ SILLERO CROVETTO: Comentario al artículo 992 del Código Civil, en Jurisprudencia civil comentada (Tomo I). Dirección: Pasquau Liaño. Ed. COMARES. Granada. 2000. Pág 1679. 
En nuestra opinión, dado el tenor del artículo 992 CC, se pueden hacer a este respecto las siguientes consideraciones:

$1^{\mathrm{a}}$.- de lo que no cabe ninguna duda es que impone, o es obligatorio, que la aceptación de la herencia se ha de hacer a beneficio de inventario. Ello se justifica por el hecho de proteger a los destinatarios de la disposición porque, de hacerse de forma pura y simple, al asumirse en virtud de la misma una responsabilidad ilimitada frente a las deudas del causante (art. 1003 CC), los destinatarios, los pobres, quedarían a merced de los acreedores del difunto ya que se podrían dirigir, contra los bienes de la herencia y también contra los de éstos.

2a .- Ahora bien, ¿cómo interpretar el hecho de que no aluda a la posibilidad de poder repudiar?. En principio, se puede entender, lógicamente, que no lo permite. Luego, en consecuencia, podemos decir que estaríamos ante un caso de aceptación ex lege de la herencia.

No obstante, también creemos que ese silencio no significa, o no se tiene por qué entender en el sentido de que esté prohibiendo, o no esté permitiendo, la repudiación, porque, si así fuere, ello supondría suprimir la facultad de poder repudiar, cuando resulta que la privación de derechos o facultades no se puede hacer de forma tácita, ni menos aun se puede presumir o sobreentender, sino que tendrá que ser por una causa o motivo justificado. Así ocurre cuando el sucesor ha tenido ciertos comportamientos o actitudes respecto de la herencia en que se le impone ex lege ${ }^{655}$ la aceptación pura y simple de la misma, a modo de sanción civil ante determinados actos o actitudes, lo que lleva consigo la imposibilidad de poder repudiar. En estos casos, la privación, no solo es expresa, sino que, podríamos decir que está justificada. Pero, no se trata de una privación cualquiera, sino que se produce a resultas de ese comportamiento que el sucesor ha tenido respecto de la herencia, ante lo que se le impone la aceptación de la misma sin posibilidad de que pueda repudiar. Circunstancia que aquí no se da.

$3^{a}$.- El ius delationis comprende o entraña la doble facultad u opción de aceptar o de repudiar la herencia y, en tanto en cuanto la ley no disponga lo contrario, como sucede en los casos en que se impone ope legis dicha aceptación, aquel implica esta doble facultad.

${ }^{655}$ Así: art. 1002, cuando sustrae u oculta efectos de la herencia; arts. 1004 y 1005, en los casos de interpelación judicial; art. 1018, cuando por su culpa o negligencia no se inicia o concluye el inventario dentro del plazo; art. 1019, cuando se reserva el derecho de deliberar y no manifiesta al Juez su decisión. 
Los anteriores argumentos apuntan, en principio, en nuestra opinión, a la tesis de que en el caso de que se dejare todo o parte de la herencia a favor de los pobres, sí sería posible la repudiación de la herencia.

No obstante, es cierto y hay que reconocer que, de admitirse la posibilidad de poder repudiar, tiene el inconveniente de que, lógica e inevitablemente, se puede producir un daño o perjuicio patrimonial o económico a los destinatarios de la disposición del testador por cuanto se ven privados de aquello que éste les dejó. Ya de por sí no deja de ser algo anómalo, incluso excepcional, dado el carácter personal que tiene el ius delationis en su ejercicio, dejar en manos de un tercero, aunque sea la persona designada por el propio causante, que se presupone, además, será de su confianza, y no del propio interesado, la aceptación de dicha disposición, como para que se deje a su libre arbitrio la posibilidad de poder repudiar, porque puede ser utilizado, incluso de forma deliberada y consciente, como una forma de frustrar su voluntad testamentaria. Distinto es que quien repudie sea el propio beneficiario de la disposición porque es él quien rechaza la atribución patrimonial realizada a su favor. Aun así, desde el punto de vista técnico y jurídico, y en base a los argumentos esgrimidos, es discutible que solo tengan la facultad de poder aceptar y no puedan, en su caso, repudiar, como sostiene un sector de la doctrina.

\section{1-1-2-6.- En el caso de herencia deferida a favor de sufragios y obras} piadosas.

El testador también puede ordenar disposiciones en su testamento a favor de "sufragios y obras piadosas en beneficio de su alma"656, que es como se las conoce de forma más usual y habitual, hipótesis que recoge el Código Civil en su artículo $747^{657}$.

\footnotetext{
${ }^{656}$ No se trata propiamente de que el alma sea instituida heredera, sino de disposición del testador para sufragios y obras piadosas "en beneficio de su alma”.

No obstante, tomando como referencia una Real Cédula de 30 de mayo de 1830, la jurisprudencia anterior al Código aceptó la validez de este tipo de instituciones considerando que el alma podía tener la condición de heredera (SSTS 15 de marzo y 18 de junio de 1864; 15 de diciembre de 1865; 24 de diciembre de 1866; 29 de marzo de 1869; 31 de diciembre de 1888; 29 de mayo de 1893; 17 de noviembre de 1896). Pero, en Sentencias posteriores, la jurisprudencia terminó por asimilar este tipo de instituciones a la inversión de los bienes hereditarios en sufragios y obras piadosas como una disposición por la que se establecen reglas de distribución del patrimonio hereditario (REGLERO CAMPOS: Comentario a los artículos 744 a 773 del Código Civil, en “Jurisprudencia civil comentada” (Tomo I). Dirección: Pasquau Liaño. Ed. COMARES. Granada. 2000. Pág 1386 y ss.).

657 Acerca de este artículo, la figura del Gobernador Civil desapareció hace ya años, siendo sustituida por el Subdelegado del Gobierno para cada provincia (arts 22, 29 y 30 de la Ley 6/1997, de 14 de abril, de Organización y Funcionamiento de la Administración General del Estado, o LOFAGE).

También se alude a esta clase de disposición en Aragón (art. 473 CDFA).
} 
Aquí, al igual que en el caso anterior, se plantea la misma problemática, si la herencia puede ser objeto de repudio porque la aceptación, aunque no se dice, se presupone que ha de ser a beneficio de inventario. En este sentido, lo que el Código Civil sí hace es apuntar la específica función que tiene el albacea nombrado por el testador cual es, en cumplimiento de su voluntad, proceder a la venta de los bienes deferidos y después distribuir su importe en los términos que el precepto establece, pero guarda silencio en lo que se refiere a la posibilidad de repudiar y como ha de ser la aceptación. Por lo que cabe plantearse la cuestión de si puede repudiar la herencia.

La doctrina mantiene cierta unanimidad en entender que no se puede repudiar y sí aceptar. Así, para GITRAMA ${ }^{658}$ (en igual sentido, citados por él, BAS y RIVAS ${ }^{659}$, MALDONADO y FERNÁNDEZ DEL TORCO ${ }^{660}$, MARTÍNEZ PEREDA ${ }^{661}$ ), ante el silencio legal, y por aplicación analógica de los artículos 992-2 y 749 CC, serán los albaceas a quienes les corresponderá aceptar la herencia y a beneficio de inventario (en igual sentido, MALDONADO y FERNÁNDEZ DEL TORCO ${ }^{662}$ ). A lo que añade que, también por analogía, no cabe aceptación pura y simple, como tampoco la repudiación.

ALBALADEJO ${ }^{663}$, por su parte, cita también la herencia deferida a favor del alma como uno de los supuestos en que no cabe repudiar la herencia.

Por nuestra parte, cierto es que sería admisible la aplicación analógica de los artículos 992-2 y 749 CC ante la ausencia de norma legal expresa sobre esta cuestión, pero también, de igual manera, aquí invocamos los mismos argumentos antes expuestos a propósito de la herencia deferida a los pobres para entender, en lo que se refiere a la posibilidad de poder repudiar la herencia en que se hubiere ordenado esta clase de disposiciones, que sí sea posible, en principio, en nuestra opinión, que los albaceas puedan tanto aceptar la herencia, que sería a beneficio de inventario, como repudiarla. En este sentido, dicha facultad es verdaderamente singular y excepcional porque su función propia, característica, incluso única, es la de ejecutar la voluntad del causante y procurar que ésta se lleve a cabo hasta que se cumpla en su totalidad (vid arts 901 y 902 CC).

${ }^{658}$ Op. cit: Págs 127 y 128.

659 “Herencia a favor del alma”. Revista de Derecho español y americano. Mayo. 1957.

660 "Herencias a favor del alma en el Derecho español”. RDP. Madrid. 1944.

661 “Reflexiones jurídicas sobre la llamada sucesión a favor del alma”. AAMN. 1953. Págs 151 a 189.

${ }^{662}$ Op. cit.: Pág 234.

663 “La repudiación de la herencia”. Cit: Pág 722. 
No obstante, del mismo modo, de admitirse la posibilidad de repudio, aquí se daría el mismo inconveniente que en el caso anterior, pero, no ya tanto que se pueda producir un daño o perjuicio al destinatario de la disposición dado su carácter inmaterial, sino que se contradiga o no se cumpla la voluntad del causante.

Por otro lado, también en este caso, y en otro orden de argumentos, al igual que en el supuesto anterior, se produce la peculiaridad de que el ius delationis no se ejerce por el beneficiario de la disposición, sino por un tercero, el albacea designado por el testador, si bien, aquí, es lógico que así sea habida cuenta de que dicho beneficiario no es un sujeto que pueda emitir una declaración de voluntad, sino algo incorpóreo o inmaterial como es el "alma".

\section{1-2.- En el caso de que el sucesor sea una persona jurídica.}

Acerca de la capacidad que se les exige para ejercer el ius delationis, existen algunas especialidades que varían según la persona jurídica de que se trate.

En el caso de asociaciones y corporaciones, en defecto de norma expresa ${ }^{664}$ y con carácter supletorio, dispone el artículo 993 CC refiriéndose, entre otras, a esta clase de personas jurídicas, que "los legítimos representantes de las asociaciones, corporaciones ..... capaces de adquirir podrán aceptar la herencia que a las mismas se dejare; mas para repudiarla necesitan la aprobación judicial, con audiencia del Ministerio público".

Del tenor del precepto resulta que la repudiación de una herencia deferida a una asociación, está sometida a la exigencia de la previa autorización judicial con audiencia del Ministerio Fiscal. Sin embargo, hemos de distinguir según se trate de una asociación de derecho público, que persiga fines o intereses de carácter público, o de derecho privado. En el primer caso, sí estaría justificado la limitación o control que supone la previa autorización judicial, no así en el segundo supuesto, que iría en contra de las normas o principios del derecho privado (SILLERO CROVETTO ${ }^{665}$ ). Y, en el caso de las corporaciones, dado que se trata de personas jurídicas que, aun teniendo carácter privado, son creadas o reconocidas por leyes especiales, habrá que estar al contenido de las mismas en lo que se refiere al ejercicio de este derecho.

${ }^{664}$ En este sentido, el ejercicio de los derechos y obligaciones de que sean titulares se rige, al tenor del artículo 37 CC, en el caso de las asociaciones, por sus estatutos, y en el caso de las corporaciones, "por las leyes que las hayan creado o reconocido", a cuyo tenor habrá que estar, en uno y otro caso, en lo que se refiere a la repudiación de una herencia.

${ }^{665}$ Comentario a los artículos 988 a 1034 del Código Civil, en Jurisprudencia civil comentada (Tomo I). Cit: Pág 1680. 
En el caso de las fundaciones, a resultas de su ley especial, 50/2002, de 26 de diciembre (art. $22^{666}$ ), se ha producido un cambio legislativo en el caso de repudiación de la herencia porque, en la normativa anterior, el artículo 20.3 de la Ley 30/1994, de 24 de noviembre, de Fundaciones y de Incentivos Fiscales a la Participación Privada en Actividades de Interés General, derogado por la citada Ley de Fundaciones de 2002, exigía "previa autorización del Protectorado" para poder repudiar herencias o legados, también aceptar donaciones, y, en su defecto, "aprobación judicial con audiencia del Ministerio público". Ahora, la ley de 2002 dice que "será comunicada por el Patronato al Protectorado". Así, el patronato de una fundación puede libremente repudiar aquella herencia que le hubiere sido deferida, si bien, tiene la obligación de ponerlo después en conocimiento del protectorado en el plazo máximo de diez días hábiles quien podrá "ejercer las acciones de responsabilidad que correspondan contra los patronos, si los actos del Patronato fueran lesivos para la fundación, en los términos previstos en esta Ley".

A propósito de ello, LOPEZ-MEDEL BASCONES ${ }^{667}$, manifiesta que, en la ley de 2002, en consonancia con la idea o principio de instaurar un sistema de mayor libertad y más flexible, y de tratar de reducir al mínimo la intervención de los poderes públicos, "se reducen los supuestos de actos de disposición o gravamen de bienes que formen parte del patrimonio de la Fundación en que resulta preceptiva la autorización del protectorado, sustituyéndose dicha autorización (que supone un control ex ante) por la sola comunicación (que supone un control ex post), lo cual potencia claramente el ámbito de autonomía de los entes fundacionales. También se instaura este sistema de comunicación en los casos de aceptación de legados o donaciones con carga, repudio de herencias o legados o para dejar de aceptar donaciones".

Nada dice el Código Civil acerca de la capacidad que han de tener, en su caso, las sociedades, ya sean civiles o mercantiles, para el ejercicio del ius delationis en las herencias que les hubiesen sido deferidas. Sin embargo, de conformidad con lo dispuesto en los artículos $35.2^{\circ}$ y 36 CC, su capacidad se regirá "por las disposiciones relativas al contrato de sociedad, según la naturaleza de éste". Así, habrá que estar en

666 Según su tenor, relativo al ejercicio del ius delationis: “1. La aceptación de herencias por las fundaciones se entenderá hecha siempre a beneficio de inventario. Los patronos serán responsables frente a la fundación de la pérdida del beneficio de inventario por los actos a que se refiere el artículo 1024 del Código Civil. 2. La aceptación de legados con cargas o donaciones onerosas o remuneratorias y la repudiación de herencias, donaciones o legados sin cargas será comunicada por el Patronato al Protectorado en el plazo máximo de los diez días hábiles siguientes, pudiendo éste ejercer las acciones de responsabilidad que correspondan contra los patronos, si los actos del Patronato fueran lesivos para la fundación, en los términos previstos en esta Ley”.

667 “La nueva Ley de Fundaciones”. Diario LA LEY. AÑO XXIV. Número 5725. 
cada caso particular, respecto de la sociedad de que se trate, a lo dispuesto en las normas contenidas en sus estatutos, reglas de constitución, o a la normativa que en cada caso le sea de aplicación, para saber si el ejercicio del ius delationis está sujeto a algún requisito, ya sea previo o posterior al mismo. No obstante, siendo sujetos de derecho privado y en defecto de norma expresa en sus respectivas reglas estatutarias, regirían por su carácter supletorio las normas generales del Código Civil (art. 993), en materia de aceptación y de repudiación. Y si son sujetos de derecho público que hayan sido constituidas por ley, habrá que estar al contenido de ésta.

Tratándose de personas jurídicas de carácter religioso, nada dice el Código Civil acerca del ejercicio del ius delationis por parte de las mismas. Si bien, en este punto, y en lo que se refiere a la capacidad que tiene la Iglesia frente al Estado en el ejercicio de sus derechos y obligaciones, manifiesta en su artículo 38, párrafo segundo, que "se regirá en este punto por lo concordado entre ambas potestades"668. Aunque el tenor del precepto se refiere solo a la Iglesia Católica y sus entes eclesiásticos, hemos de interpretarlo en un sentido más amplio y hacerlo extensivo a cualesquiera otras personas jurídicas o entidades de carácter religioso habida cuenta de la existencia de otras confesiones no católicas que sean o hayan sido objeto de reconocimiento por parte del Estado español ${ }^{669}$. En consecuencia, habrá que estar a lo pactado entre el Estado y dichas entidades religiosas, así como a la normativa que de modo particular y concreto les fuere de aplicación y en virtud de la cual se rigieren.

En el caso de establecimientos públicos oficiales ${ }^{670}$, dispone el artículo 994 CC que, " no podrán aceptar ni repudiar herencia sin la aprobación del Gobierno".

${ }^{668}$ Las relaciones entre la Iglesia Católica y el Estado Español están reguladas por los Acuerdos con la Santa Sede de 3 de enero de 1979, ratificados por Instrumento de 4 de diciembre del mismo año. Dichos Acuerdos reconocen la personalidad jurídica de la Iglesia como sujeto de Derecho público extraestatal.

${ }^{669}$ La Ley Orgánica de Libertad Religiosa de 5 de julio de 1980, reconoce personalidad jurídica a otras confesiones si se encuentran inscritas en el Registro Público creado al efecto en el Ministerio de Justicia (art. 5.1 de dicha Ley). Cumplido este requisito, tienen plena capacidad de obrar y por tanto pueden suceder, lo que implica poder aceptar y repudiar herencias, al amparo del artículo 993 CC.

Así, en la actualidad, respecto de otras confesiones, están las Leyes n 24, 25 y 26/1992, de 10 de noviembre, por las que se establecen conciertos con la Federación de Entidades Religiosas Evangélicas en España, Federación de Comunidades Israelitas de España y con la Comisión Islámica de España.

${ }^{670}$ Bajo la acepción de “establecimientos públicos oficiales” a que alude el Código en el artículo 994, hemos de entender aquellos sujetos de derecho público que están dotados de personalidad jurídica y capacidad propia para actuar como sujetos de derecho dentro del tráfico jurídico para la obtención o desarrollo de un determinado fin, servicio o actividad de carácter público o colectivo, de ámbito estatal, autonómico, provincial o local, pero que no forman parte de la organización administrativa del Estado, de las Comunidades Autónomas, de las provincias o de los municipios, mas no dependen de las mismas, esto es, tienen carácter “oficial”, por lo que quedan excluidos los establecimientos públicos particulares o costeados con fondos privados. De igual manera, se entienden como tales, todos los organizados, dirigidos e inspeccionados por el Poder ejecutivo mientras cumplen un servicio de carácter público y tiene un organismo que lo realiza (GITRAMA GONZÁLEZ: Op. cit.: Pág 149). 
Estos entes pueden adoptar exteriormente cualquiera de las formas o sujetos a que alude el artículo 993, asociaciones, corporaciones o fundaciones, respecto de las cuales en él se establece un régimen específico para el ejercicio del ius delationis que es distinto del contemplado en el citado artículo 994, de lo que parece existir una aparente contradicción ${ }^{671}$. No obstante, ello se salva teniendo en cuenta que aquel, el artículo 993 CC, tiene carácter general y es de aplicación a toda clase de personas jurídicas, mientras que éste, el artículo 994 CC, tiene carácter especial o particular, por lo que toda asociación, corporación y/o fundación que tenga el carácter de establecimiento público oficial, se regirá por lo dispuesto en el artículo 993 CC.

La exigencia a estas personas jurídicas de que el ejercicio del ius delationis esté sometido a la aprobación del Gobierno ${ }^{672}$, se justifica por el hecho de que al ser sujetos de derecho que realizan una actividad de carácter público y ser aquel, el Gobierno, el encargado de velar por los intereses públicos, será éste quien decida acerca de la delación ${ }^{673}$ por razón de la conveniencia o no del objeto de la sucesión.

Y si fuere llamado a una herencia el Estado o una Comunidad Autónoma:

a) en el caso del Estado (arts. 956, 957 y 958 CC), su sucesión se rige por normas de carácter administrativo ${ }^{674} \mathrm{y}$, dado el tenor del artículo 956 que emplea el término "heredará" en un tono o sentido imperativo, se entiende en el sentido de que siempre sucederá y no podrá repudiar la herencia que le hubiere sido deferida. No obstante, la aceptación "se entenderá siempre a beneficio de inventario, sin necesidad de declaración alguna sobre ello" (art. 957 CC). También cuando se trata de sucesión testamentaria, $\mathrm{y}$,

b) en el caso de las Comunidades Autónomas, solo tienen reconocido el derecho de suceder aquellas de tradición foral ${ }^{675}$. Las demás, ante la ausencia de

${ }^{671}$ Vid, GITRAMA GONZÁLEZ: Comentarios al Código Civil ........ T XIV. Vol 1º Cit: Pág 150.

${ }^{672}$ Corresponderá al departamento ministerial del que dependa el establecimiento de que se trate, si fuese el Gobierno central de la Nación. Y si es una persona jurídica de derecho público perteneciente a una Comunidad Autónoma, corresponderá al Gobierno de ésta otorgar dicha aprobación.

${ }^{673}$ Vid MANRESA: Comentarios al Código Civil español. T. VII. Cit: Pág 378.

674 Sobre ello: Ley de Bases del Patrimonio del Estado (LPE), aprobado por Decreto 1022/1964, de 15 de abril, arts $19.3^{\circ}$ y 24; Reglamento de la LPE, aprobado por Decreto 3588/1964, de 5 de noviembre, arts $49.3^{\circ}$ y 55; Decreto 2091/1971, de 13 de agosto, sobre régimen administrativo de la sucesión abintestato a favor del Estado.

675 Las Comunidades Autónomas que tienen reconocido este derecho, son:

- Aragón: arts. 517, 535 y 536 CDFA.

- Cataluña: arts. 441-2.2, 442-12 y ss, de la Ley 10/2008.

- Galicia: art. 267 y ss de la LDCG.

- Navarra: Leyes 304 n 7 y 307, párrafo último, de la CDCFN.

- País Vasco: art. 73, de la LDCF. 
norma jurídica expresa, y por aplicación subsidiaria del Código Civil, heredaría el Estado. También aquí, al igual que sucede en el caso del Estado, la herencia se entenderá siempre aceptada a beneficio de inventario y no cabe su repudiación.

\section{2.- REQUISITOS OBJETIVOS.}

La repudiación, desde el punto de vista objetivo, a diferencia de lo que sucede con la aceptación, se caracteriza por ser un acto que es eminentemente formal ya que ha de atenerse a una determinada solemnidad.

La observancia de la forma en su emisión, no solo es una característica definitoria de la misma, sino esencial y consustancial a su naturaleza, de inexcusable observancia que se ha de cumplir, en todo caso, en el momento de su realización, de tal manera que es manera de ser del negocio, "forma dat esse rei". Es un requisito "ad solemnitatem", que actúa como elemento integrador del acto y que, si no se cumple, no nace, es como si no se hubiese emitido por cuanto su inobservancia origina su nulidad de pleno derecho, de tal manera que no hay repudiación si no se cumple la forma prescrita por la ley.

De la forma que ha de obervarse se ocupa el Código Civil en el artículo $1008^{676}$ al establecer que, "la repudiación de la herencia deberá hacerse en instrumento público o auténtico, o por escrito presentado ante el Juez competente para conocer de la testamentaría o del abintestato", exigencia que se observa también en los ordenamientos jurídicos de las Comunidades Autónomas ${ }^{677}$ y de otros paises ${ }^{678}$. En concordancia con él, el artículo 1280,4 CC exige que, "la cesión, repudiación o renuncia de los derechos hereditarios", ha de constar en documento público, pero, en nuestra opinión, no añade nada nuevo, sino que, más bien, es reiteración de lo que en él se dice, aunque de manera parcial porque podemos observar cómo el artículo 1008 CC es más amplio ya que admite, además, como formas válidas de las que se puede servir el repudiante para manifestar su declaración, el documento auténtico y la comparecencia judicial.

${ }^{676}$ Con precedentes en las Partidas (Ley 18, Título VI, Partida 6 ${ }^{\mathrm{a}}$ y Ley 101, Título XVIII, Partida $3^{a}$ ) y artículo 837 del Proyecto de García Goyena, que introduce el carácter solemne en la declaración al decir que, "la repudiación de la herencia debe hacerse en instrumento público autorizado por escribano del domicilio del repudiante o del difunto".

${ }^{677}$ Cataluña: art. 461-6, Ley 10/2008, sobre sucesiones; Aragón: art. 351 CDFA.

${ }^{678}$ Francia (art. 804 Code); Italia (art. 519 Codice Civile); Alemania (§ 1945 BGB). 
Examinando su tenor, podemos observar cómo la repudiación de la herencia no solo ha de constar de modo claro, expreso y formal ${ }^{679}$, sino que ha de hacerse, en cualquier caso, por escrito, ya sea público o privado, de lo que se desprende, a su vez, la consecuencia, o conclusión, de que no será válida la realizada de forma verbal o de forma tácita ${ }^{680}$, deducida ésta última a través de actos o de comportamientos del sucesor de los que deba o pueda inferirse la intención o voluntad de repudio, como tampoco sería admisible a través de una actitud de silencio del sucesor ${ }^{681}$.

Así, la repudiación de una herencia puede realizarse, al amparo de lo dispuesto en el artículo 1008 CC, de dos formas, escritas las dos: "por instrumento público o auténtico, o por escrito presentado ante el Juez competente ...", de lo que se derivan dos modalidades: documental o instrumental y judicial ${ }^{682}$.

Por otro lado, el carácter solemne de la repudiación ha sido subrayado, de forma reiterada, por el Tribunal Supremo ${ }^{683}$, y por alguna Audiencia Provincial ${ }^{684}$.

\section{2-1.- Forma documental o instrumental.}

Acerca de ella, el tenor del artículo 1008, a nuestro juicio, induce a confusión porque parece estar dando a entender que el instrumento público y el instrumento auténtico son lo mismo al estar separados por la conjunción disyuntiva "o", lo que se refuerza al estar separado después por una coma de la otra forma, la judicial.

Así, una lectura a priori del precepto nos da a entender una posible asimilación o equiparación de los términos público y auténtico, ante lo cual, cabe preguntarse, si son análogos, significan lo mismo, y se refiere a un mismo documento o instrumento que se le puede llamar tanto público, como auténtico, o indubitado, o si, por el contrario,

${ }^{679}$ MANRESA: Op. cit.: Pág 439.

${ }^{680}$ No sucedió lo mismo en el derecho romano cuando se admitió que de manera tácita se pudiera repudiar una herencia: Digesto (fragmento 95, título II, libro XIX: "recusari herditas, non tantum verbis sed etiam re potest et alio quovis judicio voluntatis" -se puede repudiar la herencia no solo con palabras si no también con hechos y por cualquier expresión de voluntad-).

Igual sucedió en los textos de nuestro derecho histórico como se puede observar en Las Partidas donde se puede observar que sí se admitió la repudiación tácita (Título VI, Partida $6{ }^{\mathrm{a}}$ y Ley 18: "Renunciar puede el heredero la heredad de dos maneras: por palabra o por fecho").

${ }^{681}$ En este sentido, acerca del valor o significado del silencio o inactividad del sucesor ante la delación sucesoria, véase el punto número 2-5 del capítulo segundo, donde se analiza esta cuestión a propósito de si es o no obligatorio el ejercicio del ius delationis.

${ }^{682}$ RIVAS MARTÍNEZ: Derecho de Sucesiones Común y Foral. Cit: Pág 633.

${ }^{683}$ Así, entre otras muchas: SSTS de 3 de junio de 1902; 24 de diciembre de 1909; 3 marzo, 25 abril y 15 de octubre de 1986 (RJ 1094, 2002, 5791); 16 octubre 1987 (RJ 7292); 5 marzo, 3 junio, 28 y 31 octubre y 5 diciembre 1991 (RJ 1718, 4636, 7872, 7879 y 8919); 6 y 14 febrero y 3 abril 1992 (RJ 831, 1268 y 4475); 12 mayo 1993 (RJ 3541).

${ }^{684}$ SAP de Jaén de 26 de mayo de 1997 (AC 1051). 
pese a la equiparación que parece hacer el artículo, se trata de documentos diferentes. Por ello, veamos si tal equiparación es o no correcta.

En principio, por instrumento público hemos de entender el autorizado por un fedatario público ${ }^{685}$.

En cambio, respecto del instrumento auténtico, el Código Civil no dice qué se entiende por tal ${ }^{686}$, sí el Reglamento Hipotecario en su artículo 34, según el cual lo es, a los efectos de la Ley, "Ios que sirviendo de títulos al dominio o derecho real o al asiento practicable, estén expedidos por el Gobierno o por Autoridad o funcionario competente para darlos y deban hacer fe por sí solos".

Sin embargo, el tenor del precepto no es del todo claro porque, desde el punto de vista hipotecario, el documento auténtico y el documento público son sinónimos dependiendo del punto de vista que se adopte ya que, si se hace atendiendo al funcionario público del que emanan o los autoriza, hablamos de documento público, y si nos atendemos a su fuerza legal o autenticidad, hablamos de documento auténtico (CHICO ORTIZ). Aunque también puede suceder que no coincidan porque un documento privado, que no es público, es auténtico, o indubitado, si existe respecto del mismo la certeza indubitada de quien es su autor, y de que la persona de quien se dice que es, es efectivamente quien lo firma y dice, o se dice, ser su autor.

Así, si bien, un documento público es, por definición, auténtico, no todo documento auténtico es público, porque pueden serlo también los documentos privados si gozan de autenticidad y la veracidad de su contenido resulta de la propia declaración de su autor o por otros medios de prueba, como puede ser el cotejo de letras u otros documentos firmados por el sucesor, la declaración de testigos, o la de

685 El Código Civil, en el derogado artículo 1216, decía que "son documentos públicos los autorizados por un Notario o empleado público competente con las solemnidades requeridas por la Ley”. Definición o descripción que no por derogado el precepto, es inválida, sino que sigue siendo perfectamente válida en el tenor literal del mismo.

Así, al amparo de esta forma, son documentos o medios idóneos para formular la repudiación de la herencia, al tiempo que los más frecuentes, la escritura pública o el acta autorizados por Notario o agente diplomático o consular español en el extranjero que haga sus veces (vid art. 1012 CC, a propósito de la aceptación de la herencia a beneficio de inventario), o también lo es, por ejemplo, el acta dimanante de un acto de conciliación.

De los documentos públicos, de sus clases, a efectos de prueba en los procesos civiles, se ocupa la LEC a partir de su artículo 317.

${ }^{686}$ No obstante, el derogado artículo 1225 CC, decía que "el documento privado, reconocido legalmente, tendrá el mismo valor que la escritura pública entre los que lo hubiesen suscrito y sus causahabientes", lo que parecía dar a entender que auténtico era aquel documento privado que ha sido reconocido legalmente, o que, según el tenor del también derogado 1227 CC, había ingresado en un Registro Público. 
otras personas que conozcan su letra y firma y declaren que no abrigan duda racional de que el escrito está redactado y firmado por su propia mano y que es su letra.

En la doctrina, acerca de esta cuestión, se pueden distinguir dos posiciones ${ }^{687}$ : para unos, el documento auténtico es equiparable a documento público y, por tanto, uno y otro, son lo mismo, con lo cual quedaría excluido el documento privado. Mientras que, para otros, que es la posición más general y mayoritariamente admitida dentro de la doctrina ${ }^{688}$, también la nuestra, es aquel en cuya confección o redacción no ha intervenido un fedatario público pero del que no hay duda alguna de que es y pertenece a una persona determinada porque se tiene en relación a él la certeza total y absoluta, indubitada, de que es de su autoría o le pertenece. En él coinciden el autor aparente y el autor real. Así puede resultar del cotejo de letras o testimonio que se hubiere realizado sobre aquel documento privado en que constase la repudiación con otro $u$ otros de los que se tenga la total y absoluta certeza de que es de la misma persona (STS de 11 de junio de 1955 -RJ 1726-), o aquel documento privado en el que la firma del interesado se legaliza por un Notario.

Por su parte, el Tribunal Supremo, en la sentencia de 28 de mayo de 1974 (RJ 3223), entendió por documento indubitado, "el que por sí mismo demuestra una verdad claramente". En otra posterior, de 9 de diciembre de 1992 (RJ 10130), con precedente en la de 11 de junio de 1955 (RJ 1726) manifestó que, "el documento auténtico que en el citado precepto se habla no es sinónimo de documento público, sino de documento que indubitadamente procede del renunciante", de lo que se deriva la consecuencia de que es válida incluso la renuncia efectuada en documento privado, como era el caso de autos, siempre y cuando se pueda demostrar de forma efectiva e indubitada que el documento en que consta la declaración de repudiación ha sido realizada por el renunciante. Esta doctrina es posteriormente recogida en STS de 23 de noviembre de 1999 (RJ 9049), según la cual: "La repudiación de la herencia debe revestir forma de acto notoriamente sustancial, integrado por la declaración de la voluntad debidamente manifestada de quien es llamado a una concreta sucesión y precisa su correspondiente exteriorización para que pueda ser conocida por todos aquellos interesados en la sucesión de que se trate (SS. de 24-12-1909, 9-2-1992 [RJ 1992|10130] y 4-2-1994 [RJ 1994|909]), no precisándose que el documento auténtico sea documento público, pero sí que se trate de documento que indubitadamente

\footnotetext{
${ }^{687}$ Vid LACRUZ BERDEJO y SANCHO REBULLIDA: Derecho de Sucesiones. I. Parte general. Cit: Pág 138.

${ }^{688}$ Vid, entre otros: ALBALADEJO: “La repudiación de la herencia”. Cit: Pág 736, cita n 34 ; GITRAMA: Op. cit.: Pág 297 y ss.
} 
proceda del renunciante". En los mismos términos se expresa la SAP Zaragoza (Sección 4a), de 23 de septiembre de 1996 (AC 1550), que reitera y reproduce expresamente la doctrina antes citada.

De acuerdo con la doctrina anterior, la SAP Jaén de 5 de septiembre de 2002 (JUR 263025), añade alguna aclaración a lo que ya de por sí ha venido manifestando tanto la doctrina como los Tribunales, al decir que, "la autenticidad hace referencia a la concordancia del autor aparente del documento con el autor real". Pero, para gozar de plena eficacia probatoria, es decir, para que haga prueba de la veracidad de su contenido añade que, "por ello ha de reputarse "auténtico" el documento en el que las manifestaciones contenidas en él pertenecen al sujeto que lo emite, pero sólo será veraz aquel cuyo contenido guarde una fiel correspondencia con la realidad".

Sin embargo, el documento auténtico no es posible como instrumento válido a los efectos de repudiación, ni en el derecho catalán (art. 461-6.1, Ley 10/2008, sobre sucesiones), ni en el derecho aragonés (art. 351, CDFA), ya que, tanto en uno como en otro, solo se admiten a este fin el documento público y el escrito dirigido a Juez competente.

De ahí que, en nuestra opinión, a la vista de lo anteriormente expuesto, en el ámbito del Código Civil, la declaración de repudiación de una herencia, desde el punto de vista formal, se puede hacer, tanto a través de documento público, que lo será, como caso más normal, por medio de escritura pública otorgada ante Notario, como de documento auténtico o indubitado y, dentro de éste, sería admisible y gozaría de plena eficacia jurídica, la realizada por medio de documento privado, siempre que goce de autenticidad porque no exista duda alguna acerca de su procedencia, autoría, titularidad o pertenencia, y se sepa, de manera inequívoca e indubitada, que el repudiante es efectivamente el autor del mismo (STS 11 de junio de 1955 -RJ 1726-).

\section{2-2.- Forma judicial.}

La otra forma de realizar la repudiación de la herencia a que se refiere el artículo 1008 CC es, "por escrito presentado ante el Juez competente ${ }^{689}$ para conocer de la testamentaría o del abintestato", esto es, mediante "comparecencia judicial", y que lo puede hacer el propio renunciante él personalmente o por medio de representante con poder especial y expreso para ello (art. $1713 \mathrm{CC}$ ).

${ }^{689} \mathrm{Al}$ amparo de lo dispuesto en el artículo $52.4^{\circ}$ de la LEC, lo será el Juez del lugar donde el finado tuvo su último domicilio. 
El escrito, del que no dice nada más el Código Civil, será, normal y lógicamente, un documento privado suscrito y firmado por el propio renunciante, presentado ante el Juez, porque, de ser público o auténtico, ya basta por sí solo y sería suficiente para la repudiación de la herencia, lo que haría innecesaria la comparecencia ante el Juez. Después, una vez presentado el escrito, el sucesor, a requerimiento del Juez y en presencia del Secretario judicial, tendrá que ratificarse en su contenido y el Juez dictará providencia teniéndolo por ratificado $\left(\mathrm{LACRUZ}{ }^{690}\right.$ ), momento en que se produce la certeza de veracidad de la declaración y con ello, la autenticidad del documento.

Esta forma de repudiación puede tener lugar de varias formas o supuestos:

a) que la presentación del escrito en que conste la declaración de repudiación se haga por parte del sucesor de forma espontánea, por propia iniciativa, sin que se haya aun incoado procedimiento judicial alguno sobre la herencia y con independencia de que vaya, o no, a incoarse después, en un momento posterior. Como tampoco es preciso que tenga que incoarse dicho procedimiento solo por la presentación del escrito, ni tan siquiera es preciso un procedimiento de jurisdicción voluntaria.

b) Que la presentación del escrito sea con ocasión o a resultas del procedimiento de testamentaría o abintestato ya iniciado.

c) Que el escrito en que conste la repudiación se presente por parte del sucesor como consecuencia de la interpelación judicial que se le hubiere practicado a instancia de terceras personas en el caso del artículo 1005 CC, o cuando el sucesor se hubiere reservado el derecho de deliberar (art. 1019 CC).

En todos los anteriores supuestos es el propio interesado quien acude al Juzgado y presenta al Juez el escrito en que consta la repudiación. El escrito ya está previamente elaborado.

d) Pero puede suceder, aunque no es muy frecuente, que sea el propio sucesor quien comparezca de forma espontánea ante el Juez, o que en su nombre y por su cuenta con poder especial, expreso, suficiente y bastante para ello (art. $1713 \mathrm{CC}$ ), lo haga un Procurador de los Tribunales, y manifieste de forma verbal, de palabra, su voluntad de repudiar, no a través de la presentación de un escrito, como vimos más arriba, en el primer supuesto, sino de forma verbal. Ahora bien, al hacerse constar después la declaración de repudiación en la correspondiente acta que se levante por parte del Secretario judicial como consecuencia de la comparecencia, aunque se haya

${ }^{690}$ Elementos de Derecho Civil. T. V. Cit: Pág. 82. 
manifestado de forma verbal, la repudiación quedaría después plasmada y recogida en este escrito, con lo cual ya se convierte en documental.

\section{2-3.- El artículo 1008 y la repudiación de los legados.}

No obstante, todo lo dicho con anterioridad, ha de entenderse aplicable para el caso de vocaciones o llamamientos hechos a título universal o de heredero, porque, si se trata de un legado, se plantea la cuestión de si su repudiación está sujeta a la norma del artículo 1008 CC o si se puede ralizar de cualquier forma, habida cuenta del interrogante de si los legados están sometidos al régimen de los artículos 988 a 1009 del Código Civil, relativos a la aceptación y repudiación de una herencia.

En este sentido, es opinión generalizada dentro de la doctrina y posición mantenida por alguna sentencia ${ }^{691}$, que la repudiación de un legado no está sujeto en su exteriorización al formalismo de las vocaciones hechas a título universal, sino que se puede hacer de cualquier manera, si bien, ha de ser de forma expresa.

Así, SCAEVOLA ${ }^{692}$ admite que se pueda hacer sin ninguna solemnidad porque la norma de los artículos 1008 y $1280.4^{\circ}$ del Código Civil se refieren a la repudiación y renuncia de los derechos hereditarios por cuanto realmente no hay prohibición alguna ya que, "el artículo 1008 se halla escrito, al parecer, para las repudiaciones de herencias y en consideración a la distinta naturaleza de ésta, comparada con la de los legados", si bien, añade, "la renuncia es preciso justificarla".

En parecidos términos se manifiesta SÁNCHEZ ROMÁN ${ }^{693}$ para quien, después de afirmar que los artículos 988 a 1009 CC no son de aplicación a los legados, entiende que su repudiación ha de ser siempre expresa, pero no solemne, pues, "no se exige en ningún artículo del Código, como en el 1008 y en el núm. $4^{\circ}$ del 1280, para la repudiación de la herencia, ........., pudiendo hacerse en cualquier forma, con tal que resulte cierta y comprobada la renuncia del legado, por no ser objeto de aquellos preceptos legales y regirse por las doctrinas de carácter general".

\footnotetext{
${ }^{691}$ STS de 24 de diciembre de 1909. Res DGRN de 24 de mayo de 1930, que defendió la libertad de forma para la aceptación y repudiación de los legados.

${ }^{692}$ Código Civil. Comentado y concordado. Tomo XV. Instituto Editorial REUS. 4 a Ed. Madrid. 1945. Pág 470 y ss

${ }^{693}$ Estudios de Derecho civil. T. VI. Vol 2. Cit: Pág 1327.
} 
MANRESA ${ }^{694}$, de igual manera, entiende que "la repudiación de los legados no es preciso que se haga en la forma solemne o formal que exige el artículo 1008, con relación a la herencia". En igual sentido, OSSORIO MORALES ${ }^{695}$, LACRUZ $^{696}$, o GUTIERREZ JEREZ ${ }^{697}$ para quienes la repudiación de legados no está sometida a la regla del artículo $1008 \mathrm{CC}$.

DIEZ PICAZO ${ }^{698}$, por su parte, considera que los preceptos del Código relativos la herencia "pueden sin dificultad considerarse aplicables por analogía, en concepto de supletorios," a los legados, pero "no los que se refieran a la capacidad o forma de manifestar la declaración de voluntad".

Llama la atención el hecho de que la mayoría de la doctrina antes citada, no dé razones o motivos que justifiquen la no aplicación del artículo 1008 a la repudiación de un legado y se limiten, sin más, a decir que no está sujeto a dicha norma, a excepción hecha de SANCHEZ ROMAN para quien, según hemos visto, "la aceptación y renuncia se regulan por las disposiciones especiales de los artículos 88, 889 y 890", y que "ha de ser siempre expresa, pero no solemne", a lo que nosotros preguntamos, si ha de ser expresa, ¿puede ser tanto verbal como escrita?, porque, en este caso, ya está revestida de una solemnidad. Si bien, más tarde dice que, se puede hacer "en cualquier forma, con tal que resulte cierta y comprobada la renuncia al legado", de cuyas palabras se desprende, en nuestra opinión, un sistema de libertad de forma pero no exento de cierto formalismo a los efectos de demostrar la autenticidad y veracidad de la repudiación del legado.

También ALBALADEJO ${ }^{699}$, parte de que, "no debe entenderse que exista una regla general de aplicabilidad al legado de la regulación de la aceptación y repudiación de la herencia, regiría para aquel el principio de libertad de forma ( $y$ así de repudiarlo sin tener que guardar formalidad alguna), que es el que vale para todos los actos jurídicos".

${ }^{694}$ Comentarios al Código Civil español. T. VI. (arts 743 a 911) $7^{\text {a }}$ Ed. Revisada y puesta al día por OGAYAR Y AYLLÓN. Instituto Editorial REUS. Madrid. 1951. Pág 812.

${ }^{695}$ Manual de Sucesión Testada. Instituto de Estudios Políticos. Madrid. 1957. Pág 362.

${ }^{696}$ Derecho de sucesiones. Parte General. Librería Bosch. Barcelona. 1961. Pág 312.

${ }^{697}$ Op. cit.: Pág 2330.

698 Sistema de Derecho Civil. T V. Cit: Pág 432.

${ }^{699}$ Comentarios al Código Civil .......... T XII. Vol 1º. Cit: Pág 390. Cita a pie de página no 20. 
Por el contrario, DIAZ CRUZ ${ }^{700}$, sí se muestra favorable a su aplicación, pero sin dar más razón que la de no ver motivo alguno para no aplicar al legado lo dicho por el artículo 1008 CC para la herencia.

Sin embargo, en nuestra opinión, y pese a la opinión mayoritaria que impera en la doctrina que sostiene lo contrario, consideramos que la repudiación de los legados sí tendría que estar sujeta a la norma del artículo 1008 del Código Civil por varias razones:

$1^{\mathrm{a}}$.- el artículo $1280.4^{\circ}$ del Código Civil exige que los actos que tengan por objeto la cesión, repudiación y renuncia de los derechos hereditarios, además los de la sociedad conyugal, se tienen que realizar a través de documento público, de lo se desprende la necesidad de tener que observar una determinada forma, artículo del que, después, es una aplicación o extensión del mismo el 1008 de dicho texto legal.

La cuestión que al hilo de ello nos planteamos es la siguiente: ¿qué hemos de entender por la expresión "derecho hereditario" a que alude el artículo $1280.4^{\circ}$ ?. Obviamente, el que proviene de una herencia, pero, sólo el que proviene de los llamamientos que se hubieren realizado a título universal o de heredero?, o también los realizados a título particular o de legatario. Si se argumenta, o se entiende, que la expresión "derechos hereditarios", o el término "herencia" del artículo 1008, está haciendo referencia únicamente a los llamamientos que se hubieren realizado a título universal o de heredero, que es la interpretación que parece desprenderse de las posiciones doctrinales antes expuestas, entendemos que se incurre en el error, o en el equívoco, de circunscribirlo solo a ellos cuando, en realidad, dentro de dicha expresión habría que considerar también incluídos los llamamientos que se hacen a título de legatario, de tal manera que podría comprender, o se podría referir, tanto un "derecho hereditario a título universal", como a un "derecho hereditario a título particular". A la expresión "derecho hereditario", se asimilan términos, tal vez, por su semejanza fonética, como, "herencia" y "derecho del heredero", pero sería, a la vez que un concepto estricto o restringido del mismo, un equívoco, porque se olvidaría que el derecho que tiene el legatario en la herencia del causante proviene de un derecho sucesorio que, al igual que el de heredero, proviene de la voluntad del causante por cuanto deriva y tiene su origen de aquello que por éste le ha sido legado (art. 881 CC).

\footnotetext{
${ }^{700}$ Los legados. Instituto Editorial REUS. Madrid. 1951. Pág 623.
} 
Así, entendida en un sentido amplio la expresión "derecho hereditario", tendría que comprender tanto el llamamiento hecho a título universal, o de heredero, como el llamamiento hecho a título particular, o de legatario.

Tanto el que sucede al causante a título de heredero, como el que lo hace a título de legatario, son sucesores del mismo. Así lo dice el artículo 660 del Código Civil, sin perjuicio de que uno y otro lo hacen de forma diferente, tanto en cuanto a su contenido u objeto, como en lo que se refiere al distinto alcance o consecuencias que se derivan de una y otra forma de suceder. Pero, además de que se trate de dos formas diferentes de suceder y que los dos títulos sucesorios provienen o emanan de la herencia al tener por objeto bienes de la misma y en virtud de la voluntad del causante, como bien señala GUTIERREZ JEREZ ${ }^{701}$, "el llamamiento que recibe el legatario no es un simple llamamiento desnaturalizado sino que se trata de un llamamiento a suceder en bienes de la herencia, bienes y derechos integrantes de la masa hereditaria, llamamiento que no debe separarse del que recibe el heredero más que hasta donde exige la naturaleza jurídica de las instituciones".

Por otro lado, el artículo 659 CC, al referirse a la herencia, manifiesta que ésta "comprende todos los bienes, derechos y obligaciones de una persona que no se extingan por su muerte", que se deferirán, según la voluntad del causante, unos, a los sucesores que hubieren sido llamados a título universal, o de heredero, y otros, a los sucesores llamados a título particular, o de legatario (art. 660 CC). De ahí que, uno y otro llamamiento hayan de considerarse como "derechos hereditarios" porque son derechos que provienen y nacen de la herencia o, si se prefiere, son "derechos sucesorios", porque tienen su origen en la sucesión del causante. A mayores argumentos, el artículo $881 \mathrm{CC}$ afirma que, "el legatario adquiere derecho a los legados ....", y éste, el legado, es un derecho que recae o tiene por objeto, a título particular, un bien concreto y determinado de la herencia. Luego, el legatario se ha de considerar como un verdadero receptor de un llamamiento a la herencia, o derecho hereditario, aunque sea a título particular, constitutivo de una auténtica delación, sin perjuicio de que ésta sólo se entienda en sentido negativo, comprensiva de solo la facultad de repudiar, o ius repudiandi. Y no digamos de otros artículos como los 888, 889 y 890 , en los que se habla de aceptación y repudiación, términos que se aplican igualmente a los llamamientos a título universal o de heredero.

Así pues, negar, o considerar, que el derecho que tiene el legatario por razón del llamamiento que ha recibido del causante sobre un bien concreto de su herencia a

${ }^{701}$ Op. cit.: Pág 2324. 
título de legado, no es un derecho hereditario, es, en nuestra opinión, totalmente incomprensible, incluso, absurdo. De ahí que, sí le sería aplicable, en nuestra opinión, la norma de los artículos $1280.4^{\circ}$ y 1008 del Código Civil.

Además, del tenor del artículo 1008 no se desprende ni se infiere, que sólo se refiera al repudio de los llamamientos hechos a título universal y que quede excluido de él, el de los llamamientos hechos a título particular. Cierto es que el precepto habla de "repudiación de la herencia", y cierto es que quien sucede en una herencia es el heredero, luego cabe entender, en principio, que parece solo referirse a él, o más exactamente, a la repudiación de los llamamientos hechos a título universal. Pero, no es menos cierto que, tanto el objeto que se ha deferido por vía de legado forma parte de la herencia -luego, es un elemento integrante de la misma junto con aquellos que vayan a ser del heredero-, como que el derecho que tiene a su favor el legatario, proviene de ella por la voluntad del causante.

En un sentido estricto o restringido, si equiparamos herencia y heredero, sólo la repudiación de llamamientos hechos a título universal estarían sometidos a la norma del artículo 1008, pero si consideramos y valoramos de dónde proviene el derecho del legatario, que sería una posición amplia, cabría subsumir en el ámbito de dicho artículo la repudiación de los llamamientos hechos a título particular.

$2^{\mathrm{a}}$.- Razones de seguridad jurídica y de certidumbre en el proceso sucesorio para todas las personas implicadas directa o indirectamente en él, justifican también que la repudiación de los legados se ha de hacer igual que la vocación a título universal.

El hecho de que el repudio de un legado se pueda hacer de cualquier forma no contribuye a ello. $\mathrm{Si}$, a resultas de la repudiación, el legado queda sin efecto porque "se refunde en la masa de la herencia, fuera de los casos de sustitución y de derecho de acrecer" (art. 888 CC), obviamente, será preciso saber y probar, de manera efectiva, cierta y segura, si el legado ha sido efectivamente repudiado, de la misma manera que un llamamiento hecho a título de heredero. Porque, a los efectos de determinar las consecuencias que de ello se derivan y de poner en marcha el mecanismo o institución a que haya lugar, en su caso, según las circunstancias, si hay que llamar al sustituto del legatario, a los colegatarios, si los hubiere, o a los coherederos con derecho de acrecer, o si hay que proceder, en último termino, a su refundición en la masa de la herencia, ¿cómo se acredita la repudiación del legado?. 
Incluso quienes defienden que la repudiación se puede hacer de cualquier forma, siempre que sea expresa, tampoco dicen cómo se tiene que exteriorizar, ¿de manera verbal?, ¿por escrito?. Aquella, provoca incertidumbre e inseguridad si no se puede demostrar su exteriorización a través de otros medios de prueba, mientras que ésta, concede certeza y seguridad, al tiempo que se puede probar tal declaración. Recordemos aquí lo que ya dijo la sentencia del Tribunal Supremo de 24 de diciembre de 1909: "La repudiación, por razones de seguridad, no puede expresarse de cualquier forma, sino que es indispensable que se haga constar adecuadamente".

Nos preguntamos también por el supuesto del artículo 891 CC si toda la herencia se distribuye en legados. En este caso, la no exigencia de la forma en el repudio de los mismos podría llevar a que toda la herencia quedase sumergida en una situación de total y absoluta incertidumbre, así como a una extraordinaria inseguridad jurídica al no ser precisa una determinada solemnidad en la repudiación.

Y no digamos ya la importancia que tiene en lo que se refiere al valor patrimonial o económico que en sí mismo pueda encerrar el objeto legado que, en ocasiones, puede ser de cuantía muy elevada y cuya trascendencia tiene un indudable interés, no ya solo para el bien en sí mismo considerado, sino para todas las personas involucradas en la sucesión y que sean potenciales destinatarias de él.

$3^{a}$.- Exigir la forma del artículo 1008 para los llamamientos a título universal y no para los realizados a título particular, cuando ambos son dos formas de suceder (art. 660 CC), sería hacer de peor condición, someter a un régimen más estricto o diferente tratamiento jurídico, al llamamiento hecho a título universal, respecto del realizado a título particular, al exigir diferente forma en uno y otro en la exteriorización de la declaración de repudiación, por cuanto, en aquel, se exigiría una solemnidad que sí está, por otro lado, justificada, lo que no sucedería en éste.

En este sentido, en el derecho alemán, a cuyo sistema se asemeja el nuestro en la adquisición de los legados, su repudiación está sujeta a la exigencia de que se ha de declarar ante el gravado por el legado (§ 2180.2 BGB), lo que, por otro lado no está exento de cierta lógica por cuanto, no sólo el legatario hace saber de su decisión, lo que actuaría a modo de notificación, al tiempo que constituiría un formalismo, sino que se le libera de tener que cumplir con aquello que le ha ordenado el causante. Ello constituye, tanto la norma como el comentario que le hacemos, trasladado a nuestro ordenamiento jurídico, en nuestra opinión, un argumento más a favor de la necesidad de someter la repudiación de un legado al régimen del artículo 1008 CC. 
TERCERA PARTE: EFECTOS DE LA REPUDIACIÓN. 


\title{
Capítulo 7: EFECTOS DE LA REPUDIACIÓN (I): EN RELACIÓN A LOS SUJETOS INTERESADOS EN LA HERENCIA.
}

\begin{abstract}
Planteamiento general. 1.- El sucesor ante su repudiación. 1-1.- Cuando hubiere hecho uso del derecho de deliberar. 1-2.- En relación a la posesión de los bienes de la herencia. 2.- Efectos respecto de otros sujetos Ilamados a la herencia. 2-2.- En relación a los sustitutos designados por el causante. 2-3.- En el caso de sustitución fideicomisaria. 3.- Los sucesores del repudiante ante la repudiación. 3-1.- Examen del artículo 766 del Código Civil. 3-2.- El derecho de representación en el caso de repudiación en la sucesión testada.
\end{abstract}

\section{PLANTEAMIENTO GENERAL.}

Ya, a priori, se puede decir que la repudiación produce dos efectos de los que ya nos hemos hecho eco en otro momento, y que son:

a) por un lado, al ser una declaración de voluntad que es antítesis de la aceptación, produce el efecto o consecuencia contrario a ésta de no adquisición de la herencia y la condición o título de heredero, así como aquellos bienes, porción o cuota a que el sucesor ha sido llamado, y

b) por otro, ope legis (art. $989 \mathrm{CC}$ ), su retroactividad al día en que se produjo el fallecimiento de aquella persona de cuya sucesión se trate, cesando así la situación de indeterminación o transitoriedad, de yacencia, en que se encuentra la herencia en este momento, lo que da lugar a que se equipare, en cuanto a sus efectos, al sistema germano en lo que se refiere a la adquisición de la herencia. 
Pero, las consecuencias de la repudiación son muy variadas y diversas ya que se extienden o ramifican en muy diferentes órdenes, a más personas, a distintos ámbitos, y con distinto alcance y trascendencia. Haciendo un simil o comparación, los efectos que se derivan de la declaración de repudio son de tal alcance que se podrían asemejar a la propagación del movimiento que producen las ondas de un fenómeno sísmico o una ola de agua en el mar.

Estos efectos, los podemos clasificar en dos grupos:

a) subjetivo (I): referido a los distintos sujetos sobre los que repercute o afecta, directa o indirectamente, la repudiación, y,

b) objetivo (II): relativo a determinar cual es el destino ulterior de aquello que se repudia que dependerá de la institución jurídica que sea de aplicación en cada caso.

(I).- Así, en el ámbito subjetivo, la repudiación tiene efectos, en primer lugar, lógicamente, en el propio declarante que es el principal y directo afectado. Después, sobre otras personas implicadas en el proceso sucesorio cuyo derecho en relación al mismo, si bien, en un principio, es eventual o expectante al abrirse la sucesión, después se va a convertir, a resultas de dicho repudio, en presente o actual, como es, por este orden, el caso de los sustitutos, si los hubiere, demás cosucesores que hubieren sido llamados junto con el repudiante a través del derecho de acrecer (art. 981 y ss CC), y por último, sucesores abintestato del causante.

Otros sujetos sobre los que también tiene gran repercusión la repudiación y que pueden resultar seriamente perjudicados a resultas de la misma, son los acreedores, tanto de la herencia, como los particulares del repudiante, por cuanto, en el caso de aquellos $^{702}$, no se podrán dirigir contra los bienes particulares de éste al quedar fuera del proceso sucesorio y no asumir ninguna responsabilidad frente a ellos por razón de las deudas del causante y, en el caso de éstos ${ }^{703}$, sus respectivos derechos de crédito se van a ver afectados ya que los bienes, porción o cuota de la herencia que han sido rechazados a resultas de la declaración de repudio no entran en el patrimonio del repudiante-deudor, por lo que no se podrán dirigir contra ellos para hacer efectivo el importe de los créditos que tengan contra él. No obstante, pese a ello, no se van a ver en una situación de desamparo ya que la ley tutela sus derechos al permitirles dirigirse

702 De las consecuencias que para ellos se derivan de la declaración de repudiación, nos ocuparemos en el punto número 1 del capítulo noveno, al que nos remitimos.

${ }^{703}$ A propósito de las consecuencias que se derivan para los acreedores particulares del repudiante, véase en el capítulo noveno los puntos números 2 y 3, referido éste al estudio de la acción del artículo 1001 del Código Civil, a los que nos remitimos. 
al Juez para que éste les autorice para aceptar dicha herencia si tal repudio se produjo en perjuicio de sus derechos (art. 1001 CC) ${ }^{704}$.

Además de los anteriores, otros sujetos sobre los que la declaración de repudio también tiene una gran repercusión, incluso de forma muy directa y personal, es sobre los sucesores del repudiante porque van a perder, además, de forma totalmente involuntaria, por causas ajenas a su voluntad y no imputables a ellos, lo que ha sido objeto de repudio, lo que se agrava cuando son estirpe del causante. Así, los nietos, o bisnietos, pierden lo que, en su caso, hubiere de corresponderles en el futuro proveniente, previo paso por el patrimonio de sus ascendientes en grado, de la sucesión de su abuelo o bisabuelo, incluida la porción legitimaria. Cierto es que ellos no son los destinatarios directos de presente de la herencia del causante, pero sí de forma indirecta ya que son futuros sucesores de dicho patrimonio en el devenir normal de las transmisiones mortis causa porque, de haber aceptado el sucesor, pasaría a después a sus manos tambien por vía mortis causa. De ahí que, a nuestro juicio, sean los peores damnificados como consecuencia de la repudiación en el círculo o ámbito familiar del causante. Así, a resultas del repudio, salvo que exista una cláusula de sustitución a su favor, pierden toda posibilidad de poder llegar a adquirir el día de mañana lo que ha sido repudiado al no haber ninguna otra institución que lo subsane. En este sentido, una de las instituciones que propugna un sector de la doctrina para salvar sus derechos sucesorios, incluida la propia legítima, es el derecho de representación, de aplicación para otros casos, pero no para el de repudiación, como luego veremos al tratar de ellos en detalle más adelante.

Y, por último, la repudiación supone, inevitablemente, en cuanto al sujeto que va a ser destinatario final de los bienes objeto de repudio, un cambio respecto del previsto inicialmente por el causante, o la ley. La herencia o cuota repudiada será objeto de una nueva vocación a favor de otro u otros sujetos, incluso absorbida por otras vocaciones ya existentes, lo que dependerá de la institución que sea de aplicación según las circunstancias de la sucesión. Así, en primer lugar, tendrá lugar el llamamiento de los sustitutos si así lo previó el causante en su testamento (art. 774 y ss CC), en su defecto, de los coherederos si existe entre ellos el derecho de acrecer (art. 981 y ss CC) y, en último término, procedería la apertura de la sucesión abintestato (art. 912.3 $\mathrm{CC}$ ), con el consiguiente llamamiento en favor de quienes resulten ser sucesores abintestato del causante.

704 Acerca de esta acción, así como de las diversas vicisitudes que se pueden plantear en su ejercicio, véase el punto número 3 del capítulo noveno, donde se hace un exhaustivo examen de la misma, al que nos remitimos. 
(II).- Ya en el ámbito objetivo, la repudiación supone una redistribución de la herencia, tanto en el activo como en el pasivo.

En aquel, porque, de no haber previsto esta eventualidad el causante, se produce una frustración o cambio de los planes ordenados o previstos por él en su última voluntad ya que el reparto de los bienes será distinto.

En éste, desde el punto de vista del pasivo, porque de las deudas del causante ya no responderá el delado al quedar fuera de la herencia. Además, se puede producir una redistribución de la responsabilidad en el pago de las mismas entre los demás cosucesores porque se podría dar el caso de tener que asumir una mayor carga, sin perjuicio del distinto alcance de responsabilidad que asuman frente a ellas, ilimitada o limitada, según acepten la herencia de forma pura y simple (art. 1003 CC), o a beneficio de inventario (art. 1023.1 ${ }^{\circ} \mathrm{CC}$ ).

Y finalmente, la repudiación puede tener, si cabe, un efecto multiplicador de mayor alcance y repercusión si se da la circunstancia de que, al proceso sucesorio ya abierto, se le suma una segunda sucesión a resultas del fallecimiento de uno de los sucesores sin haber hecho uso de su ius delationis (art. 1006 CC). En este caso, de las opciones que tiene el transmisario, sin duda alguna, la que para él tiene más trascendencia es, como apunta JORDANO FRAGA ${ }^{705}$, aquella en que él repudia la herencia de su causante porque, como consecuencia de ello, no solo rechaza ésta, sino también la que es objeto de transmisión. Así, con una sola declaración, en un solo acto, pierde las dos herencias. En este sentido, no es exacto decir, sería, más bien, una incorrección jurídica, que, "la renuncia a la herencia del transmitente lleva consigo o significa también la renuncia a la herencia del primer causante", y sí, que, "la renuncia del transmisario a la herencia de su causante o transmitente, lleva consigo la pérdida de la posibilidad u opción tanto de aceptar como de repudiar después la herencia del primer causante u objeto de transmisión".

\section{1.- EL SUCESOR ANTE SU REPUDIACIÓN.}

Un efecto o consecuencia que para él se deriva, de forma inmediata, ya apuntado, es el hecho de que, desde el mismo instante en que emite su declaración de repudio y con efectos retroactivos al día del fallecimiento de aquella persona de cuya sucesión se trate, no adquiere la condición o título de heredero, como tampoco haría suyos los bienes, porción o cuota de la misma que le hubieren sido deferidos, ni

\footnotetext{
${ }^{705}$ Op. cit: La sucesión en el "ius delationis" pág 267.
} 
asumiría responsabilidad alguna por razón de las deudas del causante y, por otro lado, se extinguiría para él el ius delationis porque precluiría de forma definitiva la posibilidad de poder aceptar en un momento posterior esa misma herencia al ser una y otra declaración, una vez realizadas, irreversibles e irrevocables (art. 997 CC).

Los efectos son tan drásticos que sería tanto como decir que el sucesor nunca ha sido llamado a la herencia. Como si su vocación nunca hubiese existido, porque, desde el momento en que la realiza, queda totalmente desvinculado y apartado de la sucesión, siendo su situación análoga a la de un extraño a la misma. En definitiva, queda automática y definitivamente excluido de la sucesión mortis causa. Como manifiesta ROGEL VIDÉ ${ }^{706}$, "el llamado que repudia se desentiende absolutamente de la herencia deferida. En virtud del artículo 989, ni es, ni ha sido nunca heredero. En consecuencia, ni tiene, ni tuvo nada que ver con las deudas y cargas de la herencia".

A resultas de ello, se renueva la delación sobre la porción o cuota de herencia repudiada a favor de otro u otros sujetos quienes, de igual manera, la podrán repudiar, o aceptar, si bien, quienes sean, vendrá determinado en función de la aplicación de la institución jurídica que proceda según las circunstancias particulares de la sucesión (sustitución, derecho de acrecer, sucesión abintestato).

Por otro lado, si se da la circunstancia de que la delación en virtud de la cual se produjo la repudiación es solidaria, el derecho de acrecer que indefectiblemente lleva unido y que se produce ope legis en el caso de vacante del sujeto, también se rechaza. Es decir, no sólo se repudia la cuota inicial a que se tenga derecho en virtud del llamamiento del causante, sino que no es posible aceptar la parte en que aquella cuota inicial se viera acrecida porque la repudiación versó, en realidad, sobre la cuota única que eventualmente pudiera ser mayor, o no, por el derecho de $\operatorname{acrecer}^{707}$.

Y, si la repudiación recae sobre un llamamiento hecho a título particular, evita que se suponga aceptado ${ }^{708}$, al tiempo que destruye con efecto retroactivo al momento

${ }^{706}$ Op. cit.: Pág 261.

${ }^{707}$ Vid: GALVAN GALLEGOS: “El destino de la herencia repudiada”. Op. cit.: Pág 901.

708 Esta declaración, según ya apuntamos en el punto número 3 del capítulo primero, reviste un significado y trascendencia jurídica diferente respecto de la realizada sobre un título universal porque tiene una doble función o cometido: no solo sirve para decir que no se quiere el legado, sino para evitar que se suponga aceptado, habida cuenta de que su adquisición, tratándose de legados puros y simples, se produce ope legis, de forma instantánea, desde el momento en que tiene lugar el fallecimiento del testador sin necesidad de aceptación por parte del legatario sin perjuicio de que, si no lo quiere, lo repudie, lo que supone una adquisición provisional del mismo, por lo que, declarada la repudiación, se destruye con efecto retroactivo, al momento de abrirse la sucesión, la adquisición realizada. Su función es, en consecuencia, análoga a la que tiene la declaración de repudio de la herencia en el sistema sucesorio germano. 
de la apertura de la sucesión la adquisición que, de forma provisional, se produjo de dicho legado. Pero, además, la repudiación, en este caso, tiene otras especialidades, que ya abordamos en otro momento ${ }^{709}$, referidas a la divisibilidad de la declaración y que tiene lugar en diferentes casos (arts. 889 y 890 CC). En este caso, si se diere, además, la circunstancia de que quien realiza el repudio del legado son los sucesores del legatario porque éste falleció sin haberlo, en su caso, repudiado, éstos, en su condición de transmisarios podrían aceptar la herencia de su causante-legatariotransmitente, y después repudiar el legado que a éste se le defirió proveniente de la herencia objeto de transmisión ${ }^{710}$.

No obstante todo lo anterior, efectos tan importantes y de tanta trascendencia tienen como contrapartida el hecho de que no todas las consecuencias que se derivan de la declaración de repudio son negativas para el declarante porque, como vamos a ver ahora, hay otras que podríamos calificar de, al menos, no perjudiciales, ya que, pese a ello, puede conservar o mantener, o no perder, algunos derechos, incluso otros títulos sucesorios o llamamientos que hubiere a su favor en esa misma herencia.

Así, el sucesor que decide repudiar la vocación que le ha sido deferida:

a) conserva los derechos o titularidades activas que con anterioridad al momento del fallecimiento tuviere contra el difunto y que no se extingan con su muerte ${ }^{711}$. En caso contrario, de haber aceptado la herencia, se habría producido, en relación a dichos créditos, una confusión entre el causante y el ya heredero, con la consiguiente extinción de la deuda, salvo que la aceptación se hubiere realizado a beneficio de inventario (art. 1192 CC).

b) En el caso de que se trate de un "prelegado", de conformidad con lo dispuesto en el artículo 890 CC párrafo $2^{\circ}$ CC, "podrá renunciar la herencia y aceptar el legado,

709 Véase acerca de las mismas, en el capítulo cuarto, punto número 2-2, donde abordamos la cuestión de la indivisibilidad de la declaración de repudio en el caso de los legados.

${ }^{710}$ Véase, en este sentido, el punto número 2-2 del capítulo quinto a propósito de la repudiación cuando hay varios títulos y una o varias porciones o cuotas de la herencia, donde se analiza esta hipótesis.

${ }^{711}$ En este caso, tales créditos, desde el momento de la apertura de la sucesión, ya no serían contra el causante y sí contra la herencia, al quedar las deudas del difunto englobadas en el pasivo de la misma. Por tanto, si tenía la condición de acreedor del causante antes de su fallecimiento, la sigue conservando y puede actuar como tal frente a la herencia.

Así, se podrá dirigir contra los bienes que integran la herencia como un acreedor más de la misma, así como contra los bienes particulares de aquellos sucesores -los demás sucesores que fueron llamados junto con él a la sucesión-, de esa misma herencia que después la hubieren aceptado de forma pura y simple al asumir una responsabilidad ilimitada por razón de las deudas del causante (art. 1003 CC), no así respecto de los bienes de aquellos sucesores que la hubieren aceptado a beneficio de inventario al quedar sus bienes exentos de responsabilidad (art. $1023,1^{\circ} \mathrm{CC}$ ). 
o renunciar éste y aceptar aquélla"712. Así, en este supuesto, el sucesor gozará de total y absoluta libertad para aceptar uno u otro título sucesorio y repudiar el otro, de tal manera que podrá ser heredero y rechazar el legado, o al revés, ser legatario y rechazar la condición de heredero del causante.

c) De igual manera, puede repudiar el llamamiento hecho a título universal y seguir conservando la mejora que, en su caso, le hubiese sido deferida por el causante ${ }^{713}$ (art. 833 CC).

Ahora bien, pero para que ello pueda tener lugar, es preciso, a nuestro juicio, que la mejora se haya deferido o atribuido a título particular, por vía de legado ${ }^{714}$, porque, si se da la circunstancia de que el llamamiento a la mejora se ha ordenado por parte del causante a través del título universal de heredero, de tal manera que engloba o comprende también, de manera conjunta e inseparable, la atribución de la mejora, la declaración que se haga en virtud de la delación, es indivisible, no se puede disgregar o separar, por lo que recaerá sobre el todo, en virtud de lo dispuesto en el artículo 990 CC que no admite la aceptación o la repudiación parcial, por lo que si se repudia el llamamiento, se repudia la mejora y si se acepta, se acepta también la mejora. Mientras que, si la atribución de la mejora se hace a título singular, el delado goza de total libertad para poder decidir lo que estime oportuno entre uno y otro título, universal sobre la herencia y particular sobre la legítima o el legado. En este caso, puede aceptar o repudiar uno y otro de forma indistinta e independiente entre sí porque, aunque el precitado artículo $833 \mathrm{CC}$ no lo diga expresamente, se puede deducir interpretándolo a sensu contrario, y porque, por aplicación artículo 890 pfo $2^{\circ} \mathrm{CC}$, es posible la repudiación del título universal y la aceptación del singular, por lo que el sucesor puede repudiar la mejora ordenada a su favor a título de legado y aceptar el título universal o de heredero (STS 3 de julio de 1951, RJ 1829).

Luego, estaríamos ante un prelegado donde, al haber pluralidad de llamamientos y delaciones distintos entre sí, que se realizan de forma independiente el uno respecto del otro, es lo que permite que el sucesor goce de total libertad para poder aceptar un llamamiento y repudiar el otro.

\footnotetext{
712 Acerca de la declaración de repudio en este supuesto, nos remitimos al número 2-2 del capítulo quinto donde se analiza su ejercicio cuando hay pluralidad de títulos y de cuotas o porciones de la herencia.

713 Acerca de esta hipótesis, véase en el capítulo quinto el punto número 2-2, relativo al ejercicio del ius delationis cuando hay pluralidad de títulos y de cuotas o porciones de la herencia.

${ }^{714}$ Tal es el caso, p. ej., en que un hijo ha sido instituido heredero por uno de sus progenitores dejando solo la legítima estricta a los demás, o que instituya herederos a todos los hijos englobando así en el llamamiento la parte de mejora.
} 
d) Si el sucesor es llamado a la herencia por testamento y abintestato, y la repudia por el primer título, se entiende haberla repudiado por los dos, mas repudiándola como heredero abintestato y sin noticia de su título testamentario, podrá todavía aceptarla por éste (art. 1009 CC). En este caso, no obstante la repudiación, el repudiante puede volver a ser llamado de nuevo a la misma sucesión a través de otros títulos sucesorios con la posibilidad de que pueda ahora, en virtud de una segunda delación, aceptar la cuota que él ya repudió, según veíamos en otro momento ${ }^{715}$.

e) Pese a la repudiación, es posible que se pueda llegar a suceder en el futuro, a un ascendiente de segundo o ulterior grado (los nietos a los abuelos o, los bisnietos a los bisabuelos), a través del derecho de representación (art. 924 y ss CC), aun después de haber repudiado la del ascendiente intermedio, la herencia del padre, que premurió a aquel, al abuelo porque, tal y como manifiesta el artículo 928 "no se pierde el derecho de representar a una persona por haber renunciado a su herencia"716.

f) El hecho de la repudiación, en otro orden de efectos para el declarante, en el caso de que el causante le hubiere designado como albacea de su herencia, no impide que, pese a la repudiación, pueda aceptar el cargo que le ha sido encomendado por parte del de cuius como ejecutor de su última voluntad al no caber interpretación, en sentido contrario, del artículo 900 CC (GITRAMA ${ }^{717}$ ), según el cual, "el albacea que no acepte el cargo, o lo renuncie sin justa causa, perderá lo que le hubiere dejado el testador, salvo siempre el derecho que tuviere a la legítima". En este caso, si el designado como albacea es tambien legitimario del causante y no acepta el cargo o lo renuncia sin justa causa, pierde aquello que le hubiere dejado el testador, salvo lo que le correspondiere en concepto de legítima. Pero, y al revés?, ¿la repudiación de la herencia implica o lleva consigo la pérdida, o la impugnación, del nombramiento de albacea?. El Código Civil no lo dice, como tampoco puede deducirse del tenor de dicho artículo, ni interpretado a sensu contrario. No obstante, si lo hubiere dispuesto el testador en su testamento, así sucederá.

${ }^{715}$ Acerca de estas hipótesis nos remitimos a cuanto exponemos en el capítulo quinto, relativo al ejercicio de la repudiación en el caso de que existan pluralidad de títulos sucesorios y/o de cuotas, y no solo en el caso del artículo 1009 CC, sino también en otros diferentes, donde nos ocupamos más en detalle y en profundidad de su análisis.

${ }^{716}$ No olvidemos, por un lado, que el "representante", o sucesor que repudia, el nieto, a quien sucede en realidad a través de esta institución es al causante, al abuelo, y no al "representado", o persona de quien repudió la herencia, su padre, y por otro, que se trata de dos sucesiones distintas entre sí, la del causante y la del representado, que pueden o no coexistir en el tiempo, que no se confunden ni se mezclan, de tal manera que se desarrollan y desenvuelven de forma totalmente separada e independiente entre sí, cada una tiene sus respectivos sucesores, pero que se da la circunstancia de que el "representado" y el "representante", o sucesor que repudia, vienen a converger o coincidir en la del otro causante, aquel lo habría hecho por derecho propio y éste a través del derecho de representación.

${ }^{717}$ Op. cit: Pág 302. 
g) Tampoco el hecho de la repudiación implica o lleva consigo para el declarante la pérdida de aquella donación que, en su caso, el causante le hubiere hecho en vida pues queda perfeccionada en el momento de su aceptación por el donatario-sucesor, aunque, por tratarse de un acto realizado a título lucrativo, sí se puede ver afectada, pero no solo en este caso, sino siempre, como consecuencia del límite que existe para la realización de actos de liberalidad ${ }^{718}$. Así, ello no impide que pueda conservar la donación siempre que quepa en la parte de libre disposición de la herencia (art. 636 CC), como tampoco habrá lugar a colación, pero sí que esté sujeta, en su caso, a reducción por inoficiosidad (arts 636, 654, 655, 656 y 820 CC) (STS 20 de junio de 1986 -RJ 4558-). Y si tuviese la condición de heredero forzoso del causante, no podrá pretender que se le impute, en su caso, la liberalidad recibida como legítima, puesto que, al haber repudiado la herencia, se repudian todos los bienes que se pudieren recibir de la misma incluidos los que pudieren constituir anticipo de legítima.

h) Por otro lado, los actos de conservación y administración provisional (art. 999 in fine $\mathrm{CC}$ ) que, en su caso, hubiere realizado el repudiante sobre los bienes de la herencia, mantienen su eficacia porque, no por ello se destruyen o desaparecen, sino que surten plenos efectos. Actos que, por otro lado, no pueden, en modo alguno, significar el tomar o adquirir a través de los mismos el título o condición de heredero porque, en caso contrario, ya habría aceptado y no podría, en consecuencia, repudiar, al ser una declaración excluyente de la otra.

Además de lo anterior, existen otros efectos que se derivan de la declaración de repudiación y que, por su interés, entendemos que merecen un examen más detenido.

\section{1-1.- Cuando hubiere hecho uso del derecho de deliberar.}

El hecho de que el sucesor, con carácter previo al ejercicio del ius delationis, se tome cierto tiempo para deliberar al objeto de examinar cual es el estado y situación en que se encuentra la herencia para poder tomar una decisión más meditada acerca de la misma al objeto de evitar así, en la medida de lo posible, un daño patrimonial, y decide después repudiar la herencia, plantea la cuestión de qué ocurre en relación a

${ }^{718}$ Vid: MANRESA: Op. cit: Pág 442; GITRAMA: Op. cit: Pág 302.

Ahora bien, cabría incluso la posibilidad de que el donante-causante, al disponer de la donación a favor del donatario-sucesor, hubiese ordenado o establecido como una causa de revocación de la misma el hecho de la repudiación de la herencia por parte de éste (art. 647 CC), es decir, para el caso de que el donatario-sucesor repudiare la herencia, sea revocada dicha donación, no ya por el donante por cuanto ha fallecido, sino por sus sucesores, ya que el repudio no deja de ser un acto o manifestación de ingratitud o de deslealtad para con el donante-causante que se podría asimilar a los que tipifica el artículo 648 CC. En este caso, los sucesores tendrían el plazo de un año para revocar la donación, contado desde que tuvieron conocimiento del hecho de la repudiación y posibilidad de ejercitar la acción (art. 652 CC). 
los gastos que se han ocasionado relativos a la formación del inventario de los bienes de la herencia, la administración de ésta y la defensa de los derechos del sucesor.

En este sentido, el párrafo primero del artículo 1033 CC, dice: "las costas del inventario y los demás gastos a que dé lugar la administración de la herencia aceptada a beneficio de inventario y la defensa de sus derechos, serán de cargo de la misma herencia", salvo que el sucesor hubiere sido condenado por su dolo o mala fe, en cuyo caso, será él quien deba de soportarlos. A lo que añade, para el caso de repudiación, en su párrafo segundo: "lo mismo se entenderá respecto de las causadas para hacer uso del derecho de deliberar, si el heredero repudia la herencia". Sin embargo, dado su tenor, se plantea la duda de cual es el significado que tiene o qué interpretación dar a la expresión, "lo mismo", ante lo que caben dos posturas ya que puede referirse:

a) bien al inciso inicial del primer párrafo, en cuyo caso, habrá que entender que los gastos, al igual que en el supuesto de que se aceptare la herencia a beneficio de inventario, son también de cuenta de la herencia, mientras que si hubiere actuado con dolo o mala fe será el delado quien los soporte. Por tanto, rige la misma norma tanto si se acepta la herencia a beneficio de inventario como si se repudia,

b) o bien, al inciso segundo del primer párrafo, de lo que resultaría que, en cualquier caso, según esta postura, los gastos serán siempre de cuenta del delado con independencia de cómo haya actuado, si de buena o mala fe. Es decir, el sucesor que repudia la herencia se equipararía al que hubiere actuado con dolo o mala fe, sea cual fuere su comportamiento, haya actuado de una u otra manera, por cuanto, en todo caso, siempre va ser él quien soporte los referidos gastos.

La interpretación que impera dentro de la doctrina ${ }^{719}$, es la expuesta en primer lugar, de aplicar para el caso de repudiación la misma regla que en el de aceptación a beneficio de inventario porque, tanto en ésta, como en aquella, se trata del ejercicio de un mismo derecho, del ius delationis, solo que en sentido inverso, y equiparar la repudiación a una condena por dolo o mala fe, no solo no es justo, sino que no se corresponde en muchos casos con la realidad porque el repudio no tiene porqué implicar o significar haber actuado de esa manera.

${ }^{719}$ Entre otros: MANRESA: Comentarios al Código Civil. T VII. Cit: Pág 532; ROCA SASTRE: Anotaciones al Derecho de Sucesiones de Kipp. Cit: Pág 40; LOPEZ JACOISTE: Comentario al artículo 1033, en Comentario del Código Civil. Secretaría General técnica del Ministerio de Justicia. Madrid. 1993. Pág 2432; ROBLES LATORRE: Comentario al artículo 1033 del Código Civil, en Jurisprudencia civil comentada (Tomo I). Dirección: Pasquau Liaño. Ed. COMARES. Granada. 2000. Pág 1720. 
En nuestra opinión, la expresión, "lo mismo", lo que hace es repetir la regla del inciso primero del párrafo primero para el caso de repudiación, de tal manera que, también en este caso, los gastos correrían de cuenta de la herencia salvo que el sucesor hubiere sido condenado por su dolo o mala fe, en cuyo caso, los gastos serán de su cuenta y riesgo. Entender que se refiere al inciso segundo, sería no solo sancionar al sucesor cuando, actuando de buena fe, decide, libre y voluntariamente, repudiar la herencia porque no quiere suceder al causante y darle un tratamiento injusto, sino que sería una interpretación fragmentaria y parcial de la hipótesis del repudio por cuanto hay que contemplar, al igual que para el caso de aceptación a beneficio de inventario, tanto el caso de que el sucesor actúe de buena como de mala fe o con dolo en el ejercicio de su derecho. Esta interpretación significa o lleva consigo dar el mismo tratamiento al ejercicio en uno y otro sentido, positivo y negativo, del ius delationis, a la aceptación a beneficio de inventario y a la repudiación. Lo contrario, sería hacer de peor situación y dispensar distinto tratamiento al sucesor que repudia respecto del que decide aceptar la herencia. En consecuencia, habría que entender que los gastos son de cuenta de la herencia salvo condena por dolo o mala fe del repudiante en su declaración, en cuyo caso, será él quien los soporte.

No obstante, no faltan quienes, como GITRAMA ${ }^{720}$, que entienden lo contrario, que los gastos se le imponen al sucesor repudiante ".... por cuanto que su ejercicio a él solo beneficia y no sería justo que lo que a su provecho concierne fuese a satisfacerlo la herencia o, en definitiva, el siguiente heredero", lo que, según él, "viene a corroborar el artículo 1064 del Código, gemelo en espíritu", en cuya virtud, los gastos de partición de la herencia hechos en interés particular de un sucesor serán de su cargo.

No podemos por menos que manifestar nuestra disconformidad acerca de esta postura porque, si el sucesor tuviese que correr con los gastos derivados de su declaración de repudio, ello puede forzarle u obligarle a aceptar la herencia, aunque sea a beneficio de inventario, para evitar dicha sanción, lo cual coartaría o limitaría su libertad de decidir (art. 988 CC), además de penalizar una conducta, un dolo o mala fe que no ha existido, incluso se correría el riesgo de que permaneciese inactivo, en silencio, lo que daría lugar a que se crease, de manera innecesaria, una situación de incertidumbre y de inseguridad jurídica en el proceso sucesorio.

${ }^{720}$ Op. cit: Pág 509. 


\section{1-2.- En relación a la posesión de los bienes de la herencia.}

Otra de las cuestiones que suscita la repudiación de la herencia, es la relativa a la posesión de los bienes a que ha sido llamado el repudiante, dada la normativa que existe a propósito de la misma.

Recordemos en este sentido que, de según el artículo 440 del Código Civil 721 , "la posesión de los bienes hereditarios se entiende transmitida al heredero sin interrupción y desde el mismo momento del fallecimiento del causante, en el caso de que llegue a adirse la herencia"722. A lo que añade a continuación, "el que válidamente repudia una herencia, se entiende que no la ha poseído en ningún momento". Así, en su virtud, se atribuye al sucesor de manera automática, ope legis, desde el momento en que se produjo el fallecimiento de la persona, "la posesión real y verdadera pero no material de los bienes hereditarios", como decía LLAMAS Y MOLINA ${ }^{723}$, es decir, sin necesidad del concurso de su voluntad o de aprehensión material, aunque todavía no haya aceptado la herencia -de ahí que el precepto diga, "se entiende transmitida"-, y con independencia de que después acepte o repudie.

Por otro lado, el artículo 440 CC nos viene a decir que la posesión de los bienes hereditarios es una situación fáctica o de hecho, de carácter temporal o transitorio, que no forma parte de la herencia, al tiempo que supedita la efectiva, concreta y definitiva adquisición de dicha posesión a la aceptación por parte del sucesor, sin necesidad de aprehensión real o material, y ya como derecho, con efecto retroactivo al momento del fallecimiento de aquella persona de cuya sucesión se trate. Sin embargo, ello no obsta para que, en ocasiones, sea necesaria la existencia de un mecanismo legal que permita esa aprehensión material como podría ser, apunta COCA PAYERAS ${ }^{724}$, el interdicto de adquirir (en contra, como él mismo señala, HERNÁNDEZ GIL ${ }^{725}$ ).

${ }^{721}$ Este precepto, junto con otros, como son los artículos 657 y 661 CC, según ya expusimos en el capítulo primero al tratar de los sistemas de adquisición de la herencia, ha servido de fundamento y argumento a un sector de la doctrina (GARCÍA VALDECASAS, GITRAMA), para defender la vigencia en nuestro ordenamiento jurídico del sistema germano de adquisición de la herencia, al tiempo que consagra, al igual que ocurrió en el derecho romano, el principio de continuidad del heredero en la posesión de los bienes del causante a los efectos de usucapión, o possessio ad usucapionem.

${ }^{722}$ O posesión civilísima de la que dijo el Tribunal Supremo, entre otras sentencias, que "se adquiere por ministerio de la ley y tiene lugar en el momento de la muerte del “de cuius", sin necesidad de la aprehensión material de la cosa, con ánimo de tenerla para sî” (St de 3 de junio de 1947, RJ 903).

${ }^{723}$ Comentario crítico-jurídico-literal a las ochenta y tres Leyes de Toro. Banchs Editor. Barcelona. 1974.

${ }^{724}$ Comentario al artículo 440 CC, en Comentario del Código Civil. Ministerio de Justicia. Secretaría General de Publicaciones. Madrid. 1993. Pág 1190.

${ }^{725}$ La posesión. Ed. CIVITAS. Madrid. 1980. Págs 276 y 277. 
En el caso de que el sucesor aceptare, la posesión ya no es algo que se impute por la ley, sino que ya es asumida por él a resultas de su declaración, al tiempo que se confirmaría la adquisición que de la misma se produce ope legis desde el mismo momento del fallecimiento del causante.

La cuestión que nos planteamos es, si la situación fáctica o de hecho que entraña la posesión civilísima puede significar un acto de aceptación tácita de la herencia, lo que impediría, en su caso, una posible repudiación de la misma por parte del sucesor $^{726}$. En este sentido, dado que es una modalidad de posesión que se adquiere por el sucesor, ope legis, por el mero hecho del fallecimiento del causante desde este instante, sin necesidad del concurso de su voluntad, su atribución se produce de manera involuntaria, ajena a él, de tal manera que no realiza acto alguno que haya de interpretarse como manifestación de voluntad, ni expresa, ni tácita, para que se ostente esa posesión, o se produzca ese paso o continuidad de la posesión del causante al sucesor. Distinto es que ejercite alguna de las acciones interdictales que protegen la posesión o se realice algún acto que no se pueda ejercitar sino es con el título o condición de heredero (art. 999 pfo $4^{\circ} \mathrm{CC}$ ), en cuyo caso, sí que podríamos estar ente un supuesto de aceptación tácita de la herencia, o que el sucesor realice, de manera deliberada y consciente, actos que entrañen posesión, actos de señor, en los que ya habría una aceptación expresa, todo lo cual, no solo es aceptación, sino que se excluiría la posibilidad de repudiar.

Así, al no exigir la posesión civilísima acto volitivo de aceptación, ni expresa, ni tácita, por parte del delado, entendemos que no se puede interpretar dicha posesión como una manifestación en sentido positivo del ius delationis, como tampoco negativo por su inactividad, por cuanto la repudiación ha de ser siempre expresa.

${ }^{726}$ Recordemos aquí que se trata de una posesión fingida o presunta, que puede incluso no ser real en el sentido de que, el sucesor, en realidad, no está poseyendo o detentando en sentido material los bienes de la herencia y sea otra persona quien ostente esa posesión material de los mismos. Incluso, ni tan siquiera tenga conocimiento de que está en posesión, o que tiene por virtud de este precepto la posesión de los bienes de su causante aunque aún no haya hecho aprehensión material de los mismos, o no tenga intención de hacerlo, o incluso de repudiar. Por ello, como dice COCA PAYERAS (Op. cit.: Pág 1188), no debemos de olvidar "que nos movemos en el terreno de las situaciones de hecho y que esa retroacción puede ir en contra de una situación de hecho material. Es decir, el llamado puede que fácticamente no hubiera poseído en el ínterin entre muerte y aceptación, sino que fuera otro el poseedor material”.

Así, lo que hace el artículo 440 es fingir o simular que el sucesor es continuador de la posesión que en vida ha tenido el causante sobre sus propios bienes. Recurre a una fictio iuris y hace derivar de ello, a favor del sucesor, todos los efectos y consecuencias que surjan de la posesión como es el hecho de que puede, en su caso, ejercitar la acción de desahucio por precario (SSTS 13 de marzo de 1952, RJ 808; 17 de abril de 1958, RJ 1680; SAP de Asturias, de 29 de diciembre de 1994, AC 1994\2320), o instar protección interdictal de recobrar la posesión si fuere despojado por un tercero. Sin embargo, la efectiva y concreta adquisición de la posesión está en directa relación con el sistema que se adopte o se siga acerca de la adquisición de la herencia, si el sistema romano o si el sistema germano. 
Y, en el supuesto de que el sucesor decidiere repudiar la herencia, el Código Civil entiende que nunca hubo tal posesión, produciendo, en este caso, como dice CALVO MEIJIDE ${ }^{727}$, la consecuencia de "borrar o anular la posesión civilísima, es decir, en el fondo anular los efectos que ésta hubiese podido producir", a lo que añade después: "pierde la posesión civilísima detentada y con efecto retroactivo al momento del fallecimiento del "de cuius", de forma que es como si nunca hubiese poseído"728. Se destruye así la posesión que hasta entonces el sucesor venía detentando sobre los bienes hereditarios, al tiempo que se produce un efecto análogo al que tiene la declaración de repudio en el sistema germano en el que se enerva la adquisición ya realizada a resultas de la delación.

\section{2.- EFECTOS RESPECTO DE OTROS SUJETOS LLAMADOS}

\section{A LA HERENCIA.}

Ya hemos apuntado más arriba que los efectos de la repudiación trascienden más allá del ámbito meramente personal de quien la realiza ya que se va a extender también sobre aquellas otras personas que, en su caso, han sido llamadas junto al repudiante a la sucesión porque su derecho sucesorio se va a ver afectado, directa o indirectamente, en mayor o en menor medida, a resultas de su declaración.

De entre ellos, unos son sujetos que han sido llamados a la sucesión por el causante, bien de forma directa, como son los demás cosucesores ${ }^{729}$, bien de forma

${ }^{727}$ La posesión en el derecho hereditario. Tesis doctoral publicada en edición facsímil por el Servicio de Reprografía de la Editorial de la Universidad Complutense de Madrid. 1990. Págs 83 y 84.

${ }^{728}$ Op. cit.: Pág 188.

729 Acerca de ellos, la forma de cómo acceden a la porción que ha quedado vacante a resultas del repudio, o les puede llegar a ellos, es diferente según se trate de una sucesión testada o intestada:

a) en el caso de una sucesión testamentaria, el mero hecho de la declaración de repudiación no da lugar de forma inmediata a su llamamiento si se ha previsto por parte del causante en su testamento una cláusula de sustitución vulgar (art. 774 y ss CC). Éste, el sustituto designado por el de cuius, sería el primer llamado a cubrir la porción vacante y después, en su defecto, a falta de sustituto, o de que éste, también, de igual manera, hubiese repudiado la herencia, serían llamados quienes hubieren sido designados como sucesores junto con el repudiante siempre y cuando existiere entre ellos el derecho de acrecer (art. 982 y ss CC). Y, en último término, a falta de éste, la porción o cuota vacante sería para quienes fueren sucesores abintestato del causante, de conformidad con lo dispuesto en los artículos 986 y 912.3 ${ }^{\circ}$ CC.

En consecuencia, para que tenga lugar el llamamiento a la porción o cuota repudiada a favor de los demás sucesores, es precisa la concurrencia simultánea de dos requisitos o presupuestos: uno negativo, que no exista en el testamento cláusula de sustitución prevista u ordenada por el causante y, otro positivo, que exista entre los cosucesores el derecho de acrecer (art. 982 y ss CC).

b) Distinto es que se produzca la repudiación tratándose de una sucesión intestada porque en ella el acrecimiento no tiene como en aquella, la testada, un carácter voluntario y no ya porque falte la voluntad del causante, sino forzoso u obligatorio entre los cosucesores dado el tenor de los artículos 922, 923 y 981 CC. 
indirecta, como son los sustitutos o los herederos fideicomisarios, otros por la ley, como es el caso de los legitimarios, sucesores abintestato o el cónyuge viudo ${ }^{730}$. Todos ellos son sujetos que se pueden considerar incluidos dentro del círculo o ámbito más interno del proceso sucesorio mortis causa, que están más próximos a la herencia del causante y a quienes afecta de forma más directa la declaración de repudio.

Pero, además, hay otros a quienes también va a afectar dicha declaración y que podríamos considerarlos situados en un círculo concéntrico más externo, un poco más alejado de la herencia, como son los acreedores de ésta y del propio declarante, en los términos que veremos más adelante ${ }^{731}$.

\section{2-1.- En relación a los sustitutos designados por el causante.}

Ciertamente, son los primeros sobre quienes recae las consecuencias de la repudiación de la herencia -casus noluntatis (art. 774 y ss CC)-, ya que serán llamados de forma inmediata renovándose sobre ellos la delación sucesoria respecto de la porción o cuota que ha quedado vacante, siendo investidos como nuevos sucesores del causante, ahora ya por derecho propio, al igual que lo fue el repudiante.

Así, en la sucesión abintestato, más que un derecho de acrecer, se puede decir que existe entre los cosucesores un derecho de no decrecer, o derecho de acrecer en sentido impropio, que deriva del principio general de exclusión del pariente de grado más remoto por el de grado más próximo.

${ }^{730}$ Su derecho sucesorio, en principio, no se ve afectado en el caso de repudiación de la herencia por parte de un sucesor al no recaer sobre la titularidad de una cuota o participación de la herencia, sino sobre el disfrute de la misma. Luego, sea cual fuere el legitimario perceptor de los bienes, el derecho de usufructo seguirá existiendo. De ahí que, para él, el repudio es irrelevante porque le dará igual que los bienes de la herencia vayan a parar a unas u otras manos, lo único que habrá es un cambio en la adjudicación y posterior titularidad de los bienes sobre los que recaerá, en todo caso, dicho usufructo. Así, podemos incluso pensar que los efectos o consecuencias son de todo punto inexistentes.

No obstante, sin ánimo de plantear hipótesis o supuestos meramente teóricos, sí pudiera darse la circunstancia, de que el repudio, tratándose de una sucesión testada, sí que puede llegar a afectarle hasta el punto de llegar incluso a poder suceder a su propio consorte de forma directa y personal en el caso de que hubiese sido designado por él como sustituto de alguno de los sucesores (de los propios hijos), en cuyo caso sería llamado a resultas de la repudiación, o cuando, a falta de sustitutos y del derecho de acrecer fuere preciso abrir la sucesión abintestato (art. 912,3 CC), en la que el cónyuge es llamado a la misma por derecho propio a falta de parientes consanguíneos en línea recta de su consorte (arts 913, 943 y 944 CC), como sería el caso de que se tratare de una persona casada que falleciere sin descendientes ni ascendientes, bien porque no existan, bien porque hubieren repudiado, bien porque no tuvieren derecho a sucederle, en cuyo caso le heredaría en plena propiedad su consorte en la totalidad de los bienes.

En cambio, en el caso de la sucesión intestada las posibilidades de que la repudiación le afecten son mayores ya que puede llegar a ser sucesor personal y directo de su cónyuge en la totalidad de la herencia si todos los sucesores abintestato que le precedan en la sucesión, descendientes y ascendientes consanguíneos de su consorte (arts 930 a 942 y 943 y ss CC), decidieren repudiar a través de la delación abintestato, o ya no tuvieren derecho a sucederle a resultas de un repudio anterior dimanante de la delación testada (art. 1009 párrafo $1^{\circ} \mathrm{CC}$ ).

Cierto es que se han de dar toda una multiplicidad de circunstancias, tanto en la sucesión testada como intestada, pero no es menos cierto que la repudiación sí pudiera llegar a afectar a los derechos sucesorios del cónyuge viudo del causante.

${ }^{731}$ De las consecuencias que se derivan de la repudiación para unos y otros, véase el capítulo noveno donde se hace un detenido examen de los mismos. 
Si aceptaren, se subrogan en dicha porción o cuota con las mismas cargas y obligaciones, retrotrayéndose los efectos de su declaración al momento de la apertura de la sucesión. Pero, si se diere la circunstancia de que el sustituto, por su parte, también repudia, procedería, en su caso, el llamamiento de un nuevo sustituto si así se hubiere previsto u ordenado por el testador. En caso contrario, tendría lugar el derecho de acrecer entre los demás cosustitutos, si fueren varios, y sino, entre los cosucesores, si se dan los requisitos exigidos por la ley (art. 982 y ss CC) y, en último término, procedería la apertura de la sucesión intestada (art. 912,3 CC).

En este sentido, obviamente, la sustitución ha de contemplar como uno de sus presupuestos $^{732}$, la repudiación, porque, de no ser así, procedería, en su caso, el derecho de acrecer, y en su defecto, la apertura de la sucesión abintestato.

\section{2-2.- En el caso de sustitución fideicomisaria ${ }^{733}$.}

Tanto el fiduciario como el fideicomisario pueden, como cualquier otro sucesor, en uso de la libertad de que gozan para suceder al fideicomitente o causante, repudiar aquello que les fue deferido por éste en concepto de fideicomiso. Pero, las consecuencias que se derivan del mismo son diferentes según que el repudio se haga por parte del fiduciario o del fideicomisario:

a) La declaración de repudio que, en su caso, manifestare el fiduciario respecto de la delación que él ha recibido sobre los bienes fideicomitidos, a la que se equipara su premoriencia al testador, produce como efecto principal, al igual que sucedería

732 De conformidad con el artículo 774 del Código Civil, la sustitución tendría lugar, no solo en el caso de repudiación, sino también en los de premoriencia e incapacidad del primer heredero instituido, con lo que desactiva lo establecido en el artículo 766 CC porque el sustituto es llamado a lo mismo que fue llamado el sustituido y no solo a la legítima como sucedería en estos mismos casos de no existir la cláusula de sustitución.

Pero, al amparo de otros preceptos del mismo texto legal, también tendría lugar la sustitución vulgar en otros casos como serían: la muerte simultánea o comoriencia del causante y del instituido (art. 33 CC), la ausencia del instituido (art. 191 CC), la indignidad del mismo, o cuando la institución no es válida o ha sido revocada. No obstante, el causante puede en el testamento limitar o reducir el ámbito de los casos en que puede tener lugar (cfr. art. 774 in fine CC).

Desde el punto de vista formal en cuanto a su ordenación, no es preciso que el testador especifique de forma expresa con detalle todos y cada uno de los supuestos en que ha de tener lugar. Puede reducir su ámbito limitándolo a solo determinados supuestos, o ampliarlo. Como tampoco es preciso que especifique cada uno de ellos de forma expresa porque, a través de expresiones tales como: que "no sea heredero", o "no llegue a ser heredero", o "no llegue a heredar", o cualquier otra semejante formulada de forma genérica o indeterminada, quedarían englobados todos los posibles supuestos en que podría producirse una vacancia en alguna porción o cuota de la herencia y, así, en consecuencia, prever el nombramiento de un sustituto para evitar dicha vacante. "En ello -dice ALBALADEJO (Comentario del Código Civil. Ministerio de Justicia. Secretaría General de Publicaciones. Madrid. 1993. Págs 1904 y 1905)-, está implícita la previsión de que no se llegue a heredar por cualquier causa”.

${ }^{733}$ Vid, en este sentido, entre otros, GALVAN GALLEGOS: "El destino de la herencia repudiada”. Cit: Pág 906 y ss. 
respecto de cualquier otro sucesor, la extinción de su delación y la consiguiente pérdida de los referidos bienes, mas no por ello se extingue el fideicomiso ${ }^{734}$. La única especialidad o peculiaridad que se produce es precisamente ésta, el hecho de que la carga o gravamen que entraña la disposición testamentaria no desaparece, sino que pasará a quienes asuman o adquieran los bienes fideicomitidos a resultas del repudio y serán éstos, los nuevos fiduciarios quienes, de igual manera, cumplida la condición o llegado el término, tendrán que hacer entrega de aquellos al fideicomisario. En caso contrario, si se extinguiese el fideicomiso supondría hacer recaer sus consecuencias sobre el fideicomisario.

Hoy no se pone en duda, tanto por la doctrina ${ }^{735}$ como por la jurisprudencia ${ }^{736}$, que la repudiación por parte del fiduciario, ante la eventualidad de que el testador no hubiere ordenado un sustituto vulgar, el fideicomisario sucedería "en vez" de él, del fiduciario, es decir, que la sustitución fideicomisaria implica o presume, salvo prueba o voluntad del testador en contrario, la vulgar tácita, ya que, en ésta, al sustituto, el testador le quiere como heredero no para cuando deje de serlo el instituido en primer lugar, sino "en defecto" de él. Y ello aunque el testador no haya utilizado fórmula alguna que comprenda ambas instituciones o no se desprenda ser su voluntad de que, para este caso, lo querido por él es que, en defecto del primer llamado que ha repudiado, los bienes no sean para el fideicomisario, sino para los cosucesores o los herederos abintestato.

${ }^{734}$ Vid: RDGRN de 26 de julio de 2003, RJ 6179.

735 Así, entre otros: LACRUZ-SANCHO: Derecho de sucesiones. Cit Pág 302; DÍEZ-PICAZOGULLÓN: Sistema de Derecho Civil. Vol IV. Cit: Pág 413; O’CALLAGHAN: Compendio de Derecho Civil. V. Cit: Pág 241.

${ }^{736}$ Vid, entre otros pronunciamientos, SSTS de 13 de mayo de 1909; 26 de noviembre de 1926; 13 de noviembre de 1948. No obstante, ha habido algunos en contra como fueron las SSTS de 13 de febrero de 1943, RJ 134; 23 de abril de 1975, RJ 1824.

La RDGRN de 27 de marzo de 1981 -RJ 1196-, lo fundamenta del siguiente modo: “la mayoría de la doctrina afirma que la sustitución fideicomisaria lleva en sí misma el llamamiento del fideicomisario como sustituto vulgar del fiduciario en base: a) a los antecedentes históricos favorables a través de nuestros clásicos a esta solución a medida que se iba perfilando y desenvolviendo la sustitución fideicomisaria; b) a los arts. 784 y 785/1. ${ }^{\circ}$ del C. Civ., que consideran al fideicomisario como un segundo heredero designado para después del primero, y que adquiere su derecho -como ya se indicó- al morir el testador, por lo que faltando el primero corresponde ahora al nombrado en segundo lugar; c) a que en los supuestos resueltos por la jurisprudencia del $T S$ favorables a la tesis contraria se refieren o a sustituciones fideicomisarias condicionales o a fideicomiso de residuos, en donde nuestra más alta Magistratura ve una institución condicional, por lo que no es aplicable esta doctrina a los supuestos de sustituciones fideicomisarias puras o aplazadas; d) a que el art. $675 \mathrm{del} \mathrm{C.} \mathrm{Civ.} \mathrm{destaca} \mathrm{como} \mathrm{esencial} \mathrm{la}$ voluntad del testador que puede aparecer manifestada claramente en este sentido; e) a que es la solución acogida por el Derecho Comparado y por nuestras legislaciones forales, tal como lo establecen el art. 155-3. ${ }^{\circ}$ de la Compilación de Cataluña, 25 de la Compilación Balear y Ley 226, $1^{a}$, de la Compilación Navarra; f) y que en este sentido se ha manifestado la sentencia de 13 noviembre 1948 (RJ 1948\1270) y la resolución de 23 de octubre de 1908.". 
Si se tratare de una sustitución fideicomisaria en que se hubiere ordenado por parte del testador, supuesto, por otro lado, frecuente, que no tenga lugar la entrega de los bienes fideicomitidos hasta que se produzca la muerte del fiduciario, o cualquier otro que no estuviere sujeto a condición, la repudiación por el fiduciario da lugar a que se produzca sobre aquellos una situación de vacancia o yacencia hasta tanto en cuanto no tenga lugar la repudiación, o aceptación, por parte del fideicomisario, declaración que, por otro lado, podrá hacer, al amparo de lo dispuesto en los artículos 784 y 799 CC, desde el mismo momento de la apertura de la sucesión y lo transmiten a sus herederos si mueren antes de que opere la restitución. Pero, si con anterioridad al fallecimiento del fiduciario, el fideicomisario ya hubiese aceptado, adquiriría la posesión del fideicomiso.

En el caso de que se tratare de un fideicomiso a término, distinto del anterior, producida la repudiación por el fiduciario, aunque el fideicomisario hubiese aceptado, éste no tendrá la posesión de aquel hasta que no se cumpla el plazo fijado por el testador, poniéndose la herencia mientras tanto en administración (arts 801 a 804 CC).

Y si se tratare de un fideicomiso condicional, ante la repudiación del fiduciario, el fideicomisario no podrá, tratándose de una condición suspensiva, aceptar ni repudiar hasta que ésta se cumpla (art. $759 \mathrm{CC}$ ). En este sentido, y siguiendo el criterio ya establecido desde el Ordenamiento de Alcalá (Ley única, Título 19) ${ }^{737}$, tanto la doctrina como la jurisprudencia ${ }^{738}$ entienden que, a diferencia de lo que sucede en el fideicomiso a término donde, como hemos apuntado hace un momento, la repudiación del fiduciario da lugar a un caso de sustitución vulgar implícita al ser llamado el heredero fideicomisario, tanto en el fideicomiso condicional como en el de residuo, sucede lo contrario, la renuncia del fiduciario no conlleva el llamamiento inmediato del fideicomisario como sustituto vulgar de aquél, sino que habrá que esperar a que la condición se cumpla. Entonces, en este caso, al estar pendiente la condición y por aplicación de lo dispuesto en el artículo 801 CC, “...... se pondrán los bienes de la herencia en administración hasta que la condición se realice o haya certeza de que no podrá cumplirse".

b) En el supuesto de que quien repudiare los bienes objeto de fideicomiso fuere, el fideicomisario, da lugar a que, con carácter general, sea cual fuere la clase de fideicomiso, aquellos seguirán el curso que, en su caso, proceda según la institución

${ }^{737}$ Vid: VALLET: Panorama de Derecho de Sucesiones. I. Cit: Pág 259.

738 SSTS de 13 de mayo de 1909; 26 de noviembre de 1916; 13 de febrero de 1943, RJ 134; 28 de junio de 1947, RJ 920; 13 de noviembre de 1948, RJ 1270; 21 de noviembre de 1955, RJ 3115; 23 de abril de 1975, RJ 1824; RRDGRN de 27 de marzo de 1981, RJ 1196; 26 de julio de 2003, RJ 6179. 
que fuere aplicable: llamamiento del sustituto que, en su caso, hubiere designado el testador, en su falta, acrecería el fideicomiso entre los cofideicomisarios si los hubiere y se dieren los presupuestos para que entre ellos tenga lugar el derecho de acrecer, en su defecto, tendría lugar el llamamiento de los sucesores abintestato del fideicomisario y, ya en último término, en defecto de éstos, el fideicomiso se "purifica" por extinción del gravamen para el fiduciario o sus herederos por cuanto quedan liberados del encargo que recibieron del testador ${ }^{739}$ consistente en conservar y entregar los bienes al fideicomisario, al tiempo que, por otro lado, devienen definitivamente en dueños pleno dominio del fideicomiso.

No obstante, es preciso distinguir según estemos ante un fideicomiso a término (a), o condicional (b):

a) en el primer caso, como en él es cierto y seguro el derecho al fideicomiso desde el mismo momento de la muerte del testador hasta el punto de que si falleciere el fideicomisario antes que el fiduciario su derecho pasará a sus herederos (arts. 784, 799 y 1006 CC), el fideicomisario puede ejercer su ius delationis sin necesidad de esperar a que dicho término se cumpla. Pero, en este caso, si la repudiación se ha producido antes de que se cumpla el término, habrá que esperar a que éste llegue o se cumpla para dar a los bienes fideicomitidos el curso que, en su caso, proceda según las reglas que hemos apuntado hace un momento. Ahora bien, si estando pendiente el término, el fideicomisario ya aceptó, al ser ésta declaración irrevocable, aunque no tendrá la posesión del fideicomiso hasta en tanto en cuanto dicho término se cumpla, excluye la posibilidad de poder repudiar una vez que se haya cumplido el término.

b) Mientras que, si se tratare de un fideicomiso condicional, suspensivo, dado que no podrá hacer declaración alguna hasta que no se cumpla la condición (art. 759 $\mathrm{CC})$, no podrá manifestar su voluntad de repudiar, o de aceptar, los bienes que recibe en fideicomiso. No obstante, hay numerosa jurisprudencia ${ }^{740}$ que admite la posibilidad de que el fideicomisario, aun estando pendiente de cumplimiento la condición suspensiva, pueda disponer de su expectativa, en definitiva, del ius delationis, lo que comprendería también la posibilidad de repudiar, antes de que se cumpla la condición.

739 SSTS 10 de marzo de 1932, RJ 952; 20 de octubre de 1954, RJ 2636; 3 de marzo de 1964, RJ 1254; 25 de mayo de 1971, RJ 2951; 4 de diciembre de 1975, RJ 4324; RRDGRN 7 de noviembre de 1927; 5 de octubre de 1966, RJ 5050; 4 de febrero de 1980, RJ 507, entre otras.

740 STS de 3 y 28 de febrero de 1964, RJ 546, 1246; RRDGRN 3 de noviembre de 1932, RJ 1263; 14 de noviembre de 1933, RJ 681; 19 de diciembre de 1942, RJ 1510; 10 de marzo de 1944, RJ 517; 8 de febrero de 1962, RJ 744. 
Así, es admisible la disposición de la expectativa de su derecho, incluida la renuncia, estando pendiente la condición, en vida del fiduciario, aunque sus efectos quedan diferidos o aplazados hasta que se cumpla la condición. La renuncia al fideicomiso condicional sería válida, si bien, no será efectiva ni tendrá plena virtualidad jurídica hasta que la condición se cumpla, ya que será en ese momento cuando nazca con plenos efectos jurídicos la vocación de fideicomisario hecha por el testador. Luego, sería una repudiación condicionada a que llegado el momento señalado para su cumplimiento, dicha condición exista y sea real, que deje de ser conditio pendet y sea conditio existit.

\section{3.- LOS SUCESORES DEL REPUDIANTE ANTE LA REPUDIACIÓN.}

Son, sin duda alguna, unos de los sujetos más prejudicados por la repudiación de una herencia cuando son la estirpe del causante porque, como ya hemos dejado apuntado, salvo que exista cláusula de sustitución a su favor por el causante, la ley no contempla ningún mecanismo de protección, ni tan siquiera para la legítima (vid, entre otras, en este sentido, STS 10 de julio de 2003 -RJ $4628^{741}$ ), a diferencia de lo que ocurre en los casos de premoriencia, incapacidad o indignidad y desheredación (cfr: arts. 761, 766, 814, 857, 924 y ss (C), a los que podemos añadir los de comoriencia y ausencia, supuestos todos ellos en los que la ley sí que llama a la descendencia para salvar, al menos, en estos casos, sus derechos legitimarios, aunque se discute por la doctrina si para ello recurre al "ius transmissionis", o si al "ius repraesentationis""

${ }^{741}$ En ella, se manifiesta lo siguiente:

“....... la renuncia del llamado no provoca la representación de su descendencia, ni en una clase de sucesión ni en otra y su estirpe no puede representarle cuando repudia la porción que se le defiere y percibir lo que su ascendiente abdica o no quiere. Así, conforme al art. 922 del Código Civil, «si hubiere varios parientes de un mismo grado y alguno o algunos no quisieren o no pudieren suceder, su parte acrecerá a los del mismo grado, salvo el derecho de representación cuando pueda tener lugar, pero concreta y precisa el art. 923 que «repudiando la herencia el pariente más próximo, si es solo, o, si fueren varios, todos los parientes más próximos llamados por la ley, heredarán los de grado siguiente por su propio derecho y sin que puedan representar al repudiante». Por ello, los descendientes del hijo que renuncia no pueden suceder apoyándose en el derecho de representación, como ha precisado la doctrina científica y conforme al art. 981, «en las sucesiones legítimas, la parte del que repudia la herencia acrecerá siempre a los coherederos»”.

${ }^{742}$ No obstante, existen algunos supuestos o hipótesis en que, pese a la repudiación del delado, o mejor dicho, como consecuencia de la misma, sus sucesores sí podrían llegar a acceder a la herencia del ascendiente o causante actual, como serían los siguientes:

a) cuando, tratándose de una sucesión testada, hubiere lugar a la apertura de la intestada en el caso de no existir sustitución prevista por el testador y no hubiere lugar tampoco al derecho de acrecer entre cosucesores por no darse los requisitos exigidos por la ley para ello (art. 981 y ss CC). En este caso, procede la apertura de la sucesión abintestato (art. 912,3 CC), y los sucesores del sucesor que repudió podrían ser llamados a la sucesión del causante por derecho propio, como sucesores directos del mismo. 
El vacío del Código Civil en proteger a los descendientes del repudiante de las consecuencias que para ellos se derivan de esta declaración, así como a aplicar en este caso, el derecho de representación, que sería, a nuestro juicio, la institución idónea para ello, y salvar así, al menos, sus derechos legitimarios, como sucede en los casos antes apuntados, nos da pie para dejar planteada la cuestión que abordaremos más adelante, de si es aplicable dicha institución para el caso de repudiación, que es uno de los temas que se plantea en la actualidad un sector de la doctrina dentro de ese espíritu de reforma que se está auspiciando en el Derecho de Sucesiones y al que aludíamos en el capítulo primero.

\section{3-1.- Examen del artículo 766 del Código Civil.}

Según su tenor, "el heredero voluntario que muere antes que el testador, el incapaz de heredar y el que renuncia a la herencia no transmiten ningún derecho a sus herederos, salvo lo dispuesto en los artículos 761 y 857". A los tres supuestos citados (premoriencia, incapacidad y repudiación), se añade después el de desheredación a través del artículo 857. Sin embargo, solo en los casos de premoriencia e incapacidad (art. $761 \mathrm{CC}$ ), y en el de desheredación (art. $857 \mathrm{CC}$ ), se salvan o protegen por la ley los derechos legitimarios de los hijos o descendientes, supuestos que después tienen su reflejo en el artículo $929 \mathrm{CC}$ al objeto de que, en los casos de desheredación e incapacidad, tenga lugar el derecho de representación a favor de dicha descendencia, en el ámbito de la sucesión intestada. A los anteriores supuestos hay que añadir el que establece el párrafo $3^{\circ}$ del artículo 814 donde, si no ha habido preterición de un descendiente que ha premuerto al testador y aquel ha dejado, a su vez, descendencia, ésta accede por representación a la legítima que dicho descendiente hubiese sido llamado, por lo que no hay preterición de los mismos. De lo contrario, en estos casos (incapacidad, desheredación y premoriencia), los descendientes no sucederían a su ascendiente superior en grado, en lo que se refiere a la legítima, y serían llamados en su lugar los demás colegitimarios (art. $985.2^{\circ} \mathrm{CC}$ ), o los parientes más próximos en grado.

Como se puede obervar, el artículo 766 no exceptúa el supuesto de repudiación, por lo que, en este caso, no se produce esa "transmisión" de derechos. No obstante, lo en él dispuesto se ha de entender siempre, en cualquier caso, sin perjuicio de lo ordenado por el causante en testamento porque los sucesores sí suceden al causante

b) Para el caso de que se tratase de una sucesión abintestato, y en el supuesto de que un sucesor repudiare, podrían ser llamados los sucesores del sucesor que ha repudiado, por razón de proximidad de grado con el causante al amparo de lo que dispone el artículo 923 CC. 
de existir en el testamento cláusula de sustitución vulgar a su favor (art. 774 CC), en cuyo caso, no solo queda enervado el precepto, sino que se convierten en sucesores directos y por derecho propio del causante produciéndose una subrogación de aquellos en la posición y situación jurídica del sustituido ${ }^{743}$.

Sin embargo, es un precepto de dudosa técnica legislativa porque está cargado de incorrecciones e imprecisiones, como denuncia GORDILLO CAÑAS ${ }^{744}$. Por nuestra parte, hacemos las siguientes:

$1^{\mathrm{a}}$.- en él se emplea de manera impropia e incorrecta el término "heredero" porque difícilmente se puede llamar como tal a quien premuere al testador cuando, además, no se puede ser heredero antes del fallecimiento de una persona al no estar aun abierta su sucesión y no existir certeza de su derecho a la herencia (art. 991 CC). Incluso, aun después de abierta, no se es heredero si no se acepta la herencia, dado nuestro sistema de adquisición mortis causa. De ahí que se refiera, y se tendrá que hablar de sucesor, vocado o delado, o como apunta GORDILLO CAÑAS ${ }^{745}$, habría de sobreentenderse el término "instituido" antes de la referencia al heredero y hablar de, "el instituido heredero que muere antes ......".

Por otro lado, habla de "heredero voluntario", lo que no se ha de entender, según apunta MANRESA ${ }^{746}$, como contrapuesto a "heredero forzoso". Su sentido ha de ser sinónimo al de, "herederos designados en testamento, tanto si son libremente nombrados como si se trata de herederos con derecho a legítima", porque sino no tiene razón de ser la referencia que se hace en él a los artículos 761 y 857. Además, se ha de entender en el sentido de que alude a tres situaciones diferentes en que se puede encontrar el heredero, tanto voluntario como forzoso, porque si se refiere ese sólo a aquel, al voluntario, hubiera enlazado con una conjunción disyuntiva los tres supuestos que son objeto de dicho precepto. En igual sentido opina ALBALADEJO ${ }^{747}$.

${ }^{743}$ Así sucedió en el caso que conoció el Tribunal Supremo en su sentencia de 9 de junio de 1987 (RJ 4049), en que el testador había instituido como herederos suyos a sus sobrinos declarando su sustitución por sus descendientes en caso de premoriencia. Entonces, no hubo lugar a la aplicación del artículo 766 CC y sí del artículo 774 CC.

744 Comentario del Código Civil. Ministerio de Justicia. Secretaría General de Publicaciones. Madrid. 1993. Pág 1887.

${ }^{745}$ Comentario del Código Civil. Cit: Pág 1887.

${ }^{746}$ Comentarios al Código Civil español. T. VI. Cit. Pág 119 y 120.

747 Comentarios al Código Civil y Compilaciones Forales. T X. Vol 1ํ. Artículos 744 a 773 del Código Civil. EDERSA. Madrid. 1987. Pág 324. 
$2^{\mathrm{a}}$.- En base al principio de que nadie puede transmitir más derechos que aquellos de los que se es titular, es una obviedad decir que no se transmite cuando resulta que nada se ha adquirido previamente ${ }^{748}$. Difícilmente adquiere quien premuere al causante, es incapaz de sucederle por causa de indignidad, o repudia aquello a lo que ha sido llamado.

$3^{\mathrm{a}}$.- Cita el artículo 857 CC que llama directamente como legitimarios a los hijos o descendientes del sucesor en el caso de que éste hubiere sido desheredado, de tal manera que, respecto de la herencia del causante, "conservan los derechos de herederos forzosos -que éste tuviere- respecto de la legítima ${ }^{749 " . ~}$

Sin embargo, dicho precepto no tiene aquí sentido porque la desheredación no se contempla entre los supuestos de excepción del artículo 766 aunque, en palabras de GORDILLO CAÑAS, se podría justificar su inclusión por "la similitud global existente entre sus causas y las de indignidad"750, mientras que, para GIMENEZ ARNAU, se puede explicar como "una confusión técnica del legislador entre los conceptos de incapacidad y desheredación"751.

$4^{\mathrm{a}}$.- En contraste a ello, pese a citarlo, no excepciona el caso de premoriencia ${ }^{752}$, aunque sí lo está después de la reforma que se produjo en el año 1981 en la norma

${ }^{748}$ Esta doctrina, apunta MANRESA (Comentarios al Código Civil español. T. VI. Cit. Pág 119), mantenida por el derecho antiguo, ha pasado a este precepto del Código que concuerda con la Ley 17, título $3^{\mathrm{o}}$ de la Partida $6^{\mathrm{a}}$, con precedentes en la legislación romana (Código de Justiniano: Ley $1^{\mathrm{a}}, 2^{\mathrm{a}}$ y $3^{\mathrm{a}}$, título LI, Libro VI), y en algunas otras leyes del derecho patrio (leyes 22, título III; 11, título VI y 34 y 35, título IX, todas de la Partida 6 $6^{\mathrm{a}}$, y 13, título III de la Partida $7^{\mathrm{a}}$ ).

749 Acerca del ámbito del artículo 857 CC, se ha suscitado la polémica de su extensión en el sentido de:

a) si su llamamiento se contrae sólo a la legítima estricta, opinión que sustentan autores como LACRUZ (Derecho de sucesiones. Parte General. Cit. Pág 205) o VALLET (Comentario al artículo 857 del Código Civil. Comentarios al Código Civil y Compilaciones Forales. T XI. EDERSA. Madrid. 1981. Pág 572). En igual sentido STS de 23 de enero de 1959 (RJ 125), o

b) si comprende también la legítima larga, como mantiene DÍEZ-PICAZO (Sistema de Derecho Civil. Vol. IV. Cit. Pág 495), en el caso de que el testador no haya dispuesto expresamente del tercio de mejora. En igual sentido, GUILARTE ZAPATERO quien se muestra partidario de extenderlo a la legítima larga (Op. cit.: Págs 192 a 196). También VATTIER (Comentario al artículo 929 del Código Civil, en Comentario del Código Civil. Ministerio de Justicia. Secretaría General de Publicaciones. Madrid. 1993. Pág 2234).

En nuestra opinión, el término legítima empleado en este precepto, en buena lógica, comprende la legítima larga, habida cuenta de que la mejora es un acto de disposición de carácter libre voluntario por parte de los padres hacia sus hijos y/o descendientes (art. 823 CC), por lo que puede existir o no existir. $\mathrm{Y}$, en lo que no exista, los dos tercios de la herencia, son legítima. No tiene sentido entender que sólo comprendería la legítima estricta porque, ¿qué ocurre si no hay mejora en la herencia?.

${ }^{750}$ Comentario del Código Civil. Ministerio de Justicia. Cit. Pág 1887.

751 “El derecho de representación en la sucesión voluntaria”. RCDI. 1940. Pág 21.

752 En este sentido, entre otros, DÍEZ-PICAZO (Sistema de Derecho Civil. Vol. IV. Cit. Pág 492), entiende que si los artículos 761 y 857 del Código se están refiriendo a la indignidad y a la desheredación, la norma del artículo 814 ha de entenderse referida al supuesto de la muerte. 
del párrafo $3^{\circ}$ del artículo 814 CC para llamar a la legítima a los descendientes de un descendiente respecto de la herencia del ascendiente y evitar así una preterición de los mismos.

5a.- Una cuestión, ya apuntada, que ha suscitado un amplio debate en la doctrina es, dado su tenor literal, tratar de determinar cual es el mecanismo de que se sirve la ley, si el "ius repraesentationis", o si el "ius transmissionis", para salvar, siquiera, los derechos legitimarios de los descendientes del repudiante que, además, pudieren ser sucesores de ulterior grado, por ello, legitimarios potenciales del causante en los supuestos en él citados, incapacidad y desheredación, dada la remisión respectiva que hace a los artículos 761 y 857 CC -que después recoge el artículo 929 CC para el supuesto de la sucesión intestada ${ }^{753}$-, y a los que hemos de añadir el supuesto de premoriencia que sanciona el artículo 814 CC, quien, además, en concreto, y de forma expresa, emplea el término "representan"754 en su párrafo $3^{\circ}$.

Acerca de ello, si el artículo 766 se sirve del "ius repraesentationis", o si el "ius transmissionis", para salvar los derechos legitimarios, un amplio sentir mayoritario de la doctrina se inclina por considerar que es a través de aquel, del instituto de la representación, aunque no faltan voces discordantes que lo niegan o ponen en duda.

En semejantes términos, VALLET (Comentario al artículo 814 CC, en Comentario del Código Civil. Ministerio de Justicia. Secretaría General de Publicaciones. Madrid. 1993. Pág 2018).

Por otro lado, igual que en el supuesto de premoriencia sucede en el caso de que "el heredero $o$ legatario que muera antes de que la condición se cumpla, aunque sobreviva al testador” (art. 759 CC), porque en él tampoco se transmite derecho alguno a sus herederos.

753 VATTIER, en este sentido, en comentario al artículo 929 CC, ve en él "una forma de representación analógica en cuya virtud los descendientes del indigno o del desheredado subentran en el status de legitimario" (En Comentario del Código Civil. Ministerio de Justicia. Secretaría General de Publicaciones. Madrid. 1993. Pág 2234).

${ }^{754}$ El empleo de este término, aquí, ha dado lugar a toda una pluralidad de posiciones dentro de la doctrina (vid en este sentido VALLET, quien hace una relación sucinta de las diferentes interpretaciones que se han elaborado por la doctrina: Comentario al artículo 814 del Código Civil. Comentarios al Código Civil y Compilaciones Forales. T XI. EDERSA. Madrid. 1981. Pág 2018): para unos, falta rigor terminológico y equivale ex lege a "sustituir vulgarmente”, otros admiten la representación en la sucesión testada, otros hablan de sustitución vulgar legal o de representación sucesoria, etc.

DÍEZ-PICAZO, en comentario a dicho precepto, manifestó: "Ia redacción de la disposición da lugar a que surja la duda de si la representación se da sólo respecto a la legítima, o se establece un derecho de representación en la sucesión testada y como consecuencia del mismo ya no hay preterición. Teniendo en cuenta la interpretación sistemática (el precepto se halla incardinado dentro de las reglas relativas a la preterición que es una medida de salvaguarda de la legítima exclusivamente) y de la naturaleza de la sucesión testada en cuanto a la parte disponible (que pende únicamente de la voluntad del testador), parece necesario circunscribir al ámbito de la legítima la representación" (Sistema de Derecho Civil. Vol. IV. Cit. Pág 492 y antes en página 352).

También ALBALADEJO admite aquí, en este artículo 814 CC, la representación (Comentarios al Código Civil y Compilaciones Forales. T X. Vol 1º. Cit: Pág 325 y ss). 
Así, para GORDILLO CAÑAS 755 , en él se presenta "como una excepción a la normal no transmisión de derechos sucesorios por el premuerto, el incapaz o el repudiante porque, en estos casos, nada transmite el representado (art. 928 CC)", lo que, en su opinión, constituye una incorrección de técnica jurídica.

De igual manera, DE LA CAMARA ALVAREZ ${ }^{756}$, quien, al hilo de la posición del Tribunal Supremo que recoge una opinión muy extendida entre los comentaristas, entiende que el artículo 766 no debe de referirse, pese a su dicción literal, al derecho de transmisión y sí al de representación, "porque, de admitir lo primero, el precepto resultaría estéril ya que es obvio que quien no ha adquirido un derecho a la herencia no puede transmitirlo", discrepa de tal postura y entiende lo contrario, que dicho precepto se refiere al ius transmissionis y no al derecho de representación porque "proclama un principio de derecho sucesorio que probablemente podría haberse silenciado, ya que dicho principio no es más que un corolario de las normas que regulan la delación y la adquisición de la herencia".

Para DÍEZ-PICAZO ${ }^{757}$, refiriéndose no al artículo 766, sino al 761, lo que hace la ley en él, es considerar a los hijos o descendientes del incapaz como legitimarios en lugar de él, cualidad que, en otro caso, no ostentarían, pues serían preferentes los más próximos en grado, al igual que ocurre en la sucesión intestada. "Por ello, si se quiere hablar de representación, hay que puntualizar: en la simple cualidad de legitimarios, que indiscutiblemente poseía el incapaz, se daría dicha representación".

GUILARTE ZAPATERO ${ }^{758}$, también admite la existencia de un derecho de representación refiriéndose a los artículos 761 y 857 CC, al que califica de "especial o anómalo", virtud del cual "se entiende que el representante no sucede en todos los derechos que hubieran correspondido al desheredado o indigno, sino solo en la cualidad o condición de legitimario, no obstante vivir éste".

ROCA SASTRE, por su parte, califica el artículo 766 CC de inocuo o irrelevante, niega el ius transmissionis en estos casos; pero ello nada tiene que ver con el derecho de representación sucesoria ya que, en el supuesto de actuación de este derecho, la estirpe entra en la herencia intestada, no por vía de transmisión del derecho de su

\footnotetext{
755 Comentario del Código Civil. Ministerio de Justicia. Cit: Pág 1887.

756 "El derecho de representación en la herencia testada y la preterición de herederos forzosos. (En torno a la sentencia de 6 de diciembre de 1952)”. RDN. 1955-1. Pág 14 y ss.

757 Sistema de Derecho Civil. Vol. IV. Cit. Págs 352 y 492.

${ }^{758}$ Comentarios al Código Civil y Compilaciones Forales. T XIII. Vol 1º. Artículos 912 a 958 CC.
} EDERSA. Madrid. 1989. Pág 192. 
ascendiente, sino que es llamada directamente por la ley ${ }^{759}$. Y refiriéndose al artículo 857 entiende que existe, "más bien, una successio graduum inspirada en motivos de piedad, sin perjuicio de que en ella pueda actuar el derecho de representación si concurren hijos con nietos o bisnietos. La ley no hace entrar a la estirpe en legítima, por vía de representación sucesoria, en cuanto a al disposición testamentaria en sí, pus ésta no existe sino en sentido negativo; llama directamente a la estirpe a modo de devolución de la portio legítima, o sea, de una atribución directa efectuada por la misma ley". De igual manera lo niega respecto del artículo 761 donde se produce "una especie de successio graduum, si bien, referida a la portio legítima, mas no a la disposición testamentaria ya que ésta ha quedado ineficaz o inoperante por la indignidad del llamado"760.

A nuestro juicio, el artículo 766, no se refiere, ni a uno ni a otro, ni al derecho de representación ni al de transmisión. No al primero porque difícilmente se puede "representar", aunque sea de forma indirecta, o empleado incluso de manera impropia dicho término, a alguien en algo que no es suyo porque no lo ha adquirido y que, en este caso, además, no lo puede haber adquirido. Como tampoco al segundo, porque el ius transmissionis, técnica y jurídicamente, sólo existe (art. 1006 CC), cuando el sucesor, pudiendo ejercer el ius delationis, ha fallecido después de abrirse la herencia sin haberlo hecho, lo que no se da en ninguno de los casos en él contemplados.

En nuestra opinión, el término "transmiten" se emplea en un sentido impropio, y por ello equívoco, porque se debería de entender o interpretar en el sentido de que los derechos sucesorios a que fue llamado el sucesor que ha premuerto a su causante, es incapaz de heredarle o ha repudiado su herencia, no pasan, vía sucesor, por medio de él, o a través de él, a quienes sean sus sucesores, sino que ese paso o "transmisión" de derechos se produce directamente del causante a la estirpe, de tal manera que es como si, en sentido ficticio o metafórico, hubiese un "puente" entre aquel y ésta, para salvar, o pasar por encima del sucesor, como si éste no existiese. Pero, para que ello pueda ser así, como bien dice ROCA SASTRE, es preciso que tenga lugar un llamamiento directo que hace la propia ley a favor de la estirpe, que es lo que sucede en los casos de los artículos $761,814.3^{\circ}$ y 857 CC, para los casos, respectivamente, de incapacidad, premoriencia y desheredación. Aunque después, la doctrina, para fundamentar, o tratar de explicar cómo se produce este llamamiento, entiende, aunque con ciertas reticencias, que se sanciona en ellos el mecanismo de la representación.

759 “El derecho de representación en la sucesión testada”. Estudios de Derecho privado. II. Madrid. 1948. Pág 259.

760 “El derecho de representación en la sucesión testada”. Cit. Págs 271 y 272. 
Así, si en los supuestos del artículo 766 CC, concordante con él, el 761, 814.3y y 857 CC, se podría admitir el instituto de la representación, aunque con reticencias, como el recurso de que se sirve el Código Civil, a excepción hecha de la repudiación, para salvaguardar los derechos legitimarios de los descendientes del premuerto, indigno y desheredado, lo que plantea la cuestión que tiene en jaque a la doctrina desde hace ya varias décadas de, si es aplicable el derecho de representación en el ámbito de la sucesión testamentaria y más en concreto, para el caso de repudiación.

\section{3-2.- El derecho de representación en el caso de repudiación.}

A la vista de lo anterior, tratándose de la sucesión testamentaria, y partiendo de la circunstancia de que la designación del sustituto se hace, normalmente, a favor de los descendientes del sucesor instituído que, la mayoría de las veces, es la estirpe del propio causante, dada la condición de herederos forzosos suyos (cfr. art. $807 \mathrm{CC}$ ), es fácil comprender, como ya hemos puesto de relieve, la gran importancia que para ellos tiene la existencia de una cláusula de sustitución a su favor en el testamento.

De ahí que, la ausencia de dicha cláusula, o su insuficiencia porque el causante la haya previsto u ordenado para otros casos pero no para el de repudiación, dada la libertad de que goza al ordenarla (art. 774 in fine CC), supone para ellos un considerable perjuicio por cuanto a la cuota repudiada serán llamados, en primer lugar, los demás cosucesores a través del derecho de acrecer si se dieren los requisitos exigidos para el mismo (art. 981 y ss CC) y, en su defecto, los sucesores abintestato del causante. Perjuicio, por otro lado, irreparable porque nunca llegarán a adquirir los bienes que han sido objeto de repudio, bienes que, en algunos casos, se puede dar la circunstancia de que han pertenecido de forma secular e inmemorial a una familia y que, ahora, a resultas de la decisión del repudiante, se rompe esa cadena de transmisiones que se han producido por vía mortis causa a lo largo del tiempo, de manera secular, contínua e ininterrumpida, de generación en generación. Ante tal circunstancia, se les hace ser sufridores de las consecuencias que se derivan, por un lado, de la falta de previsión del testador y, por otro, de un acto que ellos no han realizado, en el que no han intervenido, no podían hacerlo, como tampoco lo podrían haber evitado, y que, además de injusto, les causa un considerable daño o perjuicio irreparable, como también, parece que no deja de actuar a modo de castigo o de sanción ante esa declaración que ellos no han emitido. 
Ante ello, cabe preguntarse si, ante la repudiación y a falta de sustitución, la ley arbitra algún remedio para que la estirpe del repudiante pueda, al menos, tener la opción de poder pronunciarse sobre lo que éste repudió, más en concreto, si es o no aplicable, en concreto, el derecho de representación al ser la institución que entendemos más idónea para protegerles, como sucede en otros casos que tipifica el Código Civil a propósito de la legítima, al igual que sucede en otros ordenamientos jurídicos, y evitar así las consecuencias tan perjudiciales que para ellos se derivan de dicha declaración.

A diferencia de lo que ocurre en la porción legitimaria, que es donde se pantea la problemática que debatimos, no sucede lo mismo en lo que se refiere a la mejora o la parte de libre disposición, porque en ellas, sea cual fuere la causa que hubiere motivado la vacante, la doctrina, a la que nos adherimos, niega la posibilidad de que los descendientes de grado ulterior puedan suceder en ellas a través del derecho de representación. Así, en lo que se refiere a la mejora ${ }^{761}$, se entiende que no procede dada la similitud que tiene con la parte libre. De igual manera, la jurisprudencia ${ }^{762}$ lo niega. $Y$, respecto de la parte libre de la herencia, tampoco sería admisible ya que, en opinión de la generalidad de la doctrina, tropieza con el tenor del artículo 766 CC que impide la transmisión de derechos sucesorios a los herederos por parte del heredero voluntario cuando éste repudia la herencia, además de los casos de premoriencia al testador o si es incapaz de suceder, aparte del paralelismo que tiene con la sustitución vulgar por cuanto la función que se pretende que cumpla aquel, el derecho de representación, lo hace ésta, la sustitución.

En el Código Civil, a diferencia de lo que sucede en otros ordenamientos de nuestro entorno ${ }^{763}$ donde la aplicación de la representación en este caso es admitida de forma expresa (§ 1953.2 del BGB; art. 467 Codice de $1942^{764}$-no así en el de 1865

${ }^{761}$ DÍEZ-PICAZO (Sistema de Derecho Civil. Vol. IV. Cit. Pág 353); VATTIER (El derecho de representación en la sucesión mortis causa. Ed. Montecorvo. Madrid. 1986. Pág 280).

En cambio MARTÍNEZ CALCERRADA, lo admite (La representación en el derecho sucesorio. Ed. Aranzadi. Pamplona. 1966. Pág 373).

762 SSTS de 6 de diciembre de 1952, RJ 2430; 18 de diciembre de 1962, RJ 4897; 5 de julio de 1966, RJ 3671.

763 Señala CASTAN, en este sentido, que, "el grupo de las legislaciones latinas concibe, por lo general, el derecho de representación como un caso de sustitución ex lege y desconoce, consiguientemente, la representación en materia de sucesión testamentaria. No es otro el sentido del Código Civil portugués y del francés" ("El derecho de representación y mecanismos jurídicos afines en la sucesión testamentaria”. RGLJ. 1942. Pág 146).

${ }^{764}$ Lo que ha sido objeto de crítica por DE LA CAMARA (Op cit. Pág 18).

Acerca de la representación hereditaria en el Código Civil italiano, véase el amplio comentario que hace de la misma CASTAN TOBEÑAS: "El derecho de representación y mecanismos jurídicos afines en la sucesión testamentaria”. Cit. Pág 162 y ss. 
que lo prohibió en su artículo 497-; Códigos Civiles latinoamericanos ${ }^{765}$; artículo 805 párrafo $2^{\circ}$ del Code francés ${ }^{766}$ ), no hay ningún precepto en el que se prohíba, tambien de forma expresa, la representación, o llamamiento, a favor de los descendientes del repudiante ante su declaración. Sí, en cambio, hay numerosos artículos del Código Civil, como ahora veremos, en los que se puede observar que excluye, o no llama, a los descendientes, lo cual se puede entender o interpretar en el sentido de que no admite la posibilidad de que puedan "representar" a su ascendiente inmediato en la sucesión del causante a resultas de la repudiación ${ }^{767}$. Así:

a) la repudiación es el único supuesto en que el artículo 766 CC, de los que en él se contemplan, no hace excepción, al no citarla, para proteger los derechos legitimarios de la estirpe.

En coherencia con ello, el Código Civil excluye el llamamiento de la estirpe en el supuesto de que dicha repudiación se produjere incluso en la propia legítima porque, en este caso, "sucederán en ella los coherederos por su derecho propio y no por derecho de acrecer" (art. $985.2^{\circ} \mathrm{CC}$ ), lo que, por otro lado, constituye una expansión

765 Véase MARTÍNEZ CALCERRADA (Op. cit.: Pág 433): Argentina (art. 3554, Código de 1882); Colombia (art. 1041); México (arts. 1609 y 1632 Código de 1928); Uruguay (arts 1018 y 1024 , Código de 1914); Chile (art. 984); Perú (art. 681, Código de 1984, antiguo 679 del Código de 1936); Ecuador (art. 974); Costa Rica (art. 575).

En la propuesta de reforma del Código Civil de Puerto Rico, publicada el 25 de octubre de 2005, se establece la representación en la sucesión testamentaria por causa de repudio (VATTIER: "El derecho de representación”. En Derecho de Sucesiones. Presente y futuro. XII Jornadas de la Asociación de Profesores de Derecho Civil. Servicio de Publicaciones de la Universidad de Murcia. 2006. Pág 545).

${ }^{766}$ El derecho francés ha sido el último en incorporar, a través de la Ley $n^{\circ}$ 2006-728, de 23 junio de 2006, la tendencia expansionista del derecho de representación que existe en otros Códigos Civiles.

Así, según el tenor del párrafo segundo del nuevo artículo 805: "Sous réserve des dispositions de l'article 845, la part du renonçant échoit à ses représentants; à défaut, elle accroît à ses cohéritiers ; s'il est seul, elle est dévolue au degré subséquent” -Bajo reserva de las disposiciones del artículo 845, la parte del renunciante, le toca a sus representantes; en su defecto, acrece a sus coherederos; si él está solo, corresponde al grado siguiente-.

Este artículo rompe con el sistema anterior en el que no se admitía (derogado artículo 787), la representación en el caso de renuncia en línea recta: "On ne vient jamais par représentation d'un héritier qui a renoncé: si le renonçant est seul héritier de son degré ou si tous ses cohéritiers renoncent, les enfants viennent de leur chef et succèdent par tête” -No se puede representar a un heredero que ha repudiado: si el que repudia es el único heredero de su grado o si todos los coherederos la repudian, sus hijos heredarán por derecho propio y sucederán por cabezas-.

Esta reforma, en opinión de VATTIER, “obedece a la situación social y demográfica actual, puesto que permite transmitir el patrimonio a las personas más jóvenes, que es cuando las necesidades son más importantes” (“El derecho de representación”. Cit: Pág 545).

${ }^{767}$ En este sentido, en el derecho aragonés, no se habla de representación y sí de sustitución legal que "tiene lugar cuando el llamado ha premuerto, ha sido declarado ausente o indigno de suceder, así como cuando ha sido desheredado con causa legal o excluido absolutamente en la sucesión” (art. 338 CDFA), incluso en la legítima (art. 339 CDFA), si bien, la excluye de forma expresa en el caso de repudiación (art. 341 CDFA). 
de la legítima individual de los restantes colegitimarios ${ }^{768}$. En este sentido, el hecho de dar el Código Civil un tratamiento distinto a los casos de premoriencia, incapacidad y desheredación, denota, de forma muy reveladora, la voluntad de no permitir el llamamiento a favor de la estirpe en el caso de repudio, ni tan siquiera en los derechos mínimos sucesorios como son los legitimarios.

b) Del tenor de otros artículos (912.3ㅇ 913 y 986 CC), también se puede deducir que no admite el derecho de representación al dar entrada a la sucesión intestada, a falta de sustituto y derecho de acrecer, cuando se ha producido una vacante en la herencia, o el 888 CC, a propósito de los legados, que establece la refundición del legado en la masa de la herencia cuando no haya lugar, de igual manera, a la sustitución ni al derecho de acrecer, como puede ser, tanto en uno como en otro caso, a resultas de la repudiación.

c) Cuando trata de la sucesión abintestato, del tenor de varios preceptos del Código Civil se desprende, de igual manera, que no procede en ella la aplicación de la representación en el caso de repudio. Así, por un lado, lo establece de forma expresa en el artículo 923 al seguir la regla "viventis non datur repraesentatio", y por otro, el artículo 929, por silencio, de forma implícita, no la cita pero, excepcionando dicha regla, sí lo admite en los casos de desheredación o incapacidad, lo que viene a ratificar la norma del artículo 923 CC, así como en el artículo 981 al dar preferencia, en el caso de repudio, al llamamiento de los cosucesores a través del derecho de acrecer.

De igual manera, en la sucesión testada se entiende que no procede cuando, habiéndose producido una vacante en alguna porción o cuota de la herencia a resultas, entre otros casos, de repudio, llama, a falta de sustitución, a los cosucesores a través del derecho de acrecer (art. $982 \cdot 2^{\circ} \mathrm{CC}$ ).

d) El tenor del artículo 924 CC es bastante elocuente cuando, al definir o dar una descripción del derecho de representación, excluye como supuesto de hecho que le da lugar, a la repudiación, desde el momento en que sólo lo admite a favor de los parientes de una persona para poder sucederle "en todos los derechos que tendría si viviera o hubiere podido heredar".

Al amparo del primer inciso, se entendería comprendido el caso de premoriencia, al que se asimilaría, la declaración de fallecimiento del sucesor anterior a la muerte del

${ }^{768}$ Véase en el capítulo siguiente el punto número 4-2, a propósito del destino de la legítima en el caso de repudiación. 
causante $^{769}$ y la comoriencia, mientras que, al amparo del segundo, aquellos en los que el sucesor vive pero no puede heredar, que serían el de indignidad o incapacidad y desheredación, después recogidos en el artículo 929 CC, y a los que GUILARTE añade el supuesto de ausencia ${ }^{770}$. Pero, obsérvese que no alude al hecho de "no querer heredar", que es lo que se manifiesta a través de la repudiación, lo que se puede entender, o se ha de entender, en el sentido de que excluye, o no permite, la representación en este caso.

e) El tenor del artículo 929 CC es también muy significativo cuando sólo admite la representación de una persona viva en los casos de desheredación e incapacidad. Luego, al no decirlo, se entiende que no lo admite en el caso de repudiación, en que también está viva la persona.

No obstante todo lo anterior, pese a que, desde el punto de vista legal, se puede afirmar que la normativa del Código Civil es muy rotunda en no admitir la aplicación del derecho de representación, se ha pretendido ver en dos artículos la posibilidad de su admisión, aunque de forma dudosa:

a) por un lado, el artículo 922 CC que establece el acrecimiento entre los sucesores del mismo grado, si hubiere varios, cuando “... alguno o algunos no quisieren o no pudieren suceder ......, salvo el derecho de representación cuando deba tener lugar", lo que se ha interpretado, en alusión a la expresión "no quisieren suceder", en el sentido de repudiación (ESPÍN CÁNOVAS ${ }^{771}$ ). Quien no quiere suceder lo que ha de hacer es repudiar la herencia. Luego, sí parece entenderse que sí procedería la representación en el caso de repudiación.

Sin embargo, MARTíNEZ CALCERRADA ${ }^{772}$ hace otra interpretación del precepto y entiende que, el derecho de acrecer "sólo dejará de operar cuando el Código permita la representación, esto es, en los casos en que el primer llamado, no vive o no puede heredar, pero no cuando no quiere heredar", achacando la redacción del texto, según sus palabras, "a un fallo de técnica redactiva", porque, "pareciendo, según el

${ }^{769}$ GUILARTE: op cit.: Pág 184.

770 Op. cit.: Pág 179 y ss.

En este sentido, GUILARTE incluye aquí la comoriencia que entiende asimilable a la expresión "hubiera podido heredar", lo que estimamos erróneo porque también, de no haber premuerto, el hijo hubiera podido heredar. Por lo lado, la ley, en el caso de muerte simultánea, presume, (art. 33 CC), que el sucesor falleció al mismo tiempo que el causante, luego hay que entender o presumir que ya no está vivo en el momento de la defunción o que no ha sobrevivido al causante ni tan siquiera por breves instantes para poderle heredar. Luego, sería asimilable a la premoriencia.

${ }^{771}$ Manual de Derecho civil español. Vol. V. EDERSA. Madrid. 1978. Págs 535 y 536.

${ }^{772}$ La representación en el derecho sucesorio. Ed. Aranzadi. Pamplona. 1966. Pág 274. 
formalismo de este artículo, que la excepción del derecho de representación se refiere, indistintamente, a la correlación "no quisieren o no pudieren", luego del espíritu y letra del Código Civil -reflejado justamente en dos artículos más adelante-, se desprende que, pese a esa expresión literal, la representación en ese caso de renuncia, de alguno o algunos, nunca puede excepcionar el acrecimiento".

b) $Y$ por otro, también se ha querido ver como un argumento a favor de la aplicación del derecho de representación en la sucesión testada, al menos en cuanto a la legítima, el hecho de que el artículo 1038 del Código Civil emplee el término "en representación" para referirse a los nietos respecto de los padres en la sucesión de los abuelos, si concurrieren con sus tíos o primos, en cuanto a la obligación que tienen de colacionar todo lo que debiera colacionar el padre si viviera, aunque no lo hayan heredado.

Pero, esta hipótesis es descartada por DE LA CAMARA ${ }^{773}$ porque, en su opinión, ello no prejuzga en qué casos ha de tener lugar la representación sucesoria, como tampoco se ha de entender en el sentido de que los nietos representan a su padre, sino que la obligación de colacionar es para el caso de que sucedan al abuelo con el carácter de legitimarios. $Y$ aclara que, desde un punto de vista técnico, tiene explicación que se refiera al derecho de representación porque está aludiendo, genéricamente, a las hipótesis en que los nietos, hijos de un hijo premuerto, sucedan directamente al abuelo.

Pese a estas dos últimas posturas, de interpretación muy forzada, todas las disposiciones antes citadas del Código Civil nos permiten obtener la conclusión de que la ley no contempla, o no admite, de forma clara y rotunda que se dé el derecho de representación en la sucesión mortis causa, tanto en ninguna parte de la herencia testada -legítima, mejora o parte libre-, como en la intestada, cuando se hubiere producido en ella una vacante a resultas de la repudiación por parte de un sucesor porque sino lo habría establecido, de la misma manera que lo ha hecho en otros casos, lo que así se quiso entender por algunos, a través de la reforma en el año 1981, en el nuevo texto del artículo 814 CC para el caso de premoriencia al proteger la legítima de los descendientes de ulterior grado en el que emplea de forma expresa el término "representan". Lo cual ya debería ser suficiente argumento como para dar una respuesta negativa a la hipótesis de que tratamos y descartar de manera definitiva, en una y otra, su aplicación.

\footnotetext{
${ }^{773}$ Op. cit.: Pág 41 y ss.
} 
Sin embargo, la aplicación del derecho de representación, no ya solo en el caso de repudiación, sino también, en general, en el ámbito de la sucesión testada, ha dado lugar, tradicional e históricamente, a una de las grandes polémicas que han existido en el ámbito del Derecho de Sucesiones dentro de la doctrina quien, a través de una abundante literatura ${ }^{774}$, ha debatido dicha cuestión en el sentido de tratar de precisar su alcance y admisión a través de distintos argumentos, tanto de lege data, como de lege ferenda, y desde diferentes puntos de vista. Aunque la posición preponderante y mayoritaria es la de entender que, en el Código Civil, el derecho de representación solo tiene lugar en el ámbito de la sucesión intestada (en los casos de premoriencia, desheredación e incapacidad -arts 923 y 929 CC-), mientras que, en la testamentaria, no con carácter general, sino sólo en la parte referente a la legítima ${ }^{775}$, después nos encontramos, según veremos más adelante, con diversas y variadas propuestas que tratan de dar una respuesta o solución afirmativa por medio de la aplicación de distintas reglas o procedimientos a través de los cuales se trata de llegar al mismo resultado que si se aplicase el derecho de representación.

No obstante, las propuestas elaboradas por la doctrina en orden a admitir la aplicación del derecho de representación en el caso de repudiación para salvar los derechos de los descendientes del declarante y darles la oportunidad de que

${ }^{774}$ Así, entre otras muchas publicaciones:

MORELL: “¿Heredan los nietos por representación en caso de renuncia del padre?”. RGLJ. Tomo 107. Año 1905. Pág 340 y ss; NOVOA SEOANE: "El derecho de representación según el Código Civil. Antinomias aparentes”. RDP. 1914. Pág 143 y ss; GIMENEZ ARNAU: “El derecho de representación en la sucesión voluntaria”. RCDI. 1940. Pág 20 y ss; CASTAN TOBEÑAS: "El derecho de representación y mecanismos jurídicos afines en la sucesión testamentaria”. Cit: Pág 137 y ss; BURGOS BOSCH: El derecho de representación en la sucesión testada. Curso de conferencias del Colegio Notarial de Barcelona. 1942; FUENMAYOR: "Estirpe única y representación hereditaria.” Revista de Estudios Jurídicos. $\mathrm{N}^{\mathrm{o}}$ 2. Octubre. 1942; ROCA SASTRE: "Observaciones críticas sobre la tendencia expansionista del derecho de representación sucesoria”. RGLJ. 1943. Pág 581 y ss; "El derecho de representación en la sucesión testada”. Estudios de Derecho privado. II. Madrid. 1948. Pág 259 y ss; DE LA CAMA ALVAREZ: Cit: "El derecho de representación en la herencia testada y la preterición de herederos forzosos”. Pág 7 y ss; ROVIRA MOLA: “Ámbito del derecho de representación sucesoria en el Código Civil”. RDP. 1951; MARTÍNEZ CALCERRADA: La representación en el derecho sucesorio. Cit; ALGABA ROS: Efectos de la desheredación. Edt. Tirant Lo Blanch. Monografías 250. Valencia. 2002. Pág 414; VATTIER FUENZALIDA: El derecho de representación en la sucesión mortis causa. Ed. Montecorvo. Madrid. 1986; "El derecho de representación”, en Derecho de Sucesiones. Presente y futuro. XII Jornadas de la Asociación de Profesores de Derecho Civil. Servicio de Publicaciones de la Universidad de Murcia. 2006.

${ }^{775}$ VALVERDE: Tratado de Derecho Civil español. T. V. Cit: Pág 404; SÁNCHEZ ROMAN: Estudios de Derecho civil. T. VI. Vol 1º. Cit: Pág 639; CASTAN TOBEÑAS: "El derecho de representación y mecanismos jurídicos .......”. Cit: Pág 147; CLEMENTE DE DIEGO, entiende que no ha lugar a la aplicación del derecho de representación en la sucesión testada porque, "como el título de la sucesión testada es de origen voluntario y carácter personalísimo, es evidente que no hay términos hábiles del derecho de representación: los llamamientos son individuales y la premoriencia del instituido, como su incapacidad, aniquilan la institución. En cambio, y por razones contrarias, puede tener aplicación en cuanto a la legítima, que no es de origen voluntario, sino legal y de carácter forzoso (arts 761 y 857, en relación con el 929)" (Instituciones de Derecho civil Español. T. III. Derecho de Sucesiones. Cit: Pág 304). 
adquieran aquello a lo que éste fue llamado, al menos, la legítima, tropiezan, como veremos ahora, con serias dificultades para su admisión.

Un argumento de carácter eminentemente técnico, bastante extendido, en el que se ha apoyado la doctrina para no admitir la aplicación del derecho de representación en el ámbito de la sucesión testada y que constituye un obstáculo importante para dar, en su caso, una respuesta afirmativa a la cuestión planteada, radica en la propia esencia, finalidad y funcionamiento del ius delationis, en el sentido que apunta ROGEL ${ }^{776}$ de que, "el llamado que repudia se desentiende absolutamente de la herencia deferida. En virtud del artículo 989, ni es, ni ha sido nunca heredero". En términos semejantes se manifiesta ALBALADEJO"777, para quien, "el ius delationis se extingue por la renuncia -artículos 766 y 988 y siguientes, en particular 997-, sin perjuicio de que dé lugar a nueva delación a favor de quien corresponda".

A resultas de la repudiación el sucesor queda en una situación análoga a la de un extraño a la herencia por cuanto queda totalmente apartado del proceso sucesorio mortis causa al que ha sido llamado, lo que sería igual que decir, que nunca se ha producido esa vocación a su favor. Pero, lo cierto es que la vocación sí ha existido y, además, la delación que de ella surge a su favor es lo que ha permitido que el sucesor se haya apartado él, por su propia decisión, de la sucesión a la que fue llamado a resultas del ejercicio del ius delationis de una de las dos maneras que lo podía hacer, repudiando la herencia, como también podía haber aceptado, ya sea de forma voluntaria o ex lege ${ }^{778}$. De ahí que, al haberse consumado el llamamiento hereditario y subsiguiente delación a resultas de su ejercicio, difícilmente se puede deferir después el ius delationis derivado del mismo, si quiera por vía del derecho de representación ${ }^{779}$, a favor de sus descendientes precisamente porque se ha extinguido por razón de su propio ejercicio, lo que hace de todo punto imposible que le puedan "representar", aunque sea en un sentido impropio, en aquella herencia. Lo que da lugar a que se produzca una delación sucesiva a favor del designado ulterior ${ }^{780}$. No obstante, existe la excepción de la legítima, en la que, de conformidad con lo dispuesto en el artículo

${ }^{776}$ Op. cit: Pág 261.

777 “La sucesión iure transmissionis”. Cit. Pág 27.

${ }^{778}$ Vid, entre otros, en este sentido: ALBALADEJO: "La sucesión iure transmissionis". Cit. Pág 26; “La adquisición de la herencia en el derecho español”. Cit: Págs 8 y 9. GUILARTE ZAPATERO: Op. cit.: Págs 175 y 176.

${ }^{779}$ En contraste a ello, el ius transmissionis se produce y tiene lugar (art. 1006 CC) precisamente porque el ius delationis está intacto, no se ha ejercitado, al haber fallecido el sucesor sin que se haya pronunciado, en uno u otro sentido, sobre la vocación que le ha sido deferida, lo que permite que pase, ope legis, a sus sucesores quienes después tendrán la misma opción que él y podrán, tanto aceptar como repudiar, esa misma herencia a la que fue llamado su ascendiente.

${ }^{780}$ Vid: ROCA SASTRE: “La designación, la vocación y la delación sucesorias”. Cit: Pág 151. 
985.2 CC, se produce una expansión de la legítima individual a favor de los restantes legitimarios ya que "sucederán en ella ...... por su derecho propio y no por derecho de acrecer". No sucede lo mismo en los casos de premoriencia, incapacidad y desheredación donde el sucesor, en ningún caso, no solo no ha ejercitado el ius delationis, sino que no ha podido hacerlo.

Cuando un sucesor decide libre y voluntariamente repudiar aquello a que ha sido llamado, en opinión de la doctrina, es él y no la ley quien desposee a su propia descendencia de esos bienes. Así, en este sentido, se ha dicho que la exclusión de la representación de la estirpe del repudiante se justifica por el hecho de que éste actúa como "jefe de la estirpe quien, al ejercitar su opción hereditaria en sentido negativo, actúa como tal jefe y renuncia para sí y para los suyos" (FUENMAYOR ${ }^{781}$ ). O que, "se ha hecho uso del derecho, y al ejercitarlo el padre, no es la ley, es el mismo padre el que desposee a sus hijos", incluso ni tan siquiera se puede decir, en este caso, que es injusto que los hijos no puedan representar al padre, o que se lastiman derechos adquiridos, o se altera el orden de suceder, porque "se respeta y deja a salvo el derecho que corresponda a los demás parientes, según la línea y grado a que pertenezcan" (MANRESA ${ }^{782}$ ).

En la misma línea de pensamiento, están ALBALADEJO ${ }^{783}$, para quien, "si el llamado repudia la herencia, la pierde para sí y su estirpe, de modo que queda vacante y va a acrecimiento", o DE DIEGO ${ }^{784}$ quien entiende que, en el caso de que el representado haya repudiado la herencia, no se da el derecho de representación, "porque al renunciar ya hizo uso de su derecho y éste no se encuentra vacante para que este título pueda ser de nuevo ejercitado por sus descendientes; estos, en tal caso, y supuesto de que sea sólo el renunciante o que renuncien todos los de su grado, suceden por derecho propio y sin representar al renunciante".

ROCA SASTRE, por su parte, que ha sido uno de los autores que ha mostrado una postura más opuesta a la aplicación del derecho de representación, no ya solo en el caso de repudiación, sino en todo el ámbito de la sucesión testamentaria, entiende que uno de los obstáculos que lo impide es una cuestión de orden institucional en base a la aplicación de la regla "viventis non datur repraesentatio" que, en su opinión, sí tiene sentido en el caso de premoriencia, que es donde la representación tiene todo

\footnotetext{
781 “Estirpe única y representación hereditaria.” Revista de Estudios Jurídicos. 1942. Pág 366, nota 67.

${ }^{782}$ Código Civil español. T 7. Cit. Pág 100.

${ }^{783}$ Comentarios al Código Civil y Compilaciones Forales. T XIII. Vol 2º Cit. Pág 301.

${ }^{784}$ Instituciones de Derecho civil Español. T. III. Derecho de Sucesiones. Cit. Págs 303 y 304.
} 
su significado al ser el supuesto para el que fue concebida, pero no en los de indignidad -al que se puede equiparar el de desheredación-, y repudiación, desde el momento en que se cuenta para estos casos con la fórmula de la "successio graduum et ordinum", o de los llamamientos sucesivos de grado en grado y de orden en orden que la ley hace en la sucesión intestada, y que equipara a, "como si actuaran varios testamentos escalonados o diversas sustituciones en serie". Propugna incluso en una futura reforma del Código Civil en esta materia, mantener aquel principio clásico regulando en toda su amplitud esta regla, dentro de la cual encontrarán cabida los supuestos de indignidad y repudiación hereditaria a los que no debe extenderse, en consecuencia, el derecho de representación y, "en su lugar, lo que ha de hacerse es admitir plenamente la figura de la delación sucesiva, la cual permite atender suficientemente y en forma racional la debida consideración que la estirpe merece" ${ }^{785}$.

Después, partiendo de la argumentación anterior, ROCA SASTRE apunta una diferencia fundamental entre los diferentes supuestos que pueden dar lugar a que entre en juego el ius repraesentationis. Así, en el caso de premoriencia, o comoriencia, al igual que en la ausencia, dado que al tiempo de producirse la apertura de la sucesión, el llamado no llegó a ocupar ningún puesto en la sucesión, no se puede decir propiamente que haya existido una vacante, ni en la vocación, ni en la delación, lo que permitiría, en este caso, la aplicación del ius repraesentationis. De ahí que, en estos supuestos, si el premuerto o el ausente deja hijos, sea la propia ley quien los llame a la sucesión, de modo que la delación ya no tiene lugar a favor del premuerto o del ausente, sino que la primera y directa delación se produce a favor de aquellos, que sería precisamente donde el derecho de representación tiene todo su sentido y alcanza su verdadero significado habida cuenta de que se trata de un llamamiento legal ${ }^{786}$. No sucede lo mismo en el caso de indignidad o desheredación, y sobre todo en el de repudiación, porque, en ellos, no sólo hay un llamamiento a favor de una persona que existe y está viva, sino que como es indigno o desheredado, aunque quiera, no puede suceder, o que, en el caso de repudio, pudiendo, no quiere suceder por propia voluntad. De ahí que, en estos casos, se produzca un doble llamamiento: el primero, a favor de un hijo que vive, pero que por causa de su indignidad o repudiación

785 “Observaciones críticas sobre la tendencia expansionista .......”. Cit: pág 589 y ss.

786 En este sentido, ROCA SASTRE define el derecho de representación en los siguientes términos: se trata de, "un llamamiento directo y propio de la ley, y no de una subrogación, que tienen los hijos de un hijo premuerto al padre causante de ocupar, en la sucesión intestada de éste, en lugar de dicho hijo premuerto, el puesto que éste hubiera ocupado de haber vivido aun al tiempo de la delación y en la misma medida o cuota que le habría correspondido" ("El derecho de representación en la sucesión testada”. Cit. Pág 260 y ss). 
resulta inoperante, lo que da lugar a que se produzca una vacante en la herencia, y el segundo, a favor de sus hijos.

Esta diferencia es lo que da lugar, en opinión de ROCA SASTRE, a que en estos dos supuestos no pueda ser objeto de aplicación por su tecnicismo el ius repraesentationis y tengan que ser tratados a través de otro mecanismo cual es la regla "successio graduum et ordinum". Aunque después reconoce que, "sea por vía de representación, sea por vía de successio, siempre se dará el mismo resultado, pues, en todo caso, se hace entrar a la estirpe cuando el hijo llamado por la ley a la herencia de su padre ha premuerto, resulta indigno o ha repudiado la sucesión".

A nuestro juicio, examinando desde otro punto de vista los supuestos que dan lugar a una vacante en la herencia, se puede observar en ellos la siguiente diferencia que, en nuestra opinión, puede tener relevancia a los efectos de la procedencia del derecho de representación: en los casos de premoriencia o comoriencia, indignidad o incapacidad y desheredación, se trata de casos en los que existe una imposibilidad real, en los dos primeros, y jurídica, en los demás, para poder suceder, aunque, en opinión de VATTIER ${ }^{787}$, tal distinción carezca de trascendencia práctica. Además, se da la circunstancia de que se trata de hechos que son totalmente ajenos a la voluntad del sucesor en el sentido de que él no los ha producido o provocado de forma directa y personal $^{788}$, aunque sí indirectamente o de manera involuntaria haya dado lugar a ellos: en aquellos, a resultas de haber fallecido antes o al mismo tiempo que el causante y, en estos, a resultas de su comportamiento. En cambio, en el caso de la repudiación es él, el sucesor, quien provoca de forma directa y personal, consciente y deliberada, a resultas de su declaración, la vacante en la herencia.

A la vista de esta diferencia, se da la circunstancia de que, cuando se producen aquellos -premoriencia, indignidad o incapacidad y desheredación-, es la propia ley quien, para llamar a la descendencia, recurre el mecanismo de la representación (arts $761,766,814.3^{\circ}, 857$ y $929 \mathrm{CC}$ ). No sucede lo mismo en el caso de la repudiación, donde se puede observar que la ley (arts. 766, 888, 912.3, 923, 929, 981, 982.2 ${ }^{\circ}$ y 986 CC), no hace ese llamamiento a favor de los descendientes del declarante, ni tan siquiera en el caso de la legítima (art. $985.2^{\circ} \mathrm{CC}$ ), de lo que se puede deducir que, ante esta declaración, no permite el juego del ius repraesentationis.

\footnotetext{
${ }^{787}$ El derecho de representación en la sucesión mortis causa. Cit. Pág. 249.

${ }^{788}$ Vid, entre otros, en este sentido: GUILARTE ZAPATERO: Op cit.: Pág 178.
} 
Parece como si, en el caso de aquellos, la ley, moviéndose por un criterio de piedad o de humanidad, tratase de reparar un daño o una injusticia. Así:

a) en el caso de premoriencia o comoriencia, lo sería el hecho de no añadir al daño personal y moral que supone la pérdida de un ascendiente, el padre, la privación de unos bienes, los que forman parte de la herencia del abuelo, que, en el devenir normal de la sucesión mortis causa, hubieran ido a parar a sus manos en el futuro.

b) En los supuestos de indignidad y desheredación del padre, lo que se trata de evitar es hacer a la descendencia también culpable o que sufra las consecuencias de un acto que no ha realizado, de un comportamiento que no ha tenido y que el único autor del mismo es el sucesor, su ascendiente, o no someterla al mismo tratamiento, castigo o sanción que a éste, porque, de lo contrario, equivaldría a considerarla también como indigna o desheredada del causante cuando resulta que, no solo es totalmente inocente, sino ajena a la causa que motivó una u otra ${ }^{789}$. En este sentido, en principio, la razón y el origen del derecho de representación está en que la descendencia ocupe el puesto que le habría correspondido al sucesor que falleció con anterioridad al momento de la defunción del causante, siendo ésta, la premoriencia ${ }^{790}$, el supuesto para el que la representación está concebida en su génesis, y que, en base al principio o regla, "viventis non datur repraesentatio" que preside o informa esta institución, no sea aplicable a los casos de indignidad y desheredación. De ahí que, para evitar el rigor que supone la aplicación de dicha norma y dé lugar a una situación de manifiesta injusticia, "summum ius, summa iniuria", la ley ha creído oportuno hacerla extensible a estos supuestos en base a un criterio de estricta justicia y equiparar el hijo indigno o desheredado con el premuerto (arts. 761, 766, 857, 929 $\mathrm{CC})$, lo que supone una derogación o excepción de aquella regla o principio. MANRESA ${ }^{791}$, en este sentido, a propósito de estos dos supuestos, dice que "la ley presume que el pariente no existe a los efectos de sucesión".

c) En cambio, en el supuesto de repudiación, rige la regla "viventis non datur repraesentatio" y que el sucesor sea consecuente con sus propios actos y sufra los efectos que de dicha declaración se derivan precisamente porque es lo que él, de forma libre y voluntaria, ha querido, lo que sería, por otro lado, de todo punto lógico.

789 Vid a propósito de ello: ROCA SASTRE: “Observaciones críticas sobre la tendencia expansionista .........”. Cit: Pág 594 y ss; MANRESA: Código Civil español. T. 7. Cit. Pág. 98 y ss; GUILARTE ZAPATERO: Op cit.: Pág 185.

${ }^{790}$ Así es como se concibió desde sus orígenes en época anterior incluso a la Ley de las XXII Tablas, denominándose en las fuentes clásicas, “successio in locum”.

${ }^{791}$ Código Civil español. T 7. Cit. Pág 100. 
En este caso, se parte, además, de la circunstancia, a diferencia de los anteriores supuestos, de que el sucesor, no solo existe y está vivo, sino que además ha ejercido el ius delationis derivado de su vocación y que, a resultas de ello, precisamente como consecuencia de su declaración de repudio, se ha producido la vacante en la herencia. Hecho que es, por otro lado, absolutamente inimputable al causante y que él, no sólo no puede, ni prohibir en vida, como tampoco impedir o evitar después, en el momento de su exteriorización, obviamente, al haber ya fallecido. Ahora bien, lo que sí puede hacer es prever esta eventualidad y poner remedio para evitar que los descendientes del repudiante sufran sus consecuencias, para lo cual tendrá que ordenar una cláusula de sustitución llamando a dicha descendencia como sustitutos al objeto de que ocupen la vacante que repudiante ha dejado, lo que no va a hacer la ley porque a ella no le compete ya que, en otro caso, sería establecer una sustitución vulgar ex lege.

En este sentido, al hilo del argumento anterior, y desde otro punto de vista, la función que se quiere que cumpla el derecho de representación en la sucesión testada para cubrir la vacante que en ella se ha producido a resultas de la repudiación lo hace la cláusula de sustitución ordenada por el causante en el testamento. Sin embargo, la inclusión de la misma en él depende exclusivamente de su voluntad al ser un acto libre y voluntario. De ahí que, si el causante no ha hecho uso de esta facultad que le concede la ley y no ha establecido la cláusula previendo esta eventualidad, se puede decir, o entender, que es porque no ha querido hacerlo pudiendo haberlo hecho. Además, tratándose de un testamento abierto, no solo probablemente habrá sido aconsejado por el Notario para que lo haga, incluso advertido por él de las consecuencias que su no inclusión puede traer consigo. De ahí que, lo que no hace la ley, o no puede hacer, es suplir la falta de voluntad del causante, que puede incluso, de manera voluntaria o deliberada, haber establecido la sustitución limitando sus causas (cfr. art. 774 in fine CC), excluyendo de la misma la repudiación para, de alguna manera, "forzar" al sucesor a la aceptación de la herencia ante la "amenaza", o la "sanción", de perder, no solo él, sino también su descendencia, todo lo que se le hubiere deferido por vía de sucesión mortis causa. En este sentido, hace observar ROCA SASTRE ${ }^{792}$, que, "la introducción del derecho de representación en la sucesión testamentaria, equivaldría a establecer una sustitución vulgar ex lege, o sea que la ley presumiría como existente en los testamentos la cláusula de sustitución vulgar. Esto constituiría una oficiosidad legal exagerada, pues tal providencia del legislador no

792 “Observaciones críticas sobre la tendencia expansionista .......”. Cit: Págs 599 y 600. 
encaja en materia testamentaria"793. Si el causante quiere que la posible repudiación de la herencia por parte de alguno de sus sucesores no perjudique también a los descendientes de éstos, incluso sucesores suyos de ulterior grado, entonces lo lógico es que los tenga en cuenta y los llame a su sucesión en lugar del repudiante a través del mecanismo de la sustitución. De ahí que, como apunta ROCA SASTRE ${ }^{794}$, "en los testamentos hay que atender a la voluntad real del testador expresa o tácitamente manifestada. Respecto de lo que en el testamento se guarde silencio absoluto, éste debe ser respetado, y tanto más ha de respetarse cuando la cláusula omitida sea usual, pues entonces tal silencio debe estimarse como clara repulsa de la misma".

En otros términos, abundando en la misma idea, apunta DE LA CÁMARA ${ }^{795}$ que, "sólo a falta de ésta -se refiere a la voluntad del causante-, entran en juego los Ilamamientos legales a la herencia (cfr. art. 659 CC). Interferir un llamamiento legal en la sucesión testamentaria es un contrasentido que la ley (art. 659 CC) no permite, salvo respecto de aquella parte de la herencia de que el testador no haya dispuesto".

Por su parte, DE LA CÁMARA, que es también manifiestamente contrario a la aplicación del derecho de representación en la sucesión testamentaria, siguiendo una línea de pensamiento parecida a la anterior, entiende que la improcedencia de su aplicación "descansa más en su naturaleza que en la exégesis o interpretación que se ha hecho de los artículos del Código Civil" ${ }^{796}$.

No obstante, apunta una solución diferente para que la descendencia no resulte perjudicada por la decisión del repudiante y pueda, pese a ella, entrar en la herencia ${ }^{797}$. Para él, el planteamiento adecuado no estriba en estudiar si el derecho de

${ }^{793}$ La construcción de la sustitución legal es la teoría que goza de una mayor aceptación dentro de la doctrina para explicar o justificar la naturaleza de la representación. Otras teorías han sido: la representación en sentido técnico-jurídico; como ficción legal; como modalidad de subrogación legal; como vocación colectiva, indirecta o “per relationem” (Vid: GUILARTE: Op. cit.: Pág 140 y ss.)

794 “Observaciones críticas sobre la tendencia expansionista .......”. Cit: Pág 601 y ss.

795 Op. cit: Pág 17.

${ }^{796}$ Op. cit: Pág 16 y ss.

A lo que sigue manifestando lo siguiente: "El mal llamado derecho de representación no es otra cosa que el derecho a heredar que adquiere la estirpe de descendientes de un heredero, en ciertos casos, y en virtud de un llamamiento que la ley hace directamente a su favor". "No se trata de que la estirpe suceda en un derecho que previamente fue adquirido por su ascendiente (heredero del causante), sino que lo que ocurre es que la estirpe adquiere directamente su derecho porque la ley se lo concede". "Ahora bien, si esto es así,......., la consecuencia que se sigue de aquellas premisas es que el derecho de representación propiamente dicho no actúa en la sucesión testamentaria porque es imposible que actúe”.

A ello añade el hecho de que, en la sucesión testamentaria, el origen del derecho hereditario es voluntario porque la vocación del sucesor proviene exclusivamente del llamamiento que ha hecho a su favor el causante a través de su testamento y sólo a falta del mismo, entran en juego los llamamientos legales a la herencia.

${ }^{797}$ Op. cit: Pág 20 y ss. 
representación puede aplicarse a la sucesión testada, sino en llegar a las mismas consecuencias prácticas, en tanto en cuanto sea posible, por vía de una adecuada interpretación de la voluntad del testador y pueda establecerse en base a los elementos suministrados por el testamento, en el caso concreto de que se trate, como sería a través de la sustitución vulgar tácita, que es, en definitiva, la idea que inspira el viejo aforismo romano o presunción, "filii apellationes omnes liberos intelligimus" (D, ley 84, título 16, Lib L), recogido por la jurisprudencia ${ }^{798}$, incluso por algún Código Civil actual como es el austriaco ( $\$ 42$ y 763 , que considera hijos todos los consanguíneos en línea recta descendente, sin distinción de grados), y, en cuya virtud, en la palabra hijos van comprendidos los descendientes de primer grado y ulteriores.

Pero aquí, para DE LA CAMARA, "la cuestión que surge es cuando se puede entender que esta sustitución haya de tener lugar porque, una cosa es la interpretación, o aclaración, de términos ambiguos o pocos claros, y otra, es la integración o complemento de una disposición testamentaria con elementos que, de hecho, son ajenos a ella". En su opinión, "esta segunda posibilidad implica el reconocimiento de que el testamento puede presentar algunas lagunas y de que éstas pueden ser llenadas por el intérprete de acuerdo con lo que se estime voluntad presunta del testador"799. Actividad de interpretación que, por otro lado, como él indica, guarda íntima relación con el problema de la llamada prueba extrínseca, es decir, si para fijar la voluntad del testador pueden emplearse datos extratestamentarios, lo que sí pareció admitir la sentencia del Tribunal Supremo de 6 de diciembre de 1952 (RJ 2430), aunque después se dio la circunstancia de que, en el caso concreto que en ella se juzgó, se rechazó la incorporación de la sustitución tácita por insuficiencia de la prueba que, en caso contrario, sí habría sido posible de haber sido concluyente dicha prueba $^{800}$.

\footnotetext{
${ }^{798}$ Entre otras muchas que dan un amplio alcance a dicha regla dejando a salvo únicamente el caso de que se haya hecho exclusión especial de los nietos por el testador, están: SSTS de 11 de marzo de 1861; 23 de abril de 1864; 24 de abril, 28 de septiembre y 14 de octubre de 1867; 31 de diciembre de 1895; 19 de noviembre de 1899; 13 de noviembre de 1903; 14 de febrero de 1914; de 10 de mayo de 1941 y 7 de junio de 1950.

En igual sentido, la jurisprudencia francesa establece que la palabra hijos comprende también los nietos nacidos de un hijo premuerto, salvo voluntad contraria del causante, según indican PLANIOL y RIPERT (Traité pratique de droit civil. T V. París. 1933. n 595. Pág 626), citados por CASTAN ("El derecho de representación y mecanismos jurídicos afines en la sucesión testamentaria”. Cit. Pág 138).

${ }^{799}$ En este sentido, el Código Civil contiene numerosas normas que tienen la función específica de llenar las lagunas del testamento a través de la interpretación de la voluntad presunta del testador (arts. 675, 765, 768, 769, 770, 771, 751, etc).

${ }^{800}$ Finalmente, DE LA CAMARA, después de exponer diferentes casos "en los que, -a su juicio-, y de no resultar nada en contrario del propio testamento, podría funcionar la sustitución tácita o presunta" cuando en él han sido instituidos descendientes o hermanos del testador, manifiesta que, "en la medida en que la voluntad testamentaria coincida con la voluntad de la ley, deben darse a los
} 
Otro de los argumentos invocados por la doctrina ${ }^{801}$ para no admitir la aplicación del derecho de representación en el ámbito de la sucesión testada, aunque no sea un criterio determinante, ha sido su encuadre sistemático en el régimen jurídico de la intestada (art. 924 y ss CC), lo que ha dado lugar a que se entienda como una institución propia y exclusiva de ésta, y que MARTíNEZ CALCERRADA ${ }^{802}$ califica de irregularidad porque, "no hubiera existido si se enjuicia el derecho de representación en las "disposiciones generales" para ambas clases de sucesión, tal y como sucede en el Código Civil italiano de 1942". En igual sentido, la jurisprudencia ${ }^{803}$, así como la DGRN que, en su Resolución de 14 de agosto de 1959 (RJ 3354), además de recordar las razones esgrimidas por el Tribunal Supremo en la sentencia de 6 de diciembre de 1952 (RJ 2430), considera que no es "institucionalmente compatible" el derecho de representación con la sucesión testamentaria, "a la que se ha provisto de otro medio similar, cual es la sustitución". Cierto es que se trataba de un caso de premoriencia del padre instituído y preterición del nieto, lo que negó invocando, además, el artículo 766 CC, sin embargo se trata de supuesto que actualmente se admite por aplicación del artículo 814 párafo $3^{\circ} \mathrm{CC}^{804}$.

No obstante, y pese a la posición mayoritaria que existe en la doctrina de considerar que el derecho de representación no procede en el ámbito de la sucesión testamentaria, salvo en lo concerniente a la legítima en los supuestos de premoriencia, incapacidad y desheredación, ha habido desde hace años, posturas que se han mostrado favorables, con argumentos más o menos convincentes, en darle una mayor

llamamientos testamentarios la misma extensión que la que tienen los llamamientos legales”. A lo que añade, "no se olvide que, en definitiva, tanto la sucesión intestada en general, como el derecho de representación, en particular, tienen su fundamento, al menos en parte, en la presunta voluntad del causante".

Así, a juicio, viene a concluir que, dada la naturaleza del derecho de representación, su emplazamiento lógico es en el seno de la sucesión intestada (Op. cit.: Pág 28).

${ }^{801}$ ROCA SASTRE también niega el derecho de representación en la sucesión testamentaria en base a este argumento al entender que "es cosa exclusiva de la herencia intestada y, por extensión, de la adquisición legitimaria, o sea, de dos tipos de vocación sucesoria de origen o creación legal”, ante lo que invoca distintos argumentos (“El derecho de representación en la sucesión testada”. Cit. Pág 267 y ss). No obstante, señala dos excepciones: la ley de 5 de noviembre de 1940 que se promulgó para salvaguardar los derechos legítimos de los hijos o nietos de aquellos que hubiesen premuerto con ocasión de la guerra civil, y los fideicomisos en Navarra, en base a una ley de las Cortes de Pamplona del año 1580.

En este sentido, a propósito de aquella, DE LA CÁMARA (Op. cit.: Pág 16), pone la objeción de que se propuso "para resolver un supuesto especial y transitorio al margen del problema general de si el derecho de representación juega o no en la sucesión testamentaria”.

802 Op. cit.: Pág 419.

${ }^{803}$ Su postura tradicional ha sido la de entender que el derecho de representación es propio de la sucesión intestada y no tiene lugar en la testamentaria, salvo por lo que respecta a las legítimas (SSTS de 22 de junio de 1931, RJ 2098; 7 de junio de 1950, RJ 1018; 6 de diciembre de 1952, RJ 2430; 18 de diciembre de 1962, RJ 4897; 5 de julio de 1966, RJ 3671; 27 de noviembre de 1992, RJ 9597.

804 Vid GONZÁLEZ PACANOWSKA: Comentario al artículo 929 del Código Civil, en Jurisprudencia civil comentada (Tomo I). Dirección: Pasquau Liaño. Ed. COMARES. Granada. 2000. Pág 1623. 
amplitud en su aplicación y dar cobijo dentro de los supuestos que dan lugar al mismo, al caso de repudiación, al tiempo que han propugnado una reforma legislativa en este sentido, necesaria e inevitable, por otro lado, para que ello pueda tener lugar.

Tal es la opinión de NOVOA SEOANE ${ }^{805}$ quien, ya a principios del siglo pasado, defendió la aplicación del derecho de representación, entre otros argumentos, en base a la dicción del artículo 925 CC, que "determina que aquel tendrá siempre lugar en la línea recta descendente, y esta palabra siempre no puede referirse, por deducciones, sólo a la sucesión legítima".

CASTÁN ${ }^{806}$, por su parte, critica la imperfección de cómo el Código Civil regula el derecho de representación, al que califica de anticuado en este punto, así como las dudas y problemas que plantea en su aplicación en diferentes supuestos, al tiempo que defiende su aplicación en la sucesión testamentaria entendiendo que su exclusión, no solo contrasta con el derecho comparado, sino que es incongruente y falta de sistema con el previsto en los artículos 761, 807 y 857, relativos a la indignidad, premoriencia, y desheredación de la legítima. De ahí que proponga una revisión general y sistemática del Código Civil, reelaborar toda esta materia, ya sea conservando esta denominación, ya sea adoptando alguna otra menos equívoca ${ }^{807}$.

En lo que se refiere al supuesto de la repudiación, propone la extensión a ésta de la representación como ya sucede en otros Códigos Civiles extranjeros (artículos $1609^{808}$ y $1632^{809}$ del Código de México de 1928, o el artículo 467 del Codice Civile), y a la sucesión testamentaria, si bien, dentro de unos límites prudentes. Ahora bien, hasta que llegue la reforma deseada, "podrían atenderse en gran parte las exigencias de la equidad, simplemente prescindiendo de todo criterio restrictivo en la aplicación del derecho de representación y dando una cierta holgura a la teoría de la interpretación de las disposiciones de última voluntad, para salvaguardar aquellos casos en que el propio testador dio entrada a dicho derecho en el ordenamiento de su sucesión". 144.

805 “El derecho de representación según el Código Civil. Antinomias aparentes”. RDP. 1914. Pág

806 “El derecho de representación y mecanismos jurídicos ........”. Cit. Pág 167 y ss.

${ }^{807}$ En este punto se remite, en cita a pie de página, a los términos de sustitución que propugnan algunos autores, o al de sucesión por estirpes que emplea el Código Mexicano de 1928.

808 Según su tenor: "Si quedaren hijos y descendientes de ulterior grado, los primeros heredaran por cabeza y los segundos por estirpes. Lo mismo se observara tratándose de descendientes de hijos premuertos, incapaces de heredar o que hubieren renunciado la herencia.”.

809 Según su tenor: "Si concurren hermanos con sobrinos, hijos de hermanos o de medios hermanos premuertos, que sean incapaces de heredar o que hayan renunciado la herencia, los primeros heredaran por cabezas y los segundos por estirpes, teniendo en cuenta lo dispuesto en el articulo anterior". 
No obstante, señala que, el derecho de representación puede entrar en la sucesión testamentaria por propia voluntad del testador ${ }^{810}$, porque, como observa MAURA, citado por él, "es institución jurídica que atañe natural y ordinariamente a las sucesiones intestadas; pero interviene también con no poca frecuencia en las testamentarias cuando quiera que, de modo expreso o de modo virtual, dan lugar a ello las disposiciones del causante" ${ }^{\prime 811}$.

GIMENEZ ARNAU ${ }^{812}$, más pragmático, rechaza la posición doctrinal contraria a dicha aplicación al entender que ésta no se acomoda a la práctica jurídica. "Cuando en un testamento no se hizo constar el derecho de sustitución (o de representación, como impropiamente se dice algunas veces) al verificarse las operaciones particionales, se afirma por la comunidad de herederos y por el fedatario autorizante de la partición, que los sucesores forzosos del heredero premuerto, cuando éste tenía la condición de legítimo, suceden por derecho de representación". Afirmación que, en su opinión, nunca ha sido objeto de controversia ni ha sido nunca obstáculo para una calificación del Registrador favorable a la inscripción de los derechos contenidos en el título particional. De ahí que se muestre favorable a admitir, al menos en el terreno del derecho constituyente, de una manera total el derecho de representación, si bien, lo refiere sólo a los casos de premoriencia, incapacidad y desheredación, mas no al de repudiación, sobre el que no se pronuncia.

MARTÍNEZ CALCERRADA, por su parte, es uno de los principales defensores de introducir el derecho de representación en el ámbito de la sucesión en el caso de repudio $^{813}$ y las razones que esgrime para ello se basa, entre otras, en las siguientes:

a) motivos de concordancia técnico-positiva, no en el sentido, como él indica, de que "el texto positivo esté desacorde, dentro de su propio articulado, con la regulación que hace del supuesto de la renuncia hereditaria a efectos representativos", que es perfectamente coherente, sino que, "como la configuración de las legítimas en el Código Civil, entre descendientes, responde a su precisa idea de que tienen una marcadísima relevancia imperativa que se impone a los mismos interesados, y la consecución de que sean una realidad tangible está perfectamente garantizada ante determinadas contingencias que pudieran impedirlo, al fallar dicho sistema en el caso de renuncia, implica una falta de concordancia técnico-positiva", cuya material

810 “El derecho de representación y mecanismos jurídicos ........". Cit. Págs 147y 148.

811 Dictámenes, seleccionados y clasificados por M. MAURA GAMAZO y J. ROMERO VALENZUELA. T III. Madrid. 1930. Dictamen nº 16, pág 476.

812 "El derecho de representación en la sucesión voluntaria”. RCDI. 1940. Pág 20 y ss.

${ }^{813}$ Op. cit.: Pág 427 y ss. 
probanza o gráfica demostración se ratifica por la inviolabilidad e indisponibilidad de las legítimas y su protección en el caso de desheredación e incapacidad. Y, al ser el único supuesto en que el Código carece de un procedimiento protector del caudal legitimario y pase éste a la estirpe, estamos ante lo que él denomina "una auténtica excepción de abandono de la estirpe en caso de renuncia", lo que "no debe interferir la superlegalidad del instituto de las legítimas", y cuyo antídoto será "la racional aplicación del instituto al supuesto de renuncia del heredero".

b) Invoca también Códigos Civiles latinoaméricanos ${ }^{814}$ favorables a la tesis de aplicar la representación en el caso de renuncia, así como una interpretación progresista o abierta de la Base Primera de la Ley de Bases de 1888.

c) Razones o motivos de justicia o humanidad para evitar el desamparo de la descendencia ante una decisión que puede incluso haber sido adoptada por el sucesor de forma precipitada, o porque circunstancias familiares de enemistad, enfrentamiento o rechazo ante el ascendiente son las que han propiciado dicha declaración, o para provocar deforma deliberada un perjuicio.

d) Motivos técnico-jurídicos que llevan a la frustración y perjuicio de la legítima futura de la estirpe porque, "la declaración de repudio lo que hace es producir su postergación actual y la no incorporación de los bienes repudiados al acervo patrimonial de la familia, lo que repercute desfavorablemente en la cuota legitimaria que, en su día, corresponda a los miembros de la estirpe en la herencia de su padre".

Más modernamente, VATTIER ${ }^{815}$, siguiendo la tendencia expansionista del derecho de representación que se observa en los distintos ordenamientos de nuestro entorno y conforme la tesis, entre otros, de MARTíNEZ CALCERRADA, se muestra también favorable a admitir la representación en el caso de repudio a favor de los descendientes del llamado que repudia, lo que fundamenta en el hecho de que, "la suerte de los descendientes es insensible ante la conducta del llamado que falta y la actitud del causante, cuyos resultados no se comunican consiguientemente a las

814 Op. cit.: Pág 433.

815 “El derecho de representación”. En Derecho de Sucesiones. Presente y futuro. Pág 543 y ss.

Incluso propugna que, "el derecho de representación no se puede encuadrar entre las normas de la sucesión intestada, sino que ha de desplazarse a la parte general, junto a las demás disposiciones aplicables a todas las sucesiones". Por otro lado, ya como cuestión de fondo, entiende que, "la expansión de la representación ha desvirtuado la figura típica del derecho de representación, tal y como la conocemos con arreglo al CC, y la ha transformado en una sustitución vulgar predispuesta por la ley a favor de descendientes en todos los casos en que falte un hijo o un hermano llamados a suceder, cualquiera que sea su ámbito de actuación". Aunque después, afirma que, "parece preferible mantener la denominación habitual del derecho de representación, simplemente por respecto a la tradición y al uso”. 
estirpes de los indignos, desheredados, excluidos y repudiantes, las cuales pueden representarles, a pesar de ello, en la sucesión del causante. Tales conductas solo afectan a la primera generación, la que ha convivido con el causante, pero no se proyectan sobre sus descendientes. De aquí que se abandone la regla viventis non datur repraesentationis y que se aparte a los representados vivos de la sucesión, no solo para aceptar o repudiar, sino también de la posesión, conservación, administración y partición de los bienes hereditarios", que después justifica en base a varias razones.

En igual sentido se pronuncia DELGADO ECHEVERRÍA ${ }^{816}$, quien tambien se muestra favorable a extender la aplicación del derecho de representación a la sucesión voluntaria al proponerlo como una de las conclusiones (la número 16) que se pueden plantear en una futura reforma del Derecho de Sucesiones a raiz de la encuesta ${ }^{817}$ que realizó al amparo de la Ponencia sobre, "Una propuesta de política del Derecho en materia de sucesiones por causa de muerte", presentada en la reunión de la Asociación de Profesores de Derecho Civil celebrada en el año 2006.

Dejando ya el panorama de las diferentes posturas adoptadas por la doctrina, ciertamente, todos sus intentos y esfuerzos por defender o justificar la "legalización", o "tipificación", de la representación, o llamamiento, de los descendientes del repudiante al objeto de terminar con esta diferencia de tratamiento que el Código Civil tiene sobre la misma respecto de otros supuestos (premoriencia, incapacidad o indignidad y desheredación), y proteger así sus derechos para que no resulte perjudicada por la decisión del sucesor, resultan, a nuestro juicio, en estos momentos, estériles porque, en lo que no se produzca una reforma del régimen legal actualmente en vigor, toda tentativa va a chocar siempre con el tenor, expreso o tácito, del articulado, absurdo, incoherente e injusto, por otro lado, del Código Civil.

A la vista del régimen vigente, se pueden esgrimir muchas y muy variadas razones o motivos desde diferentes puntos de vista, de equidad, justicia, humanidad, técnicos, jurídicos, lógicos, sistemáticos, históricos, de protección de intereses, de evitar una lesión o perjuicio, de derecho comparado, etc, para defender la tesis de que, los descendientes de quien repudia deberían de ser llamados directamente por la

${ }^{816}$ Derecho de Sucesiones. Presente y futuro. Cit. Pág 170.

${ }^{817}$ En ella se observa un amplio consenso a favor de la generalización del derecho de representación en la sucesión voluntaria (pregunta 27) que, además, cuando se trata de los casos de premoriencia, indignidad y desheredación, no debe de limitarse sólo a la legítima (pregunta 29), sino que comprenda toda la cuota del representado, si bien, se muestra más bien indecisa, en lo que concierne a su aplicación al caso de repudio (pregunta 28: 22 votos negativos frente a 18 afirmativos) (Derecho de Sucesiones. Presente y futuro. Cit. Págs 159, 160 y 167). 
propia ley, a falta de previsión testamentaria y antes que los demás cosucesores, a la herencia del causante y adquirir, si no todo aquello que al repudiante le hubiese correspondido caso de haber aceptado, sí, al menos, sus derechos legitimarios, al igual y por el mismo mecanismo que ocurre en los casos de premoriencia, incapacidad, desheredación, y que, además, previsiblemente, en el devenir normal de las transmisiones mortis causa, caso de haber aceptado el sucesor, en el futuro, al heredar a éste, hubiese sido suyo. Igual para el caso de la sucesión abintestato.

Por otro lado, desde el punto de vista legal, es cierto, como hemos visto, que, al amparo de las disposiciones que hemos comentado, es de todo punto imposible la aplicación del derecho de representación a favor de la descendencia de quien ha repudiado, tanto en la sucesión testada como intestada. Pero, no es menos cierto que se observa una diferencia de tratamiento, más bien, una discriminación, de todo punto criticable, de la repudiación respecto a otros supuestos como ya se ha puesto de relieve a lo largo de cuanto antecede, cuando no una incoherencia o un contrasentido, como se observa en las siguientes consideraciones:

a) la ley, podríamos decir que, en coherencia con el orden de llamamiento que hace a los herederos forzosos (art. 807 CC), llama a la sucesión del causante a sus nietos y demás descendientes en el caso de premoriencia del padre, o viviendo éste, en los de desheredación o incapacidad (arts. 761, 814.3ㅜ, 857, 929 CC), a diferencia de lo que ocurre en el supuesto de que hubiere repudiado la herencia (arts 766, 923, 929 y 981 CC), ni tan siquiera cuando el objeto del repudio hubiere sido la legítima (art. $985.2^{\circ} \mathrm{CC}$ ). Lo que en nuestra opinión es una incongruencia.

b) La función que se quiere que cumpla el derecho de representación en la sucesión testada lo hace la sustitución ordenada, en su caso, por el causante en su testamento y que, establecer aquella por ley, supone introducir una sustitución vulgar ex lege que no existe en la sucesión y, por ello, suplir la voluntad del causante. Pero, el derecho de acrecer, según ya hemos comentado en otro momento, no deja de ser, de alguna manera, una forma de "sustitución recíproca" entre los cosucesores que se produce ex lege, si bien, está basada en la presunta voluntad del causante, dada la forma como ha ordenado la institución entre sus sucesores.

c) Cierto es que por la repudiación se ejercita en sentido negativo, al tiempo que se extingue, el ius delationis para el declarante. Pero no por ello tiene por qué desaparecer para los descendientes de ulterior grado la posibilidad de su ejercicio a través de la renovación de la vocación-delación porque, de la misma manera que 
dicha renovación se produce para los sustitutos voluntarios por el causante en el caso de repudio por expreso deseo suyo, de igual manera tendría que ocurrir para ellos, en este mismo supuesto, a través de una sustitución legal como es el derecho de representación, lo que no deja de ser una paradoja. En aquel, tanto el llamamiento como la renovación de la vocación-delación, tendría un origen voluntario, mientras que en éste, sería legal.

d) Otra incoherencia es el hecho de que, para el causante, el sistema de legítimas tiene un carácter indisponible, inderogable e imperativo (art. 806 y ss CC), y que, al margen de la facultad de mejorar, sólo puede modificar o dejar sin efecto a través de la desheredación (art. 848 y ss CC). Aun en este caso, se sigue cumpliendo el orden de llamamiento legal establecido porque la descendencia del desheredado no pierde su derecho a la legítima al ser llamada a ella directamente por ley (arts. 857 y 929 CC).

Frente a ello, el sucesor, en cambio, sabedor de que, si él repudia la herencia a que ha sido llamado, su descendencia, aun siendo heredera forzosa en potencia del causante, es excluida en este caso por la ley para sucederle (art. $985.2^{\circ} \mathrm{CC}$ ), puede modificar dicho sistema y orden de llamamiento truncándolo y dejarlo sin efecto a través de la repudiación, a diferencia de lo que sucede en los casos de premoriencia e indignidad o incapacidad. Lo que no deja de ser, por otro lado, un instrumento en manos del sucesor para modificar y trastocar, incluso de forma arbitraria y caprichosa, a su libre albedrío, el destino mortis causa que, según la ley, ha de tener la herencia entre los herederos forzosos.

De ahí que, a la vista de los graves perjuicios, en muy diferentes órdenes, personal, económico o patrimonial, moral, etc, que ocasiona a los descendientes del repudiante el hecho de no haber sido llamados por el causante a la porción o cuota repudiada a través de una cáusula de sustitución, así como para evitar hacerles ser sufridores de un castigo o sanción que ni merecen, ni han provocado por cuanto no han dado lugar a ello, o de las secuelas que de ello se derivan, lo conveniente sería reformar el Código Civil en este punto y, al igual que ya contemplan otros Códigos Civiles de nuestro entorno, y extender o aplicar, a falta o por insuficiencia de la cláusula de sustitución, sea por omisión, o por falta de previsión por parte del causante, la representación a favor de los descendientes del sucesor en el caso de que éste repudiare la herencia para evitar así las consecuencias tan perjudiciales que para ellos se deriva de la declaración de repudio. La ley, de esta manera, pondría remedio a ello y conseguiría evitar dicho perjuicio del que no son merecedores porque, 
como ya hemos apuntado, puede incluso suceder que la decisión de su ascendiente haya sido tomada, sí de forma libre y voluntaria, pero mediatizada o provocada por circunstancias como pueden ser la animadversión, enemistad o enfrentamiento con el causante, reproche o desprecio hacia él, o el mismo intento deliberado y consciente de perjudicar a la propia descendencia. No tiene sentido hacer recaer sobre ellos la misma consecuencia que el repudio tiene para quien lo hace cuando ellos, además, no son los autores materiales del acto. Para el declarante no es un castigo, ni una sanción, y sí la consecuencia que se deriva de su propia decisión de la cual, él, es el único autor. En cambio, para su descendencia, sí que actúa como una sanción porque se ven privados, de forma involuntaria y por causas ajenas a su voluntad, de unos bienes que ellos, de haber tenido la oportunidad de hacerlo, seguramente habrían aceptado, aparte de que, si su ascendiente hubiese aceptado, el día de mañana, a través de su sucesión, habrían adquirido en el futuro. 


\section{Capítulo 8: EFECTOS DE LA REPUDIACIÓN (II): EN RELACIÓN A LO QUE SE REPUDIA Y SU DESTINO POSTERIOR.}

1.- Introducción. 2.- En el ámbito de la sucesión testada. 3.- En el ámbito de la sucesión abintestato. 4.- El destino de los bienes en casos especiales. 4-1.- En el caso de los legados. 4-2.- En el caso de la legítima. 4-2-1.- Si se hubiere atribuido por acto de disposición mortis causa. 4-2-2.- Si se hubiere atribuido por acto de disposición inter vivos. 4-3.- En el caso de la mejora. 4-4.- En el caso de bienes reservables. 4-4-1.Repudiación y renuncia de los bienes reservables. 4-4-2.- Ámbito de la repudiación. 4-5.En el caso de bienes fideicomitidos.

\section{1.- INTRODUCCIÓN.}

Desde el momento en que se emite la declaración de repudio, se produce, no solo la vacante en la porción, cuota o bienes a que se refiere y subsiguiente frustración de la previsión que inicialmente existía al abrirse el proceso sucesorio, sino que, al mismo tiempo, se van a poner en marcha los diferentes mecanismos o instituciones que la ley contempla para proveer acerca de su destino mortis causa al objeto de determinar el nuevo destinatario y proceder a su vocación y subsiguiente delación, para que se pronuncie acerca de la oferta hereditaria que ha recibido.

En este sentido, la determinación del nuevo sucesor dependerá de la institución que, en su caso, sea objeto de aplicación, lo que estará en función de la sucesión de que se trate, si testada o intestada, así como de las circunstancias que existan en ella, lo que puede dar lugar: 
a) a la incorporación de nuevos sucesores a la herencia algunos de los cuales ya pueden estar llamados a ella, bien de forma eventual, en el momento de abrirse el proceso sucesorio -serían supuestos de vocación sin delación-, caso de los sustitutos, bien de forma subsidiaria o supletoria, caso de los sucesores abintestato,

b) al Ilamamiento, no de nuevos sucesores, sino de los que ya lo son, aquellos que han sido llamados junto con el repudiante y cuya respectiva cuota va a absorber la que ha quedado vacante a través del derecho de acrecer.

\section{2.- EN EL ÁMBITO DE LA SUCESIÓN TESTADA.}

El condicionante principal y fundamental de cual va a ser el destino mortis causa de aquello que ha sido objeto de repudio cuando la herencia se defiere existiendo testamento en la sucesión, así como la individualización o determinación del nuevo destinatario, lo constituye la voluntad del causante por cuanto, al ser ésta, ley en la sucesión, habrá que estar, ante todo, a lo que él, en su caso, hubiere previsto para el supuesto de que se produjere alguna vacante por dicho motivo, y que lo será a través de una sustitución vulgar. En este caso, siendo la repudiación el hecho que motivare el llamamiento del sustituto, éste será el nuevo sucesor destinatario de aquello que fue objeto de repudio y quien tendrá ante sí la opción de aceptar o de repudiar.

En su defecto, a falta de sustituto, será la ley quien, en su condición o carácter de supletoria, establezca el destino mortis causa, primero, a través de la aplicación, en su caso, si se dieren los requisitos exigidos para ello (art. 981 y ss CC), del derecho de acrecer a favor de los demás cosucesores ${ }^{818}$, y, en último término, si no hubiere lugar

${ }^{818}$ Ante la colisión entre la sustitución vulgar ordenada por el causante y el derecho de acrecer, prevalecería aquella sobre éste pues tal previsión indica, o puede indicar, precisamente una voluntad contraria al mismo por parte del causante (Res DGRN de 6 de junio de 1929 y 26 de diciembre de 1942, RJ 1511), que puede incluso haber sido ordenada para evitarlo, o que sea deseo del causante que la parte repudiada sea antes para el sustituto, normalmente, descendientes del sustituido, incluso del propio causante, que para los demás cosucesores. Cuando el causante establece una cláusula de sustitución en el testamento manifiesta no solo el deseo de llamar a la estirpe del primer instituido en defecto de él, sino también la voluntad de que la herencia siga el destino que hubiese tenido en el caso de haber sido aceptada y que los bienes hagan tránsito a los descendientes de ulterior grado, incluso impedir que le sucedan en esos bienes, porción o cuota de herencia los demás sucesores a quienes él ya llamó a otros bienes, porción o cuota diferente.

En este sentido, el derecho de acrecer no deja de ser, de alguna manera, una forma de "sustitución recíproca", presunta y no expresa, por parte del causante, dada la forma como ha hecho la vocación entre sí de los collamados a la misma porción o cuota por parte del causante con la finalidad de que no se produzca en ella ninguna vacante y sean ellos quienes la cubran. Precisamente, si se hace así el llamamiento, de forma conjunta, sin asignación de porciones o cuotas, es porque su voluntad es que, lo que se les ha dejado, sea para ellos y solo para ellos, y no para otro u otros, porque sino habría ordenado la sustitución. Que ese todo sea para todos y solo para ellos. De ahí que la sustitución prevalezca sobre el derecho de acrecer en el caso de que se produzca una colisión o coincidencia entre las dos instituciones. 
a éste, a favor de quienes fueren sucesores del causante a través de la apertura de la sucesión abintestato (arts 658, 986 y $\left.912.3^{\circ} \mathrm{CC}\right)^{819}$.

\section{3.- EN EL ÁMBITO DE LA SUCESIÓN ABINTESTATO.}

Cuando en una sucesión mortis causa, deferida abintestato, se produce la repudiación de alguna porción o cuota de la misma por parte de alguno de los sucesores llamados a la misma, dado que aquí la vocación se hace por la ley de forma solidaria, conjunta, a favor de todos los sucesores del causante, sin que exista entre ellos una especial designación de partes o de cuotas de los bienes que forman parte de la herencia, de tal manera que todos son llamados al todo y después se hará de ese todo tantas porciones o cuotas como herederos sucedan al causante, es lo que da lugar, en consecuencia y coherencia con ello, a que el instrumento o institución de que se sirve la ley para cubrir la vacante que se hubiere producido, es el acrecimiento (arts 922, 923 y 981 CC), que, como ahora veremos, presenta algunas peculiaridades respecto del que tiene lugar en la sucesión testada. $\mathrm{Y}$ el otro es el derecho de representación (art. 924 y ss CC), si bien, solo está limitado a los casos de desheredación e incapacidad, no así al de repudiación (art. 929 CC).

El derecho de acrecer aplicado en el ámbito de la sucesión intestada, plantea dos cuestiones: la primera, viene referida a los supuestos en que tiene lugar y, la segunda, a cómo se produce el acrecimiento entre los cosucesores ${ }^{820}$.

${ }^{819}$ La vocación que se produce a través de la delación intestada, puede ser a favor de:

a) nuevos sucesores que se incorporan por primera vez al proceso sucesorio porque se trate de personas que, al abrirse la sucesión, no tenían la condición de sucesor testamentario del causante,

b) quienes ya lo eran pero que ahora vuelven a ser llamados de nuevo porque así les corresponde por su relación de parentesco con él (art. 930 y ss CC).

Tanto en unos como en otros, su llamamiento y subsiguiente delación, sólo vendrá referida, lógicamente, a aquello que se repudió pero, con la peculiaridad de que, en el caso de los segundos, se puede dar la circunstancia de que entre ellos se encuentre aquel sucesor cuya repudiación ha dado lugar precisamente a la apertura de la sucesión intestada porque así le corresponda por ley. En este caso, su vocación ya no podrá tener lugar por aplicación de lo dispuesto en el párrafo primero del artículo 1009 CC. En este sentido, nos remitimos a cuanto exponemos en el capítulo quinto donde se hace un examen más detenido del mismo y de la diferente casuística que se puede producir a propósito de la repudiación en el caso de coexistencia de la sucesión testada e intestada.

${ }^{820}$ Se ha planteado por la doctrina, expone VATTIER (Comentario al artículo 922 del Código Civil, en Comentario del Código Civil. Ministerio de Justicia. Secretaría General de Publicaciones. Madrid. 1993. Pág 2227 y ss), la discusión de, si se trata de la expansión automática de las cuotas correspondientes a los llamados del mismo grado por consecuencia de la regla general de proximidad ex art. 921, o si hay aquí, más bien, por el contrario, un auténtico derecho de acrecer que se rige, con las matizaciones del caso, por los artículos 981 y ss. Si bien, él mismo manifiesta que la cuestión carece de trascendencia práctica, dado que ambas posturas convergen en que el incremento es forzoso, casi concuerdan, por tanto, en el régimen jurídico del acrecimiento. 
En lo que se refiere a la primera, dispone el artículo 981 CC que, "en las sucesiones legítimas la parte del que repudia la herencia acrecerá siempre a los coherederos", que no deja de ser una reiteración de lo dispuesto en el artículo 922 CC. No obstante, de su tenor, se pueden hacer dos lecturas, o sacar dos conclusiones:

$1^{\mathrm{a}}$.- cuando se produce la repudiación de una cuota o porción de la herencia en la sucesión abintestato, siempre, en todo caso, tendrá lugar el derecho de acrecer de misma a favor de los demás sucesores, lo que da a entender que, sólo a través del mismo es como se determinará el destino mortis causa de aquello que se repudió, y

$2^{\mathrm{a}}$.- sólo alude a la repudiación para que tenga lugar el acrecimiento porque, si lo comparamos con el artículo $982.2^{\circ} \mathrm{CC}$, relativo a los supuestos en que éste procede en la sucesión testada, además del repudio, vemos cómo también tiene lugar en los de premoriencia e incapacidad del sucesor al causante ${ }^{821}$.

${ }^{821}$ Ante ello, surge la cuestión o el interrogante de qué ocurre cuando se producen estos dos supuestos, premoriencia e incapacidad, en la sucesión abintestato, ¿no ha lugar en ellos al acrecimiento?.

Esta diferencia de regulación ha dado lugar a una amplia polémica en la doctrina en orden a tratar, sino de justificar, sí de explicar, el por qué de esta distinta casuística.

En este sentido, expone GUILARTE ZAPATERO (Op. cit.: pág 112.) en comentario a la ausencia de la premoriencia en el artículo 922 que, "estima la doctrina dominante que la razón de no dar lugar a derecho de acrecer en la sucesión intestada y sí en la testada, radica en que, en aquella, al no existir un llamamiento previo a la muerte del causante, sino que aquel coincide con ésta, el fallecimiento anterior al de éste de alguno de los parientes que, de haber sobrevivido, hubiera sido tenido en cuenta por la ley al formular la delación, atendiendo al grado de parentesco, no origina porción hereditaria vacante, presupuesto fundamental del ius adcrescendi". Mientras que, en relación a la incapacidad, se debe a un olvido, según SCAEVOLA (Código Civil. Comentado y concordado. Tomo XVII. Cit: pág 332 y ss.), citado por GUILARTE.

Por otro lado, se da la circunstancia de que, ya con anterioridad, el artículo 922 CC, dado que está ubicado, desde el punto de vista sistemático, dentro de la sucesión intestada, habrá que entender que, en ésta, se produce el acrecimiento entre los otros parientes del mismo grado cuando alguno de ellos "no pudiere suceder", lo que se ha de entender referido tanto a la premoriencia como a la incapacidad, "salvo el derecho de representación cuando deba tener lugar”. Excepción que es de todo punto lógica, incluso loable, porque, como ya hemos comentado más arriba, de no ser así, se sancionaría a los descendientes del premuerto o del incapaz. De esta manera, los descendientes de ulterior grado, como serían los nietos del causante, no resultarían perjudicados y podrían suceder a su abuelo en defecto o por incapacidad para poder suceder de su ascendiente inmediato, el padre (Vid, en este sentido: ALBALADEJO: Comentarios al Código Civil y Compilaciones Forales. T XIII. Vol 2º Cit. Pág 301). Al dolor físico de su pérdida, en el caso de premoriencia, no se une el daño patrimonial de no poder adquirir los bienes provenientes de la herencia del abuelo que, en el devenir normal de tradición mortis causa, en el futuro, posiblemente, ellos habrían heredado de su padre.

En coherencia con ello, después, este sentido, el artículo 933 CC excluye el acrecimiento y aplica el derecho de representación, en la herencia de los abuelos, a favor de los nietos y demás descendientes cuando hubiere premuerto el padre. Y después, el artículo 929 CC, de igual manera, entiende que ha lugar al derecho de representación en el caso de incapacidad, con lo que excluye el acrecimiento.

Así, en la sucesión intestada, en el caso de premoriencia del sucesor al causante o de su incapacidad para poderle suceder, no da lugar al acrecimiento de la porción o cuota que le hubiese correspondido a favor de los demás cosucesores si procede, en su caso, el derecho de representación a favor de los descendientes de ulterior grado (arts. 922, 923 y 929 CC). 
$\mathrm{Y}$, acerca de la segunda, el acrecimiento entre los cosucesores, a diferencia de lo que ocurre en la sucesión testada en la que es preciso que concurran una serie de requisitos para que tenga lugar (art. 982 y ss CC), en la intestada, dada la forma como hace la ley el llamamiento, cuando se produce alguna vacante en cualquiera de las cuotas de la herencia, tiene lugar de forma automática, ope legis, una expansión de la misma a favor de la de cada uno de los demás cosucesores, de tal manera que éstos están obligados, incluso contra su voluntad, a soportar el aumento que como consecuencia de ello sufra su propia cuota, como tampoco se pueden oponer a ello, ni impedirlo. Ni tan siquiera pueden elegir, porque no pueden aceptar la cuota propia y repudiar la vacante, sí en la sucesión testada, donde el acrecimiento tiene un carácter voluntario y el sucesor puede aceptar la cuota propia y repudiar la parte acrecida al funcionar una y otra cuota de forma independiente. De ahí que el acrecimiento, aquí, en la sucesión abintestato tenga un carácter forzoso u obligatorio entre los sucesores, lo que se justifica por la forma de cómo se produce el llamamiento.

Se produce así una expansión natural de la cuota de cada uno de los demás sucesores, cuotas que absorben, por razón de la propia fuerza que la ley concede a la vocación sucesoria abintestato, la que ha quedado vacante. Esa expansión se produce de forma automática y forzosa por aplicación también del sistema "sucessio graduum et ordinum" a favor de los sucesores de igual grado y orden que el repudiante, antes de pasar a los del grado y orden siguiente, de tal manera que, primeramente, son llamadas las otras personas que fueren del mismo grado que el repudiante, si las hubiere, en cuyo caso, la cuota repudiada aumenta, se expande, o acrece, a la de cada una de ellas. Pero, si fuere el único sucesor, o si se diere la circunstancia de que repudiaren todos los del mismo grado, nace una nueva delación a favor de los sucesores del grado u orden siguiente (arts. 922, 923 y 981 CC), según a quien corresponda en virtud de las normas del Código Civil (art. 930 y ss).

En este sentido, una de las cuestiones que aquí se ha planteado la doctrina ${ }^{822}$ es, si dicha expansión es un efecto del derecho de acrecer en la sucesión intestada, o si es resultado de la aplicación del principio sucessio graduum et ordinum.

${ }^{822}$ Así lo recoge GALVÁN GALLEGOS (“El destino de la herencia repudiada”. Cit: Pág 918 y ss.), citando a PUIG BRUTAU, DÍEZ-PICAZO, O’CALLAGHAN y, LACRUZ y SANCHO.

No obstante, en su opinión, dado que el resultado es idéntico, entiende que hay que relativizar la cuestión, aunque "no parece desacertado hablar de acrecimiento en la sucesión intestada, partiendo de que el llamamiento que la ley hace a la pluralidad de sujetos que coinciden en grado de parentesco preferente, es un llamamiento conjunto que da lugar a la denominada delación solidaria, basada no en la voluntad del testador, sino en el criterio que la ley establece para esa sucesión de la necesidad de agotar cada orden y cada grupo de herederos antes de pasar al siguiente". 
En nuestra opinión, la expansión de la cuota que ha quedado vacante a favor de los demás cosucesores se produce en virtud de acrecimiento, en coherencia, o consonancia, con la forma de cómo tiene lugar su llamamiento por la ley a la herencia, de forma conjunta y sin especial designación entre ellos de partes o de cuotas, de tal manera que todos son llamados al todo, sin perjuicio de que, después, la división en partes o cuotas del total del acervo hereditario variará y será diferente en cada sucesión en función del número de sucesores que, en su caso, haya -división por cabezas-. Ahora bien, ese acrecimiento, dada también, o al mismo tiempo, la forma de cómo hace la ley el llamamiento de los cosucesores, por grado y por órdenes de parentesco (art. 913 y, 930 y ss CC), no se expande de cualquier forma, sino que sigue un orden, un camino, una preferencia, de ahí que se expanda en función de, o se produzca, una sucessio graduum et ordinum.

Y decimos que, a nuestro juicio, esa expansión de la cuota vacante a favor de los demás cosucesores se produce, principal y fundamentalmente, por razón del derecho de acrecer, aunque medie una razón de parentesco con el causante, porque, ante todo, prevalece la forma de cómo se hace el llamamiento por parte de la ley a los parientes del causante: en virtud de una delación solidaria -de forma conjunta y sin especial designación de partes o de cuotas-. La expansión se produce, no en atención o en consideración a los cosucesores, o su relación con el causante, sino por la forma de cómo se produce su vocación sucesoria. Igual que sucede en la sucesión testada (art. 982 y ss CC), donde puede incluso ocurrir que los cosucesores no tengan una relación de parentesco con el causante, sin perjuicio de que ese acrecimiento tenga un carácter voluntario. No ocurre lo mismo en la sucesión abintestato donde la eventual vocación al todo, propia del llamamiento que en ella se produce, nace de la necesidad de agotar cada orden y cada grupo de herederos, salvo el posible derecho de representación, antes de pasar al siguiente, lo que es consecuencia natural del sistema sucessio graduum et ordinum, de modo que el acrecimiento se produce, per se, sin posibilidad alguna de que se pueda evitar. Después, en la intestada, eso sí, se da la circunstancia de que existe, por disposición de la ley, una relación de parentesco (art. 913 CC y concordantes). De ahí que, después, al aplicarse el acrecimiento, sean llamados por razón del grado y del parentesco que tengan con el causante. Razón por la cual se da una simultaneidad en la aplicación de ambas reglas, aunque entendemos que prevalece el acrecimiento en el sentido de que es el modo o la forma, al tiempo que es el porqué, de cómo se asigna o adjudica la cuota vacante entre los demás cosucesores, si bien, después, en virtud de la segunda regla, se determina en favor de quien se produce esa asignación, quien es el beneficiario o destinatario de la misma. 
Ello, no obstante, dada la simultaneidad que existe en la aplicación de ambas reglas, es lo que ha dado lugar a que se entienda que en la sucesión abintestato, más que un derecho de acrecer, se puede decir que existe un derecho de no decrecer, porque la porción o cuota que ha quedado vacante se agrega de manera forzosa a las de los demás sucesores, lo que deriva del principio general de exclusión del pariente de grado más remoto por el de grado más próximo. O que, los parientes más próximos hacen suya la porción vacante, más que por derecho de acrecer, por derecho propio y por proximidad de parentesco.

\section{4.- EL DESTINO DE LOS BIENES EN CASOS ESPECIALES.}

Existen ciertas disposiciones, en el ámbito de la sucesión testada, en las que el destino ulterior de las mismas, en el caso de que fueren objeto de repudio por parte de su beneficiario, ofrece alguna peculiaridad o especialidad en lo que se refiere a las consecuencias o efectos que de él se derivan y que viene determinada por razón de la propia naturaleza de la disposición o institución de que se trate.

\section{4-1.- En el caso de los legados.}

El destino mortis causa de una manda o legado que fuere objeto de repudio por parte de su beneficiario, se defiere, tal y como establece el tenor del artículo 888 CC:

a) en primer lugar, por tratarse de una disposición ordenada por el causante, a favor del sustituto que éste, en su caso, hubiere sido designado en el testamento,

b) en su defecto, si hubiere varios sujetos beneficiados por el legado y el llamamiento al mismo se hubiese hecho de forma conjunta, solidaria, sin especial designación de cuotas o de partes, en el caso de repudio por parte de uno de ellos, procedería en favor los demás el acrecimiento de la parte repudiada (art. 987 CC que remite al 982 y ss CC). No obstante, como señala GUTIERREZ JEREZ ${ }^{823}$, no se produciría el acrecimiento "en el caso de que opere el derecho de transmisión en el legado, al tratarse de derechos que no pueden producir efectos superpuestos por ser esencialmente contradictorios. En estos casos, resulta indiscutible que se producirá la refundición del legado en la masa hereditaria",

c) y, en último término, a falta de las anteriores reglas, es cuando se produce la especialidad que caracteriza aquí a esta forma de disposición mortis causa por cuanto el legado desaparece ya que "se refundirá en la masa de la herencia" y se agregará al

${ }^{823}$ Op. cit.: Pág 2331. 
resto del caudal partible como un bien más de la misma entre los herederos, a diferencia de lo que sucede en el caso de una atribución a título universal que daría lugar a la apertura de la sucesión abintestato (arts. $912.3^{\circ}$ y 986 CC).

En este sentido, y en otro orden de efectos, si procediere la refundición del legado en la masa de la herencia, las cargas que eventualmente se hubieren impuesto en esta disposición testamentaria, se entiende que quedan igualmente absorbidas por la herencia, salvo las que tuvieren carácter personalísimo (cfr arts. 780, 984, 986 y 798 $\mathrm{CC})$.

No obstante, tratándose de un sublegado (arts $858.1^{\circ}$ y $859.1^{\circ} \mathrm{CC}$ ), impuesto a un heredero en particular, o a otro legatario, a modo de carga, en el caso de que fuere repudiado por el sublegatario, no debe de dar lugar, en opinión de ALBALADEJO ${ }^{824}$, a la absorción del mismo por la herencia, sino a que el heredero o el legatario gravado, queden libres del gravamen que les impuso el testador, habida cuenta de que el fundamento de la refundición en la herencia es que lo gravado sea ésta.

Por otro lado, "el ámbito de la refundición en la herencia -señala GUTIERREZ JEREZ ${ }^{825}$-, queda restringido en la práctica a los legados de cosa propia del testador puesto que si el legado lo fuere de cosa ajena, el efecto sería que el heredero gravado quedaría liberado de tener que adquirirla para el legatario".

Otra especialidad que se produce en la repudiación de un legado es aquella que tiene lugar cuando esta forma de atribución patrimonial, o título sucesorio, es el medio elegido por el causante para proceder al pago de la legítima a alguno de sus legitimarios. En este caso, las consecuencias que se derivan de la repudiación, no serían las que establece el artículo $888 \mathrm{CC}$, sino que, al haberse producido una vacante en la legítima, sería de aplicación la norma del artículo 985 CC que llama a la misma a los colegitimarios, "por derecho propio". Pero quede aquí tan solo planteado porque, de su examen más detenido nos ocuparemos a continuación, al ver cuáles son los efectos que se derivan de la repudiación de la legítima, ya que, en realidad, lo que hace el declarante en este caso, no es tanto repudiar el legado, sino la legítima.

${ }^{824}$ Comentarios al Código Civil ....... T XII. Vol 1º. Cit: Pág 368.

${ }^{825}$ Op. cit.: Pág 2331. 


\section{4-2.- En el caso de la legítima.}

Sabido es que en nuestro ordenamiento jurídico la legítima, de conformidad con lo dispuesto en el artículo 815 CC, "puede dejarse por cualquier título" ${ }^{\text {"26, }}$, por lo que el legitimario la puede percibir, bien a través de un llamamiento hecho a su favor por acto de disposición mortis causa, a título universal o de heredero, o a título particular o de legatario, bien por acto de disposición inter vivos, a través de donación, cuando el causante en vida, realiza a su favor tal acto de liberalidad ${ }^{827}$ con el carácter o la atribución de ser un anticipo de lo que por dicha legítima le vaya a corresponder después, una vez abierta su sucesión.

\section{4-2-1.- Si se hubiere atribuido por acto de disposición mortis causa.}

Siendo voluntad del causante dejar a todos, o a alguno, de sus herederos forzosos, su legítima a través de un llamamiento hecho a su favor a título universal, de tal manera que aquella y éste se realizan de manera conjunta e inseparable como si fuesen un solidum, un todo, porque el llamamiento así realizado lleva consigo de forma implícita o intrínseca la atribución de la legítima, estaríamos ante una modalidad de llamamiento del que se derivaría la consecuencia de que ésta, la legítima, no se podría adquirir si no se aceptase aquel, el llamamiento hecho a título universal.

En este caso, el delado no solo reúne la doble condición de sucesor a título universal y de legitimario, sino que el ejercicio del ius delationis es indivisible, de tal manera que su declaración de voluntad, sea de repudio o de aceptación, ha de ser única y referida a la totalidad de la delación que le ha sido deferida. Ello significa que no podrá realizar una declaración sobre la legítima y otra sobre el llamamiento que se le ha hecho a título universal, sino que lo será sobre toda la vocación, omnicomprensiva de su condición de legitimario y sucesor a título universal. Al tiempo que repudia, está repudiando tanto la vocación universal ordenada a su favor por parte del causante, como la legítima a que tiene derecho por su condición de heredero forzoso de éste y que le ha deferido a través de aquella.

${ }^{826}$ A través de esa expresión desaparece el deber formal de tener que instituir heredero a los legitimarios. Innovación que aparece en el Proyecto de 1851 (art. 645).

Igual que en el Código Civil sucede en otras Comunidades Autónomas: Aragón: art. 487.1 CDFA; Cataluña: art. 451-1, Ley 10/2008, sobre sucesiones; País Vasco: cfr arts 54 y 74 de la LDCF. Y acerca de su atribución por vía de legado en este territorio, vid STSJ de 7 de enero de 2005 (Sala de lo Civil y Penal, Sección $1^{\text {a }}$ ) -RJ 2005/1187-.

${ }^{827} \mathrm{Vid}$, entre otras, en este sentido, acerca de esta forma de disposición, aunque hay jurisprudencia muy vacilante: SSTS 20 de febrero de 1981, -RJ 534-; 10 de junio de 1986 -RJ 4558-; 17 de julio de 1996 -RJ 5800-, que cita a su vez las anteriores de 21 de febrero de 1900, 25 de mayo de 1917 y 23 de abril de 1932. 
Así, al haberse establecido u ordenado la legítima de forma implícita dentro de dicho llamamiento y estar, en consecuencia, indefectiblemente unida a él, es lo que impide que el delado pueda separar la condición de legitimario de la atribución patrimonial hecha a su favor a título universal, y al revés.

En este caso, los efectos que se derivan del repudio de la vocación sucesoria hecha a título universal, implica rechazar también lo que le hubiere correspondido por legítima al ser la declaración indivisible puesto que, tanto la repudiación, como la aceptación, "no pueden hacerse en parte, a plazo ni condicionalmente" (art. 990 CC). Por la declaración de repudiación, cierto es que el sucesor rechazará aquella porción o cuota de bienes que se le hubiere deferido por parte del causante a su favor como heredero, pero, al mismo tiempo, al estar implícitamente incluida dentro de esa porción de bienes lo que le corresponde por legítima en su condición de heredero forzoso, al repudiar la vocación a título universal, repudia también, al mismo tiempo, lo que por legítima le hubiere correspondido (VALLET ${ }^{828}$ ). De ahí que, lo que no puede hacer el legitimario, en este caso, es, conservar esta condición y adquirir lo que por ello le corresponda, y repudiar el llamamiento a título universal que le ha sido deferido, al hacerse aquella atribución a través de este llamamiento. Como tampoco, al revés: rechazar o rehusar de su condición de legitimario y pretender aceptar y adquirir lo que se le defirió por parte del causante a título universal. El sucesor no podrá separar una y otra atribución porque, en realidad, son una sola y la misma, una porción forzosa de bienes deferida a título universal. En igual sentido, GALVÁN GALLEGOS ${ }^{829}$.

Y si la legítima se dejare a través de una manda o legado ${ }^{830}$, al tener el legitimario, al mismo tiempo, la condición de legatario, ha de atenerse al régimen jurídico de la adquisición y/o repudiación de los legados ${ }^{831}$, con la peculiaridad de que, al tratarse de un legado ordenado en pago de la legítima, si lo repudiare, repudia, lógicamente, lo que por legítima se le hubiere deferido, al igual que ocurría en el caso, visto hace un momento, de que la legítima se hubiere deferido a título universal.

Así, tanto en uno como en otro caso, la repudiación de la vocación sucesoria, lleva consigo, de forma implícita, la de la legítima que a través de ella se defiere al legitimario, aunque no sea esa su intención al emitir dicha declaración de voluntad.

${ }^{828}$ Limitaciones de derecho sucesorio a la facultad de disponer. Tomo I. Las legítimas. Vol $2^{\circ}$. Madrid. 1974. Pág 798.

829 "El destino de la herencia repudiada". Cit: Pág 920 y ss.

${ }^{830}$ Se trata de una posibilidad que ha sido tratada, tanto por la doctrina, como por la jurisprudencia (vid, entre otras muchas: SSTS 16 de enero de 1895; 21 de febrero de 1900; 25 de mayo de 1917; 23 de abril de 1932 -RJ 1932-33/1022-; 20 de junio de 1986 -RJ 4558-; 17 de julio de 1996 -RJ 5800-).

${ }^{831}$ Véase, en este sentido, el punto número 3 del capítulo primero, donde nos referimos al mismo. 
Ya en lo que se refiere a los efectos o consecuencias jurídicas que se derivan de la repudiación de la legítima y su destino ulterior, es donde se produce su verdadera problemática, dado el tenor del párrafo $2^{\circ}$ del artículo 985 del Código Civil según el cual, “.... sucederán en ella los coherederos por su derecho propio y no por derecho de acrecer".

No obstante el tenor del precepto, que, a simple vista, parece establecer una norma diáfana en el supuesto de hecho que regula, una de las cuestiones, entre otras $^{832}$, que se han planteado a raíz de la colisión que, como ahora veremos, ha habido entre el Tribunal Supremo y la DGRN, es, si se puede establecer por parte del causante en su testamento una cláusula de sustitución vulgar respecto de un colegitimario a favor de sus hijos en el caso de que aquel repudie la legítima, en cuyo caso, se produciría una colisión entre dicha cláusula y la norma del artículo 985 CC. Pero, donde verdaderamente se plantea esta problemática es en relación a la legítima porque, a propósito de la parte libre, no hay problemas en su admisión.

En principio, y dado que la voluntad del causante es, o se considera, ley en la sucesión (cfr. art $675 \mathrm{CC}$ ), debería de prevalecer y ser de aplicación preferente a dicha norma. Sin embargo, dado que el Código Civil, fiel al principio "viventis non datur repraesentatio", solo permite la representación -que equivaldría a una sustitución vulgar, ex lege-, de una persona viva en los casos de desheredación e incapacidad (art. 929), no así en los de repudiación, según hemos visto más arriba, se ha planteado la disyuntiva de, si existiendo una cláusula de sustitución en el testamento, en el caso de que se repudie una porción de legítima, suceden en ella los demás colegitimarios por su propio derecho, tal y como establece dicho precepto, o si dicha norma cede ante el llamamiento de los sustitutos del que ha repudiado hecho por parte del testador. Así, de manera más gráfica, ¿se puede ordenar por el causante, el abuelo, una sustitución vulgar sobre la legítima para el caso de repudiación, a favor de los descendientes de ulterior grado, sus nietos, si el padre o la madre, repudian?.

832 Otra de orden menor, pero que no por ello deja de perder interés, aunque puede parecer de carácter meramente terminológico, es la relativa al empleo del término “coherederos” que, en realidad debería decir, o entenderse, “colegitimarios", habida cuenta de que estamos ante el repudio que se produce en esta parte de la herencia y los beneficiarios de la misma así se denominan, además de que se puede ser heredero sin tener la condición de legitimario y al revés.

De ahí que, lo correcto es que se deba de hablar y entender que a quien, en realidad, se está refiriendo el Código en este artículo es a los colegitimarios y no coherederos, porque, como tales, lo son los extraños o instituidos en la parte libre de la herencia y, por definición, nunca podrán acceder a la legítima al no ser herederos forzosos (art. 807 y ss CC). 
En concreto, y en este sentido, la DGRN, en su Resolución de 11 de octubre de 2002 -RJ 9942-, en un supuesto de repudiación de la legítima estricta ${ }^{833}$, fue rotunda al dar prevalencia a la cláusula de sustitución al establecer que, "el artículo 774 del Código Civil es categórico al respecto: la sustitución vulgar simple y sin expresión de casos, comprende tanto los de premorencia como los de incapacidad y renuncia, de modo que la renuncia del hijo a su llamamiento hereditario, determina el juego de la sustitución a favor de sus descendientes, ......, y solamente en el caso en que no existan sustitutos vulgares, podrá entrar en juego el derecho de acrecer (cfr. artículos 981 y siguientes del Código Civil) y, subsidiariamente se procederá a la apertura de la sucesión intestada (cfr. artículo 912-3 del Código Civil)".

Sin embargo, el Tribunal Supremo, en una sentencia posterior de 10 de julio de 2003 -RJ 4628- ${ }^{834}$, estimó lo contrario porque, aun admitiendo la existencia de la

${ }^{833}$ Se trataba de un testamento en el que por parte de la testadora se legan los tercios de libre disposición y de mejora, en pleno dominio, a una hija, y se instituye herederos universales a ésta y a su hermano (sus dos únicos hijos), sustituyéndolos vulgarmente por sus respectivos descendientes.

El hijo y hermano, al que solo le correspondía la legítima estricta, renunció pura, simple y gratuitamente a todos los derechos que le pudieran corresponder en la herencia de su madre.

Después, la hija otorgó escritura en la que acepta la herencia de su madre, se adjudica el único bien inventariado en la misma, se presenta para su inscripción en el Registro de la Propiedad y que suspende por el Registrador: “.... porque, estando establecida la sustitución vulgar sin distinción de casos en el testamento del causante, la renuncia del heredero instituido don Joaquín B. P. hace que se consume aquélla, siendo necesaria la intervención en la partición de herencia de los sustitutos vulgares caso de haberlos, y, no habiéndolos, habrá de consignarse así. Todo ello, de acuerdo con el artículo 774 del Código Civil”. El Notario autorizante de la escritura interpuso recurso gubernativo contra la anterior calificación que después la DGRN lo desestima, manteniendo la calificación del Registrador.

Esta Resolución ha sido comentada: a favor, por, PIERA, La Notaría. No 11-12, 2002, noviembre y diciembre. Págs 319 a 324. Y, en contra, por GARCÍA-BERNARDO LANDETA, en Boletín de Información del Ilustre Colegio Notarial de Granada, ${ }^{\circ}$ 257, $2^{a}$ época, enero de 2003. Págs 223-231, y en Revista Jurídica del Notariado, n 44, octubre-diciembre 2002. Págs 269-280.

834 Aquí, la institución de heredero comprendía los dos tercios de legítima larga al asignarse el tercio libre a la esposa del testador.

El Tribunal Supremo fue tajante al decir que: "Ia renuncia pura, simple y gratuita de la hija implica la renuncia por sí y su estirpe, incrementando la cuota que por legítima individual correspondía a la otra legitimaria, su hermana, por derecho propio y no por derecho de acrecer, como se desprende del art. 985.2 del CC, no pudiendo representarla los descendientes de la renunciante, en virtud de lo dispuesto en el art. 929 del mismo cuerpo legal, que sólo permite la representación de persona viva, en los casos de desheredación y de incapacidad. Por ello, la renuncia del llamado no provoca la representación de su descendencia, ni en una clase de sucesión ni en otra y su estirpe no puede representarle cuando repudia la porción que se le defiere y percibir lo que su ascendiente abdica o no quiere. Así, conforme al art. 922 del CC, «si hubiere varios parientes de un mismo grado y alguno o algunos no quisieren o no pudieren suceder, su parte acrecerá a los del mismo grado, salvo el derecho de representación cuando pueda tener lugar», pero concreta y precisa el art. 923 que «repudiando la herencia el pariente más próximo, si es solo, o, si fueren varios, todos los parientes más próximos llamados por la ley, heredarán los de grado siguiente por su propio derecho y sin que puedan representar al repudiante». Por ello, los descendientes del hijo que renuncia no pueden suceder apoyándose en el derecho de representación, como ha precisado la doctrina científica y conforme al art. 981, «en las sucesiones legítimas, la parte del que repudia la herencia acrecerá siempre a los coherederos». Tal desconocimiento por el legislador de la representación del repudiante resulta una fidelidad al principio viventis non datur repraesentatio, pero quiebra en los supuestos de desheredación o de indignidad, lo que no ocurre con la renuncia del heredero, pese a que con ello se abandona la 
sustitución vulgar para el caso de repudiación ("la cláusula de sustitución debe entenderse conforme a la praxis notarial, comprensiva de los tres supuestos de premoriencia, incapacidad y renuncia"), estimó el incremento a favor de la otra hija y heredera, dando por supuesto que el derecho propio del heredero forzoso al incremento de su legítima prevalece sobre la sustitución vulgar y, en consecuencia, los descendientes de la renunciante, pese a que estuviesen designados como sustitutos de ella en el testamento de su abuelo, no tuviesen derecho alguno en su herencia.

En nuestra opinión, ante tal disyuntiva, cuando existe una sustitución vulgar ordenada por el testador a favor de los descendientes del legitimario que repudia su porción de legítima, seguimos la línea de la Resolución de 11 de octubre de 2002 y entendemos que el llamamiento del causante ha de prevalecer sobre la norma del artículo 985 , párrafo $2^{\circ} \mathrm{CC}$, por los siguientes motivos:

a) la voluntad del causante es ley en materia de sucesiones, salvo en aquellas normas de derecho necesario como es la referida a las legítimas. La importancia de su voluntad se pone de relieve en el artículo 675 y concordantes (arts 668, 747, 749, 751, 774, y 1281 a 1289 CC), a propósito de la interpretación de la misma. Luego, si su deseo es que, ante la eventualidad de que se produzca una vacante en una porción de su herencia, como es en este caso la legítima, por causa de repudiación, al objeto de cubrir esa vacante y evitar el perjuicio que dicha declaración puede producir a sus descendientes de ulterior grado, sean llamados a la misma después del repudiante, entendemos que así habrá que respetarlo. No solo es su voluntad, sino que los bienes se siguen defiriendo a favor de los herederos forzosos (arts. 807 y $808 \mathrm{CC}$ ), con lo que, no solo no se infringe el llamamiento que hace la ley en favor de los mismos, sino que precisamente se cumple. Además de que, por otro lado, éste sería el curso normal y natural que tendrían los bienes objeto de repudio en el futuro caso de no haberse producido dicha declaración.

En este sentido, la norma del párrafo $2^{\circ}$ del artículo 985 se ha de entender, en nuestra opinión, como una norma, no de derecho necesario, sino supletorio, en el sentido de que regiría en defecto de sustitución ordenada por el causante. La finalidad u objetivo de la misma es tratar de impedir que, existiendo en una sucesión una institución de heredero a favor de dos o más colegitimarios y a favor de uno o más

estirpe, y aunque se ha propugnado por algunos tratadistas que se acoja por el legislador la eficacia representativa en la renuncia hereditaria, ello no es lo establecido por el CC en el sistema sucesorio y por ello y mientras no se cambie, tiene que mantenerse".

Esta sentencia fue comentada por RODRIGUEZ ADRADOS, en Revista Jurídica del Notariado, $n^{\circ} 44$, octubre-diciembre 2002. Págs 283-300. 
extraños, la cuota legitimaria que ha sido repudiada por alguno de aquellos pase a éstos por vía del acrecimiento, y se evita así que la legítima caiga en sus manos. Luego, si el causante ordena para el caso de repudio de la legítima una sustitución en la misma a favor de los descendientes de ulterior grado del colegitimario que repudia, está consiguiendo la misma finalidad o objetivo que persigue el precepto que comentamos, cual es, impedir que los herederos extraños llamados a la herencia se hagan a través del acrecimiento con la cuota de legítima repudiada cuando se ordena o instituye heredero, a la vez, a dos o más legitimarios y a uno o más extraños.

No obstante, los sustitutos, obvia y necesariamente, han de ser descendientes de ulterior grado del legitimario que repudia, estirpe del causante, y no otras personas porque sino, no solo se produciría respecto de aquellos una preterición, sino que se infringiría el llamamiento que hace el artículo 807 CC de los hijos y descendientes en su condición de herederos forzosos del causante, y se iría en contra del espíritu que inspiró la redacción del párrafo $2^{\circ}$ del artículo 985 CC.

b) El propio Código Civil establece en el artículo 986 que, "en la sucesión testamentaria, cuando no tenga lugar el derecho de acrecer, la porción vacante del instituido, a quien no se hubiese designado sustituto, pasará a los herederos legítimos del testador, los cuales la recibirán con las mismas cargas y obligaciones". El precepto habla de acrecimiento y sustitución en la sucesión testamentaria, en general, y como en ella tienen lugar y se producen en el ámbito de la misma, la legítima y la parte libre, lo que podemos entender, o nos está dando a entender, que sobre la legítima puede haber las dos instituciones, acrecimiento y sustitución, si bien, cuando concurren las dos, el acrecimiento cede ante la sustitución ordenada por el causante, de tal manera que ésta sería de aplicación en primer lugar, aparte de que, el acrecimiento no deja de ser una sustitución ex lege que actúa precisamente en defecto de la sustitución voluntaria ordenada por el causante.

c) Ya antes, el artículo $912-3^{\circ} \mathrm{CC}$ establece que procede la apertura de la sucesión abintestato cuando el heredero repudia la herencia sin tener sustituto y sin que haya lugar al derecho de acercer. Llama la atención que primero hable de sustitución y después de acrecimiento. Luego, si aplicamos este precepto al caso de la legítima, está admitiendo, o estableciendo, que procedería sobre ella la sucesión abintestato en el supuesto de que se produzca alguna vacante sobre la misma porque no exista en ella ni cláusula de sustitución ni acrecimiento. 
d) Obviar una cláusula de sustitución en este caso, sería tanto como hurtar, burlar o frustrar la voluntad del causante porque su deseo fue que la cuota legitimaria, en el caso de ser repudiada, pasase a los descendientes del repudiante, a la par, suyos de ulterior grado.

Otra de las cuestiones, ya tradicional y clásica, que se plantea la doctrina, si bien, en nuestra opinión, es meramente teórica, y, por otro lado, más de forma que de fondo, es cómo se produce la expansión de la porción vacante a los demás colegitimarios, dada la expresión que en él se emplea, "por su derecho propio", por cuanto parece excluir de forma expresa el acrecimiento. Sin embargo, la polémica se podría incluso decir que es, hasta cierto punto, estéril o inútil porque, a efectos prácticos y desde un punto de vista meramente pragmático, según se resuelva en uno u otro sentido, ya se adquiera la porción vacante por derecho propio, ya a través del derecho de acrecer, después, el resultado o las consecuencias que se derivan de una y otra posición, vienen a ser las mismas, se vienen a identificar. Si acaso su interés radica en determinar cual es la técnica, mecanismo o instrumento, a través del cual se reparte o adjudica entre los restantes legitimarios la vacante producida, así como la razón o fundamento que lo justifica.

A nuestro juicio, el quid de la cuestión radica, obviamente, en el significado que se le dé a la expresión "por su derecho propio". Entendemos que se ha de interpretar en el sentido de que, producido el repudio, los demás colegitimarios hacen suya la porción que ha quedado vacante de legítima por aplicación de la misma condición o título de herederos forzosos que les otorga la ley y, en virtud del cual, suceden al causante. Lo que significa reforzar y dar a dicho título un valor mayor e importancia, a diferencia de cómo lo harían los demás cosucesores respecto de la porción o cuota repudiada, que sería a través del derecho de acrecer. Lo que se produce es una expansión natural que emana del propio llamamiento, ope legis, a favor de quienes tuvieren la condición de legitimarios, de tal manera que la fuerza o vis atractiva que lleva consigo de forma implícita el título de legitimario basta y es suficiente para absorber por sí mismo la porción o cuota que ha quedado vacante en la legítima de la herencia, lo que tiene lugar, además, de forma involuntaria por cuanto se produce sin necesidad de declaración alguna por parte de los legitimarios o del concurso de su voluntad, incluso aun ignorando ellos mismos la existencia de la vacante producida, como también se produce de manera forzosa, por cuanto ellos no pueden, en modo alguno, impedir u oponerse a que se produzca el aumento de su cuota. Sería una expansión análoga a la que tiene lugar en la sucesión abintestato. 
Es el propio título de legitimario y su origen legal, lo que justifica y fundamenta su fuerza atractiva, que está implícita en él mismo, y hace que quienes tuvieren esta condición hagan suya y absorban de forma automática, al instante, desde el mismo momento en que se ha producido la declaración de repudio, esa porción que ha quedado vacante de la legítima. El derecho ex lege que se tiene a la legítima absorbe la cuota vacante y hace que ésta pase a aumentar de forma natural las cuotas de los demás legitimarios.

De ahí que, aunque no se quiera admitir o no se acepte la existencia de un acrecimiento propiamente dicho, que el propio precepto parece que rechaza de forma expresa, lo cierto es que, en realidad, si no deja de serlo en cuanto a la forma, sí lo es en cuanto al fondo, como también en lo que se refiere a los requisitos o presupuestos que, de forma implícita, son precisos para que tenga lugar. $\mathrm{Y}$ ello porque el llamamiento que hace la ley a la legítima a todos los legitimarios es de forma conjunta y solidaria, "sin especial designación de partes o de cuotas", expresión o requisito que recoje el artículo 982.1 $\mathrm{CC}$ para que se produzca el acrecimiento en la sucesión testamentaria, de tal manera que todos los que tuvieren la condición de legitimarios en la sucesión del causante (art. 807 y ss CC), son llamados a la totalidad de la legítima que después se repartirá entre el número que haya de ellos. O, como dice ALBALADEJO ${ }^{835}$ en este punto, que "la legítima sea un tanto alzado para todos los legitimarios" ${ }^{\prime 836}$, y sobre todo, después, en cuanto a sus resultados, los efectos o consecuencias prácticas que de ello se derivan son los mismos que los de un acrecimiento, con la diferencia de que, en este caso, tiene su origen y fundamento en la ley, habida cuenta de que es ella quien hace el llamamiento de los legitimarios, mientras que, en el caso del artículo 982 CC, lo es sobre la presunta voluntad del causante.

Así, aunque se contraponga la letra de ambos párrafos del artículo 985 CC, en que, en el primero, a propósito de la parte libre, sí se habla expresa y directamente de acrecer, no así en el segundo, donde se niega de forma expresa el acrecimiento, podríamos decir que, de facto, sí que hay un acrecimiento que se produce ope legis, por ministerio de la ley, y de forma automática, en contraste con el acrecimiento del artículo 981 y ss CC, que se fundamenta en la presunta voluntad del causante, si bien, uno y otro coinciden en la exigencia del cumplimiento de unos mismos requisitos para

${ }^{835}$ Comentarios al Código Civil y Compilaciones Forales. T XII. Vol 2º Arts 959 a 987 CC. EDERSA. Madrid. 1981. Pág 351.

${ }^{836}$ Distinto es el caso que el mismo ALBALADEJO apunta más adelante (pág 356), de que un progenitor deje a su hijo A el tercio de la legítima, a mi nieto B el de mejora. 
que puedan tener lugar. Y si comparamos el segundo párrafo del artículo 985 CC con el primero, vemos cómo entre ellos se contraponen dos formas de suceder por parte de los legitimarios: si la vacante se hubiere producido en la parte libre de la herencia, lo es a través del derecho de acrecer cuando la misma "se deje a dos o más de ellos, o a alguno de ellos y a un extraño", mientras que si la vacante se produce en la porción de legítima, lo hacen por derecho propio aunque el reparto de la cuota vacante se haga entre ellos en términos análogos a los de un acrecimiento. Ello se justifica, en nuestra opinión, por el hecho de que el llamamiento a la parte libre lo hace el testador, tiene carácter voluntario, luego, se fundamentaría en una presunta voluntad del mismo y podríamos hablar de un acrecimiento "ex voluntate de cuius", mientras que en el caso de la legítima, lo hace la ley, luego, estaríamos ante un acrecimiento "ex lege".

ALBALADEJO ${ }^{837}$, en otro orden de argumentos, distingue, entre "acrecimiento en la legítima" y "acrecimiento en la sucesión", o en la herencia: aquel, es un derecho a más legítima, éste, es un derecho a más herencia. Aquel, es un aumento de lo que se tiene derecho a percibir, éste, un aumento de lo que se hereda (con o sin derecho a que el causante nos lo deje), porque los llamados a heredar no suceden todos y los que suceden tocan a más.

$\mathrm{Y}$, finalmente, en respuesta a lo que habíamos dejado planteado, en el supuesto de que la legítima se hubiere deferido al legitimario a través de una manda o legado y éste lo repudiare, a los efectos de determinar cual es su destino mortis causa, la norma contenida en el artículo 985 CC prevalecería sobre la que establece el artículo 888 CC porque, a falta de sustituto, pasaría, por aplicación de aquel, a engrosar automáticamente la legítima de los demás legitimarios "por su derecho propio", lo que impide, no ya un acrecimiento, sino su refundición en la masa de la herencia, porque, según ya hemos apuntado, los demás colegitimarios no pueden impedir ni oponerse a que se produzca el aumento de su respectiva cuota. En este sentido, el artículo 985 no distingue cual es el título, si universal o particular, a través del cual se ha deferido la legítima, lo que, en realidad, por otro lado, es irrelevante porque dicho título no es más que el instrumento o el medio del que se sirve el causante para atribuir la legítima, y cuando el legitimario rechaza dicho título, en el fondo, lo que está rechazando es la legítima. En consecuencia, el bien legado no aumentaría la masa de la herencia sino que se adicionaría a los bienes que se le adjudicasen a los demás colegitimarios en pago de su respectiva legítima.

${ }^{837}$ Comentarios al Código Civil T XII. Vol 2º . Cit: Págs 352, 354. 


\section{4-2-2.- Si se hubiere atribuido por acto de disposición inter vivos.}

Si repudiar el título sucesorio mortis causa que lleva implícita la legítima, significa o supone, la repudiación de ésta, ¿ocurre lo mismo si se defiere por el causante a través de un acto inter vivos como es la donación que éste realiza en vida, a favor de alguno, o algunos, de sus futuros legitimarios, en el caso de que no fuese aceptada por el donatario-legitimario, y se realizase con la condición o el carácter de ser un anticipo de dicha legítima, adjudicándole así, a través de la misma, en todo o en parte, lo que después hubiere de corresponderle en la sucesión como tal heredero forzoso?.

Dado que sin aceptación no hay contrato, (arts 623, 629 CC), en este caso, ¿se está repudiando, a la vez, la legítima, al igual que sucede cuando ésta se atribuye por acto mortis causa?. Es decir, no aceptar la donación, ¿lleva consigo, de forma implícita, la repudiación de aquella, de tal manera que ello implica, sin que lo pueda evitar el donatario la pérdida de aquello que hubiere de corresponderle en la sucesión del donante en su condición de legitimario?, porque, en un principio, así pudiera pensarse, habida cuenta de que el donante realiza tal acto como anticipo de la misma y en contemplación a, o en consideración a, lo que en el futuro le vaya a corresponder al donatario como heredero forzoso suyo.

Planteado en otros términos, desde el punto de vista del donatario, nos lleva a la cuestión de si su declaración es indivisible en el sentido de, si se puede disgregar o separar la atribución o el carácter de ser un anticipo de la legítima y la liberalidad que entraña la donación, de tal manera, no aceptar la donación no implique también repudiar la legítima. Dicho con otras palabras, ¿se puede no aceptar la donación y conservar sus derechos legitimarios en la herencia del donante?.

En este sentido, hemos de tener en cuenta dos circunstancias:

a) la atribución de la legítima se realiza a través de una donación, que, como tal, es un acto enteramente libre y voluntario, no solo en el hecho de que las partes son libres de contratar, o no, sino también porque pueden establecer los pactos, cláusulas y condiciones que tengan por conveniente dada la libertad de que gozan las partes en su celebración al amparo del principio de autonomía de la voluntad que en materia de obligaciones y contratos rige en nuestro ordenamiento jurídico (art. 1255 CC).

Así, desde el punto de vista del donante-causante puede suceder que no se haga la donación si no es como anticipo de la legítima, hasta el punto de que le dé carácter de esencial en el ánimus o intención que le lleva a hacer tal acto de 
liberalidad. Es decir, la donación se hace sólo en contemplación, o en consideración, a que es un anticipo de la legítima, de tal manera que, en otro caso, no la haría, hasta el punto de que, si no es aceptada como tal por el donatario-legitimario, corre el "riesgo" de perder lo que por legítima le hubiese correpondido.

Planteado en estos términos, en caso de no aceptación de la donación por parte del donatario-legitimario, entendemos que éste no podría perder lo que por legítima le correspondiere porque el donante no puede condicionar la legítima a la aceptación de la donación bajo la amenaza para el donatario de perder lo que por legítima le corresponda en su sucesión ${ }^{838}$, ya que no dejaría de ser una coacción y, como tal, un vicio del consentimiento (art. 1265 y ss CC).

b) La segunda circunstancia a la que nos referíamos es al hecho de que, cuando se realiza la donación, la legítima no es algo actual, presente, sino futuro, por cuanto la sucesión del donante aun no está abierta, y, en este sentido, la donación así planteada por el donante infringiría el espíritu del artículo 816 CC que declara nula toda renuncia o transacción sobre la legítima futura entre el que la debe y sus herederos forzosos ${ }^{839}$, además de que atentaría contra el artículo 1271 CC.

Así, a nuestro juicio, desde el punto de vista del donatario, futuro legitimario, la no aceptación de la donación no puede entrañar, en modo alguno, una renuncia a la misma. Del mismo modo, desde el punto de vista del donante, tampoco se puede pretender que la donación sea un anticipo de legítima y se condicione la percepción o no de ésta a dicha aceptación por cuanto el ejercicio del ius delationis es un acto totalmente libre y voluntario (arts 988,1265 y ss CC).

\section{4-3.- En el caso de la mejora.}

Cuestión distinta es que el objeto del repudio lo fuere aquella parte de la legítima que se hubiere deferido por parte del causante a favor de alguno o algunos de los hijos o descendientes en concepto de mejora (art. $823 \mathrm{CC}$ ), porque, habida cuenta de que forma parte de ella y de la norma del párrafo segundo del artículo 985 CC, se debate

${ }^{838}$ Estos inconvenientes se salvarían, o se evitarían, si por pacto entre el donante y el donatario se desvincula el acto de liberalidad con la atribución de los bienes en concepto de anticipo de legítima, de tal manera que no supusiese para el donatario recibir a través de la donación lo que después le vaya a corresponder como legitimario en la sucesión de su causante-donante. Y ello, porque la donación no sería más que un mero instrumento porque es el medio del que se vale el donante para anticipar a favor del donatario lo que después, una vez abierta su sucesión, le correspondería en concepto de legítima. Por otro lado, el donatario podría, incluso con más libertad, decidir si acepta o no la donación.

839 Acerca de dicha prohibición, véase, en el capítulo cuarto, el punto número 4, relativo a los límites a la repudiación, donde se hace un examen más detenido de la misma. 
la cuestión, que ha suscitado polémica en la doctrina ${ }^{840}$, de si, siendo varios los mejorados, ha lugar a la aplicación del derecho de acrecer entre ellos porque no se ha designado sustituto por el causante, o si, como dice el precepto, "suceden en ella -en la legítima- los coherederos -colegitimarios- por derecho propio", de lo que se derivaría la consecuencia de que la porción o cuota repudiada sería, no para los demás comejorados, sino para los legitimarios.

Ciertamente, el hecho de que esta porción de la herencia se detraiga de la legítima da lugar, en principio, a entender que, para el caso de repudio, y a falta de sustituto, hay que estar al régimen de dicho precepto y, por tanto, sería para los legitimarios.

No obstante, en nuestra opinión, habría que distinguir:

a) si el mejorado fuese él solo, el único beneficiario de la disposición, ante su repudiación, no habría lugar a dudas porque, a falta de sustituto designado, en su caso, por el causante, la mejora sería efectivamente absorbida por la legítima al formar parte de ella, en cuyo caso sí que sería efectivamente de aplicación la regla del párrafo segundo del artículo 985 CC y pasaría a engrosar la porción o cuota de legítima de los legitimarios de la sucesión.

b) Si fueren varios los mejorados, dos son las circunstancias que hay que valorar y tener en cuenta para ver si es o no aplicable dicha norma:

$1^{\mathrm{a}}$.- aunque la mejora forme parte de la legítima, su existencia depende solo, única y exclusivamente de la voluntad del causante quien, al amparo del artículo 823 $\mathrm{CC}$, puede hacer uso de esta facultad que en él se le concede y beneficiar, de manera discrecional, "a alguno o algunos de sus hijos o descendientes". Luego, la mejora es potestativa del testador.

${ }^{840}$ Así: autores como MANRESA, CASTAN, VALVERDE, BONET, SÁNCHEZ ROMÁN, lo niegan entendiendo que el derecho de acrecer no puede recaer sobre la legítima porque el artículo 985 no distingue entre legítima estricta y mejora pudiendo haberlo dicho. Lo que viene corroborado por la palabra "sólo", en el sentido de permitirlo únicamente en la parte libre. Y como la mejora forma parte de la legítima, no ha lugar en ella al derecho de acrecer.

En este sentido, la STS de 26 de diciembre de 1989 (RJ 8872), se mostró favorable a la aplicación del párrafo segundo del artículo 985 CC, “.... habiendo varios descendientes si entre los mejorados queda una porción vacante, en ella suceden por derecho propio los demás que sean legitimarios” partiendo, entre otros argumentos, de que, "el derecho de acrecer no puede recaer sobre la parte de bienes que constituye la legítima de los herederos forzosos", pese a que "existe cierta relativa libertad para disponer", si bien, "es tan limitada que no cabe equipararla al tercio de libre disposición”.

Otros, en cambio, como GONZALEZ PALOMINO, GARCÍA GRANERO, ALBI AGERO, PUIG BRUTAU, LACRUZ, ALBALADEJO, sí lo admiten porque el testador, entre otras razones, puede disponer libremente de la mejora entre sus descendientes.

En este sentido, sí se admitió por la DGRN en Resolución de 14 de agosto de 1959 (RJ 3354). 
$2^{\mathrm{a}}$.- No necesariamente el mejorado ha de tener la condición de legitimario, por cuanto en nuestro ordenamiento jurídico está admitido que pueden ser beneficiarios de esta atribución patrimonial descendientes de ulterior grado, como son los nietos respecto de los abuelos, viviendo los padres quienes tendrían en la sucesión de éstos, la condición de legitimarios ${ }^{841}$.

Una y otra circunstancia son, en nuestra opinión, sólidos argumentos para entender que la repudiación de la mejora por uno de los mejorados, siendo varios y si todos han sido llamados de forma solidaria, conjunta, todos al todo de la mejora, sin especificar porciones o cuotas entre ellos, la porción o cuota repudiada no se puede someter al régimen del párrafo segundo del artículo 985 CC, sino que habría lugar, a falta de sustituto del repudiante, al derecho de acrecer entre el resto de los mejorados. En este caso, si el causante designa varios beneficiarios de forma conjunta y sin atribución de porciones o cuotas entre ellos, habrá que presumir o entender que es su voluntad, dada la forma de llamamiento, que todos han sido llamados al todo, por lo que, en el supuesto de que se produzca alguna vacante, ésta sea para los demás.

Puede incluso suceder que, siendo varios los mejorados ninguno de ellos sea legitimario del causante, o al menos uno, incluso todos ellos. Pero, aun en este caso, dado que el mejorado no tiene por qué ser necesariamente legitimario del causante, en el caso de repudio por parte de alguno de ellos de su respectiva porción o cuota, sólo respecto de ésta, los demás mejorados harán suya la porción vacante por derecho de acrecer si se dieren las circunstancias o requisitos exigidos para que ése pueda tener lugar, mas no por "derecho propio" como sucede en la legítima respecto de los legitimarios (art. 985 CC párrafo segundo).

Y si se diere la circunstancia de que no hubiere lugar, en su caso, al derecho de acrecer porque no se dieren las circunstancias o requisitos precisos para ello dada la forma cómo se ha hecho el llamamiento, o porque sólo haya un mejorado, o incluso porque lo haya prohibido el testador, la porción o cuota de mejora repudiada, habida cuenta de que la mejora es y forma parte de la legítima, entendemos que sería absorbida por ésta y pasaría a aumentar la respectiva cuota legitimaria de los herederos forzosos. Entonces, sí que habría que estar a la regla del artículo 985 CC, por lo que los legitimarios harían suya la porción vacante por "derecho propio" y no por derecho de acrecer, como si se tratase del repudio de una porción o cuota de legítima.

\footnotetext{
${ }^{841}$ La STS de 28 de septiembre de 2005 (RJ 7154) (Fdto Derecho 4º ), entre otras, como una de las más recientes, se muestra favorable a ello, al tiempo que cita otras que le preceden y se remite a los antecedentes históricos que se remontan a la Novísima Recopliación y Leyes de Toro (Ley 18).
} 


\section{4-4.- En el caso de bienes reservables ${ }^{842}$.}

La repudiación por parte del reservatario a la reserva ha planteado a la doctrina y la jurisprudencia dos interrogantes:

$1^{\circ}$.- pese a que los bienes reservables no pasan a manos del reservatario hasta que se haya producido el fallecimiento del reservista, de tal manera que no los recibe, ni tiene la efectiva y concreta posesión de los mismos, como tampoco son de su titularidad o pertenencia, sino desde entonces, lo cierto es que su derecho nace ya en vida del reservista aunque no se trate, en este momento, más que de una mera expectativa, hasta el punto de que el derecho a los bienes no lo pierde el reservatario incluso aunque falleciere antes que el reservista, dado que su condición o posición jurídica se asimila a la del fideicomisario (art. 784 CC).

Ante ello, surge el interrogante de si el reservatario puede, en vida del reservista rechazar los bienes reservables, repudiarlos. Así, en principio, parece admitirlo el artículo 970 CC cuando manifiesta que, "cesará la obligación de reservar cuando los hijos de un matrimonio, mayores de edad, que tengan derecho a los bienes renuncien expresamente a él, ......". No obstante, dado que en él no se habla expresamente de repudiación, ¿a qué tipo de renuncia se refiere ${ }^{843}$, ¿cual es su ámbito y cuáles son sus consecuencias jurídicas?.

$2^{\circ}$.- Por otro, se plantea la cuestión de, si el reservatario repudia la herencia del reservista, cual es el alcance la repudiación, en el sentido de si comprende solo aquellos bienes de la herencia a que él tuviere derecho, o si también los bienes reservables. ¿La declaración es común o única para unos y otros? o, por el contrario, puede hacer declaraciones distintas, separadas e independientes, una respecto de los

842 De las tres modalidades de reservas hereditarias que existen en nuestro derecho, a favor del ausente (arts. 191 y 192 CC), lineal o familiar (art. 811 CC) y ordinaria o común (arts 968 a 990 CC), conocida también como binupcial o del cónyuge bínubo, merecen aquí nuestra atención estas dos últimas, habida cuenta de que, en una y otra, aunque el reservatario tenga derecho a los bienes reservables en vida del reservista, la transmisión y subsiguiente adquisición de los mismos tiene lugar por vía de sucesión mortis causa, esto es, una vez que se haya producido el fallecimiento del reservista y, en consecuencia, el reservatario tendrá respecto de tales bienes la doble opción que entraña el ius delationis, de su aceptación o repudiación, por lo que será precisa aquella declaración para que se produzca la transmisión, entrega y adquisición de los referidos bienes, o ésta, si es su voluntad no quererlos.

${ }^{843}$ VALLET (Comentario a los artículos 968 a 980 del Código Civil. En, Comentarios al Código Civil y Compilaciones Forales. T XIII. Vol 2º. EDERSA Madrid. 1981. Pág 148 y ss), apunta tres modalidades de renuncia diferentes:

a) la renuncia a las medidas de seguridad que garantizan el cumplimiento de la obligación de reservar, que puede efectuarse de modo general o con referencia a bienes concretos,

b) la renuncia a la reserva, a la sujeción inter vivos y mortis causa del reservista, tanto en su ámbito real como en el personal,

c) la renuncia a adquirir, en su día, al fallecer el reservista, los bienes reservables, renuncia que ha sido confundida por algunos autores con la renuncia a la reserva. 
bienes reservables, y otra respecto de los bienes provenientes de la herencia del reservista, en cuyo caso, pueden ser de signo contrario entre sí. Pero, plantear este interrogante nos lleva, entendemos, a la cuestión previa de si los bienes que son objeto de reserva forman, o no, parte de la herencia del reservista.

\section{4-4-1.- Repudiación y renuncia de los bienes reservables.}

Acerca de la primera cuestión, los reservatarios, en vida del reservista, cierto es que tienen respecto de los bienes objeto de reserva una expectativa jurídica que, si bien no supone ostentar un derecho actual o de presente que les conceda sobre los mismos un poder o facultad de disposición, como tampoco un crédito actual, sí está jurídicamente protegida como lo demuestra el hecho de que están facultados para poder exigir, en su caso, del reservista el cumplimiento de las obligaciones que contempla la ley para asegurar la efectividad de dicha reserva (arts 185 y 187 LH, y 259 y ss RH). Entonces, retomando la cuestión planteada, en esta situación jurídica de pendencia, ¿es posible por parte del reservatario renunciar, repudiar, a la reserva pendiente, en definitiva, a los bienes reservables?.

Acerca de ello, el Tribunal Supremo en una sentencia de 1 de abril de 1914 admitió que se pudiesen enajenar de forma condicional los bienes reservables, basándose en la admisión de la renuncia a la reserva contenida en el artículo 970 CC, y entendió que la reserva no es legítima futura, pero su renuncia equivale a renunciar a los bienes reservables, mientras que, para MARÍN MONROY, por el contrario, la reserva es legítima futura y renunciar a ella es renunciar a heredar los bienes reservables. Tanto la citada sentencia, como MARÍN, incurren, en opinión de VALLET, en la incorrección de confundir entre renunciar a la reserva y renunciar a los bienes.

Así, para VALLET ${ }^{844}$, "a lo que no cabe renunciar, porque de hacerlo se incidiría en la prohibición del artículo 991 CC, es a heredar los bienes que eran reservables para el caso de que testamentariamente o abintestato correspondieren al presunto reservatorio". Sigue diciendo, "el artículo 970 no es excepción del 991, sino regulación de algo distinto: la facultad de renunciar a exigir el cumplimiento forzoso de la reserva. El artículo 816 no tiene que ver con el 970, sino que apoya un criterio opuesto para otro supuesto distinto de limitación de la facultad de disponer mortis causa. No se puede renunciar en vida del causante a exigir en su día el cumplimiento de la legítima (art. 816); en cambio, a exigir el cumplimiento de la obligación de reservar, se puede renunciar en vida del reservista (art. 970)".

${ }^{844}$ Comentarios al Código Civil T XIII. Vol 2º . Cit: Pág 152. 
En este mismo sentido, la DGRN, en Resolución de 30 de marzo de $1925^{845}$, donde se discutía la eficacia que tenía la renuncia realizada por los reservatarios durante la fase de pendencia de la reserva y que el Registrador no admitió por entender que la reserva era una herencia futura y ello en base a la prohibición del artículo 1271 CC, entendió que el artículo 970 CC está pensado precisamente para esa fase siendo, en consecuencia, válida dicha renuncia a la reserva. Doctrina que se ha visto después corroborada y consolidada en jurisprudencia posterior ${ }^{846}$. En este sentido, la STS de 22 de junio de 1995 (RJ 4978), que analiza la renuncia a las medidas de seguridad que garantizan el cumplimiento de la obligación de reservar y la renuncia a la reserva, viene a decir precisamente que el párrafo $2^{\circ}$ del artículo 970 CC acoge "la única renuncia presunta a la reserva que admite la ley".

En consecuencia, sí sería admisible la renuncia a la reserva, según expone VALLET, ya incluso en opinión de los autores de derecho común ${ }^{847}$, por cuanto la renuncia de todos los hijos del anterior matrimonio, inclusive el consentimiento de dichos hijos a las nuevas nupcias de su padre o de su madre, liberan o redimen a éste de las limitaciones de la reserva vidual. Se trataría de una renuncia a la reserva en vida del reservista a resultas de la cual desaparece o se extingue para él la obligación de reservar ("cesará la obligación de reservar", manifiesta el artículo 970 CC), y no de una repudiación por parte del reservatario a resultas del ejercicio por su parte en sentido negativo del ius delationis por cuanto éste aun no ha nacido ya que la sucesión todavía no se ha abierto. La repudiación, en su caso, sólo podrá tener lugar una vez que se haya deferido la herencia pero ya vendría referida a los bienes, no a la reserva.

En otro orden de argumentos, una cuestión que se ha llegado a debatir es la relativa a la forma que ha de revestir la renuncia en cuanto a su exteriorización, si ha de hacerse, en todo caso, de forma expresa, o si es válida la realizada de forma tácita manifestada ésta cuando se deja correr el tiempo sin exigir por parte del reservatario al reservista la constitución o el cumplimiento de los deberes o de las garantías que le imponen los artículos 977 y 978 del Código Civil y 184 de la Ley Hipotecaria.

${ }^{845}$ Esta Resolución dio lugar a muchos y variados comentarios dentro de la doctrina, tanto a favor como en contra. Vid sobre ello, VALLET: Comentarios al Código Civil ...... T XIII. Vol 2º Cit: pág 156 y ss.

${ }^{846}$ SSTS 2 de marzo de 1959, RJ 1089; 1 de junio de 1983, RJ 3284; 5 de mayo de 1989, RJ 3588; 22 de junio de 1995, RJ 4978, comentada esta última por GALICIA AIZPURÚA en CCJC. n 39. Septiembre-diciembre 1995. Pág 1137 y ss.

847 VALLET (Comentarios al Código Civil ..... T XIII. Vol 2º. Cit: pág 152), expone las vicisitudes y diferentes opiniones a que dio lugar esta cuestión. Y cita numerosos juristas castellanos del siglo XVI, CIFUENTES, ANTONIO GOMEZ, MATIENZO, BOEIRO favorables a ello. Como también tuvo sus detractores: MOLINA, BAEZA, ANTONIO PEREZ, SARMIENTO. 
En este sentido, el Tribunal Supremo, en su sentencia de 18 de octubre de 2001 (RJ 8646), con precedente en la de 22 de junio de 1995 (RJ 4978) que, a su vez, explícitamente reitera la doctrina que expuso la anterior de 2 de marzo de 1959 (RJ 1089), manifiesta que, "la renuncia, si no es expresa, debe ser clara y concluyente para ser apreciada como tácita; nunca ha sido considerada como renuncia tácita el no ejercicio o ejercicio tardío de derechos: ambas son declaraciones jurisprudenciales reiteradas e indiscutidas". No obstante, en algunas sentencias anteriores, como son las de 20 de diciembre de 1908 y 8 de octubre de 1923, el Tribunal Supremo entendió que sí hay renuncia tácita a la reserva por parte del reservatario cuando éste deja correr el tiempo sin exigir la constitución de las referidas garantías. Acerca de esta cuestión, VALLET ${ }^{848}$ entiende que, "parece excesivo considerar esa omisión como renuncia absoluta a exigir en adelante la constitución de las debidas garantías, que todavía sean posibles, sobre los bienes que aún pertenezcan al reservista".

\section{4-4-2.- Ámbito de la repudiación.}

Acerca del alcance o contenido de la repudiación, si partimos de la tesis de que los bienes objeto de reserva no forman parte de la herencia del reservista, entonces ello significaría tanto como decir, en el caso de la reserva binupcial, que el reservatario a quien realmente sucede en los mismos es al cónyuge premuerto y no al reservista. De ser así, el reservatario podría y tendría que hacer declaraciones distintas, separadas e independientes, una respecto de los bienes reservables y otra respecto de los bienes provenientes de la herencia del reservista.

Sin embargo, si los bienes objeto de reserva forman parte de la herencia del reservista, su declaración vendría referida tanto a los bienes provenientes de la herencia del reservista como a los que son objeto de reserva. Ésta interpretación es la que, desde el punto de vista legal, parece desprenderse del tenor del artículo 973 in fine del Código Civil, en el que la justa desheredación del hijo por su padre o por su madre da lugar a la pérdida de todo el derecho a la reserva, lo que da a entender que se verá privado, tanto de los bienes que por derecho propio le correspondieren en la herencia del reservista como sucesor suyo en virtud de la delación deferida a su favor, como de los mismos bienes reservables.

En nuestra opinión, los bienes reservables integrarían la herencia del reservista y puesto que no puede repudiarse, o aceptarse, una herencia de forma parcial (art. 990 $\mathrm{CC})$, el ius delationis del reservatario se entendería referido, tanto a aquellos bienes

${ }^{848}$ Comentarios al Código Civil ............ T XIII. Vol 2º . Cit: pág 149. 
que tuviese derecho a heredar por derecho propio respecto del reservista por ser sucesor suyo, como a los bienes objeto de reserva. Cierto es que éstos tienen, ya en vida del reservista, un destino predeterminado por la ley por razón de la propia naturaleza de la institución y que él no puede en modo alguno modificar (su posición es muy similar a la del fiduciario), pero no por ello se abstraen, desde el punto de vista del reservatario, al hecho de que su transmisión, entrega y adquisición sea por vía mortis causa y que, como consecuencia de ello, al integrarse en la herencia del reservista, su declaración acerca de la delación sea, no ya común, sino única, por lo que no podrá hacer declaraciones de repudiación, o aceptación, distintas, separadas e independientes, una respecto de los bienes reservables y otra respecto de los bienes provenientes de la herencia del reservista. En consecuencia, la declaración de repudio de la herencia del reservista por parte del reservatario implicaría la pérdida de los bienes reservables.

Y, acerca de la reserva troncal del artículo 811, se plantean, en nuestra opinión, los mismos problemas antes apuntados y que, de igual manera, tendrían idéntica respuesta a la que acabamos de dar respecto a la reserva ordinaria o binupcial. Por tanto, sería posible que, en vida del reservista, el reservatario renunciase a la reserva, lo que daría lugar a que cesase la obligación de reservar (por aplicación analógica del artículo 970 CC), y después, si el reservatario quiere llegar a adquirir los bienes reservables necesariamente tendrá que aceptar la herencia del reservista, mas si repudiare, no solo repudia dicha herencia -aquello que tuviere derecho a heredar como sucesor del mismo-, sino también los bienes a que tuviere derecho en virtud de la reserva al no ser posible la aceptación parcial de la herencia (art. 990 CC).

\section{4-5.- En el caso de bienes fideicomitidos.}

En un fideicomiso, la peculiaridad que se puede producir desde la perspectiva de la repudiación, es la posibilidad que tiene el fideicomisario, tratándose de un fideicomiso a término, de poder ejercer el ius delationis y, por tanto, repudiar, en su caso, incluso en vida del fiduciario, los bienes fideicomitidos.

Dado que el fideicomisario adquiere derecho a la herencia desde el momento del fallecimiento del fideicomitente, o testador ${ }^{849}$, es titular del ius delationis derivado de su delación incluso aun antes de que se cumpla el término señalado, tal y como se desprende de los artículos 784 CC, a cuyo tenor, "el fideicomisario adquirirá derecho a

${ }^{849}$ Acerca de este supuesto, véase, entre otras muchas: SSTS 19 de octubre de 1962 -RJ 3875-; 3 de marzo de 1964 -RJ 1254-; RDGRN 4 de febrero de 1980 -RJ 507-. 
la sucesión desde la muerte del testador, aunque muera antes que el fiduciario. El derecho de aquél pasará a sus herederos", y 799 CC, según el cual, "la condición suspensiva no impide al heredero o legatario adquirir sus respectivos derechos $y$ transmitirlos a sus herederos, aun antes de que se verifique su cumplimiento"850.

Así, dado que desde el mismo momento en que tiene lugar la apertura de la sucesión del causante se produce la certeza de la existencia de su derecho (art. 991 $\mathrm{CC})$, el fideicomisario adquiere y es titular del ius delationis que emana de su vocación testamentaria, dado que es cierto en el sí y cierto en el cuando de que sí adquirirá los bienes fideicomitidos, aunque sea en un momento posterior, por lo que, desde aquel instante, goza de un derecho del que ya puede disponer y transmitirlo a otra persona. En consecuencia, puede repudiar incluso antes de la llegada del término señalado, y si falleciere sin haber ejercitado el ius delationis, "pasará a los suyos el mismo derecho que él tenía" (arts. 784 y 1006 CC). No obstante, si lo ejerciere antes de que se cumpla el término señalado, los efectos de la declaración no se producirán sino desde el momento en que se cumpla dicho término por cuanto es el instante en que tendría lugar de forma efectiva la transmisión o entrega del fideicomiso.

Como también puede repudiar después de cumplido el término señalado.

Distinto es que el fideicomiso estuviere sometido a condición ${ }^{851}$, como es el caso de supervivencia del fideicomisario al fiduciario, supuesto más frecuente, porque no se

${ }^{850}$ Pese a la dicción del artículo, no se trata propiamente de una condición sino de un término suspensivo.

En este sentido, vid: STS de 20 de octubre de 1954 -RJ 2636-: “el artículo 799 del Código Civil dispone, en efecto, que la condición suspensiva no impide al heredero o legatario adquirir sus respectivos derechos y transmitirlos a sus herederos aun antes de que la condición se cumpla; y para salvar la contradicción que existe con lo dispuesto en el artículo 759 del mismo Código, según el cual el heredero o legatario que muera antes que la condición se cumpla, aunque sobreviva al testador, no transmite derecho alguno a sus herederos, ha de entenderse que en el primero de dichos artículos no se emplea la palabra condición en su sentido estricto, sino que hace referencia a un término o plazo, cuyo vencimiento se determina por el fallecimiento de una persona, que necesariamente ha de acaecer, aunque se ignore cuándo, y cuyo efecto, mientras el vencimiento no llega, es suspender la efectividad de la institución, pero sin impedir la creación de derechos a favor del instituido, transmisibles a sus herederos desde el fallecimiento del testador. Mas como quiera que en el caso resuelto por la sentencia recurrida no se hace depender el nacimiento del derecho de las demandantes del término o plazo determinado por el hecho del fallecimiento de su padre, sino de la condición de que le sobrevivan, resulta aplicable a la situación así condicionada el artículo 759, cuya preferente aplicación al 799, por su conformidad con el 1114, se halla reconocida por la Sentencia de este Tribunal, de 17 de marzo de 1934 (RJ 1934l466), procediendo por ello desestimar el tercer motivo del recurso, en el que se alega infracción del repetido artículo 799 por no haber reconocido la sentencia recurrida el derecho de las demandantes a la herencia del testador desde el fallecimiento del mismo, aunque sujeto a una condición o plazo de necesario cumplimiento".

${ }^{851}$ Al fideicomiso condicional se equipara el fideicomiso de residuo "si aliquid supererit", pues depende de que al fallecimiento del fiduciario quede algo del fideicomiso (así, entre otras muchas, SSTS 13 de noviembre de 1948, RJ 1270; 10 de julio de 1954, RJ 2028; 7 de enero de 1959, RJ 119; 25 de mayo de 1971, RJ 2951; 25 de abril de 1981, RJ 2166; 2 de julio de 1994, RJ 6578). 
produce transmisión de derecho alguno a sus herederos sino desde el momento en que la condición se cumpla, o hasta que fallecido el fiduciario pueda saberse si hay, o no, residuo, por lo que a la muerte del testador únicamente surge a favor de los herederos instituidos como fideicomisarios una expectativa de derecho a adquirir que solo se hará real y efectiva si la condición se cumple o si quedaren bienes ${ }^{852}$. Así resulta del artículo $759 \mathrm{CC}$ según el cual, "el heredero o legatario que muera antes de que la condición se cumpla, aunque sobreviva al testador, no transmite derecho alguno a sus herederos" ${ }^{\prime 853}$, puesto en relación con el artículo 791 CC a cuyo tenor, "las condiciones impuestas a los herederos y legatarios, en lo que no esté previsto en esta sección, se regirán por las reglas establecidas para las obligaciones condicionales" (arts 1113 a 1124 CC), dado que el artículo 784 CC, antes visto, solo es aplicable a los fideicomisos puros o a término cierto pero no a los condicionales ${ }^{854}$. Luego, hasta ese momento, mientras la condición está pendiente, no existe a favor del fideicomisario más que una mera expectativa del ius delationis respecto del fideicomiso por lo que, en relación al mismo, en esta situación, no solo no puede disponer, sino que, tampoco puede renunciar.

Después, una vez cumplida la condición (art. 1114 CC), al ser ya cierto y real el derecho sucesorio, nace el llamamiento y subsiguiente delación a favor del fideicomisario, quien gozará ya de forma efectiva a su favor del ius delationis y podrá, ahora ya sí, al igual que los demás sucesores, repudiar, o aceptar, de forma libre y voluntaria el fideicomiso.

No obstante, el fideicomiso de residuo puede ser, así mismo, condicional (RDGRN de 24 de octubre de 1985, RJ 5273), referido a Cataluña, en el que se hace depender de la inexistencia de hijos.

${ }^{852}$ Así, entre otras muchas, SSTS 4 de marzo de 1952, RJ 491; 20 de octubre de 1954, RJ 2636; 29 de enero de 1962, RJ 605; 29 de enero de 1964, RJ 391; 25 de abril de 1981, RJ 2166; 2 de julio de 1994, RJ 6578.

${ }^{853}$ Igual efectos produciría la premoriencia del fideicomisario al testador, o la indignidad del mismo, o que no quiera heredar.

854 SSTS 4 de marzo de 1952 -RJ 491-; 20 de octubre de 1954 -RJ 2636-; 25 de mayo de 1971 -RJ 2951-; 17 de febrero y 22 de julio de 1994 -RJ 1623 y 6578-, entre otras. 


\title{
Capítulo 9: EFECTOS DE LA REPUDIACIÓN (III) EN RELACIÓN A LOS ACREEDORES.
}

\begin{abstract}
Introducción. 1.- Los acreedores de la herencia ante la repudiación. 2.- Los acreedores particulares del sucesor ante la repudiación. 3.- Examen del artículo 1001 del Código Civil. 3-1.- Origen y precedentes. 3-2.- Fundamento de la "aceptación". 3-3.- Naturaleza de la acción. 3-4.- La autorización judicial. 3-5.- Sujetos implicados en el ejercicio de la acción. 3-5-1.- El delado-repudiante-deudor. 3-5-2.- Los acreedores. 3-5-3.- Los sujetos beneficiarios. 3-6.- Presupuestos para su ejercicio. 3-6-1.- La repudiación de la herencia. 3-6-2.- El perjuicio a los acreedores. 3-7.- Características del derecho de crédito de los acreedores. 3-8.- El plazo de ejercicio de la acción. 3-9.- Efectos. 3-10.- Su aplicación en el caso de repudiación de un legado.
\end{abstract}

\section{INTRODUCCIÓN.}

La repudiación también tiene consecuencias sobre otras personas que, aunque no estén vocadas a la herencia, sí están interesadas en ella al tener sobre la misma, o de alguno de los sucesores, algún derecho de crédito como son, los acreedores de la herencia, en el primer caso, y los particulares de cada sucesor, en el segundo, a los que nos vamos a referir en el presente capítulo.

En el caso de los primeros, su interés radica en que, su derecho de crédito, a los efectos de su pretendido cobro, sin perjuicio de que siempre podrán hacerlo efectivo sobre los bienes del caudal hereditario, se va a añadir la expectativa de poder dirigirse, en su caso, contra los bienes particulares de los sucesores del causante. $Y$, en el caso de los segundos, aunque su derecho de crédito ya existe sobre el patrimonio particular de su deudor, tienen también la expectativa de poder dirigirse, en su caso, contra aquellos bienes de la herencia a que éste hubiese sido llamado. 
Sin embargo, para unos y otros, esa expectativa está en función de cómo ejercite el sucesor el ius delationis ya que, si aceptare, los acreedores de la herencia se podrán dirigir contra el patrimonio personal del propio delado, si bien, de diferente forma dependiendo de cómo éste haya aceptado, si de forma pura y simple (arts 1003 $\mathrm{CC}$ ), o a beneficio de inventario (art. $1023.1^{\circ} \mathrm{CC}$ ), y los acreedores particulares, por su parte, podrán actuar sobre los bienes que su deudor recibiere de esa herencia. Mientras que, si repudiare, al quedar el sucesor fuera del proceso sucesorio, para los acreedores de la herencia supone que ya no se puedan dirigir nunca contra sus bienes particulares y, para los particulares del sucesor, olvidarse de aquellos bienes de la herencia a que éste hubiese sido llamado. Se puede entender así, el interés que pueden tener unos y otros de la decisión del sucesor por cuanto de ella puede depender el hecho de que lleguen a cobrar el importe de los créditos de que sean titulares, unos contra la herencia, otros contra el sucesor. Expectativa que es relativa e incierta al depender el ius delationis en su ejercicio total y enteramente de la exclusiva voluntad del sucesor, dado el carácter in tuitu personae que tiene la delación, lo que impide la posibilidad de subrogación en su ejercicio por su parte a través de la acción del artículo $1111 \mathrm{CC}^{855}$, y tratarse, además, de un acto que es libre y voluntario (art. 988 CC).

Ante ello, se plantea el interrogante de si los acreedores están totalmente desprotegidos y no pueden hacer nada ante la decisión del delado, o si, por el contrario, tienen algún medio de defensa y pueden remediar o subsanar el perjuicio que tal decisión les hubiere causado en orden al cobro de sus respectivos créditos, y más aún cuando esa decisión se puede haber realizado incluso en fraude o perjuicio de su derecho, sobre todo en el caso de los acreedores particulares del delado.

En este sentido, cualquier acreedor, tanto de la herencia como particulares del delado, lo único que sí puede hacer, como ya puntamos, al objeto de conseguir que el sucesor se manifieste sobre la herencia, así como dar por terminada la situación de incertidumbre que se deriva de su inactividad o silencio, es recurrir a la interpelación de que trata el artículo 1005 CC y compelerle a que, dentro del plazo que a tal efecto le señale el Juez, se manifieste acerca de la oferta hereditaria que ha recibido.

${ }^{855}$ En este sentido, nos remitimos a lo ya expuesto en el capítulo cuarto, punto 3-2, relativo al ejercicio de la delación por los acreedores. 


\section{1.- LOS ACREEDORES DE LA HERENCIA ANTE LA REPUDIACIÓN.}

Los acreedores de la herencia, respecto de las personas que fueren llamadas a ella como sucesores de la misma, con anterioridad al ejercicio del ius delationis, son sujetos totalmente extraños y no tienen nada que ver entre sí. Sólo les une, o tienen en común, el caudal relicto del causante respecto del cual, aquellos, los acreedores, son sujetos activos del mismo en virtud de los créditos que tienen contra él, y éstos, los sucesores, un derecho eventual o futuro cuya efectividad depende de su decisión por cuanto solo serán acreedores de aquellos bienes a que hubieren sido llamados si manifiestan su voluntad de aceptar.

Pero, si el sucesor repudia la herencia, al quedar excluído del proceso sucesorio mortis causa, deja de formar parte del mismo y, en consecuencia, no solo no hereda al causante, sino que, en lo que se refiere al pasivo de la herencia, queda totalmente exento de responsabilidad frente al pago de las deudas de ésta, por lo que se esfuma o desaparece la expectativa que dichos acreedores tenían de poder dirigirse, en su caso, contra sus bienes particulares para hacer efectivos los derechos de crédito que tuvieren contra la herencia. Como consecuencia de ello, ya sólo se podrán dirigir contra los bienes del acervo hereditario.

Ciertamente, ante la repudiación, los acreedores de la herencia ya poco o nada pueden hacer ante la decisión del delado por cuanto no tienen posibilidad alguna de recurrirla o impugnarla, a diferencia de lo que sucede con los particulares del repudiante que tienen a su favor la acción que les concede artículo 1001 CC y que más adelante examinaremos. Lo único cierto, eso sí, es que, tal decisión, para ellos muy perjudicial porque pierden la expectativa que tenían de poder actuar contra el patrimonio personal del delado en el momento de abrirse la herencia. No obstante, no se puede decir que se trate de un daño o perjuicio real y verdadero, que sea efectivo, incluso cuantificable, porque su situación sigue siendo exactamente la misma que si ese sucesor no hubiese sido llamado a la herencia.

De ahí que, en nuestra opinión, no se pueda hablar de un daño directo a los acreeodres, pero sí, indirecto, en el sentido de que pierden, o mejor dicho, no ganan, un patrimonio, el del delado, contra el que poder dirigir sus reclamaciones para hacer efectivos sus créditos caso de haber éste aceptado la herencia. 
Se puede decir que su situación, respecto del repudiante, sigue siendo la misma que antes del fallecimiento del causante, como si éste no se hubiese producido, con la novedad, eso sí, de que, al haber quedado el sucesor ya definitivamente apartado del proceso sucesorio, desaparece la posibilidad de poder dirigir sus reclamaciones contra el patrimonio de éste para hacer efectivos sus derechos de crédito, aunque su expectativa se podrá renovar respecto del sustituto que ocupe el lugar el repudiante quedando también a la espera de lo que él decida.

No obstante, en el supuesto de que los acreedores ya hubiesen realizado, en su caso, algún embargo preventivo sobre algún bien o derecho del sucesor que repudió por razón de una reclamación judicial que se hubiese iniciado contra él, o instado alguna anotación preventiva de su derecho de crédito en el Registro de la Propiedad (art. $42 \mathrm{n}^{\circ} 2^{\circ}, 3^{\circ}$ y $4^{\circ} \mathrm{LH}$, y concordantes $\mathrm{RH}$ ), deberán proceder de inmediato al levantamiento del embargo, o a la cancelación de la anotación que se hubiese extendido, al resultar ya ineficaz o inoperante su reclamación o anotación ${ }^{856}$.

\section{2.- LOS ACREEDORES PARTICULARES DEL SUCESOR} ANTE LA REPUDIACIÓN.

Diferente es el caso de los acreedores particulares del delado porque ellos, sin prejuicio de que, en cualquier caso, tienen el patrimonio personal de éste contra el que poder dirigirse para poder hacer efectivos sus derechos de crédito, su interés se centra ahora en relación a aquellos bienes, porción o cuota a que, en su caso, hubiese sido llamado su deudor a resultas de la oferta hereditaria que ha recibido.

Así, desde el punto de vista patrimonial, la declaración de repudio del delado cobra un especial relieve y trascendencia a los efectos de su solvencia para hacer frente al pago de sus propias deudas. Hasta este momento, los acreedores sólo tienen como principal y único recurso para obtener el cobro de los créditos de que sean titulares y ostenten contra su deudor, su patrimonio personal o particular, en base al principio de responsabilidad patrimonial universal que proclama el artículo 1911 CC, lo que, en todo caso, es seguro, sea cual fuere la decisión de su deudor. No obstante, la solvencia puede aumentar, o la insolvencia disminuir, si decide aceptar la herencia y ésta fuere beneficiosa, porque, si es damnosa o deficitaria, tal vez, más le interese a los acreedores que su deudor repudie dicha herencia para no empeorar su situación patrimonial.

${ }^{856}$ Vid: MANRESA: Op. cit.: Pág 442; GITRAMA: Op. cit.: Pág 302. 
De ahí el lógico interés de los acreedores en que su deudor acepte la herencia a que ha sido llamado para que los bienes, porción o cuota que le correspondan aumente su patrimonio y tener más bienes sobre los que poder hacer efectivos sus derechos de crédito ${ }^{857}$. En caso contrario, si decide repudiar, al no entrar esos bienes en su patrimonio, no se podrán dirigir contra ellos para hacer efectivos sus derechos de crédito. De ahí que, para ellos, dicha declaración supone, no ya solo una frustración de sus expectativas, sino un claro daño o perjuicio en sus intereses.

Y aquí surge uno de los debates que se ha venido planteando la doctrina acerca de cómo calificar lo que significa o supone para los acreedores la repudiación de la herencia por parte de su deudor. En este sentido se han vertido expresiones muy variadas diciendo que es un acto que para ellos implica una disminución de la solvencia, un acto de empobrecimiento, una falta de enriquecimiento, incluso, un acto en fraude de acreedores.

A nuestro juicio, su situación, una vez repudiada la herencia, en relación a la que tenían con anterioridad a la apertura de la sucesión, no empeora, no se hace de peor condición, en el sentido de que los créditos que tienen contra él permanece invariables porque su valor no se modifica, como tampoco hay pérdidas, ni sufre alteración ni merma alguna el patrimonio del deudor ya que no hay salida de bienes, pero sí es cierto que pierden la oportunidad de que sea más favorable su situación al no aumentar la solvencia del deudor, o no disminuir su insolvencia, que se habría producido caso de haber aceptado.

Por ello, lo que para ellos, en nuestra opinión, produce la repudiación de la herencia es la pérdida de una oportunidad de que mejoren sus expectativas de poder hacer efectivos sus respectivos derechos de crédito porque el patrimonio de su deudor, que es la principal, además de la única fuente a la que pueden recurrir para obtener el cobro de los mismos, se ve privado de un ingreso que daría lugar a que dicho patrimonio se enriqueciera y viese aumentada su solvencia, o disminuida la insolvencia. De ahí que, la repudiación, desde el punto de vista del delado, suponga, como ya calificó PAULO, una omissio adquirendi $(\mathrm{D} 5,16,28)$-quien cita precisamente como ejemplo de ella, la repudiación de la herencia-, una falta de adquisición, la

${ }^{857}$ No obstante, aun en el caso de aceptación, ésta puede resultar perjudicial para sus intereses si fuere pura y simple, dado que la responsabilidad que se asume frente al pago de las deudas de la herencia es ilimitada (art. 1003 CC), y se diere la circunstancia de que el deudor se encontrare en una situación de precariedad económica o de insolvencia patrimonial, o se tratare de una herencia gravosa, porque ello, no solo perjudicaría o agravaría su situación, sino que dificultaría, incluso podría hacer imposible, el pago de dichos créditos. Ante ello, los acreedores tendrán a su favor la acción revocatoria o pauliana, ex artículos 1111 y 1291 y ss CC. 
pérdida de una oportunidad de poder adquirir, de ver aumentado su patrimonio, mas no una disminución del mismo por cuanto no hay enajenación, cesión o transmisión de bienes, como tampoco, salida de los mismos de dicho patrimonio.

Ahora bien, no creemos que sea correcto decir que, como consecuencia de la repudiación, disminuya la solvencia del deudor porque ésta permanece inalterable ya que sigue siendo exactamente la misma que tenía antes de repudiar, aunque, eso sí, no es menos cierto que podría haber aumentado o disminuido la insolvencia en que se encontrase, caso de haber aceptado si la herencia fuese beneficiosa. Como tampoco se puede hablar de una disminución del patrimonio del deudor porque no hay, en modo alguno, salida ni pérdida de bienes del mismo, ni aumenta el pasivo ya que no se contraen nuevas deudas, ni los créditos de los acreedores aumentan de valor, como tampoco disminuyen.

Tampoco se puede decir, a nuestro juicio, que la repudiación dé lugar a un empobrecimiento de los acreedores porque seguirán en la misma situación, condición o estado que si su deudor no hubiese recibido la oferta sucesoria. Será exactamente la misma que antes de abrirse la herencia, si bien, lo único cierto, real y verdadero es que la oferta que ha recibido, de la que nacía la expectativa de ver mejoradas las posibilidades de cobrar sus derechos de crédito, ha desaparecido como consecuencia de la repudiación. Pero, rechazar la oferta sucesoria, entendemos que no significa que los acreedores sean más pobres, ni que estén en peor situación que antes. Simplemente, no ha mejorado su situación pudiendo haberlo hecho, lo que, en realidad, supone para ellos, de forma palpable y evidente, un claro daño o perjuicio.

No obstante, DíEZ-PICAZO ${ }^{858}$, dado que la renuncia no es otra cosa, como él manifiesta, que, "la declaración de voluntad de no adquirir", o "una falta de adquisición", se plantea la cuestión de, "hasta qué punto pueden los acreedores sentirse agraviados o perjudicados por el hecho de que su deudor no adquiera algo que pudo adquirir", o que no quiso adquirir, añadimos nosotros. Ante ello, entiende legítimo que, "los acreedores puedan reaccionar contra una merma de su garantía patrimonial o enajenación fraudulenta (acción rescisoria), o frente a la inercia del deudor que deje de ejercitar sus derechos (acción subrogatoria). Pero, ¿pueden sentirse perjudicados por el hecho de que el deudor declare su voluntad de no adquirir?. Incluso, ¿tiene el deudor la obligación de adquirir?, o derecho el acreedor a que el deudor adquiera?".

858 “La aceptación de la herencia por los acreedores del heredero”. ADC. XII 1. 1959. Pág 168. 
Según ya hemos comentado en otro momento ${ }^{859}$, con anterioridad al ejercicio del ius delationis, dado el carácter personal de éste, los acreedores sólo tienen a su favor la posibilidad de poder acudir a la interpelación del artículo 1005 del Código Civil, pasados nueve días desde el fallecimiento del causante, en el supuesto de que su deudor no haya ejercido aun el ius delationis, para tratar de obtener de él un rápido pronunciamiento acerca de la delación sucesoria que ha recibido y evitar así, además, no solo que su silencio se pueda prolongar de forma indefinida en el tiempo, sino que la situación de incertidumbre y de inseguridad que dicho silencio genera, sea lo menos duradera posible y sepan a qué atenerse. Mas, ello no significa que puedan obtener de él la aceptación de la herencia, o exigirla judicialmente, habida cuenta de que la declaración del delado es, en cualquier caso, un acto libre y voluntario (arts 988 y 997 CC) y él podrá, en consecuencia, repudiar, o aceptar la herencia.

Y después, una vez que el sucesor ha repudiado la herencia a que ha sido llamado, a diferencia de los acreedores de ésta que no pueden hacer nada ante tal declaración, como vimos antes, los particulares del repudiante, con el objeto de reparar, en la medida de lo posible, la situación de desprotección, desamparo, más bien, daño o perjuicio, que el repudio les hubiere causado, el Código Civil sí que los protege sancionando a su favor en el artículo 1001 una norma, de cuyo examen nos ocuparemos a continuación, en virtud de la cual se les faculta para poder dirigirse después al Juez al efecto de que los autorice, como dice el precepto, a "aceptar la herencia en nombre de su deudor", de tal manera que se les va a facultar para poder intervenir en el proceso sucesorio y actuar, eso sí, únicamente sobre aquellos bienes, porción o cuota que, caso de haber aceptado, le hubiesen correspondido a su deudor, si bien, solo en lo justo y necesario, con el límite "en cuanto baste para cubrir el importe de sus créditos". El resto, o exceso, no les pertenece a ellos, ni a su deudor, por cuanto él ya repudió y la repudiación es definitiva.

\footnotetext{
${ }^{859}$ Ver en el capítulo cuarto, punto número 3-2, donde tratamos la cuestión relativa a la posición de los acreedores en el ejercicio de la delación.
} 


\section{3.- EXAMEN DEL ARTÍCULO 1001 DEL CODIGO CIVIL $^{860}$.}

Dada la situación de ajenidad en que se encuentran los acreedores del sucesor que ha repudiado la herencia respecto de los bienes que éste fue llamado que, ya desde antiguo, y ante el perjuicio que dicha decisión les causaba, se arbitró algún recurso para proceder contra los mismos y tratar de que, en la medida de lo posible, pudiesen cobrar, si no todo, si, al menos, parte del importe de los derechos de crédito que tuvieren contra él.

Nace así, aunque de forma confusa como ahora veremos al examinar sus orígenes, la norma contenida en este precepto que sanciona a favor de estos acreedores una acción que plantea no pocas dudas, problemas e interrogantes porque, siendo sujetos totalmente extraños a la herencia, van a poder actuar a través de la misma, con autorización judicial, sobre los bienes a que fue llamado su deudor. No obstante, de forma excepcional, ya que no pueden ser objeto de ejecución por su parte al no ser de su deudor porque no han entrado en su patrimonio al haberlos rechazado a través de la repudiación, por lo que no tienen ningún derecho sobre los mismos. Si bien, a través de esta acción, van a poder proceder sobre ellos cumpliendo unos requisitos y limitaciones para hacer efectivo su derecho de crédito.

Así, dada la literalidad del precepto, uno de los interrogantes que ya a priori plantea y luego analizaremos, es qué significa esa "aceptación" de la herencia por los acreedores, porque ellos no tienen esta facultad, además de que el ius delationis ya se ha ejercitado y extinguido a resultas de la repudiación. A ello se añade la circunstancia de que el ejercicio de esta acción no anula ni deja sin efecto la declaración de repudio, como tampoco se les llega a considerar como sucesores del causante.

Ello ha dado lugar a que, por parte de la doctrina, con peor o mejor fortuna, se haya dicho acerca de esta acción que se trata de una "aceptación de la herencia por los acreedores del heredero" (LACRUZ y SANCHO ${ }^{861}$; DÍEZ-PICAZO ${ }^{862}$; CRISTOBAL

${ }^{860}$ En otras leyes sucesorias autonómicas:

- Aragón (art. 353 CDFA),

- Cataluña (art. 461-7, Ley 10/2008, sobre Sucesiones, con precedente en el artículo 23 del Código de sucesiones de 1991). Sobre el examen de dicho artículo 23, vid: FLORENSA I TOMÁS, C: "La naturaleza del procedimiento previsto en los artículos 1001 del Código Civil y 23 del Codi de Successions per Causa de Mort en el Dret Civil de Catalunya: la legitimación subrogatoria concedida al acreedor del repudiante" (I y II). Revista LA LEY. Año XXI. Números 5182 y 5183, de 13 y 14 de noviembre de 2000. PUIG FERRIOL: "Les bases del nou Codi de Successions", en Setenes Jornades de Dret Català a Tossa. El nou dret successori de Catalunya, Barcelona, 1994. Pág 19.

${ }^{861}$ Elementos de derecho civil. T V. Cit: Pág 74

862 "La aceptación de la herencia .............. Cit: Pág 127. 
MONTES ${ }^{863}$; BAYOD LOPEZ ${ }^{864}$ ), que es la denominación más comúnmente aceptada, y que es, a nuestro juicio, no ya insólita, sino inadmisible, desde un punto de vista técnico y jurídico, por cuanto los acreedores son sujetos extraños a la sucesión y no están, en modo alguno, facultados para aceptar, en puridad y en sentido estricto, la herencia de su deudor por cuanto es un derecho de ejercicio es personalísimo por éste, además de que el ius delationis ya se ejerció por parte del deudor. También se habla de "repudiación de la herencia en perjuicio de los acreedores". Incluso, se ha llegado a decir que se trata de una "aceptacio ficta" de la herencia ${ }^{865}$.

Por otro lado, se trata de un artículo que, en opinión de DíEZ-PICAZO ${ }^{866}$, plantea uno de los problemas más interesantes y curiosos de todo el derecho civil, "porque en él entran en colisión los principios que rigen la sucesión hereditaria con los que dominan el derecho patrimonial de bienes ya que, por un lado, el artículo 988 CC sienta el principio general de que la aceptación y la repudiación son actos enteramente voluntarios y libres, actos que sólo son impugnables cuando adolezcan de algunos de los vicios que anulan el consentimiento o apareciese un testamento desconocido (art. 997 CC) y, por otro lado, está el artículo 1911 CC que afecta a todos los bienes presentes y futuros del deudor, de entre los cuales parece, en principio, encontrarse la herencia que se le defiere, al cumplimiento de sus obligaciones". "De esta colisión surgió el artículo 1001 del Código, donde se cruzan las normas básicas del derecho de obligaciones, que marcan la amplitud y extensión del poder de los acreedores, con las normas estrictas el derecho sucesorio".

\section{3-1.- Origen y precedentes. ${ }^{867}$}

Es opinión generalizada en la doctrina, por todos DíEZ-PICAZO ${ }^{868}$, que es dudoso que dicho precepto tenga sus antecedentes históricos en el Derecho Romano,

863 "Naturaleza jurídica de la aceptación por los acreedores de la herencia renunciada en su perjuicio por el deudor”. En, Estudios de Derecho Civil en honor del profesor Castán Tobeñas. T IV. Pamplona 1969. Pág 255 y ss.

864 Así ya lo expresa en el título de su obra, La llamada aceptación de la herencia por los acreedores. Artículo 1001 del Código Civil. Ed Tecnos. Madrid. 1998.

${ }^{865}$ Res DGRN de 2 de diciembre de 1892; SAP de Tarragona (Sección 3a), de 8 de junio de 1999, AC 1999/6667.

866 “La aceptación de la herencia ............”. Cit: Pág 128.

${ }^{867}$ Vid, entre otros, acerca de ello:

BAYOD LOPEZ: Op. cit.: Pág 25 y ss; DÍEZ-PICAZO: “La aceptación de la herencia .......... Cit: Pág 131 y ss; FERRI: Rinunzia e rifiuto nel diritto privato. Cit: Pág 19 y ss; FLORENSA I TOMÁS: La naturaleza del procedimiento .....; GITRAMA: Op. cit.: Pág 231 y ss.; JORDANO FRAGA: Los acreedores del llamado a una sucesión "mortis causa”, ante el ejercicio por éste del "ius delationis". Cit Pág 150 y ss; MANRESA y NAVARRO: Op. cit.: Pág 411.

868 “La aceptación de la herencia .............”. Cit: Pág 131 y ss. 
ya que sus orígenes son confusos, al igual que sucede con sus concordantes en los Códigos civiles, francés (art. 779), e italiano (art. 524).

En el sistema sucesorio del Derecho Romano, los acreedores, en el supuesto de que su deudor repudiare la herencia a que había sido llamado, estaban totalmente desprotegidos ya que el repudio era prácticamente inatacable. La repudiación de la herencia se consideraba como una omissio adquirendi ${ }^{869}$, y no una disminución patrimonial, de lo que se derivaba la consecuencia de que no podían impugnar su decisión, como tampoco podían recurrir al medio de defensa que les concedió el Pretor por los actos perjudiciales de sus deudores cual fue la acción revocatoria por fraude, a través de la cual podían, en el plazo de un año, atacar los actos que su deudor hubiere realizado en fraude de su derecho ("quae in fraudem creditorum facta sunt ut restituantur" -D 42, 8, 4-). En el Derecho Romano clásico, este comportamiento de los deudores se vio mitigado por el interdicto fraudatorio, de naturaleza puramente restitutoria que, junto a otras acciones, como fueron, la restitutio in integrum y la actio ex delicto, en el Derecho Justinianeo, se llegaron a configurar ya en el Derecho de bizancio en lo que hoy conocemos como, acción pauliana (D'ORS ${ }^{870}$ ).

Así, para ULPIANO, que recoge el pensamiento de la época, el deudor que renunciaba a una herencia, no perjudicaba a sus acreedores, sí, en cambio, el que disminuía su patrimonio: "proinde et qui repudiavit hereditatem vel legitimam, vel testamentariam, non est in ea causa, ut huic, edicto locum faciat; noluit enim adquirere, non suum propium patrimonium deminuit" (D. 42, 8, 6, 2), y "non fraudantur creditores cum quid non adquiritur a debitore, sed cum quid bonis diminuitur" (D 50, 17, 134 y D. 50, 16, 28 -no defrauda a sus acreedores el que no adquiere, sino el que disminuye sus propios bienes-). Igualmente, PAULO por su parte, señala que, el que no usa la ocasión de adquirir, no se entiende que enajena. Omisión de adquirir que, al no ser constitutiva de fraude por parte del deudor frente a sus acreedores, daba lugar a que el edicto del Pretor aquí no se pudiese aplicar porque exigía que se produjese una disminución patrimonial que reuniese los siguientes requisitos: el "eventus damni", el "consilium fraudis" y la "scientia fraudis", que, al no darse en el caso de repudiación, daba lugar a que esta actuación, o este supuesto, no recayese dentro del ámbito de aplicación del edicto, lo que hacía imposible que la repudiación de la herencia pudiese ser atacada a través del mismo por parte de los acreedores.

${ }^{869}$ PAULO (D. 5, 16, 28): “qui occassione adquirendi non utitur, non intelligitur alienare” -el que no usa de la ocasión de adquirir no se entiende que enajena-.

870 "El interdicto fraudatorio en el derecho romano clásico”. CSIC. Roma-Madrid. 1974. Pags 179, 180 у 189. 
No obstante, lo anterior se consideraba aplicable, tal y como apunta ROSSI ${ }^{871}$ citado por BAYOD ${ }^{872}$, sólo respecto de los herederos voluntarios quienes sí tuvieron la posibilidad de poder repudiar. No así en el caso de los herederos necesarios, o suus heres, quienes no podían repudiar y sucedían obligatoria e inexcusablemente al causante ya que adquirían la herencia ipso iure.

Sin embargo, señala ROSSI ${ }^{873}$, que, ya en el Derecho Romano se previó la posibilidad de poder atacar la renuncia a la herencia cuando ello se utilizaba como un medio de fraude contra los acreedores. En igual sentido, señala DíEZ-PICAZO ${ }^{874}$ que, ya los primeros comentaristas de los textos justinianeos, comienzan a sentar las bases para modificar el rigor del principio de inatacabilidad de la renuncia hecha en perjuicio de los acreedores al poner en duda la justificación de su aplicación en determinados casos concretos, siendo la primera excepción la cuota de legítima. Se consideró que su renuncia, al ser deferida por la ley con independencia de la voluntad del testador, no era una omissio adquirendi, y no era posible renunciar porque ésta se debe al hijo no sólo al tiempo de la muerte del padre, sino aun antes, en vida de aquel, de tal manera que no puede decirse que el dominio sea adquirido ex novo por el hijo, sino como continuación por la muerte del padre.

Más tarde, por influencia del Derecho Canónico, y con apoyo en criterios morales y éticos que incluye una condena religiosa para el caso de que se produjese tal perjuicio a los acreedores, se parte de la consideración de que el deudor debe actuar de buena fe en el cumplimiento de sus obligaciones y no puede perjudicar con su actuación el derecho de los acreedores, por lo que se entiende que cuando la repudiación de la herencia causa un daño a éstos, constituye un acto injusto constitutivo de pecado mortal, que atenta contra las concepciones divinas (BAYOD ${ }^{875}$ ).

A ello se le suman después otras circunstancias, decisivas según apunta DíEZPICAZO ${ }^{876}$ : por un lado, el florecimiento comercial de las ciudades italianas y francesas de la baja Edad Media que impone, no sólo nuevos usos en el tráfico jurídico y una nueva literatura, sino también la necesidad ineludible de dotar al crédito en la actividad mercantil, de una protección superior a la que representan las viejas reglas romanas del fraude de acreedores, y, de otra parte, la penetración de los

\footnotetext{
${ }^{871}$ Della renuncia alla ereditá in danno dei creditori. Pisa. 1872. Págs 13 y 14.

872 Op. cit.: Págs 29 y 30.

873 Op. cit.: Págs 7 y 8.

874 “La aceptación de la herencia ............”. Cit: Pág 133.

875 Op. cit.: Pág 32.

876 “La aceptación de la herencia ............”. Cit: Pág 134.
} 
principios germánicos en materia de adquisición de herencia que, al consagrar la saisine hereditaria y el principio de adquisición ex lege de la herencia desde el momento de la muerte del causante, permiten considerar la renuncia, frente a los acreedores del renunciante al menos, como una verdadera enajenación sometida por ello a la acción de impugnación por fraude de acreedores. Éste fue precisamente, apunta BAYOD ${ }^{877}$, uno de los factores que más influyeron en el cambio de planteamiento para poder atacar la repudiación de la herencia: bastaba con considerar que sí era una disminución patrimonial y no una mera omisión de adquisición, lo cual se conseguía concibiendo un sistema sucesorio en el que la herencia se adquiriese ipso iure, de manera que la repudiación pudiera ser considerada como una disminución patrimonial susceptible de ser atacada a través de la acción pauliana.

En la posterior evolución del derecho de crédito, se plantea la necesidad, y exigencia, de su protección, con la finalidad de otorgarle una mayor garantía en cuanto a su cobro, ante lo que surge, por un lado, la regla de que se faculte a los acreedores para que se puedan colocar en el lugar de su deudor al objeto de que ejerciten todos los derechos y acciones de que éste sea titular en el caso de que no lo hiciere voluntariamente con excepción de los que sean inherentes a su persona, lo que da lugar a la aparición de la acción subrogatoria y, por otro, se les faculta para impugnar los actos que el deudor hubiere realizado en fraude de su derecho, con lo que se aumenta la garantía del crédito, apareciendo así la acción revocatoria o pauliana.

Todo ello influye en el derecho estatutario y en el droit coutumier francés en el que se llega a consagrar un principio radicalmente distinto del que se había recogido en el Corpus luris Civili, en virtud del cual se faculta a los acreedores para llegar a aceptar la herencia de su deudor en el caso de que éste la hubiere rechazado en su perjuicio (DÍEZ-PICAZO ${ }^{878}$ ), regla que queda después reflejada en la redacción de la Coutume de Normandía del año 1583, cuyo artículo 278 cristaliza más tarde, con precedente en la Ordenanza de 1747 , en el antigüo artículo 788 , actual $779^{879}$, del

${ }^{877}$ Op. cit.: Pág 26.

878 "La aceptación de la herencia .”. Cit: Pág 135.

${ }^{879}$ De nueva redacción por la Ley 2006-728, de 23 de junio: “Les créanciers personnels de celui qui s'abstient d'accepter une succession ou qui renonce à une succession au préjudice de leurs droits peuvent être autorisés en justice à accepter la succession du chef de leur débiteur, en son lieu et place. L'acceptation n'a lieu qu'en faveur de ces créanciers et jusqu'à concurrence de leurs créances. Elle ne produit pas d'autre effet à l'égard de l'héritier". -Los acreedores personales del que se abstiene de aceptar una sucesión o que renuncia a una sucesión en perjuicio de sus derechos pueden ser autorizados por el juez para aceptar la herencia en su nombre y en su lugar. La aceptación no ha lugar más que a favor de los acreedores y hasta donde alcance el importe de sus créditos. No producirá ningún otro efecto respecto al heredero-. 
Code de Napoleón que sirvió de modelo a los más importantes Códigos latinos del siglos XIX, entre ellos, el actual español de 1889.

Dicho artículo se constituye en el antecedente inmediato de nuestro actual 1111 del Código Civil, el cual tipifica las dos acciones, subrogatoria y revocatoria o pauliana, desarrollada ésta después en los artículos 1290 y siguientes del mismo texto legal, con fundamento en la rescisión del acto fraudulento (art. 1291.3. ${ }^{\circ}$ CC).

También influyeron en la redacción del mismo, el artículo 949 del Código civil italiano de 1865 -concordante con él, aunque con alguna modificación, el artículo 524 del actual Código de 1942-, si bien, le separan algunas diferencias, y, sobre todo, el artículo $831^{880}$ del Proyecto de 1851, que es, en los textos de nuestro derecho histórico, su precedente más inmediato. Después se mantuvo en el artículo 1013 del anteproyecto de 1881-1882, y de aquí pasó definitivamente, casi con la misma redacción, al artículo 1001 del Código Civil de 1889, cuyo tenor se mantiene invariable desde entonces hasta el día de hoy.

No obstante, la norma contenida en el artículo 1001 del Código Civil plantea, además de las ya apuntadas, otras muchas cuestiones, como es el problema de su fundamento y naturaleza dando lugar a muy distintas posiciones dentro de la doctrina dada la proximidad que tiene respecto a las acciones subrogatoria y pauliana con las que une una gran similitud o semejanza. Pero, esta misma proximidad, tiene como contrapunto la circunstancia, apunta BAYOD ${ }^{881}$, de que el artículo 1001 se traspasó mal del derecho francés del que se copió casi de forma literal. Es una norma que se importó en los mismos términos en que estaba en él redactada cuando ocurre que el mecanismo que encierra no se corresponde, ni con el sistema sucesorio español, ni con los principios de nuestro derecho patrimonial sobre los que se fundamenta la salvaguarda de los créditos.

La norma del actual artículo 779 del Code, antigüo 788, además de que está perfectamente encajada y guarda una total armonía con el sistema sucesorio francés, inspirado en los principios del derecho germánico y de adquisición ipso iure, funciona de acuerdo con los principios que informan la acción pauliana de la que viene a ser, en realidad, una aplicación concreta de la misma, porque, al formar los bienes de la

880 Según su tenor: "Si el heredero, aun sin mediar precio, repudia en fraude de los acreedores, pueden éstos pedir al Juez que les autorice para aceptar la herencia a beneficio de inventario. En este caso, la aceptación solo aprovechará a los acreedores para el pago de sus créditos, pero no al heredero que repudió”.

${ }^{881}$ Op. cit: Pág 75. 
herencia parte del patrimonio del deudor-renunciante, aunque sea de manera temporal (actual artículo 807 Code $^{882}$ ), es lo que permite a los acreedores, a través de dicha norma, actuar contra los mismos para proceder al cobro de sus créditos.

No sucede, o no puede suceder, lo mismo en el derecho español porque, partiendo de la tesis de que en él rige el sistema romano de adquisición de la herencia, los bienes de ésta sólo forman parte del patrimonio del sucesor una vez que se ha producido la aceptación. En tanto en cuanto ésta no se produzca, los bienes a que fue llamado no entran en su patrimonio y, por consiguiente, no son suyos. Luego, los acreedores no pueden hasta entonces actuar contra los mismos. Mientras que, si se produce la repudiación, los bienes no llegan a ser nunca del delado-deudor porque no los adquiere y no pasan a formar parte de su patrimonio, por lo que, en consecuencia, los acreedores no podrán proceder contra ellos para el cobro de sus créditos. Y ocurre que, el artículo 1001 permite, incluso podríamos decir, de forma insólita y sorpendente, que, pese a ello, después de haberse producido el repudio de la herencia por parte del delado-deudor, los acreedores sí puedan proceder contra los bienes de la herencia que le hubiesen correspondido caso de haber aceptado. Bienes que no son del deudor y sobre los que los acreedores, por derecho propio, no tienen ningún derecho sobre los mismos. Lo cual no deja de ser algo excepcional, incluso anómalo, a la vez que un gran contrasentido, incluso, una gran paradoja.

En conclusión, la norma del artículo 1001 CC, dado como se ha traspasado del derecho francés al español, sin perjuicio de sea, desde luego, loable la intención de los redactores del Código -cual fue, proteger a los acreedores del deudor cuando éste repudiare la herencia a que fue llamado y tal acto les perjudicare-, está en abierta contradicción con nuestro sistema sucesorio de adquisición de la herencia y los principios que informan nuestro derecho patrimonial en el ámbito de la protección del derecho de crédito, así como los mecanismos de protección que encierran las acciones subrogatoria y revocatoria o pauliana, así como los presupuestos que las informan, lo que ha dado lugar a que se hayan producido algunos inconvenientes y problemas, tanto en lo que se refiere a la fundamentación y naturaleza de la acción concedida a los acreedores, como en su aplicación.

882 Sobre la base de este precepto (antigüo artículo 790), fundamenta la doctrina francesa la posibilidad que tienen los acreedores, utilizando la vía subrogatoria, de ejercitar el derecho, de aceptar, que aquí le asiste al heredero repudiante. Así el repudiante será nuevamente heredero y los acreedores podrán cobrar sus créditos con cargo a los bienes que reciba su deudor de la herencia.

Y si no hubiese posibilidad de aplicar esta norma porque ya han aceptado los demás herederos, es cuando se abre paso para los acreedores la norma del actual artículo 779, que no deja de ser una aplicación de la acción pauliana. 


\section{3-2.- Fundamento de la "aceptación".}

Uno de los grandes problemas que plantea el precepto, es el significado que tiene, o habría que atribuirle, a la expresión, "aceptación", de la herencia por parte de los acreedores. Lo que ha dado lugar a numerosos interrogates: ¿tiene el mismo valor que la declaración que realiza el delado en virtud del ejercicio del ius delationis?, ¿cómo se puede hacer esta declaración que, no solo es personal del propio delado y respecto de la cual sólo, única y exclusivamente él está legitimado activamente para su ejercicio, sino que, además, el derecho en virtud de la cual se puede manifestar, el ius delationis, ya se ha extinguido a resultas precisamente de su ejercicio por el repudio manifestado por el deudor?. O si, como dice el precepto, "aceptan en nombre de aquel" -de su deudor-, ¿cómo puede ser cuando resulta que los acreedores no son, ni sus representantes legales $y$, menos aun, voluntarios?. O también, ¿cómo pueden llegar a actuar sobre unos bienes que no son de su deudor por cuanto, a resultas de la repudiación, él los ha rechazado, luego, no han llegado a entrar en su patrimonio y, por consiguiente, no pueden ser objeto de ejecución para el pago de sus créditos?.

Tratando de dar respuesta a la cuestión planteada inicialmente, como tesis de principio, partimos de la premisa, ya apuntada, de que el ius delationis en su ejercicio es personalísimo ${ }^{883}$ por parte de quien ha sido llamado a la herencia, de tal manera que sólo el delado es quien está legitimado para decir si acepta o repudia la delación que le ha sido deferida, ya sea por el testador o por la ley. Luego, sus acreedores no están, en modo alguno, legitimados para su ejercicio, como tampoco por vía de la representación al no ser sus representantes, ni legales, ni voluntarios. De ahí que, en un sentido propio y jurídico, no puedan "aceptar" la herencia en los mismos términos que lo haría el delado en virtud del ejercicio del ius delationis.

En este sentido, pese a que el artículo 1001 CC hable de aceptación, podemos decir en el sentido propio del término, que no se trata realmente de que los acreedores acepten la herencia a que ha sido llamado su deudor en los mismos términos y con el mismo significado jurídico que lo haría éste, sino que, en nuestro opinión, en realidad, se les atribuye la facultad, sin borrar o sin dejar sin efecto la repudiación ya realizada por su deudor, de poder dirigirse, previa autorización judicial, contra aquellos bienes de la herencia que a éste le hubiese correspondido, caso de haber aceptado, y proceder contra ellos, si bien, con el límite de sólo hasta donde alcance el importe de los créditos de que ellos sean titulares contra él en el momento de su ejercicio.

${ }^{883}$ Acerca de esta característica de la declaración, véase el punto número 3 del capítulo cuarto, al que nos remitimos. 
A nuestro juicio, se trata de la atribución ex lege, por vía subrogatoria -lo que no quiere decir que estemos ante una subrogación-, de un derecho que, en su ejercicio, es personalísimo del deudor y, además, ya extinguido a resultas de la declaración de repudio. Pero, además, el otorgamiento de esta prerrogativa a los acreedores es algo verdaderamente singular, anómalo y excepcional porque crea una situación que es la antítesis a la repudiación porque los efectos de su ejercicio se asemejan a los de la aceptación de la herencia, en el sentido de que pueden proceder contra los bienes como si efectivamente hubiesen entrado en el patrimonio del deudor a resultas de la aceptación. De ahí que, el ejercicio de esta acción va totalmente contra natura de la declaración de repudio, y supone, sino una excepcionalidad, sí alteración o trastueque del sentido unidireccional, irreversible e irrevocable que caracteriza y es identificativo el ius delationis en su ejercicio.

Aun así, al ejercitar la acción, cabe plantearse si ello significa que aceptan en virtud de un derecho propio, o si aceptan ejercitando un derecho de su deudor. Del tenor literal del artículo, más bien tendríamos que inclinarnos por la segunda opción, porque dice ".... aceptarla en nombre de aquel". Luego, nos está dando a entender que no es un derecho suyo, sino de su deudor. Obviamente, los acreedores, como antes hemos manifestado, no tienen ningún derecho propio sobre los bienes de la herencia. De ahí la proximidad que, en principio, parece que ofrece el ejercicio de esta acción en relación a la subrogatoria del artículo 1111 CC. Sin embargo, entendemos que no se puede decir que estemos ante una verdadera y propia aceptación, en el sentido estricto y propio del término, porque, por un lado, sólo el sucesor es quien está legitimado activamente para el ejercicio del ius delationis y, por otro, tampoco se puede decir que estén ejercitando un derecho de su deudor por la sencilla razón de que el ius delationis ya no existe al haberse extinguido a resultas de su ejercicio al repudiar la herencia, por lo que difícilmente se puede ejercer. De ahí que, a nuestro juicio, sea una incorrección decir que los acreedores ejercen un derecho de su deudor.

Por otro lado, tampoco se alcanza a comprender que acepten "en nombre de él" porque, no son, ni sus representantes legales y, menos aun, voluntarios. Sí podrán, a través de la acción subrogatoria, ejercer cualquier otro derecho o acción que sí exista en su patrimonio y del que sea titular su deudor, pero en el caso del ius delationis, no, por cuanto no solo es suyo personal, sino que, además, como decimos, se extinguió como consecuencia de su ejercicio a resultas de la repudiación. Por lo que no se podrá decir que los acreedores, cuando ejerciten la acción del artículo 1001, se estén subrogando en un derecho de su deudor. Se podría incluso hablar de una forma de 
representación, indirecta, que no directa, del sucesor, pero es una tesis descartable porque sus presupuestos o requisitos, tanto en ésta, la indirecta, como en la directa, ya sea legal o voluntaria, no se cumplen. También se ha llegado a decir que se trata de una gestión de negocios ajenos sin mandato, pero tampoco se da al tenor del artículo 1888 CC. En este sentido, para DÍEZ-PICAZO ${ }^{884}$, "los acreedores, no ejercitan un derecho de su deudor, sino un derecho que la ley les atribuye directamente. Actúan iure et nomine proprio".

A lo anterior, hemos de añadir que, a resultas de dicha "aceptación", ni el sucesor se convierte en heredero del causante por cuanto su decisión de repudiación es irrevocable e insustituible, como tampoco los acreedores "suceden" al causante.

En otro orden de argumentos, DíEZ-PICAZO ${ }^{885}$, quien se constituye en eco del sentir mayoritario de la doctrina, señala que el fundamento de esta acción, al igual que sucede en todos aquellos preceptos que otorgan a los acreedores en garantía de la realización de sus créditos alguna facultad sobre el patrimonio del deudor ${ }^{886}$, está en el principio de responsabilidad patrimonial universal consagrado en el artículo 1911 del Código Civil. Después, junto a él, indica otros dos principios: el patrimonio del deudor como garantía de los acreedores y, el poder de los acreedores sobre el patrimonio del deudor, dentro del cual estarían comprendidas dos facultades que permiten a los acreedores intervenir en él, que son: la de reclamar la rescisión de los actos realizados en fraude de su derecho (acción revocatoria o pauliana) y, la de ejercitar los derechos y acciones que competen al deudor (acción subrogatoria).

Pero, junto a tales principios de origen patrimonial sobre los que se sustenta el ejercicio de tal acción, hay otros, básicos y ordenadores de nuestro ordenamiento, apuntados por BAYOD ${ }^{887}$, respecto de los que se plantea la cuestión de si son también fundamento de la acción contenida en el artículo 1001 CC: la buena fe en el ejercicio de los derechos (a), la renuncia a los derechos que sanciona el artículo 6.2 del Código Civil (b), y equidad (c). Veamos cada uno de ellos.

884 "La aceptación de la herencia

885 "La aceptación de la herencia

.”. Cit: Pág 172.

.”. Cit: Pág 137 y ss.

${ }^{886}$ Así sucede en otros casos como son los artículos: 643 (a propósito del pago de deudas por parte del donatario); 1111 (en el que se consagran las acciones subrogatoria y revocatoria o pauliana); 1297 (en la celebración de contratos fraudulentos); o 1937 (que les faculta para beneficiarse de la prescripción a pesar de la renuncia expresa o tácita del deudor).

${ }^{887}$ Op. cit: Pág 42 y ss. 
a) Buena fe en el ejercicio de los derechos.

De la buena fe, principio sancionado con carácter general en el ejercicio de los derechos (art. 7,1 $\mathrm{CC}$ ), de forma particular, en el cumplimiento de las obligaciones y contratos (art. $1258 \mathrm{CC})^{888}$, y que ha de presidir la actuación del sucesor-deudor, se desprende la consecuencia de que su comportamiento ha de ser consecuente y leal con el compromiso que él asumió en su momento frente al acreedor cuando contrajo la deuda.

De ello se deriva, a su vez, una doble consecuencia: la responsabilidad de hacer frente al pago de la misma y sufrir los efectos que del incumplimiento se puedan derivar. Dicho con otras palabras, ello se traduce, aplicado aquí al caso concreto que nos ocupa, en que, el deudor, pese al carácter libre de la delación en su ejercicio, tendría la obligación de aceptar la herencia porque, en el cumplimiento de toda obligación asume, como dice RIVERO HERNANDEZ ${ }^{889}$, "el deber genérico de mantener su propia solvencia: el llamado tiene con el ius delationis la posibilidad inmediata de conseguir la herencia, y si está cargado de deudas no puede despreciarla porque ha de respetar el interés de sus acreedores. Éstos, a su vez, deben poder impedir los efectos dañosos (para ellos) de una renuncia que, al provenir de un insolvente, fácilmente puede ocultar un acuerdo entre éste y los herederos de ulterior grado para sustraer el caudal relicto al pago de las deudas". También, en igual sentido, DíEZ-PICAZO ${ }^{890}$. Deber que, como dice BAYOD ${ }^{891}$, no es más que una consecuencia de la aplicación del principio de buena fe "que ha de ser la base de todos los actos del deudor".

${ }^{888}$ Ello obliga "al sujeto de derecho en general y al contratante en particular al cumplimiento de las reglas de conducta insitas en la ética social vigente y que normalmente vienen significadas por los valores de la honradez, corrección, lealtad, fidelidad a la palabra dada y a la conducta seguida" (STS de 26 de enero de 1980, RJ 167), y "como principio general del derecho, ha de informar todo contrato y obliga a un comportamiento humano objetivamente justo, leal, honrado y lógico en el sentido de estar a las consecuencias de todo pacto libremente asumido, sin frustrar la vocación o llamada que el mismo contiene a su cumplimiento, de forma que quien contrata u oferta contratar (precontrato) queda obligado, no sólo a lo que se expresa de modo literal, sino también a sus derivaciones naturales; así, quien contrata o emite un consentimiento cual el promitente u oferente queda obligado, por un principio de normalidad instaurado en el art. 1258 del Código Civil, a todas las consecuencias que, según la manifestación de voluntad y su naturaleza, sean conformes a la buena fe, al uso y a la Ley ........ y que la buena fe de este artículo no se refiere a la buena fe subjetiva (creencia, situación psicológica), sino a la objetiva (comportamiento honrado, justo...)" (SSTS de 8 de julio de 1981, RJ 3053; 21 de septiembre de 1987, RJ 6186; 22 de octubre de 1991, RJ 7234; 26 de octubre de 1995, RJ 8349; 2 de octubre de 2000, RJ 8131).

\footnotetext{
${ }^{889}$ Elementos de Derecho Civil. T V. Cit: Pág 83.

890 “La aceptación de la herencia ........”. Cit: Pág 169.

${ }^{891}$ Op. cit.: Pág 43.
} 
No obstante lo anterior, ¿se puede decir que actúa de mala fe el deudor que repudia la oferta hereditaria que se le ha hecho?. En nuestra opinión, y partiendo como premisa esencial de la libertad y voluntariedad de que goza para decidir acerca de la oferta hereditaria que ha recibido (art. $988 \mathrm{CC}$ ), entendemos que no, porque interpretarlo así sería coartar o limitar esa libertad para evitar precisamente que se le tache de actuar de mala fe. Otra cosa es que actúe con pasividad, apatía, falta de diligencia, con culpa (art. 1104 CC), incluso con dolo (art. 1102 CC). Lo uno no impide lo otro. En este sentido, BAYOD ${ }^{892}$ también entiende que, en tanto en cuanto el llamado a una herencia no está obligado a aceptarla, de su declaración de repudio no puede extraerse la consecuencia de que actúa con mala fe. Aun así, dado que el deudor, sabedor de la situación en que se encuentra frente a sus acreedores, que no puede desconocer ni ignorar, y de la responsabilidad que ha asumido frente a ellos, ha de hacer todo lo posible para que las deudas contraídas frente a éstos sean debidamente satisfechas. Ello implica o supone para él que ha de proveerse de los medios o recursos que sean necesarios y estén al alcance de su voluntad para que ello pueda tener lugar. En otro caso, sería ir en contra del principio de la buena fe, actuar de forma desleal, no ser diligente en el cumplimiento de las obligaciones, no ser fiel a la palabra dada y a la conducta seguida (STS de 26 de enero de 1980, RJ 167).

Incluso podríamos decir que sería irrelevante la buena o mala fe en el deudor desde el momento en que, el requisito del perjuicio que la repudiación causa en el acreedor se ha de producir, a nuestro juicio, de forma objetiva por cuanto no requiere un fraude intencional o culpable ${ }^{893}$, basta que el patrimonio personal del deudor sea objetivamente insuficiente para el pago de las deudas y que el incremento que se hubiere producido, caso de haber aceptado, supusiese una disminución de la insolvencia.

b) Renuncia a los derechos que sanciona el artículo 6.2 del Código Civil.

Cierto es que la repudiación y la renuncia son dos conceptos distintos ${ }^{894}$, y que una y otra tienen un contenido diferente, como también, y sin perjuicio de ello, de alguna manera, aquella, la repudiación, según ya hemos comentado en otro momento, no deja de ser una forma o manifestación de renuncia, entendida ésta en sentido

${ }^{892}$ Op. cit.: Pág 48.

${ }^{893}$ Acerca de si el perjuicio a los acreedores como consecuencia de la repudiación del deudor, presupone o no la existencia de fraude en éste, véase en este sentido, más adelante, en este mismo capítulo, el punto número 3-6-3, donde se examina este requisito y al que nos remitimos.

${ }^{894}$ Véase, en este sentido, el punto número 3 del capítulo tercero, donde tratamos la cuestión de si la repudiación se puede considerar o no como una manifestación de renuncia. 
amplio, pero, ya en un sentido estricto y jurídico, partiendo de la circunstancia de que la repudiación no es, ni consiste, en la renuncia a un derecho, sino precisamente el ejercicio en sentido negativo del ius delationis, difícilmente se puede admitir que esté sujeta a los límites que para el ejercicio de los derechos establece el artículo 6.2 del Código Civil $^{895}$ que sólo considera válida la renuncia a los mismos cuando no se contraríe el interés o el orden público y no cause perjuicio a terceros, con la salvedad, en este último caso, del que pudiere causar a los acreedores.

c) Principio de equidad.

A juicio de BAYOD ${ }^{896}$, dada la dificultad que existe en poder encontrar un fundamento preciso satisfactorio para el ejercicio de esta acción, éste sería el de la equidad, en el sentido de que, "el legislador, aplicando principios de equidad permite a los acreedores agredir el patrimonio hereditario, tal vez ya en manos de otros herederos, para que aquellos (los acreedores del repudiante), consigan cobrar lo que se les debe". En igual sentido, JORDANO FRAGA ${ }^{897}$, para quien "el artículo 1001 es excepcional, y tiene su justificación en razones evidentes de equidad (buena fe)".

Nosotros entendemos que el sentido que debería de darse aquí a este término, como ha hecho en ocasiones la jurisprudencia, es el de "elemento de interpretación y dulcificación del derecho por la ética" (SSTS de 9 de mayo de 1983, RJ 2678; 3 de noviembre de 1987, RJ 8134; 5 de mayo de 1993, RJ 3442), o "fase o elemento de interpretación a la par que corrector de la excesiva generalidad de la ley" (STS de 29 de junio de 1984, RJ 3441), o "criterio atemperador de la norma estricta" (STS de 3 de febrero de 1986, RJ 2678). Incluso también se puede entender o interpretar en el sentido de estricta justicia, de ius suum cuique tribuere, de dar a cada uno lo suyo, de querer conceder a los acreedores un remedio excepcional de poder dirigirse contra aquellos bienes que habrían tenido a su disposición para poder hacer efectivos sus respectivos derechos de crédito en el caso de haber aceptado su deudor la herencia a que éste fue llamado. No se castiga al deudor sino que, en correspondencia por las consecuencias negativas que de su decisión se deriva para los acreedores, se otorga a éstos de esta facultad para tratar, en la medida de lo posible, de compensarles por ello y poder así obtener el cobro de sus créditos.

${ }^{895}$ En este sentido nos remitimos a lo expuesto en el capítulo tercero, punto número 4, donde se trata expresamente esta cuestión al examinar las diferencias que separan a la repudiación de la renuncia, a lo que nos remitimos.

\footnotetext{
${ }^{896}$ Op. cit.: Pág 52 y ss.

${ }^{897}$ La sucesión en el "ius delationis". Cit: Pág 155.
} 
En nuestra opinión, el único hecho que justifica, a la vez que fundamenta, la existencia de esta acción es el de conceder a los acreedores, en la medida de lo posible, un medio de garantía para el cobro de sus créditos como consecuencia del daño o perjuicio que les hubiere causado la repudiación de una herencia por parte de su deudor, habida cuenta de que, aquellos bienes a que éste fue llamado a través de la vocación sucesoria y que no entraron en su patrimonio como consecuencia del repudio, ya no podrán ser objeto de reclamación o ejecución por su parte en el devengo de sus respectivos créditos. En otro caso, de haber aceptado, serían bienes sobre los cuales sí podrían actuar para poder cobrar lo que se les debe.

Ciertamente, puede ocurrir que no haya una intención consciente y deliberada por parte del deudor en causar un daño o perjuicio a sus acreedores con su decisión de repudio, sino que haya sido de buena fe, que su actitud no sea intencional o dolosa, hecha con el propósito directo, incluso premeditado, de producir tal resultado, a sabiendas de que les perjudica, pero no es menos cierto que, habida cuenta de la responsabilidad que se asume al contraer una obligación, cual es la de cumplir frente al acreedor la prestación convenida, entendemos que el deudor ha de proveerse, en la medida de lo posible -lo que entraña, en su caso, el ejercicio de aquellos derechos y acciones de que sea titular aunque tal ejercicio sea libre y voluntario, como es la delación sucesoria (art. $988 \mathrm{CC}$ )-, de los bienes, medios o recursos necesarios para que las deudas que él ha asumido, además, de forma libre y voluntaria (art. 1091 CC), sean pagadas, incluso aunque él sepa que los bienes que, en este caso, va a adquirir a través de la delación sucesoria, no van a servir para otra cosa más que para pagar la deudas que él ha contraído y que, en consecuencia, a él no le reporte ningún provecho, beneficio o ganancia positiva que se traduzca en un aumento de su patrimonio. En este caso, realmente no tendrá ganancias, pero lo que sí es cierto es que disminuye su pasivo, atenúa o hace desaparecer la insolvencia en que se pudiere encontrar, con lo cual mejora su situación patrimonial. En este sentido, aunque el ejercicio de la delación es libre, su no ejercicio, o el mero retraso, puede llegar a constituir una actitud negligente o culposa desde el momento en que no actúa con la diligencia debida o "la que exija la naturaleza de la obligación y que corresponda a las circunstancias de las personas, del tiempo y del lugar" (art. 1104 CC).

Podríamos incluso decir, como apuntábamos más arriba, que, pese al carácter libre que preside la delación en su ejercicio, y como una consecuencia derivada del principio de buena fe, el deudor tiene el deber genérico de mantener su propia solvencia frente al acreedor y hacer todo lo posible para que ello se pueda cumplir. 
Sin duda alguna, manifestar que el delado tendría la obligación de aceptar la herencia cuando se encuentra en una situación de insolvencia porque los bienes de su patrimonio no son suficientes para hacer frente al pago de sus deudas, contradice totalmente el carácter libre y voluntario que tiene en su ejercicio el ius delationis (art. 988 CC) y el hecho de que nadie puede ser heredero en contra de su voluntad. Cierto. Pero, en este caso, entendemos que ha de prevalecer el interés de los acreedores al suyo propio. Se puede decir que hay una colisión entre dicho interés y su libertad de decisión, que incluso actuan como dos fuerzas contrapuestas entre sí en el caso de repudio, libertad que, aquí, está condicionada, aquí, de forma particular y concreta, por ese deber que tiene de mantener su solvencia patrimonial ante sus acreedores, por lo que se podría hablar de una libertad limitada.

En el fondo, late el principio de responsabilidad patrimonial universal. Pero, junto a él, hay otros como son, el de buena fe, o estricta justicia, en los términos que hemos dejado apuntado, y que también aportan su grano de justificación o de fundamento al ejercicio de esta acción.

\section{3-3.- Naturaleza de la acción.}

Qué duda cabe de que el artículo 1001, al hablar de aceptación, está utilizando dicho término en un sentido impropio, incluso incorrecto, si bien, se puede entender o justificar su uso por el sentido gramatical que tiene esta palabra de que, para poder acceder a los bienes de la herencia, es preciso manifestar que se quieren de la misma manera que lo haría el delado, luego, se aceptan, declaración que tiene sentido afirmativo o positivo, en contraste con la de repudiación, que tiene un sentido negativo y denota rechazo.

Por otro lado, la declaración de los acreedores ha de reunir los mismos requisitos que la que realiza el sucesor en virtud del ejercicio del ius delationis, pero, sobre todo, ha de ser indivisible (art. 990 CC), en el sentido de que ha de recaer sobre la totalidad de los bienes, porción o cuota a que fue llamado el sucesor-repudiantedeudor, sea cual fuere el importe de los derechos de crédito de que ellos fuesen titulares respecto de éste. En consecuencia, tendrán que aceptar todo el haber hereditario que le habría correspondido a su deudor, si bien, después, solo están facultados para tomar para sí o hacer suyo hasta donde alcance el importe de los créditos de que sean titulares. Los acreedores tendrán a su disposición la totalidad de los bienes, derechos y acciones que integren la porción o cuota que se defirió a su deudor y el repudió, que podrán incluso ejecutar o realizar por completo, pero solo 
podrán beneficiarse hasta donde alcance el importe de sus derechos de crédito. Aunque en el ejercicio de esta acción, su "aceptación" se ha de referir a la totalidad de la porción o cuota que se el defirió a su deudor, después tienen la limitación de que sólo están facultados para proceder contra los bienes que sean suficientes y basten para cubrir el importe de los derechos de crédito de que sean titulares frente su deudor. Los acreedores no pueden hacer una declaración que entrañe una aceptación parcial de la herencia limitada a aceptar sólo bienes en una cuantía exacta o igual al importe de su derecho de crédito. Después, el exceso o parte de bienes que no se hubieren realizado o aplicado para el pago de sus créditos, si lo hubiere, pertenecerá, según veremos más adelante, según el artículo 1001 CC, “.... a las personas a quienes corresponda según las reglas establecidas en este Código".

Pero, en lo que se refiere a su naturaleza, y a diferencia de lo que ocurre, a propósito de su fundamento, en que existe una amplia mayoría dentro de la doctrina que coincide en señalar que el principio de responsabilidad patrimonial universal es el pilar esencial sobre el que se sustenta en su ejercicio, aquí no sucede lo mismo.

Dadas las particulares circunstancias que han de concurrir en el ejercicio de esta acción, es lo que ha motivado que la doctrina, tanto nacional como extranjera, haya mantenido una amplia y agria polémica, según veremos a continuación, acerca de cual es la naturaleza de esta excepcional facultad que se concede a los acreedores, debatiéndose la cuestión de, si es una manifestación de la acción subrogatoria, si de la acción pauliana, si participa, de ambas a la vez, o si se trata de una acción sui generis, equidistante o intermedia a las dos, dada la proximidad y semejanza que tiene tanto de una como de otra. Ciertamente, como vamos a ver ahora, las posturas son, en muchos casos, ambigüas, porque, aunque se admita que se trata de una acción que es diferente de aquellas, al mismo tiempo se reconoce, de una forma implícita, que tiene ciertos rasgos o características que la aproximan a una u otra.

Así, autores como BONET ${ }^{898}$, ESPÍN ${ }^{899}$, GITRAMA $^{900}$, LACRUZ BERDEJO ${ }^{901}$ o ROGEL ${ }^{902}$, entienden que no se trata propiamente ni de la acción subrogatoria, ni de la acción pauliana, sino de una derivación o subespecie de ésta.

\footnotetext{
${ }^{898}$ Compendio de Derecho Civil. V. Derecho de Sucesiones. Madrid. 1965. Págs 84 y 85.

${ }^{899}$ Manual de Derecho civil español. Vol. V. EDERSA. Madrid. 1978. Pág 85

${ }^{900}$ Comentarios al Código Civil .......... T XIV. Vol 1º . Cit: Págs 231, 236 y ss.

${ }^{901}$ Derecho de Sucesiones. I. Parte general. Cit: Pág 140.

902 Op. cit: Pag 257.
} 
LACRUZ ${ }^{903}$, por su parte, dice que se trata de una acción "ad hoc" fundada en la obligación genérica que tiene el deudor de mantener la propia solvencia. En la misma línea de pensamiento está RIVERO HERNANDEZ ${ }^{904}$, para quien, "la acción del artículo 1001 es específica y distinta de la subrogatoria: se dirige a rectificar los efectos de un acto perjudicial a los acreedores, y por el mero hecho de serlo".

Por su parte, ROCA SASTRE MUNCUNILL entiende que, "el derecho del artículo 1001 está relacionado con la acción revocatoria o pauliana, mas no con la subrogatoria. Lo que ocurre es que así como en la acción pauliana se deshace totalmente la enajenación, en cambio, en el caso de dicho artículo, por la propia esencia del caso que prevé, el derecho de los acreedores sólo revoca la repudiación parcialmente, es decir, en la parte necesaria para que los acreedores puedan cobrar sus créditos, o sea, en cuanto les perjudique. Sucede como si esta parte de los bienes estuvieren sometidos a la responsabilidad patrimonial del deudor renunciante, pero no en la otra parte" ${ }^{\prime 95}$.

VALLET $^{906}$, en cambio, dice que se trata de una facultad subrogatoria.

GULLÓN BALLESTEROS, la califica abiertamente de acción pauliana ${ }^{907}$. Otros, en cambio, la identifican con la acción subrogatoria, tales como: DOMAT ${ }^{908}$, MUCIUS SACEVOLA ${ }^{909}$, GÓMEZ CALERO ${ }^{910}$, para quien, "es notorio que la facultad otorgada en el art. 1001 a los acreedores tiende a suplir la mera inacción del heredero deudor, y constituye, por tanto, un supuesto de ejercicio de la acción subrogatoria", o ROCA SASTRE ${ }^{911}$, aunque con ciertas reservas. "A ello se suma -manifiesta FLORENSA I TOMÁS a propósito de ello- ${ }^{912}$, la literalidad de los distintos preceptos que, a lo largo del movimiento codificador -e incluso antes-, han tratado de la repudiación del deudor en perjuicio del acreedor", que cita abundante normativa ${ }^{913}$.

${ }^{903}$ Derecho de Sucesiones. Cit: Pág 314.

${ }^{904}$ Elementos de Derecho Civil. T V. Cit: Pág 83.

${ }^{905}$ Derecho de Sucesiones. T. III. 1994. Cit: Págs 453, 454.

${ }^{906}$ Panorama del Derecho de Sucesiones. II Perspectiva dinámica. Cit: Pág 569.

907 "La acción subrogatoria”. RDP. T 43. 1959. Pág 113 y ss.

${ }^{908}$ Les lois civiles dans leur ordre naturel, T 1er. Livre $2^{\circ}$. Titre X, Paris, 1777, pág. 317.

${ }^{909}$ Código Civil, Tomo XVII, Madrid, 1944. Cit: pág. 521, nota 1

${ }^{910}$ La acción subrogatoria (art. 1111 del Código Civil). Madrid. 1958. Cit: pág. 53.

911 “La adquisición y la repudiación de herencia ......”. Cit: pág. 23.

${ }^{912}$ Op. cit.: (I). $\mathrm{n}^{\circ} 5182$.

913 Op. cit.: (I) no 5182 en cita 28: Código Civil francés (art. 788 antigüo, actual artículo 779), el Código Civil italiano de 1865 (art. 949), italiano de 1942 (art. 524), portugués de 1867 (art. 2040) y de 1967 (art. 2067), Brasil (art. 1586), Chile (art. 1238), argentino (arts. 3351-3353), México de 1870 (arts. 3961-3964) y el de 1932 (arts. 1673-1676), Venezuela (art. 1017). 
Con otros argumentos, no faltan quienes entienden que la acción del artículo 1001, "se integra en un tipo de acción pauliana porque la repudiación a la herencia es un fraude a los acreedores y, como tal, subsumible en el ámbito de los artículos 1111 y 1297 CC, pudiendo, en consecuencia, ser rescindido el acto de la repudiación" (así, entre otros, LAURENT, CICU, NICOLO, DE CASTRO, citados por GITRAMA ${ }^{914}$ ).

MANRESA ${ }^{915}$, que nos ofrece un amplio panorama de distintas posiciones que se pueden observar dentro de la doctrina italiana ${ }^{916}$, entiende que se trataría de un caso de aplicación especial de la acción pauliana ${ }^{917}$. En igual sentido, se manifiestan autores como MAIERINI-GIORGI ${ }^{918}$ y ATZERI-VACCA ${ }^{919}$.

FLORENSA I TOMÁS ${ }^{920}$, critica la identificación que se ha hecho de esta acción, del artículo 1001 CC, y el correlativo a él, el antiguo artículo 23 del Código de Sucesiones de Cataluña, tanto con la acción subrogatoria, como con la acción revocatoria o pauliana. Así, respecto de ésta, manifiesta que: "la finalidad perseguida por los arts. 1001 del Código Civil y 23 del Código de Sucesiones no es otra que posibilitar la realización de los derechos de los acreedores -sus créditos-, cosa que no se consigue únicamente con la acción pauliana, una acción pensada para actos de enajenación empobrecedores y no para actos omisivos impeditivos de enriquecimiento". Lo mismo ocurre respecto de la acción subrogatoria al entender que, "no faltan argumentos para afirmar que el art. 1001 del Código Civil y el artículo 23 del Código de Sucesiones se mueven en el ámbito de lo que podríamos denominar como

914 Comentarios al Código Civil español. T XIV. Vol 1º. Cit: Pág 237.

915 Comentarios al Código Civil español. T. VII. Cit: Págs 412 y 413.

916 Así, cita entre otros autores, a BORSARI (En comentario al artículo 945. Commentario del Codice civile italiano. Società l'Unione tipografico-editrice, 1871-1881. Torino) y a PACCHIONI (Trattato delle obbligazioni secondo il diritto civile italiano. Fratelli Bocca. Torino. 1927. Pág 106), para quienes se trata de un caso de aplicación de la acción subrogatoria. DE PALO (De revocatoria per frode nei resentí studii civilisciti. Filangieri. 1899. Pág 91), entiende que se trata de una acción “sui generis” en la cual concurren los principios de la acción subrogatoria y de la acción pauliana.

${ }^{917}$ En su opinión: "no se puede hablar, en efecto, de simple aplicación de la acción subrogatoria, porque ésta supone el ejercicio de un derecho que pertenece al deudor, es decir, supone que éste pueda revocar la renuncia y no lo haga, mientras que en la hipótesis del artículo 1001, los acreedores del renunciante pueden impugnar la renuncia que él ha hecho y que no podía revocar, lo que significa que ejercitan un derecho propio. ..... Por tanto, es este artículo, como el 1937, con el que tiene evidente analogía, y como el 643 y el número 3 del 1297, aplicación especial de la regla general contenida en el 1111, que faculta a los acreedores para impugnar los actos que el deudor realice en fraude del derecho de aquellos".

918 Della revoca degli atti fraudolenti: fatti dal debitore in pregiudizio dei creditori / per l'avvocato Angelo Maierini; con note dell'avv. Giorgio Giorgi. Firenze: Casa Editrice Libraria "Fratelli Cammelli", 1898. Págs 225 y 265.

919 Delle rinunzie: secondo il Codice civile italiano: con ampia rivista di dottrina $e$ giurisprudenza. Torino: Unione Tipografico-Editrice Torinese, 1915.

${ }^{920}$ Op. cit.: (I). $\mathrm{n}^{\mathrm{o}} 5182$. 
la legitimación subrogatoria, pero sí negamos convencidamente su identificación con la acción subrogatoria establecida en el art. 1111 del Código Civil".

Frente a la clásica posición doctrinal de asimilar dicha acción, ya sea a la subrogatoria, ya sea a la revocatoria, se ha alzado una tercera teoría o posición que se ha venido en llamar, "acción mixta" o "postura mixta", seguida, entre otros, por BARASSI, DEMOLOMBE o AZZARITI-MARTÍNEZ, que sería una yuxtaposición de la acción revocatoria y de la acción subrogatoria. "Habría -apunta DÍEZ-PICAZO, en este sentido ${ }^{921}$-, una acción rescisoria cuyo único objeto sería la declaración de ineficacia de la renuncia realizada en fraude de acreedores y una acción subrogatoria posterior, por cuya virtud, una vez rescindida la renuncia y trasladadas las cosas a la situación anterior, los acreedores ejercitarían la facultad de su deudor de aceptar la herencia".

Su más ferviente defensor es, según indica FLORENSA, el profesor FEDERICO DE CASTRO 922 , que la describe así: "el procedimiento que señala la ley es el revocatorio; la renuncia a la herencia no tendrá efecto respecto de los acreedores, en tanto les perjudique; en ese ámbito, el derecho a aceptar la herencia se considerará como si no se hubiese renunciado, como si permaneciese en el patrimonio del deudor. Ejercitada ya la revocatoria, el derecho a aceptar la herencia queda sometido a la acción de los acreedores, y como es un derecho, el procedimiento ejecutivo a emplear será la acción subrogatoria (arts. 1447, no 10 de Enjuiciamiento Civil y 1111 del Código Civil); los acreedores podrán usar el derecho a utilizar el derecho a aceptar la herencia"923. Pero aceptar esta solución, apunta FLORENSA, comporta una serie de inconvenientes ${ }^{924}$.

921 “La aceptación de la herencia ........”. Cit: Pág 159.

922 "La acción pauliana y la responsabilidad patrimonial. Estudio de los arts. 1911 y 1111 del Código Civil”. RDP. 1932. Págs 205 a 208.

923 Op. cit.: Pág 206.

924 “Obvio es decir que la yuxtaposición de ambas acciones, si bien aparentemente soluciona algunas de las deficiencias que tenían en su consideración por separado, no impide la acumulación de sus defectos. Entre los inconvenientes que se solucionarían está el del efecto de la revocatoria, que en hipótesis sólo conseguía la rescisión de la repudiación, aunque no por sí sola la posibilidad de los acreedores de interferir en el fenómeno sucesorio y conseguir la satisfacción de sus derechos. Se explicaría asimismo la posibilidad de la subrogación de los acreedores en el ius delationis, revivido a raíz de la rescisión de la repudiación, lo cual no era posible con el simple ejercicio de esta acción, ya que la repudiación lo había extinguido.

Pero subsisten los obstáculos propios de la idiosincrasia de ambas acciones que no repetiremos: los argumentos contrarios individualizados para cada una de las tesis anteriores siguen plenamente vigentes en la tesis de la yuxtaposición; recordemos tan sólo que la acción subrogatoria sólo conseguía un resultado parcial, en contra de la extensión propia que habría de tener, como si el derecho fuera ejercido por el deudor". 
También siguen esta posición GARCíA GARCíA ${ }^{925}$, y GITRAMA ${ }^{926}$, para quien, "no se trata de una pura acción pauliana ni de una pura acción subrogatoria, sino de una yuxtaposición de ambas acciones. Habría una acción rescisoria al objeto de declarar ineficaz la renuncia en fraude de acreedores y luego una acción subrogatoria a través de la cual los acreedores ejercitarían las facultades de su deudor en orden a aceptar la herencia".

Esta tesis, de la acción mixta, a juicio de FLORENSA 927 , "tiene a su favor la combinación de los efectos de la acción revocatoria con los propios de la subrogatoria. En efecto, con la revocatoria se conseguiría la impugnación de la repudiación con efectos sólo relativos, declarándola ineficaz frente al acreedor impugnante $y$ retrotrayendo las cosas a su situación anterior a la repudiación; con la subrogatoria posterior, los acreedores aceptarían la herencia en nombre de su deudor ejerciendo el ius delationis revivido".

Para DÍEZ-PICAZO, que ha sido, sin duda alguna, uno de los autores que más se ha ocupado del estudio de esta acción ${ }^{928}$ en nuestra doctrina, "los acreedores, no ejercitan un derecho de su deudor, sino un derecho que la ley les atribuye directamente. Actúan iure et nomine proprio". "Este poder que la ley concede directamente a los acreedores, cuyo interés se considera preferente, produce, en

${ }^{925}$ La sucesión por derecho de transmisión. Cit: Págs 373 y ss: “por una parte, se trata de una acción especial con sus propias peculiaridades, pero que tiene una buena dosis de acción subrogatoria (ejercicio de una facultad en nombre del deudor), y además, por otra parte, de acción revocatoria o pauliana (el deudor se hace adquirente en parte en virtud de la aceptación de sus acreedores, si bien la revocación es parcial y basta el perjuicio y no el fraude como en la acción pauliana). Sus especialidades la hacen sui generis, pero ese género es en buena medida similar al de las acciones subrogatoria y pauliana, a pesar de sus diferencias".

${ }_{926}$ Comentarios al Código Civil .......... T XIV. Vol 1º Cit: Pág 239.

${ }^{927}$ Op. cit.: (I) $n^{\circ} 5182$.

928 En su opinión, “aun reconociendo que el artículo 1001 tiene un cierto parentesco con las llamadas acciones pauliana y subrogatoria del artículo 1111, no puede identificarse totalmente con ninguna de ellas". A lo que añade, "no hay en puridad una acción pauliana porque esta acción presupone el fraude de acreedores y el fraude exige que el deudor se desprenda o transmita bienes o derechos que le pertenezcan o que de cualquier modo disminuya su patrimonio con merma de su solvencia, mientras que en la hipótesis del artículo 1001, el deudor deja de adquirir bienes con qué pagar, pero la omisión no es nunca un auténtico fraude, sino un no enriquecerse". "Tampoco hay en puridad acción subrogatoria, porque en la subrogatoria los acreedores ejercitan, sustituyendo al deudor, los derechos pertenecientes a éste ante su pasividad o inactividad, mientras que en el caso del artículo 1001, su "ius delationis" había sido ya ejercitado al repudiar". "Se trata, por ello, de una facultad de los acreedores que si bien se engloba dentro de las genéricas facultades de control de la gestión económica del deudor, presenta unas características propias y singulares". "Se funda en la idea de que atenta el interés justo de aquellos el deudor que ha podido adquirir bienes para pagar y no lo ha hecho". "La mecánica del artículo 1001 es objetiva, no necesita fraude, ni una especial intención dañosa. Basta que objetivamente la repudiación causa perjuicio a los acreedores. Ello ocurrirá siempre que el patrimonio personal del deudor sea insuficiente para el pago y que el incremento determinado por la herencia pudiera haberlo aumentado. No habrá, en cambio, perjuicio si la herencia estaba a su vez endeudada" (Sistema de Derecho Civil. Vol. IV. Cit: Pág 543 y ss.). 
virtud de su fuerza expansiva, los efectos reflejos que anteriormente hemos examinado: ineficacia parcial de la renuncia, adquisición por el deudor de la porción de bienes necesaria para el pago de los créditos y contracción del derecho de los beneficiados por la renuncia"929. Estos tres, serían los efectos que se derivarían del ejercicio de la acción del artículo 1001 CC. Más tarde, cuando se ocupa de analizar estos efectos, entiende que "se produce, aun en contra de las reglas generales de la sucesión, una doble adquisición de los bienes hereditarios"930: por un lado, por parte del sucesor-deudor que repudia quien adquiriría los bienes en la cuantía necesaria y suficiente para satisfacer los créditos de sus acreedores $y$, por otro, por los beneficiados por la repudiación, los demás sucesores o coherederos con derecho de acrecer, quienes adquirirían el exceso cuando lo hubiere ${ }^{931}$. De ello se deriva, apunta DÍEZ-PICAZO ${ }^{932}$, un fraccionamiento de la aceptación y de la renuncia en contra de lo dispuesto en el artículo 990 CC porque, añadimos nosotros, a resultas de su ejercicio se produce una bifurcación en el ejercicio de la delación, al tiempo que se produce una repudiación de la herencia por parte del sucesor, hay una aceptación de la misma por parte de los sucesores que solo basta y alcanza para la satisfacción del importe de los créditos de que ellos sean titulares frente al deudor-renunciante, pero que no por ello, por otro lado, devienen en sucesores del causante.

Surge así la denominada tesis o teoría de la "doble adquisición", que ha sido seguida por algunos autores ${ }^{933}$, como también ha generado numerosos detractores 0 posiciones contrarias por distintos motivos (FLORENSA ${ }^{934}$, LLEDÓ YAGÜE ${ }^{935}$ ).

En nuestra opinión, se trata de una acción que:

a) es singularísima, porque no existe ninguna otra acción análoga en nuestro ordenamiento jurídico de semejantes características y por razón de los presupuestos que se exigen para su ejercicio ${ }^{936}$.

929 “La aceptación de la herencia .........”. Cit: pág 172.

930 "La aceptación de la herencia ........”. Cit: págs 171, y 192 y ss.

${ }^{931}$ No deja de llamar la atención el hecho de que después, él, a continuación, manifieste que, esta afirmación, de que la acción de los acreedores del llamado produce una doble adquisición de los bienes hereditarios, es “irrebatible” (“La aceptación de la herencia ........”. Cit: pág 193).

932 “La aceptación de la herencia .........". Cit: Pág 172.

933 CASTÁN TOBEÑAS y otros: Derecho civil español, común y foral, VI-1º. Cit: Pág. 181; GITRAMA: Comentarios al Código Civil ..... T. XIV-1º. Cit: Pág. 240; O’CALLAGHAN: Comentario del Código Civil. T I. Cit: Pág. 2375; VALPUESTA FERNANDEZ: Derecho de Sucesiones, Valencia 1992. Pág. 540.

${ }^{934}$ Op. cit.: (I) n ${ }^{0} 5182$.

${ }^{935}$ Derecho de Sucesiones. Vol II. Cit: Pág 115.

${ }^{936}$ Véase en este mismo capítulo más adelante, el punto 3-6, al que nos remitimos. 
b) Es excepcional, incluso insólita, porque al permitir a los acreedores del delado-repudiante-deudor actuar directamente sobre los bienes que a éste le hubiesen correspondido, caso de haber aceptado, y aplicarlos al pago de los créditos de que sean titulares frente a él igual que si hubieren ingresado en el patrimonio del deudor caso de haber aceptado, es concederles un poder de actuación sobre unos bienes respecto de los cuales ellos, no solo no tienen ningún derecho propio, sino que, además, la repudiación hizo que quedaran definitivamente fuera del alcance, no solo de su deudor, sino también de ellos.

Tal excepcionalidad, por otro lado, contraviene totalmente el sistema de adquisición de herencia que rige en nuestro ordenamiento jurídico en el que, de la misma manera que sin aceptación no hay adquisición, por la repudiación se rechazan, de lo que se deriva la consecuencia de que, a resultas de ésta, que es el punto de arranque o de partida de la acción del artículo 1001, los bienes de la herencia a que fue llamado el delado-deudor no entran en su patrimonio y no pueden ser objeto de ejecución por parte de sus acreedores para el cobro de sus créditos. Sin embargo, a través de la acción del artículo 1001, los acreedores sí pueden tener acceso, pese a dicha repudiación, a estos bienes que, no solo no son de su deudor, sino que ya nunca podrán serlo porque él los repudió.

c) Es sui generis, por varios motivos:

a') porque, aunque la declaración de aceptación que hicieren los acreedores recae sobre aquello que se hubiere deferido a su deudor, solo les faculta para poder actuar en la cantidad y cuantía que sea suficiente para el cobro de los créditos de que sean titulares frente a él, perteneciendo el exceso o sobrante, si lo hubiere, no al deudor, por cuanto él ya los repudió, como tampoco a los acreedores, sino a aquellas otras personas a quienes corresponda según las reglas de la sucesión ${ }^{937}$,

b') no por el hecho de su ejercicio, los acreedores aceptan la herencia, en el sentido propio del término, en nombre de su deudor, sino que la ejercitan iure et nomine propio por concesión directa de la ley, como tampoco se convierten en sucesores del causante, ni queda sin efecto la declaración de repudiación realizada por el deudor y, menos aún, éste se convierte en heredero del causante por cuanto ya repudió,

937 Acerca de ello, véase en este mismo capítulo el punto número 3-5-3, donde se examinan quienes son los sujetos que se ven implicados a resultas del ejercicio de esta acción. 
c') requiere para su ejercicio, con carácter preceptivo, la previa autorización judicial, de tal manera que los acreedores no pueden actuar por sí solos, de forma autónoma e independiente, por propia iniciativa.

d) Se concede ad hoc (así también la califica LACRUZ ${ }^{938}$ ), a los acreedores para la protección de su derecho de crédito en atención a las particulares circunstancias en que se produce y requisitos que se exigen para su ejercicio, y al objeto de que no se vean frustradas las posibilidades de cobro. Se trata de evitar así, el posible perjuicio que por ello se hubiere causado a los acreedores.

e) Es una acción que no se identifica, ni con la acción subrogatoria, ni con la revocatoria o pauliana, porque no se dan todos los presupuestos exigidos para el ejercicio de las mismas, como tampoco los presupuestos de la acción del artículo 1001 CC se dan en cada una de aquellas.

No se identifica con la subrogatoria por varios motivos:

a') porque ésta presupone la inactividad en su ejercicio por parte del deudor, cuando resulta que aquí sí que ha habido actividad del ius delationis, una repudiación previa que es precisamente el hecho que pone en marcha la protección que el artículo 1001 concede a los acreedores,

b') tampoco porque, como consecuencia de lo anterior, se trata de un derecho que ya está extinguido a resultas de su ejercicio, por lo que difícilmente se pueden subrogar en él los acreedores, y

c') también se diferencia de la acción subrogatoria por el carácter personal que tiene el ius delationis en su ejercicio.

Tampoco se identifica con la pauliana porque, aparte de que su ejercicio presupone la existencia de fraude ${ }^{939}$ en el comportamiento del deudor, los acreedores no revocan ni dejan sin efecto la declaración de repudio por cuanto es definitiva e irrevocable. Sólo están facultados para actuar sobre los bienes, porción o cuota que, caso de haber aceptado, le hubiese correspondido a su deudor y con el límite del importe del valor de aquellos derechos de crédito que se sean titulares frente al repudiante en el momento de su ejercicio.

938 Derecho de Sucesiones. Cit: Pág 314.

939 Acerca de si el perjuicio a los acreedores como consecuencia de la repudiación del deudor, presupone o no la existencia de fraude, véase en este sentido, más adelante, en este mismo capítulo, el punto número 3-6-3, donde se examina este requisito y al que nos remitimos. 
f) Tiene carácter subsidiario porque los acreedores sólo podrán hacer uso de esta acción en el caso de que carezcan de todo otro recurso para poder cobrar lo que se les debe por parte de su deudor (SAP Tarragona, Sección 3a , de 8 de junio de 1999 -AC 1999/6667-), circunstancia ésta que sí tiene en común con la pauliana. Por tanto, antes de ampararse en el artículo 1001, tendrán que ejercitar las acciones propias que dimanan del derecho de crédito que tuvieren contra el deudor, como también recurrir por la vía de la acción subrogatoria, ex artículo 1111 CC, al ejercicio de aquellas otras acciones de que éste sea titular y sean, además, susceptibles de realización para tratar de obtener el cobro de sus derechos de crédito.

Por otro lado, también la jurisprudencia ${ }^{940}$ se ha hecho eco a través de sus sentencias de la problemática que rodea a la acción del artículo 1001 en su ejercicio, debatiéndose, de igual manera, la cuestión de si estamos ante la acción pauliana o revocatoria, o la acción subrogatoria ${ }^{941}$.

\section{3-4.- La autorización judicial.}

Una de las peculiaridades o especialidades que tiene el ejercicio de esta acción es el hecho de que los acreedores, aunque la situación patrimonial de su deudor sea de clara y manifiesta insolvencia, no pueden, a través de la misma, actuar por propia iniciativa, dirigirse contra los bienes que han sido objeto de repudio y proceder a su

940 STS de 30 de mayo de 2003, RJ 3917; STSJ Cataluña de 29 de enero de 1996, RJ 6248; SSAP Girona de 4 de junio de 1997, AC 1997/1341; Badajoz, de 28 de octubre de 1998, RJ 1964; Tarragona (Sección 3a), de 8 de junio de 1999, AC 1999/6667; Res DGRN de 2 de diciembre de 1892; de 23 de junio y 23 de julio de 1986, RJ 3843 y 4930.

${ }^{941}$ En este sentido, es relevante la citada sentencia la AP de Tarragona (Sección $3^{\text {a }}$ ), de 8 de junio de 1999, AC 1999/6667, que, en su Fundamento de Derecho $1^{\circ}$, dice lo siguiente:

"No obstante, se ha discutido doctrinalmente sobre la naturaleza jurídica de esta acción, ya que algunos autores la identifican con la acción pauliana o revocatoria, sin embargo esta última acción presupone el fraude y en la hipótesis que contempla el art. 1001 -la «aceptacio ficta»- de la herencia, como la denominó la Resolución de la Dirección de Registros y del Notariado de 2 de diciembre de 1982, no se requiere la concurrencia del ánimo de fraude. Una segunda postura la asimila a la acción subrogatoria del art. 1111 del Código Civil, pero tal tesis olvida que la acción subrogatoria descansa en la inactividad del deudor y en el caso del art. 1001 del CC se parte de la renuncia expresa de éste, porque si no existe esta renuncia, no podrá ejercerse la acción del art. 1001 del CC. Otros autores consideran que se trata de una aplicación concreta de la acción pauliana, alegando que ello no equivale a decir que se trate de una acción revocatoria en sentido estricto, sino que es una manifestación de la misma finalidad que intenta conseguir el art. 1111 del Código Civil. Por último, un moderno sector doctrinal entiende que nos hallamos ante una acción autónoma, singular y peculiar distinta de la pauliana, pues si fuera ésta se revocaría el efecto repudiatorio y éste aquí se mantiene. Ahora bien, tanto si se acogiera la tesis de la aplicación concreta de la acción pauliana como la de considerarla una acción propia e independiente, lo cierto es que no es necesario la concurrencia del elemento del fraude o el «consilium fraudis», que exige la acción pauliana en sentido estricto, sino que basta con el «eventum damni» o perjuicio del acreedor, pues esta acción tiene un carácter marcadamente objetivo, y resarcido el acreedor de sus derechos, se mantiene la repudiación de la herencia respecto del resto de su contenido (derechos, créditos, obligaciones y cargas -activo y pasivo de la herencia-)". 
ejecución para conseguir así el cobro de los créditos que tengan contra él, sino que, con carácter previo a su ejercicio, han de obtener autorización del Juez ${ }^{942}$.

No obstante, en nuestra opinión, pese a la literalidad del artículo 1001, son varias las cuestiones que suscita la exigencia dicha autorización que derivan, por un lado, de la función que está llamada a cumplir, según veremos a continuación, y, por otro, de la facultad que a través de la referida acción se concede a los acreedores.

Así, aunque el momento de su solicitud no plantea discusión alguna, es opinión generalizada sustentada por gran parte de la doctrina (entre otros, DíEZ-PICAZO ${ }^{943}$, O'CALLAGHAN ${ }^{944}$, FLORENSA TOMÁS ${ }^{945}$, BAYOD LOPEZ ${ }^{946}$, GITRAMA $^{947}$, SILLERO CROVETTO ${ }^{948}$ ), que la petición de la autorización y subsiguiente concesión por parte del Juez, ha de preceder a la declaración de "aceptación" que hagan los acreedores de la herencia que repudió su deudor. Ya el propio tenor literal del precepto así lo da a entender cuando manifiesta que, “.... podrán éstos pedir al Juez que los autorice para aceptarla ...." ${ }^{949}$, de lo que se deduce que, siguiendo el iter cronológico, aquella, la

${ }^{942} \mathrm{El}$ artículo no lo dice de manera expresa, pero el Juez que ha de conceder la autorización será el competente para conocer de todas las cuestiones que se susciten a propósito de la herencia, esto es, el de la testamentaría o del abintestato (vid arts. 1008, 1011, 1014 CC).

En este sentido, la LEC, en su artículo 52,4", establece que "en los juicios sobre cuestiones hereditarias, será competente el tribunal del lugar en que el finado tuvo su último domicilio y si lo hubiere tenido en país extranjero, el del lugar de su último domicilio en España o donde tuviere la mayor parte de sus bienes a elección del demandante”.

La exigencia de este requisito la encontramos también recogida en el actual artículo 779, antiguo 788, del Code francés, por lo que se puede considerar el precedente del artículo 1001 CC.

943 "La aceptación de la herencia ........”. Cit: Págs 188 y 189.

${ }^{944}$ Comentario del Código Civil. Cit: Pág 2375.

${ }^{945}$ Op. cit.: $n^{\circ} 5182$.

${ }^{946}$ Op. cit.: Pág 113 y ss.

${ }^{947}$ Op. cit.: Pág 245.

${ }_{948}$ Op. cit.: Pág 1689.

${ }^{949}$ No obstante, dado el tenor literal del precepto que emplea el término "podrán”, por razón de su significado gramatical, nos viene a plantear la duda de la fuerza obligatoria de vinculación que pueda tener, sobre todo, si lo relacionamos con otros términos como son, "tendrán" o "deberán", términos éstos que, a diferencia de aquel, denotan imperatividad u obligatoriedad, en consecuencia, si es o no preceptiva la autorización judicial. Igual sucede en otros casos donde se emplea el mismo término, como es el artículo 48 CC, a propósito de la dispensa de impedimentos para la celebración del matrimonio civil; o en los artículos 1376 y 1377 CC, acerca de la administración y disposición de los bienes gananciales.

Como tampoco se expresa de la misma manera que ocurre en otros artículos en los que se deduce o se infiere, a través del significado gramatical de las palabras empleadas, la necesidad de la previa autorización judicial. Así, en el artículo 166 CC, a propósito de la realización de actos de enajenación y gravamen por parte de los padres sobre los bienes de sus hijos sometidos a su potestad; artículo 271 CC, relativo a qué actos no puede realizar por sí solo el tutor; o artículo 1320 CC, para la disposición de la vivienda común de los cónyuges.

De todo ello, en principio, se podría deducir u obtener la conclusión de que la autorización judicial, aquí, en este caso, parece tener un carácter facultativo o discrecional para los acreedores, pero no la categoría de ser un elemento tan esencial, como subraya FLORENSA, para el ejercicio de la acción.

Sin embargo, pese a que el término "podrán" no tenga la misma fuerza obligatoria que el que encierran "tendrán" o "deberán", ello no impide para que, dada la función que está llamado a cumplir, los 
autorización, ha de ser anterior a ésta, a la declaración de los acreedores. De igual manera, en nuestra opinión, entendemos que ha de ser así por la función de control y de garantía que más adelante examinaremos. En igual sentido, la jurisprudencia ${ }^{950}$.

Pero, en lo que ya no hay tanta unanimidad en la doctrina es en las razones que se esgrimen para justificar o fundamentar la exigencia de este requisito que entronca directamente con la naturaleza jurídica de la facultad concedida a los acreedores. Aquí se distinguen dos direcciones opuestas protagonizadas, una, por los seguidores de la acción subrogatoria y, otra, por los de la pauliana, que se sirven, a su vez, de diferentes argumentos para justificar la exigencia de la autorización judicial ${ }^{951}$.

Pero, frente a estas posiciones, se alza la de DEMOLOMBE ${ }^{952}$, para quien la necesidad de la autorización judicial se justifica en el hecho de que los acreedores no pueden tomar por su propia autoridad los bienes de la herencia para aplicarlos al pago de sus créditos. Esta misma justificación, pero con un enfoque diferente en su planteamiento por razón de las diferencias que existen entre el derecho francés y el español ${ }^{953}$, es seguido en nuestro derecho por DíEZ-PICAZO ${ }^{954}$, para quien, el fundamento "está en la necesidad de llenar una finalidad puramente práctica: que por su propia autoridad no pueden los acreedores ocupar los bienes de la herencia para reparar el perjuicio que la renuncia les ocasionó; que el ejercicio de su derecho de aceptar debe precisar la justificación de sus presupuestos (existencia del crédito, renuncia, perjuicio, etc)." "Solamente en la necesidad de llenar este fin puramente

acreedores estén obligados a observar la exigencia de este requisito con carácter previo al ejercicio de la facultad que les concede el artículo 1001 CC. En este sentido, en los supuestos a que se refieren los artículos citados (48, 1376 y 1377 CC), se ha de obtener la dispensa o la autorización judicial con carácter previo a la realización del acto a que se refieren, si bien, su inobservancia plantea la cuestión de la validez del acto, aunque es obtenible a posteriori, lo que permite la convalidación o subsanación del acto.

Por otro lado, el término “podrán” denota una facultad en los acreedores, en el sentido de que pueden, si quieren, o no, dirigirse contra los bienes de la herencia para cobrar a través de la misma lo que su deudor les adeuda. No es obligatorio que lo hagan. Es una posibilidad más que la ley les concede.

950 STS de 30 de mayo de 2003, RJ 3917; SAP de Tarragona (Sección 3 $3^{\text {a }}$ ), de 8 de junio de 1999, AC 1999/6667.

${ }^{951}$ Vid DÍEZ-PICAZO: “La aceptación de la herencia .........”. Cit: Págs 189 y 190.

952 Traité des successions. T III. Cit: Pág 82.

953 En el derecho francés, apunta BAYOD (Op. cit.: pág 116), la autorización judicial se funda en que el deudor sí fue propietario de los bienes, bienes que enajenó mediante renuncia, disminuyendo así su patrimonio. Además, dicha renuncia ha devenido irrevocable, puesto que ni tan siquiera el deudor podía retractarse y volver a aceptar. Así las cosas, es necesario que intervenga la autoridad judicial y devuelva el derecho definitivamente perdido para que así puedan cobrarse los acreedores. Planteamiento lógico si partimos de que en el derecho francés la acción del artículo 788 del Code, no es más que una aplicación de la acción pauliana: los bienes han estado temporalmente en el patrimonio del deudor pero después dejan de formar parte del mismo como consecuencia de la repudiación. De ahí que se conceda facultad a los acreedores para su revocación a través de esta acción.

Pero este planteamiento no tiene sentido en el derecho español por cuanto, en él, el régimen de adquisición de herencia es diferente.

954 “La aceptación de la herencia ........”. Cit: Pág 190. 
práctico puede encontrarse el fundamento de la previa autorización. En definitiva significa esto: el llamado a una herencia, en virtud de un título propio (testamento o ley), puede ocupar los bienes y atribuirse la herencia aun sin declaración judicial; pero el acreedor, no llamado a ella, que pretende ocuparlos, con el fin de realizar su derecho, debe ser autorizado por el Juez". A lo que añade, en cuanto a su naturaleza jurídica, que se trata de "un acto de resolución emitido por un órgano jurisdiccional, acto de resolución, que funciona, respecto de los actos privados, en forma análoga a la de los demás actos de autorización".

En igual sentido, y en idénticas palabras, también se manifiesta GITRAMA ${ }^{955}$, para quien, "Ios acreedores no tienen la suficiente autoridad para ocupar manu militari, los bienes de la herencia para recuperar su perjuicio".

En parecidos términos se manifiesta $\mathrm{BAYOD}^{956}$ al decir que: "la necesidad de autorización judicial ha de ponerse en relación con la naturaleza jurídica de esta acción, pues, a la vez, este requisito sirve para justificar dicha postura e integrarla en el sistema sucesorio español". "En efecto, la necesidad de autorización judicial equivale a una manifestación procesal de declarar para este supuesto de hecho la responsabilidad eventual de la herencia por las deudas del repudiante, pues tal responsabilidad, condicionada por el supuesto de hecho de la norma -"si el heredero repudia la herencia-", no podría realizarse sin un acto de la autoridad competente".

FLORENSA ${ }^{957}$, por su parte, aunque sigue la misma línea de pensamiento, se desmarca de la posición mayoritaria de la doctrina en el sentido de llegar a calificar con rotundidad de, "esencial e insustituíble", la actividad del Juez, hasta el punto de que, "sin la autorización judicial el derecho del acreedor no podrá ser ejercido mediante el mecanismo previsto de la subrogación"958. No obstante, "una vez comprobada la aptitud del crédito y los demás requisitos exigidos por la norma, el Juez

${ }^{955}$ Comentarios al Código Civil ........ T XIV. Vol 1º. Cit: Pág 245.

${ }^{956}$ Op. cit.: Págs 116 y 117.

957 Op. cit.: (II) $n^{0} 5183$.

958 Y lo justifica diciendo que, "si bien es cierto que es la ley la que prevé el mecanismo de la subrogación, no lo es menos que ella misma concede al Juez la clave de la operatividad del remedio establecido. Concediendo la autorización permite el ejercicio de la cualidad del derecho de crédito del acreedor del repudiante, es decir, su interposición en el régimen de preferencias en virtud de ser un crédito privilegiado. De tal manera puede afirmarse que la preferencia del crédito es una preferencia legal-judicial”.

A lo que añade, "el fundamento de la intervención judicial -autorización- debe encontrarse en el mismo carácter excepcional de la figura: a) de una parte, el juez ha de ejercer una función de control del derecho concedido a los acreedores del repudiante .........; b) de otra parte, se demostrará que el ejercicio del derecho privilegiado no permite ejecutar los bienes por un acto de propia autoridad", en lo que coincide, en este punto, con DÍEZ-PICAZO. 
no podrá negarse a conceder la autorización, a modo de automatismo condicionado". De ello se desprende la consecuencia de que, la función que cumple la autorización judicial, en este caso, es, como bien dice FLORENSA, la de actuar a modo de "control de legalidad". Y termina, en este sentido, diciendo que, "ciertamente, el Juez no crea el derecho que, como tenemos dicho, no es otro que el mismo derecho de crédito; sólo lo declara hábil para ahormarse a la norma de los arts. 1001 del Código Civil y 23 del Código de Sucesiones".

Ciertamente, el requisito de la autorización judicial tiene, a nuestro juicio, una función que es esencial y fundamental por razón del cometido que está llamada a cumplir porque el objetivo o finalidad que se persigue a través de la misma, así lo entendemos nosotros, es saber si se han cumplido con carácter previo al ejercicio de la acción, todos los presupuestos que el artículo 1001 CC exige para ello. Dadas las particulares circunstancias que se han de producir para que los acreedores puedan, a través de dicha acción, aplicar al pago de sus créditos aquellos bienes que repudió su deudor, es preciso, establecer un mecanismo de control por medio del cual se tenga la certeza de que dichos presupuestos se han cumplido y evitar, por otro lado, al mismo tiempo, que los acreedores actuen por su propia autoridad e iniciativa y que "ocupen" o se hagan con los bienes de forma anárquica y descontrolada. Se podría incluso decir que, el derecho, o la acción, de los acreedores no se puede ejercer sino es a través de la autorización judicial porque sin la previa justificación o demostración de que se han cumplido todos los requisitos necesarios para su ejercicio, los acreedores no podrán proceder contra los bienes de la herencia que le hubiesen correspondido a su deudor, y el único medio que existe para poder acreditar que se han cumplido, es ante el Juez, quien después accederá, en su caso, a conceder la pertinente autorización.

Su carácter esencial también le viene dado por la excepcionalidad de la acción. Se trata de un recurso que, como ya hemos expuesto con anterioridad al tratar de su naturaleza, presenta unas características muy peculiares, ya que los acreedores actuan sobre unos bienes respecto de los cuales ellos no tienen ningún derecho, ni propio, ni a través de su deudor, por cuanto éste, con su repudio, impidió que entrasen en su patrimonio, lo que habría facilitado o permitido su ejecución en orden al pago de los créditos que tuviesen contra él. Así, es el propio Juez quien, además de cumplir la función de control, legitima con su autoridad la intervención de los acreedores por cuanto ellos, pese a haber hecho antes, en su caso, excusión de los bienes del deudor, tendrán que demostrar que se cumplen los requisitos precisos para el ejercicio de esta acción. Como también, el protagonismo del Juez se hace también presente 
después, en el momento de actuar los acreedores sobre los bienes de la herencia porque, entendemos, ha de ser el propio Juez quien "controle" si se ha cumplido, o no, el límite de ejecución que sobre los bienes de la herencia para el cobro de los créditos impone el artículo 1001 y evitar, así, que los acreedores cobren en exceso.

Al hilo de ello, habida cuenta de la función e importancia que tiene la autorización judicial en el ejercicio de esta acción a la vista de las anteriores consideraciones y de la trascendencia que tiene su intervención, antes, durante y después del ejercicio de la acción, cabe plantearse qué consecuencias se derivan, en su caso, si los acreedores actuan por sí solos sin haber obtenido previamente dicha autorización y ocupan por su propia autoridad o iniciativa, por su cuenta y riesgo, los bienes de la herencia, ya sea de forma individual o colectiva, y sin que se haya comprobado y acreditado que se cumplen todos los presupuestos y requisitos necesarios para el ejercicio de dicha acción.

Así, dada la función que está llamada a cumplir, los particulares requisitos que se exigen con carácter previo a su ejercicio y las circunstancias que la rodean, el carácter singular y excepcional de la acción, son razones o motivos que nos inclinan a entender que no estamos ante el mismo tipo de autorización judicial a que se refiere el Código Civil en otros casos como puede ser la que precisan los padres para repudiar la herencia deferida sus hijos (art. 166 CC), o el tutor derechos del tutelado (art. 271,3ㅇ $\mathrm{CC}$ ). De ahí que, a nuestro juicio, si no se obtiene con carácter previo la pertinente autorización judicial, el ejercicio de esta acción sería nulo de pleno derecho y no meramente anulable. Los actos realizados por los acreedores al amparo de la misma para proceder al cobro de sus créditos no tendrían ninguna validez. Ni tan siquiera sería válida la obtención de la autorización a posteriori, después de haber ejercitado la acción. No cabría la subsanación o convalidación del acto porque, posiblemente, una vez que los acreedores han procedido a la ejecución de los bienes de la herencia para el cobro de sus respectivos créditos, sea muy difícil, sino imposible, corregir el exceso o perjuicio que, en su caso, se hubiese causado, o incluso deshacer las ejecuciones de bienes que hubiesen ya realizado.

Finalmente, en otro orden de argumentos, se plantea la cuestión de cual es el procedimiento a través del cual se ha de conceder dicha autorización judicial. Aquí, la LEC, al tratar de la división de la herencia (art. 782,3) establece que, "los acreedores no podrán instar la división, sin perjuicio de las acciones que les correspondan contra la herencia, la comunidad hereditaria o los coherederos, que se ejercitarán en el juicio declarativo que corresponda, sin suspender ni entorpecer las actuaciones de la 
división de la herencia". En este sentido, para DíEZ-PICAZO ${ }^{959}$ sería "en expediente de jurisdicción voluntaria que se convertirá en contencioso en caso de oposición". En igual sentido se manifiesta GITRAMA ${ }^{960}$. En tal caso, se sustanciará como cuestión incidental dentro del juicio de testamentaría o de abintestato, si éstos se hallaren en tramitación o, en otro caso, conforme a las reglas del juicio ordinario que en cada caso corresponda según la cuantía a que ascienda el importe de los créditos que pretendan satisfacer los acreedores a través del ejercicio de esta acción. Por nuestra parte, en igual sentido, porque habrá que estar a la situación en que se encuentre la herencia, si ha sido preciso incoar algún proceso judicial para proceder al reparto de los bienes de la misma. Si no hubiere proceso de testamentaría, los acreedores sólo podrán hacerlo a través del correspondiente proceso declarativo.

O'CALLAGHAN ${ }^{961}$, en cambio, entiende que habrá que acudir al proceso declarativo ordinario que corresponda según su cuantía, demandando no solo al deudor que ha repudiado sino también, en su caso, a los terceros que se beneficiarían de la repudiación (sustitutos, coherederos con derecho de acrecer o herederos abintestato), si ya se hubiese hecho reparto de los bienes entre ellos.

\section{3-5.- Sujetos implicados en el ejercicio de la acción.}

Los sujetos que intervienen o que resultan afectados en el ámbito de la acción del artículo 1001 CC, son:

a) el delado-repudiante-deudor, que sería el sujeto legitimado pasivamente para el ejercicio de la acción,

b) los acreedores, o sujetos legitimados desde el punto de vista activo, y

c) los beneficiarios de la renuncia, o destinatarios del sobrante o exceso de los bienes que no se hubiesen aplicado al pago de los créditos de los acreedores después del ejercicio de la acción y que serían, por este orden: los sustitutos previstos, en su caso, por el testador respecto del repudiante, los demás cosucesores de la herencia y, los sucesores abintestato.

\footnotetext{
959 “La aceptación de la herencia .........”. Cit: Pág 190.

${ }^{960}$ Comentarios al Código Civil ........ T XIV. Vol 1. Cit: Pág 245.

${ }^{961}$ Comentario del Código Civil. Cit: Pág 2375.
} 


\section{3-5-1.- El delado-repudiante-deudor.}

Cuando se refiere a él, el artículo 1001 CC incurre en la imprecisión o incorrección jurídica, de emplear el término "heredero" ${ }^{\prime 962}$, porque, partiendo de la premisa de que nuestro ordenamiento jurídico sigue el sistema romano de adquisición de la herencia, en sentido propio, estricto y técnico, solo es verdadero y propio heredero, y tiene la condición de tal, el sucesor que ha aceptado la herencia, por cuanto sólo a través de esta declaración se adquiere dicho título y condición, mientras que, si se repudia, supuesto de hecho que es el punto de partida de esta norma, sucede lo contrario, precisamente, se rechaza. Y aquí, el sujeto a que se refiere el artículo 1001 CC es al sucesor que ha repudiado la herencia, por lo que debería de decir: "si el sucesor, -o el llamado, o el delado-, repudia la herencia en perjuicio de sus propios acreedores .....".

Acerca del mismo, se ha de dar la circunstancia de ha de ser él, el sucesor que repudia, el deudor presente o actual de los derechos de crédito de que sean titulares los acreedores que invoquen el ejercicio de esta acción. Decimos esto porque, puede ocurrir que, con anterioridad al momento de producirse la declaración de repudio, o después de que ésta haya tenido lugar, pero siempre antes del ejercicio de la acción, haya existido una modificación de la relación jurídica obligacional, ya sea desde el punto de vista del activo, ya desde el punto de vista del pasivo y que el acreedor haya dado incluso su consentimiento expreso. En el primer supuesto, que se hubiere producido una cesión de créditos, no estaría legitimado para el ejercicio de la acción el antigüo acreedor, o cedente, por no ser el titular activo actual del derecho de crédito; sí lo estaría, en cambio, el nuevo acreedor, o cesionario. $Y$, en el segundo supuesto, si se ha producido un cambio de sujeto pasivo, el acreedor ya no estaría legitimado para el ejercicio de la acción del artículo 1001 contra el repudiante por la sencilla razón de que ya no es el sujeto pasivo presente o actual del derecho de crédito en el momento que dicho acreedor pretende hacerlo efectivo a través de aquella.

En consecuencia, el sucesor que repudia ha de ser el deudor que esté jurídicamente obligado al pago de los derechos de créditos de que sean titulares los acreedores en el momento en que éstos ejerciten la acción del artículo 1001 para

\footnotetext{
962 En este sentido, la Ley 10/2008, sobre Sucesiones de Cataluña (art. 461-7), incurre en la misma incorrección. Lo que no sucedía en el artículo 23 de la anterior Ley de Sucesiones de 1991.

En cambio, en Aragón (art. 342 CDFA), se expresa en un sentido más propio por cuanto habla del llamado que repudia una herencia.

Incluso, en otros Códigos Civiles europeos, como el francés (art. 779), o el italiano (art. 524), se elude la palabra sucesor o llamado.
} 
hacer efectivo el importe de los mismos. Por tanto, desde el punto de vista pasivo, ha de concurrir una doble circunstancia: que el sujeto contra el que se dirija la acción sea, a la vez, el sucesor que repudia y deudor actual del derecho de crédito, porque, si se cumple aquella condición pero no ésta, los acreedores carecerán de la acción prevista en dicho artículo para poder dirigirse contra los bienes de la herencia que le hubieren correspondido a dicho sucesor al no ser éste ya su deudor. Si así fuere, la repudiación de éste no les afecta ni les legitima para el ejercicio de dicha acción, como tampoco podrán dirigir reclamación alguna contra su patrimonio y sí contra el del nuevo y verdadero deudor.

De ahí que, en relación a este sujeto hablemos de, delado-repudiante-deudor.

\section{3-5-2.- Los acreedores.}

Del tenor literal del artículo 1001 CC se desprende que la acción en él contenida sólo concede legitimación activa para su ejercicio a quienes tuvieren la condición de acreedores particulares del sucesor que repudia por razón de las deudas que éste hubiere contraído con ellos como consecuencia de las relaciones jurídicas particulares celebradas entre sí, entre unos y otros. El actor ha de ser necesariamente acreedor presente o actual del repudiante.

No obstante, sólo están legitimados quienes tengan la condición de acreedores del repudiante en el preciso momento en que se ejercita la acción, incluso aunque el crédito se haya contraído después de que se haya abierto la sucesión, pero siempre antes de que se haya producido la declaración de repudio, "pues, naciendo después, los acreedores no pueden decirse perjudicados por ella" (LACRUZ ${ }^{963}$ ) (STSJ Cataluña de 29 de enero de 1996, RJ 6248), careciendo también de legitimación activa quienes lo fueron y dejaron de serlo porque hicieron cesión de su derecho de crédito antes de realizarse la repudiación, o después, pero siempre antes del ejercicio de la acción.

En el ejercicio de la acción, si hubiere varios derechos de crédito que fueren diferentes, distintos, separados e independientes unos respecto de otros, de tal manera que no tienen nada que ver entre sí, los acreedores titulares de cada uno de ellos podrán actuar de manera individual o particular, con independencia y por separado de los demás, no siendo preciso que se pongan de acuerdo para actuar a un mismo tiempo, coordinados entre sí, incluso de forma conjunta, de tal manera que la ausencia o desistimiento en el ejercicio de esta acción por parte de algún acreedor,

\footnotetext{
${ }^{963}$ Elementos de Derecho Civil. T. V. Cit: Pág 75.
} 
enervación o nulidad de la misma frente a alguno de ellos, no perjudica ni afecta a los demás. No obstante, en el caso de que se trate de créditos mancomunados o solidarios, eso sí, los acreedores estarían sujetos en el ejercicio de dicha acción a las reglas de esta clase de obligaciones (art. 1137 y ss CC).

Por otro lado, estarían también legitimados activamente, en su caso, para el ejercicio de la acción del artículo 1001, otras personas como serían:

a) los sucesores del acreedor ${ }^{964}$ cuando no habiéndose ejercitado por éste en vida dicha acción, se transmite a aquellos por vía de sucesión mortis causa el derecho de crédito (art. $1257 \mathrm{CC}$ ). En este caso, estarían legitimados aquellos que hubieren aceptado la herencia, o el legatario a quien dicho acreedor hubiere legado su derecho de crédito (art. 870 CC),

b) si el derecho de crédito hubiese sido objeto de cesión por acto inter vivos por parte del acreedor, estaría legitimado el cesionario (arts. 1526 y 1527 CC),

c) incluso, aquel que pagó por cuenta del sucesor-deudor siempre que no lo hubiere hecho contra su expresa voluntad (art. $1158 \mathrm{CC}$ ).

Además de los anteriores, nos planteamos si están tambien legitimados, en su caso, para el ejercicio de esta acción otros sujetos, pertenecientes a una herencia en la que ha habido un ius transmissionis, por cuanto su respectivo derecho sucesorio se ve afectado como consecuencia de la repudiación que ha hecho de la misma el transmisario, y que serían: los legitimarios y el cónyuge del transmitente.

Acerca de los primeros, el supuesto, en concreto, se planteó a propósito de una herencia en la que el transmisario optó por aceptar la herencia a la que él había sido llamado, la del transmitente, y repudiar la que era objeto de transmisión, ante lo que los legitimarios de aquel, del transmitente, entendieron que habían sido perjudicados por esa decisión en base al argumento de que, de haber aceptado el transmisario los bienes de la primera herencia, éstos habrían entrado a formar parte de la de su causante o transmitente y, en consecuencia, sus respectivos derechos legitimarios se habrían beneficiado. Entonces, la cuestión que se debate es, si a los legitimarios se les puede considerar o equiparar, en virtud del derecho que tienen a la legítima, a los acreedores del repudiante, a los efectos de ejercicio de la acción del artículo 1001 CC, lo que les facultaría para actuar contra él a través de la referida acción o si, por el

\footnotetext{
${ }^{964}$ Vid: DÍEZ-PICAZO: “La aceptación de la herencia ........”. Cit: pág 176.
} 
contrario, se les consideraría como acreedores de la herencia ante lo que tendrían que recurrir a otros medios de defensa.

Tal problemática fue tratada por la Dirección General de los Registros y del Notariado en dos resoluciones idénticas de 23 de junio y 23 de julio de 1986 (RJ 3843 y 4930$)^{965}$ que, al dar respuesta a la misma, argumenta del siguiente modo (Fdtos $5^{\circ}$ y $\left.6^{0}\right):$

"en relación con esta cuestión caben dos posiciones: a) Entender que la masa patrimonial de la primera herencia queda totalmente fuera de la del transmitente en el supuesto de que la transmisaria, al ejercitar el «jus transmissionis», opte por la

${ }^{965}$ El caso que dio origen a las dos Resoluciones fue el siguiente:

Don Joaquín F. N. fallece intestado, siendo declarados herederos del mismo por Auto Judicial, sus hijos, Don José y Don Francisco. Pero resulta que éste, Don Francisco, fallece después sin haber aceptado ni repudiado la herencia de su padre, bajo testamento abierto, en el que "lega a sus dos hijos, Don Joaquín y Don Roque, lo que por concepto de legítima pudiera corresponderles e instituía heredera universal a su esposa $D^{a}$ Isabel D. B., con cláusula de sustitución vulgar a favor de sus dos citados hijos en los tres supuestos legales”.

Más tarde, $\mathrm{D}^{\mathrm{a}}$ Isabel acepta ante Notario la herencia de su esposo, D. Francisco, pero, en su condición de transmisaria y en ejercicio del “ius transmissionis”, renuncia a la herencia de su suegro, por lo que pide que se inscriba la finca que constituía el haber hereditario de éste, a favor del otro hijo, José, su cuñado.

La cuestión que se suscita es si la repudiación puede o no perjudicar la legítima de los hijos de Don Francisco, sustitutos vulgares de su herencia, por cuanto a resultas de la repudiación ya no accederían a los bienes de la herencia de su abuelo. La petición es de todo punto lógica porque, al haber renunciado a dicha herencia, queda vacante una mitad indivisa de la herencia de Don Joaquín, que acrece a favor del otro coheredero al ser éste el mecanismo legal aplicable para cubrir la vacante que se ha producido al tratarse de una sucesión intestada la herencia de Don Joaquín (la sustitución prevista lo sería respecto de la vacancia que se produjese en la herencia de Don Francisco, que sería después el argumento invocado por el Registrador para denegar la inscripción).

Presentado en el Registro de la Propiedad el documento por el que se acepta una herencia y se repudia la otra, fue calificado con la nota del siguiente tenor literal: “denegada la inscripción del presente documento, porque, figurando en testamento de D. Francisco F. A., sustitución vulgar a favor de sus hijos, para caso, entre otros, de que la heredera $D .{ }^{a}$ Isabel D. B., «no quisiera heredar», la renuncia de ésta da lugar a que entre en juego dicha sustitución respecto de la herencia renunciada, dado que el derecho de aceptar o repudiar la herencia de D. Joaquín F. N. («ius transmisionis») forma parte también de la herencia de D. Francisco F. A., defecto insubsanable, por lo que no procede anotación preventiva de suspensión, que tampoco se ha solicitado, contra esta calificación cabe interponer recurso ante el Excmo. Sr. Presidente de la Audiencia Territorial de Barcelona, y después, en su caso, recurso de apelación ante la Dirección General de los Registros y del Notariado".

El Notario autorizante interpuso recurso gubernativo, el Presidente de la Audiencia Territorial de Barcelona acogió el recurso y revocó la nota del Registrador quien interpuso recurso de apelación y la Dirección General de los Registros confirmó el auto apelado.

La DGRN, establece que, "una vez aceptada la herencia, la legítima, desde el momento en que se defiere aquella, es carga de la herencia, por lo que pasa a ser, también, deuda de la que el heredero ha de responder incluso con sus propios bienes. Los legitimarios tienen entonces, para conseguir el pago total de la legítima, acción personal frente al heredero y, a la vez, acción real sobre los distintos bienes que integran la herencia. No tienen ciertamente acción real sobre cada uno de los bienes concretos de la herencia repudiada por el transmisario en el libre ejercicio de una facultad que es personalísima suya, ni, tampoco, sobre todos ellos en su conjunto en cuanto objeto de un derecho hereditario que por sí sea enajenable y embargable”.

No obstante lo anterior, la DGRN equipara la posición de los legitimarios a la de los acreedores propios del repudiante a los efectos de poder ejercitar la acción prevista en el artículo 1001 CC. 
repudiación -como ha sucedido-; b) Entender, por el contrario, que a efectos de determinar el importe de la legítima el «jus delationis» también se computa, porque en sí es susceptible de valoración económica por lo mismo que es susceptible de venta (cf. art. 1000-1. ${ }^{\circ}$ CC) (no importa, a los efectos de esta computación, que la venta implique aceptación). Y no cabe oponer -contra esta segunda posición- que si el transmitente hubiera repudiado en vida, ningún cómputo se hubiera hecho de la herencia repudiada para la determinación de las legítimas; porque, mientras el transmitente vivía, la legítima no estaba deferida, y, en cambio, sí lo está -y es ya carga de la herencia- desde que el transmitente muere -aunque su herencia abierta, aún no haya sido aceptada-. La legítima, ya deferida, no puede, después, quedar menoscabada por las vicisitudes de la herencia del transmitente o por los actos unilaterales del que en ella llegue a ser heredero.

En favor de la primera tesis puede invocarse el principio de Derecho Común, «jus adeundi hereditatem non est in bonis nostris»; el carácter personalísimo del «jus delationis» y de la misma condición de heredero -respecto de los cuales no caben otras transmisiones que las expresamente previstas en la Ley (cf. art. 258 Compilación)- y el carácter «enteramente voluntario y libre» (cf. art. 988 C.C.) de la aceptación y repudiación de la herencia.

$Y$, en favor de la segunda tesis, el que con ella se protege mejor las legítimas, sin que haya necesidad de contradecir el indudable carácter personalísimo de la opción que implica el «jus delationis». Afirmar que el «jus delationis» debe ser incluido como valor computable para fijar el importe de la legítima no significa que, además, el «jus delationis» haya de ser considerado en sí como un bien de la herencia que está afecto directamente, como los demás bienes hereditarios (cf. art. 140 Compilación), al pago de la legítima, pues, si como queda dicho, no es, por principio, transmisible, menos podría ser susceptible de embargo o afección real. Cabe, según queda dicho, vender la herencia aún no aceptada, pero esta decisión es absolutamente personalísima por lo mismo que por sí implica aceptar la cualidad intransferible de heredero" ${ }^{\prime 66}$.

${ }^{966}$ Acerca de las dos tesis planteadas, podemos encontrar dos posiciones distintas:

VALLET, entiende que, como el ius delationis lo recibe el transmisario en la herencia del transmitente, ha de contarse también en la herencia de éste en lo que respecta a efectos del cómputo de la legítima y partes disponibles (Panorama del Derecho de Sucesiones. II Cit: Pág 400). Pero es una manifestación que no hizo a propósito de la problemática suscitada en las dos Resoluciones.

HERNÁNDEZ VALDEOLMILLOS, en cambio, entiende que el ius delationis siendo un derecho personalísimo y extrapatrimonial, no debe valorarse o evaluarse económicamente, por lo que "la herencia del primer causante y la del transmitente han de constituir masas separadas ya que el transmisario 
La DGRN, se inclina a favor de la segunda tesis y entiende que la posición de los legitimarios es equiparable a la de los acreedores propios del repudiante, por lo que, ante el hecho de la repudiación, sí podrían recurrir a la acción del artículo 1001 CC en virtud de su derecho a la legítima, lo que les facultaría para actuar contra él a través de la misma, porque, "los legitimarios podrían, como titulares de un crédito (su propio derecho legitimario) -que lo es frente a la herencia aceptada por el transmisario mismo- ejercitar el derecho que a los acreedores, en general, confiere el artículo 1001 del Código Civil cuando el llamado repudia una herencia en perjuicio de sus propios acreedores". A lo que añade, "Mas, en todo caso, si consta la repudiación de la primera herencia, nada podrá oponer el Registrador al funcionamiento, respecto de ella, del derecho de acrecer, ........, en tanto no conste que, en efecto, usaron de la facultad prevista en el artículo 1001 del Código Civil en términos que inutilicen o mengüen el derecho de acrecer".

Sin embargo, el Tribunal Superior de Justicia de Cataluña, en sentencia de 29 de enero de 1996 -RJ 6248-, resuelve en sentido contrario y niega esta posibilidad al declarar que, "la hija legitimaria no se puede equiparar, a los efectos del artículo 1001 del Código Civil, a los acreedores particulares del heredero, puesto que el legitimario tiene un derecho de crédito contra la herencia como consecuencia de la apertura del proceso sucesorio, pero no un derecho de crédito contra el heredero".

Acerca de esta cuestión, tanto BAYOD ${ }^{967}$ como JORDANO FRAGA ${ }^{968}$ disienten también de la postura de la DGRN porque lo que se ha de plantear es, si los legitimarios han recibido, o no, lo que por legítima les corresponde (en el caso que dio lugar a ambas resoluciones a los legitimarios se les atribuyó su legítima por vía de legado). Si es que sí, los legitimarios carecerían de toda acción por cuanto su derecho está satisfecho. Si es que no, la solución, según BAYOD, sería ejercitar el recurso que les concede el artículo 817 CC y procedería la reducción de la institución de heredero, pero no la vía del artículo 1001 CC. Como tampoco sería solución, si lo anterior es insuficiente, sigue argumentando BAYOD, agregar a la base del cálculo de la legítima, por la vía del artículo 818 CC, el valor económico neto de la primera herencia, por

podría aceptarlas a beneficio de inventario. En consecuencia, los derechos legitimarios sólo recaerán sobre sus respectivas herencias, pues siendo las legítimas pars bonorum cada grupo de legitimarios lo será con relación a su propio causante, y así, los legitimarios del transmitente no tendrán derecho alguno a la herencia del primer causante y viceversa, pues las normas del Código Civil sobre computación, imputación, colación, reducción de donaciones, etc, deben aplicarse a cada caudal con independencia del otro" (La transmisión del "ius delationis". Cit: Pág 488 y ss.).

${ }_{967}^{967}$ Op. cit: Pág 139 y ss.

${ }^{968}$ La sucesión en el “ius delationis”. Cit: Págs 339 a 341. 
cuanto ello supondría dar al ius delationis de la primera herencia un valor económico y patrimonial que no tiene.

Nosotros, en igual sentido, entendemos que el medio de defensa de que disponen, en este caso, los legitimarios, es efectivamente la acción que les concede el artículo 817 del Código Civil si la institución de heredero perjudicare su legítima, de lo que se derivaría una reducción en la institución ordenada por el testador. Su derecho a la legítima se traduce en un derecho de crédito, no contra el heredero, sino contra la herencia ${ }^{969}$ de la que serían acreedores de la misma en relación a sus derechos legitimarios. Luego, carecerían de legitimación para poder reclamar a través de la acción del artículo 1001.

Se da, además, la circunstancia, por otro lado, de que en el supuesto de hecho de las dos resoluciones, que es el mismo, los nietos tienen la condición de sustitutos vulgares en la herencia de su padre (transmitente) respecto del heredero instituido por éste, su madre (transmisaria), pero no en la herencia del abuelo, en la que los herederos son abintestato, su padre y su tío, y donde, lógicamente, no hay sustitutos. Luego, la repudiación que hace la madre en su condición de transmisaria, respecto de la herencia de su suegro, o abuelo de aquellos, a ellos no les afecta en absoluto (aquí entendemos que hubo un error por parte del Registrador que aplicó la sustitución en la primera herencia). Sí les afectaría si la madre hubiese repudiado la herencia de su marido porque entonces hubiese entrado el juego la sustitución vulgar ordenada a su favor. Mientras que, si la madre hubiere aceptado, los bienes prevenientes de la herencia del abuelo quedarían englobados en la herencia del padre. Lo cual les habría beneficiado en sus derechos sucesorios. Pero, no es el caso, y los nietos, como consecuencia de la repudiación de su madre, se ven perjudicados al no haber ingresado en la herencia del padre, los bienes que a éste le hubiesen correspondido de la herencia del abuelo.

$\mathrm{Y}$, en el caso del cónyuge viudo del transmitente, se plantea en idénticos términos: si su derecho sucesorio le concede, en su caso, un derecho de crédito contra la herencia o contra el transmisario. El problema surge ante el hecho de que el usufructo vidual se calcula sobre el valor del acervo hereditario de su difunto consorte

969 En este sentido, hemos de tener en cuenta cual es la naturaleza jurídica de la legítima, debatiéndose la cuestión, en la que no vamos a entrar, de si se considera: "pars valoris", parte del valor de los bienes de la herencia, o si, "pars hereditatis", parte alícuota del caudal hereditario con todo su activo y su pasivo, por lo que es cuenta herencial y ha de ser abonada con bienes de la herencia. En la jurisprudencia predomina esta segunda: SSTS 31 de marzo de 1970, RJ 1854; 8 de mayo de 1989, RJ 3673; 26 de abril de 1997, RJ 3542; SSAP, Granada, de 12 de mayo de 2001, AC 2001/1598; Asturias, de 5 de mayo de 1998, AC 1998/963; Badajoz, de 11 de julio de 1995, AC 1995/1395. 
que resulta perjudicado al no entrar en el mismo los bienes objeto de transmisión a resultas de la repudiación, lo que supone una merma y el consiguiente daño. De ahí que se plantee si puede proceder contra el transmisario por el perjuicio que pudiere haber sufrido a resultas de su declaración ${ }^{970}$. No obstante, ante ello, surge la cuestión previa de, si el usufructo vidual se calcula también teniendo en cuenta el valor de los bienes de la primera herencia, porque, en caso afirmativo, el viudo tendría la condición de acreedor del transmisario y estaría por ello legitimado activamente para el ejercicio de la acción del artículo 1001 CC.

Tratando de dar respuesta a las dos cuestiones planteadas, hemos de partir de la consideración de que el cónyuge viudo no ostenta ningún derecho propio y directo sobre los bienes, porción o cuota de la primera herencia ya por el solo hecho de que quien fue llamado a la misma fue su consorte y no él. El derecho sucesorio hubiese existido si éste, el consorte, la hubiere aceptado, porque entonces sería cuando hubiesen entrado a formar parte de su patrimonio, y después de su herencia, sobre la cual se habría calculado tal derecho sucesorio. Así, el cónyuge del transmitente no ostentaría ningún derecho vidual sobre los bienes provenientes de la herencia del primer causante ya que su causante nunca llegó a adquirirla. Como tampoco lo tendrá en el futuro porque, a resultas de la repudiación del transmisario, los referidos bienes ya no formarán parte definitivamente del patrimonio de su consorte. En este sentido, hemos de tener en cuenta que, "el derecho de usufructo es un derecho universal que recae sobre la unidad patrimonial constituida por la herencia y no sobre cada uno de los bienes $y$ es un derecho forzoso que nace con independencia absoluta de la voluntad de los interesados" (SAP Palencia de 6 de julio de 1998, AC 6315). Luego, el usufructo vidual no es un derecho que ostente el cónyuge viudo contra ninguno de los sucesores del consorte y sí contra la herencia. Por razón de su derecho sucesorio, sería, no un acreedor particular de ninguno de los sucesores y sí de la herencia. En consecuencia, entendemos que no estaría legitimado para reclamar perjuicio alguno contra el transmisario a través del artículo 1001 CC.

\section{3-5-3.- Los sujetos beneficiarios.}

Otra de las características que adornan el ejercicio de esta acción es el hecho de que los acreedores sólo se benefician de los bienes que le hubieren correspondido a su deudor de forma limitada, hasta donde alcance el importe de los créditos de que ellos sean titulares en el momento de dicho ejercicio, de tal manera que el exceso o sobrante de los mismos, si lo hubiere, no les pertenece a ellos, tampoco al repudiante,

\footnotetext{
${ }^{970}$ Vid: HERNÁNDEZ VALDEOLMILLOS: Op. cit. Pág 490.
} 
sino que va a parar, de forma genérica, según el artículo 1001, “... a las personas a quienes corresponda según las reglas establecidas en este Código". Pero no dice más. Lo que plantea la cuestión de quienes son efectivamente esas personas.

Dado su tenor, su determinación se hará, dicho con otras palabras, a través de la aplicación de los mecanismos legalmente previstos para establecer el destino mortis causa de aquello que fue objeto de repudio y que dependerá, o estará en función, de las circunstancias particulares y concretas de la sucesión de que se trate, de lo que resulta que pueden serlo: en primer lugar, los sustitutos designados, en su caso, por el testador respecto del repudiante-deudor (art. 774 y ss CC), en su defecto, los coherederos con derecho de acrecer (art. 981 y ss CC), y, en último término, los herederos abintestato de dicha sucesión (art. 912,3 CC).

No obstante, puede ocurrir que estos sujetos se vean tambien demandados, en su caso, por los acreedores a través del ejercicio de esta acción, ya que su respectiva posición jurídica se puede ver afectada como consecuencia de dicho ejercicio. Todo dependerá del momento en que éste se produzca.

Así, si al tiempo de formularse la reclamación por parte de los acreedores, ya se ha procedido a la división y adjudicación entre los herederos de todos los bienes de la herencia, incluidos, lógicamente, aquellos que fueron objeto de repudio, ignorando, o tal vez, anticipándose a la intención de los acreedores particulares del cosucesor que repudió de ejercitar dicha acción, en este caso, sí que se verían afectados por dicha reclamación, lo cual no obsta para que, en su caso, puedan oponerse a la misma en el correspondiente proceso judicial compareciendo en el mismo, defenderse ante su pretensión y alegar lo que a su mejor derecho convenga (BAYOD ${ }^{971}$, DíEZ-PICAZO ${ }^{972}$, GITRAMA $^{973}$ ).

Ahora bien, si en el momento en que los acreedores ejercitan su acción, aun no se han llevado a cabo las operaciones de división y adjudicación, y la herencia se encuentra indivisa entre quienes hubieren aceptado, la reclamación por aquellos sólo se podrá dirigir contra el delado-repudiante-deudor porque los sujetos que, en su caso, fueren beneficiarios del exceso, aun no son los adjudicatarios de dichos bienes. En realidad, al no haberse ejercitado todavía la acción, probablemente ni tan siquiera se puede saber si habrá exceso de bienes porque, incluso, puede ocurrir que alcancen para cubrir el importe de los créditos que sean objeto de ejecución, o que sean

\footnotetext{
971 Op. cit: Pág 194 a 223.

972 “La aceptación de la herencia .........”. Cit: Pág 181.

973 Op. cit: Pág 243.
} 
insuficientes, en cuyo caso, no habrá exceso que adjudicar. Y si hubiere sobrante de bienes, después, cuando se les adjudique el exceso, eso sí, verán reducida la porción de bienes que, en su caso, habrían recibido de no haberse ejercido esta acción por los acreedores, pero no por ello pueden ser demandados al no ser todavía titulares en concreto de ningún bien específico y determinado de la herencia al encontrarse ésta aun en situación de indivisión.

\section{3-6.- Presupuestos para su ejercicio. ${ }^{974}$}

El supuesto de hecho o circunstancia que da lugar al nacimiento de esta acción lo constituye, por un lado, la declaración de repudiación del delado que, podríamos decir, es el punto de ignición o de arranque de la misma, y, por otro, la existencia de unos acreedores que carecen de toda otra posibilidad de cobrar lo que su deudor les debe y a quienes dicha declaración les ha causado un daño o perjuicio porque, como consecuencia de la misma, ven frustradas sus posibilidades de poder dirigirse contra aquellos bienes de la herencia que le hubieren correspondido a su deudor, caso de haber aceptado, ante lo que se les concede el recurso de poder dirigirse contra los mismos a través del ejercicio de esta acción del artículo 1001 CC.

Los presupuestos que se exigen para que los acreedores puedan recurrir a ella en defensa de sus derechos respectivos de crédito, están referidos a: la repudiación de la herencia, las características del crédito y el perjuicio a los acreedores.

\section{3-6-1.- La repudiación de la herencia.}

Constituye el punto de partida del que nace el ejercicio de esta acción, de tal manera que actúa a modo de conditio sine qua non de la misma. Si el deudor hubiere aceptado la herencia o aun no se hubiese pronunciado acerca de la delación, los acreedores no podrían, en modo alguno, ejercitarla, incluso aunque el deudor ya se encuentre en ese momento en una situación de clara y manifiesta insolvencia porque no puede hacer frente al pago de sus deudas.

El perjuicio a los acredores nace desde el momento en que, como consecuencia del repudio, se agrava la situación patrimonial del deudor porque se ven privados de unos bienes que, en el caso de haber aceptado la herencia, habrían entrado en el patrimonio de su deudor, se podrían haber dirigido contra ellos y proceder a su

${ }^{974}$ Vid, entre otros: BAYOD: Op. cit.: Pág 96 y ss; DÍEZ-PICAZO: "La aceptación de la herencia por los acreedores del heredero”. Cit: Pág 172 y ss; FLORENSA I TOMÁS: La naturaleza del procedimiento ......; GITRAMA: Comentarios al Código Civil .... T XIV. Vol 1º Cit: Pág 241 y ss.

Vid: SAP Tarragona (Sección 3a ), de 8 de junio de 1999 (AC 1999/6667). Fdto de Derecho 1º. 
ejecución para el cobro de sus créditos. Así, puede ocurrir que, ya en el momento en que el sucesor repudia la herencia, tenga dificultades para pagar sus deudas frente a los acreedores, si bien, esta situación se agravaría con su declaración de repudio al hacer de peor condición su situación patrimonial ya que se podría haber aliviado caso de haber aceptado, lo que supone un claro y manifiesto perjuicio para los acreedores. De ahí, la relación de causa-efecto directa e inmediata que tiene que existir entre dicho perjuicio y la repudiación.

La repudiación, por otro lado, lógica y evidentemente, para que sea tenida como tal, ha de tener plena eficacia jurídica, esto es, ha de ser verdadera, válida, eficaz, y reunir en el momento de su exteriorización todos los requisitos y presupuestos de capacidad, consentimiento, objeto, tiempo y forma exigidos por la ley. No obstante, si la repudiación fuere ineficaz ${ }^{975}$, aunque los acreedores carecerían, en este caso, de la acción del artículo 1001 CC, sí tendrán a su favor de otros medios de defensa de su derecho de crédito, incluso de impugnación de la declaración de repudio de su deudor $^{976}$. En este sentido, manifiesta DÍEZ-PICAZO ${ }^{977}$ que, "si la renuncia se hubiese hecho antes de la apertura de la sucesión y de la delación de la herencia, sería ineficaz (art. 991 CC), por lo que no entraría en juego el artículo 1001 CC, sino que los acreedores tendrían una acción ordinaria para reclamar la ineficacia de la renuncia, lo mismo que si el deudor era incapaz para renunciar o la renuncia no se hubiere hecho formalmente".

\section{3-6-2.- El perjuicio a los acreedores ${ }^{978}$.}

Es el otro de pilar sobre el que descansa en su ejercicio la acción del artículo 1001 CC. Además se ha de dar la circunstancia de que el perjuicio en el patrimonio de los acreedores se ha de producir como una consecuencia directa derivada de la repudiación, de tal manera que ha de existir una relación de causa a efecto entre ésta y aquel. De no ser así, si pese al repudio, el perjuicio no se produce o no lo justifican los acreedores, éstos no estarían legitimados para poder ejercer dicha acción y a través de la misma actuar sobre los bienes de la herencia para así cobrar lo que su deudor les adeuda.

\footnotetext{
975 Acerca de las causas de ineficacia de la repudiación y sus consecuencias, véase el capítulo décimo al que nos remitimos.

${ }^{976}$ Vid: MAIERINI: Della revoca degli atti fraudolenti: fatti dal debitore in pregiudizio dei creditori. Con note dell'avv. Giorgio Giorgi. Firenze: Casa Editrice Libraria "Fratelli Cammelli", 1898. Pág 128 y ss.

977 “La aceptación de la herencia .........". Cit: Pág 181.

${ }^{978}$ Se trata de un requisito que también se exige en otras situaciones semejantes en que la ley otorga a los acreedores acción para la protección del crédito (arts 1111 y 1291,3 CC).
} 
No obstante, la noción de "perjuicio", siguiendo a DíEZ-PICAZO ${ }^{979}$, se puede contemplar desde dos puntos de vista: objetivo y subjetivo:

A) al amparo del primero, "debe ser examinada la realidad del perjuicio como requisito de la acción derivada del artículo 1001", y

B) en sentido subjetivo, la cuestión que se suscita es si tiene que existir en el deudor al realizar la repudiación, la intención de perjudicar, o un ánimo defraudatorio, hacia los acreedores.

A) La realidad del perjuicio.

En este sentido, es menester que concurran dos circunstancias: una, que afecta a la incapacidad del patrimonio del deudor para hacer frente al cumplimiento de las obligaciones, lo que se traduce en una situación de insolvencia; otra, que hace referencia a la herencia deferida y renunciada, o su objetiva idoneidad para remediar la incapacidad patrimonial del deudor para hacer frente al pago de las deudas.

Desde este punto de vista, el perjuicio, aunque no lo diga el artículo 1001 CC, "presupone la insuficiencia del patrimonio del deudor, que no hay bienes bastantes para pagar todas las deudas", porque, si dicho patrimonio es suficiente, por razón del activo de que está formado, para hacer frente a dichos pagos, de tal manera que éstos se pueden satisfacer en la totalidad de su importe a través de los bienes, derechos y acciones que lo integran y fueren realizables, es de todo punto obvio que no se puede hablar de perjuicio ya que, sencillamente, no existe porque, llegado el momento de su ejecución, se podrán dirigir contra ellos para hacerlos efectivos. Si la situación económica del patrimonio del deudor está saneada porque el deudor no tiene ninguna dificultad para el pago de las deudas que contrae, a los acreedores les es indiferente que su deudor repudie la herencia, incluso que la acepte, aunque en este caso el patrimonio aumenta de valor y con ello la garantía de pago de los créditos, lo que evidentemente interesa a los acreedores.

Ahora bien, si en el patrimonio del deudor no hay activos bastantes (bienes, derechos, acciones), que sean suficientes para solventar el importe de los créditos de los acreedores, es lo que se traduce, en una situación de insolvencia, entendiendo como tal, la incapacidad o impotencia del patrimonio del deudor para hacer frente al pago de las deudas contraídas al no existir en él bienes, derechos o acciones que fueren realizables o susceptibles de ejecución. De ahí que, el perjuicio de acreedores

979 “La aceptación de la herencia .”. Cit: Pág 183 y ss. 
supone o entraña una situación de insolvencia o una situación de peligro de insolvencia del patrimonio del deudor.

No obstante, hablar de insolvencia nos lleva a otro término con el que tiene relación pero con el que no se identifica, cual es el de, concurso. Término aquí equívoco porque la ley concursal, 22/2003, establece en su artículo 2.1, como presupuesto objetivo para la declaración de concurso que el deudor se encuentre en situación de insolvencia, entendiendo como tal (art. 2.2), cuando "no puede cumplir regularmente sus obligaciones exigibles", definición que podría ser, en principio, válida aquí a los efectos de declarar o apreciar la existencia del perjuicio para los acreedores. Pero, hay que matizar, porque, si bien el concurso presupone objetivamente una situación de insolvencia, ésta, conceptual y legalmente, no presupone, ni exige, a los efectos del artículo 1001 CC, la declaración de concurso en el deudor. Por tanto, basta una situación de insolvencia, sin necesidad de declaración de concurso de acreedores, para que éstos puedan hacer uso de la acción del artículo 1001 CC.

Por otro lado, la insolvencia en el deudor es diferente de la situación deficitaria de su patrimonio, lo que tiene lugar cuando el activo es inferior al pasivo, situación ésta que, por un lado, en el ámbito del antiguo artículo 1913 del Código Civil ${ }^{980}$ era presupuesto para instar el concurso y, por otro, significa o se puede equiparar a una situación de insolvencia. Pero, no es tampoco del todo exacto, porque la insolvencia puede existir aunque la situación del patrimonio no sea deficitaria, como sucede cuando, existiendo bienes en el activo de valor superior al importe de las deudas, todos o la mayor parte de ellos no fueren realizables o no se pudieren ejecutar por los acreedores. "La medida de la insolvencia la da la diferencia entre el importe de las deudas y el valor de los bienes realizables" (DíEZ-PICAZO ${ }^{981}$ ).

De todo ello, concluye DíEZ-PICAZO, a continuación, manifestando que, “.... el perjuicio de acreedores a que se refiere el artículo 1001 supone la insolvencia del deudor, entendiendo insolvencia como insuficiencia de los bienes del deudor para cubrir sus deudas, con independencia de que esta insolvencia pueda traducirse contablemente en un pasivo superior al activo o de que la insolvencia se canalice o no a través de un concurso o quiebra".

\footnotetext{
${ }^{980}$ Decía lo siguiente: "el deudor cuyo pasivo fuese mayor que el activo y hubiese dejado de pagar sus obligaciones corrientes, deberá presentarse en concurso ante el Tribunal competente luego que aquella situación le fuere conocida".

981 “La aceptación de la herencia ............”. Cit: Págs 185 y 186.
} 
Además de la situación de insolvencia, la segunda circunstancia a que hacíamos referencia, y que hay que valorar y tener en cuenta a los efectos de la existencia o no del perjuicio en los acreedores, es el estado o situación en que se encuentra la herencia repudiada, en el sentido de si arroja saldo positivo o negativo, una vez que han sido pagadas las deudas de la misma ${ }^{982}$, esto es, si estamos ante una herencia beneficiosa o perjudicial (hereditas damnosa).

En el primer caso, si estamos ante una herencia que es beneficiosa porque el saldo neto definitivo es positivo para los herederos porque apenas hay deudas o resta un buen sobrante después de haberlas pagado, y se da la circunstancia de que el patrimonio del deudor, con anterioridad al momento de producirse la delación, se encuentra en una situación económica solvente porque tiene capacidad suficiente para hacer frente al pago de los créditos, de tal manera que éstos no corren ningún riesgo de impago, difícilmente se puede hablar de la existencia de un perjuicio para los acreedores si el deudor repudia la herencia. Luego, en este caso, los acreedores, no sólo poco les importaría la repudiación de la herencia ${ }^{983}$, sino que no pueden alegar la existencia de un perjuicio y carecerían de legitimación, en su caso, para invocar a su favor la acción del artículo 1001 CC si pretendieren actuar a través de la misma sobre aquellos bienes de la herencia que repudió su deudor.

Distinto es que el patrimonio del deudor se encuentre en una situación de precariedad económica o insolvencia porque su activo no tenga capacidad suficiente para hacer frente al pago de las deudas. Entonces, en este caso, la repudiación sí que produciría un perjuicio en los acreedores porque, el deudor, de haber aceptado la herencia, habría permitido la entrada en su patrimonio a aquello a lo que había sido llamado, lo que habría mejorado su situación al hacer disminuir o desaparecer la insuficiencia o insolvencia patrimonial en que se encuentra, y los acreedores se podrían haber dirigido contra los bienes que le hubiesen correspondido para hacer efectivo el importe de sus créditos. En este caso, no sólo estaría justificado el ejercicio de la acción del artículo 1001, sino que los acreedores estarían totalmente legitimados para ello.

982 En este sentido, vid, entre otros: BAYOD: Op. cit.: Pág 105 y ss; DÍEZ-PICAZO: "La aceptación de la herencia ............”. Cit: Pág 186; GITRAMA: Comentarios Al Código Civil ..... T XIV Vol 1․ Cit: Pág 244.

983 Tal vez lo que les preocupe es que su deudor acepte la herencia si lo hiciere de forma pura y simple y la herencia fuere deficitaria porque esté cargada de deudas, ya que, en este caso, su patrimonio sí que se vería comprometido al tener que hacer frente a las deudas del causante con el consiguiente riesgo para sus créditos. En este caso, es la aceptación, y no la repudiación, la que puede causarles un perjuicio. 
Ahora bien, si estamos ante una herencia deficitaria porque su pasivo es superior al activo y lo único que va a recibir el deudor, caso de aceptar, son deudas del causante, obviamente, la repudiación, cualquiera que sea la situación económica del deudor -peor aun si en el momento de la delación ya se encuentra en una situación de insolvencia-, no solo no causa perjuicio a los acreedores, sino que, más bien, les beneficia, incluso les interesa, sobre todo en el segundo caso, porque además de que no empeora la situación patrimonial del deudor, se mantiene, mientras que, en el caso de aceptar, se agravaría aún más su precaria situación económica y aumentaría la insolvencia, lo que dificultaría de forma extraordinaria el pago de los créditos. Dice bien, en este sentido DÍEZ-PICAZO ${ }^{984}$, que, "no hay perjuicio cuando la herencia no es útil. Para que la herencia no sea deficitaria, es preciso que la vocación le reporte ganancias al deudor una vez liquidadas las deudas de la herencia. Por ello, en caso contrario, si la herencia fuere deficitaria, la repudiación no causaría realmente un perjuicio a los acreedores y carecería de sentido el ejercicio de la acción del artículo 1001 porque, como decimos, no hay propiamente para ellos daño o perjuicio ya que, de aceptar su deudor la herencia, recibiría deudas, lo que agravaría su situación.

Por otro lado, el hecho de que la herencia sea o no deficitaria, es una cuestión no sólo de prueba en el correspondiente proceso judicial, sino que sería un extremo a demostrar por el deudor en defensa de la demanda que, en su caso y en su contra, hubiesen dirigido contra él los acreedores, mientras que éstos, por su parte, tendrían que demostrar lo contrario, que la herencia es positiva o beneficiosa.

\section{B) La intención de defraudar.}

¿Es elemento integrante del perjuicio a los acreedores (eventus damnis), la intención de perjudicar (consilium fraudis), por parte del deudor?. Es decir, cuando él repudia la herencia, ¿es preciso que lo haga con el ánimus o intención de causarles un daño o perjuicio de tal manera que lo haga con el propósito consciente, directo y deliberado de producir tal resultado o tenga, al menos, la conciencia de que con ello les causa un daño?, o es suficiente que el perjuicio se produzca de una forma objetiva, sin apreciar la concurrencia de la circunstancia del ánimus o intención del deudor. En ello subyace la discusión de, si el perjuicio a que alude el artículo 1001 CC es equiparable al fraude a los acreedores a que se refieren los artículos 1111 y 1291 CC, lo que constituye otro de los puntos más controvertidos que plantea el artículo 1001 $\mathrm{CC}$ en su ejercicio.

984 “La aceptación de la herencia ............”. Cit: Pág 186. 
El punto de partida del que arranca la doctrina (por todos, DíEZ-PICAZO ${ }^{985}$ ), lo constituye la diferente terminología que se emplea en dichos artículos porque, en unos (arts 1111 y 1291 CC), se habla de "fraude", mientras que en éste (art. 1001 CC), de "perjuicio". Ello ha dado lugar a que se hayan dibujado en la doctrina, tanto nacional como extranjera, dos direcciones opuestas:

a) unos parten de la consideración de que esta acción es una aplicación de la pauliana y equiparan el perjuicio al fraude, por lo que exigen intencionalidad en la declaración del deudor, de tal manera que ésta se tiene que realizar con la intención consciente, directa, o deliberada de causar un perjuicio a sus acreedores, en fraude de sus derechos, a sabiendas de que les va a producir un daño patrimonial o, al menos, que el deudor tenga conocimiento de su situación patrimonial cuando la realiza.

Esta posición, apunta BAYOD ${ }^{986}$, fue defendida durante bastantes décadas, tanto por la jurisprudencia como por la doctrina francesa ${ }^{987}$, que consideró el fraude como un requisito esencial para la aplicación del artículo 788 del Code (actual 779), al entender que éste era una aplicación especial de la acción pauliana, a pesar de que en él no se hacía referencia al fraude. Y, en nuestra doctrina, se ha mantenido por autores como, TRAVIESAS ${ }^{988}$, MANRESA ${ }^{989}$, ROCA SASTRE MUNCUNILL ${ }^{990}$ o PASQUAU LIAÑO ${ }^{991}$.

GITRAMA $^{992}$, por su parte, partiendo de la consideración de que la renuncia ha de ser gratuita, la asocia con la presunción de fraude en los actos a título gratuito (art. 1297 CC), como es la donación, donde, si el donante, al tiempo de hacer la donación, no se reserva bienes bastantes para pagar las deudas anteriores a ella, se presume la existencia del fraude (art. 643.2 CC). De lo que deduce que, "el artículo 1001 no exige el fraude, le basta el perjuicio de acreedores porque en éste la renuncia equivale al fraude". Sin embargo, en este sentido, objeta DíEZ-PICAZO ${ }^{993}$ que, en estos casos, el

985 “La aceptación de la herencia ............”. Cit: Pág 186 y ss.
986 Op. cit.: Pág 100 y ss
987 DEMOLOMBE (Traité des successions. T III. Paris 1859. Pág 76 y ss); BAUDRYLACANTINERIE (Traité theorique et pratique du Droit civil. Des successions. T II. $3^{\mathrm{a}}$ ed. Paris 1905. Pág 412); POTHIER (Oeuvres completes. T 12. Cit : Pág 496); MALLET (La renonciation à succession. Paris 1931. Pág 175 y ss). En contra, AUBRY y RAU (Cours de Droit civil français. T IX. $5^{a}$ ed. Paris 1917. Pág 599).

988 “La acción pauliana”. RGLJ 127. T II. 1927. Págs 113 y 114.

989 Comentarios al Código Civil. T VII. Cit: Pág 413.

${ }_{990}$ Derecho de Sucesiones. T III. Cit: Pág 453.

${ }^{991}$ Comentario al artículo 1083 del Código Civil. En Código Civil. Doctrina y jurisprudencia. T III. Trivium. Madrid 1989. Pág 245.

${ }_{992}$ Comentarios al Código Civil ........... T XIV Vol 1º. Cit: Pág 245.

993 “La aceptación de la herencia .............. Cit: Pág 188. 
fraude "se presume siempre en las enajenaciones a título gratuito. $Y, \ldots . .$. , no puede decirse que la renuncia de la herencia sea un acto de enajenación". "Precisamente la renuncia de la herencia constituye una declaración de voluntad de no adquirir, y mal puede ser enajenado aquello que no llega a ser adquirido".

Esta fue la interpretación que del artículo 831 del Proyecto de 1851, hacía GARCÍA GOYENA"994 para quien, "en fraude: y con perjuicio, por mejor decir, respecto del deudor o repudiante, son sinónimas estas palabras: hay fraude si hay perjuicio".

b) Otros, en cambio, entienden que no es necesaria la intencionalidad del deudor en la producción del daño al repudiar la herencia. Basta la existencia objetiva del perjuicio para que los acreedores puedan acudir a la vía del artículo 1001 CC para la defensa de sus créditos. Es la postura que se puede considerar como mayoritaria en la doctrina española (DÍEZ-PICAZO ${ }^{995}$, SILLERO CROVETTO ${ }^{996}$, BAYOD LOPEZ ${ }^{997}$, JORDANO FRAGA ${ }^{998}$, O'CALLAGHAN ${ }^{999}$ ).

El argumento principal en el que se apoyan es el hecho de considerar que la finalidad de la norma no es tanto reprimir o sancionar una conducta o un comportamiento, sino, como manifiesta RIVERO HERNANDEZ ${ }^{1000}$, "rectificar los efectos de un acto perjudicial a los acreedores y por el mero hecho de serlo; esa

994 Concordancias, motivos y comentarios del Código Civil español. Reimpresión de la edición de Madrid de 1852 al cuidado de la cátedra de Derecho civil de la Universidad de Zaragoza. Zaragoza. 1974. Pág 422.

995 "Los acreedores deberán de probar que la conducta del deudor les ha perjudicado, abstracción hecha de que el deudor tuviera la intención o conciencia del perjuicio que les causaba; es decir, sin necesidad de probar el carácter fraudulento de la conducta del deudor" ("La aceptación de la herencia ............”. Cit: Págs 187 y 188.)

996 "No es preciso un fraude intencional o culpable, basta que, objetivamente, la repudiación cause perjuicio a los acreedores, lo que ocurrirá siempre que el patrimonio personal del deudor sea insuficiente para el pago de los créditos y que el incremento determinado por la herencia pudiera haberlo aumentado" (Comentario al artículo 1001 del Código Civil, en "Jurisprudencia civil comentada" (Tomo I). Dirección: Pasquau Liaño. Ed. COMARES. Granada. 2000. Pág 1689.)

997 También, entiende que "la acción ex artículo 1001, no exige una intención subjetiva por parte del repudiante encaminada a defraudar a sus acreedores, bien sea mediante la intención de dañarles o simplemente mediante el conocimiento de su propia insolvencia. A lo que creo, en el artículo 1001 CC se consagra una situación plenamente objetiva para que se desencadene la consecuencia jurídica prevista: el pago a los creedores con los bienes de la herencia repudiada”. (Op. cit.: Pág. 104).

998 En su opinión: "la acción del artículo 1001 no exige la prueba del fraude por parte de los acreedores según resulta de la aplicación de la propia letra del precepto, así como de las reglas de revocación que rigen para el caso de los actos gratuitos”. (Los acreedores del llamado a una sucesión mortis causa, ....... Cit: Págs 288 y 289).

999 Para el perjuicio al acreedor es un requisito objetivo porque "no requiere fraude intencional o culpable; basta que objetivamente la repudiación cause un perjuicio a los acreedores, lo que ocurrirá siempre que el patrimonio personal del deudor heredero sea insuficiente para el pago de los créditos y que el incremento determinado por la herencia pudiera haberlo aumentado. No hay que olvidar que la finalidad de la norma es rectificar los efectos de un acto prejudicial a los acreedores”. (Comentario del Código Civil. Cit: Pág 2375.).

${ }^{1000}$ Elementos de Derecho Civil. T V. Cit: Pág 83. 
"aceptación" no tiene otro efecto sobre al patrimonio del llamado que la extinción de las dudas que con la herencia puedan satisfacerle".

También la jurisprudencia ${ }^{1001}$ se ha inclinado por considerar que el fraude en los acreedores, cuando el deudor repudia la herencia, no es un requisito necesario a tener en cuenta a los efectos de su legitimación para recurrir a la acción del artículo 1001 para la defensa de sus derechos. Basta con el "eventum damni" o perjuicio del acreedor $^{1002}$.

En nuestra opinión, al requisito del perjuicio se le ha de dar un sentido objetivo, no siendo preciso que los acreedores demuestren si ha habido en la declaración de su deudor una actitud, intención o comportamiento fraudulento de querer causarles un perjuicio para poder ejercitar la acción del artículo 1001 en defensa de sus derechos de crédito, y que la repudiación se ha hecho con el propósito deliberado y consciente, directamente dirigido a causar un daño o perjuicio. Bastaría demostrar la situación de insolvencia en que se encuentra el patrimonio del deudor para que los acreedores estén legitimados para ello. Por mucho que quiera reaccionar el ordenamiento jurídico, en este caso en particular, contra una posible conducta del deudor y entenderla o calificarla como fraudulenta a resultas de su declaración de repudio, nos encontramos con la circunstancia de que el sucesor, en la emisión o exteriorización de su voluntad, goza de total y absoluta libertad en el ejercicio del ius delationis (art. $988 \mathrm{CC}$ ), lo que le da todo el aspecto o apariencia de licitud, incluso de impunidad.

${ }^{1001}$ STS de 30 de mayo de 2003, RJ 3917; SSAP Girona de 4 de junio de 1997, AC 1997/1341; Res DGRN de 2 de diciembre de 1892.

En este sentido, es muy expresiva la SAP de Badajoz, de 28 de octubre de 1998, RJ 1964, la cual argumenta que: "Es sintomático que una persona que es heredera única de un conjunto de cierta importancia de bienes inmuebles tarde años en pronunciarse sobre si acepta o no la herencia y termine finalmente otorgando escritura notarial de renuncia hereditaria. Es sintomático en este caso porque esa persona ha contraído deudas igualmente importantes con una entidad bancaria, sin que proceda a satisfacer las mismas a sus respectivos vencimientos. En este contexto forzosamente ha de ser calificada de fraudulenta su conducta. La renuncia en cuestión no tiene la más mínima justificación que pudiera explicarla, salvo la que se está apuntando". "La otra consecuencia que se deriva de cuanto se está diciendo es que la declaración de fraude en la no aceptación de la herencia posibilita el que la sociedad actora puede hacer uso de la facultad que contempla el art. 1001 del Código Civil, por lo que puede aceptar la herencia que en su momento no fue aceptada ...".

También la SAP de Tarragona (Sección $3^{a}$ ), de 8 de junio de 1999, AC 1999/6667, que, en su Fundamento de Derecho Primero, argumenta: “..... tanto si se acogiera la tesis de la aplicación concreta de la acción pauliana como la de considerarla una acción propia e independiente, lo cierto es que no es necesario la concurrencia del elemento del fraude o el «consilium fraudis», que exige la acción pauliana en sentido estricto, sino que basta con el «eventum damni» o perjuicio del acreedor, pues esta acción tiene un carácter marcadamente objetivo, y resarcido el acreedor de sus derechos, se mantiene la repudiación de la herencia respecto del resto de su contenido (derechos, créditos, obligaciones y cargas activo y pasivo de la herencia-)".

${ }^{1002}$ Igual sucede en el Codice civile italiano actual de 1942 que, en su artículo 524, señala que esta acción procede sin necesidad de que concurra fraude en el deudor. 
Así, nos preguntamos, ¿hasta qué punto se puede calificar de fraudulenta la repudiación de la herencia si el sucesor es libre de poder decidir lo que él quiera, o estime pertinente u oportuno a sus intereses?. Su declaración, por muy reprobable que sea, siempre estará amparada por la libertad de que goza en el ejercicio de la delación (art. 988 CC). Es muy difícil decir que existe mala fe o intención de defraudar por parte del deudor cuando él decide repudiar, por no decir que es imposible, desde el momento en que su declaración de voluntad se ejerce o emite en virtud del ejercicio legítimo de un derecho.

Ya decíamos en otro momento ${ }^{1003}$ que, el repudio, a nuestro juicio, no presupone mala fe en el deudor. En otros casos de revocación (arts 1111 y $1291.3^{\circ} \mathrm{CC}$ ), la mala fe en el deudor sería equiparable a fraude $y$, como tal, a perjuicio, al ser una consecuencia que del mismo se deriva. Pero, en el caso del artículo 1001 CC, esa interrelación entendemos que no se cumple, o no se puede mantener. No deja de ser una contradicción que, por un lado, el deudor sea libre de repudiar la herencia a que ha sido llamado y, por otro, se pretenda sancionar alguna consecuencia negativa que de esa decisión se derive, como es el perjuicio en los acreedores, alegando una intencionalidad de defraudar que se confundiría con la propia libertad del individuo, porque sería difícil de deslindar esa voluntad de perjudicar con la libertad de decisión que tiene el deudor ante la oferta hereditaria que él ha recibido. Aunque, no es menos cierto que puede haber una discordancia entre la voluntad interna o querida, causar un perjuicio a los acreedores, y otra, la externa o manifestada, el repudio, que está revestida de licitud, apariencia de realidad y de validez, lo que no impide que encierre una verdadera intención de causar un daño. Pero, lo difícil no es probar esa discordancia, sino entender o deducir que su voluntad o intención ha sido causar un perjuicio solo por el mero hecho de exteriorizar una declaración que se realiza, como decimos, no solo presidida por un principio de libertad (art. 988 CC), sino en el ejercicio legítimo de un derecho. Ello solo será posible si hubiere algún elemento más de prueba que sirva para demostrar que la intención del deudor cuando repudió fue la de causar un daño a sus acreedores, aunque ello suponga agravar su situación al tener que demostrar esa intencionalidad pero, por otro lado, la presunción de inocencia, o no culpabilidad, en el deudor que aquí también se puede predicar, lo exige. De ahí que, la declaración de repudio por sí sola, entendemos que no se puede interpretar en el sentido de que, cuando se realiza, se quiere causar un perjuicio a los acreedores si no hay otros medios de prueba que abonen en la misma dirección.

1003 Vid, más arriba, en el punto número 3-2, a propósito del fundamento de la acción, el examen del requisito de la buena fe en el deudor cuando se estudian los distintos principios sobre los que se sustenta en su ejercicio. 
Por otro lado, un argumento más a favor del carácter objetivo que ha de tener el perjuicio lo constituye el hecho de que, exigir a los acreedores la demostración del fraude en el deudor cuando repudia, supone hacer recaer en ellos la carga de la prueba de dicha intencionalidad, lo que sería una circunstancia añadida al perjuicio que ya existe, hecho que agravaría aun más su situación. En este sentido, el carácter objetivo del perjuicio les beneficia porque sólo tendrán que demostrar cual es la situación en que se encuentra el patrimonio de su deudor y no su deseo de causar un daño que, muchas veces, es muy difícil, o imposible, de probar porque solo existe en el ánimus del declarante.

De ahí que, para evitar, además de la carga de la prueba en los acreedores, o problemas de calificación de su conducta acerca de si su declaración se ha hecho con la intención de causar un perjuicio a los acreedores, o si conocía su situación patrimonial, o si tenía o no conciencia de perjuicio que causaba, lo más adecuado es atender, desde un punto de vista objetivo, a la existencia de un perjuicio lejos de toda intencionalidad subjetiva en el declarante, atendiendo exclusivamente a la situación de insolvencia en que se encontrare su patrimonio, a la propia incapacidad del mismo para hacer frente a los créditos tuviere frente a los acreedores.

\section{3-7.- Características del derecho de crédito de los acreedores.}

Los requisitos que ha de reunir el derecho de crédito cuyo cobro se pretende por parte de los acreedores a través del ejercicio esta acción no son, en principio, diferentes de aquellos que han de tener cuando es objeto de reclamación a través de la acción dimanante de los mismos, si bien, ofrecen, como ahora veremos, algunas peculiaridades:

a) ha de tratarse, ante todo, de una obligación jurídicamente perfecta, en el sentido de que el acreedor ha de tener en virtud de la misma, a su favor, acción contra el deudor para poder dirigirse contra él y hacer efectivo su cumplimiento. Lo que excluye que puedan ser objeto de reclamación a través del ejercicio de esta acción las obligaciones naturales ${ }^{1004}$, en las que el acreedor carece todo recurso o acción para poder exigir del deudor su cumplimiento, por lo que no podrá, en consecuencia, dirigirse, respecto de ellas, contra los bienes de la herencia para hacer efectivo su derecho.

${ }^{1004}$ DÍEZ-PICAZO: “La aceptación de la herencia ........”. Cit: Pág 173. 
b) La obligación ha de ser jurídicamente válida, esto es, nacida conforme a derecho, que no sea nula, ni anulable, ni rescindible, sin perjuicio de que sea susceptible de convalidación o de subsanación cuando ello fuere posible ${ }^{1005}$.

c) El crédito ha de tener existencia actual, es decir, que haya nacido y esté vivo, porque, si aun no ha nacido, el acreedor, al no existir ni ser exigible jurídicamente el derecho de crédito, aun no tiene dicha condición y, si ya se ha extinguido, carece de ella porque el crédito se extinguió. Y, por tanto, tanto en uno como en otro caso, carecería de legitimación activa para el ejercicio de la acción.

En este mismo sentido y desde otro punto de vista, el derecho de crédito ha de ser puro (art. 1113 pfo $1^{\circ} \mathrm{CC}$ ), exigible desde el mismo momento de su nacimiento.

Distinto es que estuviere sujeto a condición, o a término, que no habría problema en el ejercicio de la acción prevista en el artículo 1001 CC si aquel o éste tuvieren carácter resolutorio, al ser exigible el derecho de crédito desde el mismo momento de su nacimiento como si fuere puro, con independencia de que en el futuro se cumplan y se tenga que extinguir la obligación (art. 1113 pfo $2^{\circ} \mathrm{CC}$ ).

La cuestión surge cuando la condición tuviere carácter suspensivo, en que el acreedor, dada la situación de expectativa en que se encuentra al no haber nacido aun su derecho de crédito, tendría, en principio, que esperar a que se produjese el cumplimiento de aquella o llegare el término señalado para poder ejercer la acción del artículo 1001 CC, habida cuenta de que, al amparo del artículo 1114 CC, el acreedor no adquiere, ni puede exigir, su derecho de crédito hasta tanto en cuanto no se cumpla una u otro. No obstante, cabe plantearse si en esta situación jurídica de pendencia el acreedor está facultado para "ejercitar las acciones procedentes para la conservación de su derecho" (art. 1121 CC), lo que, aplicado al caso que nos ocupa, lleva a preguntarnos si podría hacer uso de la facultad que le concede el artículo 1001 CC.

En este sentido, DÍEZ-PICAZO ${ }^{1006}$ se pregunta, si el ejercicio de la acción del artículo 1001 CC por parte de los acreedores tiene como finalidad la conservación de su derecho de crédito. $Y$ distingue: si la función de estas facultades es de carácter ejecutivo, es obvio que no podrán ser ejercitadas por el acreedor sub conditione, cuyo crédito no es, naturalmente, realizable hasta después de cumplida la condición; pero, si no tienen otro objeto que el de conceder a los acreedores la posibilidad de mantener la solvencia del deudor que es su garantía natural, es clara la función conservativa. No

${ }^{1005}$ DÍEZ-PICAZO: “La aceptación de la herencia ........”. Cit: Pág 173.

1006 “La aceptación de la herencia ........”. Cit: Pág 174 y ss. 
obstante, aunque es consciente de que tal función podría encontrar algún obstáculo en la expresión literal del artículo 1111 CC, respecto de la acción subrogatoria, en cambio, ninguna dificultad plantea en el caso del artículo 1001 CC, en el cual no es exigencia la finalidad ejecutiva de los acreedores. A lo que añade, "una interpretación amplia y comprensiva de dicho precepto, en armonía con los principios más arriba examinados, debe permitir el ejercicio del derecho de aceptar la herencia con una finalidad conservativa. Siendo ello así, no solo ninguna dificultad hay en que pueda ser reconocida tal facultad al acreedor cuyo crédito se halla bajo condición suspensiva, sino que, además, cae bajo el ámbito estricto de poder que la ley le confía, pues siempre se trataría del ejercicio de una acción procedente a la conservación de su derecho". Así, tanto si el crédito está sometido a condición suspensiva como a término, el acreedor estaría legitimado para invocar a su favor el artículo 1001 CC, incluso en el caso de créditos con garantía real si ésta decayere (DÍEZ-PICAZO ${ }^{1007}$ ).

Por otro lado, es posición generalizada dentro de la doctrina (LACRUZ ${ }^{1008}$, DÍEZPICAZO $^{1009}$, GITRAMA ${ }^{1010}$, entre otros), que no es preciso que el crédito esté vencido, ni sea líquido y exigible, dada la función conservativa y protectora que tiene la acción del artículo 1001, por lo que, aun en estos casos, los acreedores podrían invocar su ejercicio al amparo de lo dispuesto en el artículo 1121 CC.

Como tampoco es preciso que se trate de créditos que tengan fuerza ejecutiva (LACRUZ ${ }^{1011}$, DÍEZ-PICAZO ${ }^{1012}$, GITRAMA $^{1013}$ ), esto es, reconocidos en virtud de sentencia firme $u$ otro acto de eficacia semejante que le permita al acreedor actuar contra el deudor a través de un proceso de ejecución (DÍEZ-PICAZO ${ }^{1014}$ ).

d) El crédito, además, ha de ser de fecha cierta, y “.... anterior a la fecha de la repudiación ${ }^{1015}$, pues naciendo después, los acreedores no pueden decirse perjudicados por ella" (DíEZ-PICAZO ${ }^{1016}$ ). Si resulta que el crédito hubiere nacido con posterioridad al momento de la repudiación, dado que el acreedor ya debe de conocer,

\footnotetext{
1007 “La aceptación de la herencia ........”. Cit: Pág 176.

1008 Elementos de Derecho Civil. T. V. Cit: Pág 75.

1009 “La aceptación de la herencia ........”. Cit: Pág 176 y ss.

${ }^{1010}$ Comentarios al Código Civil ........... T XIV. Vol 1º . Cit: Pág 242.

1011 Elementos de Derecho Civil. T. V. Cit: Pág 75.

1012 “La aceptación de la herencia ........”. Cit: Pág 176 y ss.

1013 Comentarios al Código Civil ............ T XIV. Vol 1º. Cit: Pág 242.

1014 “La aceptación de la herencia ........”. Cit: Pág 177.

1015 En este sentido, el artículo 461-7.1 de la Ley 10/2008, de Sucesiones, de Cataluña, así lo

${ }^{1016}$ Elementos de Derecho Civil. T V Cit: Págs 83 y 84; “La aceptación de la herencia ...”. Pág
} establece de forma expresa. 179. 
o debe de poner la diligencia debida en saber cual es la decisión del deudor y, en consecuencia, la disminución del valor, o mejor dicho, el no aumento de valor, que se ha producido en su patrimonio como una consecuencia derivada de la misma, difícilmente se puede invocar la existencia de un perjuicio, incluso de un acto fraudulento, para instar el ejercicio de la acción.

La razón fundamental que se alega por parte de la doctrina para excluir, en su caso, o privar de legitimación a aquellos acreedores cuyos créditos hayan nacido después de la repudiación de la herencia, es la circunstancia de que ellos, al tiempo del nacimiento de su derecho de crédito, ya conocían, o podían conocer, o deberían de conocer, no ya la situación del patrimonio del deudor, sino el perjuicio que la repudiación, en su caso, ha producido en el mismo (GARCíA GOYENA ${ }^{1017}$ ). Al ser créditos posteriores a la repudiación, "habrían ya nacido con la garantía patrimonial disminuida" (CASTAN, DÍEZ-PICAZO ${ }^{1018}$ ). Por tanto, su ignorancia o desconocimiento sería inexcusable y, por ello, el acreedor ya no podría alegar en su defensa el ejercicio de la acción del artículo 1001. La exigencia de que los créditos existan y sean de fecha anterior a la declaración de repudiación del sucesor también se apunta en la jurisprudencia ${ }^{1019}$.

e) Finalmente, ha de tratarse de créditos que sean realizables sobre el patrimonio del deudor en el sentido de que la prestación en que consistan sea de dar, incluso de hacer o no hacer siempre que fuere susceptible de realización dineraria, esto es, que, en el caso de incumplimiento, pueda ser objeto de valoración económica y, como tal, de indemnización, o se haya convertido en un crédito de dar (DíEZ$\mathrm{PICAZO}^{1020}$ ). En otro caso, para el acreedor, más que carecer de la acción del artículo 1001 CC, en realidad, su ejercicio sería inútil y resultaría inoperativa o ineficaz ante la dificultad o imposibilidad que existiría de poder valorar el importe del derecho de crédito, lo que se produciría, principalmente, en las obligaciones de hacer o no hacer.

1017 Concordancias, motivos y comentarios del Código Civil español. Editorial BASE. Barcelona. 1973. Pág 218. “Los acreedores posteriores a la repudiación no pueden reclamar el beneficio de este artículo porque no pudo hacerse aquella en fraude o perjuicio de acreedores o derechos que no existían al tiempo de hacerse".

1018 “La aceptación de la herencia ........”. Cit: Pág 178.

1019 Vid: STSJ de Cataluña de 29 de enero de 1996 -RJ 6248-; SAP de Tarragona, de 8 de junio de 1999 -AC 1999/6667-.

1020 “La aceptación de la herencia ........”. Cit: Pág 180. 


\section{3-8.- El plazo de ejercicio de la acción.}

Otro de los extremos sobre los que no dice nada el Código Civil acerca de esta acción, es el relativo al plazo de que disponen los acreedores para su ejercicio. Sí se dice, en las leyes sucesorias de Cataluña, que concede el plazo de un año (art. 4617.2, Ley 10/2008), y Aragón, cuatro años contados desde la repudiación (art. 353.3, CDFA). En otros Códigos como, el italiano, se establece un plazo de prescripción de cinco años contados desde que se produjo la renuncia (art. 524), o el francés, en el que, si bien, no lo dice de manera expresa en su actual artículo 779 , tampoco en el anterior 788, se considera aplicable el plazo de treinta años por ser éste el de la acción pauliana al entenderse que dicha acción es una aplicación de ésta.

Este silencio ha dado lugar, una vez más, a que la doctrina se posicione sobre ello y trate de dilucidar cual es el plazo de que dispone el acreedor para poder dirigirse a través de esta acción contra los bienes de aquella herencia a que su deudor fue llamado para hacer efectivo su derecho de crédito. Y, aquí, de nuevo, el plazo que defiende cada autor está en función de la concepción que se tenga acerca de la naturaleza de esta acción.

Así, nos encontramos, con dos posiciones: la de aquellos que aplican el plazo de cuatro años por aplicación analógica del artículo 1299 CC relativo a la rescisión de los contratos (a), y los que defienden el plazo de prescripción general de quince años establecido en el artículo 1964 CC relativo a las acciones personales que no tienen señalado tiempo especial de prescripción (b). No obstante, existe una tercera postura según la cual el plazo sería de treinta años (c):

a) la primera de ellas, seguida por un amplio sector de la doctrina, se basa en la similitud que existe entre la acción del artículo 1001 y una acción rescisoria por fraude, al entender que aquella es una aplicación de la acción pauliana, y porque, a través de ella, los acreedores "impugnan la eficacia de un acto jurídico", cual es la repudiación, siendo éste uno de los argumentos más invocados por los autores.

En esta línea nos encontramos a autores como LACRUZ ${ }^{1021}$, LETE DEL RÍO ${ }^{1022}$, ROCA SASTRE MUNCUNILL ${ }^{1023}$, LLEDÓ YAGÜE ${ }^{1024}$, GITRAMA ${ }^{1025}$, o SILLERO

${ }_{1021}$ Elementos de derecho civil. T V. Cit: Pág 84.

1022 Comentario al artículo 1001. En Código Civil, doctrina y jurisprudencia. T III. Arts 609 a 1087. Dirigido por José Luis Albacar. Ed Trivium. Madrid. 1991. Pág 1225.

${ }^{1023}$ Derecho de Sucesiones. T. III. Cit: Pág 455.

${ }^{1024}$ Derecho de Sucesiones. Cit: Pág 113.

${ }^{1025}$ Comentarios al Código Civil . T XIV. Vol 1º. Cit: Pág 246. 
CROVETTO, para quienes el plazo es de cuatro años. DíEZ-PICAZO ${ }^{1026}$, de igual manera, y pese a reconocer los inconvenientes que tiene, entiende que "el plazo aplicable es el primero, más que por aplicación analógica del artículo 1299 CC, por el hecho de suponer el ejercicio del derecho de los acreedores impugnación de la eficacia de determinados actos jurídicos -la renuncia y las aceptaciones posteriores-, cuya firmeza no puede pender del transcurso de largos plazos de prescripción, sino de los plazos normales para la impugnación de la eficacia de los actos jurídicos". En igual sentido se manifiestan otros autores como ALBALADEJO y la jurisprudencia ${ }^{1027}$, que, además, considera el plazo, no de prescripción, sino de caducidad.

Sin embargo, esta posición tiene, en nuestra opinión, varios inconvenientes o se le pueden hacer varias objeciones:

$1^{\text {a }}$ - Ios acreedores, dado el término "rescisión" que emplea el artículo 1299 a propósito del ejercicio de la acción en él contemplada y aplicado aquí, en modo alguno, se puede entender que, a través de ella, rescinden o revocan la repudiación del deudor porque su declaración no se modifica como consecuencia de su ejercicio que, además, es irrevocable. Luego, mal encaja, desde este punto de vista, aplicar aquí, en consecuencia, el plazo de los cuatro años para los supuestos de rescisión por fraude a esta acción del artículo 1001 CC que no tiene esta característica.

$2^{\mathrm{a}}$.- De igual manera, desde el punto de vista de los acreedores, es criticable porque aplicar el plazo de los cuatro años no deja de ser para ellos un claro perjuicio ya que, si se inclinan por reclamar el importe de sus derechos de crédito a través de la acción del artículo 1001 CC, se reduce de forma considerable el plazo que nace de su derecho de crédito cuando éste es superior, cinco o quince, si es un crédito personal que no tiene señalado plazo especial de prescripción, por aplicación del artículo 1964 CC, o incluso veinte como establece este artículo, si se trata de la acción hipotecaria.

Así, si el acreedor se dirige contra el patrimonio del deudor para hacer efectivo su derecho de crédito, ya sea judicial o extrajudicialmente, por medio de otra vía que no sea la del artículo 1001 CC, tendría que hacerlo dentro del plazo que corresponda según la acción de que se trate. Mientras que, si la reclamación se efectúa a través de la acción del artículo 1001 CC, el plazo, por aplicación del artículo 1299 CC, sería tan solo de cuatro años. Lo cual supone un claro perjuicio para el acreedor al reducirse, en algunos casos, de forma extraordinaria el plazo para poder reclamar.

1026 “La aceptación de la herencia ............”. Cit: Págs 190 y 191.

1027 Vid: STS de 16 de octubre de 1971 -RJ 4135-; SSAP Girona (Sección 1ª), de 4 de junio de 1997 -AC 1997/1341-; Tarragona (Sección 3ª), de 8 de junio de 1999, -AC 1999/6667-. 
$3^{\mathrm{a}}$.- También tiene el inconveniente para los acreedores de que, si antes el plazo era de prescripción, ahora sería de caducidad -así lo entiende la inmensa mayoría de la doctrina y la jurisprudencia-, lo que supone la imposibilidad de su interrupción, si bien, la caducidad puede ser apreciada de oficio, mientras que la prescripción ha de ser alegada ante los tribunales.

b) La segunda postura defiende la aplicación del plazo de los quince años que para las acciones personales prevé el artículo 1964 CC.

Se fundamenta, según BAYOD ${ }^{1028}$, en el "silencio de la ley" y, en que "no cabe aplicar por analogía plazos que, aun más breves, son de caducidad pues estos han de ser establecidos expresamente por el legislador".

En esta línea nos encontramos a O'CALLAGHAN ${ }^{1029}$, para quien el plazo, que sería de prescripción, no de caducidad, manifiesta que, “.... el plazo de los cuatro años del artículo 1299 es de caducidad y ésta tan solo puede venir impuesta por la ley; no hay analogía clara entre esta acción -del artículo 1001-, y la del artículo 1299; es constante el criterio restrictivo de la interpretación de las normas sobre prescripción y caducidad que hacen inviable aplicar un breve plazo a un caso no previsto ni análogo. Por ello debe acudirse a la prescripción -no caducidad-, de quince años".

BAYOD $^{1030}$, por su parte, que sigue a O'CALLAGHAN, también entiende que, a falta de un plazo ad hoc, el acreedor tendría el de quince años del artículo 1964, pero añade: "si este plazo se considera excesivo corresponde al legislador poner remedio, y establecer, como así lo ha hecho el legislador catalán, un plazo para el ejercicio de esta acción, que bien pudiera ser de cuatro años, y además de caducidad, si éste es el que considera la doctrina como plazo más razonable ..... Pero mientras no se produzca este cambio legislativo, tal y como está configurada esta acción en nuestro derecho vigente, no cabe deducir tal plazo".

Esta postura tiene, en nuestra opinión, dos serios inconvenientes: por un lado, es un plazo excesivamente largo, lo que da lugar a que se cree un estado o situación de pendencia que provoca incertidumbre e inseguridad jurídica y, por otro, se podría dar la circunstancia de que le concedería al acreedor un plazo muy superior para poder reclamar al que tendría, en su caso, en virtud de su derecho de crédito, cuando la prescripción que nace del mismo puede ser inferior, de uno, tres o cinco años.

\footnotetext{
${ }^{1028}$ Op. cit.: Pág 234.

${ }^{1029}$ Comentario del Código Civil. Cit: Pág 2376.

1030 Op. cit.: Págs 234, 236, 237.
} 
c) Y una tercera posición que, como dice BAYOD ${ }^{1031}$, su planteamiento no obedece más que "a una hipótesis de trabajo" porque no tiene adeptos en la doctrina española y aplica el plazo de los treinta años de que dispone el sucesor para aceptar la herencia a que fue llamado. Así, por similitud, dado que se trata de una aceptación, el acreedor gozaría de igual plazo para el ejercicio de la acción, pero tropieza con el grave inconveniente de que el acreedor no acepta la herencia en el mismo sentido y con el mismo significado que lo hace el delado, no se trata de la misma ni de una verdadera y propia aceptación porque ésta solo emana del ejercicio del ius delationis, y éste solo lo tiene y le corresponde al delado.

Nosotros, acerca de esta cuestión, mantenemos una postura que es totalmente diferente de las anteriormente de las expuestas. Cierto es que estamos ante una acción que tiene unas peculiaridades y características propias muy definidas que hacen que no participe de la naturaleza, ni de la acción subrogatoria, ni de la revocatoria, y que adolece de un plazo para su ejercicio, lo que plantea un grave problema en cuanto a su aplicación. Cierto es que no debemos de olvidar que estamos ante un recurso extraordinario que tiene como objetivo la salvaguarda y protección de un derecho de crédito para cuya defensa se concede el ejercicio de dicha acción. Como también, en nuestra opinión, es preciso tener en cuenta que estamos ante un derecho de crédito que ya existe con anterioridad a la repudiación de la herencia. Pero, precisamente por razón de esta última circunstancia, como veremos a continuación, aplicar el plazo de los cuatro o quince años, puede suponer un beneficio para una de las dos partes, el acreedor o el deudor, con el consiguiente perjuicio para la otra, porque se modificaría el plazo que ya existe entre ellos en virtud del derecho de crédito.

Así, distingamos varios supuestos y veamos las ventajas e inconvenientes que tiene en cada uno de ellos la aplicación del plazo de los cuatro o de los quince años. Descartamos la hipótesis de los treinta años a que aludía BAYOD por excesiva:

a) que se trate de un derecho de crédito que estuviere sujeto en su reclamación a un plazo especial de prescripción de uno o tres años (arts 1968 y 1967 CC):

ya apliquemos el plazo de cuatro o quince años, el acreedor tendría un plazo muy superior para poder cobrar su derecho de crédito. En consecuencia, se ampliaría el plazo para poder hacerlo efectivo, de lo que se derivaría para él un beneficio y, en contrapartida, un perjuicio para el deudor porque ve como el acreedor gozaría de un

1031 Op. cit.: Págs 231, y 234 y ss. 
plazo mucho mayor del que inicialmente tenía al constituirse la obligación, lo que produciría un claro y manifiesto desequilibrio contractual entre las partes,

b) que se trate de un derecho de crédito que estuviere sujeto en su reclamación al plazo especial de prescripción de cinco años (art. 1966 CC): en este caso, es preciso distinguir porque:

a') si a la reclamación del derecho de crédito a través de la acción del artículo 1001 se le aplica el plazo de los cuatro años, el acreedor resultaría perjudicado porque se reduce en un año el plazo que inicialmente tenía para poder reclamar, lo cual, en contrapartida, supone un beneficio para el deudor porque se reduce en un año el que él inicialmente tenía para responder frente al acreedor,

b') mientras que si se le aplica el plazo de los quince años, se produce el efecto contrario, el acreedor resultaría extraordinariamente beneficiado porque gozaría de un plazo muy superior para poder reclamar, mientras que el deudor, por el mismo argumento anterior, también resultaría muy perjudicado.

c) Que se trate de un derecho de crédito que estuviere sujeto en su reclamación al plazo general de quince años (art. 1964 CC):

de igual manera, distingamos:

a') si a la reclamación del derecho de crédito a través de la acción del artículo 1001 se le aplicase el plazo de los cuatro años, el acreedor resultaría perjudicado de forma considerable porque se recortaría a menos de un tercio el plazo que inicialmente tenía para poder reclamar, lo cual, en contrapartida, supone un gran beneficio para el deudor porque ve cómo el plazo es muy inferior al inicial del momento en que se constituyó el derecho de crédito,

b') mientras que, si a la reclamación del derecho de crédito se le aplica el plazo de los quince años, en este caso, no habría variación alguna por cuanto el plazo sería el mismo.

A la vista de lo expuesto, vemos como la aplicación del plazo de los cuatro o de los quince años puede suponer una considerable modificación del plazo que para poder reclamar dispone el acreedor en virtud del derecho de crédito y una merma o un aumento de sus posibilidades para poder hacerlo efectivo. 
De ahí que, en nuestra opinión, para que no se modifique la situación o statu quo que ya existe entre acreedor y deudor en virtud del derecho de crédito cuando aquel invoque en defensa de los mismos la acción del artículo 1001 CC, y en lo que se refiere al plazo que determina el tiempo dentro del cual los bienes que fueron objeto de repudio están sujetos a responsabilidad frente a los acreedores, lo más adecuado sería, en tanto en cuanto no haya disposición legal expresa al respecto que disponga otra cosa, o incluso pacto en contrario entre las partes sobre dicho plazo, mantener y aplicar el mismo plazo que para su reclamación tuviese el derecho de crédito en el momento de su constitución con sujeción a las reglas del artículo 1961 y ss CC.

Así, el plazo de que dispondrían los acreedores para invocar la facultad del artículo 1001 CC vendría determinado en cada supuesto particular, en función del plazo que tendrían para ejercer la acción que nace del derecho de crédito que ellos pretenden ahora cobrar y ejecutar por medio de la acción que a través de aquel se les otorga. En consecuencia, si se mantiene el mismo plazo, no se modificaría la posición o situación jurídica que existe entre las dos partes y el acreedor puede hacerlo efectivo dentro del mismo plazo, con lo cual ni el acreedor, ni el deudor, se benefician, ni se perjudican, si bien, ejercer su derecho de crédito a través del artículo 1001 CC, le proporcionaría, eso sí, el privilegio, o la ventaja, de poder ejecutarlo sobre los bienes de la herencia que rechazó su deudor, posibilidad que, de otra forma, no tendría.

A nuestro juicio, la facultad que tienen los acreedores, aunque sea excepcional en su concesión, no tiene porqué producir una novación del plazo para poder reclamar a través de esta acción, y menos aún por su decisión unilateral cuando tienen, en todo caso, la acción que emana de su derecho de crédito, como tampoco puede crear situaciones de desequilibrio o desigualdad sobrevenidas dentro de la relación crediticia existente entre el acreedor y el deudor, con el consiguiente perjuicio o beneficio que del mismo se pudiere derivar en uno $u$ otro. El hecho de que el acreedor recurra a la acción del artículo 1001 CC para hacer efectivo su derecho de crédito, no tiene por qué cambiar el statu quo de la relación jurídica existente entre ellos proveniente de la obligación de la que emana ese derecho de crédito, por lo que, para evitar el posible desequilibrio que de ello se pudiese derivar para uno u otro si se aplicase el plazo de los cuatro o quince años, el plazo para su ejercicio, en nuestra opinión, vendría determinado, de forma casuística, en función del que, en cada caso, tuviere la acción que surge del derecho de crédito que ya existe entre ellos y que ahora se pretende hacer efectivo por el acreedor a través de la acción del artículo 1001 CC. 


\section{3-9.- Efectos.}

Dadas las particulares circunstancias que motivan el nacimiento de esta acción, así como la naturaleza de las declaraciones emitidas, tanto por parte del deudor en virtud del ejercicio del ius delationis, como por los acreedores a través de esta acción, y la finalidad para la que se les concede, los efectos o consecuencias que se derivan de la misma se pueden concretar en las siguientes consideraciones:

$1^{\mathrm{a}}$.- la declaración de repudiación de la herencia realizada por el deudor, si se ha emitido cumpliendo todos los presupuestos y requisitos legales de capacidad, objeto, tiempo y forma, es jurídicamente válida, definitiva e irrevocable, y no se puede dejar sin efecto ni impugnar sino en los supuestos establecidos en el artículo 997 CC, o en aquellos otros en que se hubiere exteriorizado infringiendo algún presupuesto esencial, precepto imperativo o prohibitivo, para su emisión ${ }^{1032}$.

$2^{\text {a }}$.- La repudiación, pese a la "aceptación" realizada por los acreedores en virtud del ejercicio de esta acción, sigue siendo irrevocable. No por ello queda sin efecto, ni se invalida, o resulta ineficaz, como tampoco se revoca, ni tan siquiera de forma parcial, sino que es definitiva.

No obstante, lo que sí produce la "aceptación" es amortiguar o aminorar, cuando no hace desaparecer, los efectos que para ellos se derivan de la declaración de repudio de su deudor por cuanto, a través de la misma, se podrán dirigir contra aquellos bienes de la herencia que a éste le hubiesen correspondido y aplicarlos luego al pago de los créditos de que fuesen titulares y tuvieren contra él.

$3^{a}$.- La declaración de los acreedores, en nuestra opinión, no es una verdadera y propia aceptación como la que realiza el delado en virtud del ejercicio del ius delationis, de tal manera que sólo ésta es la verdadera y propia aceptación necesaria para adquirir la herencia.

Como tampoco, a resultas de su declaración, los acreedores llegan a adquirir, en ningún momento, la condición de sucesores del causante. Simplemente ejercitan una acción que se les concede ex lege como un medio excepcional de protección de su derecho de crédito ante el perjuicio que les hubiere causado, en su caso, su deudor a resultas de la repudiación de la herencia cuando no puedan cobrar de otro modo lo que él les adeude dado el carácter subsidiario de la misma.

1032 En este sentido, nos remitimos al próximo capítulo donde se analizan de forma pormenorizada las causas y consecuencias de la ineficacia de la declaración de repudio. 
Los acreedores, sin anular la repudiación, cobran, hasta donde alcance el importe de los créditos de que ellos sean titulares, a cargo de aquello que su deudor repudió. Su declaración de "aceptación" solo les aprovechará o beneficiará en la cuantía precisa y en cuanto baste para la satisfacción de sus créditos. El importe de sus créditos, será el límite de su beneficio.

$4^{\mathrm{a}}$.- El repudiante-deudor no se va a ver beneficiado, en modo alguno, por dicha aceptación porque él nunca va a adquirir bienes de la herencia. Él ya repudió y, a resultas de ello, rechazó todo aquello a que fue llamado y lo perdió definitivamente.

En este sentido, no se puede entender, ni siquiera de una manera ficticia, que el deudor, como consecuencia de la "aceptación" de los acreedores, llega a suceder al causante aunque solo sea en aquella parte de bienes que se apliquen al pago de los créditos de los acreedores que ejerciten esta acción. Él, a resultas de la declaración de repudio, quedó totalmente apartado de la sucesión perdió de manera definitiva la posibilidad de poder suceder al causante y como esa declaración no se revoca ni se modifica por dicha "aceptación", en ningún momento se puede considerar que el deudor ahora sucede al causante.

En consecuencia, a resultas de la declaración de sus acreedores, no se va a producir ingreso o entrada en su patrimonio de aquellos bienes, porción o cuota que le fueron deferidos ya que éstos solo van a estar a disposición de los acreedores para la satisfacción de los créditos de que éstos sean titulares y tengan contra él. Ni tan siquiera se va a beneficiar del sobrante que hubiere, en su caso, después de haberse aplicado los bienes al pago de los créditos porque no serán para él, sino para los sujetos beneficiarios que corresponda, que lo serán, según los casos: en primer lugar, para sus propios sustitutos, si los hubiere, en su defecto, los restantes sucesores si existiere entre ellos el derecho de acrecer y finalmente, los sucesores abintestato.

A este respecto, DíEZ-PICAZO ${ }^{1033}$, dice que, "parece cierto que por virtud de la aceptación de los bienes hereditarios, o la porción de ellos que baste para cubrir los créditos, ingresan en el patrimonio del deudor, pues solo en él pueden los acreedores proceder a la ejecución. Pensar en otra cosa sería absurdo y sin base legal". De lo que deduce, más adelante, para que pueda tener lugar la satisfacción de los créditos de los acreedores, que se produce, "aun en contra de las reglas generales de la sucesión, una doble adquisición de los bienes hereditarios. Adquiere el deudor llamado, que renunció, la parte necesaria para cubrir los créditos de sus acreedores, y adquieren los

1033 “La aceptación de la herencia ... Cit: Pág 192 y ss. 
sucesivamente llamados o los coherederos con derecho de acrecer el exceso, cuando lo hubiere". En igual sentido, O'CALLAGHAN ${ }^{1034}$, que sigue a DíEZ-PICAZO.

Nosotros, disentimos de esta postura y entendemos que, en modo alguno, los bienes de la herencia que son objeto de ejecución por parte de los acreedores entran en el patrimonio de su deudor para después ser aplicados al pago de los créditos de los acreedores ${ }^{1035}$. Aparte de que es innecesario, entre otras razones, por economía procesal y agilidad en el cobro, es incluso absurdo que los bienes hagan el "viaje" de ir, del acervo hereditario al patrimonio del deudor, para después ir desde éste a manos de los acreedores, cuando resulta que dichos bienes están en sede vacante de la herencia, no sólo en espera de su aceptación, en su caso, por parte de los demás sucesores, sino directamente a disposición, en su caso, de los acreedores a través del ejercicio de esta acción, de tal manera que, éstos, al estar previa y preceptivamente facultados y autorizados por el Juez para su ejercicio sólo en la medida y por el límite del importe de los créditos que ellos pretendan extinguir a través del ejercicio de esta acción, pueden acceder a ellos, lo que evita que "pasen" por las manos, o a través del patrimonio, del deudor, y, además, se da la paradoja de que, ya antes, no han podido entrar en dicho patrimonio como consecuencia de la declaración de repudio, lo que sería algo absurdo, una incoherencia.

En este sentido, ya comentamos más arriba a propósito de la autorización judicial, que la actuación de los acreedores, a nuestro juicio, está perfectamente "controlada" por parte del juez por ser quien legitima con su autoridad, previa comprobación y acreditación de los presupuestos exigidos para el ejercicio de la acción, su intervención en los bienes de la herencia y posterior aplicación de los mismos sobre los créditos que tuvieren contra su deudor. Si con carácter previo al ejercicio de esta acción, los acreedores han de obtener dicha autorización judicial, es difícil que se puedan extralimitar en su ejercicio. Otra razón más para entender que carece de sentido que los bienes hagan este recorrido por el control judicial que existe, antes, durante y después del ejercicio de la acción porque el líquido que, en su caso, se haya obtenido a resultas de la ejecución de los bienes, se entrega directamente al acreedor y el remanente, si lo hubiere, a las personas que, en su caso, corresponda. Nunca será para el deudor repudiante.

1034 Comentario del Código Civil. Cit: Pág 2376.

1035 En igual sentido, FLORENSA (Op. cit.: II. No 5183): esto hace que, "cada acreedor perjudicado por la repudiación tenga que pedir al Juez la autorización para activar el recurso y, finalmente, ejecutar sobre los bienes del patrimonio hereditario, del cual, no lo olvidemos, es titular el heredero efectivo". 
Así, solo en un sentido impropio se puede sostener lo que manifiesta DíEZPICAZO, de que el deudor adquiere los bienes que se han aplicado en ejecución de las deudas, y menos aun, en su caso, los sustitutos, ni los cosucesores, ni los sucesores abintestato porque adquirir, o no adquirir, depende exclusivamente de ellos.

No obstante, lo que sí es cierto es que, el deudor, indirectamente, sí que se va ver beneficiado por esta acción de los acreedores porque verá cómo van a resultar satisfechas o extinguidas, en todo o en parte, las deudas que él tenía frente a ellos. Es el único beneficio él que va a obtener como consecuencia del ejercicio de esta acción.

$5^{\mathrm{a}}$.- Desde el punto de vista de los acreedores, el efecto que se deriva del ejercicio de la acción sólo aprovecha o beneficia a quien la ejerce efectivamente ${ }^{1036} \mathrm{y}$ si fueren varios, "no se establecerá entre ellos ninguna preferencia, sino la ordinaria prelación entre ellos en atención a las circunstancias de sus respectivos derechos de crédito, de acuerdo con las normas de la concurrencia (arts. 1926 y ss. del Código Civil)" (FLORENSA ${ }^{1037}$ ).

$6^{\mathrm{a}}$.- Los sustitutos del repudiante, si los hubiere, los restantes sucesores de la herencia si hay entre ellos el derecho de acrecer y los sucesores abintestato, van a ser, por este orden, los sujetos destinatarios y beneficiarios ${ }^{1038}$, del remanente de los bienes que no hubieren sido objeto de ejecución a resultas del ejercicio de la acción.

No obstante, para ellos es un beneficio que se podría calificar, no engañoso, pero sí parcial, porque la cuota repudiada, de la cual ellos son los destinatarios, ha tenido previamente una rebaja en su cuantía equivalente al importe de los créditos que han resultado satisfechos como consecuencia del ejercicio de la acción por parte de los acreedores. Lo cual supone para ellos, sino un perjuicio, sí una merma en su contenido, porque, de no haberse ejercitado dicha acción, habrían recibido íntegra, en la totalidad de su cuantía, la porción o cuota del repudiante.

$7^{\mathrm{a}}$.- La responsabilidad que, en su caso, hubiere por razón de deudas de la herencia recae sobre los bienes, porción o cuota repudiada en la proporción que ésta tenga respecto de las demás cuotas de la herencia y, subsiguientemente, sobre los

1036 “La razón estriba -según BADOSA (Dret d'Obligacions, Barcelona. 1990, pág. 213), citado por FLORENSA (Op. cit.: II. N 5183)-, en que en el art. 1111 del Código Civil se pretende modificar la composición de un patrimonio sobre la base de los «derechos» y «acciones» preexistentes, mientras que en el caso de los arts. 1001 del Código Civil y 23 del Código de Sucesiones se trata de incrementar un patrimonio".

1037 Op. cit.: II. N 5183.

1038 Acerca de los sujetos beneficiarios a resultas del ejercicio de la acción, véase más arriba el punto 3-5-3, de este mismo capítulo, al que nos remitimos. 
adquirentes de esos bienes. Así, esta responsabilidad recae sobre los acreedores que ejerciten esta acción: ellos quedan obligados al pago de las deudas hereditarias que hubiesen correspondido a su deudor y en proporción a la parte que reciban del caudal relicto que a él le hubiese correspondido.

De ahí que, para evitar que sea vana, ilusoria, o insuficiente, la reclamación de los acreedores, sea preciso ejecutar bienes en una cuantía que sea superior al importe de los créditos hasta alcanzar el de las deudas que recaigan sobre la porción o cuota repudiada por el deudor para que puedan ser satisfechas que, además, habrán de serlo antes que el cobro de los mismos. Por tanto, el importe de la ejecución ha de cubrir el importe de los créditos más el de las deudas a que estén sujetos los bienes que sean objeto de ejecución porque, en otro caso, aquellos sólo se verán extinguidos de forma parcial, sino todos, sí algunos de sus créditos.

No obstante, se puede dar la circunstancia de que se trate de una herencia que sea excesivamente onerosa y que, al ser el importe de las deudas muy elevado, no haya bienes suficientes para su pago. En este caso, al ser potestativo el ejercicio de la acción, lo más lógico es que los acreedores se abstengan de la misma y no hagan nada ante el repudio hecho por su deudor.

$Y$ respecto de la responsabilidad que asumen los beneficiarios del remanente de la porción o cuota repudiada, DíEZ-PICAZO ${ }^{1039}$ distingue:

a) si aceptaron con posterioridad a la acción de los acreedores, la adjudicación de los bienes a su favor debe hacerse después de pagados con los bienes hereditarios no solo los créditos de los acreedores, sino también los de la herencia, en cuyo caso, a estos se les adjudicará el remanente, y

b) si hubieren aceptado con anterioridad a ello, está subordinada al resultado de aquella acción y su responsabilidad en el pago de las deudas hereditarias es, desde luego, con independencia de que hayan aceptado pura y simplemente o a beneficio de inventario, proporcional a la parte de bienes que hayan de recibir.

1039 “La aceptación de la herencia ... Cit: Pág 193. 


\section{3-10.- Su aplicación en el caso de repudiación de un legado ${ }^{1040}$.}

¿Pueden los acreedores de un legatario que hubiere repudiado el legado acudir a la vía del artículo 1001 CC y actuar sobre el mismo para el cobro de los créditos que tuvieren contra él de igual manera que si se tratase de un sucesor a título universal?.

En principio, la facultad concedida a los acreedores del delado en lo que hemos visto en cuanto antecede, no tiene por qué ser diferente de la que tuviere lugar, en su caso, en el de sucesión a título particular.

Sin embargo, dado el sistema que rige en nuestro ordenamiento jurídico de adquisición de los legados ${ }^{1041}$ ocurre que, desde el mismo instante en que se produce el fallecimiento del causante, se puede considerar o entender que el legado ya es del legatario-deudor (art. 881 CC), sin necesidad de aceptación, aunque no se haya efectuado la entrega del mismo (art. $885 \mathrm{CC}$ ), por lo que forma parte de su patrimonio desde entonces. De ello se deriva la importante consecuencia, a la vez que diferencia respecto de las adquisiciones a título universal, de que los acreedores podrán dirigirse contra dicho legado, ya desde ese mismo instante, para obtener el cobro de sus créditos, sin perjuicio de aquellos casos en que fuere necesaria la entrega del legado. La repudiación, en este caso, ya no es simplemente una declaración de no adquirir por parte del legatario, sino un acto que entraña una disminución positiva de su activo patrimonial, y por ello, un verdadero y manifiesto perjuicio para sus acreedores porque invalida, con efecto retroactivo al fallecimiento del causante, la adquisición del legado haciendo que éste se refunda en la masa de la herencia, salvo sustitución o que proceda el derecho de acrecer (art. $888 \mathrm{CC}$ ).

De ahí que, en este caso, la situación, a nuestro juicio, es muy diferente porque, el bien legado, en el momento de la repudiación, sí que forma parte del patrimonio del deudor, al contrario de lo que sucede en el caso de la sucesión a título universal en que los bienes repudiados no llegan a entrar en aquel como consecuencia del repudio.

De ello se deriva la importante consecuencia de que, si los acreedores del legatario entienden que la repudiación del legado les ha causado algún perjuicio en el cobro de sus derechos de crédito, entendemos que la acción del artículo 1001 CC no sería el cauce apropiado, sino la acción revocatoria o pauliana del artículo 1111 CC porque, por medio de ella, lo que conseguirán es dejar sin efecto la repudiación del

1040 Vid: DÍEZ-PICAZO: “La aceptación de la herencia ...........”. Cit: Págs 195 y 196.

${ }^{1041}$ Véase en este sentido, en el capítulo primero, el punto número 3, al que nos remitimos, donde se expone dicho sistema. 
legado y obtener el reingreso del mismo en el patrimonio del deudor, para después proceder contra él y cobrar su derecho de crédito.

Algo semejante ocure en el derecho alemán o francés, en que los bienes están en el patrimonio del sucesor, siquiera de forma provisional, pendiente de su posible repudiación, y los acreedores se pueden dirigir contra los bienes a que fue llamado su deudor mientras no hayan sido repudiados por él o no haya prescrito el plazo establecido para ello. 
CUARTA PARTE: INEFICACIA DE LA REPUDIACIÓN. 


\section{Capítulo 10: INEFICACIA DE LA REPUDIACIÓN.}

\footnotetext{
1.- Planteamiento. Significado y ámbito del término ineficacia. 2.- La ineficacia aplicada a la repudiación. 3.- Invalidez por causa de nulidad absoluta. 3-1.- Por ausencia de algún elemento esencial. 3-1-1.- Cuando la repudiación se hace en vida del causante. 3-1-2.Sin estar cierto del fallecimiento del de cuius o sin que exista vocación sucesoria. 3-1-3.Ausencia de capacidad o consentimiento para emitir la declaración. 3-1-4.- Por ausencia de objeto. 3-1-5.- Inobservancia del requisito de la forma. 3-2.- Por infracción de normas imperativas o prohibitivas. 3-2-1.- Cuando la declaración se hace de forma parcial. 3-22.- Cuando la declaración se hace bajo condición o a término. 4.- Invalidez por causa de anulabilidad. 4-1.- En el caso de que existiere un vicio del consentimiento. 4-2.- En el caso de repudiación por un menor de edad no emancipado. 4-3.- En el caso del incapaz. 4-4.- En el caso de representación legal si no se ha obtenido autorización judicial. 4-5.En el caso de infracción de lo dispuesto en los artículos 993 y 994 CC. 5.- La aparición del testamento como causa de ineficacia.
}

\section{1.- PLANTEAMIENTO. SIGNIFICADO Y ÁmBITO DEL TÉRMINO INEFICACIA.}

Hablar de la eficacia de la declaración del sucesor en ejercicio de su ius delationis, obliga a hablar también, lógica e inevitablemente, de su ineficacia, al objeto de precisar cuáles son los posibles casos o supuestos en que dicha declaración por adolecer de un vicio, defecto o irregularidad, no produce los efectos jurídicos que le son propios, así como la determinación de las consecuencias jurídicas que de ello se deriven. Éste es, sin duda alguna, otro de los aspectos más complejos que presenta dicha declaración a resultas de la problemática que encierra el tema de la ineficacia en el campo de los actos, contratos y demás negocios jurídicos, a lo que se suma la escasísima regulación que de este ámbito del ejercicio del ius delationis contiene el Código Civil dado que tan solo se refiere a ello, de forma muy parcial, su artículo 997 que más adelante analizaremos. 
En este sentido, partimos de la consideración, ya tratada en otro momento ${ }^{1042}$, de que, en nuestra opinión, la declaración que se emite en ejercicio del ius delationis constituye un acto que da lugar a la celebración de un negocio jurídico, de lo que se deriva la consecuencia de que va a estar sometida a su régimen jurídico, y, dentro de él, al ámbito de su ineficacia que, por ello, sería aquí perfectamente aplicable.

No obstante, antes de entrar en el examen de la ineficacia de la repudiación, sí queremos poner de manifiesto que, ya el mero hecho de emplear dicho término, lo hacemos con cierto temor y no sin cierta reticencia porque, es de todos conocido que estamos ante un vocablo que, en el ámbito del Derecho, no es pacífico ni sencillo, tampoco de significado fácil, dado su sentido ambigüo e impreciso, ya que, en un sentido vulgar, la idea de ineficacia, en sí misma, encierra un sentido puramente negativo por medio del cual se alude a la ausencia de efectos, mientras que, en un sentido jurídico, tiene diferentes sentidos o se le pueden atribuir distintos significados.

Así, tratar de dar definir la ineficacia y situarla en el campo de los conceptos jurídicos, como reconoce y manifiesta la inmensa mayoría de la doctrina, por todos, DÍEZ-PICAZO ${ }^{1043}$, "es tarea sumamente difícil". "En sentido vulgar, ineficacia es una idea negativa que denota la falta de eficacia, carencia total de efecto. Algo ha sido ineficaz cuando ha sido inútil, inservible para los fines que esperábamos obtener". Además, sería una tarea estéril o inútil, porque no nos llevaría a ningún resultado positivo ya que, a través de dicho término, no se alude tanto a su origen o al hecho que la motiva, sino a las múltiples y variadas formas a través de las cuales se manifiesta, así como, principal y fundamentalmente, a las consecuencias que de ellas se derivan. De ahí, que sea difícil dar un concepto unívoco o unitario, que sea comprensivo de las diferentes modalidades o tipos que existen de esta institución jurídica. En este sentido, manifiesta DÍEZ-PICAZO que, a través de la ineficacia, se alude a "la falta de producción de consecuencias, o, cuando menos, de aquellas consecuencias que normalmente deberían haberse producido y que pueden ser razonablemente esperadas en virtud de la celebración del contrato" ${ }^{1044}$, definición que aquí, en principio, puede sernos válida al objeto de nuestro estudio.

Aun así, pese a la dificultad que entraña definir la ineficacia, en nuestra opinión, entendemos como tal, desde un punto de vista amplio, comprendiendo cualesquiera tipos o modalidades a través de las cuales se pueda manifestar, y sin perjuicio de

${ }^{1042}$ Véase, en este sentido, el capítulo tercero en su punto número 6, al examinar la definición de repudiación donde se analiza su consideración como negocio jurídico.

1043 “Eficacia e ineficacia del negocio jurídico”. ADC. XIV , 4. 1961. Pág 820 y ss.

${ }^{1044}$ Fundamentos ......... Vol I. Cit: pág 450. 
cualesquiera otras que se puedan dar acerca de la misma, como: "la ausencia de aquellos efectos, ya porque surjan otros diferentes, ya por inexistencia de los mismos, que son característicos y propios del acto, contrato o negocio jurídico de que se trate, derivados de su esencia y naturaleza, y que han sido queridos o buscados por los sujetos en su celebración".

De ahí que, partiendo de esta definición, demos a este capítulo el epígrafe que tiene: "ineficacia de la repudiación", porque entendemos que es el más amplio de cuantos existen sobre esta materia ya que se pueden comprender dentro de él todos aquellos supuestos en que la declaración de repudiación del delado no surte, de manera total o parcial, los efectos que son propios y característicos de la misma, o lo hace de forma diferente, según cual fuere la causa o la circunstancia que lo hubiere motivado.

Pero, la cuestión que verdaderamente ha planteado esta institución, además de definirla, o establecer las diferentes formas, tipos o modalidades que puede revestir, o delimitar en qué supuestos se produce o qué requisitos han de reunir, incluso qué nomenclatura darle a los efectos de su identificación posterior, ha sido, tratar de determinar qué efectos o consecuencias de ellos se derivan.

En este sentido, acerca de sus clases, ya desde la época del Derecho Romano, se han elaborado distintos tipos que, al haber obedecido en sus orígenes a circunstancias muy diversas, se ha derivado la consecuencia de que se les han atribuído distintas características y efectos jurídicos pero, como manifiesta DE CASTRO ${ }^{1045}$, "sin pretender determinar cuáles sean sus supuestos".

Cada una de las figuras o modalidades de ineficacia que se han creado han surgido en diferentes épocas ${ }^{1046}$, respondiendo a distintas necesidades, concepciones y contextos, lo que ha provocado no solo diversidad de categorías, sino gran disparidad de opiniones y posiciones sobre esta materia, muchas de ellas enfrentadas entre sí dentro de la doctrina quien se ha preocupado, más de mostrar diferencias y posiciones u opiniones personales, que unir criterios o aunar posiciones, como tampoco ha habido acuerdo sobre los diferentes tipos que existen de la misma, incluso en su correspondiente rotulación o nomenclatura, lo que se observa a través de las

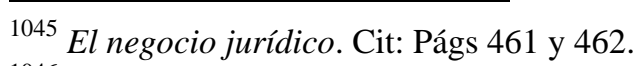

${ }^{1046}$ Acerca del régimen en materia de ineficacia en nuestro derecho con anterioridad al Código Civil y una panorámica histórica comparada de la misma, véase GORDILLO CAÑAS: "Nulidad, anulabilidad e inexistencia. (El sistema de las nulidades en un Código latino situado entre la primera y la segunda Codificación)”. Centenario del Código Civil. T I. Asociación de profesores de Derecho Civil. Editorial Centro de Estudios Ramón Areces. Madrid. 1990. Pág 935 y ss. 
distintas voces o términos que se emplean para identificar a cada una de ellas cuya semántica es, además, en ocasiones, muy semejante. Problemática que se agudiza en el siglo XIX a raíz de la tentativa de querer elaborar una categoría del negocio jurídico por parte de la Pandectística alemana (WINDSCHEID, PUCHTA, DERNBURG, REGELSBERG, SCHLOSSMANN).

En lo que se refiere a la asignación a los mismos de una denominación para después identificarlos, nos encontramos con una excesiva, variada y muy diferente nomenclatura o terminología ${ }^{1047}$ hasta formar una lista casi interminable de vocablos 0 acepciones, elaborada por la ley, la doctrina, la jurisprudencia, a lo que se añade la circunstancia de que tales términos se utilizan, en ocasiones, con gran imprecisión e inexactitud $^{1048}$, cuando no de manera equívoca y confusa, incluso contradictoria o contrapuesta entre sí ${ }^{1049}$, a lo que se suman distintas expresiones o frases ${ }^{1050}$ de significado muy diverso, lo que es una agravante añadida a la complejidad y dificultad que ya de por sí entraña el estudio de esta institución porque toda esta diversidad crea una gran confusión.

No obstante, es opinión generalizada dentro de la doctrina que el término más amplio y genérico de cuantos se han acuñado sobre esta materia es el de ineficacia por cuanto dentro de él se pueden considerar englobados o comprendidos todos los demás, opinión que compartimos. Sin embargo, el uso de este término, según ya hemos apuntado, no es nada pacífico por cuanto muchos discrepan de él.

1047 A lo largo del articulado del Código Civil nos encontramos con términos muy variados y diversos que se emplean de manera desordenada, asistemática e imprecisa, como: nulidad (arts 48, 76, 78, 79, 80, 102, 107, 630, 786, 1155, 1276, 1300 y ss, 1629), nulo (arts 6.3, 73, 628, 647, 687, 705, 741, 750, 755, 794, 816, 862, 865, 1081, 1208, 1289, 1328, 1476, 1494, 1668, 1691, 1721, 1804), anulabilidad (arts 75, 293), ineficaz (arts. 226, 743), anular (arts 814, 997, 1116, 1818), rescisión (art. 1073, 1078, 1079, 1080, 1290 y ss, 1469, 1556, 1558, 1595, 1818), revocación (arts 318, 319, 644 y ss, 737 y ss, 827, 1343, $1732.1^{\circ}$ ), válido, validez o invalidez (arts 53, 1256, 1266, 1278, 1290, 1301, 1953).

A ellos se añaden otros términos, de diferente alcance y significado, que han sido creación de la doctrina y de la jurisprudencia y que han contribuído a traer más confusión en esta materia, como son: inexistencia, resolución, impugnación, vicioso, imperfecto, inútil, irregular, imperfección, etc.

${ }^{1048}$ Véase, en este sentido, entre otros muchos, lo que dice DE CASTRO (El negocio jurídico. Cit: Pág 462).

${ }^{1049}$ Tal es el caso de los términos "anular” y "rescindir” que se observa en el artículo 1818 CC.

1050 Así, expresiones muy variadas, en ocasiones, ambigüas e imprecisas, de significado muy diverso, como: "no será válido" (art. 733 CC), "no producirá efecto” (arts 826, 1013 CC), "no surtirá

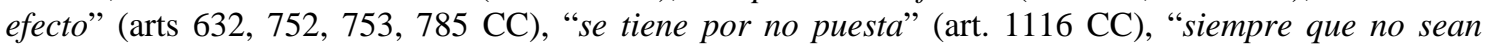
contrarios” (art. 1255 CC), "no invalidará los efectos ya producidos” (art. 79 CC), “no hay ....” (arts. 45, relativo al matrimonio, $1261 \mathrm{CC}$, relativo al contrato), "para que sea válida” (art. 633 CC), "no podrán ser atacados” (art. 297 CC). 
Así, como pone de relieve PARRA LUCÁN ${ }^{1051}$, "la doctrina, en cambio, no está de acuerdo acerca de la distinción entre nulidad e ineficacia: junto a quienes niegan la utilidad de la distinción, otros autores parten de ella para designar, con el término ineficacia la ausencia de producción de los efectos del contrato y con el de invalidez a la sanción que resulta de la negación de la fuerza jurídica vinculante de un contrato por defectos en sus elementos constitutivos o ilicitud en su contenido"1052.

DELGADO ECHEVERRÍA ${ }^{1053}$, por su parte, no habla de ineficacia, sino de validez e invalidez que, en su opinión, “....... no dependen (al menos directamente) del cumplimiento o incumplimiento de normas de conducta". Así, "la invalidez no es la consecuencia de la infracción de una prohibición. Hay actos inválidos permitidos y actos prohibidos válidos". Mientras que, "la validez no es la consecuencia o efecto jurídico de ninguna norma, sino un juicio que se expresa en un metalenguaje que tiene como objeto las normas. La invalidez (invalidez fuerte) sí forma parte del efecto de ciertas normas de incompetencia"1054.

Frente a la ineficacia se alzan otros términos, más o menos discutibles, como el de "invalidez", que goza de gran predicamento dentro de la doctrina en el momento actual, otros, de rechazo, como es el de "inexistencia" que se subsume en el de nulidad, o el de "anomalías" ${ }^{1055}$, que recoge el Anteproyecto de Código Europeo de Contratos $^{1056}$.

1051 “Las anomalías del contrato: invalidez e ineficacia en el anteproyecto de Código Europeo de Contratos. Estudio comparado con el Derecho español (Aproximación a la Sección 1 del Título XI de la Parte General del Código Europeo de Contratos)”. ADC. 2004. Vol 57. № 2. Págs 553 y 554.

1052 Por todos, LACRUZ, Elementos, II-1. Cit: Pág. 537.

1053 "El concepto de validez de los negocios jurídicos en Derecho privado. (Notas de teoría y dogmática)”. ADC. Tomo LVIII. Fascículo I. Enero-marzo 2005. Págs 10, 11, 34 y ss.

${ }^{1054}$ Distingue, tanto respecto de la validez como de la invalidez, dos definiciones inspiradas, a su vez, en las de WRIGHT, ALCHOURRÓN y BULYGIN, referidas a la validez de las normas: respecto de una norma y en el sistema, que, en su opinión, es de especial importancia para el concepto de validez de los actos de Derecho privado, como también previa para definir los conceptos de invalidez. Y, en este último, dos definiciones: "invalidez débil" e "invalidez fuerte".

Así, "un acto es válido respecto de una norma cuando esa norma confiere poder a un sujeto para realizar ese acto y es sujeto lo realiza". Mientras que, "un acto es válido en el sistema cuando es válido con arreglo a una norma perteneciente al sistema”. En este sentido, en su opinión, el concepto de validez está ligado al de normas que confieren poderes (normas de competencia), y distingue entre: normas que atribuyen el poder, normas que regulan la actualización del poder (forma y procedimiento), normas que exigen coherencia con normas superiores y normas de incompetencia.

Por el contrario, "un acto es inválido respecto de una norma cuando esa norma priva de competencia a un sujeto para realizar el acto y éste lo realiza”. Y, "un acto es inválido en el sistema cuando es inválido con arreglo a una norma perteneciente al sistema”.

${ }^{1055}$ Sin embargo, en la doctrina española, según apunta PARRA LUCAN (Op. cit.: Págs 551 y 552), el término no se refiere a la invalidez e ineficacia sino, a la deformación del tipo contractual por voluntad de los sujetos para escapar de la regulación legal. En particular, se incluyen dentro de las 
Ya en nuestro ordenamiento jurídico, la ausencia de una regulación legal precisa sobre esta materia, es otra de las circunstancias que también ha alimentado el estado o situación actual que existe sobre la misma. Las normas del Código Civil en este punto son confusas e imprecisas y además, poco sistemáticas. Ello ha dado lugar a la proliferación de una abundante bibliografía y a incontables opiniones en la doctrina que han contribuído muchas veces a crear, si cabe, un oscurantismo aun mayor. Tal vez, en el ánimo o intención de aclarar conceptos y de unificar posturas, lo que se ha hecho ha sido fijar, tal vez con excesiva precisión y meticulosidad con sus requisitos y características, el significado de las distintas modalidades de ineficacia, estableciendo entre ellas diferencias que, en ocasiones, sólo son posibles de delimitar desde un punto de vista estrictamente teórico o conceptual, o que pueden variar dependiendo del punto de vista que se adopte, porque luego, en la práctica, en cuanto a los resultados o consecuencias que de ellas se derivan, se vienen a identificar o es difícil de delimitar, resultando inútil o estéril la diferenciación de algunos tipos de ineficacia.

Diferentes, muy variadas y con arreglo a distintos criterios o puntos de vista, son las clasificaciones elaboradas por parte de la doctrina ${ }^{1057}$, incluso se podría decir que son tan innumerables como autores al hacer cada uno su propia clasificación.

anomalías, los negocios fiduciarios, simulados, indirectos y en fraude (DE CASTRO: El negocio jurídico. Cit: Pág 329 y ss).

En este sentido, manifiesta VATTIER, en comentario a ellas, entre otras cosas, lo siguiente: "aunque todas las anomalías se enfocan desde la perspectiva de la ineficacia, llama la atención la gran variedad de supuestos que se contemplan, así como lo bien perfilados que cada uno aparece, lo mismo en sus causas que en las consecuencias que provocan. Así, se conciben como supuestos diferentes la inexistencia (art. 137), la nulidad (art. 140), la nulidad sobrevenida, mal llamada caducidad (art. 142), la anulabilidad (art. 146), la ineficacia por voluntad de las partes o por disposición de la ley (art. 153), la inoponibilidad (art. 154), la simulación y la reserva mental (art. 155) y la rescisión por lesión (art. 156)" ("Inexistencia y nulidad del contrato. Código europeo de contratos". Academia de iusprivatistas europeos (Pavía). Comentarios en homenaje al Profesor Dr D José Luis De los Mozos y De los Mozos. Dykinson. Madrid. 2003. Vol. II. Págs 557 y 558).

${ }^{1056}$ Proyecto Gandolfi o del Grupo de Pavía, fruto del Congreso celebrado en esta ciudad en el año 1990. En él, su Título XI, comprensivo de los artículos 137 a 173, se refiere a "Otras anomalías y remedios del contrato". Después, en su Sección $1^{\text {a }}$ (arts 137 a 155), se refiere a las "anomalías”, y en la Sección $2^{\mathrm{a}}$ (arts 156 a 173), a los "remedios".

En comentario al mismo, PARRA LUCAN manifiesta que, "no existe, sin embargo, coherencia lógica entre ambas Secciones, porque los "remedios" no lo son de las "anomalías"”, y porque "no se ocupan exclusivamente de las consecuencias de las anomalías del contrato". Como tampoco el texto dice qué es o qué se entiende por "anomalías". Ante lo que apunta: "cabe aventurar que se considera anómala toda vicisitud o extinción de la obligación que no sea su cumplimiento", por lo que se consideran como tales, en el texto del Anteproyecto: la nulidad, la anulabilidad, la ineficacia, la nulidad parcial y la inoponibilidad (Op. cit.: Pág 552).

${ }^{1057}$ Sin ánimo exhaustivo, véanse, entre otros: DE CASTRO (El negocio jurídico. Cit: Pág 466); DELGADO ECHEVERRIA y PARRA LUCÁN (Las nulidades de los contratos. Dykinson S.L. Madrid. 2005. Pág 29 y ss); DÍEZ-PICAZO (Fundamentos ...... T I. Pág 454 y ss; "Eficacia e ineficacia del negocio jurídico”. Cit: Pág 823 y ss); GOMEZ DE LA ESCALERA (Op. Cit: Pág 22 y ss); DORAL y DEL ARCO (El negocio jurídico. Ed TRIVIUM. Madrid. 1982. Pág 328 y ss); CASANUEVA 
Así, para DÍEZ-PICAZO ${ }^{1058}$, las figuras de ineficacia son fundamentalmente tres, que son las que se utilizan de forma más usual y habitual: "nulidad radical, total o absoluta", que tiene lugar cuando en la celebración del acto, contrato o negocio se contraviene una norma imperativa o prohibitiva (art. $6.3 \mathrm{CC}$ ); "nulidad relativa o anulabilidad", en caso de que exista algún vicio o defecto del consentimiento (arts 1265 y ss, y 1300 CC), y "rescisión", cuando hay un daño, fraude o perjuicio (art. 1290 $\mathrm{CC})$. Categorías que no excluyen otras como sería, la de "resolución", o también, más discutible, la de "inexistencia", que se engloba por parte de la doctrina en la de nulidad absoluta.

GORDILLO CAÑAS ${ }^{1059}$ hace la siguiente clasificación de las diferentes formas de ineficacia cuyo alcance, por otro lado, reconoce que es más terminológico que real, dada la problemática que plantean algunas categorías. Así, distingue: una ineficacia por invalidez ("De la nulidad de los contratos" -art. 1300 y ss-) y, una ineficacia a pesar de la validez del contrato ("De la rescisión de los contratos" -art. 1290 y ss CC-). A ello añade otra distinción: la que media entre los actos o contratos automáticamente nulos (art. 6,3 $3^{\circ} \mathrm{CC}$, que expresamente habla de nulidad de pleno derecho), y contratos "que pueden ser anulados" (art. 1300 CC). A su vez, este último precepto, y con él, el artículo 1310 CC, ambos en relación con el 1261 CC, dan por supuesta la distinción de una situación específica en la que ni siquiera llega a haber contrato ${ }^{1060}$. Estas serían, según GORDILLO, las formas fundamentales de ineficacia admitidas en el Código Civil, si bien, a ellas podrían añadirse otras modalidades como son, "las originadas por causa debida a la voluntad informadora del acto mismo, o a la concurrencia de determinadas circunstancias sobrevenidas con posterioridad a la celebración del acto (condición resolutoria, resolución, revocación)".

SÁNCHEZ: Las categorías de invalidez en los negocios jurídicos. Análisis dogmático y jurisprudencial. Universidad de Extremadura. Cáceres. 2002. Pág 28.

${ }^{1058}$ Fundamentos ....... Vol 1. Cit: Pág 469.

1059 Op. cit.: Págs 937 y 953, 954.

1060 De todo ello resultan como regímenes generales y típicos de ineficacia negocial, los siguientes:

a) la inexistencia, cuando en el negocio falta algún elemento esencial para su formación (art. 1261 CC).

b) La nulidad de pleno derecho, o nulidad propiamente dicha, que tiene lugar cuando se celebra violando un mandato o prohibición legal (art. 6,3 $3^{\circ} \mathrm{CC}$ ). Consistiría en una ineficacia siempre automática, originaria y estructural, y normalmente absoluta e insanable. Sus causas serían: haberse traspasado los límites de la autonomía privada, la inexistencia, falta absoluta de determinación o ilicitud en el objeto del contrato, inexistencia o ilicitud de causa, finalmente, la falta de forma ad solemnitatem.

c) La anulabilidad, o nulidad relativa, cuando se produce vicio o defecto susceptible de motivar la anulación por acción judicial (art. 1300 CC). Deriva o procede de la falta de plena capacidad de obrar, o de la existencia de vicio de la voluntad. Vendría a constituir una ineficacia provocada, sobrevenida y estructural, y normalmente relativa y sanable.

d) La rescisión, cuando produce una lesión o perjuicio para las partes o para terceros (art. 1290 CC). Daría lugar a una ineficacia provocada, sobrevenida y funcional, y normalmente relativa y sanable. 
La jurisprudencia, también ha distinguido diferentes modalidades de ineficacia, aunque su postura es confusa, imprecisa y vacilante ${ }^{1061}$, contagiada, tal vez, por el Código Civil. Así, dejando aparte la distinción entre nulidad y anulabilidad, la más clara a este respecto, durante mucho tiempo calificó a los contratos nulos, de inexistentes, o radicalmente nulos para diferenciarlos de los anulables. En otras, el Tribunal Supremo ha distinguido ineficacia e invalidez (STS 1 febrero $1999^{1062}$ ), como tambien nos encontramos con sentencias que distinguen de forma nítida algunas de las figuras acuñadas por la doctrina ${ }^{1063}$.

\section{2.- LA INEFICACIA APLICADA A LA REPUDIACIÓN.}

Una de las circunstancias que se observan en la regulación del ejercicio del ius delationis en el Código Civil es la ausencia, prácticamente total, de una mínima regulación de su ineficacia, y no ya sólo en decir cuáles son los supuestos en que puede tener lugar, a lo que tan solo dedica el artículo 997, muy escueto, a la vez que confuso y equívoco, como ahora veremos, sino también, a las consecuencias y efectos que de ellos se derivan.

El referido precepto, después de manifestar el carácter irrevocable que tiene la declaración del delado, señala que puede ser impugnada ${ }^{1064}$, "cuando adoleciese de

${ }^{1061}$ Vid, en este sentido, GORDILLO CAÑAS: Op. cit.: Pág 935 y ss.

1062 "Es preciso partir de unos conceptos dogmáticos, con importantes consecuencias pragmáticas que en el presente caso se elevan a motivo de casación. La ineficacia del negocio jurídico o, concretamente del contrato como negocio jurídico bilateral 'inter vivos', es la carencia de efectos jurídicos típicos (si bien puede producir otros distintos, como indemnización de daños y perjuicios), que viene determinada por causa intrínseca al propio contrato provocando que carezca de validez (por inexistencia, por nulidad absoluta o por anulabilidad) y es la invalidez, o bien la ineficacia 'stricto sensu' que engloba los supuestos en que siendo el contrato válido, no produce efecto por causas extrínsecas como puede ser la resolución, que es la ineficacia del contrato con efecto retroactivo en virtud de una causa que no es una invalidez inicial, sino que viene determinada por causa de condición resolutoria, o por pacto comisorio, o por incumplimiento de las obligaciones de una de las partes en un contrato bilateral".

${ }^{1063}$ Así, la Audiencia Provincial de La Rioja, en su sentencia de 28 de mayo de 2001 (AC 2002/151), entiende que ineficaz, "es el negocio jurídico que no surte ningún efecto o no surte los efectos que corresponden a su contenido", mientras que, inválido es, "aquel negocio que no surte tales efectos a causa de un vicio de constitución, ya suceda así en absoluto (nulidad), ya sea ello solamente cuando el que tenga facultad para impedirlo no quiera que sea válido el negocio por razón del defecto de que se trate (anulabilidad); de tal forma que la ineficacia representa el concepto amplio y la invalidez el restringido".

1064 O’CALLAGHAN, lo critica por entenderlo más vulgar que jurídico y dice que equivale a la acción de declaración de ineficacia (Comentario del Código Civil. Cit.: pág 2369).

También ALBALADEJO, porque, para él, "no es una verdadera impugnación puesto que no se trata de atacar un acto (la repudiación) que padezca un vicio, sino la de hacer constar que aquel acto perfecto en sí ......, no vale porque la delación a que responde no existe realmente ya que hay un testamento (el hasta ahora desconocido, que aparece) que contiene la verdadera", lo que puede tener interés desde el punto de vista práctico a los efectos del plazo en que se puede instar la ineficacia de la declaración ("La repudiación de la herencia”. Cit: Págs 748 y 749). 
alguno de los vicios que anulan el consentimiento o apareciese un testamento desconocido".

Sin embargo, dicho artículo es criticable, en nuestra opinión, por varios motivos:

$1^{\circ}$.- ante todo, porque es, a todas luces, manifiestamente parco e insuficiente ya que tan solo recoge dos de los supuestos que pueden dar lugar a dicha ineficacia, de los cuales, la aparición del testamento, no siempre da lugar a ello como analizaremos más adelante en el último punto de este capítulo. Existen otros muchos en los que se puede instar, o puede tener lugar, la ineficacia de la declaración del delado, si bien, se puede inferir su existencia del tenor de otros preceptos, aunque, con diferente alcance y consecuencias jurídicas según las clases y causas que lo hubieren motivado.

Así, al examinar la institución de la delación, a lo largo de todo cuanto antecede en los capítulos que preceden, hemos visto que existen numerosos supuestos en los que la infracción, no cumplimiento, o inobservancia de alguno de los presupuestos y/o requisitos necesarios para su válida exteriorización, da lugar a que las consecuencias que se derivan de ello, o no se producen, o no son exactamente las mismas que las queridas por el declarante.

$2^{\circ}$.- También es criticable porque parece dar a entender -aunque, tal vez, no sea la intención del precepto-, que los dos supuestos de ineficacia en él contemplados, son análogos o equiparables entre sí en el sentido de que, uno y otro, no solo pueden dar origen a dicha impugnación, sino también, que ambos producen, a resultas de la misma, el mismo efecto o consecuencia jurídica. Y ello, no es del todo cierto porque, así como la existencia de vicios del consentimiento, por aplicación de la teoría general de los contratos y obligaciones (cfr arts 1265 y ss, y 1300 y ss CC), da lugar a un supuesto de anulabilidad, en el caso de la aparición del testamento desconocido no siempre habrá lugar a la impugnación de la declaración, ya que se producirá según las circunstancias particulares que en cada caso concurran en la sucesión de que se trate, con consecuencias también diferentes como luego analizaremos.

En nuestra opinión, ciertamente, aquello que es nulo conforme a Derecho, es inimpugnable al no tener ninguna virtualidad ni eficacia jurídica, aunque, no es menos cierto, que cuando se ejerce una acción de declaración de ineficacia de cualquier acto, contrato o negocio jurídico, en realidad, lo que se está haciendo, o persiguiendo, es la impugnación del mismo, sobre todo, en lo que se refiere a destruir y dejar sin efecto la apariencia de realidad o de validez que puede ofrecer, no ya entre las partes, sino en el tráfico jurídico.

No obstante, y sin que ello se entienda como un uso impropio del dicho término y falto de tecnicismo, nosotros aquí sí haremos uso del mismo pero siendo conscientes de la apreciación que hace la doctrina que, en el fondo, compartimos plenamente. 
Por otro lado, se trata de dos supuestos que tienen como único denominador común el hecho de que ambos son causa de impugnación de la repudiación, pero se diferencian, por un lado, en que uno y otro dan lugar a diferente clase de ineficacia y, por otro, en que las respectivas consecuencias jurídicas que de ellos se derivan, en el caso de que prospere la correspondiente acción de declaración de ineficacia, pueden ser totalmente distintas y con resultados diferentes.

$3^{\circ}$.- Dado el tenor del artículo, se puede interpretar en el sentido de que, pese a que la declaración del delado sea irrevocable, aun así, es impugnable en virtud de cualquiera de los dos supuestos que en él se indican. Esto es, que se puede dejar sin efecto, pese a su irrevocabilidad. Lo que ha dado lugar a que estos dos supuestos se hayan llegado a ver como una excepción a la misma ${ }^{1065}$.

Sin embargo, como ya expusimos en otro momento ${ }^{1066}$, tal interpretación, a nuestro juicio, no es correcta porque si la declaración del delado se ha emitido cumpliendo todos los presupuestos y requisitos legales exigidos -lo cual presupone que no ha habido vicios del consentimiento, ni que ha aparecido un testamento cuya existencia se desconocía-, es cuando propiamente se puede decir, en sentido propio y jurídico, no solo que es perfecta, sino, además, irrevocable, porque se ha realizado conforme a Derecho, de lo que se deriva la consecuencia de que ha nacido de forma válida y eficaz produciendo todos los efectos que le son propios y característicos de la misma. Sólo en este caso se puede hablar de irrevocabilidad. Y si la declaración no se ha realizado conforme a Derecho, no ha nacido de forma plenamente válida y eficaz, no se puede decir que sea irrevocable y sí susceptible de ser impugnada o dejada sin efecto porque es ineficaz. Por tanto, los dos casos que en él se tipifican, entendemos que no se pueden entender como una excepción a la irrevocabilidad de la declaración del delado, sino que son supuestos que hacen que dicha declaración sea susceptible de ser invalidada con arreglo a la ley con distinto alcance y consecuencias porque es ineficaz.

Ya entrando en el análisis de la ineficacia de la declaración de repudiación, y una vez hechas las consideraciones y apreciaciones que anteceden acerca de la institución jurídica de la ineficacia, así como de los términos que tienen más relevancia dentro de ella, y del artículo 997 CC, vamos a distinguir aquí, siguiendo la categoría de la invalidez y al amparo de las figuras que se pueden dibujar dentro de la misma, dos ámbitos o supuestos diferentes, y que son:

\footnotetext{
1065 Así, GITRAMA: Op. cit.: Pág 171.

${ }^{1066}$ Véase en el capítulo cuarto, el punto número 1.
} 
A) invalidez en la declaración por causa de nulidad total o absoluta, dentro de la cual distinguimos:

a) por un lado, aquellos supuestos en que dicha declaración se ha emitido con ausencia, inobservancia o incumplimiento de algún elemento o presupuesto que tiene carácter esencial y que es pilar básico o estructural sobre el que descansa o se fundamenta en su nacimiento o génesis, lo que impide, en todo caso, no sólo su válida exteriorización conforme a Derecho, sino su nacimiento a la vida jurídica y,

b) por otro, aquellos casos en que, habiéndose cumplido los presupuestos esenciales en la exteriorización de la declaración de repudiación, ésta, no obstante, se ha realizado infringiendo alguna norma o precepto legal de carácter imperativo o prohibitivo, por aplicación del artículo 6.3 CC.

B) Invalidez en la declaración por causa de nulidad relativa o anulabilidad, que tendría lugar cuando habiéndose emitido con observancia de todos sus presupuestos, requisitos o elementos esenciales, adolece de un vicio, defecto o irregularidad que no impide su nacimiento, como tampoco, en principio, su validez con plena producción de efectos jurídicos mientras no se inste y se decrete su declaración judicial de nulidad.

A su vez, dentro de cada una de ellas, se pueden apuntar diferentes supuestos de ineficacia, si bien, la inclusión que hagamos de ellos en una u otra categoría de invalidez somos conscientes de que no es, ni puede ser, absoluta porque, en algunos casos, su calificación variará según el distinto criterio o punto de vista que se adopte.

Por otro lado, de forma semejante al artículo 997 CC, la Ley 10/2008, de Sucesiones, de Cataluña (art. 461-10), establece como causas de nulidad de la declaración del delado (además de los vicios del consentimiento -error, violencia, intimidación o dolo-, que los cita de forma expresa, no así el Código Civil), la falta de capacidad del sucesor y la aparición, con posterioridad a la declaración, de "otras disposiciones de última voluntad que eran desconocidas y que alteran sustancialmente el contenido del título sucesorio", que se correpondería a la aparición del testamento de que habla el Código Civil en el artículo 997. Pero, tiene la peculiaridad de entender que se trata de un supuesto de error. Sin embargo, como luego veremos, la falta de capacidad no da siempre lugar a la misma clase de ineficacia, como tampoco estamos de acuerdo con el hecho de asimilar la aparición de un testamento desconocido con el error porque no siempre es así, y porque, además, ya lo veremos en el último punto de este capítulo, no necesariamente dicha aparición tiene porqué dar lugar a la ineficacia de la declaración del delado. 


\section{3.- INVALIDEZ POR CAUSA DE NULIDAD ABSOLUTA.}

Los supuestos que, en nuestra opinión, constituyen causas de nulidad absoluta en esta materia ${ }^{1067}$, no están tipificados de forma expresa como tales por el Código Civil porque, como ya hemos apuntado, los que contempla en su artículo 997, pueden dar lugar a diferentes supuestos de ineficacia con diferentes consecuencias jurídicas.

No obstante, se puede deducir o inferir su existencia, o calificarlos como tales, a resultas del tenor de su articulado al establecerse en éste cuáles son los elementos, presupuestos o requisitos que, con carácter esencial, se exigen para su existencia y válida exteriorización, y por la aplicación de la norma contenida en el artículo 6.3 del Código Civil acerca de la nulidad de los actos contrarios a las normas imperativas y prohibitivas.

\section{3-1.- Por ausencia de algún elemento esencial.}

Se trata de supuestos, como ya hemos apuntado, en los que se produce la ausencia o inobservancia de un elemento que se considera por la ley que es básico y fundamental para que sea válida y efectiva la declaración de repudiación, de tal manera que es un presupuesto estructural de la misma, un pilar sin el cual no puede existir. Son, dicho en otros términos, casos de nulidad absoluta y, por ello, de invalidez, para algunos de inexistencia, de lo que se deriva la consecuencia de que, en cualquiera de ellos, es lo mismo que si dicha declaración nunca se hubiese llegado a realizar porque se entiende, o se considera, que no ha nacido válidamente conforme a Derecho.

Así, son supuestos que se pueden ubicar en esta hipótesis, los siguientes.

${ }^{1067}$ El hecho de que distingamos aquí dos modalidades diferentes dentro de la misma, una, por ausencia de un elemento esencial, y otra, por infracción de normas imperativas o prohibitivas, no significa, en modo alguno, que estemos ante dos categorías diferentes porque, aquella, la ausencia o el incumplimiento de un elemento esencial puede ser calificado o interpretado también como un supuesto de infracción de una norma imperativa desde el momento en que la ley exige de manera necesaria u obligatoria la observancia o cumplimiento del mismo para que la declaración sea válida y eficaz desde el punto de vista jurídico, y nazca legal y válidamente a la vida jurídica, con lo cual todos los casos de nulidad absoluta se podrían reconducir a una única modalidad o categoría de la misma.

En este mismo sentido, queremos hacer la puntualización de que, aunque la ausencia de un elemento esencial pueda ser utilizado, al menos desde un punto de vista pura y estrictamente teórico, incluso usual, vulgar o coloquial, como también pedagógico o didáctico, para aludir a un supuesto de ineficacia por causa de inexistencia dentro de la nulidad, sólo lo será con el único efecto o finalidad de diferenciarlo, o separarlo, de la otra categoría o modalidad de misma, cual es la infracción de una norma imperativa o prohibitiva. Como también, en coherencia con ello, el hecho de que hagamos esta distinción no significa, en modo alguno, que demos carta de naturaleza al término y categoría de inexistencia que rechazamos por su inutilidad o inoperancia para crear un supuesto propio y específico de ineficacia y, menos aún, distinto al de la nulidad absoluta en el ámbito de la ineficacia porque ésta, la categoría de la nulidad absoluta absorbe o engloba a la inexistencia al ser una modalidad o manifestación de la misma. 


\section{3-1-1.- Cuando la repudiación se hace en vida del causante.}

Partiendo de la consideración de que el ius delationis no nace sino a resultas de la vocación y subsiguiente delación, que sólo tendrán lugar a partir del momento en que se produce la apertura de la sucesión (cfr arts 657, 661, 758, 991 CC), esto es, una vez que ha fallecido la persona, obviamente, la manifestación del delado acerca de la oferta hereditaria que ha recibido, sólo se podrá realizar una vez que su sucesión se ha abierto. En lo que no hay defunción, no hay herencia, no hay sucesión, no hay vocación ni delación sucesoria y, por tanto, no se podrá ejercer el ius delationis.

El hecho del fallecimiento de una persona es la circunstancia que constituye el punto de partida o arranque de todo el proceso jurídico y material de la sucesión mortis causa en la práctica totalidad de los ordenamientos jurídicos actuales, de tal manera que la muerte es conditio iuris de ésta, o presupuesto sine qua non, para que se ponga en marcha todo el mecanismo previsto por la Ley para que tenga lugar la transmisión de los bienes y derechos de que era titular a resultas de su fallecimiento. Los derechos sucesorios no nacen si no es a partir de este instante.

La delación deriva o proviene de la vocación. Nace con ésta. Y la vocación no se produce si no es por la voluntad del causante, o por disposición de la ley, que no tendrán lugar, en ningún caso, hasta después de la muerte de aquel. Luego, en vida del causante, el ius delationis es absolutamente inexistente ${ }^{1068} \mathrm{y}$, por tanto, la declaración que se pretenda hacer derivada del mismo, ha de entenderse como si nunca se hubiere realizado.

Así, la repudiación de una herencia aun no deferida, futura, hecha en vida de aquella persona respecto de la cual se crea tener algún derecho sucesorio, antes de que haya fallecido, ha de reputarse inexistente o, más exactamente, como si nunca se hubiese llegado a realizar y, por tanto, no tiene ningún valor ni efecto o consecuencia jurídica.

La imposibilidad del repudio en vida del causante, vendría impuesta, por un lado, por el artículo 991 del Código Civil que exige certeza en el hecho de la muerte y del derecho a heredar $y$, por otro, en el hecho de no se puede repudiar en base a una

1068 Recordemos, en este sentido, lo que ya expusimos en el capítulo segundo a propósito de la delación sucesoria, puntos 2-2 y 3, que, el delado, con anterioridad al momento del fallecimiento del de cuius, no puede, en vida de éste, antes de que se haya abierto su sucesión mortis causa, realizar acto alguno de disposición, tanto inter vivos como mortis causa, sobre el ius delationis que a él se le deferirá por cuanto ello supondría la celebración de un acto sobre herencia futura, lo que entra en el ámbito de la prohibición del artículo 1271 párrafo $2^{\circ} \mathrm{CC}$. 
futura o previsible delación porque ello supondría disponer de una expectativa, de un derecho eventual o futuro que todavía no existe. Sería un acto sobre herencia futura prohibido por el artículo $1271.2^{\circ} \mathrm{CC}$. Derecho sucesorio y herencia que no se sabe aun si va a nacer o no, ya que pende en su nacimiento de la condición futura y objetivamente incierta de que al fallecimiento del causante exista vocación y subsiguiente delación a favor del sucesor, incluso aun en el caso de los herederos forzosos cuyo derecho sucesorio es seguro.

Incluso, si se diere la circunstancia de que se manifestare de buena fe el repudio a la herencia en la firme convicción o creencia de que la persona ya ha fallecido, cuando en realidad no es así, la repudiación, de igual manera, no sería válida por cuanto el artículo 991 del Código Civil exige la concurrencia de un doble requisito en el sucesor: que esté en el hecho cierto del fallecimiento de la persona de cuya sucesión se trate y de su derecho a la herencia.

No obstante, recordemos aquí la excepción que hay en el derecho foral navarro de permitir, por las Leyes 155 y 156 CDFN, la renuncia a la herencia futura, así como la admisión en otras Comunidades Autónomas, en su respectiva legislación, a través de distintas instituciones jurídicas, de la posibilidad de poder celebrar actos, pactos o contratos sobre herencias aun sin deferir

Y también habríamos de tener en cuenta como excepción, llegado el momento, la posibilidad de que se llegue a tipificar en el ámbito del Código Civil la posibilidad de poder celebrar en vida del causante pactos sucesorios ${ }^{1069}$, renunciativos, que llamaba SÁNCHEZ ARISTI, que supusiese la repudiación de la herencia.

\section{3-1-2.- Sin estar cierto del fallecimiento del de cuius o sin que exista vocación sucesoria.}

Para el válido ejercicio del ius delationis, el artículo 991 del Código Civil exige, de forma conjunta, la concurrencia de una doble circunstancia que actúa como presupuesto de carácter objetivo, a la vez que conditio sine qua non: que el sucesor tenga la certeza del fallecimiento de la persona a quien va a heredar y de su derecho a la herencia ${ }^{1070}$.

${ }^{1069}$ En este sentido, nos remitimos a lo expuesto en el punto n ${ }^{\circ}$ 4-1 del capítulo 4, sobre los pactos sucesorios dentro de los límites a la repudiación.

${ }^{1070}$ Acerca del examen de estos presupuestos, nos remitimos a lo que expusimos en el punto número 4-3-1 del capítulo primero, donde se analizan uno y otro, el hecho del fallecimiento y la vocación sucesoria. 
Una y otra circunstancia, se pueden constatar o comprobar de forma fehaciente: el óbito, se puede averiguar, y acreditar, a través del correspondiente certificado de defunción expedido por el Registro Civil y, la existencia de la vocación y delación, una vez abierta la sucesión, se podrá conocer después de que se haya conocido, a través del certificado de últimas voluntades, cómo se va a deferir la sucesión (art. 658 CC), si por vía testada, a través de la voluntad del causante expresada en testamento, o si por ley, por vía intestada, ante la ausencia o insuficiencia, total o parcial, de aquella. De ahí que, al ser dos circunstancias que son, en su caso, perfectamente constatables y comprobables con carácter previo al ejercicio del ius delationis, entendemos que es difícil, incluso casi anecdótico, que esta inobservancia se pueda llegar a producir.

$Y$, si no se cumple este doble requisito, entendemos que el repudio es como si no se hubiese realizado y no tendría ningún valor ni efecto jurídico. El artículo 991 se expresa, entendemos que con bastante contundencia al decir que, "nadie podrá aceptar ni repudiar sin estar cierto de ......", lo cual no deja lugar a dudas: en ningún caso, tiene valor la declaración realizada si no se observa, con carácter previo a su ejercicio, la doble exigencia que impone el precepto al otorgársele a la misma carácter esencial para la válida declaración del delado. En este caso, una vez conocido por su parte, tanto el hecho del fallecimiento como su derecho a la herencia, podría ya ejercer su derecho, por lo que se podría "subsanar" el error o irregularidad cometida.

De igual manera, en el caso de sustitución vulgar, no tendría ninguna validez jurídica la repudiación que, en su caso, manifestare el sustituto sin que se hubiere producido la vacante del primer llamado o sustituido, o en el caso de una sustitución fideicomisaria sometida a condición (dies incertus an et incertus quando), como es la supervivencia del fideicomisario al fiduciario, supuesto más frecuente, no sería válido el repudio de los bienes fideicomitidos por parte de aquel antes de que se cumpla la condición porque no tiene lugar transmisión de derecho alguno a su favor sino desde el momento en que aquella se cumpla (cfr arts 759 y 791 CC). No sucede lo mismo en el caso de un fideicomiso a término (dies certus an et certus quando), habida cuenta de que el fideicomisario adquiere derecho a la herencia desde el mismo momento del fallecimiento del fideicomitente o testador por lo que, al ser titular del ius delationis derivado de su delación incluso aun antes de que se cumpla el término señalado, tal y como se desprende de los artículos 784 y 799 CC, podrá desde entonces manifestar, en su caso, el repudio de los bienes fideicomitidos. 


\section{3-1-3.- Ausencia de capacidad o consentimiento para emitir la declaración.}

Uno de los requisitos que, desde el punto de vista personal, se exige por el Código Civil a todo sucesor para poder ejercer de forma válida y eficaz el ius delationis es, según veíamos en otro momento, que tenga "la libre disposición de los bienes" (art. 992 CC $)^{1071}$, lo cual está en función de su capacidad de obrar.

En este sentido, hay algunos supuestos en que la eficacia de la declaración plantea dudas, por las circunstancias que concurren en el sujeto llamado a la herencia.

En concreto, nos referimos al caso en que el sujeto no tenga ni tan siquiera la condición jurídica de persona por lo que carecería de capacidad jurídica y, por ello, de capacidad para poder suceder ${ }^{1072}$. En realidad, habría, en nuestra opinión, no una ausencia de capacidad para poder ejercer el ius delationis, sino, más bien, al no ser aun persona, una ausencia de sujeto en la sucesión, de lo que se derivaría, además, que tampoco tendría capacidad para poder suceder (art. 744 y ss CC). Y, por ello, podemos decir que estaríamos, más bien, ante un caso de ausencia total de la misma, lo que constituiría un caso de nulidad absoluta de dicha declaración.

${ }^{1071}$ En este sentido, nos remitimos a cuanto exponemos en el capítulo sexto, punto número 1-1-1, donde se analiza dicha norma y el significado de tal expresión.

${ }^{1072}$ Tal es el caso del ejercicio del ius delationis en nombre del nasciturus, o del concepturus, por parte de quienes fueren sus progenitores, antes de que hayan nacido y cumplido los requisitos del artículo 30 CC, habida cuenta de que sólo desde este instante, se es persona, se tiene personalidad y capacidad jurídica, en consecuencia, capacidad para poder suceder (cfr. art. $745.1^{\circ} \mathrm{CC}$ ).

Algo semejante ocurre en el supuesto de fecundación post mortem fuera del plazo legal. En este sentido, de conformidad con el artículo 9.2 de la Ley 14/2006, de 26 de mayo, sobre técnicas de reproducción humana asistida, se tiene que realizar dentro de los doce meses siguientes a su fallecimiento, y en el derecho civil catalán -cfr antiguo arts. 9 del CSCMC de 1991, y 92.2 y 97.2 de la Ley 9/1998, por la que se aprueba el Código de Familia-, en el plazo máximo de 270 días contados desde el siguiente al fallecimiento del progenitor, o de noventa días más, si ha sido prorrogado, con justa causa, por el Juez.

En este sentido, si la fecundación se ha producido fuera del plazo legal y la madre pretende ejercer el ius delationis en nombre y por cuenta del hijo una vez que éste ha nacido respecto de la herencia del padre, el hijo sí será persona y tendrá capacidad jurídica porque habrá nacido cumpliendo los requisitos del artículo 30 CC, pero, al haberse incumplido uno de los presupuestos que se exigen para que se pueda determinar legal y válidamente la filiación respecto de su progenitor, no tendría capacidad para poder sucederle. El hijo sí sería suyo desde el punto de vista biológico, no así, legal y jurídicamente, por lo que, al no haberse podido establecer la filiación al realizarse la fecundación furea del plazo legal, entendemos que la declaración de repudio realizada por la madre no tendría ninguna validez ni eficacia jurídica. Algo parecido ocurrió en el caso que conoció la Audiencia Provincial de Valencia en su sentencia núm. 80/2005 (Sección $8^{\mathrm{a}}$ ), de 21 de febrero (JUR 2005\84942), en que se negó capacidad para poder repudiar a la hija la herencia de su padre por el hecho de que, en el momento de efectuar dicha declaración, aun no había sido inscrita su condición de hija no matrimonial del causante en el Registro Civil.

Igual sucede cuando se instituye como sucesor a una persona jurídica que, en el momento de abrirse la sucesión, estuviere aun en fase o proceso de formación ya que, al no estar aun válidamente constituida conforme a Derecho, no solo no tendría la consideración legal y jurídica de persona, sino que, por ello, carecería de capacidad jurídica, en consecuencia, de capacidad para suceder, además de capacidad de obrar, porque no existe ni tan siquiera como sujeto de derecho. De ahí que al no poder, en esa situación, ejercer el ius delationis dimanante de la vocación deferida a su favor, tampoco puede emitir una declaración de voluntad en este sentido, por lo que, al igual que antes, estaríamos, más bien, ante un caso de ausencia de sujeto en la sucesión. 
De igual manera, se produciría una ausencia total, no de capacidad y sí de consentimiento, cuando la repudiación se realizare en determinadas circunstancias ${ }^{1073}$, en cuyo caso, desde el punto de vista de su eficacia, sería nula de pleno derecho.

Diferente es el caso del incapaz natural ${ }^{1074}$ porque, al no tener sus facultades intelectuales y/o volitivas aun suficientemente desarrolladas, se plantea la cuestión de si puede prestar un verdadero y efectivo consentimiento. Así, la capacidad natural, o las condiciones de consciencia, entendimiento y voluntad que tiene una persona por razón de su desarrollo y que le permiten por su estado psicofísico emitir válidamente una declaración de voluntad, constituye un elemento esencial en la celebración de cualquier contrato o negocio jurídico (arts. 1263 y 1264 CC), cuya ausencia determina la nulidad total del mismo ${ }^{1075}$.

${ }^{1073}$ Así ocurriría en el caso de que el delado pretendiere repudiar, no personalmente, sino a través de apoderado a quien hubiere concedido poder que no fuere suficiente o bastante para ello, habida cuenta de que esta facultad se ha de otorgar o conceder, además, de forma expresa y especial para el caso (art. 1713 párrafo $\left.2^{\circ} \mathrm{CC}\right)$.

Igual sucedería, en sentido inverso, que el representante o apoderado, en la creencia de que, en virtud del mandato que le ha sido concedido, tiene facultad para poder repudiar aquella herencia a que su representado hubiere sido llamado, así lo manifiesta, incluso de buena fe, actuando en nombre y por cuenta de éste sin que se le haya concedido en dicho poder, de forma expresa, dicha facultad.

Tanto en uno como en otro caso, al no haber consentimiento por parte del delado, ha de reputarse totalmente inexistente la repudiación por ausencia total de voluntad de éste en el caso de que lo pretendiere manifestar el representante. Así, sucedió en el caso que conoció la Audiencia Provincial de Málaga en su sentencia $n^{\circ}$ 1053/2004 (Sección 5), de 27 de septiembre (JUR 2004\292455), que declaró la nulidad de la repudiación que la esposa manifestó en nombre de su marido ante la inexistencia de poder por parte de éste a favor de ella, ni general, ni especial.

1074 Para MORALES MORENO (Comentario al artículo 1263 del Código Civil, en Comentario del Código Civil. T II. Ministerio de Justicia. Madrid. 1993. Pág 455), existe "incapacidad natural” cuando la persona se halla en una situación corporal o psíquica en la que no le es posible entender y querer el acto jurídico que realiza. Lo que puede ser consecuencia de la edad (menor de escasa edad), o de una enfermedad mental crónica, o de una perturbación psíquica transitoria (efectos del alcohol, de la droga, de la fiebre, etc). De ella se derivaría una falta de voluntad, lo que daría lugar a que faltase uno de los elementos del contrato (art. 1261 CC) y la nulidad del mismo.

JORDANO FRAGA, por su parte, (Falta absoluta de consentimiento, interpretación e ineficacia contractuales. Studia Albornotiana. LII. Publicaciones del Real Colegio de España. Bolonia. 1988. Pág 308 y ss), al tratar de los supuestos de falta de voluntad en la celebración de los contratos, se refiere a ella diciendo que, bajo esta denominación, “se agrupan todos aquellos supuestos en que una de las partes del contrato se halla en condiciones de inteligencia y voluntad tales, que no permiten hablar, con relación al contrato aparentemente perfeccionado, con su intervención, de un verdadero y efectivo consentimiento".

A resultas de lo cual el sujeto no presta un verdadero consentimiento, bien porque le falte la misma voluntad de los signos expresivos, bien porque no es consciente del valor jurídico negocial de los mismos -en ambos casos falta la voluntad de manifestación o de declaración-, o porque no está en condiciones de darse cuenta de su alcance y significado De una u otra manera, falta la voluntad negocial (contractual) del aparente declarante y, por consiguiente, todo consentimiento.

Y cita como causas de incapacidad natural: la escasa edad, enfermedades mentales, embriaguez, estados delirantes, traumáticos, sonambulismo, etc.

1075 JORDANO FRAGA: Falta absoluta de consentimiento, interpretación e ineficacia contractuales. Cit: Pág 317 y 318. 
Sin embargo, la capacidad natural, no siempre camina en paralelo junto a la capacidad legal, en el sentido de que, así como la tenencia de ésta presupone, no la existencia del consentimiento, sino la validez y eficacia del mismo -se tiene capacidad legal, se presume, salvo prueba en contrario, que se puede emitir de forma válida y eficaz el consentimiento-, no ocurre lo mismo al revés, ya que puede suceder, que no se tenga capacidad legal suficiente para poder ejercer válidamente un determinado negocio jurídico y sí se pueda, en cambio, por tener capacidad natural, emitir una declaración de voluntad respecto de la cual se va a plantear, lógica e inevitablemente, ante la ausencia o insuficiencia de la capacidad legal, la cuestión de cual es la validez y eficacia jurídica de lo realizado a través de dicha declaración de voluntad $^{1076}$.

Llevada esta problemática al caso que nos ocupa, el incidente planteado se produce cuando el sucesor, al amparo de lo dispuesto en el artículo 992 CC, no tiene la capacidad legal exigida por éste o, por razón de diversas circunstancias, no es

1076 Hacemos este planeamiento al amparo de la cuestión, que aquí tan solo vamos a dejar planteada pero que nos va a servir de base para examinar algunos supuestos de ineficacia, y que late en la doctrina acerca del artículo 1263 del Código Civil entre capacidad y consentimiento a propósito de la celebración de los contratos porque, aquí, en el ejercicio del ius delationis, es preciso hacer también la misma diferenciación, entre la capacidad que se ha de ostentar para poderlo ejercer válidamente, a la que alude el artículo 992 CC, y el consentimiento que, en su caso, se haya otorgado por parte de quien carece de dicha capacidad a los efectos de determinar cual es la validez y eficacia jurídica de la repudiación realizada.

En dicho precepto se mezcla la prestación del consentimiento con la capacidad para poder contratar y que, sin embargo, es preciso diferenciar, como ponen de relieve, entre otros, GOMEZ LAPLAZA (Op. cit: Pág 160 y ss), o MORALES MORENO (Comentario al artículo 1263 del Código Civil, en Comentario del Código Civil. Cit: Págs 455 y 456), para quienes, la expresión que en él se contiene de, "no pueden prestar consentimiento", no indica una prohibición legal de contratar, sino, la existencia de una incapacidad para contratar derivada del estado civil (menor no emancipado e incapaz), cuyos efectos concretos se regulan en los artículos 1300 y ss CC. De su lectura se puede observar cómo se hace de la capacidad, el factor o elemento determinante de la prestación del consentimiento. El requisito de la capacidad que está implícito en el del consentimiento, en el sentido de que éste presupone aquella, de tal manera que, sólo quienes tienen la capacidad necesaria para poder contratar pueden válidamente prestar consentimiento [LOPEZ SAN LUIS (Op. cit.: Pág 58)].

Así, dado el tenor literal de los artículos 1261 y 1263 CC, y en conjunción con éste, los artículos 314 y 315 CC, un menor de edad no emancipado no tendría capacidad para poder celebrar contratos y, por tanto, los actos por él realizados no tendrían eficacia jurídica. Sin embargo, se cuestiona la validez y eficacia de los actos por él realizados pese a su menor edad.

De igual manera, DÍEZ-PICAZO, pone de relieve que, a pesar del tenor del artículo 1263 CC, "no se trata de que el consentimiento pueda ser o no prestado, sino de si el negocio jurídico generado a través del mismo, es o no válido y eficaz". Para él, "la capacidad no es un presupuesto de la existencia del consentimiento, sino un presupuesto de la validez y eficacia”. De ahí que, más que de capacidad de prestar el consentimiento, debe hablarse de, “capacidad para contratar” (Fundamentos de Derecho Civil Patrimonial. Vol I. Ed. CIVITAS. Madrid 1993. Pág 144). De igual manera, GORDILLO CAÑAS (Capacidad, incapacidades y estabilidad en los contratos. Ed TECNOS Madrid. 1986. Págs 36 y 37).

Por su parte, BADOSA COLL, sostiene que el artículo 1263 se refiere, más bien, a la "incapacidad para consentir", que sería diferente de la "incapacidad para contratar" ("Incapacidad de consentir e incapacidad de contratar. (Un estudio sobre el artículo 1263 CC)”. En Centenario del Código Civil. I. Asociación de profesores de Derecho Civil. Madrid. 1990. Pág 191 y ss).

También se hacen eco de la problemática que encierra en este sentido el artículo 1263 CC: TOLDRÁ ROCA (La anulabilidad por causa de incapacidad (reflexiones en torno al artículo 1304 del Código Civil). Monografía. Tirant lo Blanch. Valencia. 2006. Pág 21 y ss). 
suficiente para el ejercicio del ius delationis al tenerla restringida en todo o en parte, por lo que carece de la libre disposición de sus bienes, pero, al tener ya una capacidad natural por razón de sus condiciones de madurez, sí puede emitir, al igual que sucede en otros supuestos sancionados por la ley, una declaración de voluntad a través de la cual manifiesta su repudio a aquella herencia a que ha sido llamado. Repudiación de la que se discute, en consecuencia, si es plenamente válida y eficaz desde un orden legal y jurídico, o, por el contrario, si es ineficaz, qué grado de ineficacia ha producido y qué consecuencias se derivan de ello.

Así, sin ánimo exhaustivo, podemos citar, entre otros, los siguientes casos de cuyo examen nos ocuparemos en detalle más adelante:

a) que el sucesor sea un menor de edad que, por sus condiciones de madurez, ya tenga el suficiente discernimiento o consciencia, o capacidad natural, que le permita conocer, entender, querer y saber, de tal manera que, no solo comprenda el alcance, significado e importancia del acto que realiza, sino que le facultaría, en principio, para poder emitir una declaración de voluntad de la que se plantearía, en consecuencia, al ser aun menor, la cuestión de cual es la validez y eficacia jurídica de la repudiación realizada a través de la misma.

b) Que sea mayor de edad pero que, en el momento de emitir la declaración de repudio, tenga restringida su capacidad de obrar, de forma parcial, por causa de incapacidad (arts 199 y 200 CC) o de prodigalidad (arts $286.3^{\circ}$ y 288 CC; 748 a 755 y 756 a 763 LEC), en virtud de sentencia, y en la que se le impida de forma expresa realizar esta declaración de voluntad si no es a través del curador, pero que, no obstante, aun así repudia por sí mismo.

c) Mayor de edad que, al manifestar su declaración de repudio, padezca alguna de las causas que dan lugar a una incapacitación (art. 200 CC), pero que no está incapacitada al no existir sobre ella una sentencia judicial que así lo declare (art. 199 $\mathrm{CC})$, y desvirtúe la presunción legal y general de capacidad que tiene todo mayor de edad.

En este caso, conocido también como incapaz no incapacitado, incapaz de hecho, o presunto incapaz, se discute, más que una ausencia de capacidad, cual es la eficacia de la declaración de voluntad por él emitida, si su consentimiento es válido a los efectos del artículo $1263.2^{\circ} \mathrm{CC}$ y, en este caso, ante qué clase de ineficacia estamos, si es subsumible en el ámbito de la nulidad o de la anulabilidad. 
Dejando la casuística anterior, pero al hilo de ella, la Ley 10/2008, de Sucesiones de Cataluña (art. 461-10) contempla como supuesto de impugnación de ejercicio del ius delationis, junto con el hecho de que se haya emitido la declaración existiendo algún vicio del consentimiento (intimidación, violencia, dolo o error), la falta de capacidad, lo que nos lleva a hacer dos reflexiones:

$1^{\mathrm{a}}$.- el hecho de poner en un plano de igualdad la falta de capacidad y los vicios del consentimiento, parece dar a entender que, de una y otra, se desprende el mismo tipo de ineficacia, cuando resulta que aquella, la capacidad, por razón de su origen y según las circunstancias, como hemos visto, puede dar lugar a diferentes supuestos de ineficacia. Así, parece dar el mismo tratamiento jurídico y consideración a todos los casos en que se produce una falta de capacidad, con independencia de su origen, que los vicios del consentimiento $\mathrm{y}$, por tanto, está dando a entender que, tanto uno como otro, son supuestos de anulabilidad, cuando en realidad no es así.

$2^{\mathrm{a}}$.- El contenido que la ley catalana da a la falta de capacidad del delado como causa de impugnación de su declaración es extraordinariamente amplia, tal vez excesiva, como bien apunta MEZQUITA GARCÍA-GRANERO ${ }^{1077}$ a propósito de dicho artículo, porque, "abarca tanto los defectos relativos a los presupuestos como a los requisitos de la declaración negocial, desde la capacidad para suceder (capacidad jurídica, derecho y dignidad), y la capacidad para aceptar o repudiar (capacidad de obrar negocial para el ejercicio del ius delationis), hasta los requisitos de la propia declaración (libertad en formación y exteriorización de la voluntad y coincidencia entre lo querido y lo declarado".

Ello, en nuestra opinión, es un error porque, al amparo de dicha expresión, estarían englobados o agrupados bajo la misma toda una multiplicidad de supuestos que, no sólo son muy heterogéneos y dispares entre sí por cuanto no tienen nada que ver unos con otros al proceder de orígenes muy diversos y de causas y circunstancias muy distintas, sino que, y esto es lo destacable, por razón de esto último, a pesar de que el hecho que motiva cada uno de ellos es diferente, se le da el mismo tratamiento jurídico, lo que hace presuponer que, tanto en el caso de vicios del consentimiento, como todos los supuestos que cita MEZQUITA considerados como falta de capacidad, dan lugar a la misma clase de ineficacia, cuando ello, a nuestro juicio, no es así. La ausencia de un presupuesto en la declaración da lugar a un supuesto de nulidad

1077 Op. cit.: Pág 86 y ss. 
absoluta $^{1078}$. Mientras que, la ausencia de un requisito para emitir conforme a derecho la declaración puede dar lugar, tanto a un caso de nulidad, como de anulabilidad. No es lo mismo que la falta de capacidad provenga de la ausencia de capacidad jurídica en la persona por cuanto ni tan siquiera existiría el sujeto de la sucesión, o por causa de indignidad, o por una limitación a la libre disposición proveniente de una incapacitación, o que haya un defecto de forma en la declaración, que equivaldrían a casos de nulidad absoluta, o que provenga de un vicio de la voluntad, que daría lugar a un supuesto de anulabilidad. En aquellos, la declaración no produciría ningún efecto y no tendría ninguna virtualidad jurídica, mientras que en éste, sí sería, en principio, válida y produciría plenos efectos jurídicos, sin perjuicio de su posible impugnación.

Por otro lado, acerca de esta modalidad de ineficacia, y a propósito de la capacidad del sucesor, ROCA SASTRE ${ }^{1079}$ manifiesta que, "la aceptación o repudiación efectuada en contra de las prescripciones expresadas del Código Civil sobre capacidad, serán impugnables o anulables de acuerdo con lo dispuesto en los artículos 1301 y siguientes del Código Civil". Al expresarse en tales términos, parece desprenderse, en nuestra opinión, la misma conclusión que acabamos de comentar acerca de la ley catalana: que todos los supuestos en que se produzca alguna infracción de las normas sobre capacidad de la persona constituyen causa de anulabilidad. De igual manera y por el mismo motivo, no estamos de acuerdo porque la casuística es muy diversa y no parece distinguir las dos clases de invalidez, nulidad y anulabilidad, ya que, según hemos visto más arriba, en realidad, puede haber también supuestos de nulidad absoluta por causa de inexistencia o ausencia total del consentimiento o, incluso, de sujeto en la sucesión. Cierto es que algunos supuestos sobre capacidad serán impugnables a través del artículo 1301 y siguientes del Código Civil, pero habrá otros que no por ser causa de nulidad absoluta, ya sea por ausencia de consentimiento, ya por infracción de normas imperativas o prohibitivas.

\section{3-1-4.- Por ausencia de objeto.}

Entendemos que falta el objeto, no solo cuando no hay herencia, como sucede cuando ésta se repudia en vida del causante, sino también cuando no hay o no se tiene vocación en base a la cual se pueda repudiar (art. 991 CC).

\footnotetext{
${ }^{1078}$ Vid, en este sentido, por un lado, el punto número 4-3 del capítulo primero donde se examinan dichos presupuestos, y por otro, el punto 3-1-2 de este mismo capítulo en el que se analiza la ineficacia que se deriva de su infracción.

${ }^{1079}$ Derecho de Sucesiones. T. III. Cit: Pág 465.
} 
De igual manera, se puede decir que hay ausencia de objeto cuando el delado, después de haber ejercido el ius delationis, pretendiere, en su caso, hacerlo otra vez, ahora, lógicamente, con declaración de signo contrario, bien porque se arrepiente de ello, bien porque la pretenda invalidar. Una vez que se ha ejercido, se impide y precluye automáticamente la posibilidad de volver a hacerlo otra vez $\mathrm{y}$, por ello, ya no hay objeto sobre el que se pueda volver a repudiar o aceptar.

En este sentido, el Tribunal Supremo, entre otras sentencias, como es la de 28 de marzo de 2003 (RJ 3038), manifiesta que: “...... una vez realizado el acto de la aceptación en alguna de las formas autorizadas por los arts. 998 y 999, será ineficaz la posterior renuncia, y esto es así porque la ley no consiente que de modo temporal se asuma la cualidad de heredero". En los mismos términos, solo que refiriéndose al repudio, se manifestó la Audiencia Provincial de Badajoz (St nº 295/2004, Sección 2aa, de 3 noviembre, JUR 2005(132036): "la repudiación de la herencia realizada por acto posterior a la aceptación carece en absoluto de viabilidad".

\section{3-1-5.- Inobservancia del requisito de la forma.}

La repudiación, a diferencia de la aceptación, es un acto eminentemente formal o solemne ${ }^{1080}$ porque no se puede exteriorizar de cualquier manera, lo que constituye una de sus particularidades, a la vez que un elemento definitorio y esencial de la misma, por cuanto la forma es manera de ser del negocio ("forma dat esse rei"), y está incorporada a él como un presupuesto esencial de ella. Si no se cumple, es como si dicha declaración de voluntad no se hubiese realizado. No hay voluntad sin forma.

Así, la repudiación se ha de exteriorizar, so pena de nulidad absoluta, de forma solemne, a la vez que instrumental, bien sea por escrito a través de documento público o auténtico del que no quepa duda alguna de su autoría, bien de forma judicial (art. 1008 CC), no siendo válida, según se desprende del mismo, la realizada de manera verbal o tácita, o a través de documento privado no auténtico.

En consecuencia, la inobservancia de este requisito da lugar a que el repudio no tenga ningún valor jurídico, y si se quiere repudiar válidamente una herencia, se ha de manifestar de nuevo cumpliéndose la exigencia de la forma en los términos que establece el artículo 1008 del Código Civil, en concordancia con el artículo 1280,4º del mismo texto legal.

${ }^{1080}$ En este sentido, nos remitimos a lo expuesto en el capítulo cuarto y al capítulo sexto, punto número 2, donde se analiza la solemnidad de la declaración de repudiación y la forma como requisito objetivo de la misma. 


\section{3-2.- Por infracción de normas imperativas o prohibitivas.}

Distinto de lo anterior es el supuesto en que la declaración de repudio se emite sin que se produzca la ausencia o inobservancia de algún elemento o presupuesto que se considera esencial en el momento de su exteriorización pero sí con infracción o incumplimiento de alguna norma imperativa o prohibitiva.

Así, se pueden considerar, en este sentido, como supuestos radicalmente nulos, entre otros, los siguientes.

\section{3-2-1.- Cuando la declaración se hace de forma parcial.}

La repudiación es un acto de carácter indivisible ${ }^{1081}$, en virtud de lo dispuesto en el artículo 990 CC, de lo que resulta que dicha declaración ha de recaer sobre la totalidad de aquello que ha sido deferido mortis causa por virtud de la delación.

Esta exigencia entendemos que es imperativa y su infracción constituiría, a nuestro juicio, por aplicación del artículo 6.3 CC, un acto nulo. Por ello, no sería válida aquella repudiación en que el sucesor fraccione la porción o cuota a que ha sido llamado de tal manera que rechace una parte y acepte la otra, o al revés. Una declaración del sucesor aceptando solo una parte de la vocación que le ha sido deferida se tendría por no realizada, no tendría ningún valor ni efecto, por lo que tendría que emitir una nueva declaración.

No obstante, dado que la indivisibilidad de la declaración del sucesor puede ser observada desde distintos puntos de vista, subjetivo, objetivo ${ }^{1082}$, habrá que estar a las circunstancias particulares que en cada caso concurran para poder establecer dicha indivisibilidad y precisar si estamos o no ante un acto nulo.

\section{3-2-2.- Cuando la declaración se hace bajo condición o a término.}

El artículo 990 CC también dispone que la declaración, ya sea de repudiación o de aceptación, “... no podrá hacerse ...., a plazo, ni condicionalmente”. De lo que se desprende, ya lo veíamos a propósito de sus características ${ }^{1083}$, que ha de hacerse de forma pura, sin circunstancia alguna que limite sus efectos, exigencia que, en nuestra opinión, es de necesario y estricto cumplimiento, por lo que tiene carácter imperativo.

\footnotetext{
${ }^{1081}$ Acerca de esta característica y de su significado, véase en el capítulo cuarto, el punto número 2 , al que nos remitimos a cuanto en él se expone.

${ }^{1082}$ Véase en este sentido, el capítulo quinto, dedicado todo él a la repudiación en el caso de pluralidad de delaciones y/o de cuotas, al que nos remitimos.

1083 Acerca de esta característica, véase el capítulo cuarto, al que nos remitimos.
} 
De no hacerse así, entendemos que la declaración de voluntad emitida sería radicalmente nula, sin ningún valor ni efecto jurídico, como si no se hubiese llegado a manifestar.

En este caso, al igual que en el anterior, el ius delationis se mantiene intacto, como si no se hubiera ejercitado, y el sucesor podrá emitir una nueva declaración de voluntad por lo que tendrá la posibilidad, tanto de poder repudiar, como incluso, si así lo desea, de aceptar ahora la herencia a que ha sido llamado si decidiere lo contrario a como manifestó en un primer momento.

\section{4.- INVALIDEZ POR CAUSA DE ANULABILIDAD.}

La anulabilidad, en la declaración de repudio de una herencia, no difiere de la que se produce en otros contratos o negocios jurídicos en lo que se refiere a cuando tiene lugar, esto es, que se hayan cumplido los presupuestos esenciales y requisitos exigidos para su válida exteriorización conforme a derecho, pero adolece de un vicio, defecto o irregularidad que la hace susceptible de ser impugnada. De ahí que la causística venga, en parte, a coincidir y ser la misma que se puede producir en otros negocios jurídicos, si bien, como ahora veremos, hay algunos supuestos que, como es lógico, son propios de esta declaración.

Así, tenemos como tales supuestos de ineficacia, los siguientes.

\section{4-1.- En el caso de que existiere un vicio del consentimiento.}

Según el artículo 997 CC, la declaración del delado es susceptible de ser impugnada si "adoleciese de algunos de los vicios que anulan el consentimiento", porque se hubiere visto condicionada o perturbada con carácter previo, o en el momento de su emisión, por circunstancias como el error, la violencia, la intimidación o el dolo (cfr art 1265 y ss CC). Es la única causa que, junto a la aparición de un testamento desconocido, establece el Código Civil de forma expresa como supuesto de impugnación de la declaración de voluntad dimanante del ius delationis. Todos los demás supuestos que veremos a continuación y que, en nuestra opinión, se pueden calificar de anulabes, se deducen de la aplicación de otras normas jurídicas.

Por otro lado, esta causa de ineficacia, viene también corroborada de alguna manera por el artículo 988 CC, al manifestar que, "la aceptación y la repudiación de la herencia son actos enteramente ...... libres", libertad que no existiría si la declaración de voluntad se emitiere coaccionada o condicionada por un vicio de la voluntad. 
Así, si hay un vicio del consentimiento, al igual que ocurre en la celebración de cualquier otro acto, contrato o negocio jurídico, aunque, en principio, la declaración sería válida y produciría efectos, se podría instar su impugnación o anulación, por aplicación de la normativa relativa a la materia de contratos, en el plazo de cuatro años (art. 1301 CC) contados desde que se hubiere producido la cesación de los mismos, por aplicación de lo dispuesto en el artículo 1300 y ss del Código Civil.

Ya entrando en el examen de esta causa de ineficacia, de los diferentes vicios del consentimiento, nos vamos a detener, en concreto, en aquel que se produce por causa de error sobre la cuantía o contenido de la herencia, y no ya tanto por razón de las características que ha de reunir, que son semejantes al error en los contratos ${ }^{1084}$, sino por ser el más frecuente y el que más dificultades ha planteado en la práctica.

La casuística en cuanto al origen del error es muy variada, pero los supuestos más frecuentes que se producen y alegan para impugnar la declaración de repudio en virtud del mismo vienen referidos, principalmente, a la valoración y cuantía de la herencia o la composición de su caudal, como puede ser: porque el sucesor creyó que una determinada propiedad, bien o derecho, o cualesquier otro activo ya no formaba parte del caudal relicto del difunto o, en relación al pasivo, por circunstancias como es el hecho de creer que determinadas deudas no estaban extinguidas o eran de elevada cuantía, o porque no existían cargas o gravámenes o los que había son muy elevados, alegando como justificación del repudio que se creía la herencia dañosa y deficitaria descubriendo después que es lo contrario, que las deudas, cargas o gravámenes no existen o que no son de cuantía tan elevada como, en un principio, así se entendió, lo que hizo perder su interés por la herencia y luego resultó lo contrario.

Circunstancias como éstas u otras de naturaleza análoga, difícilmente pueden hacer prosperar una petición de impugnación invocando error en la declaración desde el momento en que el sucesor, no solo es libre de aceptar o repudiar la herencia (art. 988 CC), sino que la ley arbitra medios o instrumentos para poder saber y conocer, con carácter previo al ejercicio del ius delationis, cual es el estado y composición de la herencia, como son el derecho de deliberar o el beneficio de inventario (art. 1010 y ss $\mathrm{CC})$, si luego, además, resulta que el repudiante no ha hecho uso de ninguno de estos

${ }^{1084}$ El Tribunal Supremo, acerca del error como circunstancia que invalide el consentimiento, señala como requisitos del mismo: que sea esencial e inimputable al que lo sufre, es decir, excusable, ya sea de hecho o de derecho (SSTS de 9 de abril de 1980, RJ 1411; 4 de enero de 1982, RJ 179; 27 de mayo de 1982, RJ 2605; 14 y 18 de febrero, 3 y 29 de marzo de 1994, RJ 1096, 1469, 1645, 2304; de 6 febrero de 1998, RJ 408; 17 julio de 2000, RJ 6803; 12 julio de 2002, RJ 7145, entre otras muchas). 
recursos o no se ha tomado el tiempo necesario para meditar y decidir ${ }^{1085}$. En estos casos, el error no sería excusable y el sucesor tendría que sufrir las consecuencias derivadas del mismo.

A igual resultado nos llevaría el caso contrario: que se acepte por el sucesor una herencia que cree, en principio, lucrativa o beneficiosa y luego resulta que hay un pasivo muy elevado, con deudas de elevada cuantía, o con cargas o gravámenes que la hacen excesivamente dañosa y perjudicial para el ya heredero.

En consecuencia, el error es relevante a los efectos de impugnar la declaración del sucesor cuando se produce en virtud de circunstancias ajenas, extrañas o externas a él, que no pudo conocer al tiempo de emitir su declaración y no le fueren en modo alguno imputables, o no pudo prever los hechos que dieron lugar a dicho error. No obstante, la apreciación del error como causa de impugnación de la voluntad es una cuestión de hecho que se ha de valorar en cada caso particular por los Tribunales, incumbiendo la carga de la prueba al sucesor y demostrar que la causa o motivo del error por él alegado no le es imputable, o que es excusable.

Distinto es que el error recaiga sobre la persona del causante (que se repudie la herencia de otra persona distinta a la que se ha confundido por similitud en el nombre o porque se creía que era el verdadero causante), en cuyo caso, más que un supuesto de error, estaríamos ante una inexistencia de la delación (art. 991 CC). Entonces ya no estaríamos ante un caso de anulabilidad, sino de nulidad absoluta por ausencia del elemento esencial de la vocación y delación a favor del sucesor.

Por último, indicar que la ley 10/2008, de sucesiones, de Cataluña, entiende como un supuesto de error (art. 461-10) y, por tanto de anulabilidad, la aparición con posterioridad a la declaración, de "otras disposiciones de última voluntad que eran desconocidas y que alteran sustancialmente el contenido del título sucesorio", calificación de la que disentimos porque, como analizaremos más adelante, dependiendo de las circunstancias cómo se haya producido, puede ocurrir que ni tan siquiera dé lugar a la ineficacia de la declaración, lo que tendrá lugar cuando dicho testamento no afecta a la vocación del repudiante.

1085 Vid, entre otros: MANRESA: Comentarios al Código Civil. T VII. Cit: Págs 384 y 385; ALBALADEJO: “La repudiación de la herencia”. Cit: Pág 746 y ss; GITRAMA: Comentarios al Código Civil ........ T XIV. Vol 1‥ Cit: Pág 174; ROCA SASTRE: Anotaciones al Derecho de Sucesiones de Kipp. Tomo V. Vol 2º Cit: Págs 61 y 62. 


\section{4-2.- En el caso de repudiación por un menor de edad no emancipado.}

Es hipótesis poco probable, incluso casi anecdótica en la realidad, el hecho de que un menor de edad sin estar emancipado, repudie, él, por sí solo, aquella herencia a que hubiere sido llamado, dado el carácter formal que tiene la declaración de repudiación en su exteriorización por cuanto ha de hacerse, o normalmente se hace, ante Notario o el Juez ya que éstos, en el ejercicio de su función, se lo impedirían, o no lo permitirían por cuanto es su obligación valorar y apreciar la capacidad del otorgante, lo cual constituye, sino una forma de control y de garantía de legalidad, sí una barrera importante para que esta hipótesis no se produzca y evitar así la ineficacia dicha declaración. Además, se da la circunstancia de que el menor está sometido, por razón de su estado civil y la capacidad que él tiene frente a derecho en este momento, a un régimen de protección, patria potestad o tutela, en el que los padres o el tutor, por lo que, de igual manera, se lo impedirían o no lo permitirían. En este sentido, una de las facultades que éstos tienen en el ejercicio de sus funciones tuitivas es la de ejercer en nombre del menor el ius delationis de la herencia a que éste hubiese sido llamado.

No obstante, dada la ausencia de capacidad del menor frente al derecho, y a la vista de la disociación que puede existir entre capacidad y consentimiento ${ }^{1086}$, o entre capacidad natural y capacidad legal, surge el interrogante de qué eficacia jurídica tendría, en su caso, la declaración de repudio realizada por un menor de edad no emancipado ${ }^{1087}$ sin la intervención de sus padres o tutor porque su declaración choca abiertamente con la norma del artículo 992 CC al no tener más que capacidad jurídica.

${ }^{1086}$ Vid, el punto número 3-1-3, de este mismo capítulo, al que nos remitimos.

1087 Podemos distinguir varios tipos de menores, en cada uno de los cuales existen diferentes grados de capacidad:

a) en primer lugar, y atendiendo a la edad de la persona, está aquel menor que carece de capacidad natural porque no tiene suficientes "condiciones de madurez" (art. 162.2.1 ${ }^{\circ} \mathrm{CC}$ ), ya que ni tan siquiera puede discernir, conocer, saber, o querer, de tal manera que por carecer totalmente de voluntad y entendimiento no puede realizar ninguna clase de acto, en cuyo caso, si lo realizare, equivaldría a un supuesto de inexistencia por ausencia total de consentimiento.

b) Diferente es aquel menor de edad que, como manifiesta el Código Civil en reiteradas ocasiones (arts 92.6, 154 párrafo $3^{\circ}, 156$ párrafo $2^{\circ}, 177.3 .3^{\circ}, 231$ ) y la LOPJM de 1996 (artículo 9), en expresión abstracta e indeterminada, tan solo tiene "suficiente juicio", pero que, éstos, ni ningún otro texto legal, aclara ni dice en qué consiste, como tampoco conforme a qué criterio se puede establecer cuando el menor tiene suficiente juicio, o desde cuando existe.

En este sentido, ya la edad de los doce años es muy relevante en la capacidad de la persona porque es tenida en cuenta por el Código Civil en la realización de numerosos actos: en unos (art. 156 párrafo 2º), para que se oiga al menor de manera obligatoria, en otros, al objeto de que preste necesariamente su consentimiento para la realización de determinados actos como son, la adopción (art. 177.3.3 ), o la tutela (art. 231). Del tenor de los artículos citados (156.2, 177.3.3ㅜ, 231 CC), parece contraponerse el requisito del "suficiente juicio" con tener doce años, en el sentido siguiente: antes de esta edad, el menor ha de ser oído si tiene "suficiente juicio", lo que será cuestión de valoración y de apreciación, de forma libre y voluntaria, por el Juez en cada caso particular según las circunstancias que concurran en el menor ya que 
Nos planteamos este interrogante en base al hecho de que, es la propia ley quien reconoce al menor una capacidad, natural, para poder realizar por sí solo ciertos actos dadas "sus condiciones de madurez" (art. 162.2.1 $\mathrm{CC}$ ), sobre todo desde los doce años, incluso antes si tiene suficiente juicio (arts 92.6, 154, 156.2 ${ }^{\circ}, 177,3.3^{\circ}, 231$ CC). En este sentido, aunque el sucesor sea menor de edad, no es menos cierto que, cuando ya está próximo a la mayoría de edad, tiene raciocinio y juicio suficiente, voluntad y conocimiento, como para saber qué es lo que quiere y no quiere, incluso conocer el alcance, significado, trascendencia e importancia del acto que realiza, ante lo que la ley, pese a que no tenga aun la libre disposición de sus bienes, permite y autoriza la realización, por sí solo, de ciertos actos.

Así, hoy día, es una realidad social, corroborada por los usos sociales, incluso admitida jurídicamente, el hecho de que los menores de edad, aun estando bajo la potestad de sus padres o el cuidado del tutor, a medida que van creciendo y, sobre todo, cuando ya tienen una edad cercana a la mayor edad, realizan en la vida diaria numerosos actos, incluso contratos, sin que se plantee cuestión alguna acerca de su validez y eficacia, como puede ser: acceder a lugares de recreo, cine, ocio, deporte y esparcimiento, actuaciones musicales, adquisición de artículos de consumo en tiendas o establecimientos abiertos al público (ropa, alimentación, música, etc), o de entradas para un espectáculo a través de máquinas expendedoras o cajeros automáticos, incluso a través de internet, o transporte en servicios públicos, sin que por ello se necesite la presencia, intervención o actuación inmediata, o a posteriori, de sus representantes legales, padres o tutor.

Por otro lado, la Ley Orgánica de Protección Jurídica del Menor de 1996, en coherencia con la protección que del menor hace la Constitución de 1978 (art. 39), ha supuesto un notable avance en el reconocimiento de derechos a favor de la

no se dice con sujeción a qué criterio se valora ese juicio del menor. Mientras que, después de dicha edad, no se condiciona el trámite de audiencia a dicho requisito, sino que ha de ser escuchado por el Juez ya de forma obligatoria. De lo que se podría obtener la conclusión, o interpretación, de que, el "suficiente juicio" sería el criterio o regla de referencia para valorar el grado de madurez de un menor si tiene menos de doce años, y pueda, al menos, en consecuencia, ser oído y escuchado. Mientras que, después de esta edad, se entiende que ya lo tiene porque ha de ser escuchado por el Juez de manera imperativa. Con lo cual, podemos deducir que, ya antes de la edad de los doce años, la ley entiende que la persona puede tener, siquiera mínimo, cierto grado de discernimiento y puede conocer, saber y querer, aunque se trate de una voluntad aun en fase de formación, para poder emitir, al menos, una opinión.

c) Y, distinto de los anteriores, es aquel menor que aun no tiene capacidad de obrar porque todavía no ha cumplido los 18 años pero que, por su madurez, no sólo física, sino intelectual y volitiva, se le reconoce una capacidad natural para poder emitir una declaración de voluntad, incluso con pleno discernimiento y consciencia, porque conoce, sabe, entiende y comprende el alcance, significado, trascendencia e importancia del acto que va a realizar, que es el menor respecto del cual se plantea la cuestión de cual es la validez y eficacia jurídica de los actos por él realizados. 
infancia $^{1088}$. Al mismo tiempo, las transformaciones sociales y culturales operadas en nuestra sociedad en las últimas décadas han permitido ampliar el ámbito de poder de actuación y el abanico de derechos que pueden ser ejercitados por un menor de edad estableciendo su condición de sujeto de derechos en determinadas situaciones y relaciones sociales, de tal manera que se admite que él pueda, si no intervenir personalmente en ellas como sujeto activo que decide en las mismas, sí ser oído aplicando el criterio del suficiente juicio (arts 92.6, 154, 156.2, 177.3.3ㅇ, 231 CC).

En este sentido, al tiempo que la LOPJM sanciona, en su artículo 2, como uno de sus principios generales, la prevalencia o primacía del "interés superior del menor sobre cualquier otro interés legítimo que pueda concurrir", establece a continuación que, "las limitaciones a la capacidad de obrar de los menores se interpretarán de forma restrictiva". Se observa, así, una postura progresista en lo que se refiere a la intervención, incluso ejercicio, por parte del menor de aquellos derechos de los que él sea titular, aunque después, en este sentido, no ha introducido ningún cambio en el Código Civil en lo que se refiere a la capacidad de obrar o de ejercicio del menor en materia de actos, contratos y demás negocios jurídicos (cfr. arts. 992, 1263.10 CC) ${ }^{1089}$.

Ya en el caso de la celebración de actos y contratos por menores de edad, tanto la doctrina ${ }^{1090}$, aunque hay voces discordantes, como el Tribunal Supremo ${ }^{1091}$, cuando

1088 Acerca de ello, es de interés su Exposición de Motivos donde se justifica el contenido y ámbito de la ley en orden a justificar y explicar ese reconocimiento de derechos a favor de los menores de edad.

1089 Modificaciones, sí que ha habido en todo un sinfín de artículos a través de las Disposiciones Finales Primera a Décimo Octava, pero en otras cuestiones.

${ }^{1090}$ Con carácter general, se reconoce el carácter anulable de los actos y contratos celebrados por un menor de edad, si bien, el mayor o menor ámbito de poder de actuación autónoma del menor, así como la validez y eficacia de sus actos, está en función del reconocimiento que haga la ley al legitimar ciertos actos, lo que, a su vez, dependerá de sus condiciones y grado de madurez.

Así, entre otros muchos, vid: GETE-ALONSO (Op. cit.: pág 29 y ss); GOMEZ LAPLAZA (Op. cit: Pág 184); LACRUZ BERDEJO (Elementos de Derecho Civil. T I. VI. 2º BOSCH. Barcelona. 1983. Pág 69); LOPEZ SAN LUIS (Op. cit.: pág 58 y ss); MORALES MORENO (Comentario al artículo 1264 del Código Civil, en Comentario del Código Civil. Cit: Págs 457 y 458); PASQUAU LIAÑO (Comentario a los artículos 1263 y 1264 del Código Civil, en Jurisprudencia civil comentada. T I. Cit. Págs 2176 y ss).

1091 La jurisprudencia, desde tiempos pretéritos, es mayoritaria cuando proclama que los contratos celebrados por los menores de edad no son nulos ni inexistentes, sino anulables (SSTS 31 de diciembre de 1896; 17 de junio de 1904; 25 de junio de 1908; 3 de julio de 1923; 29 de noviembre de 1958, RJ 3811; 28 de abril de 1977, RJ 1697; 19 de diciembre de 1977, RJ 4763; 21 de mayo de 1984, RJ 2497; 1 de febrero de 1986, RJ 408; 2 de junio de 1989, RJ 4283; 10 de junio de 1991, RJ 4434).

En concreto, en la STS de 28 de abril de 1977 (RJ 1697), que opta por la anulabilidad, precisa que hay que discriminar "si se trata de un menor sin capacidad natural o con ella, y que, en el primer caso, el contrato será inexistente y en el segundo anulable”.

En otra posterior de 21 de enero de 2000 (RJ 2000\113), a propósito de la impugnación de un contrato de compraventa celebrado por un menor de edad, dice lo siguiente: "Para la resolución de la cuestión conviene distinguir aquellas relaciones jurídicas concertadas por menores de edad, dotados de discernimiento suficiente, con su intervención efectiva y prestando su consentimiento, por lo tanto sin la 
se han pronunciado acerca de su validez y eficacia jurídica, se manifiestan mayoritariamente en el sentido de entender que su ejecución entraña un supuesto de anulabilidad, llegando incluso a declarar el Tribunal Supremo (STS de 10 de junio de 1994, RJ 4434), que debe entenderse que se da una declaración de voluntad tácita de los propios representantes legales de los menores que impide que tales contratos puedan considerarse inexistentes, teniendo en cuenta "la realidad social del tiempo en que han de ser aplicadas (las normas), atendiendo fundamentalmente al espíritu y finalidad de aquéllas" (art. $3.1 \mathrm{CC}$ ), finalidad que es esencialmente tuitiva.

Llevada esta problemática al tema que nos ocupa, y pese a la dicción del artículo 992 CC, a nuestro juicio, ello no obsta para que ese mismo espíritu se traslade a la cuestión que aquí debatimos en el sentido de que, en atención a las facultades volitivas y de discernimiento, del desarrollo intelectual y psíquico, las condiciones de madurez que presenta un menor cuando se acerca a la mayoría de edad, al gozar ya de una plena capacidad natural y una, casi, plena capacidad legal, se pueda admitir, al menos, en principio, la posibilidad de que pueda emitir una declaración de voluntad acerca de la delación que le ha sido deferida, sin perjuicio de que, en su caso, sea susceptible de ser impugnada si se entiende que puede haber habido inmadurez o falta de consciencia en su declaración en atención a las circunstancias particulares que concurren en el menor que por sí solo ha declarado repudiar aquella herencia que le ha sido deferida, o si ha habido algún vicio del consentimiento porque se haya compelido al menor por medio de coacción o violencia, física o psíquica, a emitir una declaración de voluntad que, de no haberse producido, no habría realizado.

capacidad jurídica exigida, pero que no son radicalmente nulas, pues el consentimiento contractual existe, si bien resulta aplazado en sus efectos vinculantes. Se trata de un consentimiento hacia tiempo futuro, ya que al llegar a la mayoría de edad pueden efectuar su ratificación confirmatoria (arts. 1309, 1310 y 1311 CC), justificando así el consentimiento prestado. Lo mismo sucede si se trata de enajenaciones llevadas a cabo por los padres que ostentan la patria potestad contraviniendo el artículo 166 del Código Civil que exige autorización judicial, caso contemplado en la sentencia de 9 de mayo de 1994 (RJ 1994, 3894)", apuntando posteriormente dicha resolución que "no cabe confundir la ineficacia del consentimiento prestado en la minoría de edad con la falta del mismo que invalida radicalmente la relación jurídica (Ss 28/4/1977 [RJ 1697]) que cita las de 31/12/1896, 17/6/1904, 25/6/1908 y 3/7/1923, así como las de 9/12/1953 [RJ 1954, 284]; 25/6/1959 [RJ 2933]; 17/3/1961; 27/3/1963; 10/11/1969 [RJ 5134]; 14/03/1974 [RJ 3218]; 4/4/1984 [1926]; 1/2/1986 [408] y 2/6/1989 [RJ 4283])”.

Igual, a propósito de la capacidad de un menor de edad, la DGRN, en la célebre Resolución de 3 de marzo de 1989 (RJ 2380), revocó la nota de calificación del Registrador y admitió la inscripción en el Registro de la Propiedad de una escritura de donación, pura y simple, que había sido aceptada por un menor, sin la intervención de sus representantes legales. En ella se reconoce "como regla general la aptitud de toda persona que tenga una capacidad natural de entender y querer para aceptar donaciones, ....., y es indudable que en el menor, mayor de dieciséis años, se presupone legalmente aquel grado de discernimiento".

Todo lo cual nos lleva a decir -como manifiesta PASQUAU LIAÑO [Comentario al artículo 1263 del Código Civil, en Jurisprudencia civil comentada (Tomo I). Cit. Pág 2177.]-, que "no se puede hablar de una absoluta falta de capacidad de obrar de los menores, no ya en relación a los derechos de la personalidad, o a negocios de derecho de familia, sino incluso en materia contractual". 
Ciertamente, un menor de edad no emancipado carece de la libre disposición que exige el artículo 992 CC y, por tanto, no tendría la capacidad legal necesaria para poder ejercer por sí solo el ius delationis. Pero, no es menos cierto que cuando ya está próximo a cumplir la mayoría de edad, aparte de que goza de una capacidad natural, tiene unas condiciones de madurez que le permiten, o le pueden permitir, conocer, saber y querer con pleno conocimiento, discernimiento y consciencia lo que hace, por lo que, cuando emite una declaración de voluntad, no se puede decir, en modo alguno, que haya una ausencia total de consentimiento. Éste, el consentimiento, aunque desde el punto de vista legal se considere, o presuma por la ley, que todavía no está totalmente formado y no sea suficiente y bastante para considerarlo válido y eficaz de forma plena al no haber llegado aun a la mayor edad, incluso si se padeciere alguna enfermedad o deficiencia física o psíquica, en tanto en cuanto no exista una sentencia judicial previa de incapacitación, como tal, se puede considerar que ya tiene valor y fuerza suficiente para producir ciertos efectos jurídicos, sin perjuicio de que se pueda, en su caso, instar su ineficacia si hubiere concurrido algún vicio de la voluntad.

Por otro lado, recordemos que, en el caso de ejercicio del ius delationis, y tratándose de un menor que estuviere aun bajo la patria potestad de los padres, el artículo 166 CC, en su último párrafo, manifiesta, si éstos pretendieren repudiar la herencia a que su hijo fue llamado, "no será necesaria autorización judicial si el menor hubiese cumplido dieciséis años y consintiere en documento público"1092. Luego, si el menor puede prestar este consentimiento sin estar emancipado y su declaración tiene además, nada menos, que el valor o la función de sustituir a la autorización judicial, ¿por qué no va a ser válida, en principio, y sin perjuicio de ello, no obstante, anulable, la declaración de repudio que dicho menor hubiere emitido por sí solo, si ya la propia ley admite la hipótesis de que él consienta, desde los dieciséis años, que sus padres puedan repudiar la herencia a que él ha sido llamado?.

Por tanto, habida cuenta de que la repudiación es un negocio jurídico al que le es aplicable la doctrina de éste relativa a los supuestos de ineficacia, llevada al caso que nos ocupa, podemos concluir que la declaración, realizada aquí por un menor de edad no emancipado, sin que intervengan sus padres, que ya goce de una capacidad natural por cuanto, por razón de su edad y de sus facultades intelectuales, psíquicas y volitivas, conoce y sabe, o puede saber, cual es el significado y trascendencia jurídica

1092 Ya comentamos en su momento (vid, punto número 1-1-2-1 del capítulo sexto, al que nos remitimos), que dicha regla constituye un supuesto que se podría calificar de excepcional porque no deja de ser una forma de dispensar a los padres de obtener la pertinente autorización judicial, o una forma de legitimar su actuación. 
del acto que realiza, se podría entender que su declaración no sería nula y carente en su totalidad de efectos jurídicos, sino meramente anulable y susceptible de ser impugnada por la vía del artículo 1301 y ss CC, incluso, en su caso, convalidable si al llegar el menor a la mayoría de edad lo ratifica.

\section{4-3.- En el caso del incapaz.}

Cierto es que, no por el solo hecho de padecer una enfermedad o deficiencia persistente de carácter físico o psíquico ya se es un incapaz o hay que promover necesariamente un proceso de incapacitación porque la ley no obliga a ello (cfr. arts 199 y 200 CC), sino que, además, es preciso una sentencia que así lo declare, de lo que se deriva que la persona afectada por alguna anomalía de esta naturaleza se puede encontrar en una de estas dos situaciones: que esté efectivamente incapacitada en virtud de sentencia judicial, en cuyo caso, así se la tendrá como tal al existir sobre ella dicha resolución judicial con las consecuencias que de ello se derivan sobre su capacidad de obrar, o que, ante la ausencia de dicha sentencia ${ }^{1093}$, pese a padecer alguna de las causas que legalmente puedan dar lugar a la incapacitación, no esté incapacitada -por lo que estaríamos ante un incapaz de hecho, incapaz natural o un presunto incapaz-.

En este caso, dada la presunción iuris tantum de capacidad de obrar que rige en toda persona desde que alcanza la mayor edad (cfr. arts 199, 200 y 322 CC), gozaría de dicha capacidad y tendría, en principio, la libre disposición de sus bienes que exige el artículo 992 CC. La sentencia de incapacitación no solo desvirtúa esta presunción de capacidad de obrar, sino que la limita, en todo o en parte, según determine el Juez en la misma (art. 760 LEC). De ahí que, si no existe dicha sentencia, al no estar desvirtuada la presunción, la persona tiene plena capacidad de obrar para poder realizar cualquier acto de la vida civil $^{1094}$.

1093 En este sentido, es muy ilustrativa la STS de 19 de noviembre de 2004 (RJ 6910), recogida después por la SAP de Barcelona, de 29 de julio de 2005 -JUR 2006/38029-, que distingue entre incapaz natural e incapacitado: aquel sería "el sujeto se encuentre en una situación física o psíquica que elimine su entendimiento y voluntad y le impida entender y querer el acto que realiza”, mientras que éste, es el "resultante del estado civil de incapacitado", que es al que se refiere, añade la sentencia, los artículos 199 y ss del Código Civil, dando lugar a la constitución de "un estado civil nuevo, el de incapacitado".

${ }^{1094}$ En este sentido, la STS n ${ }^{\circ}$ 606/2001, de 11 de junio (RJ 4335), reiterando la doctrina de otras anteriores que ella misma cita (28 de julio de 1998 -RJ 6134-,y 23 de noviembre de 1981 -RJ 4543-), viene a disponer que, al supeditar el artículo 199 CC a la declaración judicial por sentencia la restricción de la capacidad de obrar, "en tanto no se diga así señalando su alcance, la persona seguirá gozando de facultad para ejercitar sus derechos y cumplir sus obligaciones sin perjuicio de la posibilidad de impugnar sus actos anteriores”. 
De lo anterior, se deriva, por otro lado, la regla que bien puede parecer un juego de palabras de que: si bien todo incapacitado es un incapaz, no todo incapaz es un incapacitado ${ }^{1095}$, porque no hay incapaz sin que exista una previa declaración judicial de incapacitación (arts. 199 y 200 CC). En este sentido, la doctrina, mayoritariamente, con apoyo en el tenor del artículo 199 CC, considera que la sentencia tiene un carácter constitutivo del estado civil de incapacitado ${ }^{1096}$, de tal manera que, sin sentencia, no existe el estado civil de incapaz, aunque no faltan quienes le otorgan un mero valor declarativo ${ }^{1097}$. De igual manera, así lo ha declarado en reiteradas ocasiones la jurisprudencia ${ }^{1098}$. A lo que hemos de añadir, por otro lado, que la sentencia no tiene carácter retroactivo, sino que solo surte los efectos o consecuencias que se derivan de la misma a partir de la fecha de su firmeza.

1095 Una de las circunstancias que se observa en esta materia es la gran variedad de términos que se utiliza por el Código Civil: “incapaz”, “incapacitado”, “incapacidad” e “incapacitación”, que, sin duda, pueden inducir a confusión.

En este sentido, pone de relieve TOLDRÁ ROCA (Op. cit.: Pág 106), el término o expresión genérica "incapacidad", utilizada como contraposición a capacidad, es susceptible de comprender dos situaciones jurídicas diferentes: tanto la que proviene de la edad, como la que tiene su origen en el padecimiento de alguna enfermedad o deficiencia persistente de carácter físico o psíquico que impida a la persona gobernarse por sí misma.

Sin embargo, aquella, la edad, no se considera propiamente como una causa de incapacidad porque el menor, por razón de la edad, no se considera en realidad un incapaz por cuanto la capacidad de obrar que él tiene se fundamenta en la capacidad natural que le otorga y nace del desarrollo de sus facultades intelectuales, psíquicas y volitivas.

De ahí que, en nuestro sistema actual, sigue manifestando TOLDRÁ, el origen genérico de la incapacidad lo es el padecimiento de alguna enfermedad o deficiencia persistente de carácter físico o psíquico.

Más adelante (pág 108 y ss), a la luz de la normativa del Código Civil, analiza los términos antes apuntados, y llega a la conclusión de que, "incapaz e incapacidad incluye todos los supuestos de personas afectadas por alguna de las causas previstas legalmente, y en cuanto a las expresiones incapacitación e incapacitado, van referidas a la existencia de una resolución judicial que determine legalmente la incapacidad".

${ }^{1096}$ Vid procesalistas como: GUASP: Derecho procesal civil. T II $3^{\circ}$ ed. Madrid. 1977. Pág 414; PRIETO CASTRO y FERRANDIZ: Tratado de Derecho Procesal Civil. II. 2 ${ }^{\mathrm{a}}$ Ed. Pamplona. 1985. Pág 231 y ss.), por cuanto da lugar al nacimiento de una situación en la capacidad de la persona que no existía con anterioridad y sin la cual no puede existir, que produce sus efectos desde el momento en que deviene firme (ex tunc), y con eficacia erga omnes (FERNÁNDEZ LOPEZ: “Los procesos de incapacitación”. En La personalitat civil. Segones Jornades Jurídiques de Lleida. Barcelona. 1984. Pág 64).

PARRA LUCÁN: “Comentario al artículo 214 del Código Civil”, en Comentarios al Código Civil. Dirigidos por Rams Albesa. T II. Vol 2. Libro Primero. (Títulos V a XII). Barcelona. 2000. Págs 1748 y 1749 .

1097 Así, para GORDILLO CAÑAS, lo verdaderamente constitutivo de la incapacidad lo son las enfermedades o deficiencias impeditivas del autogobierno responsable, la sentencia, el medio para su comprobación, y el Registro Civil, el medio de su cognoscibilidad respecto a todos (Capacidad, incapacidades y estabilidad en los contratos. Cit: Págs 99 y ss).

1098 Así, entre otras: SSTS de 9 de junio de 1997 (RJ 4735); 27 de enero y 19 de mayo de 1998 (RJ 552, 3378); 19 de noviembre de 2004 (RJ 6910); SSAP Girona núm. 431/1999 (Sección $1^{\text {a }}$ ), de 14 julio AC 1999\7735-; Barcelona (Sección 18 ${ }^{\mathrm{a}}$ ) de 26 octubre 2000 -AC 2001/42-; Barcelona (Sección 18), de 11 marzo de 2004 -AC 675-: “cuando concurre en el demandado una de las causas que prevé el art. 200 CC, le constituye en el estado civil de incapacitado y debe marcar el alcance de la incapacitación”; Barcelona, de 29 de julio de 2005, JUR 2006/38029. 
A la vista de este planteamiento y consideraciones, de la misma manera que el binomio capacidad-consentimiento no siempre caminan juntos, igual sucede en el caso de incapacidad-consentimiento, porque, tanto si existe una sentencia de incapacitación y a resultas de ella la persona tiene, en consecuencia, limitada en todo o en parte su capacidad de obrar, como si no se está incapacitado, ello no obsta ni impide para que, pese a ello, tanto en uno como en otro caso, se pueda emitir por parte del incapaz una declaración de repudiación de una herencia, lo que hace que nos tengamos que plantear cual es el valor de dicha declaración en lo que se refiere a la validez y eficacia jurídica de dicha repudiación.

Acerca de esta cuestión, como manifiesta DE CASTRO ${ }^{1099}$, "en nuestro sistema legal no se acude, en materia de incapacidad, a discriminar la naturaleza de cada acto, sino que se atiende a la situación legal de la persona para determinar la eficacia de los mismos". De ahí que sea preciso distinguir si el sujeto está o no incapacitado en virtud de sentencia judicial en el momento de realizar el acto de que se trate.

Tratándose del incapaz declarado en virtud de sentencia, y acerca de la validez de los actos por él realizados, se puede decir que, es postura generalizada dentro de la doctrina ${ }^{1100}$, también en alguna ocasión se ha pronunciado el Tribunal Supremo ${ }^{1101}$, que, no obstante el tenor del artículo $1263.2^{\circ} \mathrm{CC}$, según el cual no pueden prestar consentimiento los incapacitados, su eficacia jurídica sería encuadrable en el ámbito de la anulabilidad, por lo que las consecuencias que de su declaración se derivan se reconducirían por la vía del artículo 1301 y ss CC. Lo que sería aquí de aplicación al caso de la declaración de repudio de la herencia.

Igual respuesta tendríamos en aquellos casos en que la incapacidad fuere tan solo parcial, o se hubiere decretado la prodigalidad (arts $286.3^{\circ}$ y 288 CC; 748 a 755 y 756 a 763 LEC), en los que habrá que estar en cada caso particular al contenido de la sentencia (cfr art 760 LEC), para saber si la declaración de repudio está comprendida dentro de aquellos actos que el incapacitado, o declarado pródigo, puede realizar por sí solo y, por tanto, si dicha declaración es plenamente válida y eficaz o, en su caso, susceptible de ser impugnada. Porque, si se diere la circunstancia de que la persona no puede por sí sola repudiar la herencia, sino que ha de hacerlo por ella quien hubiese sido designado su curador (arts 288,289 y 290 CC) y, pese a ello, repudiare,

${ }^{1099}$ Derecho Civil de España. Cit.: Pág 352.

1100 JORDANO FRAGA (Falta absoluta de consentimiento, interpretación e ineficacia contractuales. Cit: Pág 312 y ss); GORDILLO CAÑAS (Capacidad, incapacidades y estabilidad en los contratos. Cit: Pág 249 y ss); TOLDRÁ ROCA (Op. cit.: Págs 119 y 120).

${ }^{1101}$ STS de 19 de noviembre de 2004 (RJ 6910). 
se plantea la cuestión de la validez o eficacia de su declaración. En estos casos, de igual manera, el acto, no sería nulo, sino anulable ${ }^{1102}$ y susceptible de ser impugnado a instancia del propio curador o de la persona sometida a curatela, de conformidad con lo establecido en el artículo 293 CC, y de acuerdo con los artículos 1301 y ss del mismo texto legal, en un plazo de cuatro años contados desde que hubiere cesado la declaración de prodigalidad, lo que es extensible, entendemos, para los supuestos de incapacidad parcial por cuanto serían casos similares.

Más problemático y discutible es el caso del incapaz no incapacitado que pretende realizar un acto de su vida civil, como puede ser el caso que nos ocupa, repudiar aquella herencia a que ha sido llamado. Se trata de un sujeto que ha sido objeto de análisis en alguna ocasión por parte de los Tribunales de Justicia por el hecho de que sus facultades intelectuales y volitivas están perturbadas por causa de una enfermedad, deficiencia o perturbación mental no declarada, como puede ser el alzheimer o la demencia senil, casos que con más frecuencia se plantean, y respecto de los cuales se cuestiona cual es la validez y eficacia jurídica de los actos realizados por estos sujetos en esas circunstancias.

Al no existir una normativa clara y diáfana en materia de capacidad y de la validez del consentimiento prestado por los incapaces, es lo que ha dado lugar a que nos encontremos con posiciones enfrentadas dentro de la doctrina. Lo único cierto es que en el Código Civil no hay ninguna norma que declare la ineficacia de los actos realizados por el incapaz no incapacitado ${ }^{1103}$, aunque sí se declara de forma expresa la inexistencia del contrato cuando falta alguno de sus elementos esenciales (art. 1261 CC). Pero, como pone de relieve TOLDRÁ ROCA ${ }^{1104}$, "en ningún caso puede presuponerse la absoluta inexistencia de los presupuestos volitivos y cognoscitivos por el hecho de no estar incapacitado y, a la vez, padecer alguna enfermedad o deficiencia persistente de carácter físico o psíquico que impidan a la persona gobernarse por sí misma (art. 200 CC)". A partir de aquí, aunque la doctrina no adopta una postura pacífica, sí se puede observar en ella, en este sentido, cierta tendencia de unificar el régimen de la ineficacia negocial y aplicar el régimen de la anulabilidad y la protección que la misma conlleva que, incluso, comporta tanto los actos llevados a cabo por el incapaz incapacitado como por el incapaz no incapacitado, si bien, tal unificación,

1102 Vid, entre otros: PASQUAU LIAÑO (Comentario al artículo 1264 CC, en Jurisprudencia civil comentada. Tomo I. Cit: Págs 2177 y 2178); MORALES MORENO (Comentario al artículo 1263 del Código Civil, en Comentario del Código Civil. Cit: Págs 455 y 456).

${ }^{1103}$ En el Codice Civile italiano se sanciona con la anulabilidad del acto (art. 1425), con las consecuencias previstas en el artículo 1443 que limita la restitución al enriquecimiento obtenido.

${ }^{1104}$ Op. cit.: Pág 122. 
apunta, TOLDRÁ ROCA ${ }^{1105}$, encuentra algunos escollos en materia de legitimación y transcurso del plazo de tiempo para el ejercicio de la acción.

Así, en el caso del incapaz no incapacitado, se observa en la doctrina ${ }^{1106}$ una posición bastante generalizada de entender que no sería satisfactorio aplicar el régimen de la nulidad absoluta a los actos que realizare, como se inclina la jurisprudencia según veremos a continuación, por cuanto sería más propio de la incapacidad natural de acuerdo con lo dispuesto en el artículo 1261 CC. De ahí que lo procedente sería someterlo al de la anulabilidad, "dado el carácter protector de ésta porque así no se hace discriminación entre los actos anteriores y posteriores a la declaración de incapacitación", y someterlo, en consecuencia, por el cauce de la normativa del artículo 1301 y ss del Código Civil.

Una posición diferente mantiene TOLDRÁ ROCA ${ }^{1107}$ para quien, en principio, los actos realizados por la persona incapaz no incapacitada deberían de caer bajo el régimen de la anulabilidad porque, partir de la base de la inexistencia del consentimiento en el acto concreto de que se trate para someterlo a la nulidad, es incorrecto y hasta incoherente con la presunción general de capacidad de obrar que toda persona tiene desde la mayoría de edad. Ahora bien, en aras de esa misma coherencia, si se constata que ha existido una ausencia total de consentimiento por la falta del elemento volitivo y cognoscitivo, entonces no estaríamos ante un negocio anulable, sino nulo.

En este sentido, en nuestra opinión, no le falta razón a TOLDRÁ, cuyo parecer compartimos, porque, habida cuenta de que ante la inexistencia de una sentencia por la que se declare la incapacitación, ha de presumirse, iuris tantum, la plena capacidad de obrar de la persona, como así ha sido declarado de forma reiterada por la jurisprudencia. En coherencia con ello, lo adecuado y procedente sería, incluso si se tienen tan solo sospechas de que puede haber existido cualquier tipo de enfermedad, deficiencia o perturbación mental en el momento de realizar la repudiación de una herencia, demostrar cual ha sido el estado de salud mental que tenía la persona en

1105 Op. cit.: Pág 126.

${ }^{1106}$ Así, entre otros: MORALES MORENO (Comentario al artículo 1263 del Código Civil, en Comentario del Código Civil. Cit: Pág 457); GORDILLO CAÑAS (Capacidad, incapacidades y estabilidad en los contratos. Cit: Pág 265 y ss); DÍEZ-PICAZO: Fundamentos de Derecho Civil Patrimonial. Vol I. Cit: págs 101, 102; JORDANO FRAGA: Ausencia total de consentimiento, interpretación e ineficacia contractuales. Madrid. 1988. Págs 319, 320, 325).

${ }^{1107}$ Op. cit.: Pág 127. 
ese instante si se pretendiere, en su caso, la impugnación dicha declaración ${ }^{1108}$. Y si efectivamente se demuestra, a través de la correspondiente actividad probatoria desarrollada en el proceso judicial que, en ese instante, existió una ausencia total de consentimiento y que la persona no regía, o no estaba, en plenitud de facultades mentales, intelectuales, psíquicas y volitivas, de tal manera que no tenía pleno y total conocimiento y consciencia de aquello que realizaba por la discapacidad que padecía, entonces lo que procedería es declarar la nulidad absoluta del acto realizado al amparo de lo dispuesto en los artículos 1261 y $1263.2^{\circ} \mathrm{CC}$ por ausencia de capacidad natural para poder realizar dicho acto. En otro caso, sí que habría lugar a aplicar el régimen de la anulabilidad y las consecuencias que de todo orden se derivan de ella.

En la jurisprudencia, pone de relieve PASQUAU LIAÑO, a diferencia de lo que ocurre acerca de la validez de los contratos celebrados por mayores de edad no incapacitados que carecen de capacidad natural al tiempo de su celebración en que apenas hay decisiones relevantes cuando la declaración judicial de incapacidad abarca el tipo de contrato celebrado, "son, sin embargo, frecuentes los supuestos de impugnación de contratos celebrados por mayores no incapacitados, de los que se predica por el impugnante falta de capacidad natural (casi siempre por causa de demencia senil)." A lo que añade, "en la mayoría de los casos, se han invocado conjuntamente los artículos 1261 y $1263.2^{\circ}$ CC; ....., con muy pocas excepciones ha considerado el TS que tales contratos son nulos radicalmente o inexistentes por falta de consentimiento, y no meramente anulables por falta de capacidad". De ahí que, la jurisprudencia, en lo que se refiere al régimen de ineficacia, "en casi todos los casos, el tratamiento que se ha dado a los contratos celebrados sin capacidad natural, ha

1108 SAP Barcelona (Sección 15ª) de 8 julio 2004 -AC 2004\1244-: “En nuestro Ordenamiento se permite una amplitud interpretativa para abarcar a todas las personas incapaces para gobernarse por sí mismas, conforme declara el artículo 200 del CC (Sentencia de 19 de septiembre de 1998 [RJ 1998, 6399]), es decir, no sólo aquéllas declaradas incapaces por resolución judicial sino también las que resulten afectadas de mera incapacidad de hecho que ha de resultar suficiente y concluyentemente acreditada (STS de 26 de septiembre de 1988, RJ 6860; 22 de junio, RJ 5460; 10 de febrero y 8 de junio de 1994 ,RJ 848, 4904; 27 de noviembre de 1995, RJ 8717; 18 de mayo de 1998, RJ 3376), por tratarse de presunción iuris tantum, Sentencia de 15 de febrero de 2001 (RJ 2001/2051). Como señala asimismo la STS 8 de junio de 1994 la insania mental exige actividad probatoria dotada de la seguridad precisa para que efectivamente concurrió. Y ello en definitiva implica que, según precisa la Sentencia de 11 de junio de 2001 (RJ 2001, 4335), la concurrencia de los requisitos exigidos por el artículo 199 del Código Civil queda supeditada a la declaración judicial por sentencia de la restricción de la capacidad de obrar de forma que, en tanto no se diga así y señalando su alcance, la persona seguirá gozando de facultad para ejercitar sus derecho y cumplir sus obligaciones, ello sin perjuicio, claro está, de la posibilidad de impugnar sus actos anteriores”. 
sido el de nulidad radical, o inexistencia, por falta de consentimiento, y no meramente anulables por falta de capacidad" ${ }^{\prime 1109}$.

En este sentido, tiene interés aquí la sentencia del Tribunal Supremo de 19 de noviembre de 2004 (RJ 6910) que distingue entre, incapacidad natural a consecuencia de que el sujeto se encuentre en una situación física o psíquica que elimine su entendimiento y voluntad, y le impida entender y querer el acto que realiza, e incapacidad resultante del estado civil de incapacitado, ante lo que entiende lo siguiente: "el que una persona no haya sido incapacitada no significa que sean válidos los actos que realice sin la capacidad natural precisa en cada caso". De ello derivó que sometiese al régimen de la nulidad ${ }^{1110}$ un contrato de compraventa porque la vendedora padecía demencia senil al tiempo de su celebración sin que existiese previa declaración judicial de incapacitación, circunstancia ésta que no fue obstáculo para que se declarase dicha nulidad por cuanto, la causa de la nulidad no es el estado civil de la persona, sino "la demostración de una falta de entendimiento y voluntad que son precisos para consentir, destruida con prueba bastante la presunción iuris tantum de la capacidad de obrar de que se trata"1111. No obstante, declara "la validez de los actos ejecutados por el incapaz antes de que su incapacidad sea judicialmente declarada (o aunque no lo sea nunca), a menos que, concreta y específicamente, se obtenga la 2178.

${ }^{1109}$ Comentario al artículo 1264 CC, en Jurisprudencia civil comentada. Tomo I. Cit: Págs 2177 y

Cita, en este sentido, las siguientes sentencias: SSTS 4 de diciembre de 1907; 21 de marzo de 1952, RJ 504; 17 de marzo de 1961, RJ 959; 27 de marzo de 1963, RJ 2121; 10 de noviembre de 1969, RJ 5134; 14 de marzo de 1974, RJ 3218; 4 de mayo de 1998, RJ 3230.

En igual sentido, la STS 4 de abril de 1984 (RJ 1926), citada por otra posterior de 19 de noviembre de 2004 (RJ 6910), sanciona tales actos de nulos o inexistentes "por falta de un requisito esencial y que esa inexistencia es perpetua e insubsanable”.

No obstante, la jurisprudencia no es pacífica porque nos encontramos con alguna sentencia en la que se aportan argumentos a favor de la anulabilidad (STS de 9 de febrero de 1949, RJ 99).

${ }^{1110}$ El Tribunal Supremo, para declarar la nulidad de la venta impugnada, esgrimió, entre otros argumentos, el siguiente: "En particular, no cabe considerar existente una declaración de voluntad contractual (de cuya coincidencia plena con la de la otra parte sobre cosa y precio nace el contrato de compraventa: artículos 1258, 1262 y 1450 del Código Civil), cuando falte en el declarante la razón natural, ya que dicha carencia excluye la voluntad negocial e impide que lo hecho valga como declaración (la Sentencia de 4 de abril de 1984 [RJ 1984|1926] precisa que la incapacidad mental determina que el negocio sea radicalmente nulo o inexistente por falta de un requisito esencial y que esa inexistencia es perpetua e insubsanable). Claro está, que al presumirse la capacidad del no incapacitado, la falta de capacidad natural debe probarse cumplidamente”.

${ }^{1111}$ La Sala, por otro lado, al debatir el objeto de la litis, no se planteó la cuestión, porque no lo hicieron los recurrentes al interponer el recurso de casación, de determinar, "si el artículo $1263.2^{\circ}$ CC se refiere sólo a los incapacitados judicialmente o también a los carentes de entendimiento o voluntad que no lo hayan sido; así como si la sanción aplicable al contrato celebrado por estos es la mas grave de nulidad del contrato, por falta de declaración y consentimiento, o la menos grave de la anulabilidad, por la aplicación del artículo 1301 y del 1302; y la de discernir si el contrato celebrado por el incapacitado en el que falte la capacidad natural de entender y querer es nulo por falta de consentimiento, además de anulable por razón de la incapacitación o sólo esto último".

No obstante, ante tal planteamiento, la Sala entendió que "se debe responder en sentido negativo, cual se declaró en la instancia y señala la jurisprudencia”. 
declaración de nulidad del acto de que se trate. Como también ha precisado que la capacidad de la persona se presume siempre, mientras que su incapacidad, como excepción, no sea probada de modo evidente y completo".

\section{4-4.- En el caso de representación legal si no se ha obtenido autorización} judicial.

Existen varios supuestos, referidos a casos de representación legal, en los que la ley exige al representante para poder, en nombre de su representado, repudiar aquella herencia o legado a que éste hubiere sido llamado, y con carácter previo a la emisión de dicha declaración, obtener la pertinente autorización judicial. Así:

a) en el ejercicio de la patria potestad, los padres, en virtud de lo dispuesto en el artículo 166 del Código Civil, no pueden, entre otros actos, repudiar libremente aquella herencia o legado que se hubiere deferido a su hijo, sino que se les impone en su segundo párrafo, la necesidad de recabar previa autorización judicial antes de emitir dicha declaración de repudio, aparte de que no lo podrán realizar si no es "por causas de justificadas de utilidad o necesidad ...., con audiencia del Ministerio Fiscal", si bien, después, a continuación, en el párrafo tercero, se dispensa a los padres de la autorización judicial, "si el menor hubiese cumplido dieciséis años y consintiere en documento público".

b) A propósito de la tutela, donde, de igual manera, el artículo $271,4^{\circ} \mathrm{CC}$ también establece que, "el tutor necesita autorización judicial: para aceptar sin beneficio de inventario cualquier herencia, o para repudiar ésta o las liberalidades".

c) En el caso de curatela, donde el curador, en el ejercicio de su función, y tratándose de una incapacitación parcial, está sujeto a las mismas autorizaciones que se le imponen al tutor, cuando la sentencia no dice o especifica cuáles son los actos en que deba de ser necesaria su intervención (art. 290 CC).

d) En el caso de ausencia, el artículo 185 del Código Civil, en su último párrafo, hace aplicable a los representantes dativos de la persona declarada en situación de ausencia legal, "en cuanto se adapten a su especial representación, los preceptos que regulan el ejercicio de la tutela", de lo que se deriva la consecuencia de que si dicha persona fuere llamada a una herencia, en el caso de que su representante decidiere repudiar, tendrá que solicitar autorización judicial al igual que si se tratase de un tutor. 
Acerca de todos ellos, nos planteamos qué validez y eficacia jurídica tiene la declaración de repudiación que, en su caso, se hubiere realizado sin que se haya obtenido previamente dicha autorización judicial o, en el caso de la patria potestad, la ausencia del consentimiento del menor.

Examinando la jurisprudencia, que es quien principalmente se ha pronunciado al respecto, sobre todo en los casos de patria potestad y la tutela, se puede observar que hay unanimidad en considerar que la omisión de la autorización judicial vicia el acto realizado haciéndolo ineficaz. Sin embargo, en lo que hay disparidad de criterios es en calificar ante qué clase de ineficacia estamos, si de nulidad absoluta o de anulabilidad: unas, se inclinan por entender que estamos ante un supuesto de nulidad absoluta ${ }^{1112}$, de tal manera que la declaración realizada no tendría ninguna validez jurídica, otras, y esta es la postura más mayoritaria, en las que se califica la invalidez, de anulabilidad $^{1113}$, como también hay sentencias que no se pronuncian al respecto y no califican la invalidez ${ }^{1114}$.

Por otro lado, se plantea igual problemática cuando, en el caso de la patria potestad, los padres no tienen o no han solicitado la pertinente autorización judicial, sino que tampoco existe el consentimiento en documento público del hijo siendo éste mayor de dieciséis años. Del tenor del mismo, se desprende que los padres no pueden repudiar libremente la herencia o legado que se le hubiere deferido a su hijo porque, si no es con dicha autorización, necesitarán el consentimiento del menor para poder repudiar. Luego, su omisión o ausencia, plantea, al igual que en el caso de la autorización judicial, la cuestión relativa a su ineficacia en los mismos términos dado que dicho consentimiento dispensa de la autorización a los padres.

En nuestra opinión, tanto en lo que se refiere a la autorización judicial como al consentimiento del hijo, obviamente no se ha cumplido la exigencia establecida por la ley $\mathrm{y}$, por tanto, se ha producido una anomalía o irregularidad, lo que plantea la cuestión de su validez y eficacia. Partiendo de la consideración de que el Código Civil, tanto en uno como en otro caso, no sanciona de forma expresa con la nulidad del acto la omisión de dicha exigencia, como tampoco entendemos que se deduce del tenor de

1112 SSTS 25 de junio de 1959 (RJ 2933); 14 de marzo de 1983 (RJ 1475); 19 de mayo de 1985 (RJ 4082); 22 de diciembre de 1989 (RJ 8864); STSJ Navarra 23 de mayo de 1997 (RJ 4469).

${ }_{1113}$ SSTS 29 de noviembre de 1958 (RJ 3811); 19 de diciembre de 1977 (RJ 4763); 21 de mayo de 1984 (RJ 2497); 30 de marzo de 1987 (RJ 1839); y, sobre todo, las de 9 de mayo de 1994 (RJ 3894) y 21 de enero de 2000 (RJ 2000\113); SAP Las Palmas 14 de enero de 1999 (AC 4103); SAP Valencia de 2 de mayo de 2001 (JUR 196570).

${ }^{1114}$ SSTS 31 de mayo de 1912; 20 de diciembre de 1932 (RJ 1369); 21 de junio de 1943 (RJ 980); 27 de marzo y 2 de junio de 1989 (RJ 2198, 4283); 17 de febrero de 1995 (RJ 1105); 16 de diciembre de 1996 (RJ 9001). 
su articulado, dicha infracción constituiría, en nuestra opinión, un caso de anulabilidad y, por tanto, susceptible de ser impugnada la declaración de repudio y más cuando el propio hijo, al llegar a la mayor edad, puede él convalidar o ratificar la repudiación que en su nombre hubiesen hecho sus padres, lo que puede tener lugar de varias formas: bien confirmando el acto, bien aceptando de forma tácita sus consecuencias, o dejando transcurrir el plazo de los cuatro años que, al amparo del artículo 1301 CC, tendría para poder impugnar, contados desde que alcance la mayoría de edad.

Por otro lado, en lo que se refiere a la exigencia de la autorización judicial, dos consideraciones:

a) su omisión, da lugar a la inobservancia de un requisito que, aunque no se califique de esencial, tampoco así se considera por la ley para la validez y existencia de declaración, de tal manera que sin dicha autorización, no se podría repudiar. La razón que, en nuestra opinión, justifica la exigencia de este requisito está en que se establece por la ley como un medio o instrumento que cumple una función de garantía y de protección o salvaguarda de los intereses del menor, del pupilo, del sometido a curatela, o del ausente, y sin que ello se pueda entender, por otro lado, como un gesto o señal de desconfianza hacia los padres, el tutor, curador o representante, ante el posible daño o perjuicio que se podría producir a resultas de tal decisión. Igual ocurre, por ejemplo, en otros casos, como es la exigencia del defensor judicial cuando existe conflicto de intereses entre los padres o el tutor y el hijo (arts 163 y 299 CC).

b) es posición jurisprudencial plenamente asentada, el hecho de que la autorización judicial solicitada u obtenida, en su caso, con posterioridad a la declaración no la convalida ni subsana ${ }^{1115}$, a la vista de lo cual, se derivaría la consecuencia, en nuestra opinión, de que, una vez que se ha producido la declaración de repudiación sería inútil, incluso absurdo, solicitar dicha autorización porque, aparte de que ya no tendría ningún sentido al estar ya realizado el acto, no produciría ningún efecto, ni tendría ninguna virtualidad jurídica porque ni tan siquiera serviría para convalidar "ex post" el acto realizado ${ }^{1116}$. Lo que no supone, según reconoce la propia

1115 STS de 30 de marzo de 1987 (RJ 1839): "si bien la venta no es inexistente en el sentido del art. 1261 CC ni tampoco nula en el del $n^{\circ} 3$ del art. 6, sino que, puede la enajenación convalidarse al llegar el menor a la mayoría de edad, no cabe, en cambio, subsanarla obteniendo posteriormente la autorización judicial, pues ésta sólo daría la validez a la enajenación verificada con posterioridad a la misma, pero no convalidaría la anteriormente estipulada", con precedente en Res DGRN de 10 de marzo de 1944 (RJ 517); SSTS 9 de diciembre de 1953 (1954/284), y después corroborada por la de 2 de junio de 1989 (RJ 4283). En igual sentido, Auto AP Las Palmas, 189/2005, de 22 de septiembre, Sección 4a, JUR 2005/242769.

${ }^{1116}$ Así lo entendió la Audiencia Provincial de Barcelona en un caso de tutela (Auto n 34/2005, de 23 de febrero, Sección 18a, JUR 2005/79965). 
jurisprudencia, que el acto sea nulo y sí anulable al admitirse la posibilidad de su convalidación posterior por parte del menor al llegar a la mayoría de edad, que es el supuesto que ha sido más tratado por los Tribunales ${ }^{1117}$, y que puede ser extensivo, en nuestra opinión, a los casos de la tutela, curatela o ausencia legal.

Otra cuestión que en relación a ello nos planteamos es la relativa a quien está legitimado para poder impugnar, en su caso, la declaración de repudiación realizada sin autorización judicial o el consentimiento del menor. Tratándose de un acto anulable, y ser posible su convalidación o subsanación, "lo estará el propio hijo, o quienes de él traigan causa, y no la tendrán quienes se sitúen fuera de la reducida esfera de los intereses del hijo que aparejan la exigencia de la autorización judicial oído el Ministerio Fiscal" (STS de 30 de marzo de 1987, RJ 1839), doctrina que podemos hacer extensiva al caso de la tutela, curatela o ausencia. Pero, quienes no lo estarán, en ningún caso, será los que dieron lugar a la nulidad, esto es, los propios padres, el tutor, el curador o el representante legal, desde el momento que ello sería ir contra los propios actos, aparte de un contrasentido y una incoherencia.

Y, finalmente, partiendo también de la consideración de que estamos ante un acto anulable, en lo que se refiere al plazo de que se dispondría, en su caso, para impugnar la repudiación realizada sin autorización judicial o el consentimiento del hijo, la mayoría de las sentencias consideran que es el de cuatro años por aplicación del artículo 1301 del Código Civil, contados desde que éste hubiere alcanzado la mayoría de edad ${ }^{1118}$, la persona hubiere salido de la tutela o de la curatela, o hubiese aparecido la persona constituída en ausencia, aunque nos encontramos con algunas sentencias, en el caso de la patria potestad, que señalan el carácter imprescriptible de la acción ${ }^{1119}$.

\section{4-5.- En el caso de infracción de lo dispuesto en los artículos 993 y 994 CC.}

Dado que la capacidad de las personas jurídicas cuando éstas han sido llamadas a una sucesión se rige, en primer lugar, por lo preceptuado en su respectiva legislación especial, si la hubiere, y, en su defecto, por lo dispuesto en los artículos 993 y 994 del Código Civil, la ineficacia de la declaración de repudio de la herencia, y, consiguientemente, las consecuencias jurídicas que de ella se deriven, dependerá de

1117 SSTS 9 de diciembre de 1953 (RJ 1954/284); 21 de mayo de 1984 (RJ 2497); 30 de marzo de 1987 (RJ 1839); 9 de mayo de 1994 (RJ 3894); SAP Las Palmas de 14 de enero de 1999 (AC 4103).

1118 SSTS 31 de mayo de 1912; 20 de diciembre de 1932 (RJ 1369); 21 de mayo de 1984 (RJ 2497); 2 de junio de 1989 (RJ 4283); 9 de mayo de 1994 (RJ 3894).

1119 SSTS 25 de junio de 1959 (RJ 2933); 19 de mayo de 1985 (RJ 4082). 
lo dispuesto en dicha legislación, por cuanto su calificación de nulidad o anulabilidad en el supuesto de su infracción, estará en función de lo establecido en la misma.

Así, tratándose de asociaciones, habrá que estar al contenido de sus estatutos y, en el caso de las corporaciones, a "las leyes que las hayan creado o reconocido" (art. 37 CC). Tanto en el caso de aquellas como de éstas, será preciso examinar cuáles son los requisitos que, en su caso, se exigen para poder repudiar válidamente una herencia y que, en el supuesto de que fuere preciso de forma necesaria u obligatoria, con carácter previo a su emisión, si así lo hubieren establecido, la aprobación por parte de sus órganos de gobierno o la obtención de la pertinente autorización judicial, la infracción u omisión de este requisito daría lugar, en su caso, a la nulidad de la declaración. No obstante, en defecto de norma expresa y con carácter supletorio, el artículo 993 CC exige a sus legítimos representantes, “...... aprobación judicial, con audiencia del Ministerio público". Aprobación y audiencia que, dados los términos en que, a nuestro juicio, se expresa el precepto, habrán de ser previos a la declaración de repudio y cuya omisión determinaría la nulidad de la misma.

En el caso de las fundaciones, después de su ley especial, 50/2002, de 26 de diciembre, el patronato de una fundación puede libremente repudiar la herencia que le hubiere sido deferida, si bien tiene la obligación de ponerlo después en conocimiento del protectorado en el plazo máximo de diez días hábiles quien podrá "ejercer las acciones de responsabilidad que correspondan contra los patronos, si los actos del Patronato fueran lesivos para la fundación, en los términos previstos en esta Ley" (art. 22.2). En este caso, la infracción o no cumplimiento de esta exigencia no determinaría la nulidad de la declaración, a diferencia de lo que ocurría en el régimen anterior en el que era precisa de manera imperativa la "previa autorización del Protectorado" para poder repudiar herencias o legados, sino su anulabilidad. Lo que es consecuencia de la instauración de un sistema de mayor libertad y más flexible en el que se trata de reducir al mínimo la intervención de los poderes públicos en la vida de las fundaciones. 


\section{5.- LA APARICIÓN DEL TESTAMENTO COMO CAUSA DE INEFICACIA $^{1120}$.}

El artículo 997 del Código Civil tipifica, junto a los vicios del consentimiento como causa de ineficacia de la declaración del delado, la aparición de un testamento del causante.

Tambien es recogido este supuesto por la ley 10/2008 de Sucesiones de Cataluña (art. 461-10), si bien, con la peculiaridad, de considerarlo como un caso de error, lo que se puede entender que lo equipara a este vicio del consentimiento, que no deja de ser un acierto, ya que la aparición de una nueva y desconocida voluntad del causante puede dar lugar a que la declaración del delado se haya emitido en base a una vocación-delación que no es aquella en virtud de la cual se va a deferir en realidad la sucesión de su causante, lo que se podría calificar, desde luego, como un supuesto de error. Sin embargo, dado su tenor, parece que la impugnación es, o procede, en cualquier caso, porque no hace excepciones, lo que, en nuestra opinión, como ahora veremos al referirnos al artículo 997 CC, no siempre es así, porque dependiendo de las circunstancias como haya producido la aparición del testamento, incluso haya sido el comportamiento del delado, las consecuencias pueden muy diversas ya que puede dar lugar, no ya a la anulabilidad la declaración, sino incluso a la nulidad total de la misma. En cambio, en nuestra opinión, el Código Civil, no incurre en esa equiparación porque lo enuncia a continuación de los vicios del consentimiento, como una causa más de impugnación de la declaración del delado.

Se trata, por otro lado, de un supuesto de hecho que también contempla el Código Civil en el párrafo segundo del artículo 1009 al admitir la posibilidad de poder aceptar la herencia a través de un título testamentario del que no se tuvieren noticias después de haberla repudiado como heredero abintestato.

Ya entrando en el análisis del artículo 997 CC, en los términos en que está redactado, dicho precepto es, a nuestro juicio, inexacto o equívoco porque, una lectura literal y no por ello estricta del precepto, dado el tenor cómo se expresa, nos puede llevar, a priori, a la conclusión, o dar a entender que, ante el mero hecho de que se

1120 Sobre el examen de esta causa de impugnación de la declaración del delado, vid, entre otros autores que lo han tratado: MANRESA (Op. cit.: Pág 386 y ss); ALBALADEJO ("La repudiación de la herencia”. Cit: Pág 748 y ss); DÍEZ-PICAZO y GULLÓN BALLESTEROS (Sistema de Derecho Civil. Vol. IV. Cit: Pág 540); GITRAMA (Op. cit.: Pág 179 y ss ); O’CALLAGHAN (Comentario del Código Civil. Cit.: Pág 2369); RIVAS MARTÍNEZ (Derecho de Sucesiones Común y Foral. Cit: Pág 623); SILLERO CROVETTO (Comentario al artículo 997 del Código Civil, en Jurisprudencia civil comentada Tomo I. Cit: Págs 1682 y 1683). 
produzca la aparición de un testamento del causante ${ }^{1121}$, lógicamente después de la declaración del delado -así se puede deducir, en principio, de dicho tenor aunque en él no se dice-, y cuya existencia se desconocía por él en ese momento, genera -parece que, siempre, en todo caso, sin excepción, por cuanto el precepto no dice lo contrario-, la facultad o posibilidad de poder ejercer, además, de forma automática o instantánea, como en una relación de causa a efecto, la acción de declaración de ineficacia de dicha declaración, al igual que cuando existe un vicio del consentimiento. Es decir, se puede entender que, siempre que aparezca un testamento del causante desconocido o ignorado por parte del vocado después de que él haya ejercitado el ius delationis, puede tener lugar, sin más, como una consecuencia directa e inmediata derivada de ello, la posibilidad de impugnación, de forma automática, ipso iure, de la declaración de repudio, o aceptación, que el sucesor hubiere hecho.

La razón o fundamento que justifica esta causa de impugnación está, comenta MANRESA ${ }^{1122}$, en que, "la ley presume que el testamento, si no existía otro, alterará algo el orden legal de suceder, y que, si existía otro, le modificará, ya en cuanto a la institución de heredero, ya en cuanto a legados y mejoras". Por lo cual, sigue diciendo, dicho precepto "ha de aplicarse racionalmente".

${ }^{1121}$ A resultas del certificado expedido por el Registro de Últimas Voluntades del Ministerio de Justicia, sólo aparecerán los testamentos otorgados ante Notario, de ahí que el supuesto que con mayor frecuencia da lugar a esta hipótesis es la aparición de un ológrafo dada la forma de su otorgamiento, privada y sin la presencia de testigos, salvo que revistiere la forma de testamento cerrado porque así haya sido entregado en plica por parte del causante al Notario para su custodia (art. 706 y ss CC).

Otras hipótesis, apunta MANRESA (Op. cit.: Pág 386), pueden ser: error en la certificación del Registro, falta de aviso por parte del Notario. Por su parte GITRAMA (Op. cit.: Pág 181): error en la confección, remisión y archivo de las fichas notariales, o por fallo del servicio postal, o como apunta en cita a pie de página $n^{\circ}$ 33, por la desconocida e inesperada declaración de herederos posterior a la aceptación de una herencia testada.

Así, acerca de la hipótesis que con más frecuencia se produce, no deja de ser extraño que, entre las pertenencias del difunto, se descubra por los herederos, sin duda, con gran sorpresa por su parte, la existencia de un testamento manuscrito suyo, de su propio puño y letra, que incluso pueda dar lugar a un cambio en el destino mortis causa de los bienes del difunto y suponga un giro en el proceso sucesorio que hasta ese momento se venía desarrollando, o incluso, se produzca dicha aparición una vez ya concluido el proceso y repartidos los bienes entre los herederos.

A ello se le añade, por otro lado, la exigencia, que habrá de ser tenida en cuenta y sin la cual no es válido, de su adveración y protocolización ante el Juez de Primera Instancia del último domicilio del testador, o del lugar en que éste hubiere fallecido, para la que el Código Civil establece el plazo de cinco años contados desde el día del fallecimiento del difunto (art. 689 CC). Con lo cual, se puede dar la circunstancia de que dentro de ese plazo, que no deja de ser, tal vez, excesivamente largo, al tiempo que pone a la herencia en una situación de pendencia y de incertidumbre durante todo ese tiempo, como también, de cierta inseguridad jurídica, se pueda producir el evento de que trata el artículo 997 y se tenga que proceder a declarar ineficaz la declaración, no de uno, sino de todos y cada uno de los sucesores implicados en el proceso sucesorio que ya dieron por cerrado y concluido porque el testamento dé al traste con él, se tenga que abrir otra vez y proceder de nuevo a realizar entre ellos todas las operaciones particionales conforme a la nueva voluntad del causante expresada en el mismo.

1122 OP. cit.: Pág 387. 
En otro orden de argumentos, se trata de una causa de ineficacia que no ha planteado grandes problemas o interrogantes cuando se ha producido un hecho de esta naturaleza en el devenir del proceso sucesorio. De ahí, tal vez, que no haya sido objeto de un análisis detenido por parte de la doctrina porque, cuando se produce, se resuelve aplicando la doctrina y normativa de la revocación de los testamentos ${ }^{1123}$, en el supuesto de que ya exista otro anterior del causante, o la regla de la prevalencia o preferencia que tiene la sucesión testada sobre la intestada (arts 658, 912 CC), si es ésta la que se abrió al iniciarse el proceso sucesorio. No obstante, el análisis de la misma, nos sugiere varias puntualizaciones o comentarios que manifestamos en esta exposición, así como algunas de las circunstancias que, entendemos, se han de tener en cuenta en la producción de la misma y que, a nuestro juicio, se tienen que valorar y examinar a los efectos de determinar cual es la clase de ineficacia de la declaración del delado que, en su caso, se ha originado y su posible impugnación porque, según y como se hayan producido, las consecuencias que de ello se pueden derivar serán diferentes, con distinto alcance y efectos, como veremos ahora, lo que también servirá para promover después la correspondiente acción de ineficacia.

Así, la aparición de un testamento del causante provoca, a nuestro juicio, en el proceso sucesorio dos conflictos o cuestiones: por un lado, determinar cómo se va a deferir desde ese momento la transmisión mortis causa de los bienes, lo que se resuelve a través la aplicación de las dos reglas antes indicadas y, por otro, que es el que aquí nos interesa, la repercusión que tiene la aparición del testamento sobre las declaraciones de voluntad que ya se hubieren emitido con anterioridad a ello, su posible ineficacia y los efectos o consecuencias que de ello se derivan.

Acerca de esta última, y volviendo de nuevo al examen del artículo 997 CC, es preciso señalar, ante todo, que, el automatismo de ineficacia (aparición-impugnación), que en él parece predicarse a resultas de este hecho, no siempre se produce porque, como bien pone de relieve la doctrina, ello dependerá, o estará en función, principal y fundamentalmente, de cual sea el contenido del testamento, sea cual fuere la fecha de su otorgamiento, siendo esta circunstancia de vital y trascendental importancia, por otro lado, lógica, que se tiene que observar o cumplir cuando se produce un hecho de esta naturaleza, y sin duda, una de las que más hay que ponderar y valorar para saber si deja sin efecto la declaración del sucesor.

${ }^{1123}$ Artículo 737 y ss, que dan contenido a la Sección 10a, “De la revocación e ineficacia de los testamentos”, del Capítulo I “De los testamentos”, del Título III, relativo a las sucesiones, del Código Civil. 
En este sentido, acerca del contenido del testamento, para MANRESA"1124, "si el nuevo testamento desconocido explica solo una cláusula dudosa, o modifica en ciertos detalles insignificantes otro testamento anterior pero las circunstancias de la voluntad del causante siguen siendo idénticas y no han variado en lo sustancial, no puede pretenderse la impugnación de la declaración". Ahora bien, si en el testamento se instituye un nuevo heredero, distinto de aquel que repudió, o resulta que en él se ordenan nuevos legados o se revocan otros, o aparecen nuevas cargas que no existían en el anterior, puede pretenderse la invalidación de la repudiación por cuanto la declaración de voluntad la realizó quien no tenía derecho a ello, o se hizo sin contar con estos nuevos gravámenes.

Por su parte, ALBALADEJO ${ }^{1125}$ puntualiza aquí lo siguiente:

"10.- La aparición de un nuevo testamento del causante no supone propiamente una verdadera causa o supuesto de impugnación por cuanto no ha existido vicio alguno del consentimiento, sino que se ha emitido una declaración de voluntad en base a una delación que realmente no existe. La verdadera delación estaría contenida en el testamento que ha aparecido después. De ahí que se trate, en realidad, de una repudiación, no viciada, sino vacía de contenido y, por tanto, inexistente.

$2^{\circ}$.- Es preciso que el contenido del testamento afecte directamente al contenido y al vigor de la delación repudiada".

A este respecto, a nuestro juicio, como bien apunta MANRESA, si el testamento que ha aparecido resulta que altera o modifica lo que es esencial o sustancial del que ya se conoce porque éste y el anterior son de todo punto incompatibles o antagónicos entre sí, hasta el punto de que la voluntad del causante resulta ser ahora otra distinta, totalmente diferente de la anterior, en este caso, se produciría una situación de ineficacia total y absoluta de todo lo actuado hasta ese momento, de tal manera que se podría decir que es como si nunca se hubiese llegado a realizar, aunque, para que se dé esta circunstancia, no es preciso, lógicamente, que aparezca un testamento desconocido del causante porque igual sucedería con uno ya conocido. Es decir, la ineficacia surge, no solo cuando aparece un testamento desconocido, sino también cuando se conocen todos a la vez y el último de ellos, por razón de su contenido, es incompatible con el anterior o anteriores que ya se conocen, lo que afectará, no solo a

\footnotetext{
1124 Op. cit.: Pág 386.

1125 “La repudiación de la herencia”. Cit: Pág 748.
} 
la declaración de todos y cada uno de los sucesores, sino también a todas las fases del proceso sucesorio que hasta ese momento se hubiesen desarrollado.

Ahora bien, si lo único que hace el testamento es aclarar, complementar o modificar detalles que se consideran intrascendentes de las cláusulas o disposiciones del que ya se conoce, o le sirve de auxilio para interpretarlo, o atribuye algún legado de poca importancia, o se limita a establecer una sustitución hereditaria, o tan solo a nombrar un albacea, etc ${ }^{1126}$, de tal manera que el causante no modifica, a través del mismo, la vocación del repudiante, o en aquello que es esencial su propia voluntad manifestada por él en el testamento anterior, entonces difícilmente se puede hablar de impugnación de la declaración por el mero hecho de la aparición del testamento y sí, en cambio, de compatibilidad o simultaneidad de ambas disposiciones testamentarias, al tiempo que no se vería afectada por ello la declaración de repudio del delado, por lo que, habiéndose emitido conforme a derecho, sería perfectamente válida e irrevocable y produciría todos los efectos que le son propios.

En este sentido, sin duda, la casuística es muy variada, lo que requerirá un examen y cotejo muy minucioso, no sólo del contenido de todos y cada uno de los testamentos que, en su caso, el causante hubiese otorgado, sino de la voluntad por él manifestada de la que será un elemento primordial y básico el tenor del testamento, sobre todo, cuando al otorgarse no se hace en él mención a la vigencia de los anteriores, lo que puede dar lugar a su tácita revocación ${ }^{1127}$.

${ }^{1126}$ Ver, en este sentido, en cuanto a otras posibles modificaciones o circunstancias que pueden dar lugar a la ineficacia de la declaración: GITRAMA (Op. cit. Pág 179); ALBALADEJO ("La repudiación de la herencia”. Cit: Pág 749).

${ }^{1127}$ Acerca de ello, el Tribunal Supremo, en la St de 1 de febrero de 1988 (RJ 581), estableció que:

"El tema de la revocación testamentaria tácita puede plantearse, en el plano de "lege ferenda", en una doble vertiente: el mero otorgamiento del nuevo testamento, considerado de manera global, deja sin efecto el testamento anterior, igualmente considerado de forma unitaria, o más bien, la revocación sólo debe producirse en tanto en cuanto que el contenido de la última disposición testamentaria, sea incompatible con el de la anterior; nuestro Código Civil se inclina por el sistema de la revocación total, producida por el mero hecho del otorgamiento de un testamento posterior, y en el art. 739-1. ${ }^{\circ}$ establece:

"El testamento anterior queda revocado de Derecho por el posterior perfecto, si el testador no expresa en ésta su voluntad de que aquél subsista en todo o en parte". Este sistema, que goza de las ventajas de la sencillez, ha prevalecido en la aplicación práctica del derecho, imponiéndose el criterio rigorista de exigir que la manifestación de voluntad del testador, dejando subsistente todo o parte del anterior testamento, tenga que aparecer constatada explícitamente en el posterior; rigorismo en contradicción con la realidad práctica de que el causante, en ciertos casos, haya querido solamente complementar, aclarar o interpretar su disposición anterior, deduciéndose claramente del propio tenor testamentario su voluntad compatibilizadora, pero sin la constancia expresa. La armonización hermenéutica es posible hacerla conciliando el comentado art. 739 del Código Civil, con el 675 del mismo cuerpo legal, e interpretando la segunda disposición testamentaria conforme a la verdadera intención del testador, deducida del propio tenor del testamento, y admitiendo la eficacia de aquellas disposiciones del primer testamento que puedan coexistir con los del posterior, según la prevalente voluntad del "de cujus", implícita en la disposición testamentaria, y deducida en el sentido literal de sus 
Pero, además de la circunstancia anterior, hay otras, según ya habíamos dejado antes apuntado, que, en nuestra opinión, hay que valorar y tener en cuenta a los efectos de determinar si procede instar la declaración de ineficacia y que serían las siguientes:

\section{A) que el testamento sea válido:}

aunque sea una obviedad, es preciso que el testamento que ha aparecido sea plenamente válido y eficaz, circunstancia o premisa que, como bien pone de relieve O'CALLAGHAN ${ }^{1128}$, el artículo 997 CC no dice, y que hay que sobreentender para que su aparición dé lugar a dicha ineficacia, porque, si resulta que es nulo o ha perdido su validez, pese a que se haya ignorado hasta este momento su existencia, no surte ningún valor ni tiene eficacia jurídica alguna, y no tendrá ninguna relevancia sobre la declaración del delado. Por ello, si se da esta circunstancia, su declaración no podrá ser objeto de impugnación por esta causa, "quod nullum est nullum producit effectum" (SSTS 18 de diciembre de 1958, RJ 4200; 30 de septiembre de 1982, RJ 4929).

B) Momento en que se ha de producir la aparición del testamento junto con el hecho de que sea "desconocido":

del tenor del artículo 997 CC parece desprenderse la premisa, más bien exigencia, de que, para que proceda la ineficacia de la declaración por esta causa, es preciso que el testamento aparezca, o se conozca su existencia por parte del sucesor, después de que él haya ejercido el ius delationis, una vez se haya manifestado acerca de la vocación que ha recibido. En este caso, la aparición del testamento facultaría para promover la correspondiente acción de ineficacia de la declaración de repudio realizada por el delado.

palabras; postura más acorde con la moderna doctrina científica, al entender que la "voluntad" que se exige en el art. 739-1. ${ }^{\circ}$ del Código Civil para dejar subsistente un testamento anterior, puede no solo ser la "expresa" allí mencionada, sino también la «deducida» que acoge 675 del mismo cuerpo legal; doctrina integradora que ya hizo suya la Dirección General de los Registros en varias resoluciones".

A la vista de ello, y en cuanto a la aplicación del artículo 675 del Código Civil en este sentido, entendió que, "es necesario dejar señalado aquí, como jurisprudencia pacífica, que el elemento primordial para conocer la voluntad del causante, ha de ser el tenor del propio testamento, y dentro de su tenor atenerse a su literalidad, "a no se que aparezca claramente que fue otra la voluntad de testador", y sólo para el caso de que surgiere la duda, "se observará lo que aparezca más conforme con la intención" pero siempre "según el tenor del mismo testamento"; sin que, por otra parte, sea lícito al interpretar extender las disposiciones testamentarias más allá de su expresión literal, y sólo permisible la búsqueda de la voluntad, por otros medios probatorios, cuando ésta aparezca oscura, ambigua, contradictoria o dispar entre las palabras utilizadas y la intención. -Sentencias 5-3-1944; 6-2-1958 (RJ 1958|1016); 19-11-1964 (RJ 1964l5108); 5-6-1979 (RJ 1979|2888); 24-3-1982 (RJ 1982l1501)-”.

${ }^{1128}$ Comentario del Código Civil. Cit.: pág 2369. 
No obstante, nos planteamos, en este sentido, el interrogante de cuando, en qué momento, se ha de producir dicha aparición y qué se ha de entender por la expresión "desconocido" porque, si bien, en principio, lo lógico es que se produzca después de ejercer el ius delationis, también puede suceder que haya aparecido antes pero se desconozca su existencia por parte del delado en el momento de manifestarse acerca de la oferta hereditaria que ha recibido, lo que puede tener relevancia a los efectos de pretender la posible ineficacia de su declaración. Así, puede ocurrir:

a) que se desconozca la existencia del testamento en el momento de ejercer el ius delationis porque su aparición o descubrimiento se ha producido después de que el delado haya repudiado la herencia ${ }^{1129}$, que sería el supuesto más factible,

b) o que el testamento ya exista, incluso se conozca su contenido por parte de alguno o algunos de los sucesores excepto por aquel que ahora pretende la ineficacia de su declaración alegando que no tenía noticias de su existencia en el momento de realizarla ${ }^{1130}$.

En este caso, aunque el testamento haya aparecido antes de manifestarse el delado, lo cierto es que es desconocido o ignorado por él en ese instante, lo que, en nuestra opinión, es lo verdaderamente relevante a estos efectos. Aquí, se puede dar la circunstancia de que haya actuado de mala fe, incluso con dolo, si hizo su declaración ignorando el testamento a sabiendas, de forma deliberada y consciente, porque sabía que le perjudicaba, o de forma negligente o culposa porque no puso toda la diligencia debida en tener la total y absoluta certeza de cual era su derecho a la herencia (art. 991 CC). En este caso, habría negligencia, mala fe, o dolo, cuando, el delado, al ejercer el ius delationis, conoce la existencia de ese testamento anterior pero lo ignora, hace caso omiso de él, a sabiendas, de forma deliberada y, no obstante, decide repudiar la herencia al saber su contenido, haciéndolo incluso como un gesto de desaprobación, desaire, reproche o desprecio al causante ya que, por ejemplo, no le ha instituido heredero, o dejado a su favor un determinado bien o derecho, o no le ha mejorado, o le ha dejado menor porción o cuota de bienes de la herencia, etc. En este caso, obviamente, no sería susceptible de ser invalidada la repudiación por esta causa por cuanto lo hizo con pleno conocimiento y consciencia de que ya existía ese testamento, y más aun si fue a sabiendas, de forma deliberada, porque le era

${ }^{1129}$ En el iter o secuencia de los hechos, sería: vocación testada o intestada, delación, ejercicio del ius delationis, aparición del testamento.

${ }^{1130}$ En este caso, el iter o secuencia de los hechos, sería: vocación testada o intestada, existencia del testamento pero desconocimiento del mismo por parte del delado, ejercicio del ius delationis en base a aquella delación. 
perjudicial. Luego, en base a ello, no se podría, en este caso, pretender impugnar dicha declaración. En otro caso, de haber actuado de buena fe, ignorando totalmente la existencia del testamento, sí que sería susceptible de ser impugnada la repudiación.

Distinto es que haya actuado de buena fe, porque cuando repudió la herencia desconocía totalmente la existencia del testamento por causas inimputables a él, en cuyo caso, sí que se podría alegar error en la declaración como causa de impugnación de la misma.

Por tanto, el quid de la cuestión, a nuestro juicio, no está tanto en el momento en que se haya producido la aparición del testamento para que éste se repute como conocido, sino en, si el delado actuó o no de buena fe, si tenía, o no, noticias de su existencia y conocimiento de su contenido en el momento de ejercer el ius delationis, en el caso de que haya aparecido antes.

c) Y, de igual manera, puede ocurrir, como tercera hipótesis, que el testamento del causante aparezca, o se conozca su existencia, incluso una vez que el proceso sucesorio mortis causa ya está totalmente concluido, después de que se hayan terminado todas las operaciones particionales, incluidas las adjudicaciones de bienes a los herederos, lo cual no obsta para que proceda, de igual manera, en este caso, si cabe con más motivo, dicha impugnación.

Por otro lado, un dato de gran relevancia que se ha de tener en cuenta a los efectos de instar, en su caso, la correspondiente ineficacia de la declaración habiendo más de un testamento, es saber cual es la fecha de otorgamiento del testamento que ha aparecido.

En este sentido, a los efectos de que prospere la pretendida ineficacia de la declaración, ha de ser de fecha posterior a aquel del que emana la vocación y delación del sucesor en virtud del cual él repudió y se ordena la sucesión del causante.

Así, si el testamento que ha aparecido es de fecha posterior, se tendrá que cotejar uno y otro para comprobar si son, o no, compatibles entre sí por razón de su contenido y si se pueden simultanear en su respectiva aplicación a los efectos de regular el proceso sucesorio, operación de la que pueden resultar consecuencias muy diferentes al poderse dar una casuística muy variada ya que puede ocurrir que ambos testamentos sean compatibles entre sí o incluso, como luego veremos, que no haya lugar a la impugnación de la declaración del delado si no afecta a su vocación, en cuyo caso, pese a ello, dicha declaración será válida y eficaz. 
Ahora bien, si el testamento que ha aparecido es de fecha anterior al que ya se conoce, a aquel en virtud del cual se repudió la herencia, y resulta que son entre sí incompatibles por razón de su contenido, dada la fecha de sus respectivos otorgamientos, se daría la circunstancia de que el posterior, el que ya se conoce, ha derogado, o revocado, de forma tácita o expresa (art. 739 CC), a aquel, al que ha aparecido. En este caso, ciertamente se puede decir que el testamento que ha aparecido es desconocido en sentido material porque, hasta este momento, se ignoraba su existencia por parte de los sucesores, sin embargo, desde el punto de vista legal y a los efectos que aquí nos interesan, no tiene ningún valor ni trascendencia jurídica en la sucesión del causante porque ha sido revocado por el que se rige la sucesión, por lo que no tendría ninguna relevancia en el proceso sucesorio, como tampoco a los efectos de la validez de la declaración del delado. En este caso, vemos, una vez más, cómo, según las circunstancias, el tenor del artículo 997 CC no es del todo exacto, como antes apuntábamos.

C) Que el desconocimiento del testamento no sea imputable al sucesor.

Ya hemos comentado hace un momento que la ignorancia o desconocimiento de la existencia del testamento por parte del sucesor que pretende instar la ineficacia de su declaración en base a esta causa, sea de buena fe. Esto es, se haya producido por causas ajenas a su voluntad, no imputables a él, que no haya habido culpa o negligencia por su parte y, por tanto, sea un error involuntario, o como ya ocurrió, se dé la circunstancia de que padezca una enfermedad mental que le impida recordar la existencia de ese testamento anterior ${ }^{1131}$.

En este caso, efectivamente el error que se ha producido en la declaración sí que sería causa o motivo para pretender instar la ineficacia de la misma en los términos que establece el artículo 997 CC, ante lo cual, el delado, por aplicación de las normas relativas a los contratos (art. 1301 y ss CC), entendemos que tendría un plazo de cuatro años para impugnar, en su caso, su declaración de repudio, contados desde que se tuviere conocimiento de la existencia del nuevo testamento.

Pero, además de la buena fe, otra circunstancia que hay que valorar y tener en cuenta en este sentido, es el hecho de que todo sucesor ha de poner por su parte toda la diligencia debida en tener la certeza, tanto del hecho de la muerte o fallecimiento de la persona de cuya sucesión se trate, como también de saber en base a qué vocación

${ }^{1131}$ Vid, sobre ello, el caso que conoció la Audiencia Provincial de Ourense, en sentencia de 28 de diciembre de 1993, AC 1993/2521. 
y delación, si testada o abintestato, nace y existe su derecho a la herencia de esa persona y que cree tener u ostentar sobre la misma (cfr. art. 991 CC).

Así, no actuaría de forma diligente, aunque sí, tal vez, de buena fe, cuando se ejerce el ius delationis al amparo de la convicción o creencia de que la vocación y delación que había a su favor era la verdadera, pero luego resulta no serlo porque no es aquella por la que se va a deferir el destino de la herencia ya que, la que tiene valor a efectos sucesorios, es la que está contenida en el testamento cuya existencia se desconoce. De ahí que, en ausencia de esta diligencia, porque ha actuado, tal vez, con precipitación, sin cerciorarse de estos extremos, el error, pese a la buena fe, se podría imputar al sucesor y podría no prosperar una acción de ineficacia por esta causa. $Y$, desde luego, como ya hemos comentado, actuaría, no ya con negligencia, y sí con mala fe si la ignorancia fue a sabiendas, de forma deliberada y consciente, al saber que el testamento le perjudicaba, en cuyo caso, a él, lógica y evidentemente, en este caso con más motivo, le sería imputable su error y no podría invocarlo a su favor como causa para impugnar su declaración de repudiación por esta causa, por lo que sería válida, definitiva e irrevocable.

Ahora bien, no se podría alegar error en la declaración, en cualquier caso, para instar la nulidad, relativa, de la misma, cuando resulte que el testamento que ha aparecido deja totalmente sin efecto la vocación y delación del sucesor, como ocurre cuando ha sido sustituida por otra al haber sido instituido otro sucesor diferente como vamos a ver más adelante. En este caso, estaríamos, no ante un supuesto de anulabilidad por causa de error, sino de nulidad absoluta de la declaración por ausencia de vocación y delación (art. 991 CC). La aparente delación en base a la cual se repudió no existe al haber un testamento posterior que la dejó sin efecto.

Por otro lado, a la vista de todo lo anterior y sin ánimo exhaustivo, podemos apuntar algunas hipótesis en cada una de las cuales se pueden distinguir diferentes modalidades de ineficacia con distinto alcance y consecuencias:

a) que se inste una petición de ineficacia de la declaración del delado porque el testamento que ha aparecido, por razón de su contenido, es total y absolutamente incompatible con la vocación-delación previa, ya sea ésta testada ${ }^{1132} 0$ intestada, de la que derivó, y en virtud de la cual, se emitió la declaración de repudio.

1132 En este sentido, a propósito de la repudiación de la herencia cuando existen otros títulos sucesorios, nos remitimos a cuanto exponemos en el capítulo quinto. 
Esta hipótesis tendría lugar cuando el testamento que ha aparecido cambia total y sustancialmente las circunstancias o presupuestos básicos y esenciales sobre los que se sustentaba hasta ese momento el proceso sucesorio, como ocurre cuando el causante instituye ahora un nuevo y diferente sucesor, distinto de aquel que ya ejerció el ius delationis, de tal manera que éste ya no lo es, o porque, habiéndose deferido la herencia por vía intestada, resulta que ahora, de igual manera, es llamado, a través del testamento, un nuevo heredero a la sucesión, o incluso el mismo que ya repudió pero a una porción o cuota diferente de la herencia. En este caso, el testamento invalida totalmente la vocación-delación del sucesor que ya se manifestó sobre la herencia del causante dejándola sin valor ni efecto jurídico alguno (art. 991 CC).

Éste sería el supuesto de ineficacia, podríamos calificar como, de mayor trascendencia que se puede producir a resultas de la aparición del testamento y que se podría equiparar, en principio, por aplicación de lo dispuesto en el artículo 991 CC, a un caso de nulidad absoluta, incluso de inexistencia de la vocación-delación. Aunque, más bien, a decir verdad, habría que hablar, en este caso, a nuestro juicio, no de nulidad, y sí de revocación de la declaración de repudiación por causa sobrevenida por cuanto la vocación-delación en base a la cual se manifestó el sucesor era, hasta ese momento, plena y perfectamente válida, eficaz e irrevocable, de haberse emitido conforme a Derecho, pero que, después, ha quedado totalmente desvirtuada, sin valor ni efecto jurídico alguno, como consecuencia de la aparición del testamento y ser otra vocación diferente por la que va a regir el destino de la sucesión por voluntad del propio causante a favor de otro sujeto, o del mismo que repudió pero a una cuota o porción distinta de la herencia. La vocación que hasta este momento determinaba el sujeto de la sucesión, ha desaparecido al haber sido sustituida por otra diferente. En consecuencia, igual ocurre con la delación y, por tanto, no hay derecho sucesorio sobre el cual se pueda sustentar la repudiación del delado.

De ahí que, desde un punto de vista estricto, técnico y jurídico, y en atención a las circunstancias que han motivado la invalidez de la declaración, habría que hablar propiamente, como ya hemos apuntado, no de una declaración de ineficacia por causa de nulidad, sino de, una revocación en virtud de la sobreveniencia del testamento a resultas de la cual dicha declaración ha quedado totalmente invalidada. Ello no obsta para que, en un principio, dicha declaración de repudiación fuese plenamente válida y eficaz si, en su momento, se emitió válidamente conforme a derecho, al tener origen o fundamento en una vocación-delación que se realizó de conformidad con las reglas por las que se regía en ese instante la sucesión mortis causa, surtiendo plenos efectos 
jurídicos con todas las consecuencias que de ella se derivan, incluso irrevocable, pero que después ha devenido en ineficaz al haber quedado invalidada en virtud de la circunstancia sobrevenida de la aparición del testamento. Además, cuando el delado repudió lo hizo seguramente con el total y absoluto convencimiento y convicción de que su vocación y delación sucesorias eran ciertas y verdaderas porque eran las que estaban vigentes en ese momento, por las que se defería, por entonces, la sucesión. Pero después, como consecuencia de la aparición del testamento y de su contenido, en fecha posterior a la delación en virtud de la cual realizó dicha declaración de repudio, ésta ha devenido, por causas sobrevenidas, en inoperante o ineficaz por la aparición del testamento del causante, lo que da lugar a su resolución o revocación.

Por otro lado, al haberse emitido, en su momento, la declaración del delado conforme a derecho, ha producido una apariencia de realidad y de validez, al tiempo que se la ha tenido como tal, no solo por el propio declarante, sino también por los demás sucesores y por terceras personas, como pudieren ser los acreedores, ya lo sean de la herencia, ya los propios del sucesor que repudió. De ahí que, en su caso, pueda ser preciso o necesario instar judicialmente su ineficacia para dejar sin efecto lo realizado hasta ese momento.

En estos términos, sería impugnable la declaración de repudio al amparo de lo dispuesto en el artículo 997 CC, pero no de la misma manera que si lo fuere por vicios de la voluntad, porque, en este caso, sería impugnable por revocación de la misma en virtud de causa sobrevenida. De ahí que, como venimos diciendo, la impugnación del repudio de que trata dicho precepto, no es la misma en los dos supuestos que en él se recogen como parece dar a entender su tenor, como tampoco es igual en cuanto a la forma de impugnación, plazo, efectos, etc.

b) Distinto es que el testamento, por su contenido, tan solo afecte de forma parcial, o relativa, a la vocación-delación del sucesor que ya repudió, como puede suceder, de forma muy casuística y variada: cuando sí sea llamado a la sucesión pero de forma diferente porque ahora el causante llame a más o menos sucesores que antes, lo que influirá después, al alza o a la baja, en las respectivas cuotas o porciones que a cada uno de ellos le corresponda en la herencia, o incluso resulten otras totalmente diferentes; o porque el causante haya hecho uso de la facultad de mejorar y resulten modificadas las legítimas; o se produzcan cambios en los legados porque se revoquen unos y/o se constituyan otros; o porque aparecen nuevas cargas en la herencia que la hacen ahora más gravosa, o al revés, que el causante haya quitado o reducido las cargas que pesaban sobre la herencia y la hagan más atractiva para los 
sucesores; o se adjudique algún legado al sucesor que le compense por las cargas de la vocación anterior, etc.

¿En estos casos se puede hablar de ineficacia de la declaración?. A resultas de la aparición del testamento lo cierto es que la vocación-delación del sucesor no ha desaparecido, aunque sí ha sufrido una novación o cambio de alguna de las bases o presupuestos sobre los que se asentaba y a la vista de los cuales el sucesor ejerció su ius delationis, ya sea en el aspecto subjetivo porque ha variado el número de sujetos con el consiguiente aumento o disminución de las respectivas cuotas, u objetivo, porque, sin variar el número de sujetos, solo se ha visto modificada su cuota o porción sucesoria. De ahí que, a diferencia de lo que ocurre en el supuesto anterior, en éste, la vocación-delación sólo se ha visto afectada, o modificada, de una forma parcial o relativa. En este caso, a nuestro juicio, no se puede hablar de una ineficacia en los términos de revocación que antes hemos visto porque aquí, el sucesor, sigue siendo llamado a la sucesión sin perjuicio de que su llamamiento ha cambiado, ya sea desde el punto de vista de los sujetos, al variar el número de sucesores, ya sea por razón del objeto al que ahora es llamado, al haberse modificado su cuota o porción sucesoria porque para él, en este caso, puede incluso tener el aliciente de que haya aumentado de valor si antes era de escasa o nula cuantía como consecuencia de las deudas o cargas que pesaban sobre ella, lo que, probablemente, motivó su repudio a la herencia, mientras que ahora puede suponer para él un estímulo para provocar la aceptación de la misma si, como decimos, se le libera de cargas, o aumenta su porción o cuota sucesoria aunque las cargas se mantengan, de tal manera que, el causante le adjudica más bienes, o le mejora, o le hace un legado que compense las deudas, etc.

De ahí que, en este caso, al haberse producido una novación o cambio en tan solo alguno de los aspectos o presupuestos que conforman la vocación del delado, su declaración sí sería susceptible de ser declarada ineficaz, aunque, entendemos, solo de forma parcial o relativa, es decir, anulable.

c) Incluso puede suceder que, pese a la aparición del testamento, la declaración del delado sea plenamente válida, eficaz e irrevocable, y surta plenos efectos jurídicos porque no se vea, en modo alguno, perturbada o afectada por dicho testamento, lo cual sucederá cuando éste no modifique la vocación-delación del delado. 
En este sentido, apunta MANRESA ${ }^{1133}$, como tales hipótesis: cuando el testamento sirve tan solo para aclarar, explicar o complementar una cláusula oscura o dudosa de otro testamento anterior, o de auxilio como medio de interpretación, o cambia detalles insignificantes del mismo, de tal manera que las circunstancias de la voluntad del causante siguen siendo las mismas y no varían en lo sustancial esa voluntad ya anteriormente emitida.

En estos casos, ambas sucesiones, testada o intestada anterior y la testada que se acaba de abrir, serían perfectamente compatibles entre sí, de tal manera que se pueden aplicar a un mismo tiempo para regir el proceso sucesorio del causante en lo que se refiere al sucesor que ha repudiado. De lo cual resulta que, ya no estaríamos ante un supuesto de ineficacia y sí de aplicación simultánea de dos, o más, voluntades del causante que, al no afectar la segunda, o ulterior, de ellas a la previa declaración de repudio del sucesor, hace que ésta sea, perfectamente válida, eficaz e irrevocable, surtiendo todos los efectos que le son propios, por lo que el repudiante quedaría, a resultas de su declaración, totalmente apartado del proceso sucesorio.

Con lo cual vemos cómo, en ese caso, la aparición del testamento, una vez más, no es causa de impugnación de dicha declaración como, en un principio, parece apuntar, con carácter general, y sin distinción de casos, el artículo 997 CC.

d) Y, por último, puede ocurrir que, habiéndose abierto el proceso mortis causa vía intestada porque del certificado de últimas voluntades en él consta que el causante no otorgó en vida ningún testamento, resulta que aparece después uno, ológrafo el más frecuente, que modifica o hace ineficaz en su totalidad el destino de los bienes deferidos por aquella vía.

En este caso, puede suceder que quien ya repudió como sucesor abintestato sea llamado ahora por el causante a su herencia a través de este testamento, bien él solo, bien junto con más sucesores, en cuyo caso, respecto de él, estamos en la hipótesis de que trata el párrafo $2^{\circ}$ del artículo 1009, de cuyo estudio y análisis ya nos hemos ocupado en otro momento ${ }^{1134}$.

1133 Op. cit.: Pág 387.

${ }^{1134}$ A propósito de la regla contenida en el mismo, nos remitimos al capítulo quinto, el cual, en su número 3-2, se analiza este párrafo así como los presupuestos precisos para su aplicación.

De igual manera, para el caso de repudiación de la sucesión por vía abintestato y posterior aparición de un testamento, véase en el capítulo quinto, el punto número 4, donde se analiza el hecho de la repudiación en el caso de coexistencia de la sucesión testada e intestada. 
QUINTA PARTE: EPÍLOGO. 


\section{Capítulo 11: CONCLUSIONES y CONSIDERACIONES FINALES.}

A modo de resumen, señalamos a continuación algunas de las principales o más relevantes conclusiones y consideraciones a que hemos llegado en esta tesis acerca de la declaración de repudiación de la herencia y que son las siguientes:

PRIMERA.- Una de las cuestiones que dicho acto suscita, dada la analogía que tiene con otros de significado gramatical, incluso jurídico, semejante a él como es, principalmente, el de la renuncia, es saber en qué consiste, qué se entiende como tal.

En este sentido, en nuestra opinión, sólo es verdadera y propia repudiación, "aquel acto en virtud del cual el llamado a una sucesión, ya sea testada o intestada, manifiesta de forma unilateral y solemne, su voluntad de rechazar el llamamiento o atribución patrimonial que le ha sido deferido mortis causa y, por consiguiente, no adir la herencia y no tomar el título o condición de heredero o, en su caso, de legatario".

Sólo hay que entender por repudiación, y no solo en sentido técnico o estricto, sino jurídico, el ejercicio, en sentido negativo, del ius delationis por el que el delado manifiesta no querer ser sucesor en la herencia a que ha sido llamado. En este sentido, así como a través de la aceptación el sucesor manifiesta querer ser heredero y adquirir aquello a lo que es llamado, por la repudiación expresa todo lo contrario.

SEGUNDA.- Su relación y parecido con la renuncia es, no innegable, sino inevitable. En este sentido, la modalidad con la que más se asemeja o tiene una mayor analogía, con la que podría estar en más consonancia y si hubiese que encajarla o aproximarla a alguno de los moldes o modelos de la misma, sería, en nuestra opinión, con la renuncia preventiva por ser, o consistir, como ya la calificó PAULO $(D 5,16,28)$ y defiende ROCA SASTRE, en una omissio adquirendi, por cuanto, a través de la repudiación, se rehúsa a hacer propio un derecho. 
TERCERA.- No obstante lo anterior, y en cualquier caso, la repudiación no se puede considerar, en modo alguno, como una renuncia propiamente dicha porque ésta, en un sentido estricto y jurídico, es un negocio jurídico de carácter abdicativo que tiene como efecto derivado del mismo para su titular, la extinción o pérdida de la cosa o derecho a que se refiere y forma parte de su patrimonio y que, además, queda abandonado, sin un titular actual, por lo que después puede ser adquirido por cualquiera. Sólo ésta, sería verdadera y propia renuncia.

CUARTA.- Tratando de delimitar la repudiación, un supuesto que ha planteado la incógnita de si constituye manifestación de la misma, es el contemplado en el inciso segundo del número $3^{\circ}$ del artículo 1000 del Código Civil, dado que en él se habla de renuncia y no de repudio.

Dadas las circunstancias como se realiza y en él concurren, es un acto que, a nuestro juicio, se puede considerar, a todos los efectos, como una verdadera y propia repudiación porque el resultado, o los efectos que de él se derivan, son exactamente los mismos que si se tratase de un repudio, ya que se hace dejación de un derecho por parte del sucesor pero sin que haya un destinatario concreto del mismo por cuanto se hace de forma genérica e indeterminada, en abstracto, a favor de todos los demás sujetos que hubiesen sido llamados a la sucesión. Además, de forma gratuita, sin recibir nada a cambio, y sin decir ni disponer nada acerca del destino de la cuota renunciada, como tampoco sin hacer distribución o reparto de la misma en porciones o cuotas entre los demás cosucesores. Por otro lado, los destinatarios no van a resultar favorecidos como haya dispuesto el "renunciante", sino con sujeción a las mismas reglas que, en su caso, habrían sido de aplicación al igual que si efectivamente se hubiere producido una repudiación de la porción o cuota, de tal manera que ésta va a tener el mismo destino que, en su caso, hubiese establecido el testamento, o la ley, para el supuesto de repudio.

QUINTA.- La sanción tipificada en el artículo 1002 del Código Civil consistente en privar al sucesor de la facultad de repudiar la herencia cuando ha sustraido $u$ ocultado algunos efectos de la misma, constituye, en nuestra opinión, un supuesto en que el ius delationis, en realidad, desaparece, no existe, porque dicho sucesor, no solo no puede repudiar, sino que ni tan siquiera tiene la opción de poder aceptar de forma libre, al imponérsele, ope legis, la aceptación pura y simple, de forma imperativa u obligatoria e investirle la ley en la condición de heredero. De ahí que, más bien, lo que se produce para el sucesor es la privación de la posibilidad misma de ejercicio del ius delationis. 
Sin embargo, dicha sanción, a nuestro juicio, es incompleta o poco eficaz, o al menos, no todo lo eficaz que sería de desear porque lo suyo hubiese sido, no solo apartar al sucesor de la herencia, como si de un caso de indignidad se tratase, sino obligarlo, además, a la devolución de lo que sustrajo u ocultó para su incorporación al acervo hereditario, lo que el Código Civil no impone, y evitar así, además, en su caso, a los demás sucesores tener que entablar un proceso judicial, ya sea civil o penal, para poder recuperar los bienes que se sustrajeron u ocultaron.

De ahí que, lo suyo, o más adecuado, dado que su comportamiento es, o se puede calificar, como un acto de ingratitud o de deslealtad, no ya solo para con la persona, honra o memoria del causante, sino contra la herencia y demás personas interesadas en la sucesión, es que se le impusiese una sanción análoga a la que entraña una indignidad o una desheredación. Tipificarlo como un caso más de indignidad del artículo 756 CC, o de desheredación "ex lege", además de obligarle a la restitución de aquello que sustrajo u ocultó y/o a que indemnice a los demás sucesores y acreedores por razón de los daños y perjuicios causados.

SEXTA.- Para que un pacto sucesorio, caso de ser introducido en el Código Civil en una futura reforma del Derecho de Sucesiones, constituya una verdadera y propia repudiación, sería preciso: a) que se trate de un acto realizado a título gratuito, sin que se reciba contraprestación alguna a cambio, esto es, se haga de forma desinteresada, porque, en caso contrario, estaríamos ante una renuncia traslativa; b) se hiciese de forma pura, no condicional, ni a término; c) que recaiga sobre la totalidad de aquello que le vaya a corresponder al sucesor en el futuro, en el momento de deferirse la sucesión, por cuanto la repudiación es un acto indivisible que no se puede fragmentar; y, d) que, además, se hiciese sin designación de las personas a quienes vaya a ir aquello a lo que se repudió, de tal manera que sea la voluntad del causante, o las reglas aplicables a la sucesión de que se trate, las que determinen cual va a ser el destino de los bienes, porción o cuota, que ha sido objeto de dicho pacto.

Cualquier otra clase de pacto renunciativo que no reúna las características de la repudiación, entendemos que no tendría la consideración de repudio en el sentido propio y estricto del término, y sí, en cambio, sería una forma de renuncia y, como tal, de aceptación, tácita, de la herencia, al igual que ocurriría con la celebración de los denominados pactos dispositivos. 
SÉPTIMA.- La indivisibilidad de la declaración del delado depende, no ya solo del objeto de la vocación sucesoria, sino que también estará en función de cómo se haya producido el llamamiento por parte del causante porque, cuando éste tiene por objeto una pluralidad de títulos y/o de cuotas, se plantea la cuestión de si el delado, en este caso, puede emitir una sola declaración de voluntad, o si varias, tantas como títulos y/o cuotas.

En estos casos, para determinar la divisibilidad o indivisibilidad de la declaración se ha de atender al criterio de que exista lo que se ha denominado, "único fundamento de vocación", "unidad o identidad de la causa", o "el mismo fundamento en la vocación", lo que se puede ver alterado o modificado, en su caso, por la voluntad del testador o el criterio interpretativo del artículo 675 CC por cuanto éste, el testador, puede en su testamento declarar separables o independientes las cuotas que de por sí no lo sean, o no separables los distintos llamamientos que, en principio, parezcan o puedan serlo. De ahí que haya que estar, como apunta LACRUZ, también en nuestra opinión, en cada caso concreto a la voluntad del causante porque habrá que presumir que es su voluntad hacer dos distintos llamamientos, o llamar a dos porciones o cuotas independientes, cuando en cláusulas distintas de un mismo testamento, o en varios, atribuye a un mismo heredero partes distintas de la herencia.

OCTAVA.- No obstante el tenor del párrafo primero del artículo 1009 del Código Civil, pese a haber sido repudiada la delación testamentaria, en nuestra opinión, se podrá aceptar la intestada cuando ésta se abre por causas ajenas, no imputables al repudiante, en el sentido de que la apertura de la sucesión abintestato lo haya sido, no como consecuencia de su declaración de repudio, sino por otro motivo distinto. A lo que hay que añadir determinados supuestos especiales como es aquel en que se repudia la herencia en la condición de transmisario y después se es llamado de nuevo a la sucesión pero, esta vez, ya como sucesor abintestato, ya como sustituto a resultas de la propia repudiación.

NOVENA.- El consentimiento que otorga un menor de edad en documento público autorizando a que sus padres puedan repudiar la herencia que le fue deferida eximiéndoles de la autorización judicial (art. 166 CC, in fine), se justifica, fundamenta o legitima en la capacidad natural que ya tiene el menor para poder realizar por sí solo ciertos actos "de acuerdo con las leyes y con sus condiciones de madurez", de conformidad con el artículo 162.2.1 $\mathrm{CC}$. 
DÉCIMA.- La forma en la repudiación es un elemento esencial de la misma, un requisito "ad solemnitatem" que actúa como elemento integrador del acto y que, si no se cumple, el negocio no nace, de tal manera que es manera o modo de ser, parte de su estructura, "forma dat esse rei". No hay voluntad sin forma, por lo que, su ausencia o inobservancia da lugar a que la declaración es como si no se hubiese realizado y sea nula de pleno derecho. No hay repudiación si no se cumple la forma prescrita por la ley.

En este sentido, y acerca de la expresión "instrumento auténtico" que emplea el artículo 1008 del Código Civil, hemos de entender, no solo el autorizado por fedatario público, sino aquel del que no se tiene la más mínima duda de que es y pertenece de forma indubitada a una persona determinada, en este caso, al repudiante, porque se tiene la certeza total y absoluta de la autoría del mismo, de tal manera que coinciden el autor aparente y el autor real. Ello nos lleva a que, en el ámbito del Código Civil, se pueda hacer la repudiación de la herencia a través de documento privado cuando, de forma absolutamente indubitada, se sabe y se tiene la certeza total y absoluta de que la autoría de la declaración de repudio realizada a través del mismo pertenece al sucesor que repudió.

UNDÉCIMA.- Al hilo de la forma en la repudiación y tratándose de legados, entendemos que la declaración del legatario se ha de someter a la norma de los artículos 1008 y $1280.4^{\circ}$ del Código Civil, al igual que si se tratase de un llamamiento hecho a título universal, y ello, por varias razones: a) por su consideración como un derecho hereditario, b) por motivos de seguridad jurídica y de certidumbre en el proceso sucesorio para todas las personas que están implicadas directa o indirectamente en él, lo que se acentúa aun más en el caso de que se tratase de una herencia dividida en legados (art. 891 CC) y, c) porque, de no ser así, sería hacer de peor condición, someter a un régimen y tratamiento jurídico diferente, incluso, más estricto y formalista, al llamamiento a título universal, respecto del realizado a título particular, al exigir diferente forma, en uno y otro, a la exteriorización o manifestación de la declaración de repudiación, por cuanto, en aquel, en el título universal, se exigiría una solemnidad que sí está, por otro lado, justificada, lo que no sucedería en éste, en el título particular.

DUODÉCIMA.- Desde el punto de vista legal, existe un impedimento, podríamos decir que, total y absoluto en el régimen actualmente vigente del Código Civil (cfr. arts. $\left.761,766,814.3^{\circ}, 857,923,929,981,985.2^{\circ}\right)$, para poder aplicar el mecanismo de la representación a favor de los sucesores del repudiante y salvar así, al menos, sus 
derechos legitimarios, a diferencia de lo que ocurre en los casos de premoriencia, incapacidad o desheredación, en que sí lo permite.

Es cierto que la función que se quiere que cumpla el derecho de representación en el ámbito de la sucesión testada para cubrir la vacante que en ella se ha producido a resultas de la repudiación lo hace la cláusula de sustitución ordenada, en su caso, por el causante en el testamento, por lo que, a falta de ésta, aplicar dicha representación supondría establecer una sustitución vulgar ex lege, y si el causante no lo ha previsto, no es función ni cometido de la ley suplir su voluntad.

Pero, no es menos cierto que, para evitar el grave daño o perjuicio, no ya solo personal, sino, sobre todo, patrimonial o económico, que supone para los sucesores del sucesor su declaración de repudiación al verse privados, además de forma injusta, involuntaria y por causas ajenas totalmente a su voluntad, de unos bienes que ellos, en el futuro, muy probablemente, en el devenir normal de las sucesiones mortis causa, hubiesen sido adquirentes o destinatarios de los mismos, el mecanismo o institución aplicable, ope legis, sería el de la representación, al igual que sucede y lo provee la ley en los casos de premoriencia, incapacidad o desheredación.

Las razones que abogamos en favor de su aplicación, así como de una necesaria reforma del Código Civil en este punto, y no ya solo en materia de legítimas, sino incluso en la sucesión abintestato, son diversas: de concordancia y coherencia técnico-positiva, de equidad, piedad o humanidad, técnico-jurídicas, de protección de intereses, de derecho comparado, así como de estricta justicia.

Así, no se haría recaer sobre dicha descendencia las funestas consecuencias y efectos que se derivan de un acto que no ha realizado, como tampoco pudo evitar ni impedir, cuando, de habérseles dado, al menos, la oportunidad de manifestarse acerca de la oferta hereditaria que recibió su causante, como así habría sucedido si éste les hubiese instituído sustitutos del repudiante, tal vez hubiesen aceptado. Porque, además, en el caso de haber aceptado su causante, después, en el devenir del proceso sucesorio, la porción o cuota repudiada probablemente habría llegado a su patrimonio.

DÉCIMO TERCERA.- En el supuesto de que la legítima se pretendiere deferir de forma anticipada por parte del causante a alguno de sus legitimarios, en vida, a través de una donación, atribuyéndose a ésta la condición de ser un anticipo de la misma, la no aceptación de la donación por parte del donatario-futuro legitimario, por un lado, no puede llevar consigo la pérdida de la legítima y, por otro, no se puede entender o 
interpretar, por su parte, como una repudiación de la misma. Como, de igual manera, desde el punto de vista del donante, tampoco se puede pretender que la donación sea un anticipo de legítima y se condicione la percepción de la misma a dicha aceptación por cuanto ésta es un acto que es totalmente libre y voluntario.

DÉCIMO CUARTA.- Una de las cuestiones más polémicas que ha suscitado la repudiación ha sido el de su calificación respecto de los acreedores particulares del repudiante: si implica una disminución de la solvencia, un acto de empobrecimiento del deudor, una falta de enriquecimiento, incluso, un acto en fraude de acreedores.

No creemos que sea correcto decir que disminuya la solvencia del deudor porque ésta permanece inalterable, ya que sigue siendo exactamente la misma que tenía antes de repudiar, aunque, eso sí, no es menos cierto, y es de todo punto palpable y evidente, que podría haber aumentado, o haber disminuido la insolvencia en que se encontrase, caso de haber aceptado si la herencia fuese beneficiosa.

Como tampoco se puede hablar de una disminución del patrimonio porque no hay, en modo alguno, salida ni pérdida de bienes del mismo, ni aumenta el pasivo ya que no se contraen nuevas deudas, ni los créditos de los acreedores aumentan de valor, como tampoco disminuyen.

De igual manera, sería una incorrección decir que el repudio da lugar a un empobrecimiento de los acreedores porque ellos seguirán en la misma situación, condición o estado que si su deudor no hubiese recibido ninguna oferta sucesoria. Sería la misma que antes de abrirse la herencia, si bien, lo único cierto, real y verdadero es que la oferta que ha recibido el deudor y de la que nacía la expectativa de ver mejoradas las posibilidades de cobro ha desaparecido como consecuencia del repudio.

De ahí que, lo que sí produce para los acreedores del deudor es, de forma palpable y evidente, un claro daño o perjuicio porque su situación patrimonial podía haber mejorado en el caso de haber aceptado la herencia. Para ellos supone perder la oportunidad de que mejoren sus expectativas de poder hacer efectivos sus derechos de crédito porque el patrimonio de su deudor, principal, además de única fuente a la que pueden recurrir para obtener el cobro de los mismos, se ve privado de un ingreso que daría lugar a su enriquecimiento y así ver aumentada su solvencia, o disminuida la insolvencia, lo que permitiría el cobro, si no de todos, sí de parte de los créditos de los acreedores. 
DÉCIMO QUINTA.- Acerca del significado que se puede atribuir al término "aceptación" que emplea el artículo 1001 CC a propósito del recurso concedido a los acreedores particulares del repudiante, entendemos que se trata de la atribución ex lege, por vía subrogatoria -lo que no quiere decir que estemos ante una subrogación, aunque sí ofrece cierta semejanza a la acción del artículo 1111 CC-, de un derecho -el ius delationis-, que, en su ejercicio, es personalísimo de su deudor, concedido a él in tuitu personae, en el que se da, además, la circunstancia de que está extinguido a resultas de la declaración de repudio. Como bien dice DíEZ-PICAZO, "Ios acreedores, no ejercitan un derecho de su deudor, sino un derecho que la ley les atribuye directamente. Actúan iure et nomine proprio".

Por otro lado, ello tampoco significa que acepten "en nombre de él", de su deudor, porque no son, ni sus representantes legales y, menos aun, voluntarios. Sí podrán ejercer, a través de la acción subrogatoria, cualquier otro derecho o acción que sí exista en su patrimonio y del que sea titular su deudor, pero no el ius delationis por cuanto no solo es suyo personal, sino que, además, se extinguió como consecuencia de su ejercicio a resultas de la repudiación.

DÉcIMO SEXTA.- A nuestro juicio, acerca de los caracteres de la acción del artículo 1001, entendemos que:

a) es singularísima, porque no existe ninguna otra acción análoga en nuestro ordenamiento jurídico de semejantes características y por razón de los presupuestos que se exigen para su ejercicio,

b) es excepcional porque permite a los acreedores del delado-repudiante-deudor actuar directamente sobre los bienes que a éste le hubiesen correspondido y entrado en su patrimonio, caso de haber aceptado, y aplicarlos después al pago de los créditos de que sean titulares frente a él,

c) es sui generis por razón de los requisitos que se exigen para su ejercicio así como por las consecuencias que de la misma se derivan y se concede ad hoc a los acreedores para poder cobrar los créditos que tuvieren contra su deudor,

d) no se identifica, ni con la acción subrogatoria, ni con la revocatoria o pauliana, porque no se dan los presupuestos exigidos para el ejercicio de las mismas, como tampoco los presupuestos de la acción del artículo 1001 CC se dan en cada una de aquellas, y 
e) tiene carácter subsidiario porque los acreedores sólo podrán hacer uso de esta acción en el caso de que carezcan de todo otro recurso para poder cobrar lo que se les debe por parte de su deudor.

DÉCIMO SÉPTIMA.- Uno de los pilares sobre los que descansa en su ejercicio la acción del artículo 1001 CC, es la producción de un perjuicio a los acreedores que se produce desde el momento en que el patrimonio del deudor es insuficiente para atender sus deudas porque no hay bienes bastantes para satisfacer su pago. En este sentido, si la situación económica del patrimonio del deudor está saneada porque no tiene ninguna dificultad para dicho pago de deudas, a los acreedores les es indiferente que su deudor repudie la herencia, en cuyo caso, no se puede hablar de perjuicio.

Además de lo anterior, un dato o circunstancia que hay que valorar es el estado o situación en que se encuentra la herencia a que ha sido llamado el deudor, a los efectos de analizar si arroja saldo positivo o negativo una vez que han sido pagadas las deudas de la misma, esto es, si estamos ante una herencia beneficiosa o perjudicial (hereditas damnosa). Así, si se trata de una herencia beneficiosa porque el saldo neto definitivo es positivo para los herederos al haber apenas deudas o resta un buen sobrante después de haberlas pagado, es cuando se puede decir que el repudio causa un perjuicio a los acreedores. Mientras que, si es deficitaria, el deudor, al repudiar, rechaza deudas y no bienes o ganancias. Incluso ni tan siquiera les interesa a los acreedores que acepte porque se agravaría su situación patrimonial. De ahí que, si la herencia es deficitaria, la repudiación no les causaría ningún perjuicio y carecería de sentido el ejercicio de la acción del artículo 1001 por cuanto, como decimos, no hay propiamente para ellos daño o perjuicio.

DÉCIMO OCTAVA.- La producción del perjuicio en los acreedores a que alude el artículo $1001 \mathrm{CC}$, no requiere como elemento integrante del mismo que exista la intención de perjudicar o de causar un daño (consilium fraudis) por parte del deudor, o mala fe por su parte.

En nuestra opinión, al requisito del perjuicio se le ha de dar un sentido objetivo, en el sentido de que no es preciso que los acreedores demuestren si ha habido en la declaración de su deudor una actitud, intención o comportamiento fraudulento por su parte de querer causarles un perjuicio para ejercitar la acción del artículo 1001 en defensa de sus derechos de crédito. Es decir, que la repudiación se haya hecho con el propósito deliberado y consciente, directamente dirigido a causar dicho perjuicio. Bastaría y sería suficiente con demostrar la situación de insolvencia en que se 
encuentra el patrimonio del deudor para que los acreedores estén legitimados para ello. De no ser así, se haría recaer sobre ellos la carga de la prueba de dicha intencionalidad, lo que sería una circunstancia añadida al perjuicio que ya existe y que agravaría aun más su situación. En este sentido, el carácter objetivo del perjuicio les beneficia porque sólo tendrán que demostrar cual es la situación en que se encuentra el patrimonio del deudor y no su deseo de causar un daño que, muchas veces, es muy difícil, sino imposible, de probar porque solo existe en el ánimus del declarante.

DÉCIMO NOVENA.- El artículo 997 CC, al aludir a las causas de ineficacia de la declaración del delado es, a todas luces, manifiestamente insuficiente. Insuficiencia que se suple aplicando la doctrina general que dicho texto legal contiene relativa a la ineficacia de los actos, contratos y demás negocios jurídicos.

Además, es inexacto y equívoco en su contenido porque, su tenor literal, tal y como está formulado, parece dar entender que los dos supuestos a que alude, no sólo constituyen causas de ineficacia análogas o equiparables entre sí, en el sentido de que dan lugar al mismo tipo de ineficacia, sino que ambos producen, a resultas de la misma, el mismo efecto o consecuencia jurídica, lo cual no es del todo cierto porque, así como la existencia de vicios del consentimiento, por aplicación de la teoría general de los contratos y obligaciones (cfr arts 1265 y ss, y 1300 y ss CC), da lugar a un supuesto de invalidez por causa de nulidad relativa, o anulabilidad, en el caso de la aparición del testamento desconocido no siempre habrá lugar a la impugnación de la declaración, ya que ello dependerá de las circunstancias particulares que en cada caso concurran en la sucesión de que se trate, con consecuencias también diferentes.

VIGÉSIMA.- El tenor del artículo 997 CC también es equívoco porque después de hablar de la irrevocabilidad de la declaración del delado, plantea la posibilidad de su impugnación cuando se produzca alguna de las dos circunstancias que en él se señalan: que exista un vicio del consentimiento o aparezca un testamento desconocido del causante.

La confusión a que induce está en que, a nuestro juicio, la declaración del delado es irrevocable, en sentido propio y jurídico, sólo en el supuesto de que se haya exteriorizado conforme a derecho al cumplirse los presupuestos y requisitos exigidos por la ley para su plena y perfecta validez y eficacia -lo que presupone que no haya habido vicios del consentimiento ni haya aparecido un testamento cuya existencia se desconocía y que afecte a la vocación-delación del sucesor que repudió-. Sólo en este caso se puede hablar de verdadera y propia irrevocabilidad. Mientras que, si se dan, 
no sólo alguno de los casos del artículo 997, sino cualesquiera otros en que dicha declaración puede ser declarada ineficaz conforme a derecho al tenor de las diposiciones del Código Civil, aparte de que sería imperfecta porque no ha nacido de forma válida a la vida jurídica, no se puede decir por ello, en modo alguno, que la declaración del delado sea revocable, y sí, en cambio, susceptible de ser impugnada de forma diferente según el vicio o defecto de que adoleciere, ya como un supuesto de anulabilidad (art. 997 CC), ya de nulidad radical total y absoluta o de pleno derecho (art. $6.3 \mathrm{CC}$ ), pues difícilmente se puede revocar algo que incluso se puede llegar a decir que no ha llegado a nacer válidamente, en ningún momento, a la vida jurídica.

Por tanto, los dos supuestos que se tipifican en el artículo 997 CC, entendemos que no se pueden entender o interpretar como casos de excepción a la irrevocabilidad de la declaración del delado, sino que son supuestos que hacen que dicha declaración sea susceptible de ser impugnada con arreglo a la ley con distinto alcance y consecuencias porque es ineficaz al no haber nacido de forma válida a la vida jurídica.

VIGÉSIMO PRIMERA.- No obstante el tenor del artículo 997 CC, la aparición de un testamento del causante no siempre es causa o motivo de impugnación de la declaración del delado ya que, no solo dependerá de que por su contenido afecte a la vocación-delación del repudiante así como a aquello a que fue llamado y que a resultas de su declaración repudió, sino también de otras circunstancias que en cada caso hayan concurrido, como son: la validez del testamento, la fecha de su otorgamiento y de su aparición, así como el desconomiento de su existencia por parte del sucesor en el momento de repudiar y que su ignorancia no le sea imputable.

De ahí que, el automatismo de su ineficacia, o la relación de causa-efecto entre aparición e impugnación que de él parece desprenderse, no siempre se produce y, además, con distinto alcance y consecuencias según la clase y causa de ineficacia. 


\section{BIBLIOGRAFÍA ${ }^{1135}$}

ALBACAR LOPEZ, J.L., DE CASTRO GARCIA, J.:

- Comentarios al Código Civil. Doctrina y Jurisprudencia. Ed. TRIVIUM. Madrid. 1991.

ALBALADEJO GARCIA, M.:

- Anotaciones de Derecho español al Derecho de Sucesiones, Parte General, de CICU. Publicaciones del Real Colegio de España en Bolonia. 1964.

- "Comentario a la Sentencia del Tribunal Supremo de 27 de noviembre de 1992". CCJC. № 31. Enero-marzo 1993. Pág 73 y ss.

- Comentarios a los artículos 774 a 789 del Código Civil. En Comentario del Código Civil. Ministerio de Justicia. Secretaría General de Publicaciones. Madrid. 1993.

- Comentarios al Código Civil y Compilaciones Forales. T X. Vol 1º. Artículos 744 a 773 del Código Civil. EDERSA. Madrid. 1987.

- Comentarios al Código Civil y Compilaciones Forales. T XII. Vol 1‥ Artículos 858 a 891 del Código Civil. EDERSA. Madrid. 1981.

- Comentarios al Código Civil y Compilaciones Forales. T XIII. Vol 2ª . Artículos 981 a 987 del Código Civil. EDERSA. Madrid. 1981.

- Curso de Derecho Civil. T. V. Sucesiones. Librería Bosch. 1979-1980. Barcelona. 1982.

- Derecho civil. I. Introducción y parte general. Vol. 1: Introducción y derecho de la persona. Vol. 2: La relación, las cosas y los hechos jurídicos. Librería BOSCH. Barcelona. 1975.

- Desde el instante en que nace, todo niño es persona e inscribible en el Registro. EDERSA. Madrid. 1997.

- El negocio jurídico. BOSCH. Barcelona. 1958.

- "Invalidez de la declaración de voluntad". ADC. X 4. 1957.

- "La adquisición de la herencia en el derecho español". ADC. 1955.

- "La delación solidaria". Libro homenaje a Ramón Ma Roca Sastre. Vol. III. Junta de Decanos de Colegios Notariales. Madrid. 1977. Pág 275 y ss.

- "La repudiación de la herencia". AC no 36/3-9. Octubre 1994.

- "La sucesión iure transmissionis". ADC. 1952. Pág 5 y ss. Separata de: ADC. Tomo V, fasc. III, p. 912-971.

${ }^{1135}$ A continuación se hace mención de la bibliografía de las diferentes publicaciones nacionales y extranjeras que están relacionadas, directa o indirectamente, con las materias que se han tratado en esta tesis y que han sido objeto de consulta en su elaboración. 
- "Sucesor universal o heredero y sucesor particular o legatario". RDP. Sept 1978. Pág 737 y ss.

\section{ALBI AGERO:}

- "Derecho de acrecer entre herederos forzosos". RDP. 1942. Pág 114 y ss.

ALGABA ROS, S:

- Efecto de la desheredación. Edt. Tirant Lo Blanch. Monografías 250. Valencia. 2002

ALONSO PEREZ, M:

- "Estatuto jurídico del menor emancipado tras las recientes reformas del Derecho de familia". En La tutela de los derechos del menor. 1er Congreso nacional de Derecho Civil. Departamento de Derecho Civil de la Facultad de Derecho. Universidad de Córdoba. 1984. Pags 13 a 44.

\section{ALVAREZ VIGARAY:}

- "La distribución de toda la herencia en legados". RGLJ. Madrid. 1965. I.

\section{ALVAREZ-CAPEROCHIPI, J.A.:}

- Curso de derecho hereditario. $1^{\text {a }}$ Ed. Civitas. Madrid. 1980.

\section{ARMERO DELGADO, M.:}

- Testamentos y particiones: (doctrina, legislación, jurisprudencia y formularios). Tomo primero: Titulos sucesorios. Madrid. Instituto Editorial Reus. 1951.

\section{ASOCIACIÓN DE PROFESORES DE DERECHO CIVIL:}

- Derecho de Sucesiones. Presente y futuro. XII Jornadas de la Asociación de Profesores de Derecho Civil. Servicio de Publicaciones de la Universidad de Murcia. 2006.

ASUA GONZÁLEZ, C.I., y otros:

- Estudio sobre Derecho sucesorio Vasco. Bases para un nuevo régimen. Departamento de Derecho Civil. Servicio editorial. Universidad del Pais Vasco. 2011.

\section{ATTARD:}

- "Algunas consideraciones jurídicas que exige el desenvolvimiento técnico de nuestro sistema hipotecario" (Ensayo de construcción sistemática de las titularidades ob rem). RDP. 1924. 


\section{ATZERI-VACCA:}

- Delle rinunzie: secondo il Codice civile italiano: con ampia rivista di dottrina e giurisprudenza. Torino: Unione Tipografico-Editrice Torinese. 1915

AUBRY y RAU:

- Cours de Droit civil français. T IX. 5a ed. Paris 1917.

\section{AZZARITI y MARTÍNEZ:}

- Successioni per causa di morte e donazioni. 7. ed. Padova. CEDAM. 1979.

\section{BADOSA COLL, F:}

- "Incapacidad de consentir e incapacidad de contratar. (Un estudio sobre el artículo 1263 CC)". En Centenario del Código Civil. I. Asociación de profesores de Derecho Civil. Madrid. 1990. Pág 191 y ss.

\section{BALLESTER GINER, E.:}

- Derecho de sucesiones: aspecto civil y fiscal. EDERSA. Madrid. 1988.

\section{BARASSI:}

- Instituciones de Derecho civil. Vol 1. J. Ma Bosch Editor. Barcelona 1955.

- Le successioni per causa di morte. $3^{\mathrm{a}}$ Ed. Milano. 1947.

\section{BAS y RIVAS:} 1957

- "Herencia a favor del alma". Revista de Derecho español y americano. Mayo.

\section{BAUDRY-LACANTINERIE:}

- Traité theorique et pratique du Droit civil. Des successions. T II. $3^{\mathrm{a}}$ ed. Paris 1905.

BAYOD:

- La llamada aceptación de la herencia por los acreedores. Artículo 1001 del Código Civil. Ed Tecnos. Madrid. 1998.

\section{BEKKER:}

- System des heut. Pandektenrechts. Wiemar. 1886.

\section{BELLO JANEIRO, D:}

- Los pactos sucesorios en el derecho civil de Galicia. Editorial Montecorvo, S.A. Madrid. 2001 


\section{BELTRÁN DE HEREDIA:}

- "Naturaleza jurídica del acrecimiento hereditario". RDP. 1955.

\section{BERCOVITZ RODRIGUEZ-CANO, R:}

- Comentarios a las reformas del Derecho de Familia. Vols I y II. Ed. TECNOS. Madrid. 1984.

\section{BETTI:}

- Teoría general del negocio jurídico. Traducción y concordancias con el Derecho español por A. Martín Pérez. Editorial Revista de Derecho Privado. Madrid. 1959.

\section{BINDER, J:}

- Bürgerliches Recht, Erbrecht. Berlín. 1930. Traducción por Lacruz Berdejo con el título Derecho de Sucesiones. Barcelona. 1973.

\section{BIONDI:}

- Diritto ereditario romano. Parte generale. Milán. 1954.

- Sucesión testamentaria y donación. Barcelona. 1960.

\section{BONET RAMÓN:}

- Compendio de Derecho Civil. V. Derecho de Sucesiones. Madrid. 1965.

\section{BONFANTE:} 1979.

- Instituciones de Derecho romano. Traducción española. $5^{a}$ Ed. REUS. Madrid. 1926.

- La successio in universum ius e l'universitas. Scritti Guiridici varii. I. Torino.

\section{BORREL SOLER:} 1944

- Derecho civil de Cataluña. V. Sucesiones por causa de muerte. Barcelona.

\section{BORSARI:}

- Commentario del Codice civile italiano. Società I'Unione tipografico-editrice, 1871-1881. Torino.

\section{BOTANA GARCÍA:}

- "La mejora". Actualidad Civil. № 6. 2005. Pags. 719-746. 
CALVO MEIJIDE, A.:

- La posesión en el derecho hereditario. Tesis doctoral publicada en edición facsímil por el Servicio de Reprografía de la Editorial de la Universidad Complutense de Madrid. 1990.

\section{CAMARA LAPUENTE, S:}

- “¿Derecho Europeo de Sucesiones?. Un apunte”. Capítulo 41. Derecho Privado Europeo. Coordinador Sergio Cámara Lapuente. COLEX. Madrid. 2003.

\section{CAMY SANCHEZ-CAÑETE, B.:}

- Comentarios a la legislación hipotecaria. III. Inscripciones especiales abintestato; aceptación y repudiación de herencia. 3ª Ed. Pamplona. 1985.

\section{CANO MARTÍNEZ DE VELASCO, J.I.:}

- "La disponibilidad del derecho subjetivo". RDN. Enero-marzo 1985. Pág 55 y ss.

- La renuncia a los derechos. BOSCH. Casa Editorial. S.A. Barcelona. 1986.

CANO ZAMORANO, L. Ma

- "La acción de petición de herencia: Concepto, naturaleza, personas legitimadas activa y pasivamente". RCDI. 1981, II, nº 58.

CAPILLA RONCERO, LOPEZ y LOPEZ, ROCA i TRÍAS, y otros:

- Derecho de sucesiones. TIRANT LO BLANCH. Valencia 1992.

\section{CARIOTA FERRARA:}

- El negocio jurídico. Madrid. 1956.

- Il negozio giuridico nel diritto privato italiano. Napoli. Morano Editore. (¿?).

\section{CARRION, S:}

- "Aceptación tácita de la herencia. La petición de liquidación y el pago del impuesto sucesorio no significan aceptación tácita [Comentario a la STS (Sala $1^{\mathrm{a}}$ ) de 20 enero 1998 (RJ 1998, 57)]" RDP. Madrid. Diciembre 1999. Págs 877-892.

\section{CASADO IZQUIERDO, J.:}

- "La acción de petición de herencia". AC. n 11/11-17 marzo 1996.

\section{CASANUEVA SÁNCHEZ:}

- Las categorías de invalidez en los negocios jurídicos. Análisis dogmático y jurisprudencial. Universidad de Extremadura. Cáceres. 2002. 


\section{CASARES J.:}

- Diccionario Ideológico de la Lengua Española. 2a Ed. Gustavo Gili, S.A. Barcelona. 1975.

\section{CASTÁN TOBEÑAS, J:}

- Derecho Civil Español Común y Foral. T. VI. Vols 1, 2 y 3. REUS S.A. Madrid. 1978 y 1979.

- "El derecho de representación y mecanismos jurídicos afines en la sucesión testamentaria". RGLJ. Madrid. 1942. Pág 137 y ss.

- "El problema de la determinación del título de herencia". RGLJ. Madrid. 1959.

- "La concepción estructural de la herencia (Discurso de apertura de Tribunales)". RGLJ. Madrid. 1959.

- "La dogmática de la herencia y su crisis actual". RGLJ. Madrid. 1959. $2^{\circ}$ sem.

\section{CASTÁN VAZQUEZ, J.M.:}

- El derecho de sucesiones y las normas constitucionales. Estudios de derecho Civil en homenaje al Profesor José Luis Lacruz Berdejo. José $M^{a}$ Bosch Editor S.A. Barcelona. 1993. Pág 1141 y ss.

\section{CASTILLO TAMARIT:}

- "Reflexiones sobre la modificación del Código Civil en materia de patria potestad". RDN no 112. Abril-junio. 1981.

\section{CASTRO LUCINI, F.:} 1987.

- Temas de derecho sucesorio. Artes Gráficas Iberoamericanas S.A. Madrid.

\section{CAVANILLAS MÚGICA, S:}

- "La herencia no aceptada: apuntes de derecho comparado". En LibroHomenaje al profesor Manuel Albaladejo García. T I. Colegio de Registradores de la Propiedad y Mercantiles de España. Servicio de Publicaciones. Universidad de Murcia. 2004. Pág 1003 y ss

\section{CICU, A.:}

- Derecho de Sucesiones. Parte General. Anotaciones de Manuel Albaladejo. Publicaciones del Real Colegio de España en Bolonia. Ed. Bosch. 1964.

- Successioni per causa di morte (en el Trattato de CICU-MESSINEO). Parte General. 2 vols. Milano. 1954-1958.

\section{CLEMENTE DE DIEGO, F:}

- Curso elemental de Derecho civil español, común y foral. Madrid. 1923. 
- Instituciones de Derecho civil Español. T. III. Derecho de Sucesiones. Derecho hereditario. Madrid. 1932. (nueva edición revisada y puesta al día por COSSIO y GULLÓN. Madrid. 1959).

COCA PAYERAS, M.:

- Comentario a los artículos 430 a 445 CC, en Comentario del Código Civil. Ministerio de Justicia. Secretaría General de Publicaciones. Madrid. 1993.

COMPORTI, M.

- "Considerazioni conclusive e prospettive di riforma legislativa". En La trasmissione familiare della richezza. Limiti e prospettive di riforma del diritto successorio. CEDAM. Padua. 1995.

\section{CRISTOBAL MONTES, A:}

- Estudios de derecho de sucesiones. Mira Editores. Zaragoza. 1987.

- "La renuncia a la legítima en el Derecho Civil Aragonés". RCDI. 1980 Pág 9

- La vía subrogatoria. TECNOS. Madrid. 1995.

- "Naturaleza jurídica de la aceptación por los acreedores de la herencia renunciada en su perjuicio por el deudor". En, Estudios de Derecho Civil en honor del profesor Castán Tobeñas. T IV. Pamplona 1969. Pág 255 y ss. También en: en Anales de la Academia Matritense del Notariado. 1976, 21.

\section{COLIN y CAPITANT:}

- Curso elemental de derecho civil. Con notas sobre el derecho civil español por Demófilo de Buen. Madrid. Reus. 1927.

COSSÍO y CORRAL, A:

- Lecciones de Derecho Hipotecario. Bosch. Barcelona. 1945.

D'AVANZO, W:

- Delle successioni. (2 Tomos). Firenze. 1941.

\section{D'ORS:}

- "El interdicto fraudatorio en el derecho romano clásico". CSIC. Roma-Madrid. 1974.

DE CASTRO y BRAVO, F:

- Derecho Civil de España. Ed. CIVITAS. Madrid. 1984.

- El negocio jurídico. Ed. CIVITAS. Madrid. 1985. Edición facsímil de la edición original publicada en el año 1971 por el Instituto Nacional de Estudios Jurídicos. 
- "La acción pauliana y la responsabilidad patrimonial. Estudio de los arts. 1911 y 1111 del Código Civil", RDP. 1932.

DE GASPERI, L.:

- Tratado de Derecho Hereditario. Tomo I. Parte General. Tipografía Editora Argentina. Buenos Aires. 1953.

DE LA CAMARA ALVAREZ, M:

- Compendio de derecho sucesorio. La Ley. Madrid. 1990.

- El derecho de representación en la herencia testada y la preterición de herederos forzosos (En torno a la sentencia de 6 de diciembre de 1952). RDN. 1955-1. Pág 7 y ss.

DE LOS MOZOS y DE LOS MOZOS, J L:

- El negocio jurídico. Ed. MONTECORVO. Madrid. 1987

- "Inexistencia, nulidad y anulabilidad en el Anteproyecto de Código europeo de contratos de la Academia de Pavía". En Libro-Homenaje al profesor Manuel Albaladejo García. T II. Colegio de Registradores de la Propiedad y Mercantiles de España. Servicio de Publicaciones. Universidad de Murcia. 2004. Pág 3409 y ss.

DE LOS MOZOS y TOUYA, A. Ma:

- "La anotación preventiva del derecho hereditario". RCDI 1982. Pág 1423 y ss.

DE PALO:

- De revocatoria per frode nei resentí studii civilisciti. Filangieri. 1899.

DEL ARCO TORRES, PONS GONZALEZ:

- Diccionario de Derecho Civil. Ed. Aranzadi. 1984.

DEL MORAL Y DE LUNA, A.:

- "Hacia el heredero limitadamente responsable". AAMN. Tomo nº 7. Año 1953.

\section{DELGADO ECHEVERRIA, J:}

- "El concepto de validez de los actos jurídicos en Derecho privado. (Notas de teoría y dogmática)". ADC. Tomo LVIII. Fascículo I. Enero-marzo 2005. Págs 9 a 74.

- "Una propuesta de política del Derecho en materia de sucesiones por causa de muerte". En Derecho de Sucesiones. Presente y futuro. XII Jornadas de la Asociación de Profesores de Derecho Civil. Servicio de Publicaciones de la Universidad de Murcia. 2006. Pág 13 y ss. 


\section{DELGADO ECHEVERRIA, PARRA LUCÁN:}

- Las nulidades de los contratos. Dykinson S.L. Madrid. 2005.

\section{DEMOLOMBE:}

- Cours de code Napoleón. Bruxelles: Meline, Cans et Compagnie 1847.

- Traité des successions. T III. Paris 1859.

\section{DIAZ CRUZ:}

- Los legados. Instituto Editorial REUS. Madrid. 1951.

\section{DÍEZ-PICAZO, L.:}

- "Eficacia e ineficacia del negocio jurídico". ADC. XIV, 4. 1961.

- Fundamentos de Derecho Civil Patrimonial. Vols I y II. Ed. CIVITAS. Madrid 1996.

- "La aceptación de la herencia por los acreedores del heredero". ADC. XII 1 1959. Pág 127 y ss. 1967.

- Lecciones de Derecho Civil. Facultad de Derecho. Universidad de Valencia.

\section{DIEZ-PICAZO, L.; GULLÓN BALLESTEROS, A.:}

- Instituciones de Derecho Civil. Vol II. Ed. TECNOS S.A. Madrid. 1995.

- Sistema de Derecho Civil. Vol. I. Ed. TECNOS S.A. Madrid. 1997. 9ª Edición.

- Sistema de Derecho Civil. Vol. II. Ed. TECNOS S.A. Madrid. 2001. 9a Edición.

- Sistema de Derecho Civil. Vol. IV. Derecho de Familia. Derecho de Sucesiones. Ed. TECNOS S.A. Madrid. 1997. $7^{\text {a }}$ Edición.

DOMINGUEZ REYES, J.F.:

- "Vocación y delación de la herencia". RCDI. Julio-agosto 2000. № 660. Pág 2279 y ss.

DORAL:

- "Titularidad y patrimonio hereditario". ADC. 1973.

DORAL, DEL ARCO:

- El negocio jurídico. Ed TRIVIUM. Madrid. 1982.

EGEA I FERNÁNDEZ, J y FERRER RIBA, J (directores):

- Comentaris al Codi de Familia, a la Llei d'unions estables de parella i a la Llei de situacions convivencials d'ajuda mútua. Ed. TECNOS. Madrid. 2000. 
ENNECCERUS-KIPP-WOLFF:

- Tratado de Derecho Civil. Tomo V. Vols $1^{\circ}$ y $2^{\circ}$. BOSCH, Casa Editorial S.A. Barcelona. 1976.

ESPÍN CÁNOVAS, D:

- La adquisición de la posesión inmaterial en el derecho español. Seminario de Derecho Civil de la Universidad de Salamanca. 1965.

- Manual de Derecho civil español. Vol. V. EDERSA. Madrid. 1978.

ESPINAR LAFUENTE:

- La herencia legal y el testamento. Barcelona. 1956.

FADDA:

- Concetti fondamentali del Diritto romano. I. Nápoles. 1900.

\section{FALCÓN:}

- El Derecho Civil español común y foral. T. III. 6ª Ed. Barcelona. 1902.

FERNANDEZ ARROYO, M.:

- La acción de petición de herencia y el heredero aparente. Ed. Bosch. Barcelona. 1992.

\section{FERNÁNDEZ LOPEZ:}

- "Los procesos de incapacitación". En La personalitat civil. Segones Jornades Jurídiques de Lleida. Barcelona. 1984.

- Derecho procesal civil. IV. Barcelona. 1988.

\section{FERRANDIS VILELLA, J:}

- La comunidad hereditaria. BOSCH. Barcelona. 1954.

\section{FERRANDO BUNDIO, R.:}

- Todo sobre los derechos y deberes de los herederos. Colección Legal De Vecchi. 1986. Barcelona. Barcelona.

- Todo sobre sucesiones y testamentos. Colección Legal De Vecchi. 1985.

\section{FERRARA:}

- "Estudio sobre la sucesión a título universal y particular con especial aplicación a la legislación española". RDP 1923.

- Le successioni per causa di morte. 1955. 
FERRI, L:

- Rinunzia e rifiuto nel diritto privato. Milano: A. Giuffrè. 1960

FERRINI: 1889.

- Teoría generali dei legati e die fedecommessi secondo il Diritto romano. Milán.

- Manuale di Pandette. Milán. 1908.

FLORENSA I TOMÁS, C:

- "La naturaleza del procedimiento previsto en los artículos 1001 del Código Civil y 23 del Codi de Successions per Causa de Mort en el Dret Civil de Catalunya: la legitimación subrogatoria concedida al acreedor del repudiante" (I y II). REVISTA LA LEY, AÑO XXI. Números 5182 y 5183, de los días 13 y 14 de noviembre de 2000.

\section{FONT SEGURA, A:}

- "La sucesión hereditaria en Derecho interregional". ADC. Tomo LIII. Fascículo I: Enero-marzo 2000. Págs 23 a 81.

\section{FUENMAYOR:}

- "Estirpe única y representación hereditaria." Revista de Estudios Jurídicos. No 2. Octubre. 1942.

- "Intangibilidad de la legítima". ADC. 1948.

\section{GALGANO:}

- El negocio jurídico. Tirant lo Blanch. Valencia. 1992.

\section{GALVÁN GALLEGOS, A.:}

- "El destino de la herencia repudiada". RDP. Octubre. 1995. Pág 899 y ss.

- La herencia: contenido y adquisición. La aceptación y repudiación de la herencia. Madrid: La Ley-Actualidad. Madrid. 2000.

- "La indivisibilidad de la aceptación y repudiación de la herencia". ADC. Tomo L. Fascículo IV. 1997 Pág 1817 y ss.

- "Los plazos para repudiar la herencia". AC. n²0/15-21. Mayo 1995.

GANGI:

- I legati nel diritto civile italiano con riguardo alla giurisprudenza, al diritto romano ed alle moderne legislación. Parte generale. Vol 1. $2^{\mathrm{a}}$ Ed. Padova. CEDAM. 1933.

GARCÍA GARCÍA, J M:

- La sucesión por derecho de transmisión. Ed CIVITAS. Madrid. 1996. 
GARCIA GARNICA, M ${ }^{\mathrm{a}} \mathrm{C}$ :

- El ejercicio de los derechos de la personalidad del menor no emancipado. Aranzadi. Cizur Menor (Navarra). 2004

GARCIA GOYENA, F:

- Concordancias, motivos y comentarios del Código Civil español. Ed. BASE. Barcelona. 1973.

\section{GARCIA GRANERO:}

- "Estudio dogmático sobre la mejora y el tercio de mejora". RDP. 1942 (apartado IV, B, titulado El derecho de acrecer en la mejora) pág 824 y ss.

GARCÍA RUBIO, M ${ }^{\mathrm{a}} \mathrm{P}$ ::

- La distribución de toda la herencia en legados (un supuesto de herencia sin heredero). Universidad de León. Servicio de Publicaciones. Ed. CIVITAS S.A. 1989.

\section{GARCÍA SÁNCHEZ, J A:}

- "Las instituciones sucesorias". El Notario del siglo XXI. Revista on line del Colegio Notarial de Madrid. Marzo-abril de 2009. № 24.

\section{GARCIA VALDECASAS, G.:}

- "De nuevo sobre la adquisición de la herencia". RDP. T. XXXV. 1951. Pag. 991 y ss.

- "La adquisición de la herencia en el derecho español". RDP. 1944. Pag. 89 y ss. 1953.

- "La comunidad hereditaria en el Derecho español". AAMN. Tomo no 7. Año GARCIA-BERNARDO LANDETA, A.:

- "Designación "mortis causa", vocación hereditaria y adquisición automática". $R D N n^{\circ}$ XXIV. Abril-junio 1959.

GARCÍA-GALLO, A.:

- "El problema de la sucesión mortis causa en la alta Edad Media española". AAMN Tomo X. Año 1959.

GARCIA-RIPOLL MONTIJANO, M:

- La protección civil del enfermo mental no incapacitado. José María Bosch. Editor S.A. Barcelona. 1992. 


\section{GETE ALONSO y CALERA:}

- Comentarios al Código Civil y Compilaciones Forales. T XXIX. Vol $3^{\circ}$. Ed. EDERSA. Madrid. 1986.

- La nueva normativa en materia de capacidad de obrar de la persona. Ed. CIVITAS. Madrid. 1985.

- La nueva regulación de la filiación en el Derecho Catalán. Ed. Tirant lo Blanch. Valencia. 1992.

- Determinación de la filiación en el código de familia de Catalunya. Ed. Tirant lo Blanch $n^{\circ}$ 59. Valencia. 2003.

\section{GIMENEZ ARNAU:}

- "El derecho de representación en la sucesión voluntaria". RCDI. 1940. Pág 20 y SS.

\section{GITRAMA GONZÁLEZ. M:}

- Comentarios al Código Civil y Compilaciones Forales. (Art 988 a 1034 CC). T XIV. Vol $1^{\circ}$. EDERSA. Madrid. 1989.

- "La administración de herencia en el derecho español". EDERSA. 1950.

- "Los supuestos de administración de la herencia". RDP. Madrid. 1948.

GOMEZ DE LA ESCALERA, C:

- La nulidad parcial del contrato. Colección Doctrina y Jurisprudencia. Actualidad Editorial S.A. Madrid. 1995.

GOMEZ LAPLAZA, M ${ }^{\mathrm{a}} \mathrm{C}$ :

- Comentario al artículo 1263 del Código Civil, en Comentarios al Código Civil y Compilaciones Forales. T XVII. Vol 1-B. EDERSA. Madrid. 1993. Pág 155 y ss.

GONZALEZ COLLADO, S:

- "El legitimario no es sucesor". AAMN. T $\mathrm{n}^{\circ}$ 3. Año 1946. Instituto Editorial REUS. Madrid.

\section{GONZALEZ PACANOWSKA, I:}

- Comentario a los artículos 912 a 955 del Código Civil, en Jurisprudencia civil comentada (Tomo I). Dirección: Pasquau Liaño. Ed. COMARES. Granada. 2000. Pág 1605 y ss.

- El legado de cosa ajena. (Estudio sobre las disposiciones "mortis causa" a título singular en el Código civil). Madrid. Ed. Montecorvo. 1985.

GONZALEZ PALOMINO:

- "El acrecimiento en la mejora". AAMN. II. 1950. Pág 513. 
GORDILLO CAÑAS, A: 1986

- Capacidad, incapacidades y estabilidad en los contratos. Ed TECNOS Madrid.

- Comentarios a los artículos 766 a 773 del Código Civil. En Comentario del Código Civil. Ministerio de Justicia. Secretaría General de Publicaciones. Madrid. 1993.

- "Nulidad, anulabilidad e inexistencia. (El sistema de las nulidades en un Código latino situado entre la primera y la segunda Codificación)". Centenario del Código Civil. T I. Asociación de profesores de Derecho Civil. Editorial Centro de Estudios Ramón Areces. Madrid. 1990. Pág 935 y ss.

GUASP:

- Derecho procesal civil. T II. $3^{\text {a }}$ ed. Madrid. 1977.

GUILARTE ZAPATERO:

- Comentarios al Código Civil y Compilaciones Forales. T XIII. Vol 1². Artículos 912 a 958. EDERSA. Madrid. 1989.

\section{GUTIERREZ JEREZ, L.J.:}

- "La adquisición y la renuncia de los legados". En Libro-Homenaje al profesor Manuel Albaladejo García. T I. Colegio de Registradores de la Propiedad y Mercantiles de España. Servicio de Publicaciones. Universidad de Murcia. 2004. Pág 2317 y ss.

HERNANDEZ DÍAZ-AMBRONA, Mª D.:

- "Algunos aspectos sobre la herencia yacente". RDP. Junio. 2002. Pág 460 y ss.

- La herencia yacente. Biblioteca de Derecho Privado n 61. J M ${ }^{a}$ Bosch Editor S.A. Barcelona. 1995

HERNANDEZ GIL, A: Madrid. 1969.

- Lecciones de Derecho sucesorio (resumen de explicaciones de Cátedra).

- La posesión. Ed. CIVITAS. Madrid. 1980.

HERNANDEZ VALDEOLMILLOS, G.:

- "La transmisión del ius delationis". Libro Homenaje a Juan B. Vallet de Goytisolo. Junta de Decanos de los Colegios Notariales de España. Vol IV. Madrid. 1988. Pág 465 y ss.

\section{IGLESIAS SANTOS, J:}

- Derecho Romano. Instituciones de Derecho Privado. ARIEL. Barcelona. 1972.

- "La herencia en el derecho romano y en el derecho moderno". AAMN. T no 6. Año 1952. Instituto Editorial REUS. Madrid. 
IMAZ ZUBIAUR:

- La sucesión paccionada en el Derecho Civil Vasco. Monográficos "La Notaría". $N^{0}$ 6. Col-legi de Notaris de Catalunya. Marcial Pons. Madrid-Barcelona 2006.

JORDANO FRAGA, F:

- Ausencia total de consentimiento, interpretación e ineficacia contractuales. Madrid. 1988.

- Falta absoluta de consentimiento, interpretación e ineficacia contractuales. Studia Albornotiana. LII. Publicaciones del Real Colegio de España. Bolonia. 1988.

- "La capacidad general del menor". RDP. 1984. Págs 883 a 904.

- La sucesión en el "ius delationis": una contribución al estudio en la adquisición sucesoria "mortis causa". Ed. CIVITAS. Madrid. 1990.

- Los acreedores del llamado a una sucesión mortis causa, ante el ejercicio por éste del ius delationis. Colegio de Registradores de la Propiedad y Mercantiles de España. Centro de Estudios Registrales. Madrid. 1996.

\section{JÖRS-KUNKEL:}

- Derecho privado romano. Traducción de Prieto Castro. Barcelona. 1937. Sexta parte. Derecho hereditario.

JOU I MIRABENT, L (coord.):

- Comentarios al Código de Sucesiones de Cataluña: Ley 40/1991, de 30 de diciembre. BOSCH. Casa Editorial. Barcelona. 1994.

KASER, M:

- Das römenische Privatrecht. Munich. I 1955, y II 1959.

\section{LACA FUENTES, P.:}

- "El derecho de acrecer entre herederos forzosos". RCDI. 1931. Pag. 260.

- "Herederos y legitimarios". RCDI. 1948. Pág. 455. Pág 577.

- "La prohibición de dividir la herencia en nuestro derecho positivo". RCDI. 1931. 826.

- "Las expectativas de derechos y los derechos expectantes". RCDI. 1931. Pág

- Un caso de aplicación del art. 811 del Código Civil. 1932. Pág. 577.

LACAL:

- "El derecho de acrecer entre los herederos forzosos". RCDI. 1931. Pág 260 y SS. 


\section{LACOSTE, J.:}

- La mejora: su origen y desenvolvimiento en el Derecho español. Su comparación con las instituciones similares del derecho extranjero. Hijos de Reus, Editores. Madrid. 1913.

LACRUZ, ALBALADEJO:

- Derecho de sucesiones. Parte General. Librería Bosch. Barcelona. 1961.

\section{LACRUZ BERDEJO, J.L.:}

- "Condición universal o particular de la sucesión en el usufructo de la herencia". RCDI. 1985. Págs 269 a 287. También en Estudios de Derecho Privado Común y Foral. Tomo II. Centro de Estudios Registrales. Barcelona. 1992. Pág 365 y ss. 191.

- "La responsabilidad del heredero en el Código civil". RCDI. 1961. № 34. Pág

- Notas al "Derecho de Sucesiones" de Binder. Ed. LABOR. Barcelona. 1953.

- Sucesión universal e institución de heredero en la Historia y en el Derecho Comparado. Estudios de Derecho Civil. BOSCH Casa Editorial. Barcelona. 1958. Pág 569 y ss.

- "Sucesión universal, sucesión a título de heredero y designación del heredero". RDN. XXXII. Abril-junio 1961. Pág 41 y ss.

LACRUZ BERDEJO, J.L. y SANCHO REBULLIDA, F:

- Derecho de Sucesiones. I. Parte general. Librería Bosch. Barcelona. 1971.

- Elementos de Derecho Civil. T. V. Derecho de sucesiones. $5^{\mathrm{a}}$ Ed. José $\mathrm{M}^{\mathrm{a}}$ Bosch Editor. S.A. Barcelona. 1993.

LACRUZ BERDEJO, SANCHO REBULLIDA, LUNA SERRANO y otros:

- Elementos de Derecho Civil. T. V. Sucesiones. Ed. DYKINSON. Madrid. 2001.

LASARTE ALVAREZ, C:

- Curso de Derecho Civil Patrimonial. Introducción al Derecho. 6a Edición. Ed. TECNOS S.A. Madrid. 1995.

- Principios de Derecho Civil. Tomo Séptimo. Derecho de Sucesiones. Ed. TRIVIUM. Madrid. 2001.

LELEU, Y, U:

- "Necesité et moyens d'une armonization des régles de transmission successoriale en Europe". ERPL. 6 (1998). Págs 159-193.

LOPEZ BELTRAN DE HEREDIA, C:

- La nulidad contractual. Consecuencias. Tirant lo Blanch. Valencia. 1995. 
LOPEZ PEREZ, J:

- "Reglas de capacidad personal en la aceptación, repudiación y partición de la herencia". AC. 1999. Junio 21-27; (25) Págs 667-691.

LOPEZ SAN LUIS, R:

- La capacidad contractual del menor. Madrid. Dykinson, 2001.

LOPEZ-MEDEL BASCONES, J:

- "La nueva Ley de Fundaciones". Diario LA LEY. Año XXIV. Número 5725, de 24 de febrero de 2003.

LOUZAO: 1913-1914.

- "Aceptación y repudiación de la herencia por los hijos menores de edad". RDP.

\section{LLAMAS Y MOLINA:}

- Comentario crítico-jurídico-literal a las Ochenta y tres Leyes de Toro. Banchs Editor. Barcelona. 1974.

\section{LLEDÓ YAGÜE, F.:}

- Derecho de Sucesiones. Universidad de Deusto. Bilbao. 1991.

\section{MAIERINI-GIORGI:}

- Della revoca degli atti fraudolenti fatti dal debitore in pregiudizio. Firenze: Eugenio e Filippo Cammelli, 1874.

- Della revoca degli atti fraudolenti: fatti dal debitore in pregiudizio dei creditori. Con note dell'avv. Giorgio Giorgi. Firenze: Casa Editrice Libraria "Fratelli Cammelli". 1898.

\section{MALDONADO y FERNÁNDEZ DEL TORCO:}

- "Herencias a favor del alma en el Derecho español". RDP. Madrid. 1944.

\section{MALLET:}

- La renonciation à succession. Paris 1931.

MANRESA y NAVARRO, J.M.:

- Comentarios al Código Civil español. T. V. (arts 609 a 743) 6ª Ed. Corregida, aumentada y puesta al día por P. MARÍN PÉREZ. Instituto Editorial REUS. Madrid. 1951

- Comentarios al Código Civil español. T. VI. (arts 743 a 911) $7^{\text {a }}$ Ed. Revisada y puesta al día por OGAYAR Y AYLLÓN. Instituto Editorial REUS. Madrid. 1951 
- Comentarios al Código Civil español. T. VII (arts 912 a 1087). 6ª Ed. Revisada por BONET RAMÓN. Instituto Editorial REUS. Madrid. 1943.

MARTÍ Y MIRALLES, J.:

- Principios del Derecho Sucesorio. Aplicados a fórmulas de usufructo vidual y de herencia vitalicia. Instituto Nacional de Estudios Jurídicos. Madrid. 1.964

MARTÍN BLANCO:

- "La adquisición de la herencia en el Código Civil español”. RGLJ. 1956. Pág 45.

MARTÍN PÉREZ, J. A.:

- Comentario a diversos artículos del Código Civil, en Jurisprudencia civil comentada (Tomo I). Dirección: Pasquau Liaño. Ed. COMARES. Granada. 2000.

\section{MARTÍN-GRANIZO FERNÁNDEZ, M:}

- La incapacitación y figuras afines. Ed COLEX. Madrid. 1987.

MARTÍNEZ CALCERRADA, L:

- La representación en el derecho sucesorio. Ed. Aranzadi. Pamplona. 1966.

MARTÍNEZ DE AGUIRRE Y ALDAZ, C.:

- Preterición de derecho de representación en el artículo 814,3 del Código Civil. $1^{\text {a }}$ Ed. CIVITAS. Madrid. 1991.

MARTÍNEZ PAZ, E:

- Introducción al Derecho de la Sucesión Hereditaria. Tipografía Editora Argentina. Buenos Aires. 1953.

\section{MARTÍNEZ PEREDA:}

- "Reflexiones jurídicas sobre la llamada sucesión a favor del alma". AAMN. 1953. Págs 151 a 189.

MARTY, G; RAYNAUD, P:

- Droit Civil. Les successions et les libéralités. Éditions. SIREY. Paris. 1.983.

\section{MENDEZ APENELA:}

- "Evolución histórica de la emancipación en el Derecho español". RDN. Abriljunio. 1.971

- "La capacidad del menor emancipado mayor de dieciocho años". RDN. Tomo no 83. Año 1974. 
- "El complemento de capacidad del menor y la ineficacia de sus actos". RDN. Año 1975-1.

MERINO Y HERNÁNDEZ, J. L.: 1397.

- La renuncia al derecho expectante de viudedad aragonés. RCDI. 1976. Pág

\section{MESSINEO:}

- Derecho civil y comercial. Traducción española de SENTíS. Buenos Aires. 1971

\section{MEZQUITA GARCÍA-GRANERO, E:}

- Comentarios a los artículos 16 a 37 del Código de Sucesiones de Cataluña, en Comentarios al Código de Sucesiones de Cataluña: Ley 40/1991, de 30 de diciembre. BOSCH. Casa Editorial. Barcelona. 1994.

\section{MONSERRAT VALERO, A.:}

- "La sucesión "iure transmissionis", el concurso de delaciones en un mismo heredero y el impuesto de sucesiones". RCDI. Año LXX. Mayo-junio 1.994. № 662. Pág 1037 y ss.

\section{MORALES MORENO, A.M:}

- Comentario a los artículos 1263 y 1264 del Código Civil, en Comentario del Código Civil. T II. Ministerio de Justicia. Madrid. 1993.

- Comentario al artículo 1265 del Código Civil, en Comentarios al Código civil y Compilaciones forales. $2^{\mathrm{a}}$ ed. EDERSA. Madrid. 1993. T. XVII. Vol $1^{\circ}$ B. Pág. 210 y ss.

\section{MORELL:}

- “¿Heredan los nietos por representación en caso de renuncia del padre?". RGLJ. Tomo 107. Año 1905. Pág 340 y ss.

\section{NADAL OLLER, N:}

- La incapacitación: comentarios al Título IX del Libro I del Código Civil, según redactado de la Ley 13/83 de 24 de octubre y Ley Orgánica 1/1996, de 15 de enero. Barcelona. Bosch, 1999.

\section{NICOLO:}

- La vocazione ereditaria diretta e indiretta. Annali Messina. 1934.

\section{NOVOA SEOANE:}

- El derecho de representación según el Código Civil. Antinomias aparentes. RDP. 1914. Pág 143 y ss 
- "La repudiación y la renuncia de la herencia". RDP. 1919.

NUÑEZ LAGOS, R:

- "El derecho sucesorio ante la tradición española y el Código Civil". RGLJ. T. XXI. Madrid. 1951.

O'CALLAGHAN MUÑOZ, X:

- Comentario del Código Civil. Secretaría General técnica del Ministerio de Justicia. Madrid. 1993.

- Compendio de Derecho Civil. T. V. Sucesiones. EDERSA Madrid. 1987.

- "La renuncia a la legítima". Libro homenaje a Roca Sastre. Junta de Decanos de los Colegios Notariales de España. T. III. Madrid. 1977. Pág 311 y ss.

ORTEGA PARDO:

- "Heredero testamentario y heredero forzoso". ADC. III-2.

\section{OSSORIO MORALES, J.:}

- Comentarios al Código Civil y Compilaciones Forales. T XII. Vol $1^{\circ}$ Arts 858 a 891 del Código Civil. EDERSA. Madrid. 1981.

- "El legado de parte alícuota. (En torno a la distinción entre heredero y legatario)". Boletín de la Universidad de Granada. 1940. También en, Estudios de Derecho Privado. BOSCH Casa Editorial. Barcelona. 1942. Pág 115 y ss.

- Manual de Sucesión Testada. Instituto de Estudios Políticos. Madrid. 1957.

OURLIAC y DE MALEFOSSE:

- Histoire du Droit privé. III. París. Presses universitaires de France, 1968.

PACCHIONI, G:

- Manual de Derecho Romano. Traducción de Isidoro Martín Martínez y Antonio Reverte Moreno. Librería Santaren. Valladolid. 1942. 1927

- Trattato delle obbligazioni secondo il diritto civile italiano. Fratelli Bocca. Torino.

\section{PANZA, GIUSEPPE y FABRICIO:}

- Successioni in generale tra codice civile e Costituzione, en el Trattato di diritto civile del Consiglio Nazionale del Notariato. VIII. 2. Edizioni Scientifiche Italiane. Nápoles. 2004.

\section{PARRA LUCAN:}

- "Las anomalías del contrato: invalidez e ineficacia en el anteproyecto de Código Europeo de Contratos. Estudio comparado con el Derecho español (Aproximación a la 
Sección 1 del Título XI de la Parte General del Código Europeo de Contratos)". ADC. 2004. Vol 57. № 2. Págs 549 a 637.

PASQUAU LIAÑO, M:

- Nulidad y anulabilidad del contrato. Ed CIVITAS. Madrid. 1996.

- Comentario a los artículos 1258 a 1270 del Código Civil, en Jurisprudencia civil comentada (Tomo I). Dirección: Pasquau Liaño. Ed. COMARES. Granada. 2000.

\section{PASSARELLI, S:}

- Vocazzione legale all'eredità. 1940.

- Vocazzione legale e testamentaria. Rivista di Diritto civile. 1943.

\section{PEÑA Y BERNALDO DE QUIROS:}

- "La herencia y las deudas del causante". En Tratado práctico y crítico de Derecho civil. T LXI, La herencia. Vol I. Madrid. 1967.

PEREZ DE CASTRO, N:

- El menor emancipado. Ed. TECNOS. Madrid. 1988

\section{PEREZ PASCUAL:}

- "El artículo 768 del Código Civil. La institución de heredero en una cosa cierta y

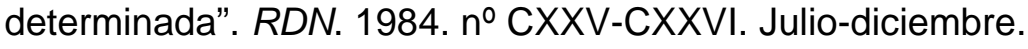

PEREZ SAUQUILLO, G: Año 1952.

- "Responsabilidad del heredero respecto de los legados". AAMN. Tomo $\mathrm{n}^{\circ} 6$.

\section{PEROZZI:}

- Istitucioni di Diritto romano. $2^{\mathrm{a}} \mathrm{ed}$. Tomo II. Roma. 1.928.

PRADA GONZÁLEZ, J.M.:

- "La patria potestad tras la reforma del Código Civil". AAMN. T. XXV. Pág 413.

PRIETO CASTRO y FERRANDIZ, L:

- Tratado de Derecho Procesal Civil. II. 2a Ed. Pamplona. 1985.

PUIG BRUTAU, J.:

- Fundamentos de Derecho Civil. T. V. Vols $1^{\circ}, 2^{\circ}$ y $3^{\circ} .3^{a}$ Ed. Bosch, Casa editorial, S. A. Barcelona. 1984. 
PUIG FERRIOL, L:

- "Les bases del nou Codi de Successions", en Setenes Jornades de Dret Català a Tossa. El nou dret successori de Catalunya, Barcelona, 1994.

PUIG FERRIOL L., ROCA TRÍAS E.:

- Fundamentos del Derecho Civil de Cataluña. T. III/10 y $2^{\circ}$. Derecho sucesorio catalán. Bosch. Casa Editorial, S.A. Barcelona. 1979.

REGLERO CAMPOS, F:

- Comentario a los artículos 744 a 773 del Código Civil, en Jurisprudencia civil comentada (Tomo I). Dirección: Pasquau Liaño. Ed. COMARES. Granada. 2000

RIVAS MARTINEZ, J.J:

- Derecho de Sucesiones Común y Foral. DYKINSON. Madrid. 1987.

ROAN MARTÍNEZ:

- "Texto refundido de la Ley Hipotecaria de 8 de febrero de 1946". RDP. XXX.

ROCA SASTRE, R. M ${ }^{\mathrm{a}}$ :

- Anotaciones al Derecho de Sucesiones de Kipp. Tomo V. Vols $1^{\circ}$ y $2^{\circ}$. BOSCH. Casa Editorial S.A. Barcelona. 10ª Ed. 1976.

- "Crítica institucional del Código Civil". RCDI. 1940.

- Derecho Hipotecario. T I y II. Ed. BOSCH. Barcelona.

- "El derecho de transmisión" Estudios de Derecho privado. Vol II. Sucesiones. Madrid. 1948. Pág 294 y ss.

- "El derecho de representación en la sucesión testada". Estudios de Derecho privado. II. Madrid. 1948. Pág 259 y ss

- "La adquisición hereditaria en el derecho comparado" XXV. Estudios sobre sucesiones. T. I. Madrid. 1981. Publicado también en Revista del Instituto de Derecho Comparado. № 1. Julio-diciembre de 1953. Págs 61 a 87.

- "La adquisición y la repudiación de la herencia en el derecho común y en el derecho foral". Estudios de Derecho Privado. Vol II. Sucesiones. RDP. Madrid. 1948. Pág 1 y ss.

- "La adquisición hereditaria de la posesión". RGLJ. Número extraordinario. Año 1953. Págs 333 a 387.

- "La designación, la vocación y la delación sucesorias". Estudios sobre Sucesiones. Tomo I. Madrid. Instituto de España. 1981.

- La sustitución fideicomisaria en el Derecho común y en el Derecho foral. Estudios de Derecho privado. Vol II. Sucesiones. Madrid. 1.948. Pág 29 y ss.

- "Observaciones críticas sobre la tendencia expansionista del derecho de representación sucesoria". RGLJ. 1943. Pág 581 y ss. 
- "Problemática de la Ciencia del Derecho". Libro Homenaje al Profesor José $M^{a}$ Pi Suñer. Editorial BOSCH. Barcelona. 1962. Págs 735 a 770.

ROCA-SASTRE MUNCUNILL, L.:

- Derecho de Sucesiones. T. I. 1989. T. II. 1991. T. III. 1994. Bosch. Casa Editorial S.A. Barcelona.

ROGEL VIDE, C.:

- "Renuncia y repudiación de la herencia". RGLJ. T II. 1980. Pags 221 y ss, y 323 y ss.

- Renuncia y repudiación de la herencia. Colección Derecho español contemporáneo. Editorial REUS. Madrid. 2011

\section{ROMERO CERDEIRIÑA, A:}

- "En torno al concepto del derecho hereditario. La última moda". AAMN. Tomo $n^{\circ}$ 5. Año 1950. Instituto Editorial REUS. Madrid.

\section{ROMERO COLOMA, A. M.:}

- "En torno a la problemática de la herencia yacente". RCDI. Año LXXIII. Nov-Dic. 1997. N 643. Pág 2217 y ss.

\section{ROSSI:}

- Della renuncia alla ereditá in danno dei creditori. Pisa. 1872.

ROVIRA JAÉN, F. J.:

- "En torno a las deudas de la herencia". RCDI. 1969. Pág 1573.

\section{ROYO MARTÍNEZ:}

- Exposición elemental del Derecho civil español: Derecho sucesorio "mortis causa". Sevilla. 1951.

\section{SÁNCHEZ ARISTI, R:}

- Dos alternativas a la sucesión testamentaria: pactos sucesorios y contratos post mortem. Editorial Comares. Granada 2003.

- "Propuesta para una reforma del Código Civil en materia de pactos sucesorios". En Derecho de Sucesiones. Presente y futuro. XII Jornadas de la Asociación de Profesores de Derecho Civil. Servicio de Publicaciones de la Universidad de Murcia. 2006. Pág 477 y ss. 


\section{SÁNCHEZ CALERO, FCo J.:}

- Comentarios al artículo 659 CC. Comentarios al Código Civil y Compilaciones Forales. Ed. EDERSA. Tomo IX. Vol 1-A. Madrid. 1990.

- Comentario a los artículos 881 a 891 CC, en Comentario del Código Civil. Ministerio de Justicia. Secretaría General de Publicaciones. Madrid. 1.993. Pág 2.155 y ss.

\section{SÁNCHEZ ROMÁN:}

- Estudios de Derecho civil. T. VI. Vols 1 y 2. Derecho de Sucesiones. $2^{\mathrm{a}}$ Ed. Madrid. 1910.

\section{SANCHO GARGALLO, I:}

- Incapacitación y tutela: (conforme a la Ley 1/2000, de Enjuiciamiento Civil). Con la colaboración de Teresa Sol Ordis. Valencia. Tirant lo Blanch, 2000.

\section{SAPENA TOMAS:}

- "Un caso de renuncia a herencia futura admitido por el Tribunal Supremo". RDP. 1954.

\section{SCAEVOLA:}

- Código Civil. Comentado y concordado. Tomo XII. Instituto Editorial REUS. Madrid. 1950.

- Código Civil. Comentado y concordado. Tomo XV. Instituto Editorial REUS. $4^{\mathrm{a}}$ Ed. Madrid. 1945.

- Código Civil. Comentado y concordado. Tomo XVII. Instituto Editorial REUS. Madrid. 1944.

\section{SCHULZ:}

- Derecho romano clásico. Traducción española de Santa Cruz Teigeiro. Barcelona. 1960.

\section{SCIALOJA:}

- Diritto ereditario romano. Concetti fondamentali. Roma. 1.934.

\section{SIERRA BERMEJO, L:}

- "El derecho de representación en la sucesión testada". AAMN. Tomo nº 4. Año 1948. Instituto Editorial REUS. Madrid.

\section{SILLERO CROVETTO, B:}

- Comentario a los artículos 988 a 1034 del Código Civil, en Jurisprudencia civil comentada (Tomo I). Dirección: Pasquau Liaño. Ed. COMARES. Granada. 2000. 
SILLERO CROVETTO, B; SÁNCHEZ HERNANDEZ, C.:

- "La herencia yacente ante los tradicionales y actuales sistemas germánico y romano de adquisición de la herencia". RDP. Septiembre. 1995. Pág 798 y ss.

SOLS GARCÍA, P:

- "El heredero. Ideas para su estudio". RCDI. 1944. Pág 568.

\section{STEPHEN:}

- Comentaries on the law of England. 1928. II.

TOBAJAS GÁLVEZ, O.:

- "El testamento mancomunado en Aragón". AC n 18. De 1 a 7 de mayo de 2000

TOLDRÁ ROCA, M $M^{\mathrm{a}} \mathrm{D}$ :

- La anulabilidad por causa de incapacidad (reflexiones en torno al artículo 1304 del Código Civil). Monografía. Tirant lo Blanch. Valencia. 2006.

\section{TRAVIESAS:}

- "Sobre derecho hereditario". RDP. 1921.

- "La renuncia". RGLJ. 1929. II.

- "Legados". RDP. 1931. n 211, 212, 213.

TROPLONG, R:

- Des donations entre vifs et des testaments ou commentaire du titre II, livre III du Code Napoleón. Bruxelles. A. Labroue et compagnie. 1855.

UNGER, J:

- System des österreichischen allgemeinen Privatrechts. Leipzig : Breitkopf und Härtel, 1892.

URIBE SORRIBES, A:

- "La representación de los hijos". AAMN. T. XXV. Pág 239.

VALVERDE:

- Tratado de Derecho Civil español. T. V. Valladolid. 1916.

VALLET DE GOYTISOLO, JB:

- Apuntes de Derecho sucesorio. Madrid. 1955. 
- Dictámenes e informes de un Notario. Dictamen XXXI. Ed. Montecorvo. Madrid. 1987.

- Comentario a los artículos 806 a 857 CC, en Comentario del Código Civil. Ministerio de Justicia. Secretaría General de Publicaciones. Madrid. 1993. Pág 1974 y ss.

- Comentarios al Código Civil y Compilaciones Forales. (Arts 806 a 857, y 968 a 980 CC). T XI y XIII. Vol 2. EDERSA. Madrid. 1981.

- "El fenómeno sucesorio". RCDI. Pág 757.

- Estudios de derecho sucesorio. Ed. Montecorvo. Madrid. 1983.

- Limitaciones de derecho sucesorio a la facultad de disponer. Madrid. 1974.

- Panorama del Derecho de Sucesiones. I Fundamentos. II Perspectiva dinámica. Ed. Civitas S.A. Madrid. 1982 y 1984.

VATTIER FUENZALIDA, C:

- Comentario a los artículos 912 a 929 CC, en Comentario del Código Civil. Ministerio de Justicia. Secretaría General de Publicaciones. Madrid. 1993. Pág 2215 y ss.

- "El Anteproyecto de Pavía". Derecho Patrimonial Europeo. Coord. por PAPALO MORENO, PRATS ALBENTOSA y REYES LÓPEZ. Cizur Menor (Navarra) 2003. Pág. 419 y ss.

- "El derecho de representación". En Derecho de Sucesiones. Presente y futuro. XII Jornadas de la Asociación de Profesores de Derecho Civil. Servicio de Publicaciones de la Universidad de Murcia. 2006. Pág 543 y ss.

- El derecho de representación en la sucesión mortis causa. Ed. Montecorvo. Madrid. 1986.

- "Inexistencia y nulidad del contrato". Código europeo de contratos. Academia de iusprivatistas europeos (Pavía). Comentarios en homenaje al Profesor Dr D José Luis De los Mozos y De los Mozos. Dykinson. Madrid. 2003. Vol. II. Págs 553-572.

VAZQUEZ DE CASTRO:

- Ilicitud contractual. Supuestos y Efectos. Ed. Tirant lo Blanch. Valencia. 2003.

VIVAS TESÓN, I:

- Voluntad del testador y plazo del derecho a suceder. Edt Práctica del Derecho. SL. Valencia. 1998

VOCl:

- Istituzioni di diritto romano. Milano. A Giuffrè. 1948.

VON THUR:

- Parte General del Derecho Civil. Traducción de Roces. 2ª ed. Madrid. 1927. 
WINDSCHEID:

- Diritto delle Pandette. III. Torino. 1925.

YZQUIERDO TOLSADA, M.:

- Estudios sobre incapacitación e instituciones tutelares: Comentarios a la ley de 24 de octubre de 1983 de reforma del código civil títulos IX y X del libro I. Madrid. ICAI, DL 1984.

ZOPPINI, A:

- Le successioni in diritto comparato, en Tratatto di diritto comparato diretto da $\mathrm{R}$. Sacco, UTET, Turín, 2002, pp. 8 ss. 